


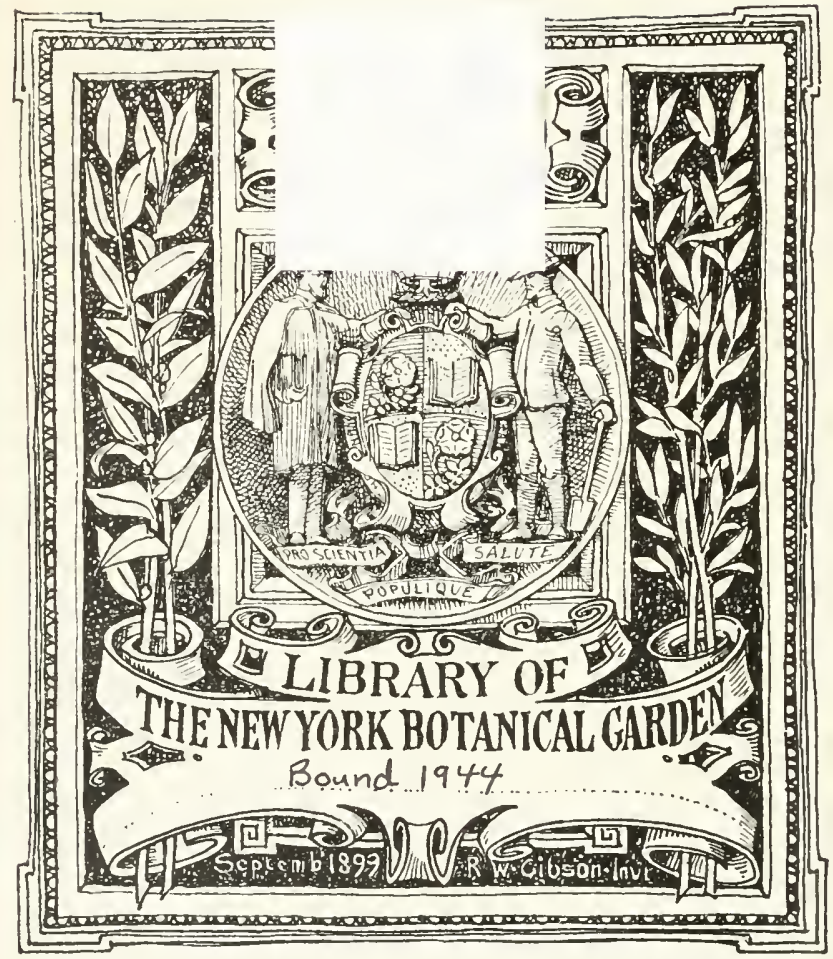






CONTRIBUTIONS FROM THE NEW YORK BOTANICAL

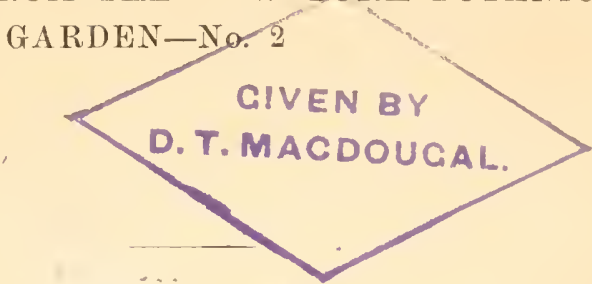

\section{NEW SPECIES FROII THE WESTERN UNITED STATES}

BY P. A. RYDBERG

NEW YORK

1899 
- Rq19 


\title{
New Species from the Western United States
}

\author{
By P. A. RYDBERG
}

\section{Juncus Suksdorfii}

Stem about $3 \mathrm{dm}$. high, strict, light green, $2-3 \mathrm{~mm}$. in diameter ; leaves terete or slightly flattened, distinctly septate; the basal ones short; stem leaves, except the upper ones, often $3 \mathrm{dm}$. long all with a conspicuous, scarious sheatl ; heads in a contracted panicle, brown and shining, 5-8-flowered; bracts ovate, cuspidateacuminate; perianth segments subequal, about $4 \mathrm{~mm}$. long, narrowly lanceolate, acute or acuminate ; stamens 6 ; anthers longer than the filaments; style long-exserted; capsule dark brown and shining, oblong, acuminate, 3-angled.

Dr. Watson has labeled this Juncus Nezadensis var, to which it may be nearest related if the structure of the flower is taken in consideration. It is different in habit, however, being much stouter, having more numerous and larger heads, and longer leaves.

Washington: Falcon Valley, i 883 , Suksdorf, 217 ; i 885,680 ; Spangle, Spokane Co., I 884, t6 $^{6}$ (all in Gray Herbarium).

\section{Allium Neo-Mexicanum}

Bulb oblong, membranaceous, crowning a more or less persistent rhizome ; coat membranaceous; scape slender, terete; leaves narrow, I-3 mm. wide, apparently almost flat, slightly keeled; umbel $8-2 \mathrm{O}$-flowered, nodding; involucre very small; perianthsegments oblong-ovate, acute, nearly white, without a distinct midvein ; stamens and style exserted; capsule 6-crested.

This resembles most $A$. cernum, but differs in the fewer flowered umbel, the narrower perianth-segments, and in the thinner and narrower leaves, which are only slightly keeled.

New Mexico : Organ Mountains, I 894, E. O. IVooton; I 85 I-2, C. IVright, I9I 3 .

South Colorado: i 86i, C. C. Parry', 350.

Arizona: Tanners Cañon, i 892, Dr. T. E. Wilcox.

\section{Astragalus Cusickii}

Perennial from a creeping rootstock: stem about $5 \mathrm{dm}$. high, strigose, somewhat branched; leaves pinnate of 6-9 pairs of linear 
leaflets which are $2-3 \mathrm{~cm}$. long and about $2 \mathrm{~mm}$. wide, glabrous above and slightly strigose beneath; raceme with a I-2 dm. long peduncle, rather lax and few-flowered ; flowers almost sessile, about I $2 \mathrm{~mm}$. long; calyx about $7 \mathrm{~mm}$. long, strigose with dark hairs ; lobes short, lanceolate and unequal; corolla yellow; pod with a stipe which is about I cm. long and curved upwards, upright, oblong, obcordate in cross-section, with the dorsal suture strongly inflexed to about half-way to the ventral one, subcoriaceous, the body being about $2 \mathrm{~cm}$. long.

The specimens were named $A$, arrectus Gray?, to which species it has a superficial resemblance, differing in the pod, the structure of which places it near A. Drummondir and $A$. scopulorum. From these it differs, however, in the short erect pod. It grows on dry hillsides.

Oregon: Malheur, i 885, II. C. Cusick, I 238 (Gray Herbarium).

\section{Potentilla rosulata}

Glandular and viscid pubescent throughout; caudex thick and lignose, topped with dense rosettes of leaves and short stems; the latter, at least in the type specimens, less than I dm. high; basal leaves 4-5 cm. long, long-petioled, pinnately 5-foliolate; stemleaves ternate, short-petioled, or the upper subsessile; lower stipules lanceolate and thin; the upper ovate and rather thick; leaflets thick, densely viscid and glandular pubescent, broadly obovate, or the terminal orbicular, deeply crenate, or somewhat cleft, 7-IO mm. long; pedicels 5-I $5 \mathrm{~mm}$. long; hypanthium about $5 \mathrm{~mm}$. in diameter, densely viscid pubescent; bractlets ovate, about half as long as the broadly triangular ovate acute or acuminate sepals; petals small, oblong, whitish or light yellow, about as long as the bractlets; stamens between 30 and 40 ; anthers decidedly didymous; pistils 20-40; style filiform, attached near the apex of the ovary.

This is nearest related to Potcntilla saxosa Greene, * but differs in the less numerous leaflets of the basal leaves, the much thicker and less inciscd leaflets, the shorter and stouter stems, the smaller

* In my monograph I transferred this species to Horkelia, on account of its close resemblance to Horkelic Baileyi, but a study of better material in Mr. T. S. Mrandegee's herbarium has persuaded me that I made a mistake. The species is a true Potentilla. There are three species, all belonging to the Potentilleae, that are almost identical in the vegetative parts, but still must be placed in three different genera. These are: Potentilla saxosa Greene, Horkelia Baileyi Wats., and Purpusia saxosa Brandegee. 
petals and the shorter hairs of the receptacle. It resembles also $P$. rivalis somewhat in habit and leaves, but it has a thick perennial caudex, much more numerous stamens and filiform style.

California: 29 Palms, Colorado Desert, i $898, A$. H. Alicrson (type in the herbarium of T. S. Brandegee).

\section{Horkelia chaetophora}

Caudex stout, covered with the remains of leaf-stalks and stipules from former years; stems several, I-I.5 dm. high, almost scapose, finely puberulent; basal leaves numerous, about I $\mathrm{dm}$. long, with I 5-20 pairs of leaflets; their stipules broad, brown, obtuse, bristly ciliate; leaflets $3-5 \mathrm{~mm}$. long, divided to near the base into linear-oblong segments, densely puberulent and tipped with bristles; cyme rather many-flowered and open; hypanthium 5-7 mm. in diameter, puberulent and hirsute; bractlets linear-oblong, one third shorter than the broadly lanceolate acute sepals; petals yellow, oblong, about equaling the sepals; stamens Io; filaments filiform; pistils about 20.

This is intermediate between H. Utahensis and H. pygmaca. It resembles the former most in habit and flowers, but has the bristles and obtuse stipules characteristic to H. pygmaea. From the latter it differs in the larger size of the plant and flower and the manyflowered and open cyme. It grows in rocky places in the mountains at an altitude of 3000-3400 m.

California: Farewell Gap and Little Kern River, Tulare Co., I 996, C. A. Purtus, Ifog; Keweah Peak, IS95 (both in the herbarium of T. S. Brandegee).

\section{Horkelia Congdonis}

Perennial with a woody caudex; stems erect, 3-4 dm. high, few-leaved, somewhat branched above, glandular puberulent; basal leaves $\mathrm{I}-\mathrm{I} .5 \mathrm{dm}$. long, with $3 \mathrm{O}-4 \mathrm{O}$ pairs of leaflets; stem-leaves similar but smaller; upper stipules deeply cleft ; leaflets $3-5 \mathrm{~mm}$. long, cleft to the base into $4-5$ oblong divisions, obtuse, glandular puberulent; cyme with a few ascending branches and short-pediceled flowers; hypanthium campanulate, $7-8 \mathrm{~mm}$. in diameter, glandular puberulent; bractlets lanceolate, one half or two thirds the length of the lanceolate acuminate sepals ; sepals almost equaling the sepals, oblong, obtuse; stamens 20; filaments slightly dilated, subulate; pistils numerous.

This is nearest related to Horkclia purfurascens, but differs in the 
taller habit, the more branched cyme, the more acuminate sepals, which in the type specimens are not reflexed, and the petals, which are not retuse or emarginate as in that species.

California: Casa Diabolo, i 895, J. II. Congdon (type in the herbarium of T. S. Brandegee).

\section{Mertensia tubiflora}

Perennial; stem 2-3 dm. high, glabrous striate, and somewhat angled, branched above; basal leaves oblanceolate, short petioled; stem-leaves sessile, lanceolate to ovate, about $4 \mathrm{~cm}$. long and $\mathrm{I}-2$ $\mathrm{cm}$. wide, glabrate, except the hispid ciliolate margins, muricate above, obtuse; panicle contracted; pedicels very slender and drooping, about I cm. long, strigulose; calyx slightly strigose, about $4 \mathrm{~mm}$. long, cleft half-way into oblong-lanceolate acutish lobes ; corolla I $3-15 \mathrm{~mm}$. long ; tube about $\mathrm{Io} \mathrm{mm}$. long and $3 \mathrm{~mm}$. in diameter, more than twice as long as the limb; the latter campanulate with very short lobes; nutlets very strongly muricate.

This species combines the general habit of $M$. lanccolata with a corolla which is most like that of 11 . oblongifolia.

Wroming: Headwaters of the Tongue River, Big Horn Mountains, July, I $898, F$. Touedy, II9.

\section{Symphoricarpos Utahensis}

Symphoricarpos montamus Wrats. King's Exp. 5: 132 partly: not H.B. K.

Shrub a meter or more high, with brownish bark; leaves broadly ovate, more or less rounded at both eirds, obtuse or often mucronate, often coarsely sinuately toothed, pubescent when young, glabrate in age, $3-4 \mathrm{~cm}$. long and $2-3 \mathrm{~cm}$. wide; flowers in terminal one-sided, drooping short spikes, or with smaller clusters in the upper axils; corolla somewhat funnelform, about $8 \mathrm{~mm}$. long.

This resembles most S. raccmosz in inflorescence and leaves, but differs in the form of the corolla. The inflorescence, the larger and less pubescent leaves and the size of the bush separate it from S. rotundifolius.

Utah : Logan, August, I 895, P.A. Rydberg (Type); WVahsatch Mountain, I 869 , S. W Watson, 775 , in part.*

* Watson includes under this number not less than three distinct forms. Of these one belongs to this species, one from Virginia Mountain, Nevada, to S. oreophilus, and the third from the Uintahs to the next or an undescribed species. 


\section{Symphoricarpus Parishii}

Apparently rather tall shrub for the group; bark of the old stems gray, of the young twigs brown; leaves of older stems small, about $1.5 \mathrm{~cm}$. long, narrowly oval, acutish at both ends, densely pubescent, more or less bluish green, rather thick; those of the young shoots larger, about $3 \mathrm{~cm}$. long, deeply 3 -lobed and coarsely toothed; corolla elongated campanulate, $6-7 \mathrm{~mm}$. long.

This resembles mostly $S$. rotundifolius in pubescence and flowers, but is evidently a larger plant and the leaves are bluish green and acutish at both ends. It seems to be confined to Southern California.

Calmfornia: San Bernardino Mountains, is92, S. B. Parish, $2514 ;$ I 994,3024 .

\section{Erigeron flabellifolius}

Perennial with a long slender creeping rootstock; stem I-2 dm. high, few-leaved, glandular puberulent above; basal leaves petioled, about $3 \mathrm{~cm}$. long, slightly glandular puberulent, cuneateflabelliform in outline, deeply $3-5$-cleft into cuneate 3 -lobed divisjons or the lower simply 5-9-lobed at the apex; stem-leaves cuneate or obovate, smaller, subsessile and less divided; heads about $10 \mathrm{~mm}$. high and IO-I $5 \mathrm{~mm}$. in diameter; bracts linear, acuminate, with more or less spreading tips, dark brown or purplish black, glandular puberulent; rays $7-8 \mathrm{~mm}$. long and $1.5-2 \mathrm{~mm}$. wide, light pink or white.

This is a member of the E. compositum group, easily distinguished from its relatives by the form of the leaves, which are never compound, but simply cleft two thirds their length or less. It is also characterized by the lack of hirsute pubescence generally found in that group. It grows in rocky slides at an altitude of $3600 \mathrm{~m}$.

Wroming: Yount's Peak, Teton Forest Reserve, August, I 897, Tiucedy, 536 .

\section{Erigeron spathulifolius}

Perennial from an ascending rootstock; stems $5-8 \mathrm{~cm}$. high, generally ascending, glabrous or slightly puberulent above, 3-5leaved; basal leaves about $2 \mathrm{~cm}$. long, perfectly glabrous, somewhat fleshy, broadly spatulate, tapering into a short petiole, entiremargined, obtuse or acutish ; stem leaves I-I.5 cm. long, linearoblong or oblanceolate, sessile, obtuse; head solitary, $7-8 \mathrm{~mm}$. high and IO- $5 \mathrm{~mm}$. in diameter, excluding the rays; bracts 
linear-lanceolate, acute, black, slightly puberulent; rays light blue, in age white, about $8 \mathrm{~mm}$. long and $2-3 \mathrm{~mm}$. wide.

In leaves and heads, this resembles most E. simplcx Greene, but has a different root-system, is a much more glabrous plant and lack altogether the long villous hairs on the involucre characteristic of that species. On account of its root-system, it may be associated with E. ursinus and E. radicatus, but lacks the hirsute pubescence of those species and has broader rays. The same characters, together with the single head and broad leaves, separate it from E. Eatonii, which also has somewhat the same habit. It is. an alpine species growing at an altitude of $3000 \mathrm{~m}$. or more.

IVroming: Black Rock Creek, Teton Forest Reserve, August, I 897, Troecd, 5 43.

\section{Antennaria angustifolia}

Surculose-proliferous; leaves of the stolons linear or linearoblanceolate, about $1.5 \mathrm{~cm}$. long, finely tomentose on both sides; stem-leaves narrowly linear, erect, the uppermost subulate; heads few in a subcapitate cluster, $4-5 \mathrm{~mm}$. high; involucre campanulate, tomentose at the base; bracts of the fertile head linearoblong, acute, yellowish or brownish white.

This is nearest related to $A$. provifolia and $A$. microphylla, from which it differs in the subcapitate heads and the very narrow leaves.

California: Tosemite Valley, is65, J. Tomey (labeled $A$. stcnophylla?); Hat Creek, J. S. Newberry (labeled A. luzuloidcs; both in the Torrey Herbarium). 
CONTRIBUTIONS FROM THE NEW YORK BOTANICAL GARDEN-No. 5

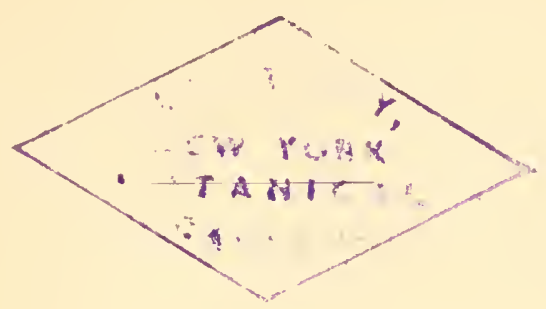

\title{
STUDIES ON THE ROCKY MOUNTAIN FLORA-I
}

\author{
BY P. A. RYDBERG
}

NEW YORK

1900 



\title{
Studies on the Rocky Mountain Flora,-I*
}

\author{
By P. A. RyDBerg
}

(With Piates 5 AND 6.)

SPECIES OF SENECIO OF THE LOBATUS, AUREUS, SUBNUDUS AND TOMENTOSUS GROUPS

It may seem strange that I present here a paper on SEnecio, when it is well known to me that Mr. Greenman is occupied in preparing a monograph of the genus in all North America, from the arctic regions to the Isthmus. My work was begun a year ago, and before I knew of Mr. Greenman's work. I have not been able to present my results in print before now, and I do it with the good will of the gentleman mentioned, and with the understanding that I confine myself to the Rocky Mountain region.

The four groups treated here are closely related and grade into each other. They might have been treated as a single group but even this would have been more or less artificial and ill-defined, because there are several intergradations with related groups. The more foliose species of the Aurer as S. platylobus and S. Idahocnsis described below connect with the Eremophili; S. cymbalarioides with the AlpicolaE, and S. conovirens with the CANI.

The work presented here is based on my own studies in the field and the specimens found in the herbaria of the New York Botanical Garden, Columbia University and College of Pharmacy, all in New York City.

\section{LOBATI}

Annuals or biennials or perennials with a taproot, perfectly glabrous in age or slightly floccose at the bases of the leaves, more or less leafy throughout, $3 \mathrm{dm}$. or more high: leaves, all except

* The author intends to publish under this title a series of papers on the Botany of the Rocky Mountain Region. The intention is not however to limit these studies to the botany of the mountains proper, but will inclucle also the Great Plains to the eastward. They will comprise the following states and territories : eastern British Columbia, Alberta. Saskatchewan, Assiniboia, Montana, Idaho, Wyoming, Colorado, New Mexico, eastern Utah, and the extreme western portions of the I akotas, of Nebraska, Kansas, Oklahoma and Texas. 
the very first, pinnately divided: heads rather small and minutely calyculate. In habit resembling the Aurei and Tomentosi, to which the last two form a transition, but have more divided leaves and a root of less duration.

I.eaves thin ; root annual or biennial.

Head about $\mathrm{I} \mathrm{cm}$. high ; terminal segments of the basal leaves $3-5 \mathrm{~cm}$. wide.

I. S. sansuisorboides.

Head 5-8 $\mathrm{mm}$. high; terminal segments of the basal leaves less than $2 \mathrm{~cm}$. wide. Basal leaves with few segments; segments crenate or dentate.

2. S. Greggii.

Basal leaves with numerous segments; segments lobed or cleft.

Leaves rather thick; root perennial.

3. S. millelobatus.

Bracts thick, much shorter than the disk.

Bracts thin, almost equaling the disk.

4. S. multilobatus.

5. S. Nelsonii.

\section{Senecio sanguisorboides sp. nov.}

Tall and simple, perfectly glabrous, annual or maybe biennial : stem terete, about $6 \mathrm{dm}$. high, leafy : basal leaves thin, I-2 dm. long, petioled, pinnately divided with $3-5$ segments; terminal segments reniform, $3-5 \mathrm{~cm}$. wide, coarsely crenate; lateral segments almost orbicular, crenate: lower stem leaves similar; the upper with 7-II segments, short-petioled or the uppermost subsessile; the base of the petioles with large round, laciniate auricles; terminal segment ovate, incised-crenate; the lateral ones obovate or broadly cuneate: cyme rather contracted: heads about $1 \mathrm{~cm}$. high; bracts I 2-I6, linear-lanceolate, acute, about I $\mathrm{mm}$. wide, with membranous margins; the calyculate ones very few and minute, lanceolate: rays about $\mathrm{IO}, \mathrm{S} \mathrm{mm}$. long and $3 \mathrm{~mm}$. wide, about 4-nerved: achenes glabrous and angled.

This has been referred to S. Sanguisorbae DC.; but a comparison with De Candolle's description shows several discrepancies. According to the description S. Sanguisorbac should have only 8 -IO bracts and 5 rays, the leaves should be puberulent beneath and the terminal segment orbicular, characters not found in the present species. The latter grows at an altitude of 2500-3000 m. [Plate 5, f. I 4.]

New Mexico: Santa Fe Cañon, is97, A. A. E. Gertrude Heller, 3820 (type in the herbarium of the N. Y. Botanical Garden); White Mountains, I 897, E. O. Wooton, 79.7.

\section{Senecio Greggii sp. nov.}

Sencio Tampicams A. Gray, Pl. Fendl. I09. I 849 ; not DC., I 837 ; S. lobatus A. Gray, Pl. IVright. 2 : 99. I 852 ; not Pers. I 807 . 
Biennial or annual, with several stems from the base, perfectly glabrous in age : stems about $3 \mathrm{dm}$. high: leaves pinnately divided or the very first ones simple: basal leaves with $3-5$ segments, the terminal one round and crenate, about $\mathrm{I} \mathrm{cm}$. in diameter; the lateral ones small, obovate; stem leaves with $7-9$ small segments and more or less auricled at the base of the very short petiole: cyme compound: heads rather many, only 5-7 mm. high; bracts about 20, linear-acuminate; the calyculate ones minute and few: rays $S-10$, about $3 \mathrm{~mm}$. long and $\mathrm{I} .5 \mathrm{~mm}$. wide, 3 -nerved: achenes angled and strigose.

This is nearest related to S. lobatus but smaller and characterized by the many stems from the same root, the few segments of the basal leaves, the small heads and the narrow bracts. Only Vright's specimens were collected in the region here treated. [Plate 5, f. 8.]

Mexico: Santa Rosalia, Dr. Grogg (type in Torrey Herbarium).

Texas: Near El Paso, i $S_{5}$ I-2, C. Irright, I I $_{3}$; between Frio and Nueces Rivers, I 8SO, E. Palmor, 75,; Loredo to Frontera, Wright (Mexican Boundery Survey), 659, in part.

\section{Senecio millelobatus sp. nov.}

Sinccio Tampicants A. Gray, Pl. Wright. 2 : 99. IS 52 ; not DC. I $S_{37} ;$ S. multilobatus A. Gray, Syn. Fl. $\mathbf{x}^{2}: 394$, in part. I $8 \&_{4}$; not T. \& G. I 849 .

Annual or biennial, perfectly glabrous or slightly floccose at the base of the leaves: stem branched, 3-5 dm. high, very leafy : all leaves pinnately divided, $3-7 \mathrm{~cm}$. long, lanceolate or oblanceolate in outline; segments I $3-23$, obovate, $3-10 \mathrm{~mm}$. long, lobed or cleft into oblong or ovate lobes; the upper segments more or less confluent: cyme compound: heads about $S \mathrm{~mm}$. high; bracts oblong-lanceolate, acuminate, $12-15$ in number; calyculate ones minute and few : rays $5-8 \mathrm{~mm}$. long and $1.5-2 \mathrm{~mm}$. wide: achenes very scabrous on the angles.

This is nearest related to the preceding and to S. lobatus but is easily distinguished by the numerous and lobed or cleft segments. It may be related to S. Tampicanus which I have not seen, but that species is described as having only 4 or 5 pairs of segments and glabrous achenes. [Plate 5, f. I I.]

New Mexico: Hills on the Limpia, I $85 \mathrm{I}-2$, C. I Tright, I $2 S_{7}$ (type in the Torrey herbarium); P. I. Le Rol. 
Texas: Lower Rio Grande, 1852, Parry' (Mexican Boundary Survey), 6.58 .

4. Senecio multilonatus Torr. \& Gray; Gray, Pl. Fend. Iog. I 849

The type of this species is in the Torrey herbarium and very unlike the plant regarded by Gray as $S$. multilobatus. It is characterized by its fleshy leaves and stands perhaps nearer to $S$. compactus than to the group with which it was associated by Dr. Gray. I have placed it in this group on account of its pinnatifid basal leaves. The earliest of these are, however, entire, in the same manner as they occasionally are in S. rosulatus. This analogy and the close relationship to S. compactus undoubtedly made Prof. Greene name Baker, Earle and Tracy's specimens "Senecio compactus Rydb., verging towards S. Fondleri." These specimens differ from Fremont's plant only in the fact that the basal leares are shorter and less divided. Eastwood's specimens are exactly like the type. The base of these specimens shows that the plant is a perennial rather than an annual as stated in the original description. It grows at an altitude of about $2000 \mathrm{~m}$. [Plate 6, f. I 1 .]

UTAн : Uintah River (a tributary of Greene River), Frcmont, $5+9$ (type in the Torrey herbarium); Ogden, I87 I, Hayden Survey"; South Utah, J. E. Johnson.

Colorado: Grand Junction, i 892, A. Easta'ood; Mancos, I 898, Baker, Earlo \& Tracy, +76; Dolores, is92, C. S. Crandall; South Park, is7 i, II. M. Canby'.

5. Senecio Nelsonil Rydb. Bull. Torr. Club, 24: 483. i 899

Prof. Greene in Pittonia, 4: I I 2, devotes over a page to this species, claiming it to be the same as S. Fondlor, and criticises both Prof. Nelson and myself. We had, however, both investigated the matter thoroughly before the species was published. In claiming that the two species are the same, Prof. Greene must either not know one of the plants or both, or else do it for the purposes of finding fault. S. Nilsonii has the leaf form of S. Fendleri, but there ends the similarity. In the former the caudex is short, not woody, and with numerous fibrous roots, placing it nearer to $S$. multilobatus and S. compactus, while $S$. Fendleri has a very thick 
and woody rootstock. The heads of S. Nisonii are larger, S-IO $\mathrm{mm}$. high, and the bracts are thin and in anthesis almost equal the disk, while in S. Fendliri they are thick and much shorter. The former also lacks the fine tomentum of the latter; it is merely floccose when young in the manner of S. multilobatus and S. compactus. S. Nelsonii is dark green while $S$. Fondlcri is more or less yellowish. Neither of the species forms mats, as Prof. Greene states. Heller's specimens, from the type locality of S. Fondlcri, agree fully with Gray's description of that species, except that they are more glabrate than the type. They represent a plant of several season's growth, but show nothing to indicate a matted plant. I think that Prof. Greene has here confused S. rosulatus with the two. Prof. Greene's conception of S. Fondleri must be very comprehensive, indeed, as he also includes in that such forms as $S$. subuncatus, S. conoirirus, and another species, nearly related to S. fastigiatus Nutt. This statement is founded on specimens determined by Prof. Greene only a year or two ago and found in the herbarium of the New Tork Botanical Garden. By comparing Plate 5, Fig. 6, and Plate 6, Figs. I, 3, 4 and 9, with each other, one can get an idea of Prof. Greene's conception of S. Fcndleri.

I have seen no specimens of $S$. Visonii except the type.

\section{AUREI}

Slender perennials, over 2 dm. high, with a short erect caudex or rootstalk, glabrous or slightly floccose when young, the wool remaining in age only at the base of the leaves : basal leaves entire, merely toothed: stem leaves more or less pinnatifid and the upper more or less reduced: heads small, cymose, with very small and few calyculate bracts,

\section{Heads radiate.}

Leaves thick, more or less fleshy.

Basal leaves narrowly oblanceolate.

Plant low, less than $2 \mathrm{dm}$. high, often with several stems from the base; basal leaves short-petioled.

Cyme dense; upper leaves generally pinnatifid with narrow lobes.

6. S. compactus.

Cyme more open; stem leaves entire or merely crenate.

Basal leaves subentire or 3 -toothed at the apex.

Basal leaves crenate.

7. S. tritenticulatus

S. S. oblancedatus. 
Plant about 4-6 dm. high, simple.

Leaves serrate or subentire; basal leaves $\mathbf{I} \mathrm{cm}$. or more, slenderpetioled.

9. S. longipetiolatus.

Stem leaves with long, triangular lobes; basal leaves $5 \mathrm{~cm}$. or less.

IO. S. fulgens.

Basal leaves cuneate, spatulate or broadly oblanceolate, subentire at the base.

Lower stem leaves spatulate with a broad-winged petiole; upper ones sessile and with much enlarged bases. II. S. crocatus.

Stem leaves neither broad-winged nor with much enlarged bases.

Basal leaves crenate above the middle.

12. S. cymbalarioides.

Basal leaves angularly dentate.

13. S. Jonesii.

Basal leaves sharply dentate or serrate above the middle.

Lower stem leaves cuneate, plant 3-4 dm. high.

I4. S. subcuneatus.

Lower stem leaves oblanceolate; plant about $2 \mathrm{dm}$, high.

Leaves thin.

15. S. acutidens.

Lasal leaves ovate or more commonly cordate, serrate. I6. S. pseudaureus.

Basal leaves obovate or oval, crenate or sinuate-dentate.

Stem leaves orate in ontline, with broad segments.

17. S. platylobus.

Stem leaves lanceolate or oblanceolate in outline, with narrow segments.

I8. S. fazozirens.

Stem leaves spatulate or oblanceolate in outline, with short and broad segments.

19. S. aurellus.

Head discoid.

First basal leaves reniform.

20. S. nethropliyllus.

None of the leaves reniform.

Plant stout; stem leaves with broad laciniate segments.

21. S. Ilahoensis.

Plant slender; stem leaves with narrow segments.

Plant yellowish or light green; bracts not purple-tinged.

Plant dark green.

17. S. flavovirens.

Basal leaves crenate; head $S-10 \mathrm{~mm}$. high; bracts purple-tinged, linear.

22. S. pancifonus.

Basal leaves wavy ; heads about $6 \mathrm{~mm}$. high ; bracts broadly lanceolate or oblong, not purple-tinged.

23. S. fedifolizes.

6. Sexecio compactus (A. Gray) Rydb. Mem. Torr. Club, 5 :

$$
\text { 342. I } 893
$$

Senccio aureus var, compactus A. Gray, Syn. Fl. I²: 39I. I 884.

Dr. Gray's description covers two if not three species. For which of these S. compatus should be used is a matter of question. I have adopted it for the plant of the plains with a dense cyme and usually pinnatifid-dentate stem leaves. Dr. Gray evidently had this plant in mind when he adopted the name com- 
pactus. The description seems to indicate mostly this species, which also I had in mind when I raised the variety to specinc rank and it is this that is described and figured in Britton and Brown's Illustrated Flora. On the other hand if synonomy and the citation of specimens are taken in consideration, the name may have been applied to the next, for the first synonym and the first specimen cited belong to that species. [Plate 5, f. I 5.]

Nebraskd: Valentine, J. M. Bates, 3t; Lewellen, G. D. Sivicisy, Sz; Fort Niobrara, Isss, T. E. Hiliox; Thedford, IS93, P. A. Rydborg, I 31 ; Platte Bottom, IS9I, 2I I.

Colorado: Plains, IS\&2, Allcn \& Brewster; Colorado Springs, I S92, Isabel Mulford.

\section{Senecio tridenticulatus sp. nov.}

Senccio aureus var. borealis A. Gray, Pl. IVright. I : I25. I \&52; not T. \& G. I $8_{43} ;$ S. aureus var. compactus A. Gray, Syn. Fl. $\mathrm{I}^{2}: 39 \mathrm{I}$; in part.

Perennial with a branched caudex, in age perfectly glabrous, or slightly floccose at the base of the leaves: stems very slender, about $3 \mathrm{dm}$. high : basal leaves very narrowly oblanceolate, thick with a slender petiole, slightly 3-toothed at the apex or wholly entire, $4-8 \mathrm{~cm}$. long and $4-5 \mathrm{~mm}$. wide: stem leaves linear and subentire: cyme open and corymbiform: heads $7-S \mathrm{~mm}$. high : bracts lanceolate, acute $z_{3}$ or $3_{4}$ as long as the disk: rays light yellow, about $\delta \mathrm{mm}$. long and $\mathrm{I}-\mathrm{I} .5 \mathrm{~mm}$. wide, 3 -nerved; achenes hispid-puberulent on the angles.

This species differs, from the preceding in the slender stem and the open cyme, and also in the form of the leaves. The latter character also separates it from the next following. It grows in wet sandy soil. The type was growing at an altitude of $2400 \mathrm{~m}$. Wright's specimens are past blooming, and good characters could not be taken from them, wherefore I have made Shelcion's specimens the type. The latter were mixed with some of the next. [Plate 5, f. I 2.]

Colokado: Cottonwood Creek, Buena Vista, i 892, C. S. Shcldon (type in the herbarium of N. Y. Botanical Garden).

Texas: Mountans beyond the Limpia, is 49, Wright, fo3.

\section{S. Senecio oblanceolatus sp. nov.}

Perennial with several stems from a strong root, in age glabrous or rarely slightly floccose at the base of the leaves: stems short and 
stout, about $2 \mathrm{dm}$. high : basal leaves oblanceolate, thick and fleshy, 4-6 cm. long, obtuse, crenate with entire long tapering bases or the first subentire: stem leaves similar or reduced and linear in outline: cyme corymbiform, not compact: heads about $8 \mathrm{~mm}$. high; bracts linear acute, yellowish green; the calyculate ones minute and few: rays $5-6 \mathrm{~mm}$. long and about $1.5 \mathrm{~mm}$. wide, 4-nerved: achenes minutely scabrous on the angles.

This species has also been included in S. aurcus compactus, but lacks the dense inflorescence of $S$. compactus as here understood. The stem leaves never show any indication of being pinnatifid with narrow lobes as in that species. S. compactus is a plant of the Great Plains, while S. oblanccolatus is a mountain plant growing at an altitude of ISOO-3000 m. [Plate 5, f. 9.]

Colorado: Como, South Park, i S95. C. S. Crandall (type in the herbarium of N. I. Botanical Garden); El Paso County, I 89\%, A. A. \& E. Gertrude Hcller, 350S; Cottonwood Creek, Buena Vista, is92, C. S. Shcldon.

\section{Senecio longipetiolatus sp. nov.}

A tall, simple, perfectly glabrous perennial, with a short erect rootstock: stem strict, $3-6 \mathrm{dm}$. high, terete : basal leaves oblanceolate, I-I.5 dm. long, with a slender petiole, from serrate to subentire: lower stem leaves similar; the upper reduced, lanceolate, sessile, sharply serrate, or laciniate-dentate, often auricled at the base: cyme dense, corymbiform: heads $8-9 \mathrm{~mm}$. high: bracts about 20, linear, acute: the calyculate ones few, minute, subulate and crisp: rays dark orange, $4-7$ 11mm. long and $1.5 \mathrm{~mm}$. wide, 3-4-nerved : achenes strongly angled, glabrous.

In the type the basal leaves are strongly serrate, but in the Colorado plants they are indistinctly so or subentire. Baker, Earle \& Tracy's specimens were named by Professor Greene, Sencio crocatus Rydb. but it is entirely distinct from anything collected by Hall \& Harbour, and has nothing that fits any description of $S$. aurcus var. crocus, except the dark rays. See further remarks under $S$. crocatus. S. longipetiolatus grows at an altitude of 2000-3000 m. [Plate 6, f. I o, Ioa.]

Wroming: Spread Creek, Teton Forest Reserve, i 897, F. Taredy', 585 (type in the herbarium of N. I. Botanical Garden).

Colorado: Medicine Bow Range, isgr, C.S. Crandall; Hamor's Lake, north of Durango, I 898, Baker, Earle \& Tracy', 625. 


\section{IO. Senecio fulgens sp. nor.}

Simple and glabrous perennial with a very short caudex: stem about $3 \mathrm{~cm}$. high:: basal leaves oblanceolate, thick and somewhat fleshy, with the petiole about $5 \mathrm{~cm}$. long, dentate or subentire: lower stem leaves spatulate with a winged petiole, coarsely dentate; upper stem leaves sessile with an auricled base, lobed with triangular or triangular lanceolate lobes, acute: cyme corymbose and rather dense: heads about $\$ \mathrm{~mm}$. high: bracts about 15 , oblong, acute, with a broad membranous margin ; the calyculate ones few, lanceolate: achene striate, glabrous: rays $4-5 \mathrm{~mm}$. long and $2 \mathrm{~mm}$. wide, dark orange.

Closely related to the preceding, but differing in the short basal leaves and the lobed upper stem leaves and also in the fewer and broader bracts. It grows at an altitude of about $2700 \mathrm{~m}$. [Plate 6, f. I 3.$]$

Wroming: Grand Creek, Teton Forest Reserve, is97, F. Toucedy, $5 \&_{+}$(type in the herbarium of N. Y. Botanical Garden).

1 I. Senecio crocatus Rydb. Bull. Torr. Club, 24: 299. 1S97 Scnecio aurcus var. croccus A. Gray, Proc. Acad. Nat. Sci. Phila. I863: 68, I 863 ; not $S$. croccus DC. I $S_{37}$.

When the above name was published I did not know that this variety of Gray's was a complex one. Hall \& Harbour's no. 332, which is the type, consists of two different things; but as one of them is rayless it can not be taken as the type of the var. crocutus, which was named from its orange rays. That I did not draw a new diagnosis, I admit, was perhaps careless, but this blunder I think was not worth a page and a half of discussion as it was given by Professor Greene in Pittonia, 4: I I4-1 I6. I committed just the same mistake as Professor Greene himself in establishing Antennaria midia Greene, Pittonia, 3: 286. What Professor Greene says of Mr. E. Nelson in Pittonia, 4: 85 can be applied to himself. Gray's description of the var. crocus in the Proceedings of the Philadelphia Academy is perhaps not adequate, but this description is supplemented in the Synoptical Flora and elsewhere and I think that Senccio aureus var. croceus Gray is amply published according to all rules we have. If so, Soncio crocous Rydberg is not a nomen nudum, whatever Professor Greene may say. Professor Greene in I $\$ 97$ or I $\$ 9 \&$ accepted my name, for he named Baker, Earle \& 
Tracy, no. 625, S. crocatus Rydberg. This mistake is just as unpardonable because that plant shows none of the characters, assigned to S. aureus var. croceus Gray, except the color of the rays, and this character Professor Greene, agrees with me in regarding as of little value. That Professor Greene and other botanists may know what I now mean by S. crocutus I shall give a diagnosis, here following Professors Greene's example in the case of Antcnnaria medic.

A glabrous perennial with a short erect rootstock: stem 1.5-3 dm. high : basal leaves $2-3 \mathrm{~cm}$. long, obovate or spatulate, crenate or subentire with a winged petiole: lower stem leaves similar but with broader, winged petioles which are somewhat auricled at the base, or else oblong without distinction between blade and petiole and then more auricled: upper stem leaves ovate or triangular with very large and large-toothed auricles : cyme small and compact with $2-5 \mathrm{~mm}$. heads, which are $8-10$ $\mathrm{nm}$. high: bracts about 20 , linear: rays $7-8 \mathrm{~mm}$. long and I.5-2 mm. wide, orange to pale yellow, achenes striate, glabrous. [Plate 5, f. I 3.]

Colokado: Middle Park, I862, Hall \& Harbour, 332, in part (type); 329, in small part; I 868, Geo. T'ascy (Powell's Expedition), 3 fo B ; South Cottonwood Gulch, is92, C. S. Sheldon; Gray's Peak, I 872 , John Torry'; (?) Little Kate Mine, IS9\$, Baker, Earle \& Tracy, 569; * South Park, I87I, Canby'; Long's Peak, I8S6, Lettomenn (depauperate).

Wroning: La Plata Mines, i 995 , Aacn Viclson, r769:

\section{Senecio dimorphophyluds Greene, Pittonia, 4: 109. 1900}

I have not seen any specimens of this species, and have not been able to include it in the key. It is described as being a foot (about $3 \mathrm{dm}$.) high, light green and with long golden-yellow rays. Otherwise the description reads much like that given above for S. crocatus. The type was collected about Pagosa Peak, Colo, in 1899 , by C. F. Baker.

12. Sexecio crubalarioides Nutt. Trans. Am. Phil. Soc. II., 7 : 4I2. I $S_{4}$ I

Senccio aurcus borealis Torr. \& Gray, F1. 2 : 442. 1 $843 ;$ S. aurcus ohozatus Eat. King's Exp. 5: I 90, in part. I 87 I.

*These specimens were named Senecio heterodoxus Greene n. sp., but I can not find any published description. They differ from the rest in being cespitose, with less marked differentiation in the leaves and with traces of floccose pubescence at the bases of the leaves and heads. The species may be distinct. 
This has sometimes orange rays and has then been confused with S. crocatus, but it lacks the winged petioles of the lower leaves and the large auricles of the upper. It often reaches a height of $3 \mathrm{dm}$. and then many of the stem leaves are also spatulate. Such a form with more permanent woolliness is V'atson's no. 669; otherwise I cannot distinguish it from S. cymbalariodes. [Plate 5, f. I.]

British America: Maclienzie River, is6I-2, I. S. Onion.

Montand: Park Co., iss7, Tiucedy, jł3, in part; Silver Bow Co., Mrs. Moore; Jack Creek, I S97, Ryelberg \& Bessey, 5266.

Wroming: Beaver Cañon, I 895 , Rydberg; Bacon Creek, i S94, Aren Nelson, go6.

IDAно: Mt. Chauvet, I 897 , Rydberg \& Bessey, 5267.

UtaH : Wasatch Mts., i 869, S. ITatson, 669.

Washington: Mt. Paddo, is82, IT: . V. Suksdorf; Columbia, Nuttall (type).

\section{3. Senecio Jonesii sp. nov.}

A glabrous perennial : stem about $3 \mathrm{dm}$. high, slender, terete : basal leaves rounded-obovate, sinuately toothed, sometimes with a pair of small lobes at the base; their petioles often tinged with red: stem leaves oblanceolate in outline, pinnatifid with oblong segments, generally short-petioled: cyme corymbiform: heads about $8 \mathrm{~mm}$. long: bracts $12-\mathrm{I} 5$, lanceolate, acuminate, about $2 / 3$ as long as the disk, membranous margined; calyculate ones few; linear : rays about $5 \mathrm{~mm}$. long and $2 \mathrm{~mm}$. wide, $t$-nerved : achenes very strongly striate, glabrous.

Nearly related to the preceding, but differing in the toothing of the leaves and the form of the bracts. The type was collected at an altitude of $3300 \mathrm{~m}$. [Plate $6, \mathrm{f} .5$.

Utah: Alta, Wasatch Mountains, I879, M. E. Jones, II25 (type in the Columbia Herbarium).

\section{Senecio subcuneatus sp. nov.}

Perennial with a branched caudex, slightly floccose when young, glabrate in age: stems 3-4 dm. high : basal leaves about $5 \mathrm{~cm}$. long, spatulate or cuneate, dentate or serrate abore the middle, entire at the base and tapering into a short petiole, rather thick: lower stemleaves narrowly cuneate, short.petioled, dentate at the apex : upper ones linear and sessile, often sharply dentate: cyme corymbiform: heads about $\$ \mathrm{~mm}$. high : bracts about I 5 , 
lanceolate, acute, shorter than the disk: rays $4-5 \mathrm{~mm}$. long and I.5 wide, 4-nerved: achenes striate, glabrous.

This species is nearest related to S. cymbalarioides but is taller, with narrower basal leaves, which have sharper teeth; the heads are also much more numerous. It grows at an altitude of 2000$2500 \mathrm{~m}$. Baker, Earle and Tracy's specimens were labeled by Prof. Greene Sencio Fendlcri, approaching S. compactus. This is strange from one that claims that he has known $S$. Fendliri since 1870.* This plant has little in common with that species or with S. Nelsonii Rydb. [Plate 5, f. 6.]

Colorado: Grizzly Creek, i 896, C. F. Baker (type in the herbarium of N. Y. Botanical Garden); Lake City, $1878, H . M$. Peasc (depauperate); Mancos, I S98, Bakcr, Earlo \& Tracy', 3.

\section{I5. Senecio acutidens sp. nov.}

Perennial, with a thick woody rootstock and short caudex, in age glabrate or slightly floccose at the base of the leaves: stems several, about $2 \mathrm{dm}$. high, angled, more or less tinged with red: basal leaves about $5 \mathrm{~cm}$. long, thick, fleshy and somewhat glaucous, obovate or spatulate: sharply dentate above the middle, at the base entire and abruptly contracted into a slender petiole: lower stem leaves similar or oblanceolate and acute; the upper reduced, linear, laciniate-dentate or somewhat pinnatifid: cymes corymbiform and rather dense: heads $8-10 \mathrm{~mm}$. high: bracts broadly linear, acute, $2 / 3$ or $3 / 4$ as long as the disk: rays about $5 \mathrm{~mm}$. long and $1.5 \mathrm{~mm}$. wide, 3-4-nerved: achenes slightly angled, glabrous.

Nearest related to $S$. cymbalarioides but the leaves are thicker, more glaucous and very acutely dentate. The perennial rootstock and caudex are also thicker and more woody. [Plate 5, f. 2.]

Wroning: Union Pass, I 894, Aien Nelson, 858 (type in the herbarium of N. I. Botanical Garden).

16. Senecio pseudaureus Rydberg, Bull. Torr. Club, 24: 298.

$$
\text { I } \$ 97
$$

This is nearest related to the eastern $S$. aureus and has the same subcordate, thin, basal leaves, but these are distinctly serrate, instead of crenate. It is the most common species of the group in the Rockies, growing in wet meadows at an altitude of $1000-$ $3000 \mathrm{~m}$. [Plate 5, f. 10.$]$

* See Pittonia, 4: II 2. 
Movtaxa: Little Belt Mountains, I896, Flodman, ois (type); Madison Co., Mrs. McNulty'; Bear Gulch, is87, F. Triecdy', 3 to ; Columbia Falls, Mrs. Kemedy, 9; Spanish Basin, I 897, Rydberg \& Bessey, 5263 ; Indian Creek, 5264 .

Wroming: Lone Star Geyser Basin, Yellowstone Park, I 897. Rudberg \& Besscy, 5262 .

Colorado: Grizzley Creek, i 896, C. F. Baktr; Long's Peak, I 886, G. W. Lettoman; Mancos, is9s, Bakrr, Earle \& Tracy, $+5$.

New Mexico: Pecos River, 8 miles east of Glorietta, I 897 , A. A. \& E. Gertmuli Holler, 3682 .

Uтан : E. I Iumbolt Mts., i 868 , S. IVatson, 667.

\section{7. Senecio platylobus sp. nov.}

S. aurcus var. croceus D. C. Eaton, King's Exp. 5: I90, in part. i 87 I ; not Gray. I $\$ 63$.

A stout, perfectly glabrous perennial: stem about $4 \mathrm{dm}$. high, rather leafy, striate and somewhat angled: basal leaves $6-10 \mathrm{~cm}$. long, slender-petioled, obovate or broadly oval, sinuately crenatedentate, thin: lower stem leaves oblanceolate, petioled, deeply lobed or divided with rounded lobes: upper stem leaves broadly ovate in outline, sessile, pinnately divided into broadly oblong or cuneate divisions which are more or less deeply sinuate-dentate: cyme compound; its branches corymbiform: heads about $\$ \mathrm{~mm}$. high ; bracts broadly lanceolate, acute, membranous margined and slightly shorter than the disk: rays $6-7 \mathrm{~mm}$. long, and $3 \mathrm{~mm}$. -wide, 5-nerved: achenes striate, glabrous.

Probably nearest related to the preceding, but easily distinguished by the form of the leaves and the broad rays. It grows at an altitude of about I $500 \mathrm{~m}$. [Plate 6, f. S.]

UTAH : Wasatch Mountains, I 869, S. II atson, 6TI (type in the Torrey Herbarium).

\section{S. Senecio flavovirens sp. nov.}

S. Balsamitac Rydberg, Mem. N. Y. Bot. Gard., I : 446, mainly; I 900 ; not Muhl. I 804 .

Light or yellowish green, slender, perennial, in age glabrate or slightly floccose at the base of the leaves: stem 3-4 dm. high, striate, pale : basal leaves $3-8 \mathrm{~cm}$. long, obovate or broadly oval, generally tapering into the petioles, but sometimes truncate at the bases, obtuse, crenate or sinuate, light green : lowerstem leaves ob- 
lanceolate in outline and petioled; the upper lanceolate or linear in outline and sessile; all deeply pinnatifid with narrow, oblong or linear segments: cymes contracted, corymbiform: heads $7-S \mathrm{~mm}$. high ; bracts linear, acute, yellowish-green, and occasionally with brownish tips, a little shorter than the disk; calyculate ones few, linear, small and crisp: rays pale yellow, about $6 \mathrm{~mm}$. long and $1.5 \mathrm{~mm}$. wide, 4 -nerved, or very often lacking : achenes hispidpuberulent on the angles.

Nearest related to the eastern S. Balsamitac, but characterized by its yellowish green color and a more contracted cyme. It grows at an altitude of $2000-3000 \mathrm{~m}$. [Plate 5, f. 4.]

I DAHo: Beaver Cañon, I 895 , Rydberg (type in the herbarium of $\mathrm{N}$. Y. Botanical Garden).

Montana: Deer Lodge, I 895, Rjelbug, 2850 (rayless); Helena, iss7, F. D. Kilscy, 501 .

Wroming: Buffalo Fork, I 897 , Tacedy', j86 ; Laramie Plains, I\$89, E. L. Grecu (rayless); Green River, I\$94, Aien Nilson, Io36 (rayless).

\section{9. Senecio aurellus sp. nov.}

Perennial with a short rootstock, somewhat floccose when young, soon glabrate: stem striate, $4-5 \mathrm{dm}$. high : basal leaves spatulate or cuneate, dentate-serrate, about $5 \mathrm{~cm}$. long, with a short petiole, soon glabrous: lower stem leaves long-petioled, cuneate or spatulate, lyrately lobed, the upper narrowly oblanceolate and subsessile, slightly auricled at the base: cyme compound but with rather few heads, which are about $8 \mathrm{~mm}$. high: bracts I $2-16$, glabrous, yellowish-green, lanceolate, thin ; calyculate ones minute, lanceolate: rays golden-yellow, 5-6 mm. long and $2 \mathrm{~mm}$. wide, 4-nerved: achenes scabrous hispidulous on the angles.

In the form of the stem leaves this most resembles, perhaps, S. rosulatus, but these are thinner and perfectly green, only slightly floccose when young. Otherwise it is intermediate between the eastern S. Balsamitac and S. multilobatus. The type was determined by Professor Greene as "S.psiudaurcus Rydb., not typical." To that species it does not have any close relationship. [Plate 6 , f. 12, г 2а. 7

Colorado: Mancos, isg8, Baker, Earle \& Tracy, 998 (type in the herbarium of New York Botanical Garden). 
20. Senecio nephrophyluts Rydberg, Mem. N. I'. Bot. Garden,

$$
\text { I : } 446 . \quad 1900
$$

Related to the two preceding, but characterized by the rayless heads, the reniform first basal leaves which resemble those of Oryria digyna, and the pinnatifid stem leaves with their oblong blunt segments. The Colorado specimens are much lower than the type, being about $2 \mathrm{dm}$. high. [Plate 6, f. I 5.]

Montana: Big Blackfoot River, $\mathrm{I}_{3}$, Camby, 203.

Colorado: South Park, 1872, T. C. Porter; Middle Park, Hall \& Harbour, 332, in part.

\section{2r. Senecio Idahoensis sp. nov.}

Stout perennial, in age glabrate or slightly floccose at the base of the leaves : stem $4-5 \mathrm{dm}$. high, branched, striate, tinged with purplish: basal leaves obovate, serrate: lower stem leaves oblanceolate in outline, about I dm. long, petioled; the upper ovate or lanceolate in outline, sessile and auricled at the base; all bluish-green, pinnately divided into oblong or oblique-cuneate incised segments : heads numerous, about $\mathrm{I} \mathrm{cm}$. high; bracts about 25 , very narrowly linear, equaling the disk: rays none: achenes striate, glabrous.

A species somewhat related to $S$, aurcus, but characterized by its broad and laciniate leaves, rayless heads and numerous very narrow bracts. [Plate $6, \mathrm{f} .5$.

IDAHO : Granite Station, r892, Samdberg, McDongal \& Heller. So3 (type in the N. I. Botanical Garden herbarium).

22. Sexecio pauciflorus Pursh, Fl. Am. Sept. 529. I 8 i 4

This species, characterized by its few (2-6) rayless heads, linear purple tinged bracts, equaling the disk in length, and its small rounded-oval crenate basal leaves, has been collected several times in Labrador; but exactly similar specimens are in the Torrey herbarium and were collected by Burke in the Rocky Mountains, but the locality is not given. [Plate 5, f. 3.]

\section{Senecio fedifolius sp. nov.}

A delicate glabrous perennial with a very short caudex and a clump of fibrous roots: stem slender, weak, about $1.5 \mathrm{dm}$ high: basal leaves $3-5 \mathrm{~cm}$. long with a slender petiole; blade $\mathrm{I}-2 \mathrm{~cm}$. long, rounded-ovate or broadly oval, wavy or subentire: stem 
leaves mostly small, pinnately divided into short oblong segments: heads 2-3, about $6 \mathrm{~mm}$. high, somewhat turbinate; bracts I $2-15$, broadly lanceolate, conspicuously membraneous margined: rays none: achene glabrous.

The species is named from the resemblance the basal leares have to those of certain species of I'alcrianclla which genus has also been known under the name Fedia. [Plate 5, f. 7.]

Colorado: South Park, is7 I, $I . M$. Canby (type in the herbarium of the College of Pharmacy, New York).

\section{SUBNUDI}

A slender perennial with a long slender horizontal rootstock, perfectly glabrous, sparingly leafy, monocephalous: basal leaves broadly obovate, coarsely crenate-dentate: heads decidedly turbinate with narrow inear-acuminate bracts; calyculate bracts, if present, few, and hatf as long as the main series. A single species.

\section{Senecio subxudus DC. Prod., $7: 428$. I 837} Senecio aurcus vas. subnudus Gray, Syn. Fl. I²: 39I. I 884.

This species has been included as a variety of $S$. anreus, but I think it should be regarded as the type of a distinct group. The long slender horizontal rootstock and the decidedly turbinate involucre is not found in any of the aurcus allies. The latter characters would place it near S. frigidus. [Plate 6, f. 2.]

Washington: Chiquash Mountains, I 892, Suksdorf, 2167: Cascade Mountains, I 882 , Brandegec, II 8 .

Oregon: i 882, T. Howell; i S7, Elihu Hall, 307.

California: Butterfly Valley, is74, Mrs. R. M. Austin.

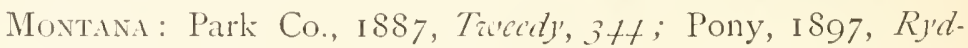
berg \& Bessey, 5270 .

Wroming: Wind River, I 842 , Fremont; Buffalo Fork, I 897 , Tovedy', 587; Yellowstone Park, IS84, Tivecdy, I20.

\section{TOMENTOSI}

Perennials, over $2 \mathrm{dm}$. high, with a short caudex or rootstock, which often is subligneous and cespitose, floccose when young, becoming more glabrate in age, but with some wool always remaining: basal leaves, except the very first ones, from serrate or dentate to pinnatifid: stem leaves always present, but often reduced, generally pinnatifid or pinnately lobed or toothed: heads cymose, small, with few and very small calyculate bracts. 
The group is closely related to the Aurei and Lorati with which it is connected through $S$. Plattensis and S. Findleri respectively. S. Nilsonii and S. multilobus in young state may also be sought here.

Basal leaves mostly dentate or crenate.

Basal leaves suborbicular, ovate or cordate ; margins of the petioles arachnoidtomentose.

25. S. fluvulus.

Basal leaves obovate or spatulate.

Lower stem leaves acute; plant dark green.

26. S. Plattinsis.

Lower stem leaves obtuse; plant yellowish.green.

Basal leaves lanceolate or oblanceolate.

Basal leaves narrowly oblanceolate, serrate.

Basal leaves lanceolate, sinuate-dentate.

27. S. Neo-1Yexicanus.

$2 S$ S. salicinus.

29. S. canovirens.

Some of the basal leaves entire or dentate, the rest pinnatifid or pinnately lobed.

Plant conspicuously rosulate-stoloniferous; stem leaves sinuately round-lobed.

3o. S. rosulatus.

Plant not stoloniferous; stem leaves pinnatifid with toothed lobes.

26. S. Plattensis.

All leaves pinnatifid with toothed segments.

Caudex subligneous; plant tomentose; bracts shorter than the disk.

Caudex not subligneous; plant glabrate.

3I. S. Findleri.

Bracts almost equaling the disk.

Bracts much shorter than the disk.

5. S. Nelsonii.

4. S. multilobus.

\section{Senecio flavulus Greene, Pittonia, 4: io8. I900}

I have seen no specimens of this species, but from the description it must be most nearly related to the next, differing in the more slender habit, the small leaves and their form and the peculiar arachnoid tomentum on the margins of the petioles. The type was collected by C. F. Baker at Aboles, Colo., in I 899.

26. Senecio Plattensis Nutt. Trans. Am. Phil. Soc. II. 7:4 I3.

$$
\text { I } S_{4} \text { I }
$$

This species is exceedingly variable as to the leaf form as well as to the pubescence; usually the basal leaves are merely serrate and obovate or oval in outline, but sometimes some of them are like the lower stem leaves, more or less lyrately pinnatifid. It is conspicuously floccose when young, but in age the leaves beconıe almost glabrous and the wool remaining only on the lower part of the stem and petioles. The species belongs to the region of 1) e plains. [Plate 6, f. I 4 .] 
South Dakota: Brookings, I 897, L. IV. Carter; Hot Springs, I $892, P$. A. Rredborg, $\& 2 \delta$.

Colorado: Fort Collins, i 895, C. S. Crandall.

Indian Territory: Sapulpa, is95, B. F. Biush, I2 +9; False Washita, is68, Edi'. Palmer, f6r.

Kansas: Riley Co., I895, /. B. Norton, 303; Nanhattan, I 887 , II. A. Killeman; Osborn Co., I894, C. L. Sharr, 28; Fort Riley, I892, E. Li. Sayle, 452 .

Nerraska: Lincoln, I887, H. J. Webber; Fort Niobrara, ISS8, T. E. ITilcox: Mrs. Austin; Creete, G. D. Srucescy.

Mıssourı: St. Louis, I $S_{43}$, Richl; McDonald Co., I 89 I, B. F."Bush.

Illinois: Oquawka, I873, H. N. Pattcrson.

27. Senecio Neo-Mexicanus A. Gray, Syn. Fl. I²: 392. I 884

The original publication of this species is generally given as Proc. Amer. Acad. 19: 55 , but no description is there to be found. As far as I can find, the one in the Synoptical Flora is the first published. Probably more than one species is included in that description and in the specimens cited below there are apparently three different types, but it has been impossible for me to find any constant characters by which to distinguish them. In one of them the stem leaves are more or less lyrate-pinnatifid and even the basal ones occasionally have a few lobes on the petiole, while in the others the stem leaves are narrow and merely toothed. The tomentum is sometimes deciduous, sometimes almost persistent. It grows at an altitude of $1200-2500 \mathrm{~m}$. [Plate 6, fig. 7 .]

New Mexico: Silver City, Pinos Altos Mits., isso, E. L. Grecne: between Santa Fe and Canoncito, I 897, A. A. \& E. Girtrude Heller, 3779 ; Organ Mts., I 895, E. O. W'ooton ; P. I'. LcRoy.

Arizona: Fort Huachuca, i S92, T. E. Hilicox; i 876, E. Palmer, 617: Santa Catalina Mts, i 883, C. G. Pringle; San Francisco Mits., I8Si, H. H. Rusby, 2т2; Mogollon Mts., IS87, E. A. Mcarns, 58; Squaw Creek, i 887, E. A. Mcarns, I7I; Santa Rita Mts., iss i, C. G. Pringle.

\section{Senecio salicinus sp. nov.}

A floccose peremnial, with a short cespitose caudex: stems several, about 4 dm. high, simple below, striate and floccose: basal 
leaves 5-10 cm. long, narrowly oblanceolate, the first ones subentire, but most of them serrate except at the tapering base, fincly tomentose on both sides, but in age more glabrate above : stem leaves small, linear, sessile, dentate, slightly auricled at the base: cyme compound: the heads subumbellate at the ends of the branches, 7-8 $\mathrm{mm}$. high, slightly floccose at the base: bracts yellowish, thin, lanceolate, shorter than the disk: rays light yellow, short and broad, $3-4 \mathrm{~mm}$. long and $2 \mathrm{~mm}$. wide: achenes striate, glabrous.

A species related to $S$. Fendleri, but characterized by the narrow, merely serrate basal leaves, the small subumbellate heads in a short, flat-topped inflorescence with widely spreading ultimate branches. It grows in the foothills at an altitude of about I $800 \mathrm{~m}$. [Plate 6, f. 6.]

Colorado: J. Laramie Co., I895, J. H. Coricn (type in the herbarium of N. I. Botanical Garden).

\section{Senecio canovirens sp. nov.}

Stout perennial with a short erect rootstock, dark green, floccose with more or less deciduous wool : stem $4-5$ dm. high, loosely floccose: basal leaves 5-I $2 \mathrm{~cm}$. long, short-petioled; blades lanceolate or oblanceolate, sinuately toothed, dark green, firmly floccose, in age almost glabrate above: lower stem leaves similar; upper ones linear, sinuately dentate with rather acute teeth : cyme with erect or ascending branches: heads $7-S \mathrm{~mm}$. high, turbinate campanulate; bracts I2-I4, oblong, linear, floccose at the base and more or less villose, acute, brownish on the back and with yellowish margins: rays $5-6 \mathrm{~mm}$. long and $2 \mathrm{~mm}$. wide, at first orange, in age paler, +-nerved: achenes glabrous, striate.

The type was determined by Prof. Greene as Sencio Findlori, but it is very unlike the typical form of the aggregate that has been known under that name. The dark green color, the leaves which are merely toothed, never pinnatifid and still less bipinnatifid as they often are in S. Fendlori easily distinguish it from that species. The perennial caudex and rootstock are similar to that of S. FendIcri but less thick and less woody and, as far as seen from the specimens, not branched. It grows at an altitude of about 2000 m. [Plate 6, f. 9.]

New Mexico: White Mountains, I897, E. O. Wooton, 2tt (type in the herbarium of N. Y. Botanical Garden); Organ Mountains, 793 .

Colorado: Pike's Peak, I 895, Mrs. S. L. Clarke. 
Senecio iutabilis Greene, Pittonia, 4: I I 3 . I900

As I have seen no specimens of this species I have not been able to include it in my key. It may be the same as the preceding, but several characters given in the description do not agree with it, especially the deeply tridentate rays. Professor Greene is always criticizing other botanists for drawing vagure descriptions. No better example of just such a description can be given than the one here made by himself.

\section{Senecio rosulatus sp. nov.}

Sencio aurcus var. Balsamitac A. Gray, Proc. Acad. Nat. Sci. Pliila. I863: 68, in part.

More or less tomentose perennial, with a branched rootstock and generally numerous underground stolons producing leafy offsets : stems $2-3 \mathrm{~cm}$. high, floccose or sometimes becoming almost glabrate in age; first leaves of the offsets spatulate and entire; other basal leaves and lower stem leaves oblanceolate, finely white tomentose especially on the lower surface, occasionally becoming more glabrate in age, sinuately pinnatifid with rounded lobes, petioled : upper stem leaves lanceolate or linear, sessile, auricled at the base also with rounded lobes: cyme corymbiform, open: heads small, 5-6 mm. high, floccose at the base: bracts about I 2, broadly lanceolate, acute, vellowish with rather broad membranous margins, much shorter than the disk : rays about $5 \mathrm{~mm}$. long and $2 \mathrm{~mm}$. wide, 4-5-nerved: achenes strongly striate, glabrous.

The species has been confused with S. Fondlori, but is distinguished by the more slender rootstock and the numerous branches forming offsets, the entire first leaves not seen in that species and the short rounded entire lobes of the stem leaves. The heads are usually also smaller. It grows at an altitude of $2500-4000 \mathrm{~m}$. [Plate 6, f. 4, 4a.]

Colorado: Georgetown, Is85, 2. H. Pattirson 79 (type); Golden City, I \$92, E. L. Gricnc; is62, Heall \& Harbour; 333 , in part; IS7 I, $I$. $H$. Canby'; Twin Lakes, I $873, J$. M. Coultor; Pike's Peak, I884, G. IV. Lettrman, 260; Caribou, IS91, E. Pcnard, 228; Fort Collins, I896, C. F. Bakcr; Silver Plume, Gray's Peak, and Georgetown, is95, I. A. Rydberg.

3 I. Serecio Fexdleri Gray, Mem. Am. Acad. II, 4: IOS. I 849

The typical S. Fendleri is a rather rare plant with a decidedly woody rootstock and caudex. None of the specimens seen show 
any sign of entire leaves nor of subterranean stolons. The leaves are often bipinnatifid or pinnatifid with oblong toothed, and acutish segments. See also the remarks given under S. Nclsonii. [Plate 6, f. 3.]

New Mexico: Santa Fe Cañon, i 897, A. A. \& E. Gortrude Hiller, $377+$.

Colorado: i 873 , Brandegce, $5 \neq 6$.

UтAн : Salt Lake City, I 869, S. Watson.

\section{Explanation of Plates}

Unless otherwise stated, the drawings represent basal leaf, stem leaf selected a little above the middle of the stem and the head of each species. The leaves are reduced to one half and the heads are of natural size.

Plate 5

1. S. cymbalarioides Nutt.

2. S. acutidens Rydb.

3. S. panciflorus Pursh.

4. S. flavovirens Rydb.

5. S. Jonesii Rydb.

6. S. subcuneatus Rydb.

7. S. fedifolius Rydb.

S. S. Greggii Rydb.

1. S. Nelsonii Rydb.

2. S. subnudus DC.

3. S. Fendleri A. Gray.

4. S. rosulatus $\mathrm{Rydb}$.

4a. An offset of the same.

5. S. Iduhoensis Rydb.

6. S. salicinus Rydb.

7. S. Neo-Aexicanus A. Gray.

S. S. platylobus Rydb.

9. S. canovirens Rydb.
9. S. oblanceolatus Rydb.

IO. S. psendaurezs Rydb.

II. S. millelobatus Rydb.

12: S. tridenticulatus Rydb.

13. S. crocatus Rydb.

I4. S. sanguisoiboides Rydb.

I5. S. compactus (A. Gray) Rydb.

\section{Plate 6}

IO. S. longipetiolatus Rydb. (from type).

IOa. Basal leaf from Baker, Earle \&o Tracy, 625 .

II. S. multilobatus Torr. \& Gray.

12. S. aurcllus Rydb.

I $2 a$. Lower stem leaf of the same.

13. S. fulgens Rydb.

14. S. Plattensis Nutt.

15. S. nephrophyllus Rydb. 



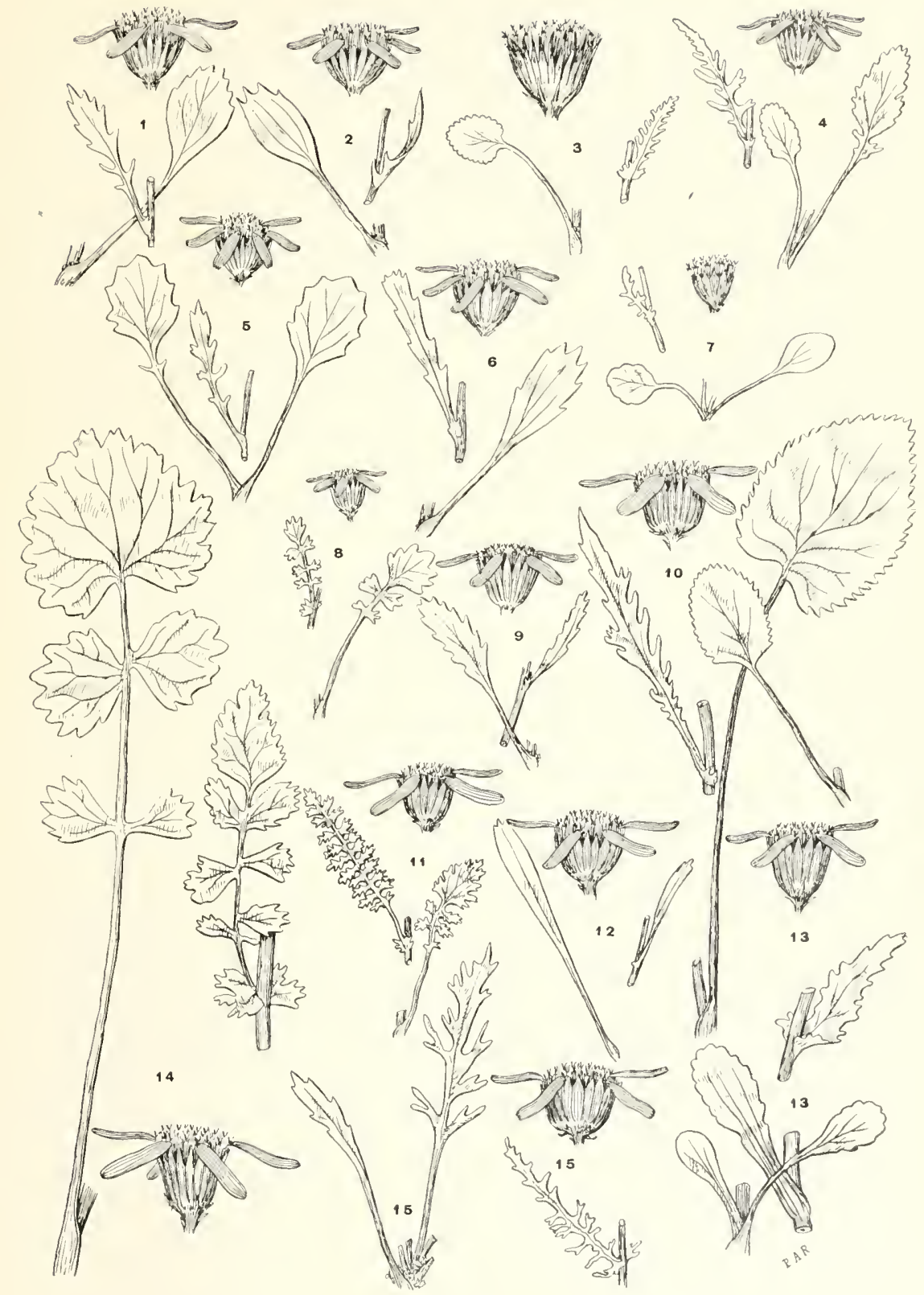

RYDIEKG (IN SENECIO 



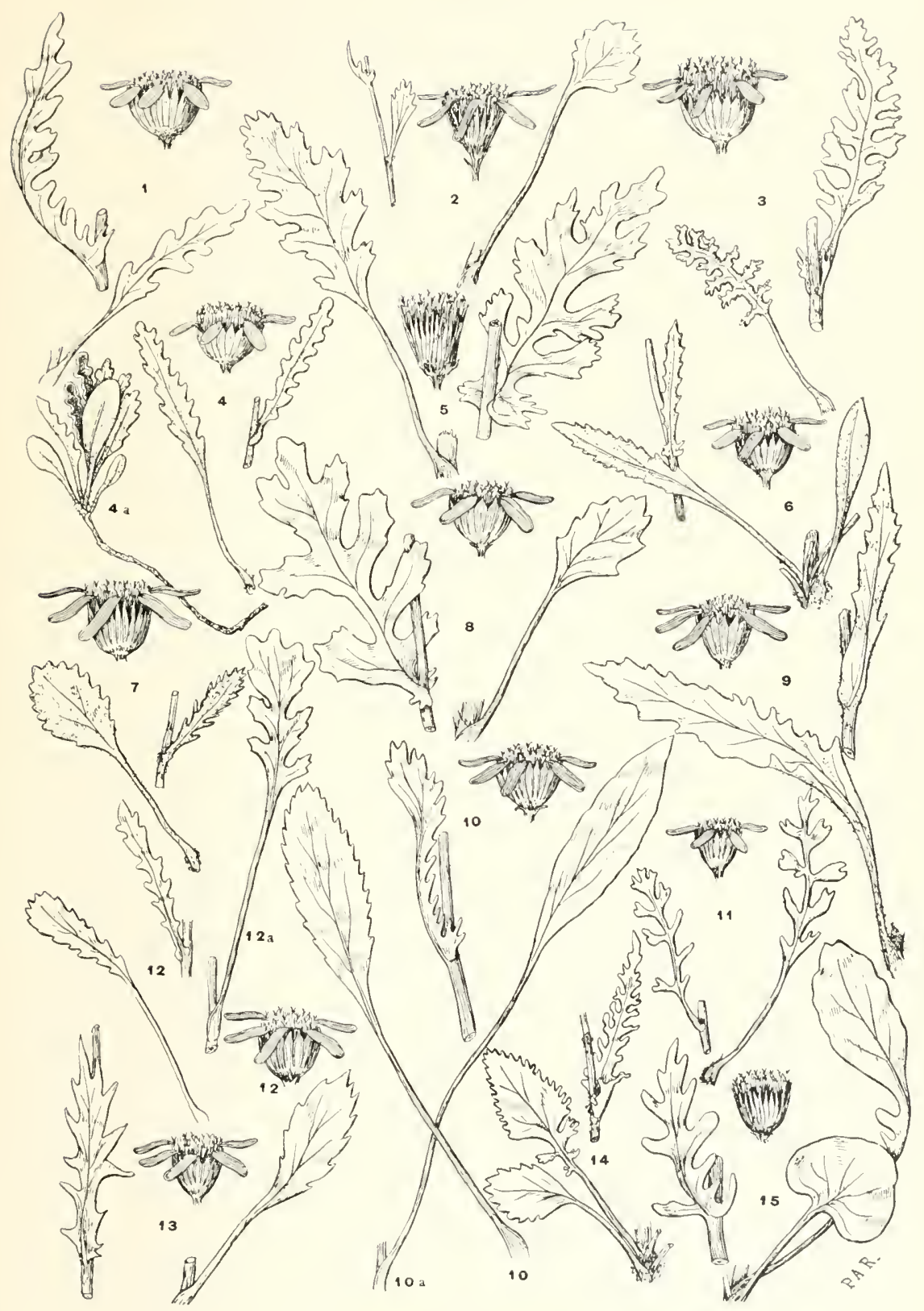

KIDBERG ON SENECIO. 

CONTRIBUTIONS FROM THE NEIV YORK BOTANICAL

- GARDEN-

No. 9

\title{
STUDIES ON THE ROCKY MOUNTAIN
}

\author{
FLORA-II
}

BY P. A. RYDBERG

NEW YORK

1900

[Reprinted from the BUl.LETiN OF ThE TORREy BOTANical ClUB, 27 : 528-535. 26 Oct., 1900. 



\title{
Studies on the Rocky Mountain Flora-II
}

\author{
BY P. A. RYTBERG
}

THE ROCKY MOUNTAIN SPECIES OF MELANTHACEAE

There has been a great deal of misunderstanding regarding the species belonging to the family Melanthaceae (perhaps more commonly regarded as a sub-family of Liliaceae). Especially is this true with respect to the species growing in the Rocky Mountain region. In order that some of the confusion may be cleared up and a way may be opened to further study of the group my present views are here offered.

The family is represented in the Rockies by at least five genera and seventeen species. Of these I have found myself obliged to describe one genus and seven species as new. The genera are as follows :

\section{TOFIELDIA Huds.}

This is represented by three species, distinguished as follows: Stem glabrous, scapose ; seeds unappendaged.

Stem viscid-pubescent at least above; seeds appendaged.

T. palustris.

Bractlets broadly triangular, connate for two thirds of their length.

T. intermedia.

Bractlets lanceolate-triangular, connate half their length or less. T. occidentalis.

Tofieldia palustris Huds. Fl. Ang. Ed. 2, r : i 75

A subalpine species of wet places, growing in America from Greenland to Alaska and from the Arctic coast south to Quebec and British Columbia. It is also found in subarctic Europe. The following specimen from the Rockies is in the New York Herbaria :

British Columbia: Rocky Mountains, is9o, John Macoun.

\section{Tofieldia intermedia sp. nov.}

Tofieldia glutinosa Hook. Fl. Bor. Am. 2 : I 79, in part. ${ }_{13} 8$. Wats. Bot. Calif. 2: 184. Not Pursh.

A slender perennial with more or less leafy stem, I.5-3 dm. high, viscid-pubescent above. Leaves 5-20 cm. long, 2-5 $\mathrm{mm}$. wide, obtuse or acute: raceme short, dense, $1-2 \mathrm{~cm}$. long: bracts 
broad, ovate: pedicels usually 3 together, rery short, in fruit $1-4$ $\mathrm{mm}$. long: bractlets under the flowers 3 , broadly triangular, connate for about two thirds their length: flowers yellow: sepals obovate, $4-5 \mathrm{~mm}$. long: petals somewhat narrower and longer: capsule ovoid, about $5 \mathrm{~mm}$. long : beaks about $\mathrm{I} \mathrm{mm}$. long, spreading : seeds appendaged.

This has been confused with the eastern $T$. glutinosa Pers. which has an elongated raceme, longer pedicels, and oblong subequal sepals and petals, about $4 \mathrm{~mm}$. long. All specimens from the west referred to $T$. glutinosa may belong to $T$. intumadia. At least all that I have seen do so. T. intirncdia grows in bogs to an altitude of 2,700 m. from Saskatchewan to Alaska, British Columbia and Wyoming. The following specimens belong to it:

Alaska : Sheh-Shooh Lake, i $895, \ldots . W^{\prime}$. Gorman, 78 (type); Yes Bay, is95, Thos. Howell, I666; Khantaak Island, i892, F. Funston, 77 ; Sitka, Bongard.

British Columbia: Summit of Selkirk Mountains, is9o, John Macoun.

Washingtox: Totoish Mountains, I 897, O. D. Allcn 274.(?)

Montana: Flathead River, I892, R. S. Milliams, 9I5; Granite, I 892, Kelsey'; Upper Marias Pass, I $88_{3}$, Canby, 328 .

Wyoung: Cement Creek, $1897, F$. Tiucedy, 336.

Tofieldia occidentalis Wats. Proc. Am. Acad. I4: 283. i 879

This species is distinguished from the preceding by the narrower, less connate bractlets, longer pedicels, narrower sepals, larger capsule, $8 \mathrm{~mm}$. long, and longer ascending beaks. The following specimen from the Rocky Mountain region is in the New York Herbaria.

British Colunbia: Avalanche Mountain, is9o, J. M. Macoun.

\section{XEROPHYLLUM}

This genus is represented by two species:

Petals and sepals $7-10 \mathrm{~mm}$. long.

X. tenax.

Petals and sepals $4-6 \mathrm{~mm}$. long.

X. Douglasii.

Xerophyllum texax (Pursh) Nutt. Gen. Am. i : 235. i i 8 Hilonias tenax Pursh Fl. Am. Sept. 243. I 8 I4.

X. Douglasii Rydb. Mem. N. I. Bot. Gard. I : 92 ; not Wats. 
This has been greatly confused with the following. Watson stated that X. Douglasii was collected on the Hayden Surveys of the Yellowstone Park, but does not cite any locality in the Rocky Nountains for $X$. tcnar. Coulter in his Manual of the Rocky Mountain Region included consequently a description of the former, but none of the latter. As this book is the one most used by Rocky Mountain botanists, all specimens of Aerophyllum from that region have therefore been labeled .I. Douglasii. I made the same mistake in preparing my Catalogue of the Flora of Montana. All the specimens cited there belong to $X$. tena $x$ instead of $Y$. Douglasii. Besides the Montana specimens there cited, the following Rocky Mountain specimens belong to this species:

British Columbia: Toad Mountain, Kootenay Lake, i 890 J. M. Macoun.

Idaho: Kootenay Co., isss, J. H. Semuders; Viessner's Peak, I S92, Sandberg, MacDougal \& Holler, js\&.

Xerophyllui Docglasil Wats. Proc. Am. Acad. I4: 284. I 879 .

I have not seen any Rocky Mountain specimen of this species, but include it on the authority of Dr. VTatson who referred to it the specimens from the Hayden Collection metioned above.

\section{Stenanthella gen, nov.}

Erect bulbous glabrous herbs with few narrow leaves and racemose or paniculate perfect greenish, brownish or purplish flowers. Petals and sepals each 3 , subequal, withering-persistent, narrowly lanceolate, acuminate, with reflexed tips, and at last involute, without gland and distinct claw. Stamens 6, free, included; anthers reniform, confluently I-celled. Ovary ovoid, superior; styles 3. Capsule lance-ovoid, 3-beaked, septicidal to the base, wholly superior. Seeds oblong, winged.

Dr. Gray included the species belonging here in Stcumthinm, but the genus is better defined than many of the recognized genera in the family. In Stcnanthium, the flowers are polygamous, open, notcampanulate in outline, the base of the ovary is inferior, the tip of the petals and sepals not reflexed and the general habit different. The genus Stcnanthella contains two known species, one from the island Sachalin, S. Sachalinensis (Stenanthium Sachalinense F. Schmidt), and the following: 
Stenanthella occidentalis (A. Gray) Rydb. n. n.

Stenanthinm occidentale A. Gray, Proc. Am. Acad. 8:405.

The species ranges from Alberta and British Columbia to Oregon and Idaho. The following specimens are from the Rockies:

Montana: Deer Lodge, I892, Miss Emma IVare; Flathead River, 1883 , Canly', 332 ; Big Blackfoot, Canby'; divide between Hell Gate and Blackfoot, I8So, II ittson; Columbia Falls, I 894, R. S. Williams.

Alberta And British Columbia: Rocky Mountains, i 858 , E. Trourgean; Kicking Horse Lake, i 887, Jolnn Macoun.

Idaho: Kootenay Co., I 890, J. B. Leiburg, 7912.

\section{VERATRUM L.}

Flowers greenish, bractlets foliaceous, often equaling or exceeding the flowers.

$$
\text { T. viride. }
$$

Flowers white or yellowish white; bractlets membranous, much shorter than the pedicels and flowers.

I. speciosum.

Veratrem tiride Ait. Hort. Kew. 3: 422. I 789

I. lobclianum $\beta$ Eschscholtwianum R. \& S. Syst. 7: I 555 . I 829.

I'. Eschscholtiai Gray, Ann. Lyc. N. I. 4: I I $9 . \quad$ I 837.

If the westem plant should be included in $I$. irivie or not, is doubtful. The eastern plant extends west to Minnesota and the western is found first on the Pacific slope in Idaho and British Columbia. Both are very variable and no good character has been found to separate the two. As a rule the western plant has shorter stamens and bracts; the former scarcely half as long as the petals and sepals. The western range of $I^{\prime}$. eiride or $I$. Eschscholtwiamm whatever name it should bear, is from southern Alaska to Oregon and Idaho. The following are the only specimens seen from the Rockies.

IDAHo: Packsaddle Peak, I 892, Sandberg, MacDongal \& Hiller, $86_{3}$.

\section{Veratrum speciosum sp. nov.}

Ieratrum Californicum Wats. Proc. Am. Acad. 14: 277; in part. I879. Not Durand.

A stout, more or less pubescent, very leafy plant, $\mathrm{I}-3 \mathrm{~m}$. high. Leaves, except the uppermost, broadly oval, 2-3 dm. long, I-2 
dm. wide, obtuse or acute, glabrous above, finely soft-pubescent beneath, sessile and sheathing: panicle many-flowered with ascending branches: bracts lanceolate, foliaceous : bractlets membranous, yellowish, ovate, acuminate, shorter than the flowers and pedicels : petals and sepals yellowish white, oval or broadly oblanceolate, mostly obtuse, 5-7-nerved, $8-10 \mathrm{~mm}$. long, $4-5 \mathrm{~mm}$. wide: capsule oblong, about $3 \mathrm{~cm}$. long and $\mathrm{I} 2 \mathrm{~mm}$. in diameter: seeds oblong, $7-8 \mathrm{~mm}$. long with a wide white wing-margin.

In looking over the specimens of $I$. Califormicum in the Columbia Herbarium I found one specimen collected in Oregon on the Wilkes' Expedition, which looked very unlike the rest, having a narrower and denser panicle and narrower and more acutish petals and sepals. I took it out and placed it in the corer used for the specimens not named. I found in that cover a similar specimen. On the label was giren neither locality nor the collector's name; but on the sheet was pasted a paper with a tracing of the basal leaves, the description of $I$. Californicum E. Durand and some remarks, among others the words "petiole $3-4$ inches long." The specimens are presumably a part of the type of $I$. Californicum or at least have been compared with Durand's specimens and the notes made by Durand himself. Durand in his description expressively states that the lower stem-leaves are petioled. As this is never the case in the plant of the northern Rockies and the Columbia Valley, I an certain that the plant generally regarded as $I$. Californicum and from which Dr. Watson's description in his revision was mainly drawn is perfectly distinct from Durand's plant. The latter is a rare plant judging from the fact that I have not seen more than the two specimens mentioned above.

$T$. spiciosum ranges from Montana to Washington, California and Colorado, reaching a maximum altitude of 2,500 $\mathrm{m}$.

Montaxd: Bridger Mountains, I $\$ 96$, Flotman, ift (type); Little Belt Mountains, $3+t^{1} / 2$; Bozeman, P. Koch; Deer Lodge Co., Enme IVare; Belt Park, I $886, R$. S. Williams, 475 ; Belt Creek, ISs3, Siribner, $2 S_{7}$; Lo-Lo Creek, isso, Watson.

IDAHO: Lake Pend d'Oreille, IS92, Sandberg, HacDougal \& Heller, $7 \neq I$; Kootenay Co., IS86, J. H. Sandberg; Lake Waha, I $896, A$. A. \& E. Gertrude Heller, 3380; i \$92, Isabel Ahulford.

UTAн : Heber Valley, is69, S. Watson, I I65; American Fork Cañon, i $880, M$. E. Jones. 
Washington: isS9, G. R. I'ascy.

Oregon: J. S. Ncabemy.

Califorxia: Modoc Co., i 893, M. S. Baker; i $865, H . N$. Bolander, 6255; Mt. Shasta, I897, H. E. Brow'll.

Colorado: Pagosa Peak, is99, C. F. Bakcr, $258(?)$. (This has smaller flowers, petals and sepals being only $6-8 \mathrm{~mm}$. long.)

\section{ZYGADENUS Michx.}

Much confusion has existed in this genus. The species of Colorado, Wyoming and Montana have been variously named $Z$. $\checkmark$ Tuttallii, $Z$. venenosus and more rarely $Z$. paniculatus, but much complaint has been made that they do not fit Watson's descriptions. Some have complained that those descriptions have been too narrow, others that there is no line to be drawn between $Z$. acnenosus and $Z$. paniculatus and that both those species come tonear Z. Nuttallii. Dr. Watson's descriptions of Z. v'cnenosus and Z. paniculatus are unusually good and correct. He knew them both from the field. The common Rocky Mountain plants belong to neither. Z. acnonosus does not grow east of Idaho and $Z$. paniculatus not east of Utah, while Z. Nuttallii is a species of the plains and I doubt that it is found at all in the Rocky Mountain States. The Rocky Mountain species are distinguished as follows:

Gland obcordate; base of ovary inferior.

Petals and sepals 7-S mm. long, 7-1 3-nerved.

Z. elegans.

Petals and sepals 5-6 mm. long, 3-7-nerved.

Z. Coloradinsis.

Gland obovate or semi-orbicular; ovary wholly superior.

Petals and sepals more or less clawed; filaments adnate to the base of the claws.

Petals and sepals rounded or obtuse at the apex.

Upper leaves without sheaths at the base; both petals and sepals longclawed and sub-cordate at the base*; gland with a thick margin.

\section{Z. a'enenosus.}

All leaves with distinct sheaths; petals long-clawed and sub-cordate at the base; sepals short-clawed; margin of the gland ill-defined.

Petals and sepals $4-5 \mathrm{~mm}$. long; petals ovate; leaves $3-5 \mathrm{~mm}$. wide.

Z. gramineus.

Petals and sepals $6-\delta \mathrm{mm}$. long; petals oblong; leaves 5-9 $\mathrm{mm}$. wide.

Z. intermedius.

Petals and sepals acute or acuminate at the apex; all leaves with sheaths; sepals cuneate at the base and short-clawed.

Leaves less than $5 \mathrm{~mm}$. wide; petals and sepals both cuneate at the base and short-clawed.

Z. acutus. 
Leaves orer $5 \mathrm{~mm}$. wide.

Raceme simple; petals long-clawed and sub-cordate at the base.

Z. falcatum.

Raceme branched; petals short-clawed, not sub-cordate at the base.

Z. paniculatum.

Petals and sepals clawless; gland obovate with a poorly defined margin; filaments free.

Z. Nuttallii.

Zrgadexus elegins Pursh, Fl. Am. Sept. I : 24 I. I 8 i 4

The typical Z. clegans is a western plant, mainly belonging to the Rocky Mountain region, where it grows in meadows up to an altitude of $2500 \mathrm{~m}$. If the eastern plant or Z. glaucus of Nuttall, should be included in this species, is very doubtful. It is always darker green, more glaucous, inflorescence more paniculately branched, the petals and sepals narrower and more greenish. It ranges from New Brunswick to Minnesota and south to Vermont. The range of Z. clegrans proper is from Saskatchewan to Alaska, south to Colorado and Nevada.

\section{Zygadenus Coloradensis sp. nor.}

A rather slender glabrous plant, 2-4 dm. high. Bulb ovoid, about $2 \mathrm{~cm}$. long and $\mathrm{I}-\mathrm{I} .5 \mathrm{~cm}$. in diameter: leaves narrow, erect, about $2 \mathrm{dm}$. long, $3-5 \mathrm{~mm}$. wide: flowers racemose, yellowish white-tinged with brownish or purplish: bracts linearlanceolate, all equaling or exceeding the pedicels: petals and sepals 5-6 mm. long, 3-7-nerved, oblong or narrowly obovate, acute: capsule ovoid, I $5-18 \mathrm{~mm}$. long and $7-8 \mathrm{~mm}$. in diameter.

$Z$. Coloradensis is closely allied to $Z$. clegans, differing in the smaller flowers, greener foliage, long and narrow bracts equaling or exceeding the pedicels and a brownish or purplish tint of the inflorescence, bracts and flowers. It grows in the mountains at an altitude of $2500-3500 \mathrm{~m}$.

Colorado: Idaho Springs, I 995 , Rydberg (type); Leroux Creek, I892, J. H. Coa'en; La Plata, 1873, Coulter; Caribou, is9i, Dr. E. Penard; Empire, is92, H. N. Pexttcrson, 298.

Zygadenus venexosus IVats. Proc. Am. Acad. I4: 279. I 879

This species is characterized by its narrow leaves, of which the upper lack the scarious sheaths, and by the thick, prominent

* When the petals or sepals are sub-cordate at the base and long-clawed the gland is at the very base but when they are acute at the base the gland is a little higher up on the blade. 
glands. It is more slender and strict than all the species except Z. acutus, which is easily distinguished by its acute sepals and petals. Z. vcncnosus grows mostly on hillsides at low altitudes, scarcely ascending higher than $2000 \mathrm{~m}$. It ranges from Idaho and British Columbia to California and Utah. The following Rocky Mountain specimens belong here:

UтAн: Parley's Peak, i 869, S. Watson, i i63.

In৯но: Keẹley's Hot Springs, i 892, Isabd Mulford; Big Potlash River, I 892, Sandberg, MacDougal \& Heller, 3I9; Little Potlash River, fof.

\section{Zygadenus gramineus sp. nov.}

Zygadenus a'nenosus Rydb. Cont. U. Dep. Ag. 3: 525 . I 896. Mem. N. Y. Bot. Gard. I : 93 in part. Not S. Wats.

A slender yellowish-green plant, 2-3.5 dm. high. Bulb elongated ovoid, $2-3 \mathrm{~cm}$. long and $\mathrm{I}-\mathrm{I} .5 \mathrm{~cm}$. in diameter: leaves narrowly linear, scabrous on the margins and the midrib, I-2 dm. long, 3-5 $\mathrm{mm}$. wide, conduplicate and somewhat falcate, all with distinct scarious sheaths surrounding the stem: racemes rather short: bracts scarious, lanceolate, long-acuminate: flowers light yellow : sepals broadly ovate, obtuse at the apex, acute at the base and very short-clawed: petals ovate, obtuse, subcordate at the base and with claws about $\mathrm{I} \mathrm{mm}$. long: glands almost semi-orbicular; upper margin toothed, but thin and not well defined: capsule elongated ovoid, $S-10 \mathrm{~mm}$. long, $3-4 \mathrm{~mm}$. in diameter.

Z. gramineus resembles somewhat the preceding, but is lower, of a yellowish color; its stem leaves are evidently sheathed, the sepals are short clawed, not subcordate at the base and the gland thin and without a distinctly thickened upper border. Z. gramincus grows on hillsides up to an altitude of $2500 \mathrm{~m}$.; from Saskatchewan and Alberta, south to western Nebraska and Idaho.

Montana: Spanish Basin, I 897, Rydberg \& Bessy', $38+9$ (type); i 896, Flodman, 373; Helena, i 891, F. D. Kclscy.

I dAно: Beaver Cañon, i 995, Rydberg.

South Dakota: Hot Springs, 1892, Rydberg, I05I.

Wroming: Yellowstone Park, isss, Dr. Chas. H. Hall. Saskatchewan: is 58 , E. Bourgcau.

Zygadenus intermedius sp. nov.

Zygadenus acnenosus Rydberg, Mem. N. Y. Bot. Gard. I : 93 in part. I900. Not Nutt: 
A rather stout light green plant, 3-6 dm. high. Bulb elongated ovoid, about $3 \mathrm{~cm}$. long and $1.5 \mathrm{~cm}$. in diameter: leaves scabrous on the midrib and margins, $2 \mathrm{dm}$. or more long, 5-9 mm. wide, keeled and sometimes conduplicate; all with conspicuous scarious sheaths at the base: raceme rather long: flowers light yellow; petal and sepals $6-8 \mathrm{~mm}$. long, obtuse; the former broadly ovate, and acute or rounded at the base and shortclawed; the latter oblong subcordate at the base and with a claw I $\mathrm{mm}$. long: glands as in the preceding.

Like the preceding but taller and stouter, in habit resembling mostly Z. paniculatus, except that the inflorescence is seldom branched. It is easily distinguished from that species by the obtuse petals and sepals and by the distinct claws and the subcordate bases of the petals. It grows on dry hillsides up to an altitude of $2000 \mathrm{~m}$. in Montana, Idaho, Wyoming and Utah.

Idaho: Nez Perces Co., I892, J. H. Samalbers, I0 567 (type); Peter Creek, I892, Sandberg, MacDougal \& Heller, IIt; Lewiston, i 896, A. A. \& E. Gertinde Heller, 3093.

Utah: Farmington, is81, Mr. E. Jonts, 2091.

Wroming: Laramie Hills, I 894, Are'n Litson, 25 .

Montana: Deer Lodge, i 895, F. N. Notestein: Bridger Mountains, I 897, Rydberg \& Bessey', $3 S_{49}$.

\section{Zygadenus acutus sp. nov.}

A very slender light green plant, 3-5 dm. high. Bulb rounded ovate, $1.5-2 \mathrm{~cm}$. long, $1-1.5 \mathrm{~cm}$. in diameter: leaves narrowly linear, scabrous on the margin, about $2 \mathrm{dm}$. long and $4-5 \mathrm{~mm}$. wide, keeled and often conduplicate: flowers pale yellow: petals and sepals $4-5 \mathrm{~mm}$. long; both acute at the apex and at the base, very short-clawed: glands obovate or cuneate; upper margin toothed, thin and not well defined.

In habit closely resembling $Z$. ancuosus, but easily distinguished by the acute, short-clawed petals and sepals, which are both cuneate at the base. The only specimens seen are the following :

South Dakota: Box Elder Creek, Black Hills, i $887, I V . S$. Rusby.

Zygadenus falcatus sp. nov.

Z. Vuttallii Porter \& Coult. Syn. F1. Colo. I33. In part. I 874. Not A. Gray. 
A rather stout light green plant $3-4 \mathrm{dm}$. high. Bulbs rounded ovoid, $3-4 \mathrm{~cm}$. long and about $3 \mathrm{~cm}$. in diameter: leaves scabrous, especially on the margins and midribs, $1.5-2.5 \mathrm{dm}$. long, 5-8 $\mathrm{mm}$. wide, keeled, conduplicate, and generally decidedly falcate, all with scarious sheaths: raceme short, in fruit elongated: flowers yellow: petals and sepals about $5 \mathrm{~mm}$. long, acute; the former deltoid ovate, acute at the base; the latter ovate, sub-cordate at the base and with claws I mm. long: glands semi-orbicular, upper margin toothed, thin and not well defined : capsule ovoid cylindrical.

All the specimens cited below have been named $Z$. Nuttallii though the plant is more closely related to $Z$. paniculatus, from which it differs in the distinctly clawed petals which are subcordate at the base. These characters, together with the more distinct glands and the slightly adnate filaments, distinguish it from $Z$. Nuttallii. 2. falcatus inhabits the foothills of Colorado at an altitude of about i $500 \mathrm{~m}$.

Colorado: Fort Collins, i 893, C. S. Crandall (type); I 896. C. F. Baker; Denver, I873, J. M. Coulter.

Zygadenus Paniculatus (Nutt.) Wats. Bot. King's Exp. 5: 343, is 7 I

Helonias paniculata Nutt. Journ. Phila. Acad. $7: 57$. I 834 .

It is well characterized by IVatson and easily distinguished by its stout habit, generally branched inflorescence, and rhombicovate acute and almost clawless petals and sepals. It grows on hills up to an altitude of $1500 \mathrm{~m}$., ranging from Montana and Washington to New Mexico and California. The following Rocky Mountain specimens belong here:

Utali : Ogden, Capt. Stansbury; City Creek Cañon, i 88o, M. E. Jones, $167+$.

IDaho: Boise, i 892, Isabcl Mulford.

Montaxi: Grasshopper Valley, I880, Watson (?).

Zygadenus Nuttalli A. Gray, in Wats. Proc. Am. Acad. I4: 279 . I 879

Amianthium - Vutterllii Gray, Ann. Lyc. N. Y. 4: 123.

This is evidently a species belonging to the plains. All the specimens in the Columbia and N. Y. Botanical Garden herbaria are from Arkansas and Kansas. Dr. WVatson included Texas and 
Rydberg: Studies on Rocky Mountain Flora 538

Colorado in the range. The Texan plant referred here by him, belongs to an altogether different plant. I think that Colorado also should be excluded, believing that all specimens found there and labeled $Z$. Nuttallii belong to $Z$. falcatus, which resembles it most in general habit, but has an altogether different flower. 

CONTRIBUTIONS FROM THE NEW YORK BO'TANICAL GARDEN-No. 10

\section{STUDIES ON THE ROCKY MOUNTAIN FLORA-III}

BY P. A. RYDBERG

NEW YORK

1900

[Reprinted from the BuLletin of THE TORREY BotanicaL CLUB, 27 : 614-636. 29 Dec., 1900.] 



\title{
Studies on the Rocky Mountain Flora,-III
}

\author{
By P. A. RydberG
}

\section{SOME SMALLER GENERA OF COMPOSITES}

\section{STENOTUS Nutt.}

This genus was established by Nuttall in I 840 . It was retained as a genus by Torrey and Gray in their Flora, but merged with several others into Aplopappus by Gray in his Synoptical Flora. A few years ago (IS94), Professor Greene reëstablished the genus, removing from it, however, a member erroneously placed in the genus by Torrey and Gray, viz., Stinotus prymacus Torrey and Gray (Aplopappus pygmacus Gray), which he referred to MTacronema.* If such a transfer was the very best is questionable, for that species is as much a stranger in M/acroncma as it is in Stcnotus. It has the outer bracts foliaceous and the style-appendages long and attenuated which are characters found in Macroncma; but the habit is very unlike Macroncma and the outer foliaceous bracts are numerous as in Pyrrocoma. I had some transient thouglit of transferring it to that genus; but the purely white pappus, the densely cespitose habit, and the lack of the thick taproot, debar it from Pyrocoma. These characters ally it to Solidago: but the difference in structure of the outer and the inner bracts makes it unnatural to place it there as well. It is very hard to decide which would be the best course to take, either to place it as an anomalous member of one of these genera or to make it the type of a new genus. Perhaps some other and better relationship may be found.

Of the other species included in Aplopappus $\$$ Stexotus by Gray, A. Parryi is, I think, rightly referred to Solidago. A. Lyallii was altogether omitted by Professor Greene, when he made the segregation in Pittonia. He may have overlooked this, but it is more probable that he omitted it, because he did not know where to place it. The relationship is without any doubt closest with Solidago, notwithstanding the solitary head.

* In a recent distribution of plants from Colorado delermined by Professor Greene, this was distributed under its original name Stcnotus pygmaeus. 
By removing Stenotus lincarifolins Torr. \& Gray and S. interior Greene, which constitute a good genus, the genus Stcnotus becomes a very natural one, with only one somewhat aberrant member, S. lanuginosus which approaches Prrrocoma innloides and its relatives in habit.

The Rocky Mountain species are distinguished as follows:

Plant glabrous or puberulent; leaves firm and evergreen.

Leaves linear to filiform.

I. S. stenophyllus.

Leaves mostly oblanceolate.

Bracts lanceulate, acute.

I'lant puberulent.

Bracts in 3 series, broad, with broad scarious margins.

2. S. acaulis.

Bracts in 2 series, narrow, with narrow scarious margins.

3. S. Andersonii.

Plant glabrous.

Stem-leaves oblanceolate, $1-2 \mathrm{~cm}$. long. 4. S. caespitosus.

Stem-leaves linear, $4-7 \mathrm{~cm}$. long. 5. S. falcalus.

Bracts oval or oblong, very obtuse. $\quad 6$. S. armerioides.

Plant floccose; leaves softer, not evergreen. 7. S. lamugino us.

I. Stenotus stexophylus (A. Gray) Greene, Erythea, 2: 72. I $\$ 94$

Aplopappus stcnopleyllus A. Gray; U. S. Expl. Exp. I7: 347. I $862-74$.

This species grows on stony hills and mountains and ranges from western Idaho and Washington to California.

2. Stenotus acallis Nutt. Trans. Am. Phil. Soc. II. $7: 334$. I 840

Chrysopsis acaulis Nutt. Journ. Phil. Acad. 7: 33. I834.

Aplopappus acaulis A. Gray, Proc. Am. Acad. $7: 353$. I 867.

This is a rather common species, growing on dry rocky hills and mountains at an altitude of I000-2500 m., from Saskatchewan and Washington to Wyoming and California.

\section{Stenotus Andersonii sp. nov.}

A puberulent, cespitose, but less woody perennial than the preceding and the three next following species. Flowering stems about $\mathrm{f}$ dm. high, leafy at the base, few-leaved above: leaves narrowly oblanceolate, not rery rigid, distinctly 3 -ribbed, $3-5 \mathrm{~cm}$. long, 3-4 $\mathrm{mm}$. wide: bracts narrowly lanceolate, acute, glandular. 
puberulent, with a very narrow scarious margin, imbricated in 2 series: achenes somewhat fusiform, about $4 \mathrm{~mm}$. long, grayish or white villous as in the other species.

This species is nearest related to the preceding, but characterized by the less rigid leaves, the fewer and narrower involucral bracts, the involucre being more that of S. lamuginosus.

The type was collected on dry open hills.

Montaxa: Belt Mountains, i 886, F. Wr. Anderson, 356 I.**

4. Stenotus caespitosus Nutt. Trans. Am. Phil. Soc. Iİ. $7: 335$. I 840

Chry'sopsis caespitosa Nutt. Jour. Acad. Phila. 7 : 33. I 834. Aplopappus acaulis var. glabratus D. C. Eaton, King's Exped. 5: I6I. I 87 I.

This grows on dry hills and mountains, at an altitude of rooo$3000 \mathrm{~m}$., from Montana and Idaho to Nevada, Arizona and Wyoming.

\section{Stenotus falcatus sp. nov.}

A glabrous cespitose perennial, with a woody caudex, resembling $S$. armerioides in habit. Flowering stems $10-15 \mathrm{~cm}$. high, leafy, I-3-cephalous: basal leaves oblanceolate, rigid, obtuse or acute, $4-5 \mathrm{~cm}$. long, 4-6 mm. wide, 3-ribbed; stem leaves linear, 4-7 cm. long, $2-3 \mathrm{~mm}$. wide, more or less falcate: heads about I $\mathrm{cm}$. high : bracts lanceolate, acute, with scarious margin : rays $6-7$ $\mathrm{mm}$. long, 2.5-3 $\mathrm{mm}$. wide.

This species differs from S. armorivides, which it closely resembles in the narrower and acute involucral bracts. It grows in barren soil at an altitude of about $1500 \mathrm{~m}$.

Utaн: Red Creek, is77. Dr. E. Palmer, 202 (type); Milford, isSo, M. E. Jones, ISO4.

6. Stexotus arierioides Nutt. Trans. Am. Phil. Soc. II. 7 : 335. I 840

Aplopappus armerioides A. Gray, Syn. F1. I²: I32. I 884.

This species grows on dry hills and bad-lands, at an'altitude of I $000-2000 \mathrm{~m}$, from Manitoba and Assiniboia to Utah, New Mexico and western Nebraska.

* Unless otherwise stated, the types of the new species described are preserved in the herbaria of the New York Botanical (iarden or of Columbia Lniversity. 
7. Stenotus Lanuginosus (A. Gray) Greene, Erythea, 2: 72. I 894 .

Aplopafpus lamuginosus A. Gray, U. S. Expl. Exped. I7 : 347. I $862-74$.

This species is a rather anomalous member of the genus, as the leaves are not rigid, and scarcely evergreen. In habit it resembles somewhat some species of Pyrrocoma, as for instance, $P$. innloides; but it has the thin involucral bracts and the white pappus of Stenotus. It grows on the mountains of Washington, northern Idaho and Montana.

\section{Stenotopsis gen. nov.}

Low shrubs with fastigiate branches, narrow fasciculate glandular punctate leaves and large peduncled heads. Involucre broadly hemispherical; its bract subequal, almost in a single series, linear lanceolate, thin scarious-margined, not at all hebaceous. Receptacle naked, alveolar. Ray-flowers about I 2, ligulate, yellow, large, pistillate and fertile. Disk-flowers perfect: their corollas tubular-trumpet shaped, deeply 5-lobed. Anthers obtuse at the base. Style branches stigmatic their whole length, with ovate to lanceolate-subulate appendages. Achenes densely silvery-villous. Pappus of white capillary bristles, rather deciduous.

The genus contains two known species. It differs mainly from Stenotus in its shrubby habit and glandular punctate leaves.

Leaves 3-4 cm. long; rays $\mathbf{I} \mathbf{I}-\mathbf{I}+4 \mathrm{~mm}$. long. Leaves $\mathbf{I}-2 \mathrm{~cm}$. long; rays $9-\mathbf{I} \mathbf{I} \mathrm{mm}$. long.
I. S. linearifolius.

2. S. interior.

\section{Stenotopsis linearifolia (DC.)}

Aplopappus linearifolius DC. Prod. $5: 347 . \quad$ I 836.

Stcnotus lincarifolins Torr. \& Gray, Fl. N. Am. 2 : 238.1842.

This species is a shrub $3-10 \mathrm{dm}$. high, and grows on dry hills, from Utah to California and Arizona.

\section{Stenotopsis interior (Coville)}

Aplopappus intrior Coville, Proc. Biol. Soc. WVash. 7: 65. I 892.

Stenotus interior Greene, Erythea, 2: 72. I 892.

Its range is further southwest, from southern Utah to Arizona and southern California. 


\section{MACRONEMA Nutt.}

This genus was also established by Nuttall in 1840 and reestablished by Greene. The latter included, as is stated before, also Stcnotus pygmacus Nutt. (Aplopappus pygmacus A. Gray). As the relationship of that species is rather doubtful, I have not included it in the treatment below. The species can be separated as follows :

Heads radiate.

Heads small, fastigiate clustered; disk 5-8 $\mathrm{mm}$, in diameter.

Leaves broadly obovate, mucronate-cuspidate.

Leaves oblanceolate, acute or pointed.

Heads larger, solitary : disk $\mathbf{I} \mathrm{cm}$. or more in diameter.

Leaves oblanceolate, acute.

Leaves spatulate, obtuse or mucronate.

Heads discoid.

Leaves oblong-oblanceolate.

Outer bracts ollong, acute.

Outer bracts broadly oblong, obtuse.

Leaves linear.
I. M. olovalum.

2. M. Walsonii.

3. M. suffrulicosum.

4. M. grindelifolium.

5. .1. discoideum.
6. M. oblusum.
7. .1. lineare.

I. Macronema obovatum sp. nov.

A glandular-puberulent undershrub, 2-3 dm. high, with light yellow bark on the branches. Leaves broadly obovate, $\mathrm{I}-2 \mathrm{~cm}$. long, 7-IO $\mathrm{mm}$. wide, mucronate-cuspidate: heads usually 2-3 together, about Io $\mathrm{mm}$. high, and $8 \mathrm{~mm}$. broad: its bracts firmer than in the other species, oblong-linear, abruptly obcuneate-acute at the apex, unequal, imbricated in about 4 series: rays short, 4-5 $\mathrm{mm}$. long and $\mathrm{I}-\mathrm{I} .5 \mathrm{~mm}$. wide, about $\mathrm{Io}$ in number.

The species is nearest related to $M$. Watsonii, differing mainly in the broad leaves and the abruptly acute bracts. The type was collected at an altitude of $1600 \mathrm{~m}$.

Utah : City Creek Cañon, M. E. Jones, IoST.

2. Macronema Watsonil (A. Gray) Greene, Erythea, 2: 74. I 894

Aplopappus Watsonii A. Gray, Proc. Am. Acad. I6 : 79. I 88 I. This grows on mountains at an altitude of 2000-2500 m., in Utah and Nevada.

3. Macronema suffruticosum Nutt. Trans. Am. Plil. Soc. II.

$$
7: 322, \quad 1840
$$

Aplopappus suffruticosits A. Gray, Proc. Am. Acad. 6 : 542. I 865 . 
This species grows in the mountains of Oregon and California up to an altitude of $3000 \mathrm{~m}$. It has also been reported from Wyoming, but possibly some specimens of the next have been mistaken for it.

4. Macronema grindelioides Rydberg, Mem. N. Y. Bot. Garden,

$$
\text { I : } 384 . \quad \text { I } 900
$$

The habitat of this species is rocky places on mountain-sides, at an altitude of 2500-3000 m. It grows in Montana, Idaho and northern Wyoming.

5. Macronema discoineum Nutt. Trans. Am. Phil. Soc. II. 7 :

$$
\text { 322. I } 840
$$

Aplopaptus Macronema A. Gray, Proc. Am. Acad. 6 : 542. I 864 .

This species grows on the higher mountains at an altitude of 2500-3000 m., from Wyoming and Colorado to California.

\section{Macronema obtusum sp. nov.}

A dense glandular-pubescent undershrub, 2-4 m. high, with white-tomentose branches. Leaves oblong-oblanceolate, about $3 \mathrm{~cm}$. long and $6 \mathrm{~mm}$. wide, obtuse or mucronate: heads about IS mm. high, IO-1S mm. in diameter: their bracts linear, acute, scarcely more than half as long as the flowers, subequal, except the outermost, which are foliaceous, broadly oblong, obtuse or mucronate: rays none.

The species is closely related to the preceding, differing in the stouter habit and the larger and broader, more obtuse outer bracts. It grows on high mountains at an altitude of about $2500 \mathrm{~m}$.

Colorado: South Cottonwood Gulch, i892, C. S. Sheldon, 5838 (type); Twin Lakes, I 873 , John Wolfe, $45 \mathrm{I}$.

7. Macronema lineare Rydb. Mem. N. Y. Bot. Garden, I : 384. I 900

In habit, this species resembles some species of Chrysothammus and Prof. Aven Nelson insists that it should be referred to that genus. It has, however, the foliaceous outer bracts and long styleappendages of Macronima and is clearly congeneric with the two preceding species. It cannot very well be referred to Chrysothammus, for it lacks the most essential character of the genus, viz., the 
arrangement of the involucral bracts in distinct vertical rows. It grows in gravelly places in northern Wyoming, at an altitude of 2000-2500 m.

\section{SIDERANTHUS Fraser}

The name Sidcranthus appears first in Fraser's Catalogue, but there only as a nomen nudum. Pursh in his Flora on page 750 gives Sideranthus integrifolins Fraser and $S$. pinnatifudus Fraser as synonyms of Amcllus zillosus and A. spimulosus described on page 564 . There may be a doubt as to which of these should be regarded as the type of Sidcranthus. Amellus villosus with its relatives was made a genus Chrysopsis by Nuttall in I 8 I 8 or by Elliott in I 824, according to different interpretations, long before Eriocarpum was established (1840). This leaves Sideranthus pinnatifulus as the residue of the genus Sideranthus. Besides Nuttall, who was the real author of Fraser's Catalogue, made Sidorenthus a subgenus of Dietcria containing the only species D. spinulosa (Aplopappus spimulosus DC. See Trans. Am. Phil. Soc. II. 7 : 301); and thus shows that he regarded it as the type of Sidcranthus.*

Leaves spinescent toothed, not pinnatifid.

Heads discoid; perennial with woody caudex.

I. S. grindelioides.

Heads radiate; annual.

2. S. mbiginosus.

Leaves pinnatifid.

Stem more or less floccose, or cinereous especially when young.

Plant cinereous pubescent, more or less glandular. 3. S. australis.

Plant more or less floccose, not at all glandular. 4. S. spinulosus.

Plant neither floccose nor cinereous.

Plant perfectly glabrous or sparingly glandular puberulent.

Plant finely puberulent.

5. S. glaberrimus.

Heads hemispherical; bracts slightly glandular. 6. S. puberulus.

Heads somewhat turbinate; bracts densely glandular puberulent.

7. S. turbinellus.

I. Sideranthus grindelioides (Nutt.) Britton

Eriocarpum grindclioides Nutt. Trans. Am. Phil. Soc. II. 7: 32 I. I 840 .

Aplopappus Nuttallii Torr. \& Gray, Fl. N. A. 2: 240.1842.

* Professor Greene (Pittonia 2: I15) seems to think Sideranthus is derived from the Latin sidus, star, and the Greek, avvos, flower. It is better to regard the first part also as Greek, oífipos, iron. Why accuse Nuttall of making a hybrid word, which we would not permit ourselves? 
The species is not uncommon on barren hills and in bad-lands, up to an altitude of $\mathrm{I} 500 \mathrm{~m}$. Its range extends from Saskat. chewan and western Nebraska to Colorado and Arizona.

2. Sideranthus rubiginosus (Torr. \& Gray) Britton

Aplopappus mbiginosum Torr. \& Gray, Fl. N. Am. 2 : 240. I $S .+2$.

Eriocarpum mabiginosum (Torr. \& Gray) Britton, Mem. Torr. Bot. Club, 5 : 3 I6. I 894 .

The species was first described as a perennial. Our plant is evidently only annual. Possibly two different species have been confused under the name E. mbiginosum. It grows in sandy soil from Texas to Colorado and western Nebraska, reaching an altitude of $1500 \mathrm{~m}$.

\section{Sideranthus australis (Greene)}

Eriocarpum australe Greene, Erythea, 2: Io8. I 894.

This grows on the plains of western Texas, Colorado, New Mexico and Mexico.

4. Sideranthus spinulosts (Pursh), Sweet, Hort. Brit. 227. I 826

Amellus spinulosus Pursh, F1. Sept. Am. 564. I 8 I 4.

Sideranthus pinnatifidus Fraser; Pursh, Fl. Am. Sept. 750 . I 8 I 4 Aplopappus spimulosus DC. Prod. $5: 347$. I 836.

Eriocarpum spinulosum (Pursh) Greene, Erythea, 2: 108. I 894.

The species is rather common on plains and dry prairies, from Saskatchewan, Nebraska and Texas to Mexico, Arizona and Idaho.

\section{Sideranthus glaberrimus sp. nov.}

Perennial, with a short woody caudex, perfectly glabrous, or very sparingly glandular-puberulent. Stems several, branched above, very leafy, $\mathrm{I}-3 \mathrm{dm}$. high : leaves rather rigid, about $2 \mathrm{~cm}$. long, bluish green, glabrous, pinnatifid; segments oblong, $2-5 \mathrm{~mm}$. long and I mm. or less wide, spinulose-tipped: heads numerous, corymbose, depressed hemspherical, $8-10 \mathrm{~mm}$. high and $8-15 \mathrm{~mm}$. broad: bracts imbricated in $6-7$ series, the outer gradually shorter, firm, appressed, with a herbaceous tip, acute; the inner tinged with purplish : rays about $20,4-5 \mathrm{~mm}$. long and about $\mathrm{I} \mathrm{mm}$. wide.

The species is closely allied to the preceding, differing mainly in the total lack of tomentum, even when young, the bluer color and the smaller, generally purple-tinged bracts. It grows on plains and hills, from Iowa and Indian Territory to New Mexico and Wyoming. 
Ripberg: Studies on the Rocky Mountain Flora 622

Kansas: Osborn City, I 894, C.L. Shear, II6; Harper, I 888, IV. A. Kellerman; Hamilton Co., 1895 , Hitcheock, 222.

Nebraska: I 893, Rydberg, Ifoza (type); G. D. Surecacy, 55. Indan Territory : i 868, Edward Palmer, $4 \neq 2$.

Colorado: Platte, Dr. James.

Wroming: Platte, Fremont, Dayton, i 899, Tre'eedy', 2076.

\section{Sideranthus puberulus sp. nov.}

A low densely puberulent perennial, less than $1.5 \mathrm{dm}$. high : Stems ascending, branched above: leaves $2-3 \mathrm{~cm}$. long, pinnatifid or bipimnatifid; segments $\mathrm{I}-5 \mathrm{~mm}$. long, less than $\mathrm{I} \mathrm{mm}$. wide, spinulose-tipped: heads $2-4$ in a small corymb, hemispherical, 8-9 $\mathrm{mm}$. high, 10-1 $2 \mathrm{~mm}$. broad: bracts narrowly linear-lanceolate, appressed, acute, with small herbaceous tips, finely puberulent, but only slightly glanular : rays about $20,8-9 \mathrm{~mm}$. long and about $1.5 \mathrm{~mm}$. wide.

This is perhaps nearest related to E. allstrale; but is easily distinguished by the fine pubescence.

Colorado: Salida, Mrs. C. B. Clarke, I7t.

\section{Sideranthus turbinellus sp. nov.}

A low and bushy puberulent perennial, 1.5-2 dm. high. Stems corymbosely branched and very leafy : leaves $.5-2 \mathrm{~cm}$. long, pinnatifid or the upper reduced and merely toothed; segments narrow, I $-5 \mathrm{~mm}$. long, about . $5 \mathrm{~mm}$. wide: heads numerous, small, hemispherical-turbinate, $7-8 \mathrm{~mm}$. high, and scarcely as broad: bracts imbricated in 6-7 series, linear-lanceolate, acute, appressed glandular-puberulent : rays IO-1 5, 7-8 $\mathrm{mm}$. long and $1.5 \mathrm{~mm}$. wicle.

Perhaps nearest related E. spinulosum, the species is easily known by the small, somewhat turbinate heads and the dense and fine pubescence.

Idaho: Pocatello, I\$92, A. Isabel Mulford.

\section{PYRROCOMA Hook.}

This genus was established by Hooker in I 840 , and based on one species, $P$. carthamoides. In I 894, Professor Greene extended the genus so as to include the genus Homopappus of Nuttall, the difference between the two genera being only that the ligules of the ray-flowers in the former are very small and inconspicous or wanting. 
Heads apparently discoid, the sterile rays being concealed in the pappus.

Inner bracts recurved cuspidate.

I. P. subsquarrosa.

Bracts not recurved cuspidate.

Bracts oblong or oval; heads hemispherical.

Leaves and bracts more or less spinulose-toothed, the latter with a narrow scarious margin.

2. P. carthamoides.

Leaves and bracts not spinulose-toothed, the latter with a broad scarious erose margilu.

Pappus sordid; plant almost glabrons.

Pappus brownish red; plant villous.

3. P. rigida.

4. P. erytliropappa.

Bracts lanceolate; head campanulate-turbinate.

Heads distinctly radiate.

Bracts except the innermost obtuse, obovate or oblong.

Bracts mostly acute or acuminate.

5. P. Cusickii.

6. P. crocea.

Plant not glandular.

Heads large; disk $2 \mathrm{~cm}$. or more in diameter; bracts in about 3 series.

Upper part of stem and involucre decidedly villous; bracts wholly foliaceous.

Bracts oblanceolate, abruptly acute. 7. P. Clementis.

Bracts lanceolate, long-acute. S. P. villosa.

Stem and involucre almost glabrous; bracts chartaceous at the base with foliaceous tips.

Heads smaller; disk less than $2 \mathrm{~cm}$. in diameter.

Bracts in $2-3$ unequal series.

Leaves 5-15 $\mathrm{mm}$ wide; disk $\mathbf{I}-2 \mathrm{~cm}$. wide.

Inflorescence corymbiform; bracts long-acute.

Io. P. lanceolata.

Inflorescence racemiform; bracts abruptly acute.

II. P. Taseyi.

Leaves 2-4 mm. wide; disk I cm. or less wide.

Bracts nearly of the same length.

12. P. tenuicaulis.

Stem-leaves oblanceolate; bracts long-acuminate.

13. P. acuminatu.

Stem-leares lanceolate; bracts acute or short-acuminate.

Plant villous.

14. P. inuloides.

Plant, except the upper parts, glabrate in age.

Plant decidedly glandular.

15. P. uniflora.

I6. P. hirta.

I. Pyrrocona subsquarrosa Greene, Erythea, 3: 22. I $\$ 95$

I have seen no specimen of this species; but the description indicates a plant wholly unlike the other species of the Rocky Mountains, that I do not hesitate in accepting it as a good species. The type of $P$. subsquarrosa was collected in northern Wyoming, by Dr. J. N. Rose in I 893 .

2. Pyrrocoma Carthamoides Hook. Fl. Bor. Am. I : 307 . I 333 Aplopappus carthamoides A. Gray, Proc. Acad. Sci. Phila. I $863: 65$. I 864 . 
As treated by Dr. Gray, A. carthamoides comprises more than one species, and probably both of the two following species are covered by his description. There is no doubt, however, as to which species shall bear the name, for Hooker's description and figure point clearly to the plant with more or less spinulosetoothed leaves and bracts. The latter are also longer, narrower and more acute than in the other two species. $P$. carthamoides ranges from Alberta and British Columbia to Oregon and Idaho.

\section{Pyrrocoma rigida sp. nov.}

A perennial with a thick woody tap-root. Stems I-3, erect or ascending, finely pubescent when young, glabrate in age, 2-4 $\mathrm{cm}$. high, leaves pale bluish green, firm, oblanceolate, acute, entiremargined, finely puberulent, or glabrate; the lower petioled, 8-I 5 $\mathrm{cm}$. long, $1.5-3 \mathrm{~cm}$. wide; the upper smaller and sessile: heads apparently discoid, i $5-20 \mathrm{~mm}$. high, I $5-25 \mathrm{~mm}$. broad: bracts very firm, imbricated in 3-4 series, broadly oblong, acute or mucronate; the inner at least with broad scarious or semi-chartaceous margins, which generally are erose, but not spinulose-dentate: ligules of the ray-flowers erect, slightly longer than the light brownish or sordid pappus: achenes glabrous, shining.

In general habit, this species resembles closely $P$. carthamoidcs but has broader leaves and bracts, paler foliage and no indication of spinulose toothing. It grows in sandy places and meadows in Idaho, Montana and Washington.

IDAнo: Granite Station, Kotenay County, I892, Sandberg, MacDougal \& Holler, 785 (type).

Montana: Columbia Falis, i 894, R. S. Hilliams.

Washingtox: Loomiston, I897, A. D. E. Elmor, 603.

\section{Pyrrocoma erythropappa sp. nov.}

A finely villous pubescent perennial. Stem 1.5-3 dm. high, with $\mathrm{I}-4$ heads: stem-leaves $3-6 \mathrm{~cm}$. long, $\mathrm{I}-\mathrm{I} .5 \mathrm{~cm}$. wide, firm, oblanceolate or oblong, acute, subsessile, finely pubescent, or glabrate on the upper surface: heads very short-peduncled in the axils of the upper leaves, IO- $15 \mathrm{~mm}$. high, about $15 \mathrm{~mm}$. in diameter : bracts imbricated in $4-5$ series, pubescent, broadly oval or oblong, obtuse, mucronate, or the outer acute, with a thin erose margin: pappus intensely brownish red: otherwise as the preceding. IDAHO: Clear Water, Row. Spalding (type in Torrey Herbarium). 
5. Prrrocoma Cusickil (A. Gray) Greene, Erythea, 2 : 59 . I 894 Aplopappus corthamoiles var. Cusickit A. Gray, Syn. F1. 2': I 26. I 886 .

The range of this species is limited to Oregon and western Idaho.

6. Pirroconia crocea (A. Gray) Grecne, Erythea, 2: 69. IS94

Aplopappus crocens A. Gray, Proc. Acad. Sci. Phila. I $863: 65$. I 864 .

This species is not uncommon in the mountain regions of Colorado at an'altitude of I $800-3000 \mathrm{~m}$.

\section{Pyrrocoma Clementis sp. nov.}

A perennial with more or less villous ascending stem, I.5-4 dm. high: lower stem-leaves linear-oblong, about I dm. long, somewhat fleshy, glabrous except the ciliate margin, saliently dentate; the upper lanceolate or ovate-lanceolate, more or less auricled at the base, dentate or entire-margined; heads solitary; disk about I $5 \mathrm{~mm}$. high and $2.5-3 \mathrm{~cm}$. broad : bracts all foliaceous, imbricated in 3-4 series, but the outer almost equaling the inner, oblanceolate, abruptly acute, villous : rays $10-12 \mathrm{~mm}$. $\operatorname{long}$ and 2-3 nm. wide, bright yellow : achenes sparingly strigose-hirsute : pappus yellowish white.

Coloramo: Mt. Iarvard, I 896, Frederick Climents, 4 .

\section{Pyrrocoma villosa sp. nov.}

A low perennial with a thick woody tap-root. Stems 1-3, ascending, I-I.5 dnu. high, purplish, more or less villous, especially above: batsal leaves oblanceolate, $7-10 \mathrm{~cm}$. long, I-I.5 cm. wide, somewhat glaucous and rigid, entire-nargined or occasionally slightly spinulose denticulate; stem-leaves linear-lanceolate, 2-4 $\mathrm{cm}$. long: heads solitary: lisk about $2 \mathrm{~cm}$. broad: bracts foliaceous, imbricated in 3-4 series, but the outer fully as long as the imner, broadly linear or lanceolate, long-acute, more or less villous : rays about $\mathrm{I} \mathrm{cm}$. long and $2 \mathrm{~mm}$. wide: achenes glabrous: pappus dirty white.

In habit this species resembles most $P$. miflora and $P$. imuloides; but is easily distinguished by the larger heads and the foliaceous bracts in several series. It grows in meadows at an altitude of about $2700 \mathrm{~m}$.

Wroman: Willow Creek, Big Horn Mountains, I 899, F. Tovedy, 2063. 
Rydberg: Studies ox the Rocki Mountain Flora 626

9. Pyrrocoma integrifolia (Porter) Greene, Erythea, 2: 69. I 894 Aplopappus integrifolins Porter; A. Gray, Proc. Am. Acad. I6 : 79. I 88 I.

This species grows in meadows, at an altitude of $1000-2500$ m., from Saskatchewan to Idaho and Wyoming.

Pyrrocoma integrifolia pumila var. nov.

Pyrrocona Hozucllii Rydb. Mem. N. Y. Bot. Garden, I : 382 . 1900. Not A. Gray.

Stem low, I dm. or less, monocephalous; bracts shorter and less acute.

Montana : Butte, I 895, Rydborg, 2808 .

io. Prrrocona lancenlata (Hooker) Greene, Erythea, 2: 69. I 894

Donia lancelata Hook. F1. Bor. Am. 2: 25. I $S_{34}$.

Aplopappus lanccolatus Torr. \& Grạy, Fl. N. Am. 2 : 24I. I 842.

The range of this species is from Saskatchewan to British Columbia, Nevada and Wyoming. It ascends to an altitude of $2000 \mathrm{~m}$.

\section{I. Pyrrocoma Vaseyi (Parry)}

Aplopappus lanccolextus var. I'ascyi Parry; 1). C. Eaton, King's Exped. 5: i60. I 87 I.

I believe that this deserves a specific rank, as the racemose disposition of the heads is accompanied with shorter, closer and oblanceolate, abruptly acute bracts. It ranges from Saskatchewan (according to Gray) south to Utah and Colorado.

i2. Pirrocona tenuicaulis (D. C. Eaton) Greene, Erythea, 2 : 69. I 894

Aplopappus tcruicaulis D. C. Eaton, King's Exped. 5: I60. I $87 \mathrm{I}$.

Aplopappus lanceolatus var. temuicaulis A. Gray, Syn. Fl. $2^{1}$ : I 29. I 884 .

This grows in alkali meadows of Utah, Nevada and Oregon, at an altitude of about $2000 \mathrm{~m}$.

\section{3. Pyrrocoma acuminata sp. nov.}

A low finely villous perennial with a woody tap-root. Stems several, slender, about I dm. high, monocephalous: leaves nar- 
rowly linear-oblanceolate, with strong midrib, $2-4 \mathrm{~cm}$. long, $2-4$ mm. wide, entire-margined, acute, finely villous on both sides: heads on naked peduncles, which are $3-4 \mathrm{~cm}$. long: disk about I $\mathrm{cm}$. high and I $2-15 \mathrm{~mm}$. broad: bracts in about 2 series, broadly lanceolate, contracted into a long slender tip: rays about $\mathrm{I} \mathrm{cm}$. long and $\mathrm{I} .5 \mathrm{~mm}$. wide: achenes pubescent : pappus tawny.

In habit this species resembles most $P$. imuloides, but differs in the smaller leaves, the shorter pubescence and the acumination of the bracts.

Wroming: Fort Bridger, I873, Dr. J. I'. Carter (type in Columbia Herbarium).

14. Pyrrocona inuloides (Hook.) Greene, Erythea, 2 : 60. 1894 D mia innloides Hook. Fl. Bor. Am. 2: 25 . I $8_{34}$.

Aplopappus imuloides Torr. \& Gray, Fl. N. Am. 2: $241 . \quad 1842$.

Dr. Gray included this in A. uniflorus, but I agree with Professor Greene that it ought to be kept distinct. It ranges from Montana to Idaho and Wyoming.

I 5. Pyrroconia uniflora (Hook.) Greene, Erythea, 2: 60. 1894 Donia miftora Hook. Fl. Bor. Am. 2: 25. I 834 .

Aplopappus uniflons Torr. \& Gray, F1. N. Am. 2: $24 \mathrm{I}$. I 842 .

This species grows in alkaline meadows, up to an altitude of $2500 \mathrm{~m}$., and ranges from Saskatchewan and Montana to Utah and Colorado.

16. Pyrrocona hirta (A. Gray) Greene, Erythea, 2: 69. 1894 Aplopappus hirtus A. Gray, Syn. Fl. $2^{1}:$ I $27 . \quad$ I 884.

The range of this species includes eastern Oregon, Washington and western Idaho, where it reaches an altitude of $1000 \mathrm{~m}$.

\section{BALSAMIORRHIZA Hook.}

Leaves entire or bluntly toothed, never pinnatifid.

Ilant white-tomentose.

Leaves with entire margins or slightly undulate, oblong-cordate to hastate.

1. B. sagittata.

Leaves more or less distinctly toothed, ovate-lanceolate, with subcordate base.

2. B. tomentosa.

Plant hirsute puberulent; basal leaves cordate.

Rays linear, deciduous; achenes glabrous.

3. B. deltoidea.

Rays oval, becoming papery, and more or less persistent : achenes puberulent. 4. B. Careyana. 
Rydberg: Studies on the Rocky Mountain Flora 628

Leaves mostly pinnatifid or at least incisedly toothed.

Plant canescent or white-tomentose.

Plants loosely white-tomentose.

Stem $\mathbf{I}-3 \mathrm{dm}$. high; segments of the leaves $\mathbf{I}-3 \mathrm{~cm}$. long, ovate, entire or slightly toothed.

5. B. incana.

Stem $3 \mathrm{dm}$. or more high ; segments of the leaves $3-5 \mathrm{~cm}$. long, lanceolate, coarsely toothed.

6. B. floicosa.

Plant finely canescent, tomentose only on the involucre; some of the leaves merely toothed

7. B. terelinthacea.

Plants more or less hispid, neither canescent nor tomentose.

Lisk $3^{-4} \mathrm{~cm}$. broad; segments of the leaves mostly entire,

S. B. macrophylla.

Disk $2-2.5 \mathrm{~cm}$. broad; segments of the leaves mostly toother.

9. B. hirsuta.

i. Balsanorrmiza sagittata (Pursh) Nutt. Trans. Phil. Soc. II.

$$
\text { 7: } 350 . \quad 1840
$$

Bupthalminm saggittatum Fl. Am. Sept. 564. I 8 I4.

Growing on hillsides at an altitude of $1000-2500 \mathrm{~m}$., this species is not uncommon from Alberta and British Columbia to California, Colorado and the Black Hills of South Dakota.

\section{Balsamorrhiza tomentosa sp. nov.}

A white-tomentose perennial with thick root; but the tomentum is shorter and finer than in B. sagittata. Basal leaves with long petioles; blades about i $2 \mathrm{dm}$. long, ovate-lanceolate with subcordate bases, I $5-20 \mathrm{~cm}$. long, acute, coarsely toothed; stemleaves generally two, including the slender petioles about I dm. long, lanceolate to linear elliptic, acute at both ends: stem 3-4 $\mathrm{dm}$, high, involucre densely floccose, over $2 \mathrm{~cm}$. broad: outer bracts half longer than the inner, reflexed: rays about $3 \mathrm{~cm}$. long and $\mathrm{I} \mathrm{cm}$. wide; achenes glabrous.

Closely related to $B$. sagittato this species differs mainly in the toothed leaves, shorter tomentum and longer outer bracts.

Wroming: Headwaters of Tongue River in the Big Horn Mountains, I $\$ 98, F$. Tuucedy, IO.*

3. Balsamorrhiza deltoidea Nutt. Trans. Am. Phil. Soc. II.

$$
7: 351 . \quad 1840
$$

The name of this plant is rather unfortunate, as the leaves are rarely deltoid, but on the contrary usually broadly cordate. $B$. deltoidea ranges from British Columbia to California and Idaho.

* A specimen collected by Tweedy on Teepee Creek in IS99 (no. 2II.7), may also belong here. It has smaller heads, not reflexed bracts and lanceolate leaves. 
4. Balsahorrhiza Careiana A. Gray, Pl. Fendl. 8 i. I 849

This species grows on sandy plains of Idaho and Washington.

5. Balsamorrhiza incana Nutt. Trans. Am. Phil. Soc. II. 7 : $350 . \quad$ I 840

Balsamorhiza Hookeri var. incand A. Gray, Syn. Fl. $2^{1}$ : 266. I 884 .

This species grows on dry stony hills, up to an altitude of 2500 m., from Montana and Washington to California and Wyoming.

\section{Balsamorrhiza floccosa sp. nov.}

Balsamorrhiza Balsamorrhiza Rydb. Mem. N. Y. Bot. Garden, I : 417. I900. Not Hiliopsis Balsamorhiza Hook.

A loosely white or gray-tomentose perennial with very thick tap-root. Leaves mostly basal, floccose on both sides, 2-3 dm. long, regularly pinnately divided to near the midrib: some sometimes only coarsely toothed : segments lanceolate, acute, $3-5 \mathrm{~cm}$. long coarsely toothed: stem-leaves 2, near the base, similar but smaller, about I dm. long: stem scapiform, 3-5 dm. high, villous or the upper portion densely floccose: involucre about $3 \mathrm{~cm}$. broad, densely floccose : bracts numerous in several series, lanceolate; the outer often spreading with recurved tips; rays $3-4 \mathrm{~cm}$. long, about I cm. wide; achenes glabrous, cuneate oblong, with truncate apex.

This species has been mistaken for B. Balsamorrhiza (Hook.) Heller or B. Hookeri Nutt., but the latter has much finer dissected leaves and its pubescence is quite different. The latter is very short and appressed, never consisting of long villous hairs, and there is never dense wool at the base of the head as in this species. B. Balsamomliza ranges from Washington to California; but is evidently not found in the Rocky Mountain region. All that I have seen from the region and referred to $B$. Balsamorrliza by Heller, Holzinger and myself belong to B. floccosa. Those collected by Parry, and if I am not mistaken, named by Gray, belong to B. incana.

B. floccosa grows on hillsides at an altitude of $1000-2500 \mathrm{~m}$. The following specimens are in the New York herbaria:

Montaxd: Spanish Basin, Gallatin Co., I 897, Rydberg \& Bessey, 5175 (type).

IdAHo: Lake Waha, i 896, A. A. \& E. Gertrude Heller, 3298; 
Craig Mountain near Lake IVaha, I S92, Sandberg, MacDougal \& Heller, 278 .

Wroming: Headwaters of Tongue River, Big Horn Mountains, isgS, F. Twecdj', $I I$.

7. Balsanorritza terebinthacea (Hook.) Nutt. Trans. Am. Pliil. Soc. II. 7 : 349. I 840

Heliopsis? terebinthacea Hook. F1. Bor. Am. I : 3 IO. I 833. In this species, as well as in the next, it often occurs that some of the leaves are not pinnatifid, but merely coarsely dentate. It is a rare plant growing in stony soil in eastern Oregon and western Idaho.

8. Balsamorkhiza macrophisla Nutt. Trans. Am. Phil. Soc.

$$
\text { II. } 7: 350 . \quad \text { I } S 40
$$

This grows on rocky hillsides in Wyoming, Utah and Idaho.

9. Balsamorrhiza hirsuta Nutt. Trans. Am. Phil. Soc. II. 7 : 349. $1 \$_{40}$

This species is found at an altitude of $1000-2000 \mathrm{~m}$. in the dry regions of Utah to British Columbia and California.

\section{THELESPERMA Less.}

Heads radiate.

Leaf-segments linear-filiform, I mm. or less wide.

Anmual or biennial; outer bracts subulate-linear, more than half as long as the inner.

r. Trifidum.

Peremnial from a rootstock: outer bracts linear-lanceolate, half as long as the inner or less.

2. T. tenue.

Leaf-segments linear, over $1 \mathrm{mmm}$. wide; plant perennial or the first only biennial.

Plant with tap-root, leafy throughout.

3. T. intermedium.

Plant with creeping rootstock or woody caudex; leafy only near the base.

Involucre not cleft below the middle; throat of the disk-flowers cam. panulate, shorter than the lobes.

4. T? ambisumm.

Involucre cleft below the middle; throat of the disk-flowers cylindraceons, longer than the lobes.

5. T. subuudum.

Heads discoid; perennials with rootstock or woody caudex.

Plant less than $2 \mathrm{dm}$, high; involucre with very broad scarions margins.

6. T. marginatum.

Plants $3-6 \mathrm{dm}$. high ; involucre with very marrow scarious margins.

7. T. gracile. 
631 Ridferg: Studies on the Rocki Mountain Flora

I. Thelesperma trifidum (Poir.) Britton, Trans. N. Y. Acad. Sci. 9: I82. I 890

Coreopsis trifide Poir. Suppl. Lam. Encycl. 2: 353. I S I I.

Thelesperma filifolium A. Gray, Kew Journ. Bot. I : 253. I $\$ 49$.

This species grows in dry soil from Nebraska to Texas and eastern Colorado.

\section{Thelesperma tenue sp. nov.}

A slender, glabrous plant with perennial rootstock. Stems $\mathrm{I}-3$, slender, less than $2 \mathrm{~mm}$. in diameter, light green, mostly simple and leafy to near the top, I.5-4 dm. high : leaves twice pinnately dissected into linear filiform segments, mostly appressed to the stem: peduncles $[-3,5-10 \mathrm{~cm}$. long: outer bracts $6-8$, linearlanceolate, half as long as the inner or less; the inner united to the middle, broadly scarious-margined : rays $8-12 \mathrm{~mm}$. long, 4-6 mm. wide: awns of the pappus very short, about half as long as the width of the summit of the dark shining achenes.

This species resembles most the preceding but has a simpler stem and perennial rootstock. It grows in sandy soil at an altitude of about $2800 \mathrm{~m}$.

Colorado: Veta Pass, I900, Rydbergo \& Trecland, 5773 (type); isjo, Dr. G. WV. Hulse: Plains, is7 I, Hm. M. Canby.

\section{Thelesperma intermedium sp. nov.}

A glabrous bushy plant with a biennial or perhaps perennial tap-root. Stems several, much branched and very leafy, 2-6 dm. high: leaves once or twice pinnately divided into linear segments, $\mathrm{I}-3 \mathrm{~mm}$. wide: peduncles very numerous, $1-1.5 \mathrm{dm}$. long: involucre about $1 \mathrm{~cm}$. broad: outer bracts very narrowly linear-lanceolate, about half as long as the inner; these united to about the middle, scarious-margined: rays Io-1 $2 \mathrm{~mm}$. long, 6-8 mm. wide, rounded, 3 -toothed at the apex: teeth of the pappus longer than the width of the achenes.

This has been confused with $T$. ambigumm, but is of a quite different habit. T. intermedium is much branched and very leafy throughout, has a vertical tap-root of short duration, numerous heads, rather long outer bracts and the inner with narrow scarious margins. T. ambigumm is leafy only at the base, has a creeping rootstock, very short outer bracts and the inner with a very broad scarious margin. 
Rydberg: Studies ox the Rocky Mountain Flora 632

T. intcrmcdium grows in sandy or loose soil, often taking possession of old fields and acts much like a weed. The following specimens are at hand.

Nebraska: Banner County, IS90, Rydberg, I9z (type); Crawford, I 889, H.J. Wcbbcr.

Wroming: Pine Bluffs, I897, Aiten Nelson, 3503.

Colorado: i 862, Hall \& Harbour, 280 , at least in part.

Colorado or IVyoming : I 843 , Fremont.

New Mexico: Between Santa Fe and Canoncito, i 897, A. A. \& E. Gertrude Heller, 3747 .

4. Thelesperma ambiguum A. Gray, Proc. Am. Acad. ig: i6. ${ }_{1} S_{3}$

This species seems to be confined to the plains of western Texas, New Mexico and southern Colorado. The specimens reported from Nebraska and Wyoming belong mostly to the preceding, and those from Montana to $T$. marginatum. The latter resembles $T$. ambigun in many respects, especially as to the involucral bracts; but it is always without ray-flowers.

5. Thelesperma subnudum A. Gray, Proc. Am. Acad. io: 72. 1874

This is an inhabitant of the more arid regions of New Mexico, Arizona, Utah and Colorado.

6. Thelesperma marginatum Rydb. Mem. N. Y. Bot. Garden, I : 42 I. 1900

This grows on dry plains of Alberta and Montana.

7. Thelesperma gracile (Torr.) A. Gray, Kew Journ. Bot. I :

$$
\text { 253. } 1849
$$

Bidens gracilis Torr. Ann. Lyc. N. Y. 2: 2 I $5 . \quad 1827$.

This species is the most common and most widely distributed species of the genus. It is common on dry plains from Nebraska to Montana, Arizona, Mexico and Texas.

\section{HYMENOPAPPUS L'Her.}

Throat of the corolla $1-1.5 \mathrm{~mm}$. long, not orer twice as long as the lobes.

Pappus over I mm. long, equaling the corolla-tube or nearly so. ,

Stem 3-6 dm. high, leafy throughout ; heads numerous. 
Plant sparingly and loosely floccose; leaves glabrate in age.

I. II. tenuifolius.

Plant densely tomentose; leaves permanently tomentose.

2. H. tomentosus.

Stem less than $3 \mathrm{dm}$. high.

Stem-leaves much reduced; stem white-tomentose or nearly so; heads few.

3. H. scaposus.

Stem-leaves not much reduced; stem sparingly grayish tomentose.

5. H. cinereus.

Pappus I $\mathrm{mm}$. or less long, shorter than the corolla-tube; stem-leaves and heads few.

Pappus not hidden by the hairs of the achenes.

Stem permanently densely white-tomentose; achenes silky.

4. II. arenosus.

Stem sparingly grayish tomentose, glabrate in age; achenes loosely villous 5. H. cinereus.

Pappus hidden by the hairs of the achenes, or sometimes none.

Leaflets glabrate in age, at least above; ultimate segment 5-30 $\mathrm{mm}$. long.

6. H. flifolius.

Leaves permanently densely white-tomentose; ultimate segments short, I-5 $\mathrm{mm}$. long.

7. II. lutews,

Throat of the corolla 3-4 mm. long, 3-4 times as long as the lobes. S. II. macroglottis.

I. Hymenopappus tenuifolius Pursh, Fl. Am. Sept. 742. I 8 i 4

This is generally described as a biennial; occasionally the root is of a longer duration and the plant becomes a shortlived perennial and then hard to distinguish from a large specimen of $H$. filifolius except by the pappus. H. temifolius grows on prairies, from Nebraska and Wyoming to Texas.

\section{Hymenopappus tomentosus sp. nov.}

A densely and permanently white-tomentose plant, apparently biennial. Stem 3-4 dm. high, leafy and branched above: leaves 5-7 cm. long, bi-pinnately divided into linear segments, 4-Io mm. long, about $1 \mathrm{~mm}$. wide: heads many, corymbose-paniculate, about $8 \mathrm{~mm}$. high and broad; involucre densely woolly, somewhat turbinate: flowers yellow: corolla tube and throat each a little over I min. long; the latter broadly campanulate, of about the same length as the lobes; achenes silky strigose; scales of the pappus a little shorter than the corolla-tube.

Nearest related to the preceding, this species is easily distinguished by the dense permanent tomentum and the yellow flowers.

Uтлн: St. George, is77, Dr. E. Palmer, 270 (type in the Columbia Herbarium). 


\section{Hymenopappus scaposus sp. nov.} Nutt. 184 I.

Hynenopappus luteus A. Gray, Pl. Fendl. 97. I 849 . Not

An almost scapose perennial with a respitose caudex. Stem almost naked, with $\mathrm{I}-2$ reduced leaves, more or less densely tomentose: leares mostly basal, 5-7 cm. long, bipinnately divided into linear segments, 3-10 mm. long, more or less densely tomentose, especially at the base : heads few, corymbose, hemispherical, about I cm. high and broad: bracts obovate with yellowish or purplish scarious margins : corollas yellow; tube and throat each nearly $2 \mathrm{~mm}$. long; the latter campanulate and longer than the lobes: achenes densely silky, scales of the pappus fully $2 \mathrm{~mm}$. long, longer than the tube of the corolla.

This species has been confused with H. luteus Nutt. but is easily distinguished by the long pappus and also by the longer segments of the leaves. H. scaposus grows in dry soil up to an altitude of $2200 \mathrm{~m}$. from New Mexico and Arizona to Utah and Nevada.

Arizond: Vicinity of Flagstaff, i $\$ 98$, D. T. Mac Dougal, I29 (type).

New Mexico: Santa Fee, i S97, A. A. \& E. Gertrude Heller, 3555; i $\$ 47$, A. Fondler, 456; i \$69, E. Palmer, II.

Utan: Southern Utah, I 874, C. C. Perry, 107.

Nevada: is68, S. ITatson, 612.

4. Hymenopappus arenosus Heller, Bull. Torr. Club, 25: 200. I $\mathrm{S} 9 \mathrm{~S}$

This resembles somewhat the preceding, but is taller, more leafy, and has much shorter pappus. It grows in sandy soil, up to an altitude of 2200 m., in New Mexico and southern Colorado.

\section{Hymenopappus cinereus sp. nov.}

A grayish tomentose perennial with a cespitose caudex. Stems about $2 \mathrm{dm}$. high, branched, with $2-4$ leaves: these bi-pinnately divided into linear segments $\mathrm{I}-2 \mathrm{~cm}$. long and about $\mathrm{I} \mathrm{mm}$. wide, sparingly grayish tomentulose : heads corymbose, $8-10 \mathrm{~mm}$. high, I O-1 $2 \mathrm{~mm}$. broad, hemispherical or somewhat turbinate: bracts oblong-obovate, with narrow scarious margins: corollas yellow: tube and throat each about $1.5 \mathrm{~mm}$. long; the latter broadly campanulate, longer than the lobes: achenes loosely villous; scales of the pappus variable, in the type fully $1 \mathrm{~mm}$. long and nearly equal. 
ing the corolla-tube, but often shorter, yet never hidden by the hairs of the achenes.

This species has been confused with $H$. filifolius and $H$. flac'escons. Baker, Earle \& Tracy's specimens were determined as the latter by Professor Greene. The species is, however, much nearer related to $H$. filifolius, from which it differs mainly in the lower habit and the longer scales of the pappus. These characters, together with the longer lobes of the leares distinguish it from $H$. lutcus. It grows on dry hills, at an altitude of I 500-3000 m.

Colorado: Walsenburg, I900, Rydberg \& Treeland, $5+79$ (type); Mesas near Pueblo, 5777 ; Cuchara Valley, 5778; Durango, I 898 , Balicr, Earle \& Tracy, IO2S; Garden of the Gods, near Pikes Peak, I 895 , E. A. Bcssey'.

6. Hriesopappl's filifolils Hook. F1. Bor. Am. I : 317.1833

This species is common on plains and prairies to an altitude of $2000 \mathrm{~m}$., and ranges from Saskatchewan and Montana to Colorado and Nebraska.

7. Hraexopapes luteus Nutt. Trans. Am. Phil. Soc. (II.) 7 : $374 . \quad$ I $S_{4} \mathrm{I}$

Dr. Gray in his Synoptical Flora referred this species to $H$. filifolius, which, however, does not fit Nuttall's description. Many years before he had named Fendler's specimens H. Iutcus. These agree fairly well with Nuttall's clescription, except as to the pappus, which in them is much more prominent than in any of the other species. Nuttall states that the scales of the pappus of $H$. lutirts are very short and hidden by the hairs of the achenes.

In 1897 Prof. Aven Nelson collected a Hymenopappus on Green River, which he intended to describe as new, especially as the type specimen was without pappus. A closer examination revealed, however, that some of the specimens really had some small scales. These agreed perfectly with Nuttall's description. Nelson's specimens and my own, collected two years before, also on Green River, are the only ones that perfectly agree with Nuttall's description of H. Inturs. His type was collected on the Ham's Fork of the Colorado of the IVest. What the present name of Ham's Fork is or its exact location I have been unable 
to find; but from the route that Nuttall took it is undoubtedly some stream of the Green River system.

\section{S. Hymenopappus macroglottis sp. nov.}

Slightly tomentose perennial with a woody caudex. Stems several, 3-4 dm. high, striate, slightly floccose when young, with I-3 leaves: leaves mostly basal, about I $\mathrm{dm}$. long, bi-pinnately divided into linear lobes $8-25 \mathrm{~mm}$. long, I-2 $\mathrm{mm}$. wide; stemleaves generally simply pinnate or the uppermost simple: heads few, corymbose, I $2 \mathrm{~mm}$. high and $12-15 \mathrm{~mm}$. broad, hemispherical : bracts oblong, with very narrow yellowish scarious margins: corolla yellow; tube about $2 \mathrm{~mm}$. long; throat deeply campanulate, $3-4 \mathrm{~mm}$. long, $3-4$ times as $\mathrm{long}$ as the lobes: achenes elongated obpyramidal, about $5 \mathrm{~mm}$. long, hirsute: scales of the pappus about $\mathrm{I} \mathrm{mm}$. long.

The long and broad lobes of the leares and the long throat of the corolla distinguishes it from other species of the Rocky Moun. tains. The latter character it has common with only /I. lugens Greene from southem California. This has, however, much more finely dissected leaves. H. macroglottis grows in arid regions from Texas to Arizona and north to Colorado or Utah.

Arizoxi: Oak Creek, $188_{3}$, H. H. Rusby (type).

New Mexico: I 55 I-52, IThight, I252.

Texas: Camp 42, i 853 , Bigilow, 730 :

Colorado or Utall : is 43 , Firmont. 

CON'TRIBUTIONS FROM THE NEW YORK BO'TANICAL GARDEN-No. 12.

\section{STUDIES ON THE ROCKY HOUNTAIN FLORA.-IV}

BY P. A. RYDBERG

NEW YORK

1901

[Reprinted from the Bulletin of the Torrey Botanical Club. 28: $20-3831$ Jan., 1901.] 



\title{
Studies on the Rocky Mountain Flora, - IV
}

\author{
IY P. 1. RYTHER:
}

\section{Arnica tomentulosa sp. nor.}

A leafy perennial with slender horizontal rootstock. Stem villous, about \& dm. high : leaves oblanceolate, obtuse, sessile or the lower with short-winged petioles, denticulate, finely villouspubescent, almost tomentulose, with two pairs of stronger veins, the larger I 3 dm. long, somewhat yellowish: heads few, hemispherical ; disk about i 5 mm. high and $2 \mathrm{~cm}$. broad: bracts ovate or ovate-oblong, obtuse, villous, I $2-16$ in 11 mber: rays light yellow, over I $\mathrm{cm}$. long, 4 mm. wide.

This species is nearest to 4 . mollis, but differs in the broad obtuse involucral bracts. It grows at an altitude of about $2700 \mathrm{~m}$.

Wromag: Buffalo Fork, IS97. F. Tavedy, 52.3.

\section{Arnica tenuis sp. nov.}

A low slender perennial with horizontal rootstock. Stem sparingly villous pubescent, about $2 \mathrm{~cm}$. high, monocephalous: leaves usually 3 pairs, sparingly villous when young, entire; the lower two pairs oblanceolate or spatulate, the upper lanceolate : involucre turbinate-campanulate, villous, about I $3 \mathrm{~mm}$. high, IO-I $2 \mathrm{~mm}$. broad: bracts linear, I-I.5 mm. wide, green; rays orange, I6I 8 nmm. long and + mm. wide.

This species resembles $A$. gracilis in the size of the plant and form of the head, but the leaves are much narrower and the heads solitary. It is intermediate between that species and 4 . fulgons. It grows at an elevation of about $2200 \mathrm{~m}$.

IVyoming: Big-Horn Mountains, IS99, F. Taceidy, 2094.

\section{Artemisia diversifolia sp. nov.}

A white tomentose perennial with horizontal rootstock. Stems simple, leafy, white-tomentose, 5- ro dm. high: leaves densely tomentose on both sides, subsessile, 5-10 cm. long: the lower pinnately cleft into 3-5 narrowly lanceolate acuminate lobes, which are directed forward: the upper entire, linear-lanceolate, passing into the bracts of the inflorescence: inflorescence a narow panicle, I.5-3 dm. long: heads numerous, conglomerate, sessile, 3-4 mm. high and $3 \mathrm{~mm}$. broad: bracts oblong or ovate-oblong, scarious- 
margined, densely villous-tomentose: flowers heterogamous, but all fertile, light yellow : receptacle glabrous.

This species belongs to the A. Luloriciond group, and in many respects agrees with the original description thereof. It is, however, a western species, not growing near the region from which $A$. Ludoriciana was described. What the latter really is I have been unable to settle. The one that $\mathrm{I}$ think is the only one that has any claim for the name, is a lower plant from Missouri to Colorado, with shorter leaves, more green above, with more divergent lobes and brownish flowers. A. diversifolia grows on sandy beaches up to an altitude of $2200 \mathrm{~m}$.

Inaho: Priest River, I900, D. T. MacDougal, Igo (type): Farmington Landing, Lake Coeur d'Alene, I892, Sandberg, MacDougal \& Heller, 509.

Washington: is89, G. R. I'irsey, tio.

Wyoming: Yellowstone Lakc, I 899, Ai'n \& Elius Nilson, 6603.

\section{Picradenia helenioides sp. nov.}

A comparatively tall, finely pubescent plant with apparently only biennial root. Stem leafy, about $5 \mathrm{dm}$. high, with several to many erect branches: leaves rather firm, distinctly ribbed, finely pubescent; the lower petioled and with half clasping bases: basal leaves cntire, very namowly lincar-oblanceolate; middle stem-leaves crect, fully i dm. long, parted into 3-5 linear divisions: upper stem-leaves linear, entire: heads corymbose: involucre somewhat tomentose, $8-10 \mathrm{~mm}$. high and often $15 \mathrm{~mm}$. broad; outer bracts united only at the base, lanceolate, longer than the inner, $14-18$ in number: rays orange, about $1 \mathrm{~cm}$. long, 2-3 $\mathrm{mm}$. wide, 3 -toothed at the apex: achenes silky: scales of the pappus broadly lanceolate, acuminate.

It is nearest related to I'. bicmuis (A. Gray) Greene; but differs in the yellowish green herbage, the erect branches, the broader segments of the leaves and the darker flowers. It grows in mountain valleys at an altitude of about $2700 \mathrm{~m}$.

Colokano: On Sangre de Christo Creek, 1900, Rydbres is Fredand, 5+9.5.

Antennaria Piperi sp. nov.

Somewhat surculose-rosuliferous: basal leaves $2-4 \mathrm{~cm}$. long, obovate or oval with a short petiole, densely floccose on the lower surface, only slightly so on the upper surface when young, but 
soon glabrate, I-ribbed or indistinctly 3-ribbed, generally distinctly mucronate: flowering stems $1-\mathrm{I} .5 \mathrm{dm}$. high, somewhat glanduliferous above ; its leaves small and bractlike, oblanceolate or linear ; heads 5-7 in a short raceme: fertile heads $7-8 \mathrm{~mm}$. high and 6-7 $\mathrm{mm}$. in diameter; its bracts imbricate in about 4 series, slightly floccose, green at the base, purplish in the middle and with a light brownish scarious margin above; the outer short and ovate; the inner lanceolate, acute: pappus very slender, filiform, dirty white: sterile heads about $5 \mathrm{~mm}$. high and about as broad; its bracts broadly oblong, more floccose, brown and with a broader scarious margin of the same color as in the fertile head, obtuse or truncate; pappus only slightly broadened above, white.

It is nearest related to $A$. racimosa, but differs in the more copious and more persistent tomentum, in the broader and brighter colored bracts of the fertile head and the broad scarious margins of those of the sterile one.

Oregon: Olympic Mountains, is95, C. I'. Piper (fertile plant in herbarium of Washington Experiment Station, Pullman); mountains of northern Oregon, Irilkes Erpetition (sterile plant in the Torrey herbarium).

\section{Aster mollis sp. nov.}

A strict perennial with a horizontal rootstock. Stem densely villous, almost tomentose, or in age more glabrate, $4-S$ dm. high, simple below, with short flowering branches above; leaves obovate to oblanceolate, 5-IO cm. long, densely and softly grayish pubescent on both sides, sessile, slightly clasping, and occasionally a little auricled at the base: heads terminating the short branches, hemispherical; disk about If $\mathrm{mm}$. high and broad; bracts herbaceous, oblong, obtuse, villous-pubescent; rays numerous, bluish purple, about I $\mathrm{cm}$. long and $2 \mathrm{~mm}$. wide.

This species reaches an elevation of $2200 \mathrm{~m}$.

Wroming: Big-Horn Mountains, I S99, F. Truccily, 2029 (type).

IVashingtox: Pullman, i S93, C. I'. Pipir, r6o

\section{Townsendia Vreelandii sp. nor.}

A dark green biennial, branching near the base. Stems and branches simple, erect, I.5-4 dm. high, mostly erect, sparingly villous. Leaves numerous, all oblanceolate, short-petioled, glabrous, mucronate, $4^{-S} \mathrm{~cm}$. long, 5-8 mm. wide: involucre about $\mathrm{I} 5 \mathrm{~mm}$. high and 25-30 $\mathrm{mm}$. broad: bracts lanceolate, acuminate, scarious, light green with dark green center: rays 
bluish purple, I $2-15 \mathrm{~mm}$. long, $2 \mathrm{~mm}$. wide : achenes thin, oblong. truncate: pappus of 2 subulate bristles, with a few intermediate squamellae.

It is nearest related to $T$. crimia, but has larger heads, is more leafy, and even the upper leaves are oblanceolate. It grows at an altitude of 2500-3000 $\mathrm{m}$.

Colorado: Side of Veta Mountain, igoo, F. K. Trecland. 639 (type); Veta Pass, 1900, Rydberg \& Trecland, 5 fof and $5+05$; West Spanish Peak, 5700.

\section{Erigeron leucotrichus sp. nov.}

Perennial with a somewhat branching rootstock. Stems about $2 \mathrm{dm}$. high, sparingly villous below, more copiously so above: basal leaves oblanceolate or spatulate, $3-5 \mathrm{~cm}$. long, short-petioled, bright green and sparingly hairy: stem-leaves oblanceolate to linear, I-2 cm. long; head solitary; involucre white-villous with multiceptate hairs; bracts very numerous, lanceolate, almost black, acuminate with spreading tips: rays very numerous, about $6 \mathrm{~mm}$. long and I mm. wide, light purplish pink or white.

This species is nearest related to E. molanociphalus, but easily distinguished from it by the white, not black, hairs of the involucre. It differs from $E$. simplex in the taller habit, the larger heads and the darker bracts of the involucre. It grows at an altitude of about $2500 \mathrm{~m}$.

Wyomng: Big-Horn Mountains, July, I 899, Frank Ta'ecdy', 2003.

\section{Erigeron incanescens sp. nov.}

(?) Erigeron glabollus var. mollis A. Gray, Proc. Acad. Phil. I $863: 64$, in part.

A densely and finely cinereous pubescent plant with perennial rootstock. Stem simple, I.5-3 dm. high, mostly ascending, striate densely pubescent, leafy : basal leaves oblanceolate or spatulate: stem-leaves about $5 \mathrm{~cm}$. long and I cm. wide, oblong, oblanceolate or the upper lanceolate, sessile and somewhat clasping : heads $\mathrm{I}-4$; disk about $S \mathrm{~mm}$. high and $\mathrm{I} 5 \mathrm{~mm}$. broad: bracts very numerous in one series, narrowly linear, cinereous as the rest of the plant ; rays pale blue or violet, very numerous, about $15 \mathrm{~mm}$. long and less than I $\mathrm{mm}$. wide.

From Dr. Gray's description, this species must have been included in E. glabollus var. mollis; but all specimens that I have 
seen under that name belong to E. subtrinoris Rydb., which is its nearest relative. From this it differs in the dense grayish pubescence, the narrower stem-leaves, which are not 3 -ribbed, and the lower habit. E. incanescons grows in rocky places at an altitude of about $3000 \mathrm{~m}$.

Colorado: West Spanish Peak, I900, Rydterg \& Ireckmet, $5+15$.

\section{Erigeron viscidus sp. nov.}

A low cespitose perennial. Stems ascending, a little over I $\mathrm{dm}$. high, more or less hirsute and glandular-puberulent, especially above; leaves $3-5 \mathrm{~cm}$. long, oblanceolate, dark green, sparingly hirsute and ciliate on the entire margins: heads few : disk about i $\mathrm{cm}$. high and $15 \mathrm{~mm}$. broad: bracts very numerous, subequal in one series, narrowly linear, fuscous, acuminate, glandular-puberulent, but not hirsute: rays very numerous, pale blue, about $S \mathrm{~mm}$. long and $.5 \mathrm{~mm}$. wide.

This species is intermediate between E. glandulosus and E. macranthus. It has the habit of the former, although larger, and the large heads and numerous narrow rays of the latter. It grows in wet ground, at an altitude of about $2700 \mathrm{~m}$.

Colorado: Near the Gray-Back Mining Camps, I 9oo, Rydberg \& Irecland, $5+16$.

\section{Valeriana acutiloba sp. nov.}

A bright green plant with horizontal or ascending rootstock and polygamo-dioccious flowers. Fertile plant 4-5 dm. high: basal leaves entire with a short wing-margined petiole, $5-7 \mathrm{~cm}$. long; blade spatulate or obovate, acute: stem-leaves usually 3 pairs, pinnately divided; lateral divisions lanceolate to linear, longacuminate; the terminal one large, oblanceolate or of the uppermost very small leaves linear-lanceolate, entire or saliently toothed : cyme dense, contracted, $2-5 \mathrm{~cm}$. long and about as wide; glandular-puberulent: bracts linear subulate, about $\mathrm{I} \mathrm{cm}$. long: flowers perfect; corolla funnelform, about $4.5 \mathrm{~mm}$. long; tube proper about I mm.; fruit broadly ovate, about + mm. long: pappus about $7 \mathrm{~mm}$. : staminate plant lower, 3-4 dm. high, with more sterile shoots, which have much longer leaves: stem-leaves usually only 2 pairs, less divided, with only $1-2$ pairs of lateral divisions : cymes denser, flowers all or nearly all staminate: their corollas larger, 5-6 mm. long, more oblique; the limbs about $5 \mathrm{~mm}$. wide.

This species has the dense cyme of $I^{\gamma}$. capitata; but the plant is taller, the corolla shorter and is easily distinguished from all its 
American relatives by the narrow, long-acuminate divisions of its stem-leaves. It grows in wet places, especially under snowdrifts, at an altitude of 2500-3300 $\mathrm{m}$.

Colorado: Near Gray-Back Mining Camp, Sangre de Christo Range, 1900, Rydberg \& Ireclend, 5576 (type, fertile plant); Mountain near Veta Pass, 5575 (staminate plants): Bear Creek Cañon, i 895, Ernst A. Bessicy (fertile); Pagosa Peak, I899, C. F. Baker, 620 .

\section{Campanula MacDougalii sp. nov.}

A slender glabrous perennial, about $3 \mathrm{dm}$. high with slender horizontal rootstock. Leaves very thin : the basal ones and lower stem-leaves with slender petioles $2-4 \mathrm{~cm}$. long: blades broadly ovate, $2-3 \mathrm{~cm}$. long, coarsely sinuate-dentate: upper stem-leaves lanceolate to linear, entire; the largest $5-6 \mathrm{~cm}$. long: sepals linear subulate, IO-I $2 \mathrm{~mm}$. long, at last reflexed: corolla I $_{3-\mathrm{I}} 5 \mathrm{~mm}$. long, nearly of the same shape as that of $C$. rotundifolia: style exserted, straight: fruit not seen.

The species is nearest related to $C$. Scoulcri; but is easily distinguished from that species by the lack of the sharp toothing of the leaves. The lower leaves resemble somewhat those of $C$. rotundifolia, and were it not for the exserted style and the smaller corolla it may be referred to the var. Alaskana of that species.

I DAно: Priest Lake, I900, D. T. Mac Dougal, 66.

\section{Castilleja linearis sp. nov.}

A rather slender perennial, with a rootstock. Stem simple, 3-4 dm. high, finely villous pubescent: leaves narrowly linear, about $5 \mathrm{~cm}$. Jong and $2 \mathrm{~mm}$. wide, pubescent, entire or the upper with a pair of narrowly linear lobes: bracts broader, deeply cleft into three linear lobes, tipped with brick-red: calyx villous, 2-2.5 $\mathrm{cm}$. long, cleft almost equally deeply in front and behind, more than half way down : lateral lobes linear, 8 - $10 \mathrm{~mm}$. long: corolla 2.5$3 \mathrm{~cm}$. long, greenish yellow: galea about i $2 \mathrm{~mm}$. long, with red margins: lower lip dark green, about $3 \mathrm{~mm}$. long, 3 -lobed.

This species resembles in habit most the subarctic $C$. pallider, but has the corolla of $C$. mincata. It grows in meadows at an altitude of about $2500 \mathrm{~m}$.

Colorano: Near IVest Spanish Peak, I900, Rydberg \& Irecland, 5619 . 


\section{Castilleja trinervis sp. nov.}

A tall perennial with rootstock. Stem more or less villous, especially the upper portion, solitary, simple or branched, 3-6 dm. high: leaves dark green, finely puberulent, entire, acute, usually 3-ribbed; the lower linear, $5-8 \mathrm{~cm}$. long and about $.5 \mathrm{~cm}$. wide: the upper lanceolate and often I $5 \mathrm{~mm}$. wide: lower bracts green, similar but shorter and broader and usually 3-5-lohed: the upper with almost crimson tips: calyx densely white villous, about $3 \mathrm{~cm}$. long, equally cleft in front and behind, each division laterally cleft into two oblong lobes, $5-8 \mathrm{~mm}$. long, tipped with the same color as the bracts : corolla about $4 \mathrm{~cm}$. long, slightly curved, green, but the galea with almost crimson margins: galea about $15 \mathrm{~mm}$. long: lower lip 4-5 mm. long, dark green, with three narrow lobes: style about $5 \mathrm{~mm}$. longer than the corolla.

This species is nearest related to C. rherifolia and C. confusa, but is characterized by the copious white villous pubescence of the upper part of the stem and the calyx. It grows in open woods at an altitude of $2700-3000 \mathrm{~m}$.

Colorado: Headwarters of Sangre de Christo Creek, 1900, Rydberg \& Irecland, 5620 (type); Gray-Back Mining Camps, 5621 .

\section{Castilleja luteovirens sp. nov.}

A simple perennial with rootstock, often turning black in drying. Stem 3-4 dm. high, leafy, slightly pubescent when young, soon glabrate, except the upper portion which is slightly villous: leaves lanceolate to almost linear, $3-4 \mathrm{~cm}$. long, 3-9 $\mathrm{mm}$. wide, finely puberulent, 3-ribbed, acute, cntire, or rarely the upper 3lobed: lower bracts ovate, obtuse, entire, tipped with light greenish yellow or greenish white; the upper ones 3 -toothed at the apex and greenish yellow througliout: calyx villous, $15-17 \mathrm{~mm}$. long, almost equally cleft in front and behind, laterally cleft about $3 \mathrm{~mm}$; lobes lanceolate : corolla 22-24 mm. long, greenish ; galea 6-7 mm. long with yellow margins; lower lip $2.5-3 \mathrm{~mm}$. long. bluntly 3-lobed.

This species has been referred to C. siptintrionalis and C. pallida, but differs from both in the broader, less acuminate leaves and broader, more entire yellowish bracts. Neither of the two species mentioned is found in the southern Rockies. Mostly all the material that has been determined as either belongs to the present species. This grows in meadows at an altitude of $1200-2700 \mathrm{~m}$. Colorado: Sangre de Christo Creek, Igoo, Rudbug \& Irec- 
land, 5616 (type) and 5617; Wahatoya Creek, 5618 ; Middle Park, I861, C. C. Parry, 2fI: Chicken Creek, is98, Baker, Earle \& Tracy, 37t: near Denver, is69, B. H. Smith; Ford of Chama, 1859. Ncwbery, in Nacomb's Expedition; Seven Lakes, Pikes Peak, I 894 , Ermist A. Bcsscy.

Wroming: Big-Horn Mountains, I899, F. Tucedy, 2370; Laramie Plain, I884, C. S. Slucldon, 80.

UтAн: Salt Lake City, i 879, M. E. Joncs, IO5I.

\section{Mimulus gratioloides sp. nov.}

A low, branched annual of more or less reddish color, generally less than I dm. high, somewhat viscid puberulent especially above. Leaves oblong-lanceolate, sessile, about I cm. long, sinuate-dentate: pedicels slender, in fruit I 5-20 $\mathrm{mm}$. long; caly'x 7$8 \mathrm{~mm}$. long, cylindraceous in fruit: lobes subequal, short, broadly ovate, acute, ciliate on the margins; corolla yellow, about I $\mathrm{cm}$. long and $3 \mathrm{~mm}$. broad, only slightly bilabiate: throat beardless.

This species is nearest related to $M$. mbcllus and the specimens from Colorado referred to that species may belong here. MT. gratioloides differs, however, in the smaller yellow corolla and the acute calyx-lobes. It grows in exposed places among rocks and gravel at an altitude of about $2300 \mathrm{~m}$.

Colorido: Butte, 5 miles southwest of La Veta, I900, Rydbirg Fredand, 5660 .

\section{Pedicularis lunata sp. nov.}

A perennial, perfectly glabrous up to the inflorescense, with a rather stout, but simple rootstock: stem about $4 \mathrm{dm}$. high, slightly. striate and purplish: leaves alternate, dark green, 5-I $2 \mathrm{~cm}$. long, pinnately divided to near the midrib; segments linear or linearoblong, crenate: spike I $5-20 \mathrm{~cm}$. long, rather lax; bracts pectinately divided with prolonged endlobes, the lower often equaling the flowers in length, slightly arachnoid villous: calyx about $9 \mathrm{~mm}$. long; its teeth broadly lanceolate, about $3 \mathrm{~mm}$. long: corolla pinkish, over $2 \mathrm{~cm}$. long; its tube about twice as long as the calyx, strongly curved; galea strongly arcuate, produced into a rather long beak and almost crescent-shaped; lower lip almost meeting the beak of the upper, very broad, indistinctly 3-lobed with large rounded lateral lobes.

The very broad lower lip, and long-beaked galea suggest somewhat $P$. contorta and $P$. ctinophora, but the corolla-tube is 
much longer and the beak not spirally twisted. The species may therefore be placed with $P$. Canby $i, P$. Parryi and $P$. Hallii, but the corolla and beak are much more arcuate. It is a handsome species growing at an altitude of nearly $2800 \mathrm{~m}$.

Wroning: Big-Horn Mountains, i 899, F. Täecdy', 2317 (type).

\section{Pentstemon erosus sp. nor.}

A glabrous cespitose perennial, 2-4 dm. high. Basal leaves oblanceolate, short-petioled, $3-5 \mathrm{~cm}$. long, entire, mostly acute: stem-leaves opposite, sessile, oblong or lanceolate, entire, acute or the uppermost acuminate: flowers in a dense interrupted spikelike inflorescence : calyx-lobes broadly ovate, almost cuspidate-acuminate, tinged with dark purple and white and with an erose-dentate margin : corolla purple with very dark limb: lower lip broad with 3 rounded reflexed lobes, bearded on the inside: upper lip with 2 erect narrower lobes: sterile stamens narrowly clavate, shortbearded.

This species is nearest related to $P$. procerus, but easily distinguished by the erose sepals and more reflexed lower lip. It grows at an altitude of 2000-2700 m.

Colorado: Indian Creek Pass, I900, F. K. Frecland, 615 (type); South Park, I 873, John Holfi (Wheeler Expedition), 293; Chicken Creek, West La Plata Mountains, I 898, Baker, Earle \& Tracy, 6, 8 .

\section{Pentstemon Wilcoxii sp. nov.}

An almost glabrous perennial with a cespitose caudex. Stems 3-6 dm. high, glabrous or slightly puberulent above, simple: leaves opposite, glabrous and somewhat glaucous, dentate with small sharp callous teeth, acute: the basal ones petioled, lanceolate: the lower stem-leaves sessile, oblanceolate or oblong, $3-5 \mathrm{~cm}$. long; the upper lanceolate and slightly clasping: inflorescence an elongated interrupted thyrse: branches $1-2 \mathrm{~cm}$. long, fastigiatecymose: calyx glabrous, about $4 \mathrm{~mm}$. long, cleft $3 / 4$ its length: lobes lanceolate, acute, slightly margined below and there often sinuately toothed: corolla straight, purple, glabrous on the outside, about $15 \mathrm{~mm}$. long; the lower lip longer than the upper, slightly bearded within: sterile stamen club-shaped, with a short dense brown beard.

This species is probably nearest related to P. Mumilis; but easily distinguished by the tall stems, the sharper toothed leaves, and the numerous purple flowers. 
Montana: Kalispell, I900, E. V. Wilcox, 370 (type in United States National Herbarium) and 368 .

\section{Polemonium delicatum sp. nov.}

A small glandular perennial with slender horizontal rootstock. Stem very slender, about I dm. high: leaves $3-8 \mathrm{~cm}$. long; leaflets 5-I I pairs, very thin, ovate, ovate-lanceolate or oblong, mostly acute, 3-IO mm. long: inflorescence usually branched; branches 3-4-flowered; pedicels slender, 5-15 mm. long; calyx glandular, 4-5 mm. long: lobes lanceolate, acute: corolla blue, open-campanulate, about $7 \mathrm{~mm}$. high and $8 \mathrm{~mm}$. broad: stamens about equalling the corolla.

This is nearest related to $P$. pariflorm Nutt., but is still smaller and characterized by its slender pedicels, small flowers and acute calyx-lobes. It grows at an altitude of over $3000 \mathrm{~m}$.

Colorado: West Spanish Peak, I900, Rydberg \& I recland, 5720 (type).

Colorado or New Mexico: Canadian?. Dr. James.

\section{Polemonium speciosum sp. nov.}

A low viscid-villous plant, cespitose with a perennial rootstock. Stem I-2 dm. high with 2-3 leaves: basal leaves numerous, 8-I 5 $\mathrm{cm}$. long with wing-margined rachis; leaflets opposite, 7-9 pairs, ovate, 6-1 $2 \mathrm{~mm}$. long, acute: stem-leaves similar but smaller: inflorescence capitate: calyx viscid-villous, I $5-20 \mathrm{~mm}$. long, cleft to about the middle: lobes lanceolate, acute : corolla pale blue, deeply campanulate-funnelform, $2-2.5 \mathrm{~cm}$. long: limb about $1.5 \mathrm{~cm}$. broad.

The form of the corolla, the dense capitate inflorescence and the viscid pubescence place this species nearest $P$. riscosum, and $P$. comfortum, but the leaflets are not verticillate, the corolla is larger than that of the former and broader than in the latter.

Colorado: Mount Garfield, 1900, Fred. Clements.

\section{Gilia candida sp. nov.}

A glandular perennial with short caudex. Stems often more than one, ascending or erect, simple, 4-6 dm. high, leafy : leaves rather fleshy, divided into linear-filiform, spinulose-tipped segments; the upper gradually smaller: inflorescence a very narrow panicle: branches usually very short and few-flowered: flowers subsessile : calyx glandular-pubescent, about $\$ \mathrm{~mm}$. long; its lobes lanceolate, bristle-tipped: corolla white, or rarely pale pink, 2-3 
cm. long, salverform: its lobes oval or obovate, obtuse: stamens inserted unequally below the throat, included.

This species is nearest related to $G$. agrorigata; but differs in the white corolla and its rounded obtuse lobes: It is also lower and the upper leaves more reduced. It grows on dry hillsides at an altitude of $2000-2700 \mathrm{~m}$.

Colorado: Mesas near La Veta, 1900, F. K. Treclemel, 602 (type); Veta Pass, Igoo, Rydbirg : Froldud. 5730: Calham, I 893, Dc it. Sammdirs.

\section{Phacelia alba sp. nov.}

A viscid-villous annual or biennial, 2-4 dm. high. Stem leafy, strict and simple viscid-villous and glandular above: leaves twice interruptedly pinnatifid, about I dm. long, glandular-puberulent, hispid ciliolate on the margins and veins; ultimate segments ovate or oblong, 3-6 mm. long : inflorescence branched, dense, in flowers almost capitate, but branches in fruit spiciform : flowers nearly sessile, 2-ranked: calyx glandular, cleft to near the base: sepals broadly linear, obtuse, about $2 \mathrm{~mm}$. long, about one third shorter than the white corolla: the lobes of the latter rounded, crenate: appendages 10 , broadly ovate: stamens and style much exserted: capsule ovoid, about $6 \mathrm{~mm}$. long: seeds often solitary in each cavity, finely pitted.

This species is nearest related to $P$. Neo-Mixicam and $P$. Popit, resembling the latter most in habit, but having the viscid-pubescence and the crenate corolla-lobes of the former. It differs from both in the small white corolla and the long-exserted stamens. It grows in mountain valleys at an altitude of $1800-3000 \mathrm{~m}$.

Colorado: Sangre de Christo Creek, I900, Ryelberg \& I ricland, 5755 (type); Valley of Upper Arliansas River, I873, Ju/m Wolfe (Wheeler Expedition), 99; Headwaters of Clear Creek, I 86 I, C. C. Parry, 31 .

New Mexico: Ruidoso Creek, White Mountains, I S95, E. (). Wooton.

\section{Lappula calycosa sp. nov.}

A hirsute annual, simple below, branched above with long virgate branches. Stem hirsute, 3-4 dm. high: leaves oblong, obtuse, $3-4 \mathrm{~cm}$. long, $7-8 \mathrm{~mm}$. wide; those of the branches smaller: pedicels short, in fruit $2-3 \mathrm{~mm}$. long, generally $+\mathrm{mm}$. below the leaves; corolla pale blue, about $1.5 \mathrm{~mm}$. long and I mm. broad: calyx-lobes enlarged in $f_{1}$ it, foliaceous, $4^{-6} \mathrm{~m} m$. 
long and reflexed: fruit about $4 \mathrm{~mm}$. in diameter: nutlets surrounded by a single row of subulate glochinate prickles, somewhat flattened at the base but not united into a wing-border: back of the nutlets strongly muricate.

It is nearest related to L. occidentulis (Wats.) Greene, but differs in the oblong obtuse leaves, the enlarged and reflexed fruiting calyx-lobes, and the virgate branches. It grows in deserted fields at an altitude of about $2000 \mathrm{~m}$.

Colorado: Walsenburg, I900, Rydberg \& lredand, 5715.

\section{Lappula cupulata (A. Gray)}

Echinospermum Redowskii var. cupulerte A. Gray, Bot. Calif. I : 530. 1876.

I think that this should be regarded as distinct from L. Texana (Scheele) Britton, as the habit is quite different. L. cupulata is diffuse, branching at the base, with elongated branches, while $L$. Tixanc is simple at the base, and branched above with short branches.

L. Tcranc is a southern plant, ranging from Texas to New Mexico. The range of L. cupulata is from Nevada to Nebraska, south to Colorado.

\section{Cryptanthe minima sp. nov.}

A dwarf hirsute annual, beginning to bloom when only $\mathrm{I} \mathrm{cm}$. high. Stems several, erect, in the specimens seen only $\mathrm{I}-4 \mathrm{~cm}$. high, long hirsute: leaves spatulate or oblanceolate obtuse, hirsute on both sides, 5-1 $5 \mathrm{~mm}$. long and 2-3 $\mathrm{mm}$. wide: flowers crowded, $2.5-3 \mathrm{~mm}$. long, subsessile: lobes of the calyx linear, hispid: corolla white; limb a little over I mm. broad; nutlets whitish, about I mm. long, dissimilar; 3 ovoid, strongly muricate; the fourth somewhat larger, smooth; the inside edge with a slender groove, triangular-clilated at the base.

In size and general habit, this species is strikingly like $C$. fusilla; but the fruit is different; the nutlets being dissimilar, one of them smooth, and all with rounded lateral angles and more rounded backs. The specimens of our collection are rather young and only two fully developed fruits were found. C. mimima was found on dry hillsides at an altitude of about $2200 \mathrm{~m}$.

Colorado: Cucharas River, above La V'eta, I 900, Rydbirg \& liredend, 5697 . 


\section{Mertensia lineariloba sp. no:}

A slender perennial with glabrous simple stem, 2-3 dm. high, basal leaves $5-15 \mathrm{~cm}$. long, long-petioled; blades oblanceolate, obtuse: stem-leaves subsessile, linear or linear-lanceolate, acute, 3-6 cm. long, 4-9 mm. wide, strigose above, glabrous beneath: flower clusters 3-4-flowered in the axils of the upper leaves: pedicels very slender, 2-6 $\mathrm{mm}$. long, strigose: calyx divided to near the base : lobes linear, acute, 3-4 $\mathrm{mm}$. long, almost equaling the tube of the corolla, slabrous on the back, but hispid ciliate on the margins: corolla blue, $7-8 \mathrm{~mm}$. long, tube nearly of the same length as the throat and limb; the latter $4-5 \mathrm{~mm}$. long: stamens almost equaling the corolla: filaments dilated, and broader than the anthers.

It is nearest related to $M$. linearis, but characterized by the narrow, strongly ciliate calyx-lobes and the filiform pedicels. It grows in shaded situations at an altitude of 2500-2700 m.

Colorado: West Indian Creek, Trichera Range, I goo, Rydberg \& Irecland, $569 I$ (type); near Empire, I885. H. N. Patterson. $I I 5$.

\section{Mertensia ovata sp. nov.}

A low cespitose, somewhat fleshy perennial. Stems I-1.5 $\mathrm{dm}$. high, glabrous: leaves $2-5 \mathrm{~cm}$. long, $1-1.5 \mathrm{~cm}$. wide, minutely strigose above, glabrous beneath; the lower obovate and short-petioled; the upper broadly ovate and sessile : flower-cluster dense; pedicels very short: calyx cleft to near the base: sepals lanceolate, ciliate on the margin, about $4 \mathrm{~mm}$. long and one third shorter than the corolla-tube: corolla $10-12 \mathrm{~mm}$. long; its tube nearly one half longer than the throat and limb: the latter about $7 \mathrm{~mm}$. broad: stamens nearly equaling the corolla; filaments dilated and broader than the anthers.

This species is probably nearest related to $\%$. lancelatir: but differs in the stunted habit and the broad leaves. It grows among rocks, at an altitude of $2800-3500 \mathrm{~m}$.

Colorado: West Spanish Peak, I900, Rydberg \& Vircland, 5690 (type) and 56000.

\section{Mertensia obtusiloba sp. nor.}

A low cespitose perennial. Stems ascending, glabrous, I-2 $\mathrm{dm}$. high : lower leaves spatulate or oblanceolate, obtuse, tapering into a winged petiole, dark green, glabrous beneath, minutely strigulose above, glabrate in age, $3-5 \mathrm{~cm}$. long; the upper broadly lanceolate, sessile: flower-clusters several from the axils of the 
upperleaves : pedicels very short, often sparingly strigulose : calyx divided to near the base; sepals oblong, obtuse, ciliate on the margins, 2-3 mm. long, scarcely more than half as long as the tube of the corolla : corolla dark blue, about $7 \mathrm{~mm}$. long: tube nearly equaling the throat and limb: stamens short, included in the tube, filaments very short, not broader than the anthers.

This species is nearest related to $M$. Trucetyi, but differs in the shorter, obtuse calyx-lobes, the broader and thinner leaves and the stem which is not depressed or prostrate. It grows at an altitude of 2000-3500 m.

Colorado: Pikes Peak, I900, Fret. Clements (type); Garden of the Gods and Pikes Peak, I894, Ernst A. Bessey; Argentine Pass, 1878, Harcus E. Jones, 57 .

\section{Mertensia membranacea sp. nov.}

A tall erect perennial with a rather thich tap-root. Stem glabrous or sparingly hirsute above, 6-8 dm. high : leaves all petioled, or the upper sessile; blades ovate, acute or more often short acuminate, 4-8 cm. long, $1.5-4 \mathrm{~cm}$. wide, very thin, hispid-stringulose on both sides: flower-clusters terminal and in the axils of the upper leaves, branched and many-flowered: pedicels 5-10 mm. long, hispidulous: calyx-lobes 2-3 min. long, hispidulous, lanceolate, acute, one-third or one-fourth as long as the tube of the corolla: corolla about $\mathrm{I} \mathrm{cm}$. long; the pale blue or almost white tube longer than the dark blue limb and throat: limb about $4 \mathrm{~mm}$. broad: stamens much shorter than the limb; filaments dilated and broader than the anthers: nutlets strongly rugose and spotted.

This species is related to M. paniculate. Mr. Bessey and myself collected it in 1897 , but as the specimens were rather poor. they were referred doubtfully to that species. As more and better specimens have now been received, it has been possible to draw a description. It differs from $M$. paniculata, in the thinner leaves which almost always show an acumination, in the short calyx-lobes which scarcely enlarge in fruit and the smaller and numerous flowers. It grows in moist places at an altitude of 300-2000 m.

Inaho: Priest River, 1900, D. T. MacDongal, 3 (type); Cedar Mountain, I 892, Sendberg, Mac Dougal \& Heller, t20.

Montand: Electric Peak, 1897, Rydborg \& Bcssey, 4867 .

Mentzelia ctenophora sp. nov.

A diffuse cespitose scabrous perennial. Stems 3-6 dm. long, branched, in age straw-colored: lower leaves linear or linear-lan- 
ceolate in outline, tapering at both ends, often $2 \mathrm{dm}$. long: the upper lanceolate with a broad base: all pectinately laciniate with linear-oblong divergent obtuse lobes; hypanthium cylindrical, I 5-I $8 \mathrm{~mm}$. long; sepals ovate-lanceolate, acute, $4-5 \mathrm{~mm}$. long: petals obovate, light yellow, about $8 \mathrm{~mm}$. long: seeds irregularly angled, but not winged, finely muricate.

This species is perhaps nearest related to M. albicaulis, but differs in the large size of the plant, the diffuse habit, and the larger flowers. It was collected on railroad banks and in loose barren soil on hillsides, at an altitude of $1800-2100 \mathrm{~m}$.

Colorado: On Cucharas River, below La Veta, I 900, Rydbcrg \& Irceland, 5769 (type); near Walsenburg, 5768 .

\section{Impatiens aurella sp. nov.}

A slender glabrous annual, about $6 \mathrm{dm}$. high. Petioles I.5-3 $\mathrm{cm}$. long : leaf-blades ovate or oval, thin, bright green, a little paler beneath, $4-5 \mathrm{~cm}$. long, coarsely toothed, acute; teeth and apex finely mucronate: peduncles ascending, mostly 2 -flowered : bracts minute, linear, about $2 \mathrm{~mm}$. long: flowers orange, not mottled: sack conical, about $\mathrm{I} \mathrm{cm}$. long and $6 \mathrm{~mm}$. broad at the base; its spur recurved, about $\$ \mathrm{~mm}$. long.

This is nearest related to I. biffora, but differs in the much smaller flowers, which are scarcely more than half the size of that species and without any spots, the comparatively longer spur and less pale leaves. It grows in swamps at an altitude of about $600 \mathrm{~m}$.

IDAHO: Priest River, 1900, D. T. ILacDougal, 20.

\section{Geranium nervosum sp. nov.}

A tall peremnial with thick root and short caudex. Stems 4-8 dm. high, minutely retrorsely strigose, in age more glabrate: basal leaves with petioles $2-4 \mathrm{dm}$. long; blades reniform in outline, $8-$ $12 \mathrm{~cm}$. in diameter, finely strigose on both sides, divided to near the base into 5-7 obovate-cuneate or oblanceolate-cuneate divisions which are again 2-3-cleft and coarsely toothed: stem-leaves none, except those subtending the inflorescence; these sessile, 3-5-cleft ; branches of the cymes and calyx very densely glandular pubescent: sepals oval, $8-9 \mathrm{~mm}$. long, terminated by a filiform tip, I$2 \mathrm{~mm}$. long: petals broadly obovate, I j-I $8 \mathrm{~mm}$. long, pale violet or almost white, with dark purple streaks: carpels as well as their column densely glandular; the latter nearly $2 \mathrm{~cm}$. long: style beyond the column about $5 \mathrm{~mm}$. : seeds glabrous, minutely reticulate.

This species is somewhat intermediate between $G$. aiscosissimum 
and G. Richardsonii, having the general habit, the leaves and pubescence of the stem of the latter, but the densely glandular pubescence of the inflorescence and the calyx and carpels of the former. The color of the flower is most like G. Richardsonii, but scarcely pure white and with much more prominent veins. It grows at an altitude of $\mathrm{I} 800-2700 \mathrm{~m}$.

Wroming: Fish Creek, Teton Forest Reserve, 1897, F. Tiucedy', $79+$ (type).

Colorado: Continental Divide, Routt County, I894, C. S. Crandall.

\section{Lupinus candicans sp. nor.}

A low cespitose perennial, densely white-silky throughout. Stems ascending, I.5-2 dm. high, 3-4-leaved, often branched: stipules linear subulate, $5-8 \mathrm{~mm}$. long: petiole $3-8 \mathrm{~cm}$. long : leaflets about 7 , densely white-silky and shining, $1.5-2.5 \mathrm{~cm}$. long, oblanceolate, acute, mucronate, mostly conduplicate : raceme rather dense, $3-S \mathrm{~cm}$. long on a peduncle $2-5 \mathrm{~cm}$. long: bracts small and early deciduous: calyx densely silky-villous, only slightly saccate on the upper side; lower lobe about $4 \mathrm{~mm}$. long: banner dark blue with a light brown spot, about $7 \mathrm{~mm}$. long, very broad, and with the sides strongly reflexed; wings dark blue, as well as the banner glabrous, about $9 \mathrm{~mm}$. long and about equaling the keel: the latter whitish, tipped with dark purple: pod densely white-silky, 3-4-seeded.

This species has the white pubescence of $L$. scricuts and $L$. Hcllerac; but is in every way a much smaller and more cespitose plant: the flowers are much smaller and of a darker and more intense blue.

Montana: (locality not given), I900, E. I . IIIlcos, f5I (type in U. S. Nat. Herb.) ; Boulder, 125 and 129 , in part; Big Timber, 385; Highwood Mountains, t2; Columbia Falls, I $897, R . S$. llilliams.

\section{Lupinus cyaneus sp. nov.}

A stout and tall perennial with rather simple caudex. Stem 4-9 dm. high, densely villous, but not white, very leafy and in age somewhat branched: stipules subulate, over $1 \mathrm{~cm}$. long: petioles 5-10 cm. long: leaflets 7-I I, oblanceolate, 3-9 cm. long, glabrous above, almost velvety beneath, acute: raceme long and dense. I. 5-2 dm. long: bracts rather persistent, often over I cm. long: flowers very numerous, $2-4 \mathrm{in}$ each verticil, very short-pediceled : calyx white-velvety, somewhat saccate above: lower lobe about 
$8 \mathrm{~mm}$. long: banner slightly hairy on the back, light blue, with a light brownish spot at the center, about $8 \mathrm{~mm}$. long : wings light blue, about $1 \mathrm{~cm}$. long, equaling the keel, which is whitish with purple tip: pod densely silky-villous, about $25 \mathrm{~mm}$. long and 8 mm. wide, $4-5$-seeded.

This species has the general habit and the long dense raceme of I. lcucophyllus, but is much greener and the flowers are much smaller and lighter in color. No. 435, cited below, is referred here doubtfully. It is more silvery and more branched and had apparently almost white flowers.

Montana: (locality not given), I 900, E. Ir. Hilcox, +76 (type in U. S. Nat. Herb.) ; Coal Spur, $\$ 35$ (?) and +79 (the latter in fruit): Gallatin Valley, I $896, J$. H. Flodman, 617.

\section{Astragalus sulphurescens sp. nov.}

A light green cespitose perennial. Stems ascending, about 4 dm. high, angled, glabrous, somewhat branched: stipules ovate to lanceolate, membranaceous, free from the petioles : leaflets I $3-19$, elliptic, obtuse or acutish, mucronulate, $12-30 \mathrm{~mm}$. long, with a few scattered strigose hairs: spike dense and elongated: flowers ascending: bracts lanceolate-subulate, about $8 \mathrm{~mm}$. long: calyr white-strigose with scattered black hairs: tube about $5 \mathrm{~mm}$. long: lobes almost filiform, fully $5 \mathrm{~mm}$. long: corolla light yellow: banner narrow, I5-I $8 \mathrm{~mm}$. long, much exceeding the wings and keel : wings very narrow, only about $\mathrm{I} .5 \mathrm{~mm}$. wide : pod 2 -celled, with dorsal suture deeply inflexed, deeply obcordate in section, about $\mathrm{I} \mathrm{cm}$. long, 3-4 mm. wide, strigose, with black hairs.

This species is closely related to $A$. adsurgens, but differs in the yellow, ascending flowers, narrow petals, more scant pubescence, the long slender calyx lobes and the black hairy pod. It grows at an altitude of $1600-3000 \mathrm{~m}$.

Colorado: Georgetown, i 895, P. A. Rydberg (type); along Platte River, Denver, i 878 , M. E. Jones, 851 .

\section{Aragallus villosus sp. nov.}

Densely and intricately cespitose perennial. Leaves basal, numerous, 5-IO cm. long: leaflets 25-31, rather crowded but not verticillate, $\mathrm{I}-1.5 \mathrm{~cm}$. long, lanceolate, very acute, densely but somewhat loosely silky: scape about I.5 dm. long, loosely silky, almost hirsute, with spreading hairs: spike dense, $4-5 \mathrm{~cm}$. long: bracts linear or narrowly linear-lanceolate, $8-10 \mathrm{~mm}$. long: calyx 
white-silky villous: lobes very short, about $2 \mathrm{~mm}$. long : corolla ochroleucous without any purple, I $2-15 \mathrm{~mm}$. long: keel very short and round, abruptly tipped with a small tip: pod thin, perfectly 2-celled, white-silky, about $1.5 \mathrm{~cm}$. long, more than twice as long as the calyx, tipped with a slender beak which is abruptly hooked at the apex.

This belongs to the A. campestris group and is characterized by the coarse spreading pubescence of the scape and the ochroleucous flowers without any trace of purple.

Montand: Craig, I 900, E. I I Itilcox, 378 (type in U. S. Nat. Herb.).

\section{Trifolium lilacinum sp. nor.}

A densely cespitose dwarf subscapose perennial with very deep root. The short branches of the caudex covered with the scarious stipules and remains of old leaves: leaves 3 -foliolate, bright green ; petioles $2-5 \mathrm{~cm}$. long, strigose : leaflets elliptic or lanceolate-oblong, acute at each end, $\mathrm{I}-2.5 \mathrm{~cm}$. long, strigose: peduncle $5-\mathrm{I} 2$ $\mathrm{cm}$. long, bracts minute, less than $1 \mathrm{~mm}$. long, 3 -toothed: flowers reflexed in fruit: calyx densely strigose; tube $3 \mathrm{~mm}$. long; teeth subulate-filiform, 4-6 mm. long: corolla pale rose-purple or lilac, in age turning light brownish, about I cm. long; banner straight and obtuse.

This species is related to T. dasyphlllum; differing in the minute 3 -toothed bracts and their shorter and comparatively broader leaflets. It is still nearer related to T. acmminatus Greene ; from which it is distinguished by the smaller flowers and the not acuminate banner. It is an alpine plant growing among rocks at an altitude of about $3000 \mathrm{~m}$.

Colorado: West Spanish Peak, I900, Rydberg \& Irccland, 5950 (type), 5951 and 59,52 .

\section{Lathyrus leucanthus sp. nov.}

A glabrous or slightly pubescent perennial with a very slender rootstock. Stem about $3 \mathrm{dm}$. high, angled: stipules very narrow, semi-sagittate: leaflets 2-4 pairs, elliptic, veiny, glaucous, acute, mucronate, $1-3 \mathrm{~cm}$. long, 3-10 mm. wide: tendrils of the lower leaves mere tips; of the upper elongated and sometimes 3-divided: racemes short, in the axils of the middle leaves, $3-4 \mathrm{~cm}$. long, 2-4-flowered: calyx glabrous, cleft to about the middle: lobes lanceolate, acuminate: corolla white, about $15 \mathrm{~mm}$. long: banner broad. 
Rrdberg: Studes on THE Rucky Moundan Fior. 38

This is nearest related to I. Arisonicns, but differs in the broader leaves and banner. It grows at an altitude of $2400-$ $3000 \mathrm{~m}$.

Colorado: Ojo, 1900, Rydberg \& I reeland, 6020 (type); Pass Creek, 6021; West Indian Creek, 6022; mountain near Veta Pass, 602.3; Veta Pass, I890, Mr. and M/rs. G. H. Hicks, 19: Ridgway, I895, F. Tueced', 239. 

CONTRIBUTIONS FROM THE NEW YORK BOTANICAL GARDEN-No. 14

\section{STUDIES ON THE ROCKY MOUNTAIN FLORA-V.}

BY P. A. RYDBERG

NEW YORK

1901 



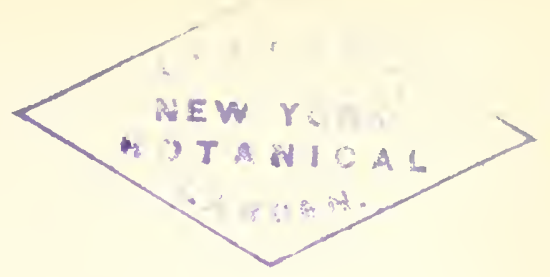

\title{
Studies on the Rocky Mountain Flora, - V.
}

\author{
By P. A. RYumirg
}

\section{Sporobolus aristatus sp. nov.}

Vilfe depauperate var. filiformis IVats. King's Exp. 5: 376, in part (as to the awned form). IS7I. Not Thurb.

Perennial with short branching rootstock. Culm usually only 4-6 cm. high : internodes short, usually covered by the open strongly striate sheath ; ligules lanceolate, acute, about $\mathrm{I} .5 \mathrm{~mm}$. long: leafblades $8-14 \mathrm{~mm}$. long, and about I $\mathrm{mm}$. wide, striate and puberulent on the upper surface: panicle few-flowered, very narrow, with short erect branches; empty glumes almost equal, or the inner slightly longer, I-I.25 mm. long, less than half as $\operatorname{long}$ as the flowering glume, ovate, acutish or obtuse and somewhat erose at the apex: flowering glume about $2.5 \mathrm{~mm}$. long, strongly veined, long-strigose on the veins and tipped with an awn . 5- $\mathrm{mm}$. long; palet almost equal to the flowering glume (awn excepted) in length, acuminate, but not awned, strigose.

This species is closely related to S. filiformis (Thurb.) Rydb. differing in the lower habit, less exserted panicle, firmer empty glumes and the presence of a distinct awn. It grows in wet places at an altitude of 2000-2500 $\mathrm{m}$.

Wroming: Big Horn Mountains, Sheridan Co., IS99, F. Ticeedy, 2196 (type); Spread Creek, 1897, 27.

Utah: Bear River Cañon, i 869, S. Watson, I $2 \&_{1 .}$.

\section{Poa platyphylla Nash \& Rydb.}

Poa trizialis var. occidentalis Vasey, Desc. Cat. Grasses 85 . I S85. Not Poaflexuosa var. occidentalis Vasey. I 878.

Poa occidentalis Vasey, Cont. U. S. Nat. Herb. I : 275. I $\$ 93$.

\section{Carex ebenea sp. nov.}

Perennial by a cespitose rootstock. Stem 2-4 dm. ligh, strongly striate; sheath with a conspicuous membranaceous ligular portion, ligule proper rounded, about $2 \mathrm{~mm}$. long; leaf-blades flat, I-2 dm. long, 3-6 mm. broad, strongly nerved: spikelets about I cm. long in a dense globular or rounded-conical head: 
shining, brownish black with a lighter midrib, lanceolate, acute, 3-4 mm. long: perigynia lanceolate, tapering gradually into a long beak, with the beak about $5 \mathrm{~mm}$. long, dark brown; staminate flowers at the base and mixed with the pistillate: upper portion of the wings and the beak scabrous on the margins; teeth at the apex of the beak very short, subulate: styles 2 : achene oblong, lenticular, nearly $2 \mathrm{~mm}$. long and fully $\mathrm{I} \mathrm{mm}$. broad.

This species is nearest related to $C$. fistici $x$ and has been labeled C. festiva Haydeniana, but it is not the same as the original of that variety, which has broadly ovate perigynia. C. cbenca differs also from all forms of $C$. festic'a in the form of the perigynia and in the dark glossy color of the bracts and perigynia.

Colorado: Pikes Peak, I900, F. Clements (type); Windy Point, I900; Mt. Harvard, I 896, 7 ; Grecian Bend, I \$96, Bottomless Pit, and Saddle, Clements; between Cheyenne Mountain and Seren Lakes, I896, E. A. Bessey"; Ironton, is99, C. C. Curtis; Telluride, I 894, F. Tu'cedy, I9t; Chambers Lake and Cameron Pass, is96, C. F. Baker; Clear Creek Cañon, is78, M. E. Jones, 267 ; Silver Plume, I 895, Ry'dberg, 2460; Pagosa Peak, I899, C. F. Baker, 233 .

\section{Streptopus curvipes Vail sp. nov.}

Simple, glabrous, except the margins of the leaves and the peduncles. Stems $\mathrm{I}-3 \mathrm{dm}$. high, from a slender rootstock covered with few fibrous rootlets: leaves sessile, oval or oblonglanceolate, $3-8 \mathrm{~cm}$. long, acuminate at the apex, rounded and slightly clasping at the base, $3-5$-nerved, the margins finely glandular-ciliate: flowers $3-5$, solitary: peduncles not geniculate, 5-15 $\mathrm{mm}$. long, glandular-pubescent: flowers pale purple or rosecolored: perianth-segments lanceolate, $5-7 \mathrm{~mm}$. long, minutely glandular-pubescent on the inner surface: anthers 2-beaked; beaks slender, about half the length of the anther: style 3 -cleft, the spreading branches stigmatic along the inner side: berry globose, when mature brick red, 7-9 mm. in diameter : seeds clavate, 3-4 $\mathrm{mm}$. long, with many cross-striate ridges.

Differs from Strcptopus roscus in its simple habit and the nongeniculate and much shorter peduncles. The beaks of the anthers seem to be a trifle longer than in S. rosens. It is closely related to S. brevipes Baker, but is larger and coarser in every respect. The flowers of the latter species are not known.

British Columbia: Asulkan Pass, alt. $4400 \mathrm{ft}$, June to July, 
I 897 , Mrs. Zö̈W. Palmer (type); Glacier, alt. 41 $22 \mathrm{ft}$., June to July, I 897, Mrs. Zö HI. Palmor; Glacier, June, I 897, Mr. \& Mrs. Cornelius Lan Brunt.

Alaska : Juneau, along the mountain side, July 24, I 89 I, Miss Grace E. Coolcy' Yes Bay, July I0, I 895, Thomas How'll, I66, (all in Herb. N. Y. Botanical Garden or Columbia University); Ford. Bishoff.

OrEgON: E. Hall, 521 .

Washingtox: Skamania Co., Aug., is86, Suksdorf; Mt. Adams, 3-400 ft., Suksdorf, ft; June, I 879, J. How Holl (the last five specimens in Herb. Gray).

\section{Vagnera brachypetala sp. nov.}

A tall stout perennial, 5-S dm. high. Stem striate, puberulent, especially the upper portion: leaves subsessile or shortpetioled, oval or ovate, $8-18 \mathrm{~cm}$. long, $4-7 \mathrm{~cm}$. wide, often shortacuminate and tivisted at the apex, with $5-7$ stronger nerves and numerous weaker ones: panicle on a peduncle 4-5 cm. long, rather dense, $3-10 \mathrm{~cm}$. long and $2-5 \mathrm{~cm}$. broad : petals and sepals oblong, $\mathrm{I}-1.5 \mathrm{~mm}$. long, scarcely half as long as the broadly dilated, lanceolate-subulate petaloid filaments: style about $.5 \mathrm{~mm}$. long: berry dark purple, about $6 \mathrm{~mm}$. in diameter.

This species is closely related to $T^{r}$. racemosa and $T^{r}$. amplexicaulis, perhaps most nearly to the former, but is easily distinguished by the short petals and the purple fruit. In $T$. racomosa the petals and sepals are almost as long as the filaments and the fruit is $7-8 \mathrm{~mm}$. in diameter and red with purple spots. IT. brachypctala grows on hillsides up to an altitude of $2500 \mathrm{~m}$.

British Columbia: Glacier, at the "Loup," 1897, Mr. \& Mrs. Cornelins I'an Brunt (in fruit, type); Deer Park, Columbia River, I 89o, Jolm Macoun; Victoria, Vancouver Island, I 893, Jolun Macoun, 5998 .

IVashington: Seattle, $189 \mathrm{I}$, C. $I^{\prime}$. Piper, $19 S$.

IDAно: Lake Waha, IS92, Sandberg, Mac Dougal \& Heller. $22 S$.

\section{Vagnera leptopetala sp. nov.}

A slender glabrous perennial, 2-3 dm. high. Rootstock very slender for the genus, white, only about $2 \mathrm{~mm}$. in diameter: stem erect, strict or the upper portion somewhat zigzag, striate and pale: leaves oblong-lanceolate, $6-8 \mathrm{~cm}$. long, $1-2 \mathrm{~cm}$. wide, light 
green, sessile, long-acute, with $3-5$ stronger nerves and I 2-I4 weaker ones: raceme terminal, simple, 3-6-flowered: pedicels 5-8 mm. long: petals and sepals linear, acute, about $4 \mathrm{~mm}$. long and less than $\mathrm{I} \mathrm{mm}$. wide, very thin, white: fruit not seen.

This species is nearly related to $V$. stcllata and $V$. litiacca, but differs in the narrow petals and sepals, the slender rootstock and the lighter green foliage. It grows in rich soil in cañons at an altitude of 2000-2100 $\mathrm{m}$.

Colorado: Headwarters of Sangre de Christo Creek, 1900, Ryelberg \& I'recland, 6+tI (type); Dark Cañon, Pikes Peak, 1900, Fred Clements.

\section{Limnorchis purpurascens sp. nov.}

A rather stout plant, 3-5 dm. high, with fleshy-fibrous roots. Leaves ovate to lanceolate, acute, $6-10 \mathrm{~cm}$. long, $1.5-3 \mathrm{~cm}$. wide, dark green : bracts lanceolate, the lower exceeding the flowers: spike rather dense: flowers IO-1 $2 \mathrm{~mm}$. long: lateral sepals green, oblong-linear, or linear, obtuse, 4-5 $\mathrm{mm}$. long; the upper sepal tinged with purple, broadly ovate, erect, obtuse : petals slightly shorter, erect, purple, lanceolate, oblique: lip broadly linear-lanceolate, about $5 \mathrm{~mm}$. long, purplish, scarcely at all dilated at the base, the edges almost straight : spur scarcely more than half as long as the lip, much thickened and saccate.

This species belongs to the L. hyperborea group, and is perhaps nearest related to that species. It differs, however, in the purple petals and lip and the shorter and more saccate spur. The spur has almost the same form as that of L. stricta; but from that species it differs in the dense spike and the broader lip. L. purpurescens grows in damp woods at an altitude of 2700-3000 $\mathrm{m}$.

Colorado: Iron Mountain, igoo, Rydberg \& Trecland, 6fIt (type): Manitou, I900, Fred Clcments, I72; Georgetown, I 878 , II. E. Jones, iIf.

\section{Piperia gen. nov.}

Montolizaca Rydb. Mem. N. Y. Bot. Gard. I : I06. I 900. Not Reichenb.

Professor C. V. Piper of the Agricultural Experiment Station at Pullman, Washington, has called my attention to the fact that the genus Montolinaca was based not on Platanthera clegans Lindley, or Habenaria elegans Bolander; but on Montolivaca clegans Reich- 
enb., or Habenaria digans Jackson, of a much later date. The genus that I shortly characterized under the name of Montoliari ? in the Memoir cited above, is therefore without a name. As I find that no genus has at yet been dedicated to Professor Piper, I take the pleasure in naming this for him. The genus contains at least three species, viz.

\section{Piperia elegans (Lindl.)}

Platanthera clegans Lindi. Gen. \& Sp. Orch. $285 . \quad$ I 835.

Habenaria elegans Boland.; Wats. Bot. Calif. 2: I 33. I 876. Montolivaea clegans Rydb. Mem. N. Y. Bot. Gard. I : Io6. I900. Not Reichenb.

\section{Piperia Unalaschensis (Spreng.)}

Spiranthes Unalaschinsis Spreng. Syst. 3: 708. I 826.

Habenaria Unalaschensis Wats. Proc. Am. Acad. I2: 277. I $S 76$.

Montolizaca Linalaschensis Rydb. Mem. N. Y. Bot. Gard. I : I07. I 900 .

\section{Piperia elongata sp. nov.}

A slender strict plant, 4-7 dm. high. Corm ellipsoid, about 2 $\mathrm{cm}$. long and I $\mathrm{cm}$. in diameter: leaves 2 , near the base; blades lanceolate or oblanceolate, acute, $8-15 \mathrm{~cm}$. long, $\mathrm{I}-2 \mathrm{~cm}$. wide: spike elongated and lax, $2-3 \mathrm{dm}$. long: flowers about $\mathrm{I} \mathrm{cm}$. long: sepals green, about $5 \mathrm{~mm}$. long, the upper lanceolate, the other two linear obtuse : petals lanceolate, oblique, equalling the sepals: lip entire, broadly lanceolate : spur slender, scarcely clavate, almost cylindrical, arcuate, I O- $12 \mathrm{~mm}$. long, about .7 $\mathrm{mm}$. thick.

This is somewhat intermediate between the two preceding. It has almost the same flowers as the first and the general habit of the second. P. clegans, with which it has generally been confused, has a stouter, more fleshy stem, thicker bracts and a short crowded spike. P. Unalaschensis has the same habit as the present species, but the spur is very short and saccate. P. elongata grows in open woods, up to an altitude of $700 \mathrm{~m}$.

IDAho: Priest Lake, near lower end, I 900, D. T. MacDongal, I68 (type); Priest River Valley, 37.

Wasinngton: W. Klickitat County, i $885, W$. . T. Suksdorf; Seattle, I 889, C. I'. Piper, Io\&I. 


\section{Corallorrhiza Vreelandii sp. nov.}

Scape rather stout, 2-4 dm. high, dark purplish brown. Sheaths, especially the lowest one, much inflated, purplish brown with dark purple striations: flowers 6-I 5 , about i $5 \mathrm{~mm}$. long, in fruit drooping : sepals oblong, $7-8 \mathrm{~mm}$. long, brown with 3 purple stripes: petals similar but slightly broader and with 4 stripes: lip ovate, entire, with a small gibbosity at the base: spur none.

This is nearest related to $C$. striata, from which it differs in the smaller flowers and narrower sepals and petals. The type was found growing among alders and willows at the margin of a small lake, at an altitude of about $2700 \mathrm{~m}$. It was first discovered by Mr. F. K. Vreeland, my enthusiastic associate and pleasant companion in field work last summer.

Colorado: Veta Mountain, I900, Rydberg E Trecland, 6.tIS.

\section{Salix Wyomingensis sp. nov.}

A shrub I m. high or less. Bark of the main trunk gray; that of the branches dark-brown or grayish, shining, somewhat flaky; young branches appressed-villous; buds brown, shining, pubescent when young: leaves small, rather crowded; petioles 2-4 $\mathrm{mm}$. long; blade oval or obovate, acute, $\mathrm{I}-3 \mathrm{~cm}$. long, entire or exceedingly minutely-callous-denticulate, upper surface green and shining, slightly pubescent when young, glabrate in age; lower surface pale bluish green, appressed silky-villous: aments borne on very short leafy branches, about $3 \mathrm{~cm}$. long, 8-10 $\mathrm{mm}$. in diameter: bracts brown, oblong or ovate, obtuse: pedicels scarcely I $\mathrm{mm}$. long: ovary villous, but green, when fully developed only about $3 \mathrm{~mm}$. long: style. $5 \mathrm{~mm}$. long: stigmas short, slightly 2-cleft.

This species is nearest related to S. glaucops Anderson, but differs in the small oval or obovate leaves and the much smaller and greener ovaries. It grows at an altitude of $2100-2700 \mathrm{~m}$.

Wroming: Eastern Slope of Big Horn Mountains, headwaters of Clear Creek and Crazy Woman River, I 900, F. Truccdy, 3434 (type) and 3733 .

\section{Salix stenophylla sp. nov.}

A shrub $2-5 \mathrm{~m}$. high. Bark of older stems light brownish green, smooth; that of the slender strict branches brown: young shoots silvery pubescent: leaves narrowly linear, $3-7 \mathrm{~cm}$. long, about $3 \mathrm{~mm}$. wide, acute, entire or minutely and distantly denticulate, permanently finely silky strigose, but not white: pistillate 
aments 3-4 cm. long at the ends of short leafy branches: bracts yellow, oblanceolate, deciduous, acute, 2-2.5 mm. long, rather sparingly silky-villous: pistil green, about $4 \mathrm{~mm}$. long. glabrous except the swollen portion at the end just below the red stigma: stipe about I mm. long: style none: stigma minutely 4-lobed: fruit glabrous, narrowly ovoid-conic, about $6 \mathrm{~mm}$. long, and I.5 $\mathrm{mm}$. in diameter: staminate aments $2-3 \mathrm{~cm}$. long, $5 \mathrm{~mm}$. in diameter: bracts like those of the pistillate aments, but more obtuse and more villous: stamens 2, about twice as long as the bracts: filaments slightly hairy, especially below.

This species is a member of the longifolid group and nearest related to S. exiguc Nutt., at least as understood by Professor Rowlee; but differs in the narrower leaves, the distinct stipe and the peculiar swelling just below the stigma. It grows on river banks up to an altitude of $2500 \mathrm{~m}$.

Colorado: Cuchara River, below La Veta, igoo, Rydbirg \& Irecland, 6392 (staminate flowers) and 6393 (pistillate, type); Mancos, IS98, Baker, Earle \& Tracy, I 27 (staminate) and $I O 2$ (pistillate in fruit).

New Mexico: i $8_{5}$ I-2, Wright, IS $7+$ and $18_{75} ;$ i $S_{47}$, Fentler, $\mathcal{S}_{13}$.

Arizona: San Francisco Mountains, i S8 i, Rusby', 371 .

\section{Salix padifolia sp. nov.}

A shrub I-7 m. high, with light brown smooth bark. Toung twigs strict, glabrous and shining, yellow, or often brown or purple: stipules ovate or rounded, glandular-dentate: leaves with petioles $58 \mathrm{~mm}$. long; blade oval or broadly elliptic, crenate, short-acute or obtusish, rounded at the base, $3-5 \mathrm{~cm}$. long, $1.5-2 \mathrm{~cm}$. wide, when young sparingly covered with silky hairs, but soon glabrate. dark green above, paler beneath: pistillate aments $3-4 \mathrm{~cm}$. long, densely flowered, appearing usually before the leaves, borne on very short branches and subtended by $\mathrm{I}-4$ small leaves: bracts obovate, fuscous, covered on the outside with white wool: pistils nearly sessile, glabrous: style about $1.5 \mathrm{~mm}$. long: stigmas 2, nearly I $\mathrm{mm}$. long, 2-cleft: capsules ovate-conic, about $6 \mathrm{~mm}$. long: staminate aments almost sessile, $2-3 \mathrm{~cm}$. long, IO-I $2 \mathrm{~mm}$. in diameter: bracts as those of the pistillate aments: stamens 2; filaments glabrous.

This is a species of the cordata group and nearest related to S. Mackeniana; but differs in the shorter oval leaves, the shorter and thicker aments and the exceedingly short stipes. It has gen- 
erally been referred to S. cordate; but has much thicker and shorter aments and the leaves are quite different, thin, very short and broad, never acuminate and never sharply serrate. It grows along streams at an altitude of 2000-3000 m.

Colorado: Tributaries of Turkey Creek, I900, Rydborg \& I'reclenul, 6,389 (fruit, type); Ojo, 6386 (staminate) and 6,87 (pistillate); Pass Creek, 6388 (pistillate); Los Pinos, I $S_{99}, B a k c r$, 27I: Bob Creek, I 898, Baker, Earle \& Tracy, I75; Silverton, I $895, F$. Triectly', 268 (?).

Wronixg: Golden Gate, I S99, Ainn \& Elicrs Netson, $55+9$.

Montana: Ten miles east of Monida, is99, Aven \& Elias Nelson, $5+27$.

\section{Salix flava sp. nov.}

A shrub or small tree, 4-7 m. high, with grayish yellow rough bark. Branches short and divergent, light yellow, smooth and shining: stipules rounded, entire: leaves with petioles $2-6 \mathrm{~mm}$. long; blades lanceolate, short-acuminate or acute, entire or indistinctly crenulate, rather firm, yellowish green, glabrous on both sides, $3-7 \mathrm{~cm}$. long: pistillate aments $2-3 \mathrm{~cm}$. long, almost sessile, subtended by $\mathrm{I}-2$ leaves or naked: bracts very short, obovate, fuscous, densely long-woolly : pistil stipitate, glabrous; stipe in fruit often $2 \mathrm{~mm}$. long: style about $.5 \mathrm{~mm}$. long: stigmas oblong, subentire: capsule ovate, about $6 \mathrm{~mm}$. long: staminate aments 2-3 cm. long, sessile: bracts as in the pistillate aments: stamens 2 ; filaments glabrous.

This is also a member of the cordata group and nearest related to S. lutca Nutt., differing in the less acuminate and subentire leaves, which are not paler beneath, and the longer stipes. It grows along streams at an altitude of $1500-2000 \mathrm{~m}$.

Wroming: Green River, i S95, Rydborg (type); Spread Creek, I 897, F. Trued dy, 302.

Montana: Boulder River, isss, F. Tuecely, $6_{3}$.

IDAho: Beaver Cañon, i 895 , Ryelberg.

Nerada : Unionville, i 868, S. ITatson, I097.

UTAH: Wahsatch Mountains, I S69, S. W'atson, Iog6, in part.

Colorado: South Park, i 873,J. Wolfe; Cucharas Valley, near La Veta, I900, Rydberg \& F recland, 6377; Manitou, is78, M. E. Jonis, 30 .

\section{Blitum hastatum sp. nov.}

A slender annual, 2-4 dm. high. Leaves very thin; blades 
3-7 cm. long, ovate or ovate-lanceolate in outline, but often hastately lobed at the base, which is broadly cuneate and decurrent on the slender petiole; the upper ones smaller and generally not hastate: lower petioles $2-4 \mathrm{~cm}$. long; flowers in small glomerules in the upper axils and on a slender interrupted terminal spike: seeds brownish black, smooth and shining, about I mm. long.

This species differs from $B$. cafitatum in the hastate or entire, never toothed, thin leaves and in the inflorescence which is more inclined to be naked above, more lax and with smaller glomerules. It grows at an altitude of 2000-3000 m.

Wyomixg: Buffalo, 1900, F. Trucedy, 3295 (type).

Utaн: Alta, Wahsatch Mountains, is79, M. E. Joncs, $I I S I$.

Nevada: Above Thousand Springs Valley, is68, S. T'atson, 977.

\section{Alsine Curtisii sp. nov.}

Slender, erect, branched, 2-6 dm. high with a slender horizontal rootstock. Stem sharply f-angled, glabrous, except at the inflorescence : leaves linear or lance-linear strongly I-nerved, sessile, rounded and half clasping at the base, long-attenuate at the apex, 3-6 cm. long, 3-5 mm. wide, those of the inflorescence smaller: branches of the many-flowered cymes divergent, very viscid-pubescent: sepals about $3 \mathrm{~mm}$. long, thick, ovate-oblong, obtuse or acutish with a narrow white margin: petals about $7 \mathrm{~mm}$. long, cuneate with a broad and deep sinus at the apex: seeds very few, dark brown, almost $2 \mathrm{~mm}$. in diameter.

This species is nearest related to $A$. Jamesii and has been confused with it; the differences are mostly in the leaves and sepals. In $A$. Curtisii the former are scarcely half as wide as those of $A$. Jamesii, and the sepals of the former are rather thick while in the latter almost membranous. A. Curtisii grows at an altitude of I 800 to $3000 \mathrm{~m}$.

Wyoming: Headwaters of Cliff Creek, igoo, C. C. Curtis (type).

UTAн: Wahsatch Mountains, I 869 , S. ITotson, I59 (in part); Beaver Valley, I877, E. Palmor, $5 I_{1} \mathrm{I} ;$; Alta, Wahsatch Mountains, I 879, M. E. Jonc's, I I60.

NevadA: East Humboldt Mountains, is68, S. Hatson, I59 (in part).

Arizoxa: Mogallon Mountains, iSSI, H. H. Rushy'. 


\section{Arenaria confusa sp. nov.}

A slender diffuse plant with cespitose, perennial, but not ligneous base. Stems slender, branched, 4-6 dm. long, finely puberulent: leaves opposite, linear-lanceolate, pointed, with a strong midrib, puberulent, $I-2 \mathrm{~cm}$. long: pedicels in fruit divergent, about $\mathrm{I} \mathrm{cm}$. long, slightly bent under the calyx : sepals linear-lanceolate, acuminate, scarious-margined, not tuberculate-punctate, about $3 \mathrm{~mm}$. long: petals about three fourths as long as the sepals: capsule broadly ovoid, about $4 \mathrm{~mm}$. long.

This species is related to $A$. Lam ginoser and $A$. satos $\alpha$, and somewhat intermediate between the two. In habit it resembles most the former, but does not have the subverticillate or fascicled leaves ; the sepals are narrowly lanceolate instead of ovate and not tuberculate-punctatc, the stem is not retrorsely pubescent as in that species and the petals are larger. In all specimens of A. lamuginosa seen by me the petals are either lacking or not more than half as long as the sepals. A. sarosa is subligneous at the base, has low stems, short leaves, mostly less than $1 \mathrm{~cm}$. long and sepals even in flower 4-5 mm. long. Dr. B. L. Robinson, in the Synoptical Flora, remarks under A. alsinoides (A. lannginosa): "A more western form, represented from New Mexico by Fendler's 58 and 62 and Wright's 864 , has slightly firmer stems, more numerous subpaniculate flowers, and leaves less narrowed at the base. In all these respects it shows a transition to the following." I have not seen the numbers of Fendler's collection cited; but Wriglnt's 864 as represented in Columbia University Herbarium belongs to A. confuse. On the sheet of Rusby's 38 , cited below, found in the Columbia University herbarium, Dr. Robinson has written in pencil: "Apparently this is merely a lax form of A. saxose Gray. The earliest leaves are crowded, the upper internodes much elongated, and later flowers are always smaller. (B. L. R.)" Wilcox's plant cited below was also determined by Dr. Robinson as A. sarosi. Both of these agree perfectly, however, with Wright's specimens; but neither with our material of A. lamuginosa from the Southern States and Mexico, nor with the type of $A$. saxosa. A. confusa grows in cañons at an altitude of $2000-3500 \mathrm{~m}$.

New Mexico: White Mountains, IS97, E. O. IVooton, 295 (typc); is 851, C. Wright, $s 6+$; Burrow Mountains, r $880, H$. $H$. Rusby, is. 
Arizond: Ft. Huachuca, is92, T. E. Wilcort; Rincou Nountains, I891, Nially', II9; Flagstaff, I 894, J. WV. Toumy'.

Colorado: La Plata Mountains, I896, F. Taveedy, t26; Wahatoya Creek, I900, Rvelbers \& Trecland, 627t; Pagosa Peak, is99, C. F. Baker, 300.

\section{Delphinium ramosum sp. nov.}

A tall perennial, often $2 \mathrm{~m}$. high. Stem glabrous and shining up to the inflorescence, often tinged purplish or bluish: petioles I-I.5 dm. long; leaf-blacle glabrous above, finely puberulent beneath, divided near the base into $5-7$ segments, which are $4-7 \mathrm{~cm}$. long, oblanceolate or obovate, cuneate in outline, unequally 3 -cleft and these segments again cleft into oblong or lanceolate lobes 3-6 $\mathrm{mm}$. broad: inflorescence with slender branches, these sparingly and finely puberulent: bracts linear-subulate, 5-10 $\mathrm{mm}$. long: pedicels slender, $1-3 \mathrm{~cm}$. long: bractlets filiform, $2-5 \mathrm{~mm}$. long, inserted $2-5 \mathrm{~mm}$. below the calyx: sepals dark blue, striately nerved, slightly brownish at the base, about I $\mathrm{cm}$. long, ovate; the upper and lower ones acute; the lateral ones obtuse, all puberulent : spur about I cm. long, straight, or slightly curved at the apex: upper petals dirty-white, tinged with brown and blue, about $8 \mathrm{~mm}$. long: spur slender, almost I cm. long: lateral petals dark blue, bearded, with a slender claw, somewhat corniculate, bent at right angles and only slightly 2-lobed at the apex: follicles 3, I 2-I 5 $\mathrm{mm}$. long, somewhat spreading and with divaricate beaks.

This species has without doubt been included in D. scopulumm, but is evidently distinct from the type of that species. It is taller, with more branched inflorescence, glabrous stem and the flowers are usually tinged with brown at the base. The type of D. scopulormm has narrow, very acute and divergent lobes of the leaves and the calyx is purely dark blue. D. ramosum grows at an altitude of 2000-3000 $\mathrm{m}$.

Colorado: North Cheyenne Cañon, i 896, E. A. Bessey (type); also in Williams Cañon, Artists Glen and other places near Pikes Peak; "Colorado," I 889 , Alice Eastüood.

\section{Delphinium robustum sp. nov.}

A tall and stout perennial, often $2 \mathrm{~m}$. high or more. Stem leafy; striate, puberulent throughout, often I $\mathrm{cm}$. in diameter at the base; petioles $1-2 \mathrm{dm}$. long, puberulent; leaf-blade finely and 
sparingly puberulent on both sides, divided to the base into $5-7$ segments, which are $6-\mathrm{I} 2 \mathrm{~cm}$. long and twice cleft into linear lobes 3-5 $\mathrm{mm}$. broad: inflorescence branched, densely many-flowered: pedicels $\mathrm{I}-3 \mathrm{~cm}$. long, rather stout, usually equalled or surpassed by the linear bracts: bractlets filiform, 5-IO $\mathrm{mm}$. long, inserted close under the calyx: sepals dark blue, paler at the base, elliptical, all cxcept the upper one obtuse, I 2-I $5 \mathrm{~mm}$. long; spur i 2 mm. long, slightly curved: upper petals narrow, light brownish, striate: lateral petals with slender claws bent at right angles, bearded only within, deeply 2 -cleft at the apex.

This species in perhaps closest related to D. cucullatum A. Nelson but differs in the longer and narrower leaf-segments, the more branched inflorescence, the stouter habit, the longer bracts and bractlets and narrower upper petals. It grows at an altitude of about $2500 \mathrm{~m}$.

Colorado: Wahatoya Creek, below the Spanish Peaks, I900, Rydborg \& Trecland, 6217 (type); Colorado Springs, I S95, E. A. Bessey ; Ruton, i $8_{40}$, Albert.

\section{Erysimum alpestre (Cockerell)}

Erysimum asperum $f$. alpestre Cockerell, Bull. Torr. Club, I8 : I 68. I $89 \mathrm{r}$.

A tall strigose perennial with a deep tap-root: stem strict, simple, 3-6 dm. high, striate : basal leaves linear or narrowly linearoblanceolate, 5-IO cm. long, 2-7 mm. wide, subentire or sinuately denticulate, grayish strigose, gradually tapering below with a short petiole: stem leaves mostly narrowly linear, the upper sessile: raceme at first short and corymbiform, in fruit much elongated: pedicels short, in fruit scarcely $\mathrm{I} \mathrm{cm}$. long, ascending: calyx IOI $2 \mathrm{~mm}$. long, yellow: two of the sepals strongly saccate at the base: petals with slender claws: blades broadly obovate-cuneate, slightly emarginate, about $\$ \mathrm{~mm}$. long and broad, varying from orange or brown to rose-purple or the older pale yellow: pods four-angled, slender, erect, $7-\$ \mathrm{~cm}$. long and $1.5 \mathrm{~mm}$. in diameter : style about $2 \mathrm{~mm}$. long, stout.

In general habit, this species closely resembles E. asponm. Mr. Cockerell, who seems to have been the first to observe this interesting plant of the Sangre de Christo region, took it to be a form of E. asperum with peculiarly colored petals, found only at high altitudes. I was first of the same opinion until I saw the fruit in the type number and still better developed in Mr. Bessey's 
specimens. This resembles more that of E. asporrimum (Chairanthus asporimum Greene) than that of E. asporum. The present species is also less densely and more finely strigose than either of them. E. alpestre grows at an altitude of $2500 \mathrm{~m}$. or more.

Colorado: Headwaters of Pass Creek, I900, Ryelberg \& I Tecland, 6200 (type); mountain near Veta Pass, 6r99; Veta Mountain, 6r97; tributary of Turkey Creek, 6ros; East Indian Creek, 6rg6; Ojo, 6202; Bald Mountain, near Pikes Peak, I 896, E. A. Bessey.

\section{Draba aureiformis sp. nov.}

A slender grayish stellate plant with perennial tap-root: stem strict, 2-4 dm. high, simple or branched above, with slender erect branches: basal leaves spatulate, $2-3 \mathrm{~cm}$. long, acute, entire: stem-leaves closely sessile, oblong-lanceolate, acute, entire or sinuately denticulate: petals sulphur yellow, 3-4 mm. long, broadly spatulate: pedicels ascending : pod erect, linear-oblonglanceolate, IO-I $5 \mathrm{~mm}$. long, about $3 \mathrm{~mm}$. wide, slightly if at all twisted, stellate: style about I mm. long.

This species is nearest related to $D$. anr $a$, but characterized by the small light yellow petals, the slender style, the less dense pubescence, and slender stem. It grows in dry soil at an altitude of $2700-3300 \mathrm{~m}$.

Colorado: Headwaters of Pass Creek, I 900, Rydburg \& I reeland, 6157 (type); Middle Park, I861, C. C. Parry, 103; Graymount, is $85, G$. $\mathrm{H}$. Letterman, 28.

\section{Physaria vitulifera sp. nov.}

A densely tufted finely stellate-pubescent perennial with deep tap-root. Basal leaves numerous, fiddle-shaped, the larger 4-5 cm. long; terminal lobe nearly orbicular to broadly obovate, subentire, obtuse; upper sinuses rounded: lateral lobes I-2 pairs, much smaller: stems ascending, or decumbent, $\mathrm{I}-2 \mathrm{dm}$. high : stem-leaves $\mathrm{I}-2 \mathrm{~cm}$. long, obovate or oblanceolate, entire: pedicels short, usually curved in fruit: sepals about $4 \mathrm{~mm}$. long, oblong, acute: petals clawed, $8-9 \mathrm{~mm}$. long: fruit obtuse at the base, deeply divided above; cells much inflated, round-obovate, divergent, about $5 \mathrm{~mm}$. in diameter: style about $5 \mathrm{~mm}$. long.

This species, as well as the two following, differs from $P$. didy'mocarpa in the smaller fruit, which is divided only above, not at 
the base. In this respect they resemble P. Newberryi; but the fruit is much smaller and not flattened on the sides. $P$. vitulifera. differs from the following in the form of the leaves and the curved pedicels. It grows in dry places at an altitude of about $2500 \mathrm{~m}$.

Color.tDo: Idaho Springs, i S95, P. A. Rydberg (type); Middle Park, is6i, C. C. Parry', I01.

\section{Physaria floribunda sp. nov.}

Densely tufted peremnial with thick tap-root. Flowering stems very numerous, ascending or almost erect, $\mathrm{I}-2.5 \mathrm{dm}$. high : basal leaves less crowded and more erect than in the preceding, oblanceolate or spatulate, sinuately toothed, acute, 5-IO cm. long: stem-leaves oblanceolate, entire, about $3 \mathrm{~cm}$. long: sepals about $5 \mathrm{~mm}$. long, linear-lanceolate: petals bright yellow, $\$-9 \mathrm{~mm}$. long, oblanceolate with broad claws : fruit obtuse or slightly cordate at the base, deeply divided above: cells much inflated, about 8 mm. in diameter, almost globular: style $6 \mathrm{~mm}$. long.

In the size and form of the fruit, this species is intermediate between the preceding and $I$. didymocarpa; but it is taller than either. Sometimes the leaves are deeper sinuate, and then become slightly fiddleform; but the terminal lobe is sinuately toothed and acutish. From $P$. didymocarpo it differs in the smaller fruit, which is less cordate at the base, and the longer, more acute leaves. It grows in loose sandy soil in mountain valleys at an altitude of 2000-2700 m.

Colorado: Sangre de Christo Creek, I900, Rydburg \& Vredand, 6135 (type) and 6I36; Hills about Golden, I S92, Crandall, 53.

\section{Physaria acutifolia sp. nov.}

A small tufted perennial with a deep rather slender tap-root. Basal leaves numerous, I.5-2.5 cm. long, oblanceolate or obovate, acute, entire or slightly wary, very finely stellate: stem-leaves rather few, oblanceolate: flowering stems $4-6 \mathrm{~cm}$. long, ascending or depressed: fruit small, obtuse or slightly cordate at the base, deeply divided above : cells inflated, almost spherical, 4-6 mm. in diameter: style about $5 \mathrm{~mm}$. long.

This species differs from $I$ ? ditlymocarper in the smaller size, in the acute leaves, and the smaller fruit, which is more deeply divided above and less so below. In general habit it resembles more $P$. Goreri, from which it differs in the turgid more spherical cells. It grows in the mountains, reaching an altitude of $3000 \mathrm{~m}$. 
Colorado: Grand Junction, I 893, Alice Eastivood (type).

Wroming: Mount Leidy, i897, F. Tuwcell', 39 I.

\section{Cardamine cardiophylla sp. nov}

Stem stout, 3-ro dm. high, densely hirsute with short white hairs, almost pilose : leaves rounded-cordate or the lower reniform, simple, coarsely sinuately toothed: blades $3-4 \mathrm{~cm}$. broad, more or less pubescent : petioles more or less densely pilose, those of the basal leaves 5-S cm. long, those of the upper stem-leaves very short: sepals also pubescent, about $3 \mathrm{~mm}$. long : petals white, broadly spatulate, about $8 \mathrm{~mm}$. long : pedicels in fruit spreading, $1.5-2 \mathrm{~cm}$. long : pods $2.5-3.5 \mathrm{~cm}$. long, ascending, $1.5 \mathrm{~mm}$. wide.

This species is nearest related to C. cordifolia, and differs mainly in the thicker leaves and the dense pubescence. It reaches an altitude of $3300 \mathrm{~m}$.

Colorado: Tennessee Pass, Lake County, 1900, Gio. E. Osterhout, 217S (type); I893, Di Alton Saunders; Camp beyond Bent's Fort, i 845 , Fremont, +29 .

\section{Thlaspi Coloradense sp. nov.}

Perennial; rootstock or caudex cespitose, the branches rosuliferous at the apex. Basal leaves broadly spatulate, $1-2 \mathrm{~cm}$. long, fleshy, $4-7 \mathrm{~mm}$. wide, sinuately crenate or subentire: flowering stems $2-8 \mathrm{~cm}$. long, leafy: stem-leaves oblong or obovate, 3-IO $\mathrm{mm}$. long, obtuse: inflorescence short and dense, even in fruit seldom over $2 \mathrm{~cm}$. long: sepals rounded-ovate, obtuse, with a white margin, about $2 \mathrm{~mm}$. long: petals large, obovate-spatulate, 5-6 mm. long: silicle obovate, about $6 \mathrm{~mm}$. long, only slirghtly emarginate at the apex: wing-margins very narrow; carina on the sides rather prominent: seeds red, about I $\mathrm{mm}$. long.

This species has been included by American authors in T. alpestre, which is not found in America. The European species has very small flowers and a different pod which is obcordate with a narrow and deep sinus at the apex. Professor Greene has determined $T$. Coloradense as T. Fendleri Gray. The latter was described from flowering specimens and might be the present species; at least it is much like it. Specimens in fruit from the same region as the type of $T$. Fendleri were collected later and were referred by Dr. Gray to T. Fendlcri; in these the fruit is larger, decidedly inverted triangular in outline, broader margined at the corners and almost truncate at the apex. 
T. Coloradcuse grows at an altitude of $2500 \mathrm{~m}$. or more, among rocks.

Colorado: Bald Mountain near Pikes Peak, isg6, E. A. Bessey (type); South Cheyenne Cañon, Colorado Springs, I900, Rydborg \& Ireclund, 6126; West Spanish Peak 6127 and 6128; Pikes Peak, i 894, E. A. Bessey; Pikes Peak and Baldy, i896, F. Cloments; Pikes Peak and Tennessee Pass, I893, De Alton Saunders; Laramie County, I893, C. S. Crandall, 60; Pikes Peak, I 89 I, Dr. E. Pcnard, 57 ; Arapahoe, 55 ; Los Pinos, i 899, C. F. Baker; Cheyenne Mountain and Seven Lakes, i 896, E. A. Bcss'y'.

\section{Thlaspi purpurascens sp. nov.}

Perennial with a tap-root crowned by a very short caudex and a rosette of leaves; flowering stems generally several, less than I dm. high : basal leaves oval or broadly spatulate, $2-3 \mathrm{~cm}$. long, petioled, usually more or less sinuate-dentate: stem-leaves ovate, obtuse, with a truncate base, closely sessile: sepals $2.5-3 \mathrm{~mm}$. long, oblong-oval, obtuse, purplish with broad white margins: petals broadly spatulate, about $6 \mathrm{~mm}$. long: silicle triangularobovate, distinctly winged above and with a very broad and shallow sinus at the apex, $7-8 \mathrm{~mm}$. long.

This species is closely related to the preceding and intermediate forms are not lacking. The principal difference is in the fruit, which in T. purpurascons is comparatively broader, distinctly winged and with a broad and open sinus at the top, almost truncate and less keeled on the sides. The sepals in all specimens seen are purplish and broader, the stem leaves are larger, more ovate and usually with a truncate base, and the branches of the caudex are very short.

Arizona: i 876, E. Palmer, 57 (type) ; San Francisco Mountains, г881, H. H. Rusby, 28: i887, Dr. E. A. Meams, 37 ; Flagstaff, i $898, D$. T. MacDougal, 228.

Colorado: Headwaters of Sangre de Christo Creek, I900, Rydberg \& Irecland, 6125; Iron Mountain, 6124.

\section{Sophia glandulifera sp. nov.}

Biennial. Stem simple below, branched above, about $6 \mathrm{dm}$. high, slightly grayish pubescent with branched hairs, decidedly glandular-viscid above; branches spreading, with upwardly curved ends: leaves pubescent and viscid, bipinnately divided; segments 
linear-lanceolate or of the upper leaves filiform, acute or attenuate: flowers light yellow : petals scarcely exceeding the sepals : pedicels very short in flower; in fruit $4-6 \mathrm{~mm}$. long, ascending or almost erect : pods $8-10 \mathrm{~mm}$. long, erect, more or less curved, especially those of the branches, scarcely exceeding $7 \mathrm{~mm}$. in, width, more or less constricted between the seeds; beak slender, short, about .5 $\mathrm{mm}$. long: seeds uniserial, red, a little over $1 \mathrm{~mm}$. long.

This species has the short pedicels and erect pods of S. Hartwucgiana, but the pod of the latter is more slender, and often curved, the whole plant is greener and conspicuously glandular, and the segments of the leaves are more slender. The latter character and the short ascending or erect pedicels distinguish it from S. incisa Engelm. It grows at an altitude of $1000-1500 \mathrm{~m}$.

IVyoming: Rolling plains between Sheridan and Buffalo, I900, F. Truecdy', 3502 .

\section{Sedum frigidum sp. nov.}

Perennial with a fleshy rootstock, clioecious. Stems usually less than I dm. high, light green : leaves flat, I-I.5 cm. long and 5-7 mm. wide, sessile, obovate or oblong-obovate, often dentate above the middle, or entire, acute : inflorescence dense, usually dark purple: flowers 4-5-merous, usually 5-merous: sepals of the staminate flowers lanceolate, acute, I.5-2 mm. long, dark purple or rarely greenish : petals oblanceolate or oblong, acute, about $3 \mathrm{~mm}$. long, dark purple or very rarely greenish tinged with purple : filaments filiform, purple, about one third longer than the petals, the pistillate similar but with somewhat shorter and more obtuse petals: follicles $3-5 \mathrm{~mm}$. long, oblong, with a very short beak about .5 $\mathrm{mm}$. long, divergent or at last recurved.

This species has gone under the name of S. roscum (L.) Scop., but is quite unlike the northern European plant, which must be regarded as the type of Rhodiola rose $\mathrm{L}$. This has a very short, almost tuberous rootstock, more oblanceolate leaves about $3 \mathrm{~cm}$. long, usually with very sharp clentations, usually yellow petals, longer filaments almost twice as long as the petals and follicles, 6$8 \mathrm{~mm}$. long. This form is also found in the mountains of southern Europe ; but there seems to be another European plant ; this is described and figured under the name Rhodiola rose $\mathrm{in}$ the " Flora von Deutschland " published by Schlechtendal, Langethal and Schenk. It resembles more the Rocky Mountain plant in the purple, flowers and short stamens, but it has more inversely deltoid leaves, 
the fertile flowers have very minute petals or none and the follicles have long beaks. In all systematic botanies of Scandinavia and Russia, S. roscum is described as having yellow petals, which is never the case in the Rocky Mountain and Alaskan plants. In this respect plants from eastern North America agree with the European.

S. frigidum is an alpine-arctic plant growing in Colorado at an altitude of $3000 \mathrm{~m}$. or more. In Montana it is found at an altitude of about $2700 \mathrm{~m}$. and in Alaska at low altitudes. It grows among rocks, associating with several species of Sarifraga and Adoxa Moschatellina.

Montana: Old Hollow Top, I 897, Rydberg \& Bessey, 72,8 (type); Long Baldy, I 896, Flodman, 513 ; Haystack Peak, I 899, P. Koch.

Colorado: West Spanish Peak, I900, Rjwberg \& Trecland, 6112 ( 9 ); 6II4 (大) and 6II5 (with greenish, merely purpletinged flowers); Grayback Mining Camp, 6II6; Pikes Peak, I 900, F. Cluments; I82 I, Dr. James; Arapahoe Peak, i \$9 I, Dr. E. Penard; Pikes Peak, I 894, E. A. Bessey'; i \$93, De Alton Saunders.

Nevada: Mineral King, Sierra, Nevada, is9i, Corille \& Funston, 1529.

IDaнo: Packsaddle Peak, i 892, Sandborg, MacDougal \& Heller, 860 .

Washington: Mt. Paddo, i 886, W. H. Sukselorf, 859.

Alaska: Muniak Island, I89I, Jas. M. Maconn, 88 ; Shumagin, I 87 I-1 $872, M$. $W$. Harrington; King Island, I897, E. A. Mcllhemi, 83 .

\section{Sedum polygamum sp. nov.}

Perennial with a thick fleshy rootstock. Stem I-3 dm. high : leaves obovate or oblanceolate, acute, sessile, flat, entire or minutely denticulate, $1.5-2.5 \mathrm{~cm}$. long: inflorescence dark purple, dense: flowers dioecio-polygamous: sepals of the staminate ones lanceolate, $2 \mathrm{~mm}$. long, acute : petals oblanceolate, dark purple, about 3 $\mathrm{mm}$. long: filaments about half longer than the petals, purple, broader than in the preceding species, abruptly acuminate above: fertile flowers with more lanceolate petals and usually with stamens which however have shorter filaments scarcely exceeding the petals: follicles $6-\$ \mathrm{~mm}$. long with an ascending or spreading beak, about I mm. long. 
Rydberg: Studies ox the Rocky Mountain Flora 284

This species is closely related to the preceding, but is stouter, the fertile flowers usually with stamens, the follicles larger and with less divaricate beaks. It has also been included in $S$. roscum, but is really nearer related to $S$. atropurpurcum of eastern Asia, which however has larger leaves. S. polygamm grows at an altitude of $3000 \mathrm{~m}$. or more.

Colorado: West Spanish Peak, Igoo, Rydberg \& I'recland, 6 II3 (type); Silverton, I895, F. Turecty I27; Mt. Hesperus, I $\$ 98$, Bakcr, Earle \& Tracj, $f \delta_{I}$; Basin Creek, La Plata Mountains, $f_{S O}$; Mt. Lincoln, I $873, J$. M. Coulter; Chambers Lake, I 894, C. S. Crandall.

New Mexico: White Mountains, i 897, E. O. Wooton, 677. 

CONTRIBUTIONS FROM THE NEW YORK BOTANICAL GARDEN-No. 15

\title{
STUDIES ON THE ROCKY MOUNTAIN FLORA.-VI
}

\author{
BY P. A. RYDBERG
}

NETV YORK

1901 



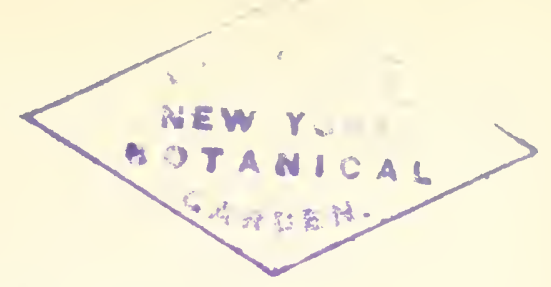

Studies on the Rocky Mountain Flora. - VI

BY P. A. RYDBERG

Salix padophylla n. n. Anderson.

S. padifolia Rydb. Bull. Torr. Club, 28: 272. I901. Not

In the May number of the Bulletin appeared a new species of willow under the name $S$. podifolia. The name should have been S. padophylla, as S. padifolia is preoccupied by one of Anderson's species. Besides, padus is originally a Greek word, rurios.

\section{Trifolium stenolobum sp. nov.}

A densely cespitose and scapose perennial. Branches of the caudex covered by the large stipules which are $2 \mathrm{~cm}$. long; petioles 5-10 cm. long, finely strigose ; leaflets 3 , narrowly lanceolate or oblanceolate, I.5-4 cm. long, finely strigose, very acute or acuminate: scape $\mathrm{I}-\mathrm{I} .5 \mathrm{dm}$. long: heads many-flowered; bracts minute; flowers reflexed in fruit: calyx-tube silky-strigose, $4-5 \mathrm{~mm}$. long; teeth almost filiform, 7-9 $\mathrm{mm}$. long: banner about $\mathrm{r} 8 \mathrm{~mm}$. long, obtuse, mucronate.

This is related to $T$. dasyphyllum but is easily distinguished by the minute bracts, the long slender calyx-teeth and the larger corolla. It grows at an altitude of $3600 \mathrm{~m}$.

Colorado: La Plata Mountain, is96, F. Ta'ecdy', 757 (type in U. S. Nat. Herb.).

Trifoliun subcaulescens A. Gray, Ives, Rep. Colo. Riv. Bot.

\section{O. I 860}

Trifolium ncmorale Greene, Pittonia, 4: I 36. I 900.

Dr. Watson referred this species to $T$. gymnocarpum, to which it is nearest related, but it differs in the larger size and the manyflowered head. The specimen of C. F. Baker's no. +46 in the herbarium of the New York Botanical Garden matches perfectly Newberry's specimen in the Columbia University herbarium. The former is the type number of $T$. nemorale Greene, and the latter that of $T$. subcaulescons A. Gray. Unless the type sheets repre- 
sent different species from those represented in our herbaria, Prof. Greene's name has to pass into synonymy.

\section{Trifolium bracteolatum}

Trifolium lilacinnm Rydb. Bull. Torr. Club, 28: 37. I 90 I. Not Greene. I 896.

\section{Vicia producta sp. nov.}

A very slender, sparingly hairy cespitose perennial. Stems decumbent or ascending, 2-3 dm. long, much branched and leafy, striate and somewhat angled : stipules narrow, semi-hastate, entire, 3-5 $\mathrm{mm}$. long; leaflets 3-5 pairs, oblong to linear, 5-1 $5 \mathrm{~mm}$. long, obtuse, mucronate; tendrils 3 -cleft: peduncles $2-4 \mathrm{~cm}$. long, usually 2 -flowered, produced beyond the upper flower: calyxtube about $2 \mathrm{~mm}$. long, strigose, teeth about $\mathrm{I} \mathrm{mm}$. long, lanceolate-subulate: corolla about $8 \mathrm{~mm}$. long, yellowish-white, tipped and tinged with purple.

This species is probably closest related to $V$. Inmilis H. B. K., but is characterized by having the peduncle produced beyond the two flowers and by different calyx-lobes. The type was growing among rocks on the south side of a butte, at an altitude of about $2400 \mathrm{~m}$.

Colorado: Butte, 5 miles southwest of La Veta, I900, Rydberg \& Freland, 6006 .

\section{Primula Americana sp. nov.}

Primula farinose A. Gray, Syn. Fl. $2^{1}: 58$, in part. I 878. Not L. 1753 .

Perennial with a short rootstock and fleshy-fibrous roots. Basal leaves oblong or oblong-oblanceolate or spatulate, $2-8 \mathrm{~cm}$. long, obtuse, gradually contracted at the base, usually with short winged petioles, sinuate dentate above the middle or subentire, thin, more or less mealy, especially on the lower surface: scape I-2 dm. high, mealy when young: bracts 6-10 mm. long, linearlanceolate, usually acute: pedicels in flower little if any exceeding the bracts, in fruit sometimes $2 \mathrm{~cm}$. long, erect from the beginning : calyx more or less mealy, 6-8 mm. long, lobes oblong-obtuse: corolla lilac; tube $8-9 \mathrm{~mm}$. long, only slightly exceeding the calyx; lobes of the corolla obcordate, $2-3 \mathrm{~mm}$. long.

This species has been confused with $P$. farinose, but I think it distinct. All specimens from the Rocky Mountain region under that name differ from the European and especially the Scandi- 
navian $P$. farinosa in the longer bracts, in the longer calyx and in the short corolla lobes. The specimens of northeastern America seem to be like the European plant. In the latter the bracts arc only 4-6 $\mathrm{mm}$. long, acuminate, the calyx less than three fourths the length of the tube of the corolla and the lobes of the latter 4-5 mm. long. P. Ancricana grows in swamps and wet meadows of the Rocky Mountain region at an altitude of $1200-2500 \mathrm{~m}$.

Montana: Deer Lodge, I 895, P. A. Rydherg, $274^{6}$ (type).

Wroming: Little Laramie River, i S96, Aien Telson, I961; Hams Fork and La Barge, s900, C. C. Curtis.

Alberta: Devil's Head Lake, Banff, is99, WT. C. McCalla, $2+22$.

Colorado: North Park, isg6, Gio. E. Osterhout.

\section{Cuscuta gracilis sp. nov.}

Stem filiform, about .25 mm. in diameter. Flowers in dense globular clusters: calyx gamosepalous but cleft to near the base, lobes ovate: corolla urceolate, less than $2 \mathrm{~mm}$. high, lobes ovate, widely spreading, acute, delicate, about $\mathrm{I} \mathrm{mm}$. long; scales ovate, crenate, not divided, almost half as long as the corolla-tube: filaments subulate, about twice as long as the anthers: styles distinct, equal, about as long as and somewhat thicker than the red filiform curved stigmas: capsule about $2 \mathrm{~mm}$. high, acute-globose, circumscissile near the base : seeds about I mm. long.

Thts species is nearest related to $C$. cpilinum, which, however, has shorter and broader corolla-lobes, shorter filaments, scarcely longer than the anthers and short emarginate and crenate scales. C. gracilis grows parasitic on species of Erigcron. Chrysothamms and Solanmm.

Wyoming: Rolling plains between Sheridan and Buffalo, I900, F. Ta'cedy', 3292 (type); Laramie, I 894, Aven Nolson, I I39.

\section{Cuscuta megalocarpa sp. nov.}

Stem stout, usually over $\mathrm{I} \mathrm{mm}$. in diameter. Flowers in dense globular clusters: pedicels very short, at most $2 \mathrm{~mm}$. long: calyx gamosepalous, lobes rounded, scarcely i $\mathrm{mm}$. long: corolla about $3 \mathrm{~mm}$. high and broad, lobes broadly triangular, acutish, about $\mathrm{I} \mathrm{mm}$. long, with incurved tip; fringed scales attached near the bottom, equalling about half the corolla-tube, deeply 2-lobed, and fringed only in the open sinuses: stamens about as long as the lobes of the corolla, filaments subulate, about twice as long as the 
rounded anther: styles distinct, short, stigmas capitate: capsule 5-6 mm. in diameter, acute-globose, about 4-seeded: seeds about $2.5 \mathrm{~mm}$. long and $2 \mathrm{~mm}$. broad, finely muricate.

A plant parasitic on willows and other shrubs, at an altitude of about $2000 \mathrm{~m}$.

Colorado: Cucharas Creek, near La Veta, I900, F. K. Trecland, 670 .

Wroming: Dayton, Sheridan Co., i 899, F. Tavedy', 2278.

\section{Monarda comata sp. nov.}

Perennial with a horizontal, slender rootstock. Stem obtusely4-angled, 4-6 dm. high, simple, sparingly silky-villous, especially below the nodes and on the upper portion : lower leaves with more or less hairy petioles, which are about $1 \mathrm{~cm}$. long, the upper subsessile; blades ovate or lance-ovate, more or less cordate at the base, acute or acuminate, serrate with small teeth which are directed forward, 4-6 cm. long, sparingly silky-strigose on both sides: bracts green or tinged with purplish, ovate, $1-2 \mathrm{~cm}$. long: calyx about $1 \mathrm{~cm}$. long, minutely puberulent, with a ring of hairs at the base of the teeth, which are subulate, $.7 \mathrm{~mm}$. long: corolla red-purple, almost wine-color, densely villose-puberulent, the exserted portion about $2 \mathrm{~cm}$. long.

This is nearest related to $M$. stricter Wooton, but differs in the long pubescence of the stem, leaves and bracts, shorter caly'x-teeth and clarker flowers. It grows in meadows among bushes, at an altitude of 2000-2500 m.

Colorado: Wahatoya Creek, 1900, Rydberg \& Viecland, 567,3 (type); Ruxton, 1900, Fred Clements.

\section{Castilleja Wyomingensis sp. nov.}

A more or less cespitose perennial with a short woody caudex. Stems 3-4 dm. high, striate, sparingly puberulent and the upper portion viscid-pubescent: leaves linear, $4-5 \mathrm{~cm}$. long, 4-7 $\mathrm{mm}$. wide, minutely puberulent, more or less distinctly 3 -nerved, entire, or the upper 3 -lobed: bracts lanceolate to ovate, puberulent and ciliate on the margin and veins tinged with sulphur-yellow, 3lobed at the apex or the lower entire, middle lobe oblong and rounded at the apex, the lateral ones lanceolate or linear, acute: calyx villose, nearly $2 \mathrm{~cm}$. long and almost equalling the corolla, sulphur-yellow, cleft about half way down, slightly deeper on the lower than on the upper side, lateral cleft $3-4 \mathrm{~mm}$. deep: corolla greenish, tinged and bordered with sulphur-yellow, galea about $6 \mathrm{~mm}$. long, lip about $2 \mathrm{~mm}$.: capsule ovoid, $\mathrm{I} 2-13 \mathrm{~mm}$. long. 
Rydierg: Studies on the Rocky Mountain Flora 503

The species is nearest related to $C$. sulphuria, from which it differs in the narrow leaves and in being more puberulent. It grows in northern Vyoming at an altitude of 2200-27.00 m.

Wroming: Big Horn Mountains, Sheridan Co., I899, F. Truecdy, 23,I (type) and 23,2; Headwaters of Clear Creek and Crazy Woman River, I goo, Taccity', ifoo.

\section{Pentstemon suffrutescens sp. nov.}

Pintstomon cacspitosus var. suffuticosus A. Gray, Syn. F1. $2^{1}$ : 270. is7S. Not P. suffruticosus Dougl. i 846.

Excellent specimens of what I take to be Gray's variety cited above, which was described from imperfect material, have been collected by Mr. Tweedy, and these show that the plant is nearer related to $P$. pminilus than to $P$. cacspitosus, but the calyx lobes are broader, shorter and blunter than in that species, the corolla slightly smaller and the leaves glabrous.

Colorado: Ridgway, is95, F. Tuitedy, I70.

\section{Sambucus microbotrys sp. nov.}

A low shrub, 5-20 dm. high, glabrous throughout and with pale green foliage. Leaflets orate or rarely ovate-lanceolate, acute or short-acuminate, $3-9 \mathrm{~cm}$. long, mostly rounded and oblique at the base, coarsely serrate: cyme thyrsoid-paniculate, small, about as long as broad, about $3 \mathrm{~cm}$. in diameter and of the same height ; flowers whitish: fruit bright red, $4-5 \mathrm{~mm}$. in diameter: seeds finely punctate-rugose.

This species is nearest related to $S$. fubcus and perhaps all specimens from the southern Rockies referred to that species belong here. The main distinctions from S. pubins are the total absence of pubescence and the smaller inflorescence. It grows at an altitude of $1500-2700 \mathrm{~m}$.

Colorado: Bottomless Pit, and below Halfway House, Pike's Peak, I896, E. A. Bissiy (type); Gray's Peak, I895, P. A. Rydlerg; East Indian Creek, I900, Rydberg \& Besscy', 5j82; Little Veta Mountain, $55 S_{3}$.

\section{Chrysothamnus filifolius sp. nov.}

A small shrub, about $3 \mathrm{dm}$. high, very bushy. Bark of the stems and larger branches gray and somewhat fissured, that of the young branches white and shining: leaves very narrow, linear- 
filiform, I-2 cm. long, less than I $\mathrm{mm}$. wide, dark green and glabrous except the minutely scabrous-ciliolate margins: cyme large, flat-topped: heads very numerous, 5-6 mm. high, $2 \mathrm{~mm}$. in diameter, turbinate; bracts in 5 vertical rows with usually 3 in each row, lanceolate-acuminate, the outer with green tips, the inner wholly chartaceous.

In habit and leaves, this species resembles C. stcnoplyyllus, but the leaves are still narrower and in that species the bracts are obtuse or merely acute.

Colorado: Granite, is96, Fred. Climents, 390.

\section{Chrysothamnus scoparius sp. nov.}

Perennial with a woody caudex and deep tap-root. Stems I-2 $\mathrm{dm}$. high, glabrous and shining, with a white bark: leaves narrowly linear, light bluish-green, glabrous, $2-3 \mathrm{~cm}$. long, a little over I $\mathrm{mm}$. wide, more or less twisted: cyme flat-topped: heads numerous, 6-8 $\mathrm{mm}$. high, $2-3 \mathrm{~mm}$. wide; bracts chartaceous, lanceolate, acuminate.

This species is still more like C. stenophyllus in habit, but the bracts are different, being acuminate instead of obtuse or acute and more keeled. The perennial portion is also much shorter and the general color of the plant is much lighter.

Colorado: Mesas, La Veta, I900, F. K. Tridund, 698.

Aster crassulus sp. nov.

Aster multiflorus A. Gray, Pl. Wr. 2: 75. In part. I853.

Aster incano-pilosus Rydb. Mem. N. Y. Bot. Gard. I : 393. In part. I 900.

Perennial with a horizontal, stoloniferous rootstock. Stems erect or ascending or rarely decumbent, usually simple below, branched above, 4-7 dm. high, terete, brownish, densely hirsute with short divaricate hairs: stem-leaves linear, or oblong-linear, 3$6 \mathrm{~cm}$. long, $2-3 \mathrm{~mm}$. wide, rather firm, hirsute with short spreading hairs, sessile and slightly clasping, in age usually reflexed, acute with a short spinulose tip; those of the branches smaller; those of the branchlets only $3-5 \mathrm{~mm}$. long and merging into the bracts of the involucres: heads numerous, borne at the end of leafy branchlets which are $\mathrm{I}-2 \mathrm{~cm}$. long; involucre turbinate, $5-8 \mathrm{~mm}$. high, $8-10 \mathrm{~mm}$. broad; bracts in $3-4$ series, the outer successively shorter, broadly spatulate, minutely spinulose-mucronate, very thick, hirsute especially on the margin, chartaceous at the base with a broadly oval herbaceous tip : rays numerous, white, 5-7 $\mathrm{mm}$. long and fully I $\mathrm{mm}$. wide: achenes strigose. 
This is a member of the A. multiflorus group and has been confused with A. commutatus (T. \& G.) Gray or A. inceno-pilosus Sheldon. In $A$. commutatus, the stem is strigose-pubescent, the branchlets more elongated and the outer bracts longer than in $A$. crossulus and often equalling or surpassing the inner bracts. It may be the same as described by Lindley in Hooker's Flora and DeCandolle's Prodromus as "A. rammlosus $\beta$, incano-pilosus": but here it is to be noticed that the word "incano-pilosus" is printed in the same type as all the descriptions and not the special type used for names. Hence "incano-pilosus" was a descriptive term for the A. ramulosus $\beta$, and not the name. If, however, it should be taken as a name, which Mr. Sheldon did, it is a nomen mudum, as no further description is given, and then should be disregarded. As Sheldon's Astor incano-pilosus, which is amply distinct, has as a synonym, the older A. commutatus (T. \& G.) Gray it must be dropped and $A$. commutatus substituted.

$A$. crassulus grows on dry plains and table-land at an altitude of $1200 \mathrm{~m}$.

Colorado: Mesas, La Veta, i goo, F. K. Trecland, 6goa (type) and 69o; Denver, is 7 I, Dr. Gio. Smith, $S_{3}$; Ridgway, I $894, F$. Tuecidy, zo6; Pagosa Spring, i 899, C. F. Baker, 637.

New Mexico: is 5 I, C. Wright, I I5j; Rio Dolores, Ncwbcry.

California: Valley, near San Filipe, i 858 , S. Hayes.

Wyoumg: Bear Lodge Mountains, I898, L. II: Carter; Moorcroft, I $897, \mathrm{~L}$. W. Carter; Dayton, I899, F. Tiweedy', 203I.

North Dakota: Minot, is91, Wright; Custer, IS92, Rydberg, 773 .

Montana: Park Co., is87, F. Taicdly, 359; Colgate, Sandberg, MacDougal \& Hcller, IOzI; Montana Valley, Madison Co., 1899, Av'n \& Elias Nelson, 6839.

\section{Aster exiguus (Fernald)}

Aster ciliatus Muhl.; Willd. Sp. Pl. 3: 2027. ISO4. Not Walt. I $78 S$.

Aster hobecladus A. Gray, Syn. Fl. 2' : i 55 , under A. multiflonts. Not DC.

Astcr multiflorus var. crigums Fernald, Rhodora, I: I 87 . I 899.

I think that Aster ciliatus Muhl. is distinct from A. multiflorus; 
but unfortunately it is antedated by $A$. ciliatus Walt. In $A$. multiflom the pubescence is mostly appressed and the bracts are narrow-oblanceolate and rather thin. In A. cxignus the pubescence is much denser and divaricate and the bracts are thick, broadly spatulate or obovate. In fact 1 . cxigums differs from the preceding only in the smaller, more crowded heads and the shorter rays; the former are less than $5 \mathrm{~mm}$. high and the rays are only 5-6 $\mathrm{mm}$. long. The New Mexican form which Gray regarded as A. hebcledus DC. and for which Dr. Greene has revived the name belongs here, but is evidently not $A$. hobcladus DC. for this is described as having glabrous stem and linear bracts.

A. criguns grows on prairies and plains along roads, etc., and westward is much more common than 1 . multiflorus. It ranges from Vermont and Pennsylvania to Washington and south to Texas and Arizona.

\section{Machaeranthera rubricaulis sp. nov.}

Biennial or perhaps perennial. Stem erect or nearly so, simple below, branched above, 4-6 cm. high, terete, striate, usually tinged with red or purple, finely strigose-puberulent, not viscid: leaves linear or linear-oblanceolate, sessile, acute, entire or sparingly dentate, scabrous-ciliolate on the nargins; the largest $8 \mathrm{~cm}$. long, and $8 \mathrm{~mm}$. wide: heads corymbose-cymose, numerous : involucre IO-I $2 \mathrm{~mm}$. high, I 2-I $5 \mathrm{~mm}$. in diameter : bracts numerous, linearlanceolate with attenuate, almost terete squarrose tips, viscidpuberulent: rays numerous, dark blue, about $\mathrm{I} 2 \mathrm{~mm}$. long and $\mathrm{I}$ mm. wide: pappus sordid: achenes flat, sparingly and minutely strigose.

The species grows in dry soil at an altitude of 2000-2700 $\mathrm{m}$.

Colorado: Mesas, La Veta, i 900, F. K. Trecland, 68 I (type); Telluride, I 894, F. Tricedy', 304 and 305.

\section{Eitgeron laetevirens sp. nov.}

Perennial with a woody tap-root. Stems several, 1.5-2 dm. high, slender, erect or ascending, striate, silky strigose: basal leaves very narrowly linear-oblanceolate, acute, 5-10 cm. long, I-3 $\mathrm{mm}$. wide, sparingly strigose; stem-leaves narrowly linear, $2-6 \mathrm{~cm}$. long, scarcely over I $\mathrm{mm}$. wide: heads solitary: involucre $12-15 \mathrm{~mm}$. in diameter, grayish villous-hirsute: bracts in $2-3$ series, subequal, linear-lanceolate, long-acuminate: rays numerous, blue or purple, $7-8 \mathrm{~mm}$. long, I-I.5 mm. wide. 
This species is nearest related to E. Montencusis, from which it differs in the narrower, blue or purple rays and longer and less pubescent leaves. It grows at an altitude of 2000-2700 $\mathrm{m}$.

IVromng: Little Goose Creek, 1899, F. Tiuced), 2005 (type); Headwaters of Clear Creek and Crazy WToman River, I $900,3010$.

\section{Carduus Centaureae sp. nov.}

(?) Cnicus corlinoides var. Americanus A. Gray, Proc. Am. Acad. I0: 48. I874. Not Cirsimm acanle var. Americomus A. Gray. I 863 .

(?) Cnicus Amcricamis A. Gray, Proc. Am. Acad. I9: 56.

Biennial or perennial. Stem rather slender, 6-10 cm. high, striate, often tinged with red, slightly floccose when young: basal leaves about $2 \mathrm{dm}$. long, thin-petioled, deeply pinnatifid to near the midrib, above light green, sparingly floccose when young, glabrate in age, beneath more or less permanently grayish-tomentose; lobes lanceolate or triangular, $2-+\mathrm{cm}$. long, more or less toothed and tipped with weak spines, $1-3 \mathrm{~mm}$. long; lower stem-leaves similar but petiole more winged, dilated at the base and short decurrent; the upper sessile and clasping with an auricled base; the uppermost lanceolate and undivided: heads $2-2.5 \mathrm{~cm}$. high and $1.5-2 \mathrm{~cm}$. in diameter: outer bracts narrowly lanceolate, yellowish, often with darker center, fimbriate on the margin and tipped with a flat weak spine $1-2 \mathrm{~mm}$. long: the inner with dilated deltoid scarious fimbriate tips which are merely acuminate: flowers ochroleucous.

This species may be the Cnicus Americamus A. Gray or Corduns Amcricanus Greene, but the name Americanus is preoccupied. The species is, however, not nearest related to C. Paryi, where Dr. Gray placed it; but to $C$. livocphalus and $C$. conovirens, from which it differs in the less spinose, more dilated and fimbriate bracts. A seedling of apparently this species was collected by Cowen and it has long oblanceolate 3-4 dm. long, undivided leaves. It grows at an altitude of $2200-2600 \mathrm{~m}$.

Colorado: Laramie County, i 895, J. H. Cocicn (type); 4-mile Hill, Routt County, I896, C. F. Bakrr; Penn's Gulch, I 865. Littiman, $7 \mathrm{~S}$.

\section{Carduus erosus sp. nov.}

Biennial. Stem stout, about $7 \mathrm{dm}$. high, angled and striate, often red, loosely floccose when young : lower leaves about $2 \mathrm{dm}$. long, rather thin, green and slightly floccose above when young: 
grayish-tomentose beneath, deeply pinnatifid to about one fourth from the midrib: lobes about $2 \mathrm{~cm}$. long, lanceolate, few toothed or lobed and tipped with moderately strong spines $4-10 \mathrm{~mm}$. long: heads hemispherical, $2.5-3 \mathrm{~cm}$. high and $2.5-3.5 \mathrm{~cm}$. broad: outer bracts ovate, slightly floccose when young, entire, with a narrow dorsal line, tipped with weak spines $\mathrm{I}-2 \mathrm{~mm}$. long, the inner with dilated deltoid erose scarious acuminate tips: flowers ochroleucous.

A species closely related to the preceding, differing in the larger heads, longer spines, broader bracts and with erose instead of fimbriate tips. It grows in moist meadows at an altitude of about $2200 \mathrm{~m}$.

Colorado: Durango, I896, Frank Tucedy, 517 (type in U. S. Nat. Herb.).

\section{Carduus Americanus (A. Gray).}

Cirsium acule var. Amcricanus A. Gray, Proc. Acad. Phila. I $863: 68$.

Cnicus Drummondii acaulescens A. Gray, Proc. Am. Acad. Io: 40, in part.

Dr. Gray's Cirsium acaule var. Ancricanum is amply distinct from $C$. Drummondii not only by the acaulescent habit, but also by the narrower bracts and their long stout spines which are $\mathrm{I}-2$ $\mathrm{cm}$. long while in C. Drummondii they are only a few $\mathrm{mm}$. in length and very weak. It is an alpine species growing at an altitude of $2800-3500 \mathrm{~m}$. To this belong the following specimens.

Colorado : Silver Plume, I 895, P. A. Rydberg; Como, South Park, IS95, C. S. Crandall; South Park, I $88_{4}$, Littrman.

\section{Carduus acaulescens (A. Gray)}

Cuicus Drummondii var. acuulescens A. Gray, Proc. Am. Acad. I0: 40 , in part.

Gray's variety acaulescens was based on two previously published things, viz., Cirsium acanle var. Americamus A. Gray, given above, and Cirsium Drummondii, "acaulescent form" D. C. Eaton in King's Report. As the first already has a valid name, I here adopt the name acaulescens for the other part on which the variety was founded. C. acanlescons resembles closely C. Americanus in habit, but the spines of the outer and middle bracts are shorter and 
weaker, seldom over $5 \mathrm{~mm}$. long, and the inner are acuminate, wholly unarmed. The true C. Drummondii, even in its subacaulescent state, has very broadly ovate outer bracts and the spine is so fine that it is better called a bristle. The inner bracts have a long acuminate very crisp tip. In C. acoulescens it is scarcely crisped. The following specimens belong to C. acaulescens:

UтAн : Bear River Valley, i 869, S. IT'atson, 690.

Wroming: Woods Creek, i 897, Aicn Velson, if 83.

Colorado: Grizzly Creek, is 96, C. F. Baker.

\section{Carduus oreophilus sp. nov.}

Cirsium Drummondii, D. C. Eaton, King's Rep. 5: 195. I87 I. Not T. and G.

Biennial stem 4-S dm. high stout, angled and striate, slightly arachnoid-hairy when young, leafy: basal leaves about $2 \mathrm{dm}$. long, thin, short-petioled, green and glabrate above, more or less grayish-tomentose beneath, pinnately lobed a little more than half way to the midrib; lobes triangular, usually 2-3-lobed, with rather slender spines 3-IO $\mathrm{mm}$. long: heads hemispherical, 2-2.5 $\mathrm{cm}$. high, $2.5 \mathrm{~cm}$. broad: outer and middle bracts narrowly lanceolate, slightly arachnoid, tipped with flat spines 3-6 nm. long, the inner with a long attenuate soft tip : flowers red.

This species has been included in C. Drummondii but is taller with smaller head, narrower bracts, the outer with longer spines, and the tips of the inner scarcely crisp. It grows at an altitude of I 500-3000 m.

Colorado: Georgetown, I 895, P. A. Rydberg (type); Pagosa Springs, 1899, C. F. Bakcr, 6tt.

Nevada: Run Valley, is68, S. Ilatson, 689.

\section{Carduus griseus sp. nov.}

Biennial. Stem stout, sparingly floccose when young, angled and striate: basal leaves oblanceolate in outline, thin, glabrate above, grayish-tomentose beneath, deeply pinnately divided; segments 3-4 cm. long, deeply 2-3-lobed and toothed, tipped and margined with rather slender spines $3-5 \mathrm{~mm}$. long; the upper similar but less deeply divided, sessile and half clasping by the dilated rounded shortly decurrent base: heads about $3 \mathrm{~cm}$. high and broad: bracts subequal, without dorsal glandular ridge, the outer narrowly lanceolate, with a long-attenuate tip gradually changing into a flat spine, and somewhat laciniate or spinulose- 
dentate on the margin: the inner bracts less rigid, their tips not spinose but long-attenuate, scarious and somewhat crisp: flowers ochroleucous.

This species is probably nearest related to C. lcioceplualus (D. C. Eaton) Heller but differs in the less divided, less spinose leaves and the bracts which are lacking the long yellow spines on the margins. C. lizocephalus has red flowers. Carduns grisens grows at an altitude of $3400 \mathrm{~m}$.

Colorado: Telluride, Is94, F. Tuiculy, 321 (type in U.S. Nat. Herb.).

\section{Carduus pulcherrimus sp. nov.}

Biennial. Stem about $4 \mathrm{dm}$. high, very leafy, grayish-tomentose, especially when young, angled: lower leaves I-I.5 dm. long, oblanceolate in outline, short-petioled, pinnately divided, bright green and glabrate above, densely white-tomentose beneath; segments lanceolate or triangular, lobed and toothed with slender spines 3-5 $\mathrm{mm}$. long: the upper leaves similar, sessile and half clasping : heads $2.5-3 \mathrm{~cm}$. high, $2.5-4 \mathrm{~cm}$. broad: outer bracts lanceolate with a narrow glandular ridge, slightly floccose, tipped with yellow spines about $5-7 \mathrm{~mm}$ long : the innermost narrowly lanceolate and with long-attenuate tips : flowers rose-colored.

In habit this species resembles most $S$. undulatus and $S$. ochroccntrus, but has smaller heads, narrower bracts and narrower glandular ridge. It is perhaps intermediate between those species and C. canowirns, from which latter it is easily distinguished by the dense tomentum on the lower surface of the leaves. It grows in open woods, etc., at an altitude of about $2500 \mathrm{~m}$.

IV'roms : Headwaters of Clear Creek and Crazy Woman River, I900, F. Tǘced)', $307 S$ (type); Medicine Bow, I89S, Elias Nolson, $\$ 396$.

\section{Carduus oblanceolatus sp. nov.}

Apparently perennial. Stem rather slender, 3-6 dm. high, almost terete, densely white-tomentose: lower leaves about I $\mathrm{dm}$. long, oblanceolate, thick, short-petioled, merely spinulose-dentate or rarely with a few triangular lobes, loosely floccose above, densely white-tomentose beneath, spines slender, 2-5 $\mathrm{mm}$. long; upper leaves lanceolate, sessile and half clasping: heads I-3, campanulate, $3-3.5 \mathrm{~cm}$. high, $1.5-2.5 \mathrm{~cm}$. broad: bracts slightly floccose at first, with a narrow glandular dorsal ridge, the outer ovatelanceolate, the middle lanceolate, with a slender divergent spine, 
3-5 mm. long, the innermost long-attenuate, unarmed: flowers rose-colored.

This species is nearest related to $C$. Flodmanii, differing in the more simple habit, the smaller, thicker, not pinnatifid leaves and shorter and weaker spines. From $C$. altissimus it differs in the denser tomentum, the simple habit, the narrower and fewer bracts and their narrower dorsal ridges.

Colorado: Twin Lakes, i S96, Fred. Climents, j\&5 (type).

\section{Agoseris arachnoidea sp. nor.}

Perennial with a tap-root, more or less floccose throughout. Leaves I.5-2 dm. long, more or less runcinate-lobed, oblanceolate in outline, long-attenuate at the apex, densely floccose when young, more glabrate in age: scape I.5-4 dm. high, densely woolly abore, less so below: head $2-2.5 \mathrm{~cm}$. high, $1.5-2 \mathrm{~cm}$. broad: bracts in about 3 series, linear-lanceolate, long attenuate, the inner one-third longer than the outer: flowers at least in age rose-purple: beak of the achenes fully as long as the body.

Perhaps nearest related to $A$. amrantiace but differing in the larger heads, the dense pubescence and the lighter flowers. It grows in meadows at an altitude of 2000-2800 $\mathrm{m}$.

Colorado: Gray-Back Mining Camp, Igoo, Rydloreg \& Vrecland, 5553 (type); La Veta, I S96, Fred. Clinints, I67.

\section{Agoseris pubescens sp. nov.}

Perennial with a tap-root and short branching caudex. Leaves narrowly oblanceolate, about I dm. long, .5-I cm. wide, acuminate, slightly glaucous but even in age villous-pubescent: scape I.5-2 $\mathrm{dm}$. high, sparingly villous : involucre about $2 \mathrm{~cm}$. high and $\mathrm{I.5}$ $\mathrm{cm}$. wide, villous and somewhat viscid: bracts with a dark median line and sometimes tinged with purple, the outer ones ovate-lanceolate, about $2 / 3$ the length of the linear-lanceolate long-acuminate inner ones: flowers lemon-yellow, the outer striate or tinged with purple: beaks of the achenes short and striate throughout.

This species is nearest related to 4 . glanca and 1. scorsoneratfolia but differs in being very pubescent. It grows in moist meadows at an altitude of 2000-2500 $\mathrm{m}$.

Wroming: Big Horn Mountains, Sheridan County, IS99, F. Tivecdy, 2055 (type); Buffalo Fork, I 897,578 ; Amethyst Creek, I S99, Aven \& Elias Nelson, 5760 (in part). 


\section{Taraxacum Alaskanum sp. nov.}

A low delicate plant with perennial root: leaves linear-oblanceolate in outline, $3-5 \mathrm{~cm}$. long, deeply runcinate-pinnatifid with triangular retrorse lobes: scape $4-5 \mathrm{~cm}$. high: involucre campanuate, IO-I $2 \mathrm{~mm}$. high, $6-8 \mathrm{~mm}$. broad: bracts fuscous, not corniculate; the inner linear-lanceolate, long-acuminate; the outer scarcely half as long, lanceolate, spreading or somewhat reflexed : achenes brownish, spinulose-muricate above, fusiform, $4 \mathrm{~mm}$. long.

This in size and habit most resembles $T$. scopulorum, but is easily distinguished by its triangular acute lobes. It was found "on steep side bank facing the ocean."

Alaska: Pt. Barrow, isg\&, Mc Tlhcmny.

\section{Crepis glaucella sp. nov.}

Perennial with a slender tap-root. Stem slender, about $3 \mathrm{dm}$. high, glabrous and shining: basal leaves glabrous and shining, somewhat glaucous, thin, 5-10 cm. long; blades oblanceolate, acute at the apex, tapering downward into a more or less winged petiole, remotely sinuate-dentate with divaricate or retrorse short teeth or entire; stem-leaves $1-2$, much reduced, $\mathrm{I}-2 \mathrm{~cm}$. long, linear or nearly so: heads $\mathrm{I}-4$, on slender branches: involucre turbinate, about $\mathrm{I} \mathrm{cm}$. high and $6-8 \mathrm{~mm}$. wide, sparingly hirsute; bracts linear-lanceolate, acuminate: achenes brown, IO-striate, glabrous: pappus white.

This species is nearest related to $C$. glauca but differs in the smaller, narrower, longer-petioled leaves and hirsute involucre.

Wroming: Pacific Creek, 1897, F. Twocely',603.

Hieracium macranthum Nutt. Trans. Am. Phil. Soc. II. $7: 446$. I 840

Hicracium umbellatum Hook. F1. Bor. Am. I : 300, in part; Rydb. Mem. N. Y. Bot. Garden I : 463, mainly. Not L.

The plant of the Rocky Mountain region which has been referred to H. umbellatum and sometimes to $H$. Canadonse is quite distinct from both. The leaves are usually broader than in the first but narrower than in the second and the heads are usually fewer than in either. The best character by which to distinguish it is, however, the pubescence. The leaves are densely puberulent and decidedly scabrous-ciliolate on the margins. The upper portion of the stem and the branches of the inflorescence are also scabrous puberulent. 
H. macranthum ranges from Wyoming and Washington northward to subarctic America. It apparently also extends eastward to the upper Mississippi River (Nicollet's specimens seem to belong here) and therefore may be Schweinitz' H. scabrrimum, which has been referred to $H$. umbillatum and $H$. Canadense. I have not seen Schweinitz' original description and can not venture an opinion. Nuttall's name belongs to the plant without any doubt.

\section{Hieracium Columbianum sp. nov.}

Perennial. Stem about $6 \mathrm{dm}$. high, terete, more or less tinged with purple, more or less white- or yellowish-hirsute below, glitbrous or puberulent above: lower leaves oblanceolate, $8-10 \mathrm{~cm}$. long, light green and somewhat glaucous beneath, usually more or less silky-hirsute, sinuately dentate, acute; the middle leaves lanceolate or ovate-lanceolate with rounded or obtuse base, sessile, more glabrate; the uppermost much reduced and bract-like: inflorescence corymbose-cymose, small and contracted: heads $2-6$, I 2-I $5 \mathrm{~mm}$. high : bracts lanceolate, unequal and more or less imbricated, dark, puberulent when young, glabrous in age: pappus very light brownish.

This species is nearly related to $H$. Camadensi and $H$. umbellatum, but differs from both in the long hairs of the lower part of the plant. The leaves are thin as in H. Canadonse but narrower and the heads are fewer. It grows in low ground at an altitude of about $600 \mathrm{~m}$.

IDAHO: Priest River Valley, I900, D. T. MacDongal, Iog (type); cañons near Farmington Landing, i 892, Sandberg, HacDougal \& Hiller, 573 . 

CONTRIBUTIONS FROM THE NEW YORK BOTANICAL GARDEN-No. 22

\section{STUDIES ON THE ROCKY MOUNTAIN FLORA VII.}

BY PER AXEL RYDBERG.

NEW YORK

1902

[Reprinted from Bulletin Torrey Botanical Club, 29: 145-160. 24 March, 1902]. 



\section{Studies on the Rocky Mountain Flora-VII}

By Per Axel Rywherg

\section{Aquilegia Columbiana}

Perennial with a short thick rootstock: stem 6-io dm. high, glabrous or sparingly and finely pubescent above; basal leaves twice ternate; petioles $\mathrm{I}-2 \mathrm{dm}$. long; segments rounded, obovate, $2-3 \mathrm{~cm}$. long, more or less glaucous beneath, 2-3-cleft and deeply crenate at the apex; lower stem-leaves similar to the basal leaves, but with short winged petioles, the upper similar but often with larger segments: sepals and spurs very bright red; laminae yellowish: sepals ovate-lanceolate, acute, i 5-25 mm. long, exceeding the spur, widely spreading or reflexed: lamina very short, scarcely $3 \mathrm{~mm}$. long, truncate; spur I 2-I $8 \mathrm{~mm}$. long, thick, abruptly contracted about the middle: follicles erect, densely pubescent; styles about i $2 \mathrm{~mm}$. long.

This species is somewhat intermediate between A. formosa and A. truncato and has been mistaken for both. It has the habit, the spur and sepals of the former and the short truncate lamina of the latter.

Washington: Montesano, isg\$, A. A. \& E. Gertrude Heller, 3936 (type in herb. N. Y. Bot. Garden); upper valley of the

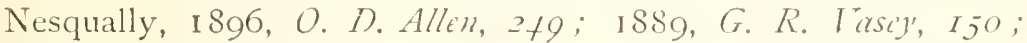
Humptulips, I $895, F$. H. Lamb, rISO; Puget Sound, IVilkes Exped., 6 fo.

British Columbia: Banff, I897, Zoc It'. Palmer.

Alaska: Short Bay, I\$95, Gomarm, I05; Disenchantment Bay, ISq2, F. Finston, I 21 .

I DAHO: Florida MIt., I $\$ 92, A$. Isabel Mulford.

\section{Aquilegia thalictrifolia}

Perennial with a short rootstock: basal leaves twice ternate; petioles I-2 dm. long; segments broadly obovate-cuneate, 2-3cleft and crenate at the apex, $1-1.5 \mathrm{~cm}$. long, bluish-green: stem 2-5 dm. high, glabrous below, finely viscid puberulent above: stem-leaves subsessile or very short-petioled, otherwise similar to the basal ones: flowers yellow: sepals I O-I $8 \mathrm{~mm}$. long, ovate to ovate-lanceolate, acute: laminae of the petals 7-12 $\mathrm{mm}$. long, truncate or rarely rounded at the apex; spur very slender from 
the base, 4-5 cm. long: follicles without the styles, about $3 \mathrm{~cm}$. long and $5 \mathrm{~mm}$. wide, strongly reticulate and pubescent, strongly curved above.

'This species is nearest related to $A$. chrysantha with which it has been confused, but differs in the smaller flowers, blunter sepals, smaller and bluer segments of the leaves and the more curved follicles. It grows at an altitude of I 500-3000 $\mathrm{m}$.

Colorado: Cañon City, is73, E. L. Grene (type in herb. Columbia University); Colorado Springs, is93, De Alton Sanndors; Grand Cañon of the Arkansas, I873, Brondegec; Bear Creek Cañon, I892, C. S. Shcldon.

Texas: West Texas, I 888, Neallicy.

Arizona: Mt. Humphrey, I 897, R. E. Kunic.

\section{Aquilegia Eastwoodiae}

Aquilegia cealcarata Eastwood, Zoe, 2: 226. I89I. Not Hortul.; Steudel. I 84 I.

This has been regarded as a spurless form of $A$. micrantha Eastw., but the form of the terminal segments of the leaves is different from any American species, being rhombic in outline and acute.

\section{Aquilegia oreophila}

Aquilegia coerulca alfina A. Nelson, First Rep. Fl. Wyo. 78. I896. Not A. alpina L. I853; Aquilegia coemulea var. fariescens Jones, Cont. West. Bot. 8: 2. I898. Not A. fariescens Vats. i 871.

This is evidently what Jones regards as A. flevescens IVats., but is not Watson's species, for he describes the spur as being curved. Specimens of both numbers cited by Watson, viz. 35 and 36 , are in the Columbia University herbarium and these as well as the plant cultivated under the name A. floriescens at Harvard have curved spurs and can not be referred as a variety to $A$. cocrulea. Therefore, I can not see why Mr. Jones' A. depaupcrata should not pass into synonomy, being the same as the true $A$. flavesccns. The flowers of $A$. orcophila resemble most those of $A$. pubcscens Coville, but the habit is different and nearer $A$. cocrulea.

\section{Delphinium alpestre}

A low cespitose perennial: stems several, about I dm. high, puberulent and viscid above, densely leafy; leaves digitately di- 
vided into about 5 divisions, finely and sparingly puberulent when young, dark green; petioles $4-5 \mathrm{~cm}$. long; divisions of the blades $1.5-2 \mathrm{~cm}$. long, cuneate-obovate in outline, divided half-way into oblong mucronate lobes: inflorescence short and few-flowered; pedicels ascending, I cm. or less long, viscid; bractlets minute: sepals dark blue, oblong, obtuse or the upper acute, viscid-puberulent; spur 8-9 mm. long: upper petals blue and yellowish, 2toothed at the apex; lateral petals 2-cleft; lobes lanceolate: follicles not seen.

This is not closely related to any of the American species. It has the cespitose habit of $D$. glaucescens, but is a much smaller plant. It grows among rocks at an altitude of $3300 \mathrm{~m}$. or more.

Colorado: Mountains northwest of Como, I S95, Crandall \& Corecn, I8, $S$ (type in herb. State Agric. Coll., Colo.); West Spanish Peak, I900, Rydlicro \& Irecland, 6218.

\section{Delphinium multiflorum}

A tall perennial with a woody caudex; stem about I mm. high or more, viscid above, glabrate below: leaves palmately divided into $5-7$ divisions, glabrous and glaucous, pubescent only on the margins and veins; petioles $1-2 \mathrm{dm}$. long, slightly dilated at the base ; segments obovate-cuneate in outline, $5-7 \mathrm{~cm}$. long, first cleft about half-way and then again cleft into lanceolate, ovate or oblong acute lobes: inflorescence long and dense, often branched; bracts linear; pedicels ascending, $\mathrm{I}-\mathrm{I} .5 \mathrm{~cm}$. long, densely viscid-pubescent: bractlets small, linear, close under the calyx: sepals light blue with darker median lines or blotches towards the tips, oblong-oval, obtuse or the upper acutish, finely puberulent; spur thick, straight or slightly curved, I $2-15 \mathrm{~mm}$. long, almost horizontal : petals of the same color as the sepals; the lateral ones cleft only at the apex, often wavy-toothed: follicles erect, densely viscid-pubescent.

This is nearest related to $D$. cuculatum $\mathrm{A}$. Nelson on one hand and to $D$. occidentalc on the other. From the former it differs in the pubescence, which in $D$. cuculatum is strigose, in D. multiflorum viscid. D. occidentale has much darker flowers and more acute sepals. D. multiflorum grows along streams and in damp meadows or open woods at an altitude of 2000-2500 $\mathrm{m}$.

Wroning: Spread Creek, I $\$ 97, F$. Tiwedy', I 79 (type in herb. N. Y. Bot. Gard.) ; Yellowstone Lake, iss8, R. S. IVilliams; Laramie Mountains, I899, Charics Schuchut; between Upper 
Buffalo Fork and Du Noir River, IS99, C. C. Curtis; Snake River, I S99, Aven \& Elias Velson, 6707.

Idaho: Henry's Lake, I 897, Rydberg \& Bessey, 7079 .

Colorado: North Park, i 896, C. F. Baker.

\section{Delphinium Brownii}

Perennial: stem about $\mathrm{I} \mathrm{m}$. high, glabrous and shining throughout, simple: leaves palmately divided into about 5 divisions, puberulent; lower petioles $8-10 \mathrm{~cm}$. long : divisions $4-6 \mathrm{~cm}$. long, oblanceolate in outline, once to twice cleft into lanceolate, acute, somewhat spreading lobes: inflorescence a rather lax raceme: bracts linear; pedicels slender, $\mathrm{I}-2 \mathrm{~cm}$. long, almost erect, curved and twisted; upper portion sometimes slightly puberulent ; bractlets linear-subulate, small, 3-4 mm. long: sepals dark blue or purple, oblong-oval, obtuse or the lower and upper acutish, IO-I 2 mm. long: lateral petals also blue or purplish; blade cleft only about one third its length: upper petals of the same color or paler, obliquely cuneate, acute; spur short and rather thick, I cm. or less long, straight and ascending : follicles erect, glabrous.

This is nearest related to $D$. glanum, but differs in the puberulent leaves with narrower segments, the lax raceme with more erect pedicels and the darker flowers.

Alberta: Banff, i 893, Addison Brow'n (type in herb. Columbia University).

Alaska: Porcupine River, i\$91, J. H. Turner.

\section{Delphinium elongatum}

Tall perennial with a short woody caudex: stem glabrous and glaucous up to the inflorescence, which is slightly strigose: leaves digitately divided into about 7 divisions, glabrous and glaucous beneath; petioles fully I dm. long; divisions of the blade oblanceolate in outline, $5-7 \mathrm{~cm}$. long, cleft into lanceolate, acute lobes: inflorescence strict and elongated; bracts small, linear, almost filiform; pedicels $\mathrm{I}-2 \mathrm{~cm}$. long, at first ascending, in fruit almost erect; bractlets minute, subulate: sepals and petals dark blue, the former oval, obtuse or acutish, about I cm. long; spur short, straight, about I $2 \mathrm{~mm}$. long: lateral petals cleft at the apex, more or less toothed: follicles erect, I 2-I $5 \mathrm{~mm}$, long, strigose-puberulent.

In some respects nearest to $D$. glaucum, but differing in the puberulent pod, strigose pubescence at least on the pedicels, and the narrower divisions and lobes of the leares. It grows at an altitude of about $2000 \mathrm{~m}$. 
Colorado: Larimer county, I 895. Crandall \& Cowen, I5 (type in herb. N. Y. Bot. Garden); Villa Grove, I 896, F. Clements, 338 ; Middle Park, r 86 r, C. C. Parry, $\mathcal{S}_{5}$; Baxton's Ranch, I 890 , Crandall, $15+7$.

Montana: Lima, I 895 , Rydberg.

\section{Delphinium diversicolor}

Perennial with a thick fleshy root, the branches of which are often fusiform: stem about $4 \mathrm{dm}$. high, simple, strict, densely viscid-pubescent above: leaves finely pubescent, palmately dissected into linear lobes; petioles of the lower leaves 3-5 cm. long, slightly dilated below; segments $\mathrm{I}-3 \mathrm{~cm}$. long, about $2 \mathrm{~mm}$. wide: inflorescence a narrow raceme; pedicels $.5-1 \mathrm{~cm}$. long, or in fruit $\mathrm{I} .5$ $\mathrm{cm}$., densely viscid, almost erect: sepals dark blue, oblong-oval, obtuse, IO-I $3 \mathrm{~mm}$. long, slightly pubescent ; spur almost straight, horizontal : petals all white with blue veins and yellowish below; the upper about $5 \mathrm{~mm}$. long, obliquely spatulate, obtuse ; the lateral ones slightly longer, curved; the blades deeply 2-cleft; each lobe of the form of one third of a circle: follicles densely hairy.

This species is perhaps nearest related to $D$. simplex and $D$. Burkei. From the former, it differs in white lateral petals and the pubescent leaves, and the latter is described as subscapose. The type was collected in a bog, at an altitude of $2000 \mathrm{~m}$.

Montana: Rattlesnake Creek, Beaver Head county, IS87, Frank Taecdy, if (type in herb. Columbia University).

\section{Aconitum tenue}

Perennial with small tubers about $8 \mathrm{~mm}$. long and $4 \mathrm{~mm}$. thick: stem very slender, about $3 \mathrm{dm}$. high : leaves few; the lower with petioles $5-8 \mathrm{~cm}$. long, the uppermost subsessile: blades glabrous, thin, shining, almost pentagonal in outline, $5-7$-divicled to near the base; divisions rhombic in outline, 3 -cleft and the lobes often again cleft, the ultimate divisions oblong-linear to linear-lanceolate, acute: inflorescence racemose, 2-6-flowered: pedicels erect and bent near the glabrous blue calyx: hood I 5-I $\mathrm{Smm}$. long, boat-shaped, slightly saccate, almost semicircular in outline; lateral sepals rounded ovate, only slightly oblique, IO-I $2 \mathrm{~mm}$. long; lower sepals oblong, obtuse at the apex, $8-10 \mathrm{~mm}$. long: fruit unknown.

The type was collected in a damp cañon among rocks at an altitude of about $2000 \mathrm{~m}$. It is perhaps nearest related to the Alaskan 4. delphinifolium. 
South Dakota: Sylvan Lake, Black Hills, i S92, P. A. Ry'dberg, 507 (type in herb. Columbia University).

\section{Aconitum atrocyaneum}

Perennial with thickened-fusiform roots : stem stout, 4-6 dm. high, leafy, glabrous below, densely glandular viscid and purplish above: lower leaves with petioles $5-10 \mathrm{~cm}$. long; blades about $6 \mathrm{~cm}$. wide, glabrous, pentagonal in outline, $5-7$-divided to near the base; divisions rhombic-cuneate to oblanceolate, usually twice cleft ; ultimate segments lanceolate acute; upper stem-leaves similar but with short petioles or those of the inflorescence lanceolate, toothed and often with recurved basal lobes: inflorescence racemose, many-flowered, leafy: pedicels $\mathrm{I}-3 \mathrm{~cm}$. long, erect, very viscid: flowers dark indigo blue, more or less pubescent: hood deeply saccate, helmet-shaped, about is mm. long, with the front line more or less concave : beak somewhat porrect, acuminate, the lower margins nearlyhorizontal : lateral sepals broadly roundedovate, somewhat oblique, I 2-I $5 \mathrm{~mm}$. long : lower sepals 9-I $2 \mathrm{~mm}$. long, oblong, obtuse.

This species is perhaps closest related to $A$. ramosum A. Nelson, but the divisions of the leaves are broader and the hoods are different, having a porrect beak, while in $\mathrm{A}$. ramosum the beak is short and directed downward. The flowers are also darker and the inflorescence more viscid. It grows at an attitude of 2,500 $-3,400 \mathrm{~m}$.

Colorano: Boreas, i 897, C. S. Crandall (type in herb. N. Y. Bot. Garden; cotypes in herb. State Agric. College, Colo.); mountains about Steamboat Springs, IS9I, C. S. Crandall; near Ironton, I 899, C. C. Curtis; Cameron Pass, is96, C. F. Faker.

UTAнl : Uinta Mountains, Is73, T. C. Portor.

\section{Aconitum porrectum}

Perennial with thick fusiform roots: stem stout, $6-7 \mathrm{dm}$. high, leafy, glabrous below, densely viscid-pubescent above; basal leaves glabrous, with petioles about $1 \mathrm{dm}$. long; blades reniform-pentagonal in outline, 6-10 cm. wide, 5-7 divided to near the base ; divisions rhombic or rhombic-oblanceolate, variously cleft above, cuneate at the base: inflorescence racemose or somewhat paniculate, not leafy; pedicels ascending, I-3 cm. long: sepals dark blue, ciliate on the margins; hood very saccate, helmet-shaped; beak acuminate, porrect, horizontal or even slightly ascending, 15-I $8 \mathrm{~mm}$. long; lateral sepals broadly obovate or semi-reniform, 
about I 2-14 mm. long, very oblique; lower sepals lanceolate or oblong, acute, 7-10 mm. long.

This is closely related to the preceding, but differs in the broader and less deeply divided divisions of the leaves, the shorter lower sepals, the more open and less leafy inflorescence, and the more oblique lateral sepals. It grows at an altitude of $2400-$ $2800 \mathrm{~m}$.

Colorado: Coffee Pot Spring, I 894, Crandall (type in herb. N. Y. Bot. Garden ; cotypes in herb. State Agric. College, Colo.); Graymount, I 892, Crandall; foothills, Larimer county, I 895 , Crandall \& Cowen; Arapahoe Pass, I891, Crondall, 26; Lake City, 1881, J. S. Ncrubory; North Park, near Teller, I884, C. S. Sheldon.

\section{Aconitum glaberrimum}

Perennial with a tap root: stem aimost I m. high, perfectly glabrous: leaves 5 -divided, thin, perfectly glabrous, the lower longpetioled; the uppermost subsessile; divisions oblanceolate to rhombic-oblanceolate in outline, 5-10 cm. long, cuneate and entire at the base, irregularly doubly cleft above; lobes or teeth lanceolate, acute or acuminate: inflorescence compound; branches and pedicels spreading or divergent, glabrous: flowers blue: lower sepals lanceolate, I $2-15 \mathrm{~mm}$. long; lateral ones very oblique, as broad as long, about I $5 \mathrm{~mm}$. each way, rounded, slightly reniform on the upper side; hood about $2 \mathrm{~cm}$. long, deeply saccate, elongated helmet-shaped; beak long-attenuate, very porrect or even ascending.

The type specimen was included in $\mathcal{A}$. Colmmbianum by Dr. Gray, his "Syn. Fl. N. Amer." label being on the sheet; but it is so unlike all other material of that species that I can not see the reason why it should be included therein. The perfectly glabrous stem, the branched inflorescence, the peculiar, deeply saccate hood and the slender porrect beak are characters not found in any other American aconite.

Southern Utah, Northern Arizona: i 877, Dr. E. Palmir, II (type in herb. Columbia University).

\section{Anemone tuberosa}

Ancmone splucnoplylla Britton, Ann. N. I. Acad. 6: 224, in part. Not Poepp. 1827-29.

Perennial with a thick tuberous root, basal leaves with petioles 
about $5 \mathrm{~cm}$. long, twice ternate; divisions rhombic-cuneate in outline, ternately cleft and toothed; teeth oblong-ovate: scape $I-3$ $\mathrm{dm}$. high, perfectly glabrous below the involucre; peduncles finely appressed silky; involucral leaves similar to the basal ones, but short-petioled and with longer lobes and teeth; peduncle solitary or a second one with a smaller involucre: sepals white or purplish, 8-IO, oblong-linear, I-2 cm. long, finely silky: head of fruit ellipsoid, about $\mathrm{I} \mathrm{cm}$. thick and $2 \mathrm{~cm}$. long: achenes densely woolly: style filiform, about $1.5 \mathrm{~mm}$. long.

This is closely related to $A$. sphenoplyylla of Chili, but in that species the whole scape is decidedly pubescent with spreading hairs and the segments of the involucral leaves are narrower. The following species belong here:

Arizona: Sierra Tuscon, i 884, C. G. Pringle (type in herb. Columbia University); Fort Huachuca, I892, S. E. ITilcox.

New Mexico: Mountain near Las Cruces, i895, E. O. llooton.

Utah: St. George, isSo, M. E. Jones, I607.

California: Panamint Mountains, i891, Coaille \& Funston, 500; I 849 (locality not given), Fremont.

\section{Anemone lithophila}

Perennial with a short thick rootstock: basal leaves several, glabrous or nearly so, thickish, shining, somewhat glaucous; petioles $5-8 \mathrm{~cm}$. long; blades ternate; divisions obovate-cuneate, about $3 \mathrm{~cm}$. long, strongly veined, deeply 3 -cleft, again cleft and toothed; the ultimate segments short, oblong-oblanceolate: scape I-2 dm. high, sparingly pubescent with long silky hairs: involucral leaves subsessile or short-petioled; divisions similar to those of the basal leaves: sepals silky, ochroleucous, tinged with blue, I 2-I $5 \mathrm{~mm}$. long, broadly obovate or oval: achenes densely villous all over: style filiform, about $2 \mathrm{~mm}$. long.

The type was growing with $A$. pariflore at an altitude of I Soo m. As none of the specimens there had well-developed fruit and the plant is intermediate between A. pariffora and A. globose Nutt., which also grew in the neighborhood, this species may be a hybrid. The strong veins and shiny glaucous leaves suggest the former but the general leaf-form the latter, although the segments are broader and shorter and the leaves more glabrate. Watson's specimen, which resembles the type perfectly has fully developed fruit, however. The type was labelled $A$. Tetonensis, 
which it resembles most in habit; but the achenes are wooly all over, not merely strigose on the back as in that species and the flowers are larger and lighter. The following specimens are to be referred here:

Montana: Little Belt Mountains, nine miles from Barker, 1896, J. H. Flodman, 59 (type in herb. N. Y. Bot. Garden), and $46_{3}$; Lake Stanton, I 894, R. S. Williams.

UTaн : Uinta Mts., i 869, S. Watson, IO.

\section{Anemone Piperi Britton}

Perennial with a rather slender rootstock: stem $1.5-3 \mathrm{dm}$. high, slender, very sparingly appressed silky; basal leaves ternate, minutely appressed-puberulent when young, in age glabrous; petioles I-2 dm. long; middle lobe rhombic-obovate or rhombic-cuneate, coarsely toothed above the middle, $2-7 \mathrm{~cm}$. long; the lateral ones broader, obliquely ovate, 2 -cleft to about the middle, coarsely toothed: involucral leaves similar, but the lobes usually narrower: petioles $\mathrm{I}-3 \mathrm{~mm}$. long: pedicel $2-5 \mathrm{~cm}$. long, erect in fruit, sparingly appressed silky: sepals elliptic-obovate to oval, about I 5 $\mathrm{mm}$. long, 6-8 mm. wide, white, glabrous: achenes about $4 \mathrm{~mm}$. long, densely short-pubescent, ellipsoid, slightly compressed, tapering to both ends: beak very short.

This has been included in A. quinquefolia and all specimens cited for that species from the Northwest may belong here. It differs, however, from that species in the form of the basal leaves, the erect pedicels and the short, almost straight beaks of the achenes.

Iddho: Latah county, I 893, C. IV. Piper, I f69 (type in herb. Columbia University); Craig Nountain, 1892, Sandberg, MacDougal \& Heller, 197 .

Washington: Kamiac Butte, i 896, A. D. E. Elmir, 393.

\section{Clematis Jonesii (Kuntze)}

Clcmatis Douglasii var. Jonssii Kuntze, Verh. Bot. Ver. Brandenburg, 26: iso. I 886.

Perennial with a thick rootstock or caudex: stems $3-6 \mathrm{dm}$. high, simple or later in the season branched, more or less woolly when young: leaves twice pinnately divided, $I-I .5 \mathrm{dm}$. long, villous when young, in age glabrate, rather firm, segments lanceolate to linear-lanceo ate, often cleft, $1-5 \mathrm{~cm}$. long, acutish: flowers nod- 
ding : calyx campanulate, brown, more or less villous, especially near the margins; sepals $2-2.5 \mathrm{~cm}$. long, ovate, acute or acuminate, upper half with a wavy dilated margin: achenes about $5 \mathrm{~mm}$. long and $4 \mathrm{~mm}$. wide, flattish, densely silky; tails of the achenes $4-5 \mathrm{~cm}$. long, beautifully plumose throughout.

This is nearest related to $C$. Dorrglasii, with which it has been confused. It differs from that species in the dilated margins of the sepals, the distinctly petioled and less compound leaves. In the true $C$. Douglasii the upper and middle leaves are twice pinnately divided and subsessile, so that they with the first pair of primary divisions look as if verticillate. Kuntze's description of C. Douglasii var. Joncsii is so meager that nobody could know from it what he meant, but fortunately we have one of Jones' specimens. The following specimens belong to C. Jonisii.

Colorado: Howe's Gulch, is99, H. F. MI.; Dolores (7300 ft.), I 892, Crandall: lat. $39^{\circ}-41^{\circ}$, I 862 , Hall \& Harbour, 2; Howe's Gulch, I893, C. F. Baker; near Boulder, IS92, H. M. Penterson, i68: Dixon Cañon, is91, J. H. Couten, 368.

Utan : Uinta Mountains, i 869, S. Il atson, I; American Fork, I $880, .1 \%$. E. Jones, 1351 .

Wroming: Headwater of Tongue River, Big Horn Mountains, isgs, Frank Tricedy, $17 I$.

\section{Clematis eriophora}

Perennial, from a woody caudex : stems and leaves prominently white-villous, the former $3-5 \mathrm{dm}$. high, simple: leaves $5-10$ $\mathrm{cm}$. long, distinctly petioled, twice pinnately divided; ultimate segments narrowly linear, $\mathrm{I}-3 \mathrm{~cm}$. long, $\mathrm{I}-2 \mathrm{~mm}$. wide: flowers nodding; calyx villous, campanulate, about $3 \mathrm{~cm}$. long; sepals oblong, obtuse, the upper third spreading, with a dilated margin : achenes oblong, about $6 \mathrm{~mm}$. long and $3 \mathrm{~mm}$. wide, silky, with a blunt ridge on each side; tails about $4 \mathrm{~cm}$., beautifully plumose.

This is closely related to the preceding and to C. Bakcri, but differs from the former in the narrower leaf-segments, the obtuse and thicker sepals and the denser and more persistent pubescence, and from the latter in the longer leaf segments and the obtuse dilated sepals. It grows at an altitude of I 500-2000 m.

Colorado: Vicinity of Horsetooth, i 896, J. H. Cowen (type in herb. N. Y. Bot. Garden ; cotypes in herb. State Agric. College, Colo.); Foothills, Larimer county; I 893 , C. S. Crandall ; Colorado, 
I870, Dr: G. IV. Hulse; I 844, Fremont, 567; Pagosa, I S83, Brandegec; Golden City, I87 I, E. L. Grocue; Clear Creek, is73, John W'olf, 92; Colorado Springs, I900, Rydberg \& Treclend, 6232; Rist Cañon, I 890, Crandall, 272; I 893, I379; Horsetooth Gulch, I898, Crandall.

Clematis Wrethi Nutt. Journ. Acad. Phila. $7: 6$ I $\$ 34$

I think that this species is distinct from C. Douglasii Hook, the leaves being never twice pinnately divided, having much broader segments and never being falsely verticillate as in that species. The specimens from Beaver Cañon, Idaho, cited in the synoptical flora under C. Douglasii var. Scottii and in Howell's flora of the Northwest under $C$. Scottii belongs undoubtedly here. A broad-leaved C. Wyethii and a narrow-leaved $C$. Scottii resemble each other very much and can be distinguished only by the flower, which in the former is campanulate with oblong-lanceolate sepals and in the latter rounded urn-shaped with broadly ovate sepals. C. Hyethii is common in Montana and northern Idaho. It is represented by the specimens cited under $C$. Scottii and some under $C$. Douglasii in my catalogue of the flora of Montana.

Atragene occidentalis Homem. Hort. Hafn. I 8 I $3: 520$

Atragene Columbiana Nutt. Journ. Acad. $7: 7$. I $834 ;$ Clinatis Columbiana Torr. \& Gray, Fl. N. Am. I : Io. I $S_{3} S$; Climatis atrticillaris var. Columbiana Gray. Syn. Fl. I : S. I 895 ; Climertis Pseudoatragene a normalis Kuntze, Verh. Bot. I'er. Brandenburg, 26: I60, in part, I $\$ 84 ; C$. alpina a occidentalis 3 typia Kuntze, l.c. 161 .

Dr. Gray adopted the name occidcutolis as a varietal name for another species, and cites Homeman's plant as a synonym. It is very evident that the latter is the common plant of the Columbia Valley with simply ternate leaves and subentire leaflets, for Homeman expressedly describes them as entire. Dr. Kuntze was so far right that he placed Atragenc occidentalis Homeman with $A$. a'trticillaris, although he made both forms of Clematis alfina. His revision of Clmatis is far from good especially as to the West American species. The only distnction he makes between $C$. pseudoatragene and $C$. alpina is the absence or presence of stami- 
nodia, a very unfortunate distinction, for in most of the IVest American forms both conditions exist. The filaments of the outer stamens are flattened and more or less petaloid. In some cases the outermost have no anthers (true staminodia), but often all are antheriferous. The present species is therefore placed in both species by Kuntze. Atragcne occidcntalis differs, however, from the eastern A. Amcricana in the fact that the staminodia as far as I know always are linear, while they are in A. Ancricana decidedly spatulate. A. occidcntalis is common from British Columbia and the Canadian Rockies south to California and Colorado.

\section{Atragene grosseserrata}

Trailing or climbing over bushes: leaves ternate; petioles 5 $-8 \mathrm{~cm}$. long; petiolules $\mathrm{I}-2 \mathrm{~cm}$. long; blades broadly ovate, oblique, somewhat cordate at the base, $3-4 \mathrm{~cm}$. long, coarsely toothed and often somewhat lobed: peduncles 5-10 cm. long: sepals lanceolate, about $4 \mathrm{~cm}$. long, I O-I $3 \mathrm{~mm}$. wide, acute : staminodia about i $8 \mathrm{~mm}$. long, decidedly spatulate, a little exceeding the stamens: achenes small, sparingly hirsute: tails about $3 \mathrm{~cm}$. long, plumose throughout.

This is closest related to the eastern . A. Ancricana; but the leaves are deeper serrate and the sepals are longer, lanceolate, and resemble more those of $A$. tenuiloba. From $A$. occidcntalis it differs in the spatulate staminodia, the shorter leaflets, which are coarsely serrate except the very base. In $A$. occidcntalis the leaflets are entire or merely crenate above the middle.

IDAно: Palouse county and about Lake Coeur d'Alene, I 892 , G. B. Aiton (type in Herb. N. Y. Bot. Garden, flower).

Washington: Cascade Mountains, is82, F. Ta'celly (fruit).

\section{Atragene repens (Kuntze)}

Clematis alpina o occidentalis 2 repins Kuntze, Verh. Bot. Ver. Brandenberg, 27, I6I, in part. I 884 .

Plant trailing: leaves biternate, glabrous, firmer than in the two preceding: petioles $5-8 \mathrm{~cm}$. long: secondary leaflets subsessile except the terminal, which is short-stalked, broadly ovate, coarsely toothed with broadly ovate teeth, $3-4 \mathrm{~cm}$. long, abruptly short acuminate at the apex: peduncles over $\mathrm{I}$ dm. long : sepals ovate-lanceolate, about $4 \mathrm{~cm}$. long, acute: staminodia linear: achenes about $5 \mathrm{~mm}$. long, pubescent: tails about $4 \mathrm{~cm}$. long, plumose throughout. 
Dr. Kuntze's description of the subvariety repons is just as meaningless as the rest of his descriptions. He cites specimens, however, viz., Joncs no. $I S \mathcal{} 2$ and $I \& \mathcal{S} 7$. We have two sheets of each and they evidently do not belong together. No. I882 in both the Columbia University and New York Botanical Garden herbaria are in fruit, have simply ternate leaves with subentire leaflets and must be referred to $A$. occidentalis. No. I 887 in flowers, on the contrary, has biternate leaves, and the leaflets are coarsely toothed. Dr. Kuntze's subvariety is, therefore, "eine zusammengesetzte" and according to some Germans, should be ruled out. After the part that belongs to $A$. occidcntalis has been removed, I have adopted the name for the residue.

Utah: American Fork, ISSo, M. LE. Jones, ISS7 (type in herb. N. Y. Bot. Gard.).

Wroming: Wolf Creek Cañon, I 896, Aven Niclson, 2297, in part, the larger part belonging to $A$. timiloba.

\section{Atragene pseudoalpina (Kuntze)}

Atragene Ochotensis Gray, P1. Fendl. 4. I 849. Not Pall. I $874 ; A$. alpine var. Ochotensis A. Gray, Am. Jour. Sci. II. 33 : $24 \mathrm{I}$; Clematis alpina var. Ochotcnsis S. W'ats. Bot. King Exp. 5 : 4 ; C. alpina var. occidentalis A. Gray; Powell, Geol. Surv. Dakota, 53 I. I8So. Not Atragene occidentalis Homem. I8I 3 ; Clamatis psendoatragene i pscudoalpina Kuntze, Verh. Bot. Ver. Brandenburg, 26: i60. I $88_{4}$.

As stated above, the name occidentulis should be used for $A$. Columbiana Nutt. We are therefore obliged to adopt Kuntze's varietal name. In the Synoptical Flora Clcmatis pscudoatragen Kuntze is given as a synonym, but from the short description neither of the varieties $\alpha, \beta$ or $o$ can belong here. The var. " normalis is evidently partly A. Americana and partly A. occidentalis as here understood. The var. o subtriternate is A. timiloba (A. Gray) Britton. What Clomatis psudoatragene var. 3 Wenderothioides* is I do not know. In the Synoptical Flora the range is given as extending from New Mexico to Dakota and Washington. I have not seen any specimens from any station north of

* What a name! Translated it would mean: A variety of the false Atragene Virgin's Bower, resembling Mr. Wenderoth. 
Colorado and Utah. All specimens referred here from higher latitudes belong to A. temiloba.

\section{Ranunculus Utahensis}

Perennial with a cluster of fibrous fleshy roots, glabrous : stems I-2 dm. high, branched above; basal leaves petioled; petioles 2$5 \mathrm{~cm}$. long ; blades almost orbicular, rather thick, crenate or roundlobed : stem-leaves sessile, deeply cleft or divided into 4-5 oblong or elliptic, obtuse segments: sepals somewhat hairy, elliptic to obovate, at last reflexed: petals 4-5 $\mathrm{mm}$. long, exceeding the sepals : head of fruit oblong; achenes glabrous; style rather short.

This species resembles most a depauperate $R$. ahortions in the leaves, but the petals are much larger and the head of fruit is oblong instead of spherical. It has gone under the name of $R$. affinis var. lciocarpus, but it is not that of Trautvetter, and is distinguished from all of those species which have been included in $R$. affinis by its thicker leaves and their lobing.

UTAн: Alta, Wasatch Mts., I879, .I. E. Jones, I I3o (type in herb. Columbia University); Uinta Mts., I 873, T. C. Portcr.

\section{Ranunculus micropetalus (Greene)}

Ramunculus affinis var. micropctalus Greene, Pittonia, 2: 110. 1890.

An excellent species, very distinct from $R$. affinis Hook., and still more from $R$. cartiophyllus Hook., with which Davis associated it.

\section{Ranunculus Helleri}

Perennial with a short rootstock, perfectly glabrous: stem slender, $\mathrm{I}-2 \mathrm{dm}$. high : basal leaves and lower cauline with slender petioles $2-5 \mathrm{~cm}$. long; blades of the earlier basal leaves reniform, 3-cleft $2 / 3$ or $3 / 4$ the distance to the base; middle division oblong, entire, the lateral ones with 3 ovate lobes; blades of the other basal leaves and the lower cauline divided to near the base into 3 cuneate divisions, I 5-20 mm. long; the middle division 3lobed, the lateral ones 4-lobed; stipules of lower cauline leaves conspicuous, rounded: upper cauline leaves sessile, divided unto the base into 2-4 linear-oblong divisions: flowers solitary : sepals oblong, obtuse, about $5 \mathrm{~mm}$. long: petals oblong to obovate, golden yellow, 6-7 mm. long: head of fruit short-oblong or spherical: achenes turgid, almost spherical, I.5 $\mathrm{mm}$. long, glabrous: style slender and curved.

This species is mearest related to $R$. Eschschotzii and $R$. alpeo- 
philus. 'In the former, which is very rare in the Rockies. the upper stem-leaves have broad and short lobes, which are elliptical to obovate; and in the latter the basal leaves are not reniform but almost orbicular in outline. R. Hellerigrows in bogs at high altitudes.

IDAHo: Near Lake Pend d'Oreille, i 892, Sandbror, .1 Hac Dougal $\&$ Heller, $S_{f 2}$ (type in herb. N. Y. Bot. Gard.).

Wromins: Big Horn Mountain, I 899, F. Tauedy', 2385.

Montaxa: Sperry Glacier, I901, F. K. Irecland, II IO.

\section{Ranunculus stenolobus}

Perennial with a cluster of fibrous roots, perfectly glabrous: stems $1-3$ from the same clump, $I-2 \mathrm{dm}$. high, usually branched: basal leaves and lower cauline petioled; petioles $4-10 \mathrm{~cm}$. long; blades three times ternately dissected into almost linear segments, which are $6-15 \mathrm{~mm}$. long and $1-3 \mathrm{~mm}$. wide, usually somewhat narrowed at the base; the primary clivisions distinctly petiolulate : sepals oval, 4-5 mm. long: petals obovate, 7-S (rarely 9-II) $\mathrm{mm}$. long : head of achene spherical or slightly oblong, about 6 $\mathrm{mm}$. broad : achenes turgid, glabrous: style slender.

This species is somewhat intermediate between $R$. adoncus and $R$. tritcmatus, but the stem is more elongated and branched. Some of the specimens cited below have been referred to the former, but in that plant the stem is usually simple, the petals over I cm. long, cuneate-flabelliform and overlapping each other, the lobes of the leaves narrower and not narrowed downward. In the leaf-form and flowers it resembles more $R$. tritematus, but that grows in big clumps with numerous stems, and the segments are more decidedly petiolulate.

Wroming: Headwaters of Cliff Creek, 1900, C. C. Curtis (type in herb. N. I. Bot. Gard.).

UTAн: Alta, Wahsatch Mts., I879, M. E. Jones, I107; Wahsatch Mt., I869, S. IVatson, zo.

\section{Papaver pygmaeum}

A cespitose and scapose perennial; leaves all basal, numerous $2-3 \mathrm{~cm}$. long ; blade less than I cm. long, broadly ovate in outline, deeply cleft into rounded-oblong or obovate segments, sparingly hispid or glabrous: scape $4-6 \mathrm{~cm}$. high, sparingly hirsute; so also the calyx, which is obovate in bud: petals yellow, $1 \mathrm{~cm}$. or less long: pod obovoid, about $1 \mathrm{~cm}$. long, densely bristly.

This species is nearly related to $P$. radicatum Rottb., but is a still smaller plant, with shorter, broader, less divided, less bristly 
leaf-blades and smaller flowers. It resembles still more the European $P$. Pyrenaicum, which has larger petals, $\mathrm{I}-2 \mathrm{~cm}$. long, stamens much exceeding the ovary and spherical flower-buds.

Montana: Mountain above Stanton Lake, I 894, R. S. ITilliams, 992 (type in herb. N. Y. Bot. Garden).

Alberta: Sheep Mountain, I895, John Macoun, I0269; top of Rocky Mountains, I88 I, G. M. Dawson.

\section{Argemone rotundata}

Stem stout, densely and strongly bristly, but otherwise glabrous: leaves oval in outline ; the cauline ones sessile and broadly auricled, bristly, especially on the veins and margins, round-lobed : flowers short-pedicelled or subsessile : calyx very bristly ; its horns erect or slightly spreading, bristly: petals white, fully $4 \mathrm{~cm}$. long: pod ovoid, very bristly.

This has been mistaken for A. hispida Gray but is perhaps nearer related to $A$. intermedia and $A$. platyceras. From $A$. hispida it is easily distinguished by the absence of a finer indumentum and by the round-lobed leaves. The latter character also distinguishes it from the other two species mentioned. It is also much more bristly than the two. It grows at an altitude of I 500-I $800 \mathrm{~m}$.

Nevada: Diamond Mountains, July, I 868 , S. I'atson, 77 (type in herb. Columbia University).

Uтан : Utah Valley, i869, S. ITatson, 79.

\section{Bicuculla occidentalis}

Perennial with a very short rootstock bearing numerous tubers : scape and leaves perfectly glabrous; petioles of about $1.5 \mathrm{dm}$. long; blades twice ternate; the divisions twice pinnately divided or cleft into linear-oblong lobes, $\mathrm{I}-2 \mathrm{~cm}$. long, $3-5 \mathrm{~mm}$. wide: scape about $3 \mathrm{dm}$. high : raceme simple: sepals oval, about $5 \mathrm{~mm}$. long: petals pink; the outer about I cm. long; their spurs about I $2 \mathrm{~mm}$., divergent, forming with each other an angle of $90^{\circ} \mathrm{or}$ more: crest of the inner petals prominent ; capsule fusiform, with the style about $1.5 \mathrm{~cm}$. long.

This is nearest related to B. cucullaria, and has been confused with it, but has coarser foliage, more diverging and longer spurs, more prominent crest on the inner petals and the underground parts more gruinose and not scaly. Its range inclutes parts of Oregon, Washington and eastern Idaho, and it grows on shaded hillsides.

Washington: West Klickitat county; I 892, II. $\mathrm{N}$. Suksdorf (type in herb. Columbia University). 
CONTRIBUTIONS FROM THE NEW YORK BOTANICAL GARDEN-No. 23

\section{STUDIES ON THE ROCKY MOUNTAIN FLORA VIII.}

BY PER AXEL RYDBERG.

NEW YOR K

1902

[Reprinted from BUlletin Torrey Botanical Club, 29 : 232-246, April 24, 1902.] 



\section{Studies on the Rocky Mountain Flora--VIII \\ BY l'ER ANEL RVIDBERG.}

\section{Stanleya arcuata sp. nov.}

Perennial with a ligneous caudex, 4-IO dm. high, perfectly glabrous; stem light green and shining, in age straw-colored: leaves entire or the lower with short and broad lobes, lanceolate, longpetioled, thick, $5-12 \mathrm{~cm}$. long ; pedicels rather short, in fruit, about I $\mathrm{cm}$. long: sepals yellow, linear about $\mathrm{I} 5 \mathrm{~mm}$. long; petals yellow; blades $7-\$ \mathrm{~mm}$. long, broadly efliptic, almost as long as or at least two thirds as long as the claw : pods $7-10 \mathrm{~cm}$. long, strongly arcuate, and spreading.

This species is nearest related to S. intigrifolia, but is taller, more shrubby, with narrower leaves and broader petals. S. pinnata (Pursh) Britton, with which both have been confused, has hairy leaves, most of which are deeply pinnatifid, and the blades of its petals are linear oblong and only one third or one half as long as the claws. S. arreucter grows in dry regions from Wyoming to Nevada and south to Colorado and Arizona ; probably also in California.

Nevada: Unionville Valley, is68, S. IVatson, 105 (type in herb. Columbia University).

\section{Stanleya canescens sp. nov.}

Stout perennial $.5^{-1} \mathrm{~m}$. high ; stem light green, finely puberulent or glabrate, terete : leaves grayish puberulent, the upper entire and oblanceolate, $5-7 \mathrm{~cm}$. long; the lower pinnatifid with oblong lateral lobes and a large oval or elliptic end-lobe: raceme dense, pedicels short, in fruit $1 \mathrm{~cm}$. or less long, divergent : sepals linear, about $12 \mathrm{~mm}$. long; blades of the yellow petals linear-oblong, about half as long as the claw : pods arcuate, spreading, $5-7 \mathrm{~cm}$. long.

This is nearest related to the preceding, differing in the puberulent leaves, which are shorter and broader and more inclined to be pinnatifid.

Utah: Frisco, ISSO, MI. E. Jonles, ISOQ (type in herb. N. Y. Bot. Garden).

Arizona: Fort Verde, I887, E. A. Mearns; Verde River, $\mathrm{ISS}_{3}$, H. H. Rusby' Hexican Boundary Surrey. 


\section{Thelypodium macropetalum sp. nov.}

A glabrous perennial, 4-6 dm. high : basal leaves oblanceolate or spatulate, short-petioled, $2-5 \mathrm{~cm}$. long: lower stem-leaves oblong, obtuse, sessile, with rounded auricles at the base, 5-6 cm. long: upper leaves lanceolate-sagittate, acute; pedicels in fruit about i $\mathrm{cm}$. long, divaricate: sepals about $5 \mathrm{~mm}$, long, purplish with white margins; petals purple, spatulate, long-clawed, nearly three times as long as the sepals: pods $4-5 \mathrm{~cm}$. long, ascending or erect and somewhat incurved.

This is related to $T$. sagittatum (Nutt.) Heller and T. paniculatum A. Nelson. From the former, it differs in the smaller leaves, the rounder auricles, the erect, not reflexed nor spreading pod; and from the latter by the much longer petals. It grows at an altitude of $1,000-1,200 \mathrm{~m}$.

UTah: Farmington, isSi, M. E. Jones, is $f I$ (type in herb. N. Ir. Bot. Garden).

IDAHO: Soda Springs, r892, Isabd Mulford.

\section{Thelypodium Utahense sp. nov.}

Annual or biennial: stem 4-6 dm. high, sparingly pubescent below; leaves all lanceolate in outline, 5-IO cm. long, lanceolate, glabrous; segments broad and crowded, oblong-lanceolate to triangular: pedicels very short, in fruit scarcely more than $\mathrm{r} \mathrm{mm}$. long: sepals oblong, about $2 \mathrm{~mm}$. long : petals spatulate, almost twice as long, white: pod about $3 \mathrm{~cm}$. long, strongly reflexed.

This is probably nearest related to S. reftcrum Nutt., which is decidedly hispid on the stem and the reins of the leaves and has much narrower leaf-segments. It grows at an altitude of about $600 \mathrm{~m}$.

Utaft: St. George, isSo, M. E. Jones (type in herb. N. Y. Bot. Garden); 1877, E. Palmer, 28.

\section{Lepidium Jonesii sp. nov.}

Iefidium montanum var. alyssoides Jones, Zoe, 4: $266 . \quad$ I 893. Not L. alyssoides A. Gray. 1849 .

Perennial with a short woody caudex: stems $2-3 \mathrm{dm}$. high, glabrous, branched, glabrous: basal leaves pinnatifid with linear acute divisions; stem-leaves similar or the upper entire, narrowly linear: racemes rather short and dense; pedicels in fruit $6-8 \mathrm{~mm}$. long, spreading: sepals oblanceolate, obtuse; petals white, much 
exceeding the sepals; blade broadly obovate: pod acutish, oval in outline, about $4 \mathrm{~mm}$. long and slightly over $2 \mathrm{~mm}$. wide, glabrous, reticulate, only slightly wing-margined above, retuse; style about twice as long as the width of the wing margins.

This species is in some respects intermediate between $L$. aly'ssoidcs and L. montanum. In the former only the lowest leaves are pinnatifid, the pod is more rounded and the style is shorter, scarcely longer than the width of the wing-margin. It is closer related to L. montanum, differing mainly in the longer and narrower leafsegments, having a more persistent base and being less pubescent.

UTAh: St. George, ISSO, M. E. Jones, I6,6 (type in herb. N. Y. Bot. Garden); Price, I900, S. G. Stoke's; southern Utah, IS74, C. C. Parry, I8.

Nevada: Trinity Mountains, is68, S. ITatson, I20.

\section{Lepidium elongatum sp. nov.}

Annual: stem branched near the base, about $3 \mathrm{dm}$. high, glandular pruinose above: basal leaves spatulate or oblanceolate, about $4 \mathrm{~cm}$. long, coarsely toothed or somewhat pinnatifid with short lobes; stem leaves oblanceolate, tapering into a short petiole, entire or with a few small teeth, $3-4 \mathrm{~cm}$. long, acutish : racemes elongated, at the ends of the branches, in fruit I $\mathrm{dm}$. or more long: sepals oblong or oblanceolate, acute, thin and whitish; petals minute, linear-oblanceolate, one half to two thirds as long as the sepals or lacking : pods nearly orbicular, about $3 \mathrm{~mm}$. broad, usually broadest a little above the middle, wing-margined and deeply retuse at the apex, glabrous or slightly pruinose: stigma sessile.

This species is nearest related to L. apctalum and L. ramosissimum. From the former it differs in the branching near the base, the more entire leaves, the somewhat larger pod and the petals which are generally present; and from the latter in the longer racemes, in the lack of the small axillary racemes characteristic to that species and a different pod. In L. ramosissimum this is broadest below the middle. L. clongatum grows on rocky hilltops.

IVashington: Almata, I896, A. D. E. Elmer, 21 (type in herb. N. Y. Bot. Gard.).

IDAHO: About Lewiston, I $896, A$. A. \& E. Gertmile Heller, 3008 . 


\section{Thlaspi Nuttallii}

Thlaspi cuchleariforme Nutt. Journ. Acad. Phila. 7 : I $3 . \quad$ I 834. Not DC. I 82 I.

This species has been merged in $T$. alpcstre, but none of our American forms belong to that species. T. Nuttallii is intermediate between T. paruflomm A. Nelson and T. glaucum A. Nelson, having larger flowers than the former and smaller than the latter. The pod is obovate, rounded at the apex with a narrow sinus. In $T$. glaumm the sinus is broad and open.

\section{Roripa clavata sp. nov.}

Biennial, tall, perfectly glabrous : stem 6-1o dm. high, simple up to the inflorescence: leaves lyrate-pinnatifid, $5-10 \mathrm{~cm}$. long, more or less auricled at the base ; lobes $4-8$ pairs, oblong to ovate, obtuse or acute, broadly dentate: inflorescence branched; petioles in fruit $5-10 \mathrm{~mm}$. long, divaricate: petals spatulate, about $3 \mathrm{~mm}$. long, exceeding the sepals : pod I O-I $2 \mathrm{~mm}$. long, 2.5-3 mm. thick, decidedly clavate, obtuse, strongly curved; style nearly i mm. long.

This may have been included in W'Vatson's Vasturtium tirrestre var. occidentale; but the name occidcntale cannot be used as there is already another older Roripa occidentalis Greene. It is not, however, Roripa Pacifica Howell, which is supposed to be a synonym of Watson's variety, for that species is described as being slightly pubescent and having pods which are acute at both ends, while in $R$. clarata the pod is almost truncate at the apex.

IVashingtox: Hogeman, Chehalis county, is97, Frank $H$. Lamb, 122I (type in herb. N. Y. Bot. Gard.); IVest Klickitat county, i $885, I V . . M$. Suksdorf.

Oregon: Sauvie's Island, i 888, T. Howill, 1333.

British Columbia: Port Henry, is89, John Macoun.

I daho: Near Hope, Kootenai county, IS92, Sandberg, MacDougal \& Hcller, 1029, at least in part.

\section{Roripa Underwoodii sp. nov.}

Biennial, divaricately branched, even near the ground, perfectly glabrous; stems $2 \mathrm{dm}$. or nore high : leaves $3-5 \mathrm{~cm}$. long, lyrately pinnatifid, thin; lobes oblong, obtuse; the terminal one elliptic to broadly oval, sinuately toothed; petioles short, winged and 
conspicuously auricled at the base: racemes numerous: pedicels short, in fruit scarcely more than $4 \mathrm{~mm}$. long, diverging or even reflexed: sepals bright orange, obtuse; petals light yellow, scarcely equalling the sepals and not quite I $\mathrm{mm}$. long: fruit (immature) 5-6 mm. long, slightly thicker at the base, abruptly contracted into a minute style, not $.5 \mathrm{~mm}$. long.

In general appearance, this species resembles most $R$. palustris, but it is more branched with divaricate branches, has much shorter pedicels, rather longer and more tapering pod and not half as long style. From $R$. obtusa, it differs in the shape of the leaves, which are less dissected, the shorter style and general habit. The type grew at an altitude of $3300 \mathrm{~m}$.

Colorado: Red Mountain, south of Ouray, 1901, L. M. Cnderuood, $299 a$.

\section{Roripa integra sp. nov.}

Biennial, glabrous: stems few, strict, branched above; basal leaves not seen as they are fallen off in the type specimen; stemleaves spatulate or rhombic spatulate, $1-2 \mathrm{~cm}$. long, not auricled at the base, entire or slightly sinuate: racemes slender, lax : petals $1.5 \mathrm{~mm}$. long, scarcely exceeding the sepals; pedicels $\mathrm{I}-3 \mathrm{~mm}$. long, ascending: pod about $8 \mathrm{~mm}$. long, somewhat curved: style about $5 \mathrm{~mm}$. long.

The type specimen is labelled Vorsturtium palustre var., but it is not closely related to this species. It is nearer $R$. obtusa, but differs in the entire leaves; the more tapering and more curved pod, the erect habit and the short style. It grows at an altitude of about $2700 \mathrm{~m}$.

Utah: Wasatch Mountains, 1869, S. Watson, 67, in part (type in herb. Columbia University).

Lesquerella arenosa (Richards).

I'esicaria arenosa Richardson, Frankl. Journ. App. 743.

Lesquerella Ludoriciana var. arenosa S. Wats. Proc. Am. Acad. $23: 252$.

This is amply distinct from L. Ludoviciana (DC.) S. Wats. or L. argented (Pursh) MacM, by the more slender ascending stems, the shorter leaves, the oblanceolate, instead of linear stem-leaves and the comparatively larger and often somewhat ellipsoid pod. The range given in the Synoptical Flora should be extended to the Black Hills of South Dakota and northeastern Wryoming. 


\section{Lesquerella Shearis sp. nov.}

Perennial with a large rosette of basal leaves; stems several, ascending, I-2 dm. high, densely stellate: basal leaves $3-4 \mathrm{~cm}$. long; blades broadly oval or ovate, entire or slightly angular denticulate; stem leaves oblanceolate, about $2 \mathrm{~cm}$. long, subsessile: racerne many-flowered; pedicels in fruit bent $\mathrm{S}$-shaped: pods erect, densely stellate, $7-8 \mathrm{~mm}$. long, acute, compressed above; septum elliptic in outline: style about as long as the pod.

This species differs from L. currifes A. Nelson in the broad basal leaves, the elliptic instead of ovate outline of the septum and the longer style. It grows along creek banks at an altitude of about $2000 \mathrm{~m}$.

Colorado: Idaho Springs, 1895, C. L. Shear, 3269 (type in herb. N. Y. Bot. Gard.); also at the same locality, P. A. Ry'dberg.

\section{Physaria brassicoides sp. nov.}

A tufted perennial with a large and dense rosette of basal leaves and a thick taproot: basal leaves large, with winged petioles; blades almost orbicular in outline, sinuate-dentate, $2.5-5 \mathrm{~cm}$. in diameter: stem leaves small and few, spatulate: flowering stems about I dm. high, ascending: flowers numerous: fruit almost obcordate, acute at the base, deeply divided above; cells inflated, rounded pyriform, $8-10 \mathrm{~mm}$. long and $5-\$ \mathrm{~mm}$. in diameter: style about $5 \mathrm{~mm}$. long.

This species resembles most $P$. didy'mocarpa in habit, but differs in the smaller fruit, which is not at all cordate at the base but on the contrary usually acute, and in the larger basal leaves which form a large rosette, $7-10 \mathrm{~cm}$. in diameter and having some resemblance to a young cabbage-head. It grows in crevices of magnesian rocks in cañons and badlands.

Nebraska: Cañon south of Scott's Bluffs, i $\$ 9$ I, Rydlberg, 24.

\section{Cardamine acuminata (Nutt.)}

Cardamine hirsuta $\beta$ acuminata Nutt.; T. \& G. F1. N. Am. I : 85. $\quad 18_{3} 8$.

This species has been variously referred to C. hivsuta, C. obligosperma, and $C$. Pennsylianica. It is probably nearest related to the last, but the lower part of the stem is hairy and the pod has an evident style over I mm. long. It ranges from the Mackenzie River to British Columbia, south to California and Wyoming. 
Ridberg: Studies on the Rocky Mountaln Flora 238

\section{Cardamine multifolia sp. nov.}

Stem about $2 \mathrm{dm}$. high, very leafy, lower part hirsute: leaves 4-6 cm. long glabrous; leaflets $7-13$, oblong to oblong-obovate or oval, entire or sinuate-dentate; the terminal one larger and obovate: flowers numerous: petals spatulate, about $2.5 \mathrm{~mm}$. long; pedicels ascending, about $8 \mathrm{~mm}$. long: pod erect, about $2 \mathrm{~cm}$. long and $.75 \mathrm{~mm}$. wide.

This is perhaps closest related to $A$. parifolia $L$., but is more leafy, has shorter and broader leaf-segments and erect pods, and the plant is less diffusely branched.

IDAHo: Beaver Cañon, i 895, P. A. Rydbirg.

UTAH: Wasatch Mts., I 869, S. W'atson, $\mathcal{S}_{0}$, in part.

\section{Sophia brevipes (Nutt.)}

Sisymbrium cancscens ڤै (breaipes Nutt. MSS.) Torr. \& Gray, Fl. N. Am. I: 92. I 838 .

Sisymbrium Hortacganum Fourn. Rech. Auct. \& Tax. Fam. Cruc. \& Gen. Sisymb. 66, in part. I 865.

Sisymbrimm incisum var. Hartatgiamum S. Wats. Bot. Calif. I : $4 \mathrm{I}$.

The plant described by Dr. Watson in the Botany of California and by Dr. Robinson in the Synoptical Flora (p. I39) is I think without doubt the var. brezipes of Torrey and Gray's flora. Probably also Bourgeau's plant, cited by Fournier, belongs here; but I think that it is very doubtful that I Jartweg's plant, which must be regarded as the type of $S$. Hartwegianm Fourn., could be the same.

\section{Sophia Californica (T. \& G.)}

Sisymbrim canescens \& (Californicum) T. \& G. Fl. N. Am. I : 92. I $S_{3} 8$.

This species is characterized by the large flowers, the sparingly stellate and often glandular-puberulent stem, the uniserial linear pod and once or twice pinnatifid leaves. The segments of the lower leaves are broad and obtuse, those of the upper linear to oblong. Its range extends from Montana to Washington south to California.

\section{Sophia viscosa sp. nov.}

Biennial, 5-10 dm. high : stem, at least the upper part, decidedly glandular or viscid-villous : leaves obovate or oblanceolate in out- 
line, 3-IO cm. long, twice pinnatifid, densely pubescent; primary divisions of the lower leaves ovate and obtuse ; those of the upper lanceolate and acute; secondary divisions oblong acute or obtuse, often few-toothed: inflorescence usually much branched; pedicels in fruit $8-12 \mathrm{~mm}$. long: sepals yellowish, $1-15 \mathrm{~mm}$. long, oblong; petals bright yellow, spatulate, about $2 \mathrm{~mm}$. long: pod (in the specimens seen not fully developed) over I $\mathrm{cm}$. long and less than I mm. wide: seeds uniserial.

This is perhaps nearest related to S. incisa (Engelm.) Greene; but differs in the dense viscid pubescence of the stem, the pubescent leaves and deeper divided primary segments. It grows among rocks and on grassy slopes.

I daho: Beaver Cañon, i 895, C. L. Shcar, 3029 (type in Herb. N. Y. Bot. Garden) and $303 \mathrm{r}$.

Wroming: Trout Lake, IS99, Aích \& Elias Niclson, 58,8 ; Head of Pole Creek, I 895, titen Velson, 1321.

Sophia leptophylla sp. nov.

Stems 5-7 dm. high, sparingly glandular: leaves very thin, dark green, only once pinnate; segments of the lowest leaves rounded; those of the middle lanceolate and somewhat incised; the upper segments entire: pedicels slender, in fruit $5-8 \mathrm{~mm}$. long, spreading: petals bright yellow, about $1.5 \mathrm{~mm}$. long : pod linear, 8-ro mm. long, much less than I $\mathrm{mm}$. wide, torulose, spreading, arcuate, curved up, uniserial.

This is nearest related to S. incisa (Engelm.) Greene, but differs in the less incised leaves and horizontal curved pod. It grows at an altitude of about $2000 \mathrm{~m}$.

Colorado: Foothills, Larimer county, i 955 , Crandall \& Coren, 55 (type in herb. N. Y. Bot. Gard.).

Wroming: Antelope Basin, Albany county, r900, Aren Nelson, 7466; Centennial Hills, I 895, I 686.

\section{Smelowskia Americana}

Hutchinsia calycina Hook. Fl. Bor. Am. I: 58. I 834 . Not Desv. IS I 4 .

Smilowiskia calycina Gray, Proc. Acad. Philad. 1863: 58. Not C. A. Mey. I $s_{3}$ I.

While in Europe last summer, I looked up the Asiatic type of S. calycina, and this differs considerably from ours especially in the long villous pubescence. 


\section{Draba brachystylis sp. nov.}

Perennial with a taproot: stems several, decumbent or ascending with divergent branches, I-I.5 dm. high, hirsute: basal leaves oblanceolate or spatulate, $1.5-2 \mathrm{~cm}$. long, hirsute with branched hairs; stem leaves few, oblong or lanceolate, sessile: pedicels short, in fruit $2-5 \mathrm{~mm}$. long, spreading: pod oblong, finely stellate, 8-12 mm. long, ascending: style very short, almost obsolete.

The type sheet of this species is labeled Draba Carolina var. micrantha, but the plant evidently is a peremnial and nearest related to $D$. streptocarpa; but differs in the divergently branched stem, stellate pod and the almost obsolete style. It grows at an altitude of about $3000 \mathrm{~m}$.

Utah: Alta, Wasatch Mts., I879, M. E. Jones, 1357 (type in herb. N. Y. Bot. Gard.).

\section{Draba decumbens sp. nov.}

Perennial with a taproot, a short cespitose caudex and a large rosette of basal leaves: stems decumbent, I-2 dm. high, sparingly pubescent, few-leaved; basal leaves broadly spatulate, entire, 2-4 $\mathrm{cm}$. long, finely grayish stellate, rather thick; stem leaves ovate to ovate-lanceolate, sessile, entire, $\mathrm{I}-2 \mathrm{~cm}$. long: calyx sparingly villous: petals pale yellow, about $4 \mathrm{~mm}$. long: pedicels very short, in fruit 2-4 $\mathrm{mm}$. long: pod oblong, $8-15 \mathrm{~mm}$. long, densely pubescent, usually twisted: style about $1 \mathrm{~mm}$. long.

This is a member of the D. aurea group, and distinguished from all the North American species by its decumbent stems, large, thickish entire basal leaves.

Colorado: Gray's Peak, I 895, Ry'llergo (type in herb. N. Y. Bot. Gard.).

\section{Draba Macouniana sp. nov.}

Annual, almost scapose: stems ascending or decumbent, less than I dm. high, glabrous and shining; basal leaves numerous, broadly spatulate or obovate, 5-1 o mm. long, finely stellate, rather thick ; stem leaf usually one, oval, obtuse, $5 \mathrm{~mm}$. long: petioles in fruit spreading, 6-8 $\mathrm{mm}$. long: petals white, less than $3 \mathrm{~mm}$. long: pod oblong-linear, erect, about $\mathrm{I} \mathrm{cm}$. long and $2 \mathrm{~mm}$. wide: style obsolete.

This species is nearest related to $D$. crassifolic, but differs in the whiter flowers, and the broad and short basal leaves, which are finely stellate, not hirsute ciliate. The type grew at an altitude of about $2000 \mathrm{~m}$. 
British Columbia: Summit of Rocky Mountains, i 890, John Macoun (type in herb. Columbia University).

\section{Draba Parryi sp. nov.}

Annual, perfectly glabrous, except a few cilia on the petioles : stems several, usually less than I dm. high, scapiform or rarely with a stem leaf: basal leaves numerous, linear or narrowly linearoblanceolate, $1.5-2.5 \mathrm{~cm}$. long; pedicels spreading, in fruit $5-8$ mm. long: flowers small; petals scarcely $2 \mathrm{~mm}$. long, white or light yellow : pods erect, oblong, 5-8 mm. long, $1.5-2 \mathrm{~mm}$. wide, glabrous : style obsolete.

This is closely related to $D$. crassifolic but the latter has broader leaves, which are more or less hirsute on the surface and distinctly ciliate on the margins.

Colorado: Foot of Gray Peak, i 872, E. L. Greene (type in herb. Columbia University); I 872, C. C. Parry; Cameron Pass, I $896, C . F$. Bakcr.

Wroming: Telephone Mines, i900, Azin Nelson, 7879.

\section{Draba cana sp. nov.}

Perennial with a taproot and short cespitose caudex, whole plant densely grayish stellate; stem $1-2 \mathrm{dm}$. high, often branched : basal leaves numerous, oblanceolate or spatulate, $\mathrm{I}-\mathrm{I} .5 \mathrm{~cm}$. long, entire or minutely but sharply toothed, densely stellate; stem leaves lanceolate to ovate, about $\mathrm{I} \mathrm{cm}$. long : racemes many-flowered; pedicels short, nearly erect, in fruit $2-3 \mathrm{~mm}$. long: flowers small; petals white, about $3 \mathrm{~mm}$. long: pod linear-oblong, 6-8 $\mathrm{mm}$. long, densely pubescent : style about $5 \mathrm{~mm}$. long.

This has gone under the name of $D$. incana, but the latter is much less densely stellate and has a glabrous, much broader pod. I have seen only one specimen of true $D$. incana from this continent, and it was collected in Labrador. Most of those under this name belong to $D$. cana, which ranges from Labrador to the Yukon Territory, south in the mountains to Colorado. The following is regarded as the type.

Alenerta: Morley, foothills of the Rocky Mountains, i 887, John Macoun (herb. Columbia University).

\section{Draba McCallae sp. nov.}

Perennial with a cespitose base, whole plant sparingly stellate but green: stems several, simple, about $3 \mathrm{dm}$. high : basal leaves 
spatulate, I o- I $8 \mathrm{~mm}$. long, entire or nearly so; stem leaves ovate, about I cm. long, sharply dentate or entire: raceme elongated: pedicels slender, in fruit about I cm. long, erect: petals white, $4-5$ mm. long: pod (in the specimen not fully developed) ovate, densely but finely pubescent, much shorter than the pedicels: style 0.75 mm. long.

This species belongs also to the $D$. incana group, but differs from that species in the elongated peduncle, long pedicels, short pubescent pod and large petals.

Alberta: Valley below Mt. Aylmer, is99, II. C. McCalla, 2267 (type in herb. N. Y. Bot. Gard.).

\section{Draba Columbiana sp. nov.}

Perennial ; with a cespitose base, sparingly and finely stellate and ciliate on the margin of the leaves: stems slender, about 2 dm. high, simple: basal leaves many, oblanceolate, ro-I $5 \mathrm{~mm}$. long, denticulate or entire; stem leaves ovate to lanceolate, about I cm. long denticulate : raceme elongated, pedicels slender, ascending, 5-7 mm. long in fruit: flowers small; petals slightly over 2 mm. long, white: pods linear-oblong, finely pubescent, over I $\mathrm{cm}$. long, style very short.

This species resembles much the preceding in habit, but the flowers are much smaller and the pods longer.

British Columbia: Revelstoke, I89o, Joln Macoun (type in Herb. Columbia University).

\section{Geranium Pattersonii sp. nov.}

Cespitose perennial with a thick root and short caudex: stems ascending or diffuse, $2-4 \mathrm{dm}$. long, densely glandular villous with long spreading hairs, petioles of the basal leaves $5-10 \mathrm{~cm}$. long, also glandular villous; blades reniform in outline, about $3 \mathrm{~cm}$. broad, glandular villous on both sides, deeply 5-7-cleft; lobes broadly obovate-cuneate, 3 -toothed; teeth broadly ovate, abruptly short-acuminate: stem leaves similar, but short-petioled or the uppermost subsessile: pedicels and calyx glandular long-villous ; the former in fruit $1.5-2 \mathrm{~cm}$. long: sepals in fruit about $8 \mathrm{~mm}$. long, oval with a short bristle-tip about I $\mathrm{mm}$. long: petals obovate about I cm. long, light purple, or rose color, with darker veins : style in fruit about $2 \mathrm{~cm}$. long, glandular-pubescent; beak about $4 \mathrm{~mm}$. long: carpels pubescent: seeds finely reticulate.

This species is perhaps nearest related to G. Paryi (Engelm.) Heller, but is lower, more densely glandular, has broader and 
shorter lobes to the leaves and their teeth are broadly ovate, abruptly acuminate, instead of lanceolate. The general habit is perhaps more like $G$. cacspitosum James, but in that species the lower part of the stem is grayish-pubescent with short reflexed hairs. $G$. Pettersonii is a subalpine plant growing at an altitude of $2500-$ $3000 \mathrm{~m}$.

Colorado: Gray Peak, i $895, P$. A. Ryelberg (type in herb. N. Y. Bot. Gard.); foot of Pikes Peak, 1896, C. L. Shear, 3702 ; mountains, near Empire, I 892, H. N. Patterson, 177 and $I 76$ in part ; North Cheyenne Cañon, i 896, Ernest A. Bessey; also i 845. Frecmont, 6 I.

Geranium strigosum sp. nov.

Granimm Richardsonii Wats. King's Rep. 5: 49, in part. I871. Not Fisch \& May.

Erect perennial with a short thick rootstock: stem 4-8 dm. high, finely reflexed strigose; petioles of the basal leaves $2-5 \mathrm{dm}$. long, also sparingly strigose; blades reniform in outline, $7-12 \mathrm{~cm}$. in diameter, finely strigose on both sides, deeply 7 -cleft ; divisions rhombic in outline, 3 -cleft and toothed; teeth lanceolate, acute; stem leaves similar, but short-petioled; stipules linear-lanceolate, long-attenuate: inflorescence open, glandular pubescent: sepals densely glandular, oval, about $8 \mathrm{~mm}$. long; bristle tips $1.5-2 \mathrm{~mm}$. long; petals broadly obovate, rose color or light violet, strongly purple-veined: style in fruit about $3 \mathrm{~cm}$. long, beak about $6 \mathrm{~mm}$.: seeds reticulate.

This is nearest related to $G$. aiscosissimmm, but the corolla is lighter in color and the pubescence is different, being decidedly reflexed, strigose, not at all glandular, except on the inflorescence. It grows in the valleys to an altitude of perhaps $2700 \mathrm{~m}$.

Wroming: Copperton, igor, F. Trecedy, t59I (type in herb. N. Y. Bot. Gard.); Big Horn Mountains, 1900, $36+7$.

Uтан: City Creek Cañon, I880, MI. E. Joncs, 1871; Parley's Cañon, I9oi, S. G. Stokes; Black Rock and Uintahs, is69, S. Watson, 207.

\section{Oxalis Coloradensis sp. nov.}

Perennial with a slender rootstock: stem slender, erect, I-2 dm. high, sparingly villous; leaves digitately ternate; petioles $2-4 \mathrm{~cm}$. long, sparingly villous : leaflets broadly obcordate, gla- 
brous, S-1 $2 \mathrm{~mm}$. long: peduncles very slender, about $5 \mathrm{~cm}$. long: inflorescence cymose, but often reduced to $2-3$ flowers; pedicels sparingly strigose : sepals $4-5 \mathrm{~mm}$. long, oblong : petals yellow, 6-7 $\mathrm{mm}$. long: pod cylindric with a conical apex, $12-15 \mathrm{~mm}$. long, 2.5-3 mm. wide, glabrous.

This is nearest related to O. cymosa Small and O. Brittoniat, but differs from the former in the blunter sepals, the appressed pubescence of the pedicels and the glabrous pod, and from the latter in the simpler habit, the longer glabrons pod and paler and larger leaves. It grows in grassy valley's at an altitude of ISOO$2500 \mathrm{~m}$.

Colorado: Sangre de Christo Creek, 1900, Rydberg \& Ireeland 5920 (type in herb. N. Y. Bot. Gard.); Foothills, Larimer county, is95, J. H. Cowen (mixed with O. stricta L.).

\section{Lupinus Scheuberae sp. nov.}

Perennial; stem 4-6 dm. high, sparingly strigose or almost glabrous, slender : petioles of basal leares about I dm. long; leaflets $7-S$, oblanceolate, $5-7 \mathrm{~cm}$. long, acute and mucronate, green, glabrous above, sparingly appressed pubescent beneath; stipules lanceolate, attenuate; stem leaves similar but shorter petioled: racemes $1-1.5 \mathrm{dm}$. long, not dense; bracts lanceolate, $7-8 \mathrm{~mm}$. long, deciduous: flowers IO- $2 \mathrm{~mm}$. long: calyx densely white silvery puberulent, strongly gibbous above; lower lip lanceolate, fully twice as long as the triangular-ovate upper lip: corolla dark purple but lighter and almost white towards the base; banner slightly longer than the wings, silky puberulent on the middle of the back: pod densely white silky with appressed hairs, 2-4-seeded.

This is nearest related to L. pscudopariflorus, but differs in the somewhat larger flowers, the strictly appressed white pubescence on the calyx and pedicels, the gibbous, but not spurred calyx, and the broad and short upper lip of the latter. It grows in woods at an altitude of 2,000-2,400 $\mathrm{mm}$.

Mostana: Garnet county, i901, Mrs. Emma WVare Sheuber, I35 (type in herb. N. I. Bot. Gard.).

Wroming: Copperton, 1901, Frank Tivecdy, f216.

\section{Lupinus spathulatus sp. nov.} Nutt.

Lupimus pariflorus S. Wats. King's Rep. 5: 187I. Not 
Perennial: stem $8-10 \mathrm{dm}$. high, glabrous or sparingly strigose above, leafy ; stipules narrowly lanceolate, attenuate: petioles 3-5 $\mathrm{cm}$. long; leaflets about 7 , spatulate or broadly oblanceolate, about $4 \mathrm{~cm}$. long, mucronate, those of the lower leaves obtuse, those of the upper more acute, glabrous above, finely puberulent beneath; raceme elongated, about $2 \mathrm{dm}$. long, many-flowered: flowers subverticillate; pedicels about $.5 \mathrm{~cm}$. long, as well as the calyx, pubescent with short spreading hairs; bracts lanceolate, attenuate, deciduous, longer than the buds; calyx gibbous at the base; lower lip lanceolate, about twice as long as the short ovate upper one: corolla dark blue, with lighter keel; banner glabrous, rounded and shorter than the wings.

This has been confused with L. paraiflorus, which it closely resembles, differing mostly in the shape of the calyx; the lower lip in that species is only slightly longer than the upper and the banner is larger and less rounded. The type grew at an altitude of $2400 \mathrm{~m}$.

UTAH: Wasatch Mountains, I869, S. W'atson, 225 (type in herb. Columbia University).

\section{Lupinus flavescens sp. nov.}

Perennial: stem about $3 \mathrm{dm}$. high, appressed pubescent with rather long hairs: stipules lanceolate, densely hairy: petioles often over I dm. long, appressed silky; leaflets about 7, oblanceolate, 3-4 cm. long, appressed silky on both sides: inflorescence short; bracts lanceolate, early deciduous; pedicels $8-\mathrm{IO} \mathrm{mm}$. long, as well as the calyx densely pubescent with short, spreading hairs: calyx gibbous at the base; its lips almost equal in length, both about $8 \mathrm{~mm}$. long: corolla I $2-14 \mathrm{~mm}$. long, pale yellow; banner with a darker spot, glabrous.

The type has been known as L. sulphurcus and was included therein questionably by Watson; but differs in the larger, paler flowers, and the longer lips of the calyx, and the longer pubescence.

Idaho or Montana: Medicine Clay Prairies, Wycth (type in herb. Columbia University).

\section{Lupinus lucidulus sp. nov.}

Perennial: stem 5-6 dm. high, branched above, finely silky strigose, especially the upper portions, leafy ; stipules minute, ovate, acuminate: petioles $3-5 \mathrm{~cm}$. long; leaflets $7-8$, linear-oblanceo- 
Rydberg: Studies ox the Rocky Mountain Floka 246

late, silky and silvery on both sides, about $3 \mathrm{~cm}$. long: raceme I-2 dm. long, lax: flowers scattered; pedicels and calyx denselypubescent with short strictly appressed silky hairs; lower lip of the calyx about $5 \mathrm{~mm}$. long, lanceolate, almost twice as long as the short ovate upper one: corolla yellow or light pink; banner slightly exceeding the wings, with a few short hairs on the back, with a darker spot, about $8 \mathrm{~mm}$. long : pods densely silky pubescent.

This species is nearest related to I. sulphureus, but differs in the more silvery pubescence, the smaller flowers and the appressed pubescence of the calyx and pedicels. The type grew at an altitude of $1900 \mathrm{~m}$.

Wyoming: Spread Creek, I897, F. Trecedy, $27 I$ (type in herb. N. Y. Bot. Garden). 

CONTRIBUTIONS FROM THE NEW YORK BOTANICAL GARDEN-No. 30.

\title{
STUDIES ON THE ROCKY MOUNTAIN FLORA-IX
}

\author{
BY P. A. RYDBERG
}

NEW YORK

1902

[Reprinted from the Bulletrin of the Torrey Botanical Club, 29: Dec., 1902 ] 



\title{
Studies on the Rocky Mountain Flora-IX
}

\author{
liy P. A. RYDIERC
}

THE NYCTAGINIACEAE OF THE ROCKY MOUNTAIN REGION

The family Nyctaginiaceae has been sorely neglected by the systematic botanists in this country. Until lately we have had not even an attempt at a monographic work since Dr. Gray's notes were published in the Botany of the United States and Mexican Boundary Survey in 1859 . Gray's treatment there as a whole can scarcely be regarded as an improvement on that by Choisy, published ten years earlier in De Candolle's Prodromus, and of course, both are now out of date. Professor Heimerl's treatment in Die natiorlichen Iffanscufamilion is as good as could be expected from a European monographing an almost exclusively American family ; but this gives little help beyond the genera. Recently there has appeared a revision of the fanily by Marcus E. Jones * as it is represented on the Great Plateau. As the territory covered by Jones practically includes that treated in this article, it would seem superfluous to duplicate the work; but I have had the advantages of a large library and the rich collections of Columbia University, the United States National herbarium, and the New York Botanical Garden. These advantages are, however, somewhat balanced by Mr. Jones' longer field experiences. Jones' paper is valuable because it gives fuller descriptions of many poorly known species, descriptions drawn by a botanist who knows the species in the field. It is deplorable, however, that this paper in many places shows a good deal of carelessness, especially in the matter of citing publications. Under Allionic, it has for instance:

“ 5. A. Glaber † (Wats.) Kuntze, Am. Nat. $76, "$ and

“7. A. 'Aggregata (Vahl) Spreng. Ic. 5437 ."

In the first case, one would suppose that Kuntze published the combination in the American Naturalist, while the fact is that Watson there published Orybaphus glabir, on which Allionicr slabra is based.

* Contributions to Western Botany, ro: 34-54. June, I g02.

† This should have been $A$. glabra. 
If interpreting the second case in a similar way, one would come to the conclusion that Oxybaphus aggregatus Vahl was published in Vahl's Icones, if not in Sprengel's Icones; but neither is the case, for no book with that title was ever published by either Vahl or Sprengel. From Mr. Jones' citation no one could imagine that Ic. 5 437, stands for Cavanilles' Icones, where Mirabilis aggregata appeared. This is not the earliest appearance of the name aggregata, however, for this was originally published by Ortega * as Caly'xhymenia aggregata. As Cavanilles' plant is different from Ortega's, the former being Allionia decumbons (Nutt.) Spreng., the latter A. agrigata (Ortega) Spreng. as shown below, Jones citation becomes not only unintelligible but also incorrect. It would have been much better to leave out the citation of publications altogether, which by the way is advisable for anyone who does not possess good library facilities.

\section{Key to the Genera of the Rocky Mountain tegion}

Bracts distinct.

Fruit crested or winged; bracts in a whorl at the base of the head-like cluster; perianth salverform. i. Abronia.

Fruit globular, neither crested nor winged; bracts attached each to a pedicel of the umbel-like or corymbose inflorescence; perianth funnelform. 2. Hermidium. Bracts united.

Fruit neither strongly tubercled nor winged.

Fruit not ribbed ; involucre herbaceous, little if any enlarging in fruit, not becoming membranous.

Stamens usually 5 ; involucres campanulate, not enlarged in fruit.

3. Quamoclidion.

Stamens 3 ; involucre rotate, somewhat enlarged in fruit in the manner of the next genus, but not membranous.

4. Allionirlla.

Fruit ribbed; involucre rotate, in fruit beconing much enlarged and membranous.

5. Allionia.

Fruit with two rows of strong tubercles on the back and surrounded by two toothed inflexed wings.

6. Wedelia.

\section{ABRONIA Juss. Gen. 448. 1789}

Tricratus L'Her.; Willd. Sp. Pl. I : 807. I 799.

Cycloptera Nutt.; Gray, Am. Jour. Sc. II. I5: 3 I9. 1853.

In the original publication, no type species was mentioned. The genus was described from a plant collected on De la Peirouse's journey in California and cultivated by Mr. Colignon. Hooker in

* Nov. aut Rar. Pl. 8: pl. I1. 1798 (or 9?). 
his Exotic Flora, pl. 193 \& 194 , identifies Colignon's plant as Abronia umbellata. The type of Tricratus is the same, and that of Cycloptera is $A$. cycloptera.

Fruit narrowly winged or crested; wings or crests not completely encircling the fruit.

Fruit biturbinate, i. e., tapering at both ends, irregularly ridged or crested.

Flowers about $2 \mathrm{~cm}$. long; limb 5-10 $\mathrm{mm}$. wide.

Bracts broadly obovate, over I cm. long.

Bracts ovate-lanceolate, less than I cm. long.
1. A. fragrans.

2. A. nuilutit.

Flowers about $\mathrm{I} \mathrm{cm}$. long; $\operatorname{limb} 3-5 \mathrm{~mm}$. wide; bracts ovate to lanceolateovate, about $5 \mathrm{~mm}$. long.

Petioles of the stem-leaves shorter than the very thick blades; plant low, about I $\mathrm{dm}$. high.

3. A. fumila.

Petioles of the stem-leaves much longer than the moderately thick blades; plant slender, $2-4$ din. high.

4. A. ammophila.

Fruit turbinate or obpyramidal, i.e., almost truncate above, distinctly winged ; the wings very broad above.

Plant almost acaulescent; stem and leaves greatly surpassed by the long peduncles.

5. A. nana.

Plant with an elongated stem.

Bracts broadly ovate or obovate, acute or obtusish.

Stem distinctly viscid-pubescent ; leaves scabrous-puberulent ; bracts $\mathbf{I}-\mathbf{I} .5 \mathrm{~cm}$. long.

Blades of the stem-leaves elliptic; bracts broadly obovate, I 2I $5 \mathrm{~mm}$. wide, obtusish.

6. A. salsa.

Blades of the stem-leaves lanceolate; bracts oval, acute, about 6-7 $\mathrm{mm}$. wide.

7. A. firllax.

Stem finely puberulent or glabrous ; leaves glabrous ; bracts $5-8 \mathrm{~mm}$. long.
Stem puberulent.
8. A. elliptica.
Stem glabrous.
9. A. grabra.

Bracts oblong-lanceolate or lanceolate, attenuate or cuspidate.

Stem glabrous.

10. A. lanceolata.

Stem more or less pubescent.

Stem puberulent; wings with double lamina, coriaceous.

11. A. Carletoni.

Stem villous; wings with single lamina, membranous.

12. A. villosa.

Fruit completely surrounded by the broad netted-veined membranous wings.

Flowers $3 \mathrm{~cm}$. or more long; limb about I cm. wide; peduncles longer than the leaves.

Flowers 1. 5-2 cm. long; limb about $5 \mathrm{~mm}$. wide.

13. A. cyclopera.

Stem glabrous or nearly so ; peduncles often nearly equalling the leaves.

14. A. pedunculata.

Stem densely pubescent; peduncles at least in flower much shorter than the leaves.

15. A. micrantha.

I. Abronia fragrans Nutt.; Hook. Kew Journ. 5: 26I. i 853 On the plains from South Dakota to Montana, Idaho, New Mexico and Kansas. 


\section{Abronia nudata sp. nor.}

Perennial, stems very long and decumbent, sparingly hispidulous: leaves thich, slabrous; petioles 2-10 mm. long; blades broadly lance olate, obtusish, $2-5 \mathrm{~cm}$. long: peduncles $4-6 \mathrm{~cm}$. long, almost glabrous: bracts ovate-lanceolate, less than $\mathrm{I} \mathrm{cm}$. long: flowers many, about $2 \mathrm{~cm}$. long; limb $5-6 \mathrm{~mm}$. wide: achenes very irregular, the inner ones of the head bipyramidal, thickest a little above the middle, crested, $8-10 \mathrm{~mm}$. long, those of the margin very obliquely ovoid-fusiform, scarcely at all crested.

This species is nearest related to A. fragrans and A. ammofhila. From the former it differs in the small bracts, smaller leaves and almost glabrous stem; and from the latter in the much longer flowers and the scanty or no pubescence.

Moxtana: Colgate, near Glendive, i 892, Sandberg, MacDongal \& Heller, ros (type in herb. N. Y. Bot. Garden).

\section{Abronia pumila sp. nov.}

Perennial, caespitose: stems ascending, about I dm. long, puberulent: leaves very thick, minutely puberulent ; petioles $\mathrm{I}-2$ $\mathrm{cm}$. long, those of the stem-leaves usually shorter than blades; these $1.5-3 \mathrm{~cm}$. long, oval, elliptic or somewhat ovate: peduncles $2-3 \mathrm{~cm}$. long, puberulent: bracts elliptic-ovate or lanceolate, $7-8$ mm. long, short-acuminate: flowers about $12 \mathrm{~mm}$. long; limb about $3 \mathrm{~mm}$. wide: fruit bipyramidal, $i . c$, tapering towards both ends but more so downwards, the greatest breadth being about one third from the apex, merely crested or the inner ones somewhat winged.

Dr. Heimerl referred this to A. Iruncata Torr., but the fruit is very unlike that of that species. A. prmmila is nearest related to A. ammophila, from which it differs mainly in the thicker and shortpetioled leaves and the dwarfed habit.

UтAн: Emery, is94, 11. E. Jones, j+75q(type in U. S. Nat. herb.); six miles up Salida Cañon, $5+16 a$.

4. Abronia ammopilla Greene, Pittonia, 4: 226. 1900

Abronia archaria Rydb. Mem. N. I. Bot. Garden, I : 1 37. 1900. Not Menz. I $\$ 27$.

Yellowstone National Park.

5. Abronia nana S. Wats. Proc. Am. Acad. i6 : 294. IS70 Southern Utah to Arizona and southern California. 


\section{Abronia salsa sp. nov.} Nutt.

Abronia fragrerns S. Wats. King's Rep. 5: 284. I 87 I. Not

Perennial : stem ascending, 3-4 dm. high, densely viscid-pubescent especially above, stout: leaves very thick, puberulent; petioles $2-3 \mathrm{~cm}$. long ; blades oval or elliptic, obtuse, or the lowest rounded oval, $3-5 \mathrm{~cm}$. long, $\mathrm{I}-3 \mathrm{~cm}$. wide : peduncles $5-7 \mathrm{~cm}$. long, densely viscid-pubescent ; bracts rounded obovate, about $15 \mathrm{~mm}$. long and often as broad, pubescent: flowers many, about $2 \mathrm{~cm}$. long with a limb about $4 \mathrm{~mm}$. wide: fruit about $\mathrm{I} \mathrm{cm}$. long, similar to those of A. lanccolata and 1. follax but the wings are rather thicker.

The sheets in the National Herbarium bear the following labeling by Dr. Heimerl: "Abronia frosrans Nutt. (ad formam ellipticam (Nelson) accidens!);" but neither A. salsa nor A. ellifica A. Nelson have the fruit of A. fragrans, and therefore can not be regarded as forms of that species. A. salsa differs from A. clliptica in the stouter viscid-pubescent stem, the larger bracts and flowers. It grows in sandy saline soil at an altitude of $1000-1300 \mathrm{~m}$.

Utah: Salt Lake City, i 869 , S. IVatson, 965 (type in herb. Columbia University); same locality, Capt. Stansbury, and I87 I, Hayden; Silver Reef, I S94, M. E. Jones; Grand Junction, I9oo, S. G. Stokics.

\section{Abronia fallax Heimerl sp. nov.}

Perennial; stem erect, almost shrubby below, branched, strawcolor or white, viscid-pubescent above: leaves thick, puberulent, erect; petioles $\mathrm{I}-2 \mathrm{~cm}$. long; blades of the lower oval, of the upper long-lanceolate, $2-5 \mathrm{~cm}$. long, $\mathrm{I}-\mathrm{I} .5 \mathrm{~cm}$. wide, obtuse or the upper acute: peduncles $\mathrm{I}-2 \mathrm{~cm}$. long, densely viscid-pubescent; bracts 5-6, oval, about $1.5 \mathrm{~cm}$. long, $6-7 \mathrm{~mm}$. wide: flowers many, about $15 \mathrm{~mm}$. long: fruit with the wings about 6 $\mathrm{mm}$. wide and $8 \mathrm{~mm}$. long, cuneate-obpyramidal.

The type in the U. S. Nat. herbarium bears the following remarks from the hand of Dr. Heimerl: "Abronia fallax m. - ' Hy'brida $c x$. Aragrans it A. turbinatar. - Ab A. fragrans anthocarpinis alis apice transacese dilatatis, ab -1. turb. bracteis capitulonm magnis, scariosis diversa." * To me it seems that the plant has little to do with $A$. fragrans and is less related to $A$. turbinatir

* In a letter lately received from 1 r. Heimerl, he has authorized me to wee his name and notes. 
than to A. clliptica A. Nelson. From this it differs in the upright stem, which is decidedly viscid-pubescent instead of merely puberulent.

UTAн: Salt Lake City, I $\$ 79$, M. E. Jones, 1337 (type in U. S. Nat. herb., also in herb. Columbia University).

8. Abronia elliptica A. Nelson, Bull. Torrey Club, 26: 7 . I 899

IVyoming and Colorado.

\section{Abronia glabra sp. nov.}

Perennial: stem ascending, about half a meter high, glabrous, straw-colored: leaves thick, glabrous; petioles $\mathrm{I}-2 \mathrm{~cm}$. long; blades oval to oblong, $\mathrm{I}-4 \mathrm{~cm}$. long, obtuse : peduncles oval, $2-4$ $\mathrm{cm}$. long, glabrous; bracts obovate or about $5 \mathrm{~mm}$. long, acute : flowers $12-15 \mathrm{~mm}$. long, numerous: fruit cuneate-obpyramidal, with the wings $4-5 \mathrm{~mm}$. wide and $7-8 \mathrm{~mm}$. long: wings very thick, of two lamina, senu-cordate at the apex: wingless tip of the fruit very short.

This species is intermediate between $A$. clliptica and the next species. From the former it differs in the glabrous stem and the stricter habit, from the latter in the broader and shorter bracts and the smaller flowers.

Colorado: Grand Junction, I $S_{3}, M$. E. Jones (type in U. S. Nat. herb.).

IO. Abronia lanceolata sp. nov.

Perennial : stem glabrous, decumbent, several decimeters long: leaves rather thick, glabrous; petioles $2-3 \mathrm{~cm}$. long; blades oblong-oval, $2-5 \mathrm{~cm}$. long, I-I.5 cm. wide: peduncles $5-\mathrm{I} 5 \mathrm{~cm}$. long; bracts 6-8, lanceolate, acute or acuminate, about $\mathrm{I} \mathrm{cm}$. long: flowers numerous, about $1.5 \mathrm{~cm}$. long, with a limb 4-5 mm. wide: fruit with the thin wings about $8 \mathrm{~mm}$. wide and about as long, cuneate-obpyranidal in outline, puberulent: wings strongly reticulate, semicordate at the apex, where the tip of the achene extends for about $2 \mathrm{~mm}$.

The type was labeled $A$. frograns, which species it resembles in general habit, but it is easily distinguished both by the narrow bracts and the strongly winged fruit. These characters place it nearer 4 . Carlctoni Coult. \& Fisher which is of a different habit and has a puberulent stem. A. lancolata grows in drifting sand. 
Rydierg: Studies on the Rocky Mountain Flora 686

IDAнo: Idaho Falls, I901, Mcrrill \& Wilcox, 870. (Type in herb. N. Y. Botanical Garden.)

i i. Abronia Carletoni Coult. \& Fisher, Bot. Gaz. I7 : 349. Colorado. I 892

I2. Abronia villosa S. Wats. Am. Nat. $7: 302$. I 873

Southern Utah to Arizona and California.

I3. Abronia cycloptera A. Gray, Am. Journ. Sci. II. I5: 319. I 853

From Wyoming to Texas and Arizona.

\section{Abronia pedunculata (M. E. Jones)}

Abronia micrantha pedunculata M. E. Jones, Proc. Cal. Acad. II. 5 : 7 16. 1895 .

In the Navajo Basin of eastern Utah.

i 5. Abronia micrantha Torr. Frem. Rep. 96. i 845

From South Dakota to Montana and New Mexico.

2. HERMIDIUM S. Wats. King's Rep. 5: 296. I87 I

A monotypic genus.

i. Hermidium alipes S. Wats. l. $c$.

Nevada and western Utah.

3. QUAMOCLIDION Choisy; DC. Prod. $13^{2}: 429$. I $\$ 49$

This genus was based on two species, of which the second was referred doubtfully to the genus. The first had before been known as a species of Mirabilis, viz., M. triflore Benth. The type of the genus Mirabilis L. is M. Jalapa L. In the latter the filaments are united at the base, the fruit is not viscid and the corolla is salvershaped with a long tube and broad limb. In Quamoclidion the filaments are distinct, the fruit viscid and the corolla from nearly cylindrical to bell-shaped but with a small limb. In Nirathilis the flowers are solitary and in the typical species of Quamolidion 3-6 in the involucre; but as the number of flowers are not of value as a generic character I have here included a species with one-flowered involucres. 
687 Rydberg: Studies on the Rocky Mountain Flora

Involucre 5-6-flowered: perianth elongated funnelform.

Involucre I-flowered: perianth open-campanulate.

I. Q. multiflontm.

2. C. laeve.

1. Quimoclidion multiflorun Torr; Gray, Am. Journ. Sc. II. I5 : 32 I. I 853

O.rybaphus multiflorum Torr. Ann. 1,yc. N. Y. 2: 237. IS2S. Nyctaginia Torreyana Choisy; DC. Prod. I3²: 430. I 849 . Mirabilis multiflora A. Gray; Torr. Bot. Mex. Bound. I 73. I 859 .

Choisy, who had not seen any specimens of this species and who believed that it had distinct bracts, referred it to Nyctaginia ; but it is evidently congeneric with and closely related to Mirabilis triflora Benth., the type of Quamoclidion. Q. multiflormm ranges from Colorado and New Mexico to Arizona and California.

\section{Quamoclidion laeve (Benth.)}

Orybapluzs laciis Benth. Bot. Sulph. 44. $\quad$ I 844.

O. glabrifolius var. creassifolius Choisy; DC. Prod. I3²: 43 I. I 849 .

O. glabrifolims Torrey, Pac. R. R. Rep. 4: I 3 I. 1957. Not Vahl.

Mirabilis Califormica A. Gray; Torr. Mex. Bound. Surv. 173. I 859 .

O. Californicus Benth. \& Hook. Gen. 3: 4. I SSo.

This species has quite often been included in Orybaphus, $i$. c., Allionia, and often in Mirabilis. Professor Heimerl, in his treatment of the Nyctaginiaceae in Dic natïrliclum Pflansonfamilion, merges Orybaphus into Mirabilis; but associates this species with the one-flowered species of Allionia.

It is evident that if Allionia is to be treated as a distinct genus, Q. lae'e can not be included in the latter genus for it lacks the essential characters, viz., the ribbed fruit and the enlarging and membranous involucre. It is evidently closer related to Quamoclidion than any other genus. The only important difference between it and the typical species is the open short perianth and the flowers solitary within each involucre. The species ranges from Utah to Arizona and California.

\section{Allioniella gen. nov.}

Bracts five, united into a gamophyllous viscid rotate involucre, 
Rimberg: Studies on the Rocky Mountalx Fiora 688

which enlarges somewhat in fruit but does not become membranous: flowers in each involucre 3 : perianth open, short funnelform : stamens 3, distinct : fruit ellipsoid, neither angled nor ribbed, very indistinctly tubercled, glabrous.

Only one species.

\section{Allioniella oxybaphoides (A. Gray)}

Quamoctidion orybaphoides A. Gray, Am. Journ. Sc. II. I5: 320. I 853 .

Mirabilis oxybaphoides A. Gray, Bot. Mex. Bound. Surv. 173. I 859 .

Oxybaphlus IVrightii Hemsl. Biol. Cent. Am. 3: 3. I $\$ 82$.

Allionia oxybaphoid's Kuntze, Rev. Gen. 533. IS9r.

From the many synonyms can be seen that this species has been moved from one genus to another. Most botanists have regarded it as an Allionic (Oxyhaphus), which it resembles most in general habit, the perianth and the number of stamens; but it lacks the most essential characters of that genus, viz, the ribbed fruit and the membranous involucre. It is, therefore, more closely related to the Mirabilis series; and could be included in genus Qnamoclidion had it not the open Allimica-like perianth, only three stamens and a flat rotate involucre. It is, therefore, better to regard it as the type of a new genus, intermediate between. Illionia and Quanoclition.

A. oxybaphoides grows from southern Colorado to western Texas and Arizona; also in northern Mexico.

5. AlliONiA Loefl. It. Hisp. i 8 i. 1758

Vitmania Turra; Cav. Ic. 3: 53. I 794. Not Vitmennia Vahl. I 794 .

Oxybaplus L'Her.; Willd. Sp. P1. I : 185. 1797.

Caly-xhymenia Ortega, Nov. aut Rar. Pl. Hort. Matr. 5. 1797.

Calymenic Pers. Syn. I : 36. ISO5.

The genus was based on a plant which a year later received the specific name $A$. violacea $\mathrm{L}$. Titmania and Oryblaphus were both based on Mirabilis a'iscosa Cav.; Calyztymtnic on C. glabrifolia and Calymenia on six species without the type being designated. 


\section{Key to the species}

Leaves from cordate to broadly ovate-lanceolate: all distinctly petioled.

Leaves cordate.

I. A. nyctaginea.

Leaves ovate, rounded or cuneate at the base.

2. A. floribunda.

L.eaves ovate-lanceolate, oblong or linear, sessile or only the lower short-petioled.

Involucres in open terminal cymes.

Stem more or less hirsute as well as viscid.

Leaves ovate or broadly oblong, as well as the stem conspicnonsly hirsute.

3. A. hirsuta.

Leaves linear-lanceolate, almost glabrous; stem sparingly hirsute or glabrous except under the nodes.

Stem glabrous below, not hirsute, viscid-puberulent above.

4. A. pilosa.

Flowers solitary in the involucre on short slender pedicels; fruit nearly glabrous.

5. A. slabra.

Flowers $2-3$ in the involucres, subsessile; fruit decidedly pubescent.

Leaves of the cymes much reduced and bract-like, upper portion of the stem densely and finely puberulent. 6 . A. bracteata.

Leaves of the cymes neither much reduced nor bract-like.

Leaves erect or ascending; lobes of the involucre rounded or broadly triangular-ovate.

Plant prostrate or diffuse; involucres and branches of the inflorescence densely viscid hairy. 7 . A. diffusa.

Plants more simple, erect or ascending; branches of the inflorescence usually merely viscid-puberulent.

Leaves from ovate or obovate to linear-lanceolate, usually over $5 \mathrm{~mm}$. wide.

S. A. lanceolata.

Leaves narrowly linear, less than $5 \mathrm{~mm}$. wide,

9. A. linearis.

Leaves divergent; lobes of the involucre elliptic or oval.

I0. A. diz'aricata.

Involucres on solitary axillary peduncles, rarely also in small dense terminal clusters.

Leaves oblong, lanceolate or linear-lanceolate.

Stem hirsute.

Stem glabrous.

Leaves narrowly linear.
II. A. aggregata.

I2. A. derumbens.

13. A. Bodinii.

I. Aldionia nictaginea Michx. Fl. Bor. Am. I: ioo. ISO3 Orybaplus nyetergincus Sweet, Hort. Brit. I : 334. I 825.

A well-known and common plant growing in rich soil from Illinois and Saskatchewan to Wyoming, New Mexico and Louisiana.*

2. Allionia floribunda (Choisy) Kuntze, Rev. Gen. 533. IS9I

4. orata Pursh, Fl. An. Sept. I : 97. ISI4. Not Oxybaphus oratus Valil. 1806.

* Allionia Cervantesii has been reported from Colorado, but the specimens on which this assertion has been made belong in all cases I know to. Allioniella oxybaphoides. 
Rydberg: Studies on the Rocky Mountain Flora 690

O. floribundus Chois; DC. Prod. 132: 433. I 849.

A. nyctuginea ozata Morong, Mem. Torrey Club, 5: 146. 1894 .

In dry soil from Missouri and South Dakota to Wyoming, New Mexico and Texas.

3. Allionia hirsuta Pursh, Fl. Am. Sept. 2: 728. I 814 Oxybaphus hirsutus Sweet, Hort. Brit. I : 334 . I $\$ 25$.

In sandy soil from Minnesota and South Dakota to Colorado.

\section{Allionia pilosa (Nutt.)}

Caly'menia pilosa Nutt. Gen. I : 26. I 8 IS.

Oxvbaphus pilosus Sweet, Hort. Brit. I : $334 . \quad 1825$.

This has been confused with the preceding, but I think it amply distinct. So it was regarded by Nuttall and by Sweet. It is perhaps nearer related to $A$. floribundo and Nuttall cites $A$. orotcr Pursh as a synonym; but it is well to note that Nuttall describes the stem of his species as pubescent, which does not agree with Pursh's plant. A. pilosa grows in dry sandy soil from Wisconsin and North Dakota to Texas and Louisiana.

5. Allionia glabka (S. Wats.) Kuntze, Rev. Gen. 533. is9i Oxybaphus glaber S. Wats. Am. Nat. 7 : 301. I 873.

A rare plant from the arid districts of southern Utah, Arizona, and New Mexico.

\section{Allionia bracteata sp. nov.}

A branched, more or less viscid perennial: stem glabrous below, densely viscid-pubescent above, 4-I $2 \mathrm{dm}$. high, erect or ascending: leaves subsessile; blades oblong to linear-lanceolate or linear, 3-9 cm. long, thick, mostly ciliate, glabrate: leaves of the inflorescence elliptic or oblong, to lanceolate, reduced, less than I $\mathrm{cm}$. long, more or less viscid-pubescent: involucres often numerous in terminal cymes, IO-It mm. wide; lobes broadly ovate, obtuse: perianth white or pale, about $10 \mathrm{~mm}$. broad: fruit oblong-obovate, $5-5.5 \mathrm{~mm}$. long, prominently $S$-ribbed, apiculate, constricted near the base.

This species has been mistaken for $A$. lincaris and $A$. albida, but is easy distinguished by the reduced leaves of its inflorescence. It grows in dry rocky soil. 
M.rssouri : Malden, I894, Bush, 759 (type in herb. Columbia University); Wayne, 1900, 825 ; also Courtney, 1891 ; McDonald county, 1 893,310 .

South Dакота: Spring Basin, is9i, T. H. Milliams.

Alabama : Selma, i 888, Mc Carthy.

7. Alllonia diffusa Heller, Minn. Bot. Stud. 2 : 33 . ISgS

On dry plains, from North Dakota and Wyoming, to Kansas, New Mexico and Arizona.

\section{Allionia lanceolata sp. nov.}

A. albida Rydb. Cont. U. S. Nat. Herb. 3: 520. r\$96. Not IValt. I 788 .

A branched perennial. Stems erect or ascending, glabrous below, viscid-pubescent with short hairs, 4-15 dm. high: lower leaves short-petioled, the upper sessile; blades lanceolate or ovatelanceolate to almost linear, $3-10 \mathrm{~cm}$. long, very thick, obtuse or blunt at the apex: involucres numerous, in terminal cymes, $1-1.5$ cm. wide; lobes rounded ovate, sometimes acutish : perianth pink, about Io mm. broad: fruit obovoid, $4.5-5 \mathrm{~mm}$. long, with usually $4-5$ broad ribs and finely tuberculate faces.

This has usually gone under the name of Allionia albide which it resembles in habit, but that species has white perianths and sharply acute or acuminate thin leaves. A. albida is confined to South Carolina and Georgia and is represented by A. lanccolata in the West. The latter grows in dry soil on the plains, from Minnesota and Vyoming to Tennessee and Tcxas.

Colorado: Estes Park, Larimer county, Ostcrhout, 1556 (type in herb. N. Y. Botanical Garden).

9. Allionia linearis Pursh, Fl. Am. Sept. 2 : 72S. ISI 4

Calymoniar angustifolic Nutt. Gen. I : 26. I 8 I 8 .

Onjbapluns angustifolins Sweet, Hort. Brit. I': 334. I 826.

In dry soil on the plains, from Minnesota to Montana, Arizona, Mexico and Louisiana.

\section{IO. Allionia divaricata sp. nov.}

A slender perennial. Stems usually solitary, erect, 6-io dm. high, glabrous and shining up to the viscid-puberulent inflorescence: leaves more or less distinctly petioled, usually spreading; 
blades glabrous, thickish, linear to linear-lanceolate, acute, 5-10 cm. long: involucres numerous, in terminal cymes about $1.5 \mathrm{~cm}$. wide, cleft below the middle into elliptical or oval obtuse lobes: perianth pink, about $\delta \mathrm{mm}$. wide: fruit oblong-obovoid, slightly compressed, bluntly angled and not strongly tubercled, strigose.

Perhaps closest related to $A$. lincaris, but distinguished by the thinner divergent leaves, the form of the involucre and the fruit.

Colorado: Durango, I898, Baker, Earle \& Tracy, $52 z$ (type in herb. N. I'. Bot. Garden).

Arizona: Balers Butte, Mogollon Mountains, is87, Miarns, 253.

I1. Allionia agigegati (Ortega) Spreng. Syst. I : 3S4. 1825

Calyrhymonia aggregata Ortega, Nov. aut Rar. PI. 8: pl. II. I 798 (or 1799 ?).

Oxybaphus aggregatus Vahl, Enum. 2: 41, in part. ISo6.

This is not the plant named O. aggregatus by Torrey, Watson and others, from Arizona and northem Mexico, but one that is closely related to $A$. hirsuter and generally has been confused with it. It differs mainly in the axillary solitary peduncles and in this respect is analogous to $A$. Bodinii. Vahl evidently had two plants confused, citing as synonyms Calyxhyminia agsregata Ortega and Mirabilis asgregata Cavanilles, both illustrated and closely related species of Allionia. Ortega's plant, which was the first published, * is densely hirsute, while Cavanilles' plant is glabrous. Vahl, in his diagnosis, describes it as glabrous but remarks in parentheses " according to Ortega hirsute."

A. aggregata grows in dry soil from Wisconsin to Texas and New Mexico, also in northern Mexico.

I 2. Allionia decumi,ens (Nutt.) Spreng. Syst. I : 384 . I 825 Mirabilis aggregata Cav. Ic. 5 : 22. pl. 437. 1799.

Oxybaphus aggregatus Vah1, l. c. in part.

Calymenia decumbens Nutt. Gen. I : 26. I 8 is.

Orybaphus decunbens Siveet, Hort. Brit. I : 334. 1826.

* I have not been able to find the exact date of Ortega's fascicle in which the description appears. The ten fascicles were published in $1797-1$ Soo; but Cavanilles cites Ortega, which indicates that the latter's description was published first. 
This species stands in the same relation to $A$. lanceolata as the preceding does to $A$. hirsuta and the following to $A$. linearis, differing mostly in the mode of blooming. One of the reasons for holding them as distinct species and not as forms of the species mentioned is that their ranges are different, $A$. aggregata and $A$. decumbens extending further south into Mexico and the Gulf states, while their cymose analogues are northern, and the range of $A$. Bodinii is more limited than that of $A$. linearis. A. decumbens grows in dry soil on the plains, from Missouri and South Dakota to Wyoming, Mexico and Mississippi.

i3. Allionia Bodinil (Holz.) Morong, Mem. Torrey Club, 5: 354. I $S 94$

Oxybaphus Bodinii Holz. Contr. U. S. Nat. Herb. I: 287 . I 893. In dry soil from western Kansas to Utah and western Texas.

6. WEDELIA Loeff. Iter. Hisp. I $80 . \quad 1758$

Allionia L. Syst., Ed. IO, 890, in part. I 759.

The genus was based on a plant which the following year received the specific name Allionic incarnata $\mathrm{L}$.

I. Wedelia incarnata (L.) Kuntze, Rev. Gen. Pl. 533. I 892 Allionia incamata L. Syst., Ed. I0, 890. 1759.

From western Texas and southern Colorado to California. 
CONTRIBUTIONS FROM THE NEW YORK BOTANICAL GARDEN-No. 36.

\section{STUDIES ON THE ROCKY MOUNTAIN FLORA.-X.}

\section{By PER AXEL RYDBERG}

NEW YORK

1903 



\section{Studies on the Rocky Mountain Flora, $-\mathrm{X}$}

By Per Axel Rydeerg

Corispermum marginale sp. nov.

Annual : stem glabrous, much branched, 2-5 cm. high : leaves narrowly linear, $2-5 \mathrm{~cm}$. long, $1.5-2 \mathrm{~mm}$. wide: spike $3-8 \mathrm{~cm}$. long, rather dense; bracts usually overlapping each other, the lower lanceolate, about I $\mathrm{cm}$. long, the upper ovate, $5 \mathrm{~mm}$. long ; all more or less acuminate, with a strong midrib and conspicuous scarious margins, slightly pubescent when young or glabrate: fruit about $4 \mathrm{~mm}$. long and $2.5 \mathrm{~mm}$. wide, with a broad wing margin.

This is perhaps most nearly related to C. hyssopifolium of the salt marshes of the coast regions, but is taller, more slender, with less fleshy leaves, smaller fruit and more conspicuously scarious-margined bracts. From C. nitidum it differs in the broader bracts, denser spikes and larger fruit. It grows in similar localities, viz., in sandy soil, in draws and ravines.

New Mexico: Albuquerque, I884, C. L. Herrick (type in herb. N. Y. Bot. Garden).

Colorado: Huerfano Valley, near Gardner, i 9oo, F. K. Viecland, 657; Rocky Ford, I893, Crandall; Denver, I887, S. M. Tracy.

Chexoponium IVatsoni A. Nelson, Bot. Gaz. 34: 362. 1902

Chenopodium olidum S. Wats. Proc. Am. Acad. 9: 95. I874, mainly. Not Curt.

Annual, rather stout, sparingly farinose, 2-6 dm. high : stem branched, striate and sometimes tinged with red: leaves rather thick; petioles $2-10 \mathrm{~mm}$. long; blades $\mathrm{I}-2 \mathrm{~cm}$. long, oval, ovate or oblong, obtuse and occasionally cuspidate-mucronate, dark green and sparingly mealy: inflorescence narrow, dense: flowers I $\mathrm{mm}$. in diameter: seed $\mathrm{I} .25-\mathrm{I} .5 \mathrm{~mm}$. in diameter: pericarp mealy and closely adherent.

Watson's name being preoccupied, I apply Nelson's substitute to this species as it is Watson's C. olidum as to the description and most specimens cited. Several specimens given by him belong, however, to the next species, which has been confused with 
it. Mr. Powell sent some seeds to Elihu Hall. A specimen raised from these seeds and preserved in the herbarium of Columbia University I take as typical $C$. II'atsoni.

\section{Chenopodium Wolfii sp. nov.}

Chcnopodium olidum S. Wats. Proc. Am. Acad. 9: 95. I 874, partly.

Annual, sparingly mealy: stem erect, 3-4 dm. high, often branched, striate: leaves moderately thick, dark green, only slightly mealy; petioles about $1 \mathrm{~cm}$. long; blades $\mathrm{I}-3 \mathrm{~cm}$ long, oblong to ovate-lanceolate, entire or rarely slightly hastately toothed, obtuse: inflorescence dense, narrow : flowers small: seeds less than I mm., usually $.75 \mathrm{~mm}$. in diameter: pericarp thin and easily separated from the seed.

Closely resembling the preceding in habit, but is easily distinguished by the smaller flowers and seed and the separating pericarp. These characters place it nearest to $C$. oblongifolimm Nutt., from which it differs in the less mealiness and the smaller seeds.

Colorado: Twin Lakes, 1773, John II'olf, 253, apparently also 258 and 263 .

Wyoming: Wamsutter, is97, Aicn Nclson, 3671 .

\section{Endolepis ovata sp. nov.}

Low, annual, usually less than I dm. high: stem branched, straw-colored or pinkish, almost glabrous: leaves subsessile, usually less than I $\mathrm{cm}$. long, ovate or lance-ovate, 3 -nerved at the base, sparingly mealy : pistillate flowers solitary in the axils of the middle leaves: staminate flowers in small clusters in the axils of the upper leaves or at the end of the branches, otherwise as in $E$. Suckleyana Torr.

In my opinion Dr. Torrey was correct in separating Endolcpis from Atriflex. It is interesting to find a second species of the former genus, which hitherto has been known as monotypic. The original Endolcpis has narrowly lanceolate leaves, which are thinner and without lateral ribs.

Wyoming: Buffalo, 1900, Frank Taecedy, 3290 (type in herb. N. Y. Bot. Garden); Wallace Creek, I 898 , Elias Nclson, 4999 ; Rock Creek Station, ISS I, L. F. W W ard.

Montana: Glendive, I\$892, J. H. Sandberg. 


\section{Cleomella cornuta sp. nov.}

Annual: stem straw-colored, 2-3 dm. high, branched below with ascending branches, glabrous throughout: leaves ternate; petioles $1-1.5 \mathrm{~cm}$. long; leaflets $1-2 \mathrm{~cm}$. long, oblong or oblongoblanceolate, obtuse, mucronate: inflorescence short: pedicels very slender, almost I cm. long: sepals yellowish, ovate, cuspidate, less than I mm. long: petals light yellow, narrowly oval, clawless, about $3 \mathrm{~mm}$. long: filaments about twice as long: fruit broadly rhombic, broader than long, about $3 \mathrm{~mm}$. long and $4 \mathrm{~mm}$. broad; the corners often produced into short processes : stipe 6$8 \mathrm{~mm}$. long; beak over I $\mathrm{mm}$.: seeds about $2.5 \mathrm{~mm}$. long, 1.75 $\mathrm{mm}$. wide, smooth and unmarked.

This is related to $C$. ocorpa and C. plocaspomar, but has broader leaflets. From the former it also differs in the strongly rhombic pod and from the latter in the broader and unmarked seeds. The type grew at an altitude of $1350 \mathrm{~m}$.

Utah : Cainsville, 1894, Marmes E. Joncs, 5656 (type in U. S. Nat. Herb.).

\section{Cerastium Earlei sp. nov.}

Perennial with a slender branched and stoloniferous rootstock: stems weak, ascending, 2-3 dm. high, viscid-puberulent, branched: leaves oblong or oblanceolate, obtuse, viscid-puberulent, $1.5-3 \mathrm{~cm}$. long, $3-8 \mathrm{~mm}$. wide: inflorescence open; bracts ovate or ovate-lanceolate, not scarious; pedicels $2-2.5 \mathrm{~cm}$. long: sepals lanceolate, acute, sparingly pubescent, scarious on the margins, about $5 \mathrm{~mm}$. long: petals about $1 \mathrm{~cm}$. long or more, fully twice as long as the sepals, not very deeply cleft.

The type number was determined by M. E. Jones as Cerastium alpinum near var. glatratum, and the other two numbers of the Baker, Earle and Tracy collection are labeled Corastimm

and Corastimm arousc oblongifolium, respectively. The six sheets (two of each number) in the N. I. Botanical Garden herbarium (except one of number 621 , which represents a luxuriant state) are so alike that it is impossible to refer them to different species. In the size of the flowers, form of the leaves and general habit, the species resembles most $C$. alpinmm, but the pubescence is different: in C. alpimum long-villous and less viscid, in C. Eurlei very short and very viscid. The latter grows at an altitude of $2700-3600 \mathrm{~m}$.

Colorado: Near La Plata P. O., is98, Bakr, Earle \& Tracl, 
72 (type in Herb. N. Y. Bot. Garden); Little Kate Basin, La Plata Mts., 568; Cumberland Basin, 621 .

\section{Cerastium Leibergii sp. nov.}

Perennial with a slender, branched rootstock: stems simple, 4-5 dm. high, sparingly villous and viscid-puberulent; uppermost internode of the stem about I dm. long: leaves few and scarcely half as long as the internodes, linear-oblong, $2.5-3 \mathrm{~cm}$. long, 6-7 $\mathrm{mm}$. wide, the lower obtuse, the upper acutish, I-nerved, thin, puberulent when young, ciliate on the margins: inflorescence viscid-puberulent; bracts lanceolate, $4-8 \mathrm{~mm}$. long, not scariousmargined; pedicels in fruit $2.5-3 \mathrm{~cm}$. long: sepals about $5 \mathrm{~mm}$. long, lanceolate, viscid-pubescent, scarious-tipped and margined : petals scarcely twice as long as the sepals.

This is perhaps most nearly related to the preceding, but differs mainly in the broader, obtuse leaves and smaller flowers. It grows in open Pinus ponderosa forests at an altitude of $970 \mathrm{~m}$.

I daho: Upper St. Mary's River, i $\$ 95$, J. B. Leiberg, I103 (type in U. S. Nat. Herb.).

\section{Cerastium graminifolium sp. nov.}

Perennial with slender branched rootstock: stems $3-5 \mathrm{dm}$. high, densely short-villous and somewhat viscid, erect; uppermost node of the stem below the inflorescence elongated, 5-10 $\mathrm{cm}$. long: leaves linear-lanceolate, $2-3 \mathrm{~cm}$. long, $3-5 \mathrm{~mm}$. wide, I-nerved, short viscid-villous, mostly spreading : bracts lanceolate or ovate-lanceolate: pedicels in fruit $2-4 \mathrm{~cm}$. long: sepals narrowly lanceolate, densely viscid-pubescent, only slightly scariousmargined, acute, 5-6 mm. long: petals I 2-14 $\mathrm{mm}$. long, cleft $1 / 3-1 / 4$ their length into oblong, obtusish lobes: capsule almost straight, about $2 / 3$ longer than the sepals.

This has gone under the name of C. aricnse, but differs from the European plant, in the larger flowers, the more villous pubescence and the more acute leaves, which resemble much those of Alsine graminea. It grows in rich bottom lands.

Washingtox: Pullman, i 897 , Elmer, 177 (type in herb. N. Y. Bot. Garden).

IDAHO: near Lewiston, I896, A. A. \& E. Gertrude Heller, 3013; Upper Ferry, Clearwater Ferry, I 892, Sandberg, MacDougal \& Heller, 19. 


\section{Draba sobolifera sp. nov.}

A low cespitose perennial, but the leafy stolons often somewhat elongated: basal leaves oblanceolate, obtuse or spatulate, $1-2 \mathrm{~cm}$. long and 3-4 mm. wide, sparingly stellate-villous, thick with indistinct midrib: peduncles $3-6 \mathrm{~cm}$. long, stout, rather many-flowered: petals yellow, obovate, about $4 \mathrm{~mm}$. long, more than twice as long as the rounded sepals: pedicels in fruit $7-8$ mm. long: pod ovate, about $6 \mathrm{~mm}$. long, $3-4 \mathrm{~mm}$. wide, finely stellate: style about $5 \mathrm{~mm}$. long.

This species is related to D. aentrosa and D. alpina. From the former it differs in the longer leaves and the finer and sparser pubescence; from the latter in the more elongated stems, the shorter and stellate pod and the shorter styles. It grows at an altitude of about $2500 \mathrm{~m}$.

Utaн : Marysvale, above timber line, 1894, Marcus E. Joncs, 59,36 (type), 589,36 and $589,3 a .3$ (all in U. S. Nat. Herb.).

\section{Draba argyrea sp. nov.}

A cespitose tufted perennial, with underground horizontal stems; basal leaves obovate, $3-7 \mathrm{~mm}$. long, in dense rosettes, densely and finely stellate, almost silvery; midvein indistinct: peduncles slender, $3-5 \mathrm{~cm}$. long, naked, few-flowered: petals yellow, $3 \mathrm{~mm}$. long, obovate, about twice as long as the ovate sepals : pedicels in fruit $5-8 \mathrm{~mm}$. long: pods lanceolate, $6-7 \mathrm{~mm}$. long, 2.5$3 \mathrm{~mm}$. wide, minutely stellate: style about $1 \mathrm{~mm}$. long.

This species resembles somewhat $D$. oligosporma in general habit and flowers, but the leaves are shorter and broader, more decidedly stellate and without the strong midrib, and the pod is longer. It also reminds one of D. ventrose but is a more delicate plant with finer pubescence and longer pods. The type grew at an altitude of about $3000 \mathrm{~m}$.

IDAHO: Rock crevices, Sawtooth Mountains, head of Pettit Lake, July, 1895 , L. F. Honderson, 3539 (type in U. S. Nat. Herb.).

\section{Draba uncinalis sp. nov.}

Small cespitose and pulvinate perennial : flowering stems scapiform, 2-3 cm. high, sparingly stellate, leafless; basal leaves in dense tufts, thick, rounded obovate, $3-4 \mathrm{~mm}$. long, sparingly stellate, with indistinct midrib: inflorescence corymbiform, few-flowered; pedicels in fruit $4-5 \mathrm{~mm}$. long: pod ovate, $3-4 \mathrm{~mm}$. long and 3 $\mathrm{mm}$. wide, glabrous or nearly so: style about $0.5 \mathrm{~mm}$. long. 
A small plant characterized by the short pod, found otherwise only in two North American species, viz., $D$. andina and $D$. oligosporma; but in both of those species the leaves have strong midribs and are less stellate. In habit it resembles most D. mialis, but that species has a different pod. It grows at an altitude of $3500 \mathrm{~m}$.

Utaн: Marysvale, Tate Mine, I894, M. E. Jones, $5970 a m$ (type in U. S. Nat. Herb.).

Lesquerella Utahensis sp. nov.

A tufted perennial : stems ascending, 5- I O cm. (seldom $\mathrm{I} 5 \mathrm{~cm}$.) high ; basal leaves $3-4 \mathrm{~cm}$. long, petioled; blades oval or obovate, densely and finely stellate; stem-leaves smaller, oblanceolate or spatulate: petals yellow, about $8 \mathrm{~mm}$. long, with cuneate blades, $1 / 2$ longer than the oblong sepals: pedicels in fruit ascending, 5I $\mathrm{mm}$, long: pod almost spherical or slightly transversely flattened, 3-4 $\mathrm{mm}$. wide, finely stellate: style $4-5 \mathrm{~mm}$. long, much longer than the pod.

This species is related to L. Irardii, i. c., it has the same habit and pubescence and the pod is as in that species somewhat thicker than broad; but the latter is shorter, rounder, neither elongated nor acute at the apex. L. Utahensis grows at an altitude of 2000$3500 \mathrm{~m}$.

UTä : American Fork Cañon, ISSO, Marcus E. Joncs, 1357 (type in herb. N. Y. Bot. Garden); Friser, ISSo, 1810 ; Marysvale, $1884,5375 c, 5958 n$; Irelands Ranch, Salina Cañon, $5+t^{1}$; Cañon above Tropic, $5312 \mathrm{l}$.

\section{Stanleya runcinata sp. nov.}

Stem stout, glabrous: basal leaves about $2 \mathrm{dm}$. long, lanceolate in outline, runcinately divided, softly pubescent with long white hairs; lobes broadly triangular or the lowest ones oblong: stemleaves ovate to oblanceolate, more glabrous: raceme $\mathrm{I}-3 \mathrm{dm}$. long, many-flowered: sepals linear, about $\mathrm{I} \mathrm{cm}$. long and I mm. wide, light yellow, glabrous: petals about $1 / 4$ longer; blades oblanceolate, about $2 / 3$ as long as the glabrous claws: filaments glabrous, about twice as long as the sepals : pods almost erect and straight, 6-7 cm. long, $1.5 \mathrm{~mm}$. wide, on spreading pedicels about $\mathrm{I} \mathrm{cm}$. long.

This species is perhaps most closely related to $S$. pinnata, but easily distinguished by the lobing of the basal leaves, the straight 
pods, the oblanceolate blades of the petals and the glabrous filaments.

Iпнно (?) : I \$96, Hinderson (type in U. S. Nat. Herb.).

Thelypodium ovalifolium sp. nov.

Perennial, perfectly glabrous: stems terete, 3-5 dm. high, ascending: earliest basal leaves about $5 \mathrm{~cm}$. long, petioled $\mathbf{w}$ ith broadly oval blades, glabrous, entire, obtuse; the later ones oblanceolate; stem-leaves sagittate, $2 \mathrm{~cm}$. long, thick, sessile and clasping, with short rounded basal lobes: inflorescence elongated: sepals oblong, $3 \mathrm{~mm}$. long: petals about $5 \mathrm{~mm}$. long with spatulate blades and slender claw: pedicels in fruit 4-5 $\mathrm{mm}$. lons, spreading: pods ascending, I-2 cm. long and about $\mathrm{I} \mathrm{mm}$. wide, somewhat torulose.

This species is perhaps most noarly related to $T$. paniculatm, but differs in the short pods and the broad basal leaves.

UтAн: Panguitch Lake, IS94, M. E. Jones, 6o156 (type in U. S. Nat. Herb.).

\section{Lepidium Georginum sp. nnv.}

Apparently biennial, cespitose from a slender taproot, I-2 dm. high: stems hirsute with short spreading hairs: basal leaves $1-5$ $\mathrm{cm}$. long, deeply pinnately divided with ovate lobes; stem-leaves similar or the upper oblanceolate and entire; all more or less pubescent : inflorescence short: petals spatulate, slightly exceeding the sepals: pods pubescent, rounded oval, $4 \mathrm{~mm}$. long, broadly winged above, forming at the apex two broadly ovate obtuse lobes, over $0.5 \mathrm{~mm}$. long.

This species is in habit nearest L. Irightä with which it has been confused; but it is less hairy and the pods are those of $L$. dictyotum.

Utah : "Southern Utah," IS74, C. C. Prrry, Ig (type in herb. Columbia University); IS77, E. Perlmor, fo; St. Gcorge, i 880 , MI. E. Jones, I6It; Milford, $182 I$ in part; IS94, $5110 f$.

\section{Thysanocarpus trichocarpus sp. $110 \mathrm{~V}$.}

Annual, perfectly glabrous, except the fruit, I-3 dm. high: stem terete, branched: lower leaves oblanceolate or oblong, sinuately dentate, thick and somewhat glaucous; uppermost leaves linear or linear-lanceolate, entire: racemes often I dm. long: petals slightly over I $\mathrm{mm}$. long; blades broadly spatulate: pedicels in fruit about $5 \mathrm{~mm}$. long, recurved: pod nearly orbicular, 
about $4 \mathrm{~mm}$. wide, short-pubescent: wing-margins crenate or lobed, not fenestrate: style scarcely exceeding the wing-margin.

Uтан: Silver Reef, I $994, M$. E. Joncs, 51636, in part (type in U. S. Nat. Herb. ), 5179 d and 5 r 39 d.

\section{Trifolium lividum sp. nov.}

Perennial, densely cespitose and tufted : branches of the caudex short and covered by the remnants of the leaf-bases and scariuus stipules; free portion of the latter subulate-filiform: petioles 4-I 5 $\mathrm{cm}$. long, slender, glabrous; leaflets linear-lanceolate or oblanceolate, very acute at both ends or cuspidate at the apex, $3-4 \mathrm{~cm}$. long, glabrous above, sparingly appressed hairy beneath, green, entire-margined: peduncles $\mathrm{I}-\mathrm{I} .5 \mathrm{dm}$. high, sparingly appressed hairy: heads nearly $2 \mathrm{~cm}$. in diameter; bracts linear-subulate to almost filiform, longer than the calyx-tube, glabrous, slightly if at all scarious-margined: calyx-tube $2.5-3 \mathrm{~cm}$. long; teeth subulate-filiform, 4-5 mm. long: corolla about $12 \mathrm{~mm}$. long, light purple with a darker keel.

This species is nearest to T. dasyphyllum, but is a larger, more glabrous and greener plant, and with much larger and narrower bracts. It grows at an altitude of about $3000 \mathrm{~m}$.

Colorado: Graymount, I895, P. A. Ryelberg, 2772 (type in herb. N. Y. Bot. Garden); Alpine Tumnel, I897, C. L. Sharr.

\section{Trifolium pedunculatum sp. nov.}

Perennial, with a somewhat cespitose base: stems 2-4 dm. high, rather slender, striate, glabrous or with a few appressed hairs: stipules $2-3 \mathrm{~cm}$. long, lanceolate, $1 / 2$ or $2 / 3$ of their length adnate to the petioles, denticulate: petioles $4-6 \mathrm{~cm}$. long, slender ; leaflets 3 , oblanceolate to linear, acute, finely denticulate, $2-3.5$ $\mathrm{cm}$. long: peduncles I dm. or more long: heads $\mathrm{I} 5-\mathrm{I} S \mathrm{~mm}$. in diameter, not bracteate: flowers subsessile, IO-I $2 \mathrm{~mm}$. long, in fruit not reflexed : calyx-tube $2 \mathrm{~mm}$. long, glabrous below, pubescent towards the throat; calyx-teeth subulate, the lower $3-3.5 \mathrm{~mm}$. long : corolla purple.

This species is nearest to $T$. longlpes, but differs in the smaller purple flowers and the calyx which is glabrous below.

InAHo: Long Valley, i 895, L. F. Hinderson, 3096 (type in U. S. Nat. Herb.); near Sawtooth, I896, B. IV. Evcrmann, 592.

\section{Lotus longebracteatus sp. nov.}

Perennial, cespitose, decumbent : stems $2-3 \mathrm{dm}$. long, diffusely branched, grayish strigose: leaves thick, grayish strigose with a 
distinct rachis; leaflets 4 , linear to oblong or of the lowest leaves obovate, $\mathrm{I}-\mathrm{I} .5 \mathrm{~cm}$. long or the lower shorter: peduncles $4-5 \mathrm{~cm}$. long, $\mathrm{I}-2$-flowered ; bracts linear, about equalling the calyx : calyx strigose, its tube and teeth each about $4 \mathrm{~mm}$. long; the latter subulate: corolla about $\mathrm{I} 4 \mathrm{~mm}$. long, strongly curved upwards, the banner much exceeding the wings and keel: pod linear, straight, $2.5-3 \mathrm{~cm}$. long, pubescent.

This is in some respects intermediate between L. rigidus and L. Wrightii, differing from the former in the narrower leaflets, in the shorter peduncles, longer bracts and narrower calyx-teeth and from the latter in decumbent habit, leaves with a distinct rachis and elongated peduncles.

Utah: "South Utah," I 877, Dr. E. Palmer. 97 (type in U. S. Nat. Herb.).

\section{Lupinus depressus sp. nov.}

Perennial, cespitose: stems decumbent, $1-2 \mathrm{dm}$. long, appressed silvery silky pubescent: petioles slender, $5-7 \mathrm{~cm}$. long. also silvery silky; leaflets about $\gamma$, oblanceolate, usually obtusish, I. $5-2 \mathrm{~cm}$. long, densely appressed silvery canescent; stipules subulate: racemes short, slightly exceeding the leaves; bracts lanceolate, short, deciduous: flowers $8-9 \mathrm{~mm}$. long: calyx long-villous; lips ovate-lanceolate; the lower about 1/3 longer than the upper: corolla light bluish-purple; banner glabrous, slightly' shorter than the wings.

Being perhaps most nearly related to $L$. minimus, it differs from that in the decumbent or spreading leafy stem and more silky pubescence. It grows in gravel on dry mountain slopes, at an altitude of about $1750 \mathrm{~m}$.

IDAHO: Divide between St. Joe and Clearwater River, 1895. Jolm B. Leiberg, IzOI (type in U. S. Nat. Herb.); Lo-Lo Trail, i 880, S. IVatson, So.

\section{Lupinus Evermannii sp. nov.}

Peremnial and densely cespitose: the numerous stems about I. $5 \mathrm{dm}$. high, slender, erect or ascending, leafy, appressed hairy : petioles $2-4 \mathrm{~cm}$. long, also appressed hairy; leaflets oblanceolate to linear-oblanceolate, $1-2.5 \mathrm{~cm}$. long, densely canescent on both sides with long appressed hairs; stipules lanceolate, acuminate: raceme very short-peduncled, dense and short; bracts lanceolate, short, deciduous: flowers $6-7 \mathrm{~mm}$. long; pedicels and calyx densely pubescent with spreading hairs; lips of the latter orate- 
lanceolate, the lower about 1/3 longer than the upper: corolla purplish-blue; banner with a light spot, glabrous.

This species is nearest related to L. holoscricens, but the corolla is lighter and the pubescence of the calyx is spreading. It is also lower and more cespitose, resembling more L. candicans in habit, but has much smaller flowers.

I Daho: Near Sawtooth, I 896, B. IT. Eacmann, 5.33 (type in U. S. Nat. Herb.).

\section{Lupinus Jonesii sp. nov.}

Perennial, very stout: whole plant yellowish-green : stem over I mm. high, densely pubescent with two kinds of hairs, viz., a short pubescence and long spreading silky hairs; petioles about 5 cm. long, also pubescent with spreading hairs; leaflets $7-9$, oblanceolate, densely appressed, yellowish hairy on both sides, 4-7 $\mathrm{cm}$. long; stipules setaceous, deciduous: raceme long and dense, many-flowered; bracts subulate-filiform, much exceeding the buds; pedicels and calyx densely hairy with short spreading hairs: flowers about $16 \mathrm{~mm}$. long : lips of calys ovate-lanceolate; the lower about $1 / 3$ longer than the upper: corolla white; the banner with a faint brownish spot; keel purple-tipped.

This species is nearest related to L. lancophyllus, but is less densely pubescent, the flowers are larger and in the type sheet whitish and the bracts are much longer. It grows at an altitude of about $4200 \mathrm{ft}$.

Utan: Silver Reef, May 3, is94, Marcus E. Joncs, 5173 (type in U. S. Nat. Herb.).

\section{Lupinus adscendens sp. nov.}

Perennial : stem 4-6 dm. high, appressed silky, leafy : petioles 5-Io cm. long, ascending, also appressed silky; leaflets about 7 , linear-oblanceolate, $4-5 \mathrm{~cm}$. long, acute, appressed silky on both sides but green; stipules subulate: racemes elongated, narrow ; pedicels strongly ascending, rather long hairy: flowers about 12 $\mathrm{mm}$. long : calyx grayish silky ; the lower lip slightly longer than the upper: bract linear-subulate, much longer than the buds, almost equalling the calyx in length: corolla dark bluish-purple; the banner glabrous with a lighter spot.

This species is related to L. laxifforns, but the calyx is not spurred and the bracts are much longer.

Wroming: Headwaters of the Tongue River, isgs, F. Tiu'ced's, 129 (type in herb. N. Y. Bot. Garden); Head of Big Goose Creek, is93, F. Toecedy, I3. $_{3}$ 


\section{Lupinus argentinus sp. nov.}

Pereminal, densely appressed white-silky throughout: stem 4-6 dm. high : petioles $5-7 \mathrm{~cm}$. long; stipules lanceolate-subulate; leaflets about 7 . oblanceolate, densely silky on both sides, $3-5 \mathrm{~cm}$. long, conduplicate and with strongly curved back: inflorescence rather short and dense; bracts ovate-lanceolate, short, deciduous: flowers about I cm. long: calyx and pedicels densely white-silky, spurred at the base; lower lip lanceolate, about one third longer than the upper: corolla bluish-purple; banner pubescent on the back, about as long as the wings: pods oblong, densely pubescent, about $3 \mathrm{~cm}$. long and 5-6-seeded.

This species is nearest to L. argopluyllus, but differs in the denser and whiter pubescence, the broader curved leaflets and the more pubescent banner. It grows at an altitude of I 200-2200 m.

Utan: Near Reno, I goo, S. G. Stokes (type in herb. N. Y. Bot. Garden); Provo River, isS I, . IT. E. Jones, 2160; Salt Lake City, I 869, S. Watson, 227.

\section{Lupinus comatus sp. nov.}

Perennial, somewhat cespitose: stem about $3 \mathrm{dm}$. high, pubescent with long spreading silky hairs: petioles of the basal leaves about $\mathrm{I} \mathrm{dm}$. long, also pubescent with spreading hairs, leaflets narrowly oblanceolate, acute, $2.5-4 \mathrm{~cm}$. long, green, pubescent on both sides; stem-leaves similar, but with shorter petioles; stipules linear lanceolate, lons-acuminate: raceme short and dense, shortpeduncled; bracts lancenlate-subulate, equalling or exceeding the buds; pedicels and calyex densely pubescent with spreading hairs; lips almost equal, ovate-lanceolate: flowers $8-10 \mathrm{~mm}$. long: corolla bluish-purple, rarely white; banner slightly shorter than the broad wings.

The species is somewhat related to L. laxiflorus but the calyx is not spurred, the raceme short and dense, the flowers larger and the pubescence of the stem and petioles long and spreading.

Colorado: Lake City, is7s, F. $\mathrm{I}$. Pease (type in herb. Columbia University): Gunnison Co., I 895, C. L. Pollard (?) (U. S. Nat. Herb.).

\section{Lupinus maculatus sp. nov.}

Perennial, strict: stem $4-6 \mathrm{dm}$. high, finely appressed puberulent: petioles short, $2-4 \mathrm{~cm}$. long, almost glabrous; leaflets $5-7$, those of the lower leaves obovate-oblanceolate, mucronate; those of the upper oblanceolate and acute, sparingly appressed hairy beneath, glabrous above, $3-5 \mathrm{~cm}$. long : inflorescence short-pedun- 
cled and dense; bracts ovate-lanceolate, acuminate, deciduous; the short pedicels and the calyx densely pubescent with short spreading hairs; lips of the calyx ovate-lanceolate, the lower slightly longer than the upper: flowers $10-12 \mathrm{~mm}$. long; banner light purple with a dark spot, glabrous, much shorter than the white or purple-tinged wings; keel white with purple tip: pods oblong, densely pubescent, $2.5-3 \mathrm{~cm}$. long, 4-5-seeded.

The type was labeled Lupinus parriflorus, to which it is somewhat related, but the raceme is much denser, the flowers larger, the corolla of a different color and with a very dark spot.

UтAн : P. V. Junction, IVasatch Mts., i $88_{3}, M$. E. Joncs (type in herb. N. Y. Bot. Garden and duplicates in U. S. Nat. Herb.); Woods Class, 1882, M. E. Joncs.

\section{Lupinus pulcherrimus sp. nov.}

Perennial, more or less cespitose: stems 3-6 dm. high, sparingly appressed hairy, leafy : petioles $3-6 \mathrm{~cm}$. long, also appressed hairy or glabrate; leaflets 7-9, linear-oblanceolate, acute, appressed silky on both sides, but green; stipules lanceolate, subulate: raceme more or less elongated and rather dense, short-peduncled; bracts lanceolate, short-acuminate, shorter than the buds, deciduous: pedicels and calyx grayish silky; lips of the latter lanceolate, the upper somewhat shorter: flower about $1 \mathrm{~cm}$. long: corolla dark purple; banner with a light spot, pubescent on the back: pods broadly oblong, $3-3.5 \mathrm{~cm}$. long, 5-6-seeded.

This species is also related to L. laxiflorus, but the raceme is denser, the calyx scarcely spurred, and the flowers are larger. It also resembles L. pscudoparifforus, but in that species the leaves are glabrous above and the calyx also spurred. From L. adscendins it differs in the spreading flowers and the short bracts.

Wroming: Battle, Continental Divide, 1901, F. Truecdy, 1215 (type in herb. N. Y. Bot. Garden) ; Headwaters of Tongue River, I898, Tuvculy', I30; Big Horn Mountains, IS99, Truccly', 2365; La Barge, Uintah County, is94, E. Stcienson, 158 .

Montana: Divide between McDonald and Comas Lakes, I90I, F. K. Irecland, 996; Little Belt Pass, i \$96, P. A. Rydbcrg, 331S; J. H. Flodman, 620; Baltic, I900, L. I. Wilcox, $5 \delta$.

\section{Lupinus laxus sp. nov.}

Perennial and somewhat cespitose : stem 4-6 dm. high, slender, sparingly appressed, silky: petioles $3-12 \mathrm{~cm}$. long, appressed 
silky; leaflets $7-9$, linear or linear-oblanceolate, $3-4 \mathrm{~cm}$. long, green, but appressed silky on both sides; stipules subulate: racemes slender and lax; bracts lanceolate, short-acuminate, not longer than the buds: pedicels and calyx rather long, hairy: flowers about $8 \mathrm{~mm}$. long: calyx not spurred; lips ovate, the upper slightly shorter : corolla light bluish-purple; banner broad, somewhat shorter than the wings.

This species is closely related to L. laxifloms, but the flowers are smaller and lighter and the calyx is not spurred. It grows at an altitude of about $2000 \mathrm{~m}$.

Montana: Forks of the Madison, I 997, Ryelberg \& Bessey, $4+42$ (type in herb. N. Y. Bot. Garden), also $t+f 3 \alpha$.

Wroming: La Barge, Uintah Co., i 894, E. Stirenson, 157 (somewhat more hairy than the type).

\section{Lupinus leucanthus sp. nov.}

Perennial, about $6 \mathrm{dm}$. high: stem minutely strigose, leafy: petioles about $6 \mathrm{~cm}$. long, almost glabrous; leaflets 5-7, narrowly oblanceolate, $4-5 \mathrm{~cm}$. long, acute or short-acuminate, glabrous above, sparingly appressed hairy beneath; stipules subulate: raceme lax; bracts lanceolate, acuminate, about equalling the pedicels, 6-8 mm. long: pedicels and calyx appressed shorthairy; lower lip of the latter linear-lanceolate, about $1 / 3$ longer than the ovate upper one: corolla white with a brownish spot on the banner; the latter glabrous and almost equalling the wings.

This species is nearest related to L. Scheubcrac, but differs in the larger white flowers and the longer upper lip of the calyx. The type sheet bears the name Lupinus barbiger Wats., but the plant is not at all related to that species.

Uтан: Springdale, I894, Marcus E. Jones, 52+9c (type in U. S. Nat. Herb.).

\section{Pachylophus macroglottis sp. nov.}

Acaulescent or nearly so: leaves $8-15 \mathrm{~cm}$. long, tapering into a margined petiole; blades broadly oblanceolate, acute, sinuate-dentate, sparingly puberulent, and villous ciliate on the margins and the veins, very thin : hypanthium very long and slender, I $2-14 \mathrm{~cm}$. long, sparingly villous or nearly glabrous, gradually widening into a funnelform throat, which at the insertion of the sepals, petals and stamens, is about $\mathrm{I} \mathrm{cm}$. in diameter: sepals lanceolate, gradually long-acuminate, about $5 \mathrm{~cm}$. long and much exceeding the broadly obcordate petals, which are about $3.5 \mathrm{~cm}$. 
long and fully as wide, very thin, at first white but turning pink in age: filaments about $2.5 \mathrm{~cm}$. long: anthers versatile, $\mathrm{I} .5 \mathrm{~cm}$. long and $2 \mathrm{~mm}$. wide: style exserted; lobes of the stigma about $5 \mathrm{~mm}$. long: capsule with rather strong sinuately lobed ridges.

This species differs from P.cacspitosum (Nutt.) Raimann in the villous ciliate leaves, the longer hypanthium which is much broader at the throat than in any of the other species, the longer sepals which much exceed the petals in length, and the less tubercled ridges of the pod. It grows in cañons at an altitude of $1500-$ $2800 \mathrm{~m}$.

Colorado: Tributaries of Turkey Creek, I900, Rydberg \& I recland, 5857 (type).

Pachylophus exiguus (A. Gray) Rydb. nom. nov.

Ocnothere crigua A. Gray, Pl. Fendl. I 849.

This species was merged into $P$. cacspitosus by Dr. Watson; but it is perfectly distinct. The plant is nearly always caulescent with a stem $0.5^{-2} \mathrm{dm}$. high, the leaves and hypanthium are villous as in the preceding species, but still more so, the hypanthium is fully as long, but less widened at the throat, and the angles of the pod with more prominent sinuately lobed crests than in P. cacspitosus. This species is represented in the New York herbaria by the following specimens:

Colorido: Rocky Ford, is9r, C. S. Crandall; Mesas near Pueblo, I900, Rydlucrg \& Fraland, 5858 ; Rocky Ford, I900, G. Ostcrhout, 2085.

New Mexico: White Mountains, i 897, E. O. Hooton, 659.

Arizona: Walnut Cañon, is98, MacDougal, $3+1$.

\section{Androsace puberulenta sp. nov.}

A puberulent rosulate annual: leaves oblanceolate, $1-3 \mathrm{~cm}$. long, acute, entire or sinuately denticulate, densely puberulent : peduncles several, 3-10 $\mathrm{cm}$. long: bracts narrowly lanceolate, 3-4 mm. long : pedicels $\mathrm{I}-5 \mathrm{~cm}$. long, spreading, densely puberulent : calyx 3-4 $\mathrm{mm}$. long, cleft to the middle; tube glabrous, turbinate; lobes lanceolate, strongly keeled, densely puberulent, in fruit much exceeding the short capsule : corolla white, about equalling the calyx.

This species is in habit internediate between $A$. subumbellata and $A$. diffusa, but differs from both in the densely puberulent 
pedicels and calyx-lobes. In both specimens mentioned the calyxlobes are of the length and shape of the valves of the maturing capsules, while in 1 . puberulenta they are much longer. The range of the species extends from Manitoba and the Mackenzie River south to New Mexico. The type was collected in southern Colorado near Veta Pass, 1900, Rydberg \& Tréland, 577 ? (N. I. Bot. Garden).

\section{Gilia subacaulis sp. nov.}

Apparently biennial with a slender taproot: stem less than I dm. high, almost leafless, diffusely branched, glandular-puberulent: leaves almost all basal, $1.5-3 \mathrm{~cm}$. long, pinnatifid with triangular to oblong divisions, glandular-puberulent, or slightly white-villous when young: inflorescence open; pedicels $2-4 \mathrm{~mm}$. long: calyx $2-2.5 \mathrm{~mm}$. long, puberulent, scarious between the green ribs: lobes lanceolate, about half as long as the tube, acute: corolla 4$6 \mathrm{~mm}$. long, funnelform, fully twice as long as the calyx, its tube distinctly exserted: stamens included: capsule rounded orvid, acute, $4-5 \mathrm{~mm}$. long.

This is related to $S$. inconspicut, but differs in the almost leafless stem, and the smaller corollas which have a comparatively longer tube. The following specimens belong here.

IVroming: Point of Rocks, I901, Merrill \& Itilcox, 607 (type in Herb. N. Y . Bot. Garden).

Utah: St. George, I877, Palmer, 328; i 874 , Parry, I99.

Colorado: Gunnison River, 1894.

\section{Mertensia subpubescens sp. nor.}

Mertonsia Sibirica Rydb. Mem. N. Y. Bot. Gard. I : 335. I 90 I ; mainly.

Perennial with a thick rootstock: stem simple, stout, 6-10 dm. high, glabrous throughout: lower leaves petioled, the upper sessile; blades broadly lanceolate, $5-10 \mathrm{~cm}$. long, tapering at both ends, thin, glabrous or nearly so above, short-pubescent beneath and ciliate on the margin: inflorescence a rather manyflowered short panicle; pedicels slightly strigose: calyx-lobes oblong-linear, obtuse, ciliate on the margin, $2-2.5 \mathrm{~mm}$. long, about $1 / 4-1 / 3$ as long as the corolla-tube: corolla about $12 \mathrm{~mm}$. long: the tube only slightly longer than the limb: filaments broad and dilated, broader than the anthers and about half as long.

This is perhaps nearest related to $M$. ciliatc, but is easiest distinguished by the pubescent lower surface of the leares. It 
grows along streams at an altitude of 2000-2200 m. The following specimens from Montana belong here:

Montana: Spanish Basin, I 897, Rydberg \& Bessey, $7 \$ 76$ (type in herb. N. Y. Bot. Garden); near Indian Creek, 4872 ; Bridger Mountains, 4875 ; Mystic I.ake, 1895, C. L. Shcar, 3076 ; Deer Lodge County, igor, Mrs. Emma WV. Schuber, t2; Basin, I 902 , hilse'y.

Heliotropium spathulatum sp. nov.

Hcliotropium curassancum Hook. Fl. Bor. Am. 2 : 8 I. I 840. Not L.

? Hcliotropium curassaricum oboatum DC. Prod. 9: $538 . \quad 1845$. Not H. obovatum D. Don.

A glabrous, more or less glaucous, fleshy perennial with ascending more or less branched stems, $3-5 \mathrm{dm}$. high: leaves spatulate, fleshy, indistinctly nerved, $2-5 \mathrm{~cm}$. long, obtuse or rounded at the apex, tapering at the base and the lowermost petioled: inflorescence branched into $2-5$ racemes; these often starting from one point at the end of the common peduncle: calyx about $3 \mathrm{~mm}$. long, cleft to the middle ; its lobes ovate-lanceolate, acute: corolla white or slightly tinged with blue, $6-8 \mathrm{~mm}$. long; the limb of about the same width: nutlets $2.5-3 \mathrm{~mm}$. long, scarcely rugose.

This is the common plant of the Rocky Mountain region that has been known as $H$. curassiricum L., but has much broader leaves, more than twice as large flowers and larger fruit than the cosmopolitan plant found on our eastem seaboard and in the southem states. It is probably the same as the plant collected by Douglas in the Blue Mountains of Oregon and briefly described in the places cited above. Hooker states that in the Blue Mountains were the only places where Douglas found $H$. curassaricum. In the Columbia herbarium there is a specimen, labelled: "California, Douglas." If this specimen is one of those collected in the Blue Mountains and described by Hooker and DeCandolle, the synonyms cited above should be excluded; for the specimens evidently belong to the short-leaved and smaller-flowered form of H. curassaricum common on the Pacific coast and described by Willdenow under the name $H$. chenopodioides.

H. spathulatum is fairly common in meadows throughout the Rocky Mountain region and the great plains from Assiniboia and Washington to Iowa, New Mexico, Chihuahua and California. The type was collected at Great Falls, Montana, I $890, R$. S. IVilliams, $5+2$ (in herb. N. Y. Bot. Garden).

New York botanical Gardex. 
CONTRIBUTIONS FROM THE NEW YORK BOTANICAL GARDEN--No. 55

\section{SI'UDIES ON THE ROCKY MOUNTAIN FLORA-XI}

\section{By PER AXEL RYDBERG}

\section{NEW YORK}

1904

[From the Bulletin of the Torrey Botanical Club, 31: 399-410. July, 1904] 

Studies on the Rocky Mountain flora - XI.

Per Axel Rydberg

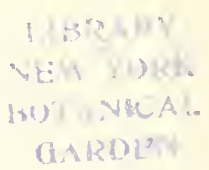

\section{Juncus balticus vallicola var. nov.}

Stem from a horizontal rootstock, rather stout, $6-8 \mathrm{dm}$. high, terete, $2-4 \mathrm{~mm}$. in diameter ; sheaths at the base short, dark brown, bladeless; bract $\mathrm{I}-2 \mathrm{dm}$. long; bractlets broadly ovate, scarious, brown, abruptly acuminate; inflorescence open; its branches $4-S$ $\mathrm{cm}$. long; sepals narrowly lanceolate, slightly if at all scarious on the margin, attenuate at the apex, about $6 \mathrm{~mm}$. long; petals much broader and shorter with broad scarious margin, about $5 \mathrm{~mm}$. long; anthers about 4 times as long as the filaments; capsules short ovoid, obtusish and mucronate, shorter than the petals.

This variety has the open inflorescence and general habit of var. litoralis but the fruit of var. montanes. It differs from both, however, in the long-attenuate sepals. It grows in wet ground, both in alkaline and sandy or gravelly soil in the valleys of the Rocky Mountain region.

Wyoming: Point of Rocks, igoi, E. D. Merrill \& E. N. Wilcox, 667 (type)*; Big Sandy River, 730; Steamboat Mountain, 1900, Aren Nelson, 7075.

Colorado: Mancos, is98, Bakrr, Earle \& Tracy, 438.

Utah : Antilope Island, Stanshury.

\section{Juncus truncatus sp. nov.}

J. alpinus insignis Coult. Man. 358 (in part as to the Colorado specimens). 1885.

Stems slender, $3-5 \mathrm{dm}$. high, terete or slightly flattened; leaves I-3 dm. long, slightly flattened laterally or nearly terete, $\mathrm{I}-2 \mathrm{~mm}$. in diameter, septate; sheaths with scarious margins which end in rounded auricles, which are $\mathrm{I}-1.5 \mathrm{~mm}$. wide; bract $\mathrm{I}-3 \mathrm{~cm}$. long, lanceolate or subulate, brown with green back; inflorescence open, $2-5 \mathrm{~cm}$. long, irregularly cymose with 4-Io heads; bractlets ovate, brown, acuminate-cuspidate; heads $6-9 \mathrm{~mm}$. in diameter, 5-10flowered; petals and sepals lanceolate, dark brown, about $3 \mathrm{~mm}$. long, acuminate, longer than the capsule which at maturity is truncate or slightly emarginate at the apex: seeds not caudate.

* Unless otherwise staled the types are preserved in the herbarium of the New York Botanical Garden. 
This species is most nearly related to J. nezadensis, J. Mertcnsianus and J. Richardsonianus, with which three it has been confused. It differs from the first in the truncate capsule, from the second in the paniculate inforescence and not caudate seeds, and from the last in the dark acuminate petals and sepals and the short capsule. It grows in wet meadows at an altitude of r $800-2700 \mathrm{~m}$.

Colorano: Meadow Height, 1898, Shear \& Bessey, 4323 (type); Elk River, Routt County, I894, C. S. Crandall.

Wroming: Copperton, I90I, F. Twecdy', 7335 ; North Fork of Clear Creek, Big Horn Mountains, ı898, T. A. Williams; Grand Encampment Creek, I897, Ai'cn Nilson, 3981.

\section{Juncus brunnescens sp. nov.}

Juncus xiphioides montanus Engelm. Trans. Acad. Sci. St' Louis, 2: 48 I (in part). I 868.

Stem 4-6 dm. high, flattened laterally and more or less winged ; leaves $\mathrm{r}-2.5 \mathrm{dm}$. long, 2-5 $\mathrm{mm}$. wide, equitant, laterally flattened, long-attenuate, septate; sheaths with scarious margins, abruptly contracted above, but scarcely auricled; bract linearlanceolate, $2-5 \mathrm{~cm}$. long, green; panicle open, 5-10 cm. long, with from 10-60 small heads; bractlets ovate-lanceolate or ovate, abruptly acuminate, scarious and light brown; heads 5-12flowered; petals and sepals subequal, lanceolate, acuminate, about $3 \mathrm{~mm}$. long, light brown with green midrib; stamens usually 6 , sometimes 4 or 5 ; style about equaling the petals ; capsule lanceovoid acute.

This was included in J. xiphioides montanus by Engelmann, but the first specimen cited by him belongs to a distinct plant with few, large, dark brown heads. This has received the name $J$. saximontanns by Aven Nelson. Besides the character mentioned, the scarious margins of the leaf-sheaths in the latter nearly always end in small auricles, a character by which it differs from all the species of the group. J. brunnescins grows in wet places in the mountains of Colorado, New Mexico and Arizona, while J. saximontanns ranges from Alberta and British Columbia to Colorado and California.

Colorado: Pagosa Springs, i 899, C. F. Baker, 275 (type).

New Mexico: Bear Mountain and Mangus Springs, Rusby, fI 7 $C,+17 D$ and $717 F$.

Arizona : Flagstaff, r898, MacDongal, 307; San Pedro Val- 
ley, J. IV. Toumu', 6; Fort Verde, E. A. Mearns; San Francisco Mountains and Clifton, Rusby', $I_{T} T A$ and $+I T E$.

\section{Juncus parous sp. nov.}

Stem 3-6 dm. high, laterally flattened and distinctly winged; leaves equitant, laterally flattened, septate, $2-3 \mathrm{dm}$. long. $3-5 \mathrm{~mm}$. wide; sheaths with scarious margins that taper upwards and without any indication of an auricle; bracts $1-2 \mathrm{~cm}$. long, green with more or less scarious margins; heads few, $\mathrm{I}-\mathrm{S}$, often clustered, I 5-20-flowered; bractlets lanceolate, light brown; petals and sepals lanceolate, sharply acuminate, subequal, light brown or greenish on the back; stamens usually 6 ; style shorter than the petals; capsule oblong, acute, shorter than the petals; secds apiculate.

This is still more closely related to J. sarimontamis than the former, but is easily distinguished by the light-colored heads and the total lack of auricles. It grows in mountain meadows of Colorado and New Mexico.

Colorado: Fort Garland, i 896, C. L. Shiar, 3666 (type) and 3668 ; North Cheyenne Cañon, i 896 , and Pike's Peak, I 895 , E. A. Bessej'.

New Mexico: Organ Mountains, i 897, E. O. Wooton, 615.

\section{Juncoides subcapitatum sp. nov.}

Stem 3-4 dm. high, glabrous; leaf-blacles lanceolate, acuminate, glabrous, 4-IO cm. long, 5-IO mm. wide; bracts $2.5-3 \mathrm{~cm}$. long, lanceolate, foliaceous; inflorescence compact, consisting of 6-Io heads, conglomerate and forming an irregular head; bractlets ovate, those subtending the individual flowers about half as long as the sepals; these and the petals subequal, I.5-2 mm. long, ovate, acuminate, dark brown but lighter on the midrib; capsule broadly obovoid, obtuse, shorter than the petals; seeds about I mm. long, ellipsoid, obtuse, dark brown, minutely punctate.

Notwithstanding the capitate inflorescence, the large foliaceous bracts, and the shorter capsule, it is most closely related to J. pariflomm, which it resembles in leaves and flowers. The type grew near timber-line on a mountain above Silver Plume.

Colorado: Silver Plume, i\$95, C. L. Shear, f6II.

\section{Allium macropetalum sp. nov.}

Bulb obovoid, about $4 \mathrm{~cm}$. long and $2 \mathrm{~cm}$. thick, coated with long loose fibers; leaves about $2 \mathrm{~cm}$. long, almost equaling the 
scapes, 2-4 $\mathrm{mm}$. wide; sheaths very broad, loose and scarious; scapes a little over $2 \mathrm{dm}$. high, stout, $3-4 \mathrm{~mm}$. thick, often 2 or 3 from the same set of sheaths: umbel many-flowered; bracts usually 3 , ovate-lanceolate, acuminate, about $2 \mathrm{~cm}$. long, veined with purple; pedicels stout, about $2 \mathrm{~cm}$. long; the outer in fruit spreading or reflexed; petals and sepals lanceolate, long-attenuate, fully I $\mathrm{cm}$. long, white, scarious, with a prominent purple midvein: capsule $5-6 \mathrm{~mm}$. long, with 6 conspicuous oblong crests which are over $1.5 \mathrm{~mm}$. high.

This species is perhaps most nearly related to $A$. Geycri, but stouter, usually with 2 or 3 scapes, loose sheaths, longer and more attenuate petals and sepals, larger conspicuous crests, and longer bulb with very fibrous coat.

Colorado: May i4, i 898, C. S. Crandall.

\section{Allium Pikeanum sp. nov.}

Bulb obliquely ovoid, about $1.5 \mathrm{~cm}$. long and $8-10 \mathrm{~cm}$. thick : coat membranous except the outer layer, which is fibrous-reticulated; scape $8-15 \mathrm{~cm}$. long, almost equaled by the narrowly linear leaves : bracts usually 3 , lanceolate, $S-10 \mathrm{~mm}$. long and very soon reflexed; umbels with IO-I 5 flowers, but no bulblets; pedicels about I cm. long: petals and sepals subequal, ovate, acuminate, red-purple; filaments subulate, dilated below, about threefourths as long as the petals; capsule slightly crested above.

This is most nearly related to $A$. 1cticulatum and $A$. Geyeri, but distinguished by the small reflexed bracts, the dark flowers and the small bulb with only the outermost layers of the coat fibrous. It grows in the higher mountains of the Pike's Peak region at an altitude of 3,000-3,800 m., while the other species mentioned belong to the plains.

Colorado: Halfway House, I 896, C. L. Shear, 3721 (type); South of Pike's Peak and Bald Mountain, 1895 and 1 \$ $96, E$. A. Bessey; Peak Valley, I901, Climents, 126.

\section{Corallorrhiza ochroleuca sp. nov.}

Whole plant light yellow; stem 2-4 dm. high, not bulbousthickened at the base; sheaths loose and rounded and mucronate at the apex; raceme 10-15-flowered; flowers $15-20 \mathrm{~mm}$. long, light yellow, unspotted; petals and sepals $7-8 \mathrm{~mm}$. long, oblonglanceolate, acute, with prominent midvein; lip ovate, sinuate but neither lobed nor toothed; spur small and adnate to the ovary.

In general habit, this resembles a large $C$. multiflora, but dif- 
fers in the yellow color of the plant, the unspotted flowers and the entire lip. It grows at an altitude of $1400-2500 \mathrm{~m}$.

Nebraska: War Bonnet Cañon, i S9o, T. A. Wrilliams, 78 (type).

Colorado: Echo Cañon, near La Veta, i 900, F. K. Iricland, 6.79 .

\section{Salix pachnophora sp. nov.}

A shrub 2-3 m. high or perhaps sometimes higher: stems yellowish; branches dark bluish with a bloom; leaves oblonglanceolate or oblanceolate, $3-5 \mathrm{~cm}$. long, or on vigorous shoots I $\mathrm{dm}$. long, acute at both ends, densely white-silky beneath, glabrous or when young slightly silky above, rather thin, with prominent veins beneath; pistillate aments subsessile, $1-3 \mathrm{~cm}$. long; bracts almost black, ovate or oblong, acutish or obtuse; pistils subsessile; ovary grayish-silky, ovold, $3-5 \mathrm{~mm}$. long; styles slender, about I.5 mm. long; stigmas slender, deeply 2-cleft; staminate aments about $1.5 \mathrm{~mm}$. long, subsessile; bracts similar; stamens 2, filaments glabrous, distinct.

This species is evidently most nearly related to $S$. bell $a$ and $S$. subcocrula, differing from the former in the smaller aments and capsules and the presence of bloom on the branches and from the latter by the sessile and naked aments. It grows in the mountains at an altitude of 2,300 to 2,500 m.

Colorado: Chambers lake, I 899 , Agricultural College of Colorado coll. (type); Rico, Dolores Co., I 899, Geo. E. Ostcrhout, 2505; along Uncompahgre River near Ouray, r901, Undrricon \& Sclby, 256.

New Mexico: Beulah, igo i \& ig02, T. D. A. Cockerill.

\section{Atriplex oblanceolata sp. nov.}

Suffruticose dioecious perennial with decumbent base and ascending branches, about $2 \mathrm{~cm}$. high ; leaves oblanceolate or spatulate, $2-3 \mathrm{~cm}$. long, obtuse or acutish, densely white-scurly on both sides, entire, short petioled, or sometimes nearly sessile; pistillate flowers in small axillary clusters; fruiting bracts ovate in outline, slightly dentate, tubercled or irregularly crested on the back; staminate flowers brown in small terminal panicles.

This species is most nearly related to - 1. . Tuttallii and A. cremicola. From the former it differs in the decumbent low habit, the more distinctly petioled leaves and the brown panicled staminate flowers (in $A$. Nuttallii they are yellow and arranged in interrupted spikes). It is more like $A$. cremicola, from which it scarcely differs except 
in the tubercled or appendaged bracts, which are broadest below instead of above the middle.

Colorado: Delta, Sept. 3, is97, J. H. Cow'n (Agric. Coll. Colo., no. f07I) (type), Hotchkiss and Smiths Fork (no. fo70).

IVroming: Gardiner River, i 899. Aven E Elias Nelson, 5995; Hams Fork, I900, C. C. Curtis; Fort Steele, I901, Tu'cedy', 7501.

\section{Atriplex odontoptera sp. nov.}

A shrubby dioecious perennial: stems with shining white more or less flaky bark; leaves narrowly oblanceolate, acute or obtusish, 2-4 cm. long, entire, white-scurfy on both sides; pistillate flowers axillary; fruiting bracts united to near the apex; united portion with 4 laciniate dentate wings, 3-4 $\mathrm{mm}$. broad, reticulate and ribbed; free portion subulate, scarcely as long as the width of the wing; staminate plant unknown.

This species is most nearly related to $A$. cancscens, differing mainly in the laciniate-toothed wings. It grows on plains at an altitude of $\mathrm{I}, 000-\mathrm{I}, 600 \mathrm{~m}$.

Wyoming: Buffalo, igoo, F. Tüeedy', 3302 (type); four miles below U. L. Ranch, I 896, Knoalton, 160 ; Steamboat Lake, I 900 , Osterhout, 2330 , in part.

\section{Coriospermum emarginatum sp. nov.}

Annual, perfectly glabrous or with a few hairs on the bracts, branched near the base, 3-4 $\mathrm{dm}$. high: leaves narrowly linear, $2-4 \mathrm{~cm}$. long, $\mathrm{I}-2 \mathrm{~mm}$. wide, cuspidate-pointed; bracts except the lowest ovate, $5-7 \mathrm{~mm}$. long, acuminate, scarious-margined, much broader than the fruit ; fruit plano-convex, $2.5-3 \mathrm{~mm}$. long and about $2 \mathrm{~mm}$. wide, almost without a trace of a wing-margin.

In habit this species resembles mostly $C$. marginale, but differs in the lack of the wing-margins of the fruit characteristic of that species. In this respect it more resembles $C$. rillosim, but is a much more slender plant and glabrous.

Wroning: Laramie, i 897, A. Nelson, 1282 (type).

Colorado: A specimen in the Torrey herbarium without any other data.

\section{Claytonia rosea sp. nov.}

Scape about I dm. high, slender, from a small corm I O-I $5 \mathrm{~mm}$. in diameter ; basal leaves rare, long-petioled; blade $\mathrm{I}-2 \mathrm{~cm}$. long, spatulate; stem-leaves linear or narrowly linear-lanceolate, sessile, $2-5 \mathrm{~cm}$. long, I-ribbed or faintly 3 -ribbed, acute, rather fleshy; 
sepals rounded ovate, rounded at the apex, about $5 \mathrm{~mm}$. long, half as long as the pink obovate petals; inflorescence 5-io-flowered, short, little exceeding the leaves, bractlets lanceolate; capsule shorter than the sepals; seeds about $2 \mathrm{~mm}$. long, black and very glossy.

The few specimens of this species that are found in our herbaria bear a variety of names, as $C$. caroliniana, $C$. caroininana lanccolata, C. caroliniana sessilifolia and C. lanccolata se'ssilifolia. The original $C$. lanceolata Pursh is a much larger plant with broad, strongly 3-ribbed stem-leaves, elongated inflorescence and large flowers, the sepals being about $6 \mathrm{~mm}$. long. The type of $C$. caroliniana sessilifolia Torr., is a plant somewhat resembling the present species, but with somewhat broader leaves abruptly contracted at the sessile base and with acutish sepals. Neither in the herbarium of the New York Botanical Garden nor in that of Columbia University is found any other specimen matching the original collected by Bigelow. Most species of Claytonia are found near water or in damp places. The type of $C$. rosea was collected on rather dry hills, at an altitude of 2200-2300 m.

Colorado: La Veta, I900, Rydbcrg \& Trecland, 6300 (type); "Colorado," G. C. IVoolson; 1875, W. A. Henry"; Graham's Peak, I S99, C. F. Baker, 305.

Wroming: Pole Creek, I 894, Aven Nilson, 27.

\section{Cerastium pulchellum sp. nov.}

Low decumbent perennial with horizontal cespitose rootstock: stems 5-10 cm. long, finely viscid pubescent; leaves oblong to oval, obtuse or rasely acutish, about $1 \mathrm{~cm}$. long and $4 \mathrm{~mm}$. wide, subsessile and slightly connate at the base, viscid pubescent on both sides; peduncles $\mathrm{I}-\mathrm{I} .5 \mathrm{~cm}$. long; inner sepals oblong; outer oval, scarious-margined both on the side and at the rounded apex, about $4 \mathrm{~mm}$. long; petals obcordate, IO-I $2 \mathrm{~mm}$. long.

This species is nearest related to C. Earlci and C. bihringianum. From the former it differs in the low habit, the very obtuse scarious-tipped sepals and the short blunt leaves; from the latter in the large petals and the scarious-tipped sepals. It grows in the mountains at an altitude of about $3900 \mathrm{~m}$.

Colorado: Hayden Peak, i 898, Bakir, Earle \& Tracy', 573. 


\section{Arenaria polycaulos sp. nov.}

Arcnaria saxosa Coult. Man. 35, I8S5, and Gray, Syn. Fl. I' 240, in part; not A. Gray, Pl. Wright. 2: I 8.

Perennial with a long tap-root, giving rise to numerous prostrate or spreading stems about I dm. long, slender, finely scabrous puberulent; leaves ovate or ovate lanceolate, spreading, about 5 $\mathrm{mm}$. long, finely puberulent; pedicels $5-10 \mathrm{~mm}$. long; sepals ovate-lanceolate, short-acuminate, scarious-margined, 3-4 $\mathrm{mm}$. long; petals 5-6 mm. long, obovate, entire.

This plant has generally been known as $A \cdot \operatorname{sax} \alpha a$, but the type collected by Wright differs considerably from it, being subligneous at the base, with short erect stems, lanceolate almost erect leaves and narrower sepals. A. polycaulos grows on dry hills at an altitude of $2600-3000 \mathrm{~m}$.

Colorado: Silverton, i 898 (type; collector not given, but specimens received from the Agricultural College of Colorado); I 895, Ta'cedy', I73; Mt. Harvard, I 896, F. E. Clcments, 5f; Gray Back Mining Camps, I900, Rydberg \& Irceland, 6288; La Plata P. O., I 898 , Bakor, Earle \& Trac', ttt; Dark Cañon, I90 I, Clcments, $115 ;$ Breckenridge, 1896 , Shcar, 45.58 and $45+5$.

Arizona: Mt. Humphrey, I 883 , Rusby, 531; i $897, R$. E. Kunic: San Francisco Mts., I892, Toumey', 87.

\section{Arenaria Tweedyi sp. nov.}

Perennial, denscly cespitose with somewhat ligneous base; leaves fleshy, linear-filiform, $2-3 \mathrm{~cm}$. lons, less than I mm. wide, somewhat curved; stem usually less than I dm. high, glandular puberulent especially on the inflorescence; this an open cyme; bracts lanceolate, scarious-margined; pedicels about I cm. long; sepals lanceolate, acute, about $5 \mathrm{~mm}$. long, scarious-margined and decidedly glandular puberulent; petals about $8 \mathrm{~mm}$. long.

This is most nearly related to A. uintahcusis A. Nelson, differing in the fleshy not pungent leaves and the more glandular puberulent inflorescence. It grows in the mountains at an altitude of about $3600 \mathrm{~m}$.

Colorado: La Plata Mountains, is96, Frank Taveedy.

\section{Arenaria Eastwoodiae sp. nov.}

Perennial with a cespitose base: stems about $2 \mathrm{dm}$. high, perfectly glabrous; leaves filiform, stiff, pungent, I-2 cm. long, 0.5 mm. wide, minutely scabrous-ciliolate on the margin below, dilated 
and somewhat connate at the base; inflorescence elongated; bracts subulate to lanceolate, scarious-margined; pedicels erect, I-2 cm. long, glabrous; sepals linear-lanceolate, about $6 \mathrm{~mm}$. long, glabrous, long-attenuate, equalling or slightly exceeding the petals.

This is most nearly related to $A$. Fendleri but is more slender and glabrous. It grows on dry hills.

Colorado: Grand Junction, I 892, Alice Eastwood.

\section{Arenaria Fendleri Porteri var. nov.}

Like the type but low, I-2 dm. high, very glandular; leaves short; branches of the inflorescence short and ascending.

It is common on dry mountain ridges of Colorado. As type I take the following:

Colorado: Gray's Peak, i 878, M. E. Jont's, 7 I 6 (type in herb. Columbia University).

\section{Alsinopsis macrantha sp. nov.}

Perennial, cespitose, diffusely branched and spreading, perfectly glabrous; branches I dm. long or less; leaves subulate-filiform, obtuse, 5-IO $\mathrm{mm}$. long, $0.5 \mathrm{~mm}$. wide, I-nerved; pedicels $1 \mathrm{~cm}$. or less long; sepals lanceolate, $4-5 \mathrm{~mm}$. long, very acute, scarious-margined, strongly 3 -nerved; petals oblong, 7-8 mm. long.

The type sheet is labelled Armarir a'erna $\mathrm{L}$., which it resembles much in habit, in the sepals and in the lack of pubescence, but it differs in the large petals and the I-nerved leaves.

Colorado: Little Kate Basin, La Plata Mts., ISgs, liaker, Earle \& Tracy', 678.

\section{Silene Antirrhina vaccarifolia var. nov.}

Stem-leaves broad, lanceolate, elliptic or oblanceolate; stem stouter than in S. Antimhina proper ; bracts more or less scariousmargined below ; flowers and capsule larger.

In the Rocky Mountain region the typical S. Antirnthinu is rather rare and evidently an introduced plant found in waste places and fields. It is there represented by two native forms, the present with broad leaves and large flowers and the next with narrow leaves and small flowers.

Id AHO: Lewiston, i 896,4 . A. \& E. Gertrude Heller, 3153 (type in herb. Columbia University); Upper Ferry, Clearwater River, I S92, Sandberg, MacDougal \& Heller, I go. 
Montana: Big Horn River, I 89 I, Tuicely.

Colorado: Foothills, Larimer County, i 895. J. H. Cowen, 82; near Golden, is78, M. E. Jones, 279; Rist Cañon, I 897, J. H. Coiten.

\section{Silene Antirrhina depauperata var. nov.}

Like the species but more slender and few-flowered; calyx in fruit very short; petals none or small, not exceeding the calyxlobes; blade cuncate, truncate or emarginate at the apex.

British Colunibia: Lower Arrow Lake, isgo, J. M. Macom (type).

Colorado: is $874, G$. C. Woolsen.

Arizoni: Tucson, i S94, J. H. Toumey'.

South Dakота: Lead City, i 892, P. A. Rydborg, 557.

Washington: WT. Klickitat County, i 89i, IV. N. Suksdorf.

Wyoming: Hartville, I 892, Aien Nelson, 493.

Nebraska: Dismal River, i\$93, P. A. Rydberg, I $3+9$.

UтAн : City Creek Cañon, isSo, M. E. Jones, I\$39.

\section{Lychnis striata sp. nov.}

Perennial with more or less cespitose base; stems 3-5 dm. high, finely puberulent and more or less viscid above; basal leaves and lower stem-leaves narrowly oblanceolate, $5-15 \mathrm{~cm}$. long with a more or less distinct petiole ; upper stem-leaves sessile and linearlanceolate; inflorescence narrow with erect branches; calyx densely viscid puberulent, strongly ro-nerved, in fruit somewhat extended by the capsule, IO- $12 \mathrm{~mm}$. long and $5 \mathrm{~mm}$. wide; its lobes oblong, obtuse, somewhat scarious-margincd; petals exserted, about i $5 \mathrm{~mm}$. long; claw long, narrowly cuneate, fully equaling the calyx; blade short, two-cleft, with obtuse lobes.

This species is most nearly related to L. Drummondii, but differs in the exserted petals and the more strongly io-nerved calyx. It grows at an altitude of 2000-3300 m.

Colorado: Cameron Pass, i896, C. F. Baker (type), also I 899 ; Silver Plume, I895, P. A. Ryalberg.

Wroming: Battle, igor, Twecdy, 4535, also Headwaters of Tongue River, I\$98, 163; Yellowstone Lake, I\$99, Ai'en \& Elias Nelson, 6634 .

UTAн : Evanston, is69, S. IVatson, I5t. 


\section{Atragene pseudo-alpina diversiloba var. nov.}

A peculiar form with merely ternate leaves, the segments of which are more or less cleft or lobed, some rounded at the apex; staminodia conspicuous, spatulate or oblanceolate.

This may be a distinct species, but the material is too scant. The most striking character is the conspicuous staminodia, which in the species are narrowly linear or more often lacking.

Colorado: Mountains near Denver, i 869, B. H. Smith (type herb. Columbia University).

\section{Stanleya glauca sp. nov.}

Tall, perfectly glabrous, 4-6 dm. high, bluish green; lower leaves I-I.5 dm. long, more or less pinnatifid with linear-lanceolate or oblong lobes, the terminal usually much longer than the rest; upper leaves usually entire, linear-lanceolate; racemes 3-4 dm. long, sometimes branched below; sepals and petals lemonyellow; the former oblong, about $1 \mathrm{~cm}$. long, deciduous; petals of about the same length, long-clawed ; claws more or less pubescent, about twice as long as the oblong blades; fruiting pedicels about I cm. long, more or less spreading; stipes about $1.5 \mathrm{~cm}$., slender; pod proper about $5 \mathrm{~cm}$. long and $1.5 \mathrm{~mm}$. thick, somewhat arcuate, but neither tortuose nor torulose; seeds oblong, dark brown, minutely pitted.

This species is perhaps most nearly related to S. integrifolic James, which, however, differs in the following respects: the stem lower, leaves thicker and broader, oval or broadly oblanceolate; the lower, if lobed, with broad and short lobes; claws of the petals broader at the base, shorter, scarcely longer than the oblong spatulate blades. S. glauca grows on the dry hills and table lands at an altitude of $1,200-2,500 \mathrm{~m}$.

Colorado: Prairie, Entrance Soldier's Cañon to Sulphur Springs, i $995, J$. H. Corven (type); McElma Cañon, I9o I, F. K. Treeland, 87I; plains near Fort Collins, i S96, C. S. Crandall; near Badita, I900, Rydberg \& I recland, 6120; Dixon Cañon, I 899, W. F. M. ; Mancos, Is98, Baker, Earle \& Tracy, tI2; Pueblo, Io; Garden of the Gods, I S94, E. A. Bessey'; Pike's Peak, I 894, T. F. Allcn.

\section{Schoenocrambe decumbens sp. nov.}

Stem slender, decumbent, $2-3 \mathrm{dm}$. long, as well as the whole plant perfectly glabrous, more or less branched; leaves narrowly 
linear, 2-6 cm. long, I-3 mm. wide, I-nerved, rather thick and more or less glaucous; raceme rather few-flowered, lax; pedicels 3-5 $\mathrm{mm}$. long, ascending; sepals oblong, about $4 \mathrm{~mm}$. long, light yellow; petals yellow, $6-7 \mathrm{~mm}$. long, spatulate or oblanceolate, obtuse, gradually narrowed into a more or less distinct claw ; pods 3-4 cm. long, about $0.75 \mathrm{~mm}$. in diameter, usually more or less arcuate, beak (i.e., portion above the end of the valves) about I $\mathrm{mm}$. long.

This species is closely related to S. linifolium, but differs in the more slender and more branched decumbent stem, usually narrower leaves, smaller flowers, and more slender pods, which are more or less arcuate and with a more distinct beak. It grows on dry plains and hills.

Montana: Melrose, i S95, P. A. Rydberg, 267 I (type); Sheridan, I 895, L. A. Fitch.

Uтан: Thistle Junction, I900, S. G. Stokes.

Colorado: Gypsum, i 894, C. S. Crandall.

New York Botanical Garden. 
CONTRIBUTIONS FROM THE NEW YORK BOTANICAL GARDEN--No. 59

\title{
STUDIES ON THE ROCKY MOUNTAIN
}

\author{
FLORA-XII
}

BY PER AXEL RYDBERG

N E W YORK

1904

[Fr:m the Bulletin of the Torrey Botanical Clob, $31: 555-575$. October, 1904] 

Studies on the Rocky Mountain flora - XII.

\section{PER AXEL RIIBERG}

\section{Draba coloradensis sp. nov.}

Annual, leafy below, often branched, 5-ro $\mathrm{cm}$. high; Ieaves obovate, entire, $\mathrm{I}-2 \mathrm{~cm}$. long, $0.5-1 \mathrm{~cm}$. wide, subsessile, coarsely hirsute, hairs often branched but not truly stellate; peduncles $5 \mathrm{~cm}$. Or in fruit often $10 \mathrm{~cm}$. long; raceme short and corymbiform at first, more elongated in fruit; sepals oval or oblong, obtuse, $1.5-1.75 \mathrm{~mm}$. long; petals white, $3-3.5 \mathrm{~mm}$. long, spatulate, emarginate ; fruiting pedicels $4-5 \mathrm{~cm}$. long, divergent ; pods linearoblong, IO-I $2 \mathrm{~mm}$. long and nearly $2 \mathrm{~mm}$. wide, hirsute; style none.

This species belongs to the $D$. caroliniana group. From that species it differs in the hirsute pods, stonter habit and larger leaves; from $D$. micrantha in the large petals, the larger leaves and the more elongated raceme in fruit; and from $D$. cuncifolia in the entire leaves and the larger pods. It grows on river flats, dry hills and plains at an altitude of about i $500 \mathrm{~m}$.

Colorado: Fort Collins, river flats, lower Armstrong, i 897, collector not given (type); plains near Denver, i 870, E. L.Grenc; Mancos, 1891, Alice Eastaiood.

\section{Draba streptocarpa Grayana var. nov.}

Low and densely cespitose, almost pulvinate; flowering stems I-3 cm. high, almost scapose; stem-leaves few and reduced; even the basal leaves much smaller than in the type.

It grows at an altitude of $3600-4000 \mathrm{~m}$.

Colorado: Gray's Peak. Aug. I \$95, P. A. Rydberg (type); same locality, I 892 , C. S. Crandall $3 I$; mountain west of Como, 1895. Crandall \& Con'an $+I$.

\section{Smelowskia lineariloba sp. nov.}

Densely cespitose; caudex densely covered by the bases of the dead leaves; leaves $2-5 \mathrm{~cm}$. long, pinnately divided to the midrib into linear acute divisions, finely stellate and the petioles ciliate; stems about $1 \mathrm{~cm}$. high, few-leaved; inflorescence at first 
short and corymbiform, in fruit elongated; sepals oblong, pubescent, about $3 \mathrm{~mm}$. long; petals clawed, 5-6 mm. long, white or pink; blades broadly spatulate; fruit I1-12 mm. long and about $1 \mathrm{~mm}$. wide, tapering at both ends.

This species is nearest related to $S$. ancricana, but differs in the narrow segments of the leaves and the long narrow pod. It grows on high peaks of Colorado at an altitude of 3,600-4,200 m.

Colorado: Douglass Mountain, i $878, M$. E. Jones $7+7$ (type in herb. Columbia University); Hindsdale Co., is 78, F. M. Pease; near Ironton, i 899, C. C. Curtis.

\section{Sophia purpurascens sp. nov.}

Stem very slender, diffusely branched above, glabrous and purplish; lower leaves not known, having all fallen off; upper leaves simply pinnate with linear-oblong divisions, slightly stellate; racemes slender; sepals broadly oblong, over I mm. long, light yellow, almost equaling the similar petals; pedicels ascending in fruit, 4-5 mm. long, $0.75 \mathrm{~mm}$. thick; fruit very slender, 5-8 mm. long, linear, 3-6-seeded, nearly cylindrical and tapering somewhat at both ends, slightly torulose; seeds in one row.

This is perhaps nearest related to S. incisa and S. leptophylla, but differs in the slender purple stem, the diverging branches above, the slender inflorescence, and slender short pod. It grows in the mountains at an altitude of about 3,300 $\mathrm{m}$.

Colorado: Red Mountain, south of Ouray, igor, Underiood \& Selby 275.

Sophia ramosa sp. nov.

Stems 3-6 dm. high, finely but sparingly stellate, branched, especially above; branches ascending or diverging, forming with the stem an angle of $45^{\circ}$ or more; leaves once or twice pinnate, sparingly stellate; divisions linear or linear-oblong; racemes oblong; petals oblanceolate, pale yellow, slightly longer than the sepals; pedicels in fruit 7-8 $\mathrm{mm}$. long, ascending; pod somewhat clavate, $8-10 \mathrm{~mm}$. long, erect or strongly ascending, about I $\mathrm{mm}$. thick; seeds in two more or less distinct rows; styles almost none.

This species is perhaps nearest related to S. intermedia, but differs in the spreading branching, the smaller and paler petals, and the shorter pedicels and style. It grows in waste ground at an altitude of about $2,750 \mathrm{~m}$.

Colorado: Pitkin, 1901, Underwood \& Selly 413. 


\section{Arabis oblanceolata sp. nov.}

- Perennial, somewhat branched at the base, $3 \mathrm{dm}$. or more high; basal leaves petioled, sparingly stellate-pubescent, 3-io $\mathrm{cm}$. long; blades oblanceolate, acute, entire; stem-leaves sessile, lanceolate, sagittate-auricled at the base; sepals oblong, acute, 3-4 mm. long, white-hairy near the apex; petals dark reddishpurple, 7-8 mm. long, spatulate with a long claw; pedicels in fruit ascending, about $\mathrm{I} 2 \mathrm{~mm}$. long; pods ascending, about $5 \mathrm{~cm}$. long and $2 \mathrm{~mm}$. wide, glabrous; seeds in 2 rows; style none.

This is perhaps nearest related to $A$. Crandallii Robinson, but is a larger plant, less stellate, with much larger basal leaves and pods, and the flowers are much darker. It grows at an altitude of about 3,000 $\mathrm{m}$.

Colorado: Valley Spur, igor, Underarood \& Selby $75+$.

\section{Arabis Selbyi sp. nov.}

Perennial, with a basal rosette of leaves; basal leaves oblanceolate, 5-10 cm. long, short-petioled, acute, sinuate-denticulate, green but stellate on both sides, not ciliate; stems 4-5 dm. high, branched; stem-leaves linear-lanceolate, sagittate at the base; racemes long and lax; sepals linear, green, obtuse, about $3 \mathrm{~mm}$. long, sparingly stellate; petals red-purple, narrowly oblanceolate, long-clawed; fruiting pedicels $3-4 \mathrm{~mm}$. long, divergent; pods divergent, about $3 \mathrm{~cm}$. long and $2 \mathrm{~mm}$. wide, obtuse at both ends; style obsolete; seeds in 2 rows.

This species is perhaps nearest related to $A$. lignifera and $A$. brachycarpa. From the first it differs in the large, denticulate basal leaves, the stouter branched stem and the narrow dark petals. The latter has hispid ciliate as well as stellate leaves. $A$. Sclbyi grows in cañons and neighboring meadows at an altitude of $2,300-2,800 \mathrm{~m}$.

Colorano: West of Ouray, igor, Underarood \& Selby 207.

\section{Erysimum oblanceolatum sp. nov.}

Biennial; stem 4-6 dm. high, strigose, rather simple; leaves narrowly oblanceolate, 5-I $2 \mathrm{~cm}$. long, entire or sinuate dentate; the lower petioled, sparingly strigose; racemes elongated; sepals linear, about $6 \mathrm{~mm}$. long, about equaling the claw of the light yellow petals ; blades of the latter broadly spatulate or almost orbicular; the whole length of the petals about $\mathrm{I} 5 \mathrm{~mm}$., fruiting pedicels about $8 \mathrm{~mm}$. long, ascending or spreading; pod tetragonal, ascending, about $8 \mathrm{~cm}$. long, almost straight, not twisted, about I. $5 \mathrm{~mm}$. thick; style about $\mathrm{I} \mathrm{mm}$. long. 
This is intermediate between E. clatum and E. Whecleri. The former has longer petals, the claws of which are much longer than the sepals and the leaves are usually more dentate. From E. Whecleri it differs in the light yellow petals. It grows on foothills and plains at an altitude of 1,500-3,000 m.

Colorado: Georgetown, i 895, P. A. Rydberg (type); La Plata P. O., I 898, Baker, Earle \& Tracy go6; mesas near Pueblo, I 900, Rydberg \& Irecland 6193; Williams Cañon, I\$94, E. $A$. Bessej.

Wroming: Buffalo, igoo, F. Tuecely 3595.

\section{Erysimum radicatum sp. nov.}

Perennial with a tap-root, branched at the base; stems $1.5 \mathrm{dm}$. or less high, slightly strigose ; leaves linear-oblanceolate, sinuately toothed, $4-7 \mathrm{~cm}$. long, strigose; raceme short and dense; sepals fully $1 \mathrm{~cm}$. long, linear, acutish, equaling the claws of the petals; the latter light yellow, about I $5 \mathrm{~mm}$. long; blades broadly spatulate, almost orbicular; fruiting pedicels about $8 \mathrm{~mm}$. long, ascending; pods ascending, tetragonal, about $4 \mathrm{~cm}$. long.

This is somewhat related to Erysimum nivale (Cheiranthus nicalis Greene) but differs in the basal rosettes of sinuate-dentate leaves. It grows at an altitude of about 3,800 m.

Colorado: Bottomless Pit (Pike's Peak), igor, Clements $f \neq I$ (type); also in I900 at the same place.

\section{Opulaster bracteatus sp. nov.}

A shrub a meter or two high; bark of the stems brownishgray, more or less flaky; that of the young twigs yellowish-green, glabrous or nearly so; stipules linear-lanceolate, about $5 \mathrm{~mm}$. long, pubescent ; petioles $\mathrm{I}-3 \mathrm{~cm}$. long; leaf-blades $3-7 \mathrm{~cm}$. long, ovate or cordate in outline, 3-5-lobed and doubly crenate, acute, glabrous or nearly so on both sides, somewhat paler beneath ; corymb rather many-flowered; bracts obovate or spatulate, often foliaceous and more or less persistent, pubescent; hypanthium sparingly stellate; sepals oblong-ovate, obtuse or acutish, about $3 \mathrm{~mm}$. long, densely stellate on both sides ; petals white, roundedovate, 4-5 mm. long; carpels 2 , densely stellate, united at least half their length; styles ascending.

This resembles mostly $O$. intermedius in habit and leaves, but has the fruit of $O$. monogynus. It differs however from both in the conspicuous persistent bracts. It grows along streams in the foothills of northern Colorado. 
Colorado: New IVindsor, is98, G. E. Osterhout 23 (type); also Buckhorn Creek, I897, and Cheyenne Cañon, I895; foothills west of Fort Collins, I893, C. F. Baker.

\section{Opulaster glabratus sp. nov.}

A shrub about $1 \mathrm{~m}$. high ; bark of the stems gray and flaky, that of the old branches dark brown and of the young shoots yellowish or reddish; petioles I-2 cm. long; leaf-blades roundedovate, orbicular or sometimes slightly reniform, $2-3 \mathrm{~cm}$. long, glabrous, slightly paler beneath, 3-5-lobed, obtuse; corymb rather small, glabrous; bracts small, lanceolate, deciduous; hypanthium almost glabrous; sepals oval or rounded-ovate, obtuse, sparingly stellate beneath, densely so above, about $3 \mathrm{~mm}$. long; petals rounded-ovate, about $4 \mathrm{~mm}$. long, pink or white; carpels 2 , united to above the middle, densely stellate.

This resembles in habit a small-leaved $O$. intermedius, but is closer related to $O$. monogymus, differing in the larger, less dissected leaves and the less stellate and larger calyx and hypanthium. The type grew at an altitude of between 3,0003,800 m.

Colorado: West Spanish Peaks, 1900, Rydherg \& Vrecland 6027 (type); Turkey Creek, 6026; Rist Canon, I 898 and $\mathrm{r} 899$ (collectors not given).

\section{Holodiscus microphyllus sp. nov.}

A low shrub; bark of the stems dark brown; that of the branches light, yellowish or brownish, soft-strigose ; leaves spatulate-cuneate, I-I.5 or rarely $2 \mathrm{~cm}$. long, evenly serrate, with strong nerves beneath, finely strigose or glabrate above, densely soft-pubescent beneath, at first almost white, in age more glabrate ; inflorescence small, $3-5 \mathrm{~cm}$. long, its branches short and fewflowered; sepals about I mm. long, ovate, as well as the peduncle and pedicels soft-villous; petals broadly obovate, a little exceeding the sepals; hairs of the carpels copious, about equaling the stamens.

This has gone under the name of $H$. dumosus, but the original Spiraca dumosa Nutt. is a larger plant with large inflorescence and larger incised or doubly toothed leaves, and apparently the same as S. discolor Pursh.

Utah: Alta, Maahsatch Mountains, I879, M. E. Joncs II 72 (type in herb. Columbia University); Uintahs, I869, S. IVatson 
305 in part; Stansbury Island, 1850 , Stansbury'; Southern Utah, I 877 , E. Palmer 1,36.

ColoRado: Chicken Creek, 1898, Baker, Earle \& Tracy 863.

\section{Potentilla Bakeri sp. nov.}

Perennial; stem rather stout, about $4 \mathrm{dm}$. high, rather loosely hirsute, branched; basal leaves usually digitately 7 -foliolate; petioles $6-8 \mathrm{~cm}$. long, loosely hirsute; leaflets oblanceolate, $3-5$ $\mathrm{cm}$. long, strongly veined, coarsely silky on both sides and slightly grayish tomentose beneath, cleft to about three-fourth to the midrib into oblong acute lobes; stem-leaves similar but smaller and short-petioled, usually only 5 -foliolate or the upper 3 -foliolate ; inflorescence open, usually flat-topped and corymbiform; hypanthium and calyx silky-hirsute and slightly tomentulose ; bractlets linear-lanceolate, about $3 \mathrm{~mm}$. long and half as long as the ovate or ovate-lanceolate acuminate sepals; petals obcordate, a little exceeding the sepals; stamens about 20 ; achenes smooth and shining; style filiform.

In my monograph I included the only specimen then at hand in $P$. airidescons, but it has deeper dissected leaves and more spreading pubescence than that species. Specimens of the present species are found in collections under the name of $P$. Blachkeana, $P$. candida and $P$. flabclliformis. It can, however, not well be confounded with any of these, except perhaps $P$. candida, which it resembles in general habit and leaf-form. $P$. candida is, however, a small plant with leaves intensely white on both sides. $P$. Bakeri grows at an altitude of 2,100-2,700 m.

Colorado: Grizzly Creek, 1896, C. F. Baker (type); Doyle's, 1901, 6+7; banks of Grizzly, 16 miles from Walden, 1894, Crandall r22,

\section{Rosa Underwoodii sp. nov.}

Shrub, I-2 m. high; bark of the old stems gray; that of preceding year's branches purplish and of the new twigs purplish or green; prickles infrastipular and scattered, strongly curved, 7-IO $\mathrm{mm}$. long, with an oblanceolate base, 5-10 $\mathrm{mm}$. long; stipules narrow, the lanceolate free portion about $5 \mathrm{~mm}$. long, glandular-dentate; leaves $5-10 \mathrm{~cm}$. long; petiole and rachis puberulent and with sessile glands; leaflets $2-4 \mathrm{~cm}$. long, obovate or oval, usually obtuse, doubly serrate, glabrous on both sides or finely puberulent and slightly paler beneath; flowers usually solitary; 
sepals lanceolate, acuminate, about $2 \mathrm{~cm}$. long, erect and persistent in fruit, tomentulose above, glandular and bristly beneath, often with linear lobes: petals obcordate, about $2.5 \mathrm{~cm}$. long and fully as wide; hip in fruit more or less pear-shaped, about $3 \mathrm{~cm}$. long and $2 \mathrm{~cm}$. in diameter, sparingly bristly.

This species has the general habit of R. Nutkana and R. MacDougalii, but differs from both in the curved prickles. It has bristly fruit as the latter, but the fruit is more tapering at the base and the bristles fewer. It grows in the mountains at an altitude of $2,300-2,700 \mathrm{~m}$.

Colorado: Hills about Box Cañon, west of Ouray, igor, Undrrwood \& Selby I22 (type) and II3; La Plata Cañon, I 898 , Baker, Earle \& Tracy 860 .

\section{Rosa oreophila sp. nov.}

A shrub 2-3 m. high; bark reddish, glossy ; prickles mostly infrastipular or lacking, weak, $5 \mathrm{~mm}$. long or less, curved with elliptic bases; stipules broad, finely pubescent and glandulardenticulate on the margin; free portion ovate, 5-I $5 \mathrm{~mm}$. long; leaves 7-IO cm. long, 5-7-foliolate; rachis and petiole finely pubescent and with sessile glands; leaflets $2-3.5 \mathrm{~mm}$. long, ovate or oval, acute or obtuse, glabrous and dark green above, sparingly and finely pubescent and paler beneath, coarsely serrate; flowers mostly solitary ; sepals narrowly lanceolate, acuminate, finely pubescent on both sides and glandular-denticulate on the margins, erect and persistent in fruit; petals obcordate, $2-2.5 \mathrm{~cm}$. long; hip glabrous, when ripe fully $2 \mathrm{~cm}$. long, often acute at the base.

This is perhaps nearest related to the preceding, but differs in the smooth and more rounded fruit and more slender prickles. It grows at an altitude of 2,300-2,500 m.

Colorado: Four-miles Hill, Routt Co., is 96 , Baker (type); Dix P. O., I 898, Baker, Earle \& Tracy t7t; Box Cañon, Ouray, 1901, Underiood \& Selby I2Ia and b.

\section{Astragalus oreophilus sp. nov.}

Erect perennial, 3-6 dm. high; stem sparingly strigose, branched with almost erect branches; leaves about $15 \mathrm{~cm}$. long, with 7-23 leaflets; stipules triangular to lanceolate, strigose, acuminate, free from the petioles but more or less united with each other across the back of the stem ; petioles $2-4 \mathrm{~cm}$. long : leaflets oblong or elliptic, about $3 \mathrm{~cm}$. long, strigose on both sides, 
glabrate above; peduncles $0.5-1.5 \mathrm{dm}$. long; inflorescence racemose, 5-10 cm. long; bracts lanceolate, acuminate, $3-5 \mathrm{~mm}$. long; pedicels very short; calyx-tube nearly cylindric, about 5 mm. long, gibbous above, white-pubescent with short hairs; lower calyx-teeth subulate, about $1.5 \mathrm{~mm}$. long; the upper lanceolate, shorter and slightiy broader; pod oblong, about I.5 $\mathrm{cm}$. long and $5 \mathrm{~mm}$. thick, often sparingly hairy when young, in age glabrous, almost terete, leathery, completely 2-celled.

This species has been confounded with $A$. Mortonii and sometimes with $A$. canadcnsis. The former is found only in the Columbia Valley region and is characterized by the intermixed black hairs on the calyx, and by the more hairy pod which is distinctly sulcate on the lower suture. A. orcophilus is really closer related to $A$. canadensis, but differs principally in the short bracts and calyxteeth. In A. canadensis the bracts are linear-lanceolate, long-attenuate, the lower almost as long as the calyx, and the calyxteeth longer, fully half as long as the tube. A. orcophilus grows in the foot hills at an altitude of $\mathrm{I}, 500-2,200 \mathrm{~m}$.

Colorado: Pagosa Springs, is99, C. F. Baker flo (type); near Boulder, I902, F. Tucedy 515t; Stone Prairie, Larimer Co., I 897, G. E. Osterhout; Wahatoya Creek, 1900, Rydberg \& Vrecland 5990; Durango, I 898 , Bakcr, Earle \& Tracy +78 .

\section{Astragalus Shearii sp. nov}

Perennials with horizontal rootstock; stems slender, strigose and striate, about $2 \mathrm{dm}$. high; stipules triangular, strigose, free from the petioles, but slightly united across the back of the stem; leaves 3-5 cm. long with $13-19$ leaflets; these 5-8 mm. long, oblong, obtuse or retuse at the apex, glabrate above, grayish strigose beneath; peduncles $4-5 \mathrm{~cm}$. long; raceme short, 5-IOflowered; calyx-tube campanulate, about $4 \mathrm{~mm}$. long, strigose, partly with black hairs; teeth triangular; corolla reddish-purple, nearly I cm. long; pod oblong, i 2-I $4 \mathrm{~mm}$. long, glabrous, reticulate, sessile, almost terete in cross-section; the lower suture intruded and forming a narrow partial partition.

In general habit somewhat resembling $A$. Hallii and $A$. flexuosus, but the structure of the pod places it nearest to A clegans.

Colokano: Twin Lakes, 1896, C. L. Shar $337 \%$.

\section{Homalobus Wolfii sp. nov.}

Low depressed cespitose perennial; stems intricately branched, less than I dm. long, covered by the scarious, strongly-veined, 
hirsute-strigose triangular stipules; leaves pinnate with 5 approximate leaflets ; these $3-4 \mathrm{~mm}$. long, lanceolate, strongly conduplicate, grayish hirsute, spine-tipped; racemes 1 -2-flowercd, very short-peduncled in the axils of the leaves; calyx-tube scarcely 2 $\mathrm{mm}$. long, grayish strigose; teeth subulate, about I mm. long; corolla ochroleucous, about $4 \mathrm{~mm}$. long.

A species related to and confounded with $H$. tegetcrins (Astragalus tegetarius $\mathrm{S}$. Wats.), but the latter is a larger plant, has long-peduncled raceme exceeding the leaves, and longer calyx teeth, which about equal the tube in length.

Colorado: South Park, I 873 , John Wolf 273 (type in herb. Columbia University).

\section{Homalobus Clementis sp. nov.}

Perennial, slightly branched, erect or ascending; stem glabrate or slightly strigose, about 2 dm. high; stipules broadly triangular, strigose, abruptly acuminate, more or less united across the back; leaves 5-7 cm. long, with I I-2 I leaflets; these oblong or lanceolate, acute, $7-12 \mathrm{~mm}$. long, glabrous above and sparingly strigose beneath; inflorescence 7-10 cm. long, 8-12-flowered; bracts lanceolate, small; flowers very short-pediceled; calyx-tube campanulate, about $3 \mathrm{~mm}$. long, strigose with black hairs, teeth lanceolate-subulate, about half as long; corolla bluishpurple, about $8 \mathrm{~mm}$. long; pod oblong, latterally compressed, sessile, about I $\mathrm{cm}$. long, 3-4 $\mathrm{mm}$. wide, black-hairy with very short hairs; both sutures prominent, the upper almost straight.

This species is perhaps closest related to Homalobus wingatensis (A. reingatensis); but that species is grayish canescent and has a glabrous pod. H. Clenentis grows at an altitude of 2,500$3,000 \mathrm{~m}$.

Colorado: Sangre de Cristo, i $896, F$. Climents 357 (type) ; Marshall Pass, igoi, C. F. Bak'r 189.

\section{Homalobus decurrens sp. nov.}

Peremnial with a rootstock, somewhat cespitose; stems erect, 3-4 dm. high, slightly strigose and angled, stipules lanceolate, free, about $5 \mathrm{~mm}$. long, strigose ; leaves I-I.5 dm. long with I II 5 leaflets; these $2-4 \mathrm{~cm}$. long, linear-oblong to oblanceolate, sparingly strigose or glabrate above; the terminal one usually larger, more or less decurrent on the rachis and without a definite node; racemes slender, I-I.5 dm. long, lax, 5-10-flowered; bracts subulate; calyx-tube campanulate, about $2.5 \mathrm{~mm}$. long, more or less 
black-hairy; teeth nearly $2 \mathrm{~mm}$. long and subulate; pod fully $2 \mathrm{~cm}$. long and $3 \mathrm{~mm}$. wide, sessile, linear, straight, glabrous.

This species is nearest related to $H$. campestris and $H$. hylophilus; but differs from both in the peculiarities of the terminal leaflets. It has broader and less hairy leaflets than the former and narrower and longer than the latter. It grows on hillsides.

Colorado: Estes Park, i 895, G. E. Osterhout (type); also in I900; Gray-Back Mining Camps, I900, Rydberg \& Vrecland 5960 .

\section{Ceanothus subsericeus sp. nov.}

A small shrub, apparently not spiny; bark of the stems gray or brown; of the twigs light gray and finely pubescent; leaves short-petioled; petioles 3-6 mm. long; blades elliptic or ellipticlanceolate, acute at both ends, $2-3 \mathrm{~cm}$. long, more or less glandular-denticulate, 3-ribbed, sparingly strigose above, grayish-silky beneath; umbels axillary and terminal; peduncles $3-10 \mathrm{~mm}$. long; pedicels 5-IO mm.; calyx about 3 mm. in diameter; sepals semi-orbicular; petals white, broadly spatulate, clawed, I-5 $\mathrm{mm}$. long ; fruit dark brown, about $4 \mathrm{~mm}$. in diameter, slightly 3 -lobed above.

This species is intermediate between $C$. owalis pubescens and $C$. Fendleri. In habit it resembles most the latter, but differs in the denticulate leaves and in not being spiny. From the former in the smaller size, the silky, instead of villous, pubescence and the principally axillary umbels. C. subsericeus grows in the foothills at an altitude of about $\mathrm{I}, \mathrm{SOO} \mathrm{m}$.

Colorado: Larimer Co., i $\$ 95, J$. H. Cowen (type); "Colorado," I 874, G. C. H'oolson.

\section{Sphaeralcea Crandallii sp. nov.}

Perennial, about $6 \mathrm{dm}$. high; stem simple, sparingly stellate; petioles 3-4 dm. long; leaf-blades cordate in outline, 5-lobed, about $5 \mathrm{~cm}$. in diameter; lobes lanceolate, coarsely toothed; inflorescence mostly terminal; pedicels and calyx sparingly and finely stellate; bractlets subulate, nearly equaling the lanceolate long-attenuate sepals; petals white or nearly so, about $2.5 \mathrm{~cm}$. long, cuneate and slightly emarginate; fruit not known.

This resembles a small $S$. rizularis, but differs in the long bractlets and the lanceolate sepals. It grows at an altitude of about 2,000 $\mathrm{m}$.

Colorado: Steamboat Springs, I S94, Crandall 9?. 


\section{Sphaeralcea grandiflora sp. nov.}

A meter or two high; stem glabrous below, stellate above; petioles of the lower leaves $\mathrm{I}-2 \mathrm{dm}$. long; blades cordate or reniform in outline, maple-like, 9-I $5 \mathrm{~cm}$. wide, deeply 5-7-lobed; lobes lanceolate or triangular, coarsely toothed with triangular teeth; flowers in small axillary clusters, but at the end of the stem the subtending leaves become diminished and the inflorescence resembles a congested panicle; pedicels and calyx densely hirsutepubescent with long stellate hairs, the branches of which are I-2 $\mathrm{mm}$. long; bractlets lanceolate, about half as long as the triangular-ovate, acute or somewhat acuminate sepals; petals pinkish, $3 \mathrm{~cm}$. or more long; fruit spherical, and deeply retuse at the apex; carpels membranous, smooth on the sides and bristly on the back, rounded at the apex; seeds reniform, brown, muricate.

A close ally of S. rizularis, but differs in the larger flowers, the broader bractlets, the long hairs of the calyx, the usually blunter leaves and more rounded carpels. It grows at an altitude of $2,200-2,800 \mathrm{~m}$.

Colorado: Mesa Verde, I90 I, F. K. Irecland 882 (type); west of Ouray, I gor, Underevood \& Selby Igot (in fruit).

\section{Touterea laciniata sp. nov.}

Biennial or short-lived perennial; stems 3-4 dm. high, white, puberulent, strict, in age branched; leaves narrowly lanceolate in outline, 5-ro $\mathrm{cm}$. long, deeply pinnatifid to near the midrib: sinuses rounded or nearly semi-rhombic; lobes oblong to lanceolate, obtuse: flowers usually bracted by I-2 laciniate bracts; sepals about I cm. long, lanceolate with a subulate tip, soon reflexed; petals golden yellow I 5-20 $\mathrm{mm}$. long, short-clawed; blades oblanceolate, acute; staminodia similar and imitating another set of petals; filaments nearly filiform, $3 / 4$ as long as the petals.

This species is closely related to T. speciosa, but differs in the deeply dissected leaves and more slender stem. In general habit it resembles somewhat $T$. multiflor $\alpha$, for which it has been mistaken; but that species has broader, obtuse petals, more dilated filaments, and more diverging branches. T. laciniata grows on dry hillsides at an altitude of $\mathrm{I}, 500-2,200 \mathrm{~m}$.

Colorado: Pagosa Springs, I 899, Baker t7o (type); Durango, I898, Baker, Earle \& Tracy 496; Cañon City, I900, Osterhout; Antonito, I 898, Earlc. 


\section{Touterea sinuata sp. nov.}

A decumbent biennial, 3-4 dm. high; stems stout, white, pubescent, much branched; lower lcaves IO-I $5 \mathrm{~cm}$. long, lanceolate or oblanceolate, tapering at the base, sinuately lobed or dentate; lobes or teeth broadly triangular, but often obtusish; upper leaves broadly lanceolate, or even ovate, sessile and cuneate or rounded at the base; flowers numerous, usually with $\mathrm{I}-2$ linear bracts; sepals lanceolate, tapering into a subulate tip, soon reflexed, about $8 \mathrm{~mm}$. long; petals golden yellow, I 5-20 $\mathrm{mm}$. long; oblanceolate, acute ; staminodia similar ; filament slightly dilated; capsule 2.5-3 cm. long, 7-8 mm. thick; seeds winged, about $3 \mathrm{~mm}$.

This species is also a close relative of $T$. speciosa, differing in the decumbent, branched habit and the broad leaves. The type grew in a cañon at an altitude of about $\mathrm{I}, 800 \mathrm{~m}$.

Colorado: Boulder, i 895, Rydberg.

\section{Acrolasia gracilis sp. nov.}

Annual, 3-5 dm. high, at first simple, but later branching; leaves $5-10 \mathrm{~cm}$. long, deeply pinnatifid to near the midrib; rachis and lobes $2-3 \mathrm{~mm}$. wide; the latter oblong or lanceolate, obtuse; floral leaves lanceolate, sessile, pinnatifid or toothed, rarely entire; sepals lanceolate, $4-5 \mathrm{~mm}$. long; petals obovate, $6-7 \mathrm{~mm}$. long, strongly striate; capsule sessile, linear-cylindric, $2.5-3 \mathrm{~cm}$. long and about $2 \mathrm{~mm}$. thick; seeds more or less prismatic, muricate.

This is Nuttall's Trachyphytum gracilc, a specimen of which is in the Columbia University herbarium. The species was never published, however. The name appears only as a synonym under Mentiselia albicaulis in Torrey and Gray's Flora, I: 534. I think, however, that it is well distinct from A. albicaulis or Bertonica albicaulis Hook. The latter is characterized by the smaller petals, only 3-4 $\mathrm{mm}$. long; the middle and upper leaves are often entire or with an entire lower and upper portion and only with a few lobes in the middle. In Hooker's type specimen the leaf-lobes are very few and Urban and Gilg confused it with $A$. integrifolicr, claiming that Mentaclia dispersa Wats. (which is the same as $A$. integrifolia) is the typical form of Mentistia albicaulis. A. integrifolic (Wats.) Rydb. and A. compacta (A. Nels.) Rydb. are, however, easily distinguished from the other species by the short linear-oblong, obtuse sepals, only $/ / 3$ as long as the petals, and by 
the seeds, which are apparently smooth, the fine murication being seen only under a strong lens. A. gracilis grows in sandy soil, on hillsides and in river bottoms at an altitude of 1,500-2,500 $\mathrm{m}$.

Colorano: Foothills, Larimer County, i 895, J. H. Con'ch (type); Ridge below Tobe Miller's, Coutn; Salida, I $\$ 9 S$, Bakcr, Earle \& Tracy' It (in part); mesas near Pueblo, I900, Ryelberg \& Trecland 5865 .

Wroming: Fort Steele, i 901, Treecdy 7573 and 757 .

Idaho: Common, i 892, Isabel Mulford.

"Oregon": Nuttall's specimens of Trachyphytum sracile.

\section{Acrolasia latifolia sp. nov.}

Stout annual, 3-5 dm. high, brancled; leaves sessile, ovate or ovate-lanceolate, coarsely toothed or entire, 5-IO cm. long, 2-3 $\mathrm{cm}$. wide; sepals lanceolate, $2.5-3 \mathrm{~mm}$. long; petals obovatespatulate, about $5 \mathrm{~mm}$. long; capsule linear, cylindric, $2.5-3 \mathrm{~cm}$. long, about $2.5 \mathrm{~mm}$. thick, sessile; seeds prismatic, muriculate.

This has been mistaken for A. integrifolia on account of its broad, merely toothed leaves, but the sepals and seeds place it in the $A$. albicaulis group and nearest the preceding and A.ctinophore. It grows on hills at an altitude of $\mathrm{I}, 200-2,400 \mathrm{~m}$.

Colorado: Mountains between Sunshine and Ward, I902, Treecdy $51+9$ (type); Boulder, I901, Osterhout 2471; Larimer County, I 895, Cowe'n.

\section{Epilobium ovatifolium sp. nov.}

Plant 2-6 dm. high, propagating by turions; stem glabrous except the decurrent lines which are more or less crisp-hairy, especially above; leaves sessile or nearly so, ovate or ovate-lanceolate and acute, or the lowest oval and obtuse, $3-4 \mathrm{~cm}$. long. entire or denticulate, glabrous; petals purple or rarely rose, $5-7$ $\mathrm{mm}$. long; pods 5-6 cm. long, I:5-2 mm. in diameter, sessile, more or less crisp and glandular hairy; seed a little over I mm. long, abruptly contracted above, but without neck; coma white, about $6 \mathrm{~mm}$. long.

The type specimens are labeled $E$. Hornmannii Reichenb. which it resembles somewhat in general habit; but that species propagates in an altogether different way and the leaves are more or less petioled. The present species is more closely related to E. brevistylum and E. glandulosum. It differs from the former 
mainly in the seeds, which lack the hyaline neck characteristic of that species. From E. glandulosum it is separated by the smaller size of the plant and of the flower, and by the light green leaves, which lack the coarse toothing of that species. It may also be confused with E. adenocanlon, but that species has smaller and lighter flowers, propagates by leafy rosettes and has usually distinct although short petioles. E. ovatifolium grows in wet places, especially in springs, in the mountains of Colorado and Utah at an altitude of 2,300-3,800 $\mathrm{m}$.

Colorado: Near Empire, I 892, Patterson 205 (type); Red Mountain, I90I, Underwood \& Selby 297; Bob Creek, I 898 , Baker, Earle d Tracy 855; Ironton Park, I90 I, Undcraood \& Sclby 3036; Columbine, I901, Twecdy +729; headwaters of Sangre de Cristo Creek, I 900, Rydberg \& Vrecland 5877.

UTAH : "Southern Utah," 1877 , Palmer 155.

\section{Epilobium rubescens sp. nov.}

Stem 3-4 dm. high, strict and simple, often more or less reddish, glabrous below, crisp-hairy above and more or less on the decurrent lines ; leaves $3-4 \mathrm{~cm}$. long, perfectly sessile, lanceolate, rounded at the base, denticulate, very acute, slightly crisp-hairy beneath when young; petals white, about $4 \mathrm{~mm}$. long; pods 4-5 $\mathrm{cm}$. long and $1.5 \mathrm{~mm}$. thick, more or less crisp-pubescent; seeds without neck, brownish, smooth, about I mm. long; coma white, 5-6 mm. long.

This species is perhaps most closely related to E. adcnocaulon, but differs in the perfectly sessile leaves and simpler habit. It grows in wet places up to an altitude of $2,700 \mathrm{~m}$.

Colorado: Pagosa Springs, I 899, Baker (type); Middle Park, I 892, Beardslec.

\section{Epilobium stramineum sp. nov.}

Stem 5-6 dm. high, simple, light and more or less straw-colored, glabrous below, more or less pubescent and somewhat glandular in the inflorescence; leaves sessile, light green, lanceolate, tapering at both ends, denticulate, $4-5 \mathrm{~cm}$. long, $1-1.5 \mathrm{~cm}$. wide, very acute; petals white, $4-5 \mathrm{~mm}$. long; pod $4-5 \mathrm{~cm}$. long and $\mathrm{I} \mathrm{mm}$. wide, more or less crisp and glandular; seeds lightbrown, without a neck; coma white.

This has been taken for $E$. Drummondii, but the type of that species has narrow, almost linear leaves, and is seldom over $3 \mathrm{dm}$. 
high. E. stramincum grows at an altitude of 2,400-3,200 m. in the mountains of Colorado, while the range of E. Drummontii extends further north.

Colorado: Idaho Springs, I905, Rydborg (type); Pagosa Peak, I 899, Baker 187 ; Sangre de Cristo Creek, I 900, Rydberg a Bessey' 58.78 ; Chicken Creek, i $\$ 98$, Baker, Earle \& Tracy $3+I$.

\section{Epilobium Palmeri sp. nov.}

Perennials propagating by turions or occasionally with more leafy rosettes; stem 4-6 dm. high, branched, glandular pilose, nearly terete, usually reddish or brownish ; leaves sessile or nearly so, ovate or ovate-lanceolate, rouncled or obtuse at the base, acute, denticulate, $3-4 \mathrm{~cm}$. long, more or less pubescent; petals pink or light purple, about $5 \mathrm{~mm}$. long; pod $4-6 \mathrm{~cm}$. long, $1.5 \mathrm{~mm}$. thick; seeds brown, more or less papillose, without a beak; coma white or in age somewhat tawny, 6-8 $\mathrm{mm}$. long.

The type was named E. tetragonum L., which species is not found in the United States. It resembles much E. brizistylum and E. orutifolium in habit, but is characterized by the pubescent stem and leaves.

Utaн : "South Utah," E. Palmor 156 (type in herb. Columbia University).

Id allo: Moscow, 1900, L. R. Abrams $\& \neq \delta$.

Montana: Camp Glazier, I gor, Umbach 327.

Colorado: Tobe Miller's Ranch, is97, A. Fro'.

\section{Gayophytum intermedium sp. nor.}

Profusely branched glabrous annual; stem white and shining, with more or less peeling bark, 3-7 dm. high, erect; leaves linear or nearly so, light green ; sepals about $1.5 \mathrm{~mm}$. long, soon spreading or reflexed, yellowish; petals $1.5-2.5 \mathrm{~mm}$. long, rose with yellow base; capsule $8-12 \mathrm{~mm}$. long, nearly twice as long as the reflexed pedicel, somewhat clavate and torulose, somewhat strigose when young; seeds $1.75 \mathrm{~mm}$. long, glabrous.

This species is intermediate between $E$. diffusum and E. ramosissimum in some respects. The flowers approach the latter more in size but the former in coloration. The pod is comparatively longer than in either. In both it is scarcely longer than the pedicels. E. intermedium grows in sandy soils in Colorado at an altitude of $\mathrm{I}, 500-3,000 \mathrm{~m}$. 
Colorado: Ouray, 1901, Underwool \& Selby 193 (type); mountains between Sunshine and IVard, 1902, Treccely 5092; near Boulder, 5091 ; Chamber's Lake, I899, and I S96, Buker; Veta Pass, 1900, Ryelberg \& Trecland 5860; Ward, I901, Osterhout 2.60 ; Caribou, I 891, Penard I22; Empire, I S92, Patterson 208.

Wroming: West De Lacy's Creek, i 899, Aven \& Elias Nolson: Headwaters of Clear Creek and Crazy Woman River, I9oo, Tivcaly j6 to; Dayton, I 899, Tricedy 2609; Biscuit Geyser Basin, I 897, Rydbirg \& Bessey +578 .

\section{Anogra cinerea sp. nov.}

Branched perennial, stem 3-4 dm. high, whitish, cinereous, strigose when young ; leaves lanceolate to ovate-lanceolate, mostly subsessile, $3-5 \mathrm{~cm}$. long, sinuate-dentate or denticulate, cinereous ; calyx glabrous or sparingly long-hairy, acuminate; tips free and rather long; petals I $5-1 S \mathrm{~mm}$. long; pods divergent at right angles to the stem, $3-3.5 \mathrm{~cm}$. long, almost straight.

This species is nearest related to Anogra latifolia (Ocnothere pallida latifolia Rydb.), but differs in the almost glabrous not cinereous calyx and the narrower leaves.

Colorado: Between Bent's Fort and Pueblo, i 885 , Fremont $23+$ (type in herb. Columbia University); Denver, i 895 , Pammel 202.

Soutil Dakota: Banks of Cheyenne River, I 89 I, 'T. $A$. lilliams.

Wyoming: St. Antony, I901, Merrill \& Irilco. 876 (this with more hairy calyx).

\section{Anogra Vreelandii sp. nov.}

Perennial; stem erect, strict, 3-5 dm. high, white and shining; leaves narrowly lanceolate, about $5 \mathrm{~cm}$. long, short-petioled or the upper sessile, glabrous, except occasionally strigose-ciliate on the margins, sinuate-dentate; calyx sparingly hairy, acute; the tips free but very short; petals about $2 \mathrm{~cm}$. long, obcordate, white turning pink; pod cylindric, divergent at right angles or reflexed, usually somewhat curved upwards.

The species is a close relative of $A$. pallida, but differs in the silky hairy calyx, the very short calyx-tips and the darker green foliage. It grows at an altitude of about i $800 \mathrm{~m}$.

Colorado: McElmo Cañon, I9OI, Tredend 861 . 


\section{Pachylophus hirsutus sp. nov.}

Cespitose, almost acaulescent perennial; leaves oblanceolate in outline, $\mathrm{I}-2 \mathrm{dm}$. long, more or less petioled, runcinate-pinnately lobed or divided, hirsute-villous, especially on the margins and the veins; teeth or lobes acute; hypanthium $8-12 \mathrm{~cm}$. long, slender, widening upward, conspicuously hirsute, at the throat $1-1.5 \mathrm{~cm}$. wide; sepals lanceolate, $3-4 \mathrm{~cm}$. long, soon reflexed; petals obcordate, 3-4 cm. long; pod 4-5 cm. long, lance-ovoid, about I $\mathrm{cm}$. in diameter, sessile; ridges low and rounded, slightly if at all tubercled.

In general habit, this species resembles most $P$. macroglottis and $P$. marginatus. From the former it differs in the hairy hypanthium and calyx, the more hairy leaves and the longer and less tubercled fruit. Fron the latter it is distinguished by the sessile pod and always subacaulescent habit. P. hirsutus grows at an altitude of 2,200-3,000 m.

Colorado: Georgetown, I 895, Rydberg (type); mountains between Sunshine and Ward, 1902, Tatecty 509t; South Pain, 1872, Wolf 132; Ruxton, 1896, Clonients 213; Pike's Peak, I896, Shar 3713; Mancos, I898, Baker, Earle \& Tracy ItI, Georgetown, 1885, Patterson; vicinity of Como, 1895, Cowen ; also I 896, Shear 7576 ; Empire, I 893, Bethel; Como, I895, Crerndall 8; Pennock, is96, Crandall 10.

Uтан : Salt Lake City, $1880, M$. E. Jones $77 \neq 6$; Diamond Valley, I902, Gooding $\&$ fo.

\section{Pachylophus caulescens sp. nov.}

More or less caulescent perennial; stem I-2 dm. high, angled, leaves with the long petioles about $2 \mathrm{dm}$. long; blades lanceolate or ovate-lanceolate, about $3 \mathrm{~cm}$. wide, pubescent on the margins and veins, sinuately dentate with a few lobes on the petiole; hypanthium about $9 \mathrm{~cm}$. long, glabrous, at the throat nearly $1.5 \mathrm{~cm}$. wide ; petals about $2.5 \mathrm{~cm}$. long, obovate; pod sessile, about $3 \mathrm{~cm}$. long, lance-ovoid with rounded low ridges.

In habit the species resembles $P$. crimius, but that species has a hirsute hypanthium and calyx and the ridges of the fruit with almost foliaceous crests.

Coloravo: Palisades, I 894, Crandail 12 (type in herb. Columbia University). 


\section{Gaura coloradensis sp. nov.}

Herbaceous, biennial or perennial with fusiform root; stem 5-7 dm. high, strict, but somewhat branched, finely strigose, more or less red; leaf-blades narrowly oblanceolate, 5-10 cm. long, gradually tapering below into a short petiole, or the upper sessile, callous-denticulate, finely strigose: inflorescence slender and rather lax, I.5-2 dm. long; hypanthium about $2 \mathrm{~cm}$. long, finely strigose; sepals about I cm., linear-lanceolate, reflexed; petals about $8 \mathrm{~mm}$. long, spatulate, pink, short-clawed; filaments about equaling the petals; anthers brown, about $4 \mathrm{~mm}$. long; fruit S-ro $\mathrm{mm}$. long, fusiform, 4-angled, tapering below into a short and rather slender stipe-like base.

In habitat and pubescence this species resembles most G. Pitch$c r i$, but the leaves are oblanceolate instead of lanceolate and the fruit is that of $G$. sinnata. $G$. coloradensis grows in meadows at an altitude of about $1,500 \mathrm{~m}$.

Colorano: Fort Collins, i 895 , Cowen (type); east of College, I 897, Crandall 1,308; east of Poudre, I 895, Cowcn I632.

\section{Suida interior sp. nov.}

Cornus Baileyi Coult. \& Evans, Bot. Gaz. I5 : 37, in part. I 890.

A shrub 2-5 m. high ; bark of the old stems grayish, of the young shoots brownish; young shoots, petioles and inflorescence densely pubescent with short villous hairs; leaves elliptic or oval, acute at both ends, $5-9 \mathrm{~cm}$. long, finely short-strigose on both sides and more or less villous on the veins and in their angles beneath; hypanthium strigose; sepals minute, about $0.5 \mathrm{~mm}$. long or less; petals linear-lanceolate, about $4 \mathrm{~mm}$. long; fruit white, about $5 \mathrm{~mm}$. in diameter; stone elliptic, slightly oblique, longer than broad, nearly smooth.

This species was included in the original description of Cormus Baileyi, but is quite different from the type thereof from the lakeshores of Michigan. This has conspicuous sepals and has a more flattened stone, channeled on the edge and with square shoulders. In reality, $S$. interior is much more closely related to $\mathrm{S}$. stolonifera (Cornus stolonifera Michx.), especially the western variety described below, but differs in the villous pubescent instead of sparingly strigose twigs and inflorescence. In S. stolonifora and its variety the stone is usually broader than long and very oblique. S. interior grows on river banks west of Mississippi River. 
Nebraska: Dismal River, I 893, Rydborg I T $^{\top}+$ (type); St. James, I 993 , Clements 2626; Pine Ridge, is89, Wibbcr; Cedar Island, i 854 , Hayden.

South Dakota: Piedmont and Little Elk Creek, I S92, Rydberg 735 ; Cobbs Creek, 1894, T. A. Willians.

Colorado: Merker, 1902, Ostcrhout 2602; Walsenburg, I 896, Shear 4774; Cañon City, 1896, Clements Ior.

Wroming: Dayton, 1899 , Tiecedy $263 I$ and 2632.

\section{Suida stolonifera riparia var. nov.}

Leaves usually oval or elliptic, acute, thinner, lighter green and less pale beneath than in the eastern type; bark on young twigs brownish; sepals and fruit smaller.

In the field this variety looks very unlike the eastern $S$. stolonifore. It grows as a high bush on river banks and is as far as I know not stoloniferous. In the eastern plant the leaves are comparatively thick, darker green above and very pale beneath, and the young shoots bright red. The plant of the interior may represent a distinct species, but on account of the lack of good diagnostic characters it is perhaps better to regard it at present as a variety of the eastern plant. The variety is the only form found in the region of the Rockies and the Great Plains. It is common from Manitoba, the Mackenzie River, to Alaska and south to Nebraska, Colorado and Arizona; as the type may be designated:

Colorado: Crystal Creek, I901, Baker 257.

\section{Aletes obovata sp. nov.}

Cespitose, glabrous, acaulescent perennial with deep tap-root; leaves $\mathrm{I}-2 \mathrm{dm}$. long, pinnate with $4-5$ pairs of leaflets; these broadly obovate, I-2 cm. long, more or less cleft and toothed with short ovate teeth, strongly veined beneath; scapes $1-3 \mathrm{dm}$. high, round-angled and striate; bracts none; branches of the umbel $2-2.5 \mathrm{~cm}$. long in fruit; bractlets lanceolate, $3-4 \mathrm{~mm}$. long, reflexed in age; pedicels very short or obsolete; Howers yellow ; calyx-teeth prominent, in fruit $.5-.75 \mathrm{~mm}$. long ; fruit $5-6$ $\mathrm{mm}$. long and $1.5 \mathrm{~mm}$. in diameter; ribs rather thick; oil-tubes I in the intervals, 2 on the commissure, rather large; seed-face only slightly concave.

This species has been confused with the closely related $A$. acaulis, which is easily distinguished by its rhombic, deeply cut 
leaflets with lanceolate, acuminate lobes and smaller fruit about $4 \mathrm{~mm}$. long.

Colokado: Near Morrison, i 889, Greenc (type, in mature fruit, in herb. Columbia University); Golden, I 892, Crandall (in flower); Lower Boulder Cañon, I 901 , Ostcrhout $2+33$ (in young fruit).

\section{Phellopterus camporum sp. nov.}

Perennial with a deep-seated thick tap-root; leaves twice to thrice pinnatifid, petioled, pale-green; petioles $4-7 \mathrm{~cm}$. long; ultimate divisions oblong, obtusish, 3-6 $\mathrm{mm}$. long; peduncles 5-20 $\mathrm{cm}$. long, usually exceeding the leaves; involucres of white hyaline bracts; branches of umbel about $2 \mathrm{~cm}$. long in fruit; bractlets orbicular, 5-7 mm. long, with greenish center and broad white hyaline border, 7-I 3 nerved; pedicels short, in fruit only $3-5 \mathrm{~mm}$. long; flowers white; fruit with the very broad wings $10-13 \mathrm{~mm}$. long and 9-1 I mm. wide; oil-tubes $3-4$ in the intervals, $6-7$ on the commissure; seed flattened with broadly concave face.

The specimens has been determined as P. furpurasccns Eastwoodiac, but it is evidently well distinct from that as shown by a duplicate of the type in the herbarium of the N. Y. Botanical Garden; the bractlets are larger and many-nerved, the flowers white and the fruit is longer than in the variety mentioned. It grows on dry mesas at an altitude of $\mathrm{I}, 500-16,00 \mathrm{~m}$.

Colorado: Pueblo, I900, Rydberg \& Vrecland 5825 (type, in flower) and $5 \delta 2+$ (in fruit).

\section{Pseudocymopterus montanus mutifidus var, nov.}

Low, about 2 dm. high ; lower leaflets broadly rhombic in outline, thrice pinnate; the upper twice pinnate; ultimate divisions linear; fruit smaller and more rounded.

On high mountains, at an altitude of 2,700-3,600 m.

New Mexico: Range between Sapello and Pecos rivers, i 90o, Cockerell.

Colorado: Ironton, 1899, C. C. Curtis; Cumberland Basin, I 898, Bakcr, Earle \& Tracy 619; West Indian Creek, I900, Rydberg \& Vredand 5798 ; Ironton Park, Underwood \& Selby 358 .

Pseudocymopterus aletifolius sp. nov.

Densely cespitose acaulescent glabrous perennial with a very thick root and short caudex, covered by the broad striate bases of 
dead leaves; leaves once or twice pinnate, dark green, glabrous, stiff and shining, $\mathrm{I}-2 \mathrm{dm}$. long; petioles about equaling the blades, striate; leaf-segments obovate to rhombic-cuneate, deeply cleft; lobes usually 3 -toothed with lanceolate acuminate teeth; scapes $\mathrm{I}-\mathrm{I} .5 \mathrm{dm}$. long; involucres lacking; branches of the umbel very unequal, in fruit $1-5 \mathrm{~cm}$. long; bractlets linear-subulate, $4-5 \mathrm{~mm}$. long; pedicels also very uncqual, in fruit $\mathrm{I}-8 \mathrm{~mm}$. long ; sepals conspicuous, in fruit $\mathrm{I}-2 \mathrm{~mm}$. long; flowers yellow ; fruit 5-6 mm. long, $2.5-3 \mathrm{~mm}$. wide; lateral wings evident but rather narrow; dorsal ribs acute or slightly winged; seed flattened and with somewhat concave face; oil-tubes usually solitary in the intervals.

This species is evidently most closely related to $P$. anisatus, but easily distinguished by the very unequal branches of the umbel, the longer, usually less winged fruit and especially by the leaves, which (although much firmer) resemble closely those of Alctes acaulis. The plant evidently connects the two genera Aletes and Pscudocymoptcms. The fruit of the present species is also intermediate between $A$. acaulis and $P$. anisaths, and were it not for the flatness of the seed and the lateral wings of the fruit, it might have been referred to Alctes. It grows in the mountains of which Pike's Peak is the center, at an altitude of 2,000-2,600 m.

Colorado: Minnehaha, I901, Clements of (type); same locality, I 895 , E. A. Bcsscy'; North Cheyenne Cañon, i 895, E. A. Besscy, and I892, C. S. Shildon; South Cheyenne Cañon, I900, Rydberg \& Vredand 5815 ; Cheyenne Mountain, I 892, Alice Eastwood; Manitou, I900, Clements; Ruxton, I S96, Clements 211 ; Halfway House, I \$96, Shear 3709 (Rydberg \& Vreeland's specimens are in flower, the others in fruit). 

CONTRIBUTIONS FROM THE NEW YORK BOTANICAL GARDEN-No. 62

\title{
STUDIES ON THE ROCKY MOUNTAIN FLORA-XIII
}

\author{
BY PER AXEL RYDBERG
}

NEW YORK

1904

[From the Bulletin of the Toprey Botanical Club, 31:681-650. December, 1pod] 



\section{Studies on the Rocky Mountain flora - XIII}

PFr AXF. RYDBER,

Dodecatheon multiflorum sp. nov.

Plant glabrous, perennial with a very short caudex and cluster of fibrous roots; leaves about $2 \mathrm{dm}$. long, sinuate-denticulate, obtusish, narrowly oblanceolate, tapering below into a short petiole; scape stout 3-4 dm. high; bracts linear-lanceolate, $1-2 \mathrm{~cm}$. long; flowers $1 \mathrm{O}-2 \mathrm{O}$; the longer pedicels often over I dm. long; calyxtube 5-6 mm. long, more or less turbinate at the base; lobes lanceolate, about $5 \mathrm{~mm}$. long; corolla bluish violet, paler in the throat but without any markings; lobes oblong, obtuse ; filamenttube obsolete; anthers narrowly linear-lanceolate, acute, $7-S \mathrm{~mm}$. long; connective narrow, lance-subulate, with a longitudinal groove, but not rugose; capsule about i $2 \mathrm{~mm}$. long, cylindricovoid, septicidal.

In habit this species resembles $D$. radicatum and $D$. pauciflormu, but differs in the stamens, which are almost without a filamenttube. In river valleys at an altitude of $2400-2700 \mathrm{~m}$.

Colorado: Sangre de Cristo Creek, I900, Rydburg \& Trecland 5781 .

Wromisg: Elk Mountains, I 899, Little \& Stanton.

\section{Dodecatheon radicatum sinuatum var. nov.}

Leaves more elongated than in the type, oblong, rarely elliptic, sinuate, thin.

Colorado: Foothills, Larmer County, I 890, Crandall (type); Buena Vista, I 892, C. S. Shcldon; Fort Collins, is96, Baker.

\section{Gentianella Clementis sp. nov.}

Annual, usually more or less branched, 2-4 dm. high; stem sharply angled; internodes usually longer than the leaves; these 3-6 cm. long, the basal ones spatulate, the cauline ones lanceolate, acuminate, truncate or even subcordate at the base, sessile; peduncles I-4 from the axils of the leaves, more or less elongated I- 6 $\mathrm{cm}$. long; sepals linear, acute, usually very unequal in length, the longer often $2 / 3$ as long as the blue or greenish-yellow corolla; corolla I 5-I $8 \mathrm{~mm}$. long; lobes ovate-lanceolate, acute. 
This belongs to the Amarella group of Gentiana and is perhaps most nearly related to $G$. plcbeja, which, however, has shorter ovate or ovate-lanceolate, acute or obtuse stem-leaves, lower stem and shorter and more nearly equal calyx-lobes. G. Clementis grows in the mountains from South Dakota and Montana to Colorado and Arizona. As the type I regard the following:

Colorado: Minnehaha, I9or, Clements 253.

\section{Frasera speciosa stenosepala var. nov.}

Usually with very numerous flowers; sepals narrowly linear, some of them usually equaling or exceeding the petals; petals large, about is $\mathrm{mm}$. long or more; floral leaves very long and narrow.

In the mountains and foothills of Colorado and Wyoming. As the type may be regarded:

Colorado: Foothills, Larimer County, i $\$ 95$, Cowen.

\section{Frasera speciosa angustifolia var. nov.}

Low, 3-4 dm. high; basal leaves very short; stem-leaves narrowly linear-lanceolate; floral leaves, except the lower, shorter than the branches of the inflorescence; petals rather small, about I $2 \mathrm{~mm}$. long.

On dry hillsides from Montana to Colorado. As the type may be regarded :

Montana: Lima, 1895, Shear 3360 .

\section{Gilia scariosa sp. nov.}

Perennial with a tap-root; stems one to several, simple, strict, 3-6 dm. high, glandular-puberulent throughout ; leaves numerous, alternate, pinnatifid with linear-filiform spinulose-tipped divisions, more or less white-villous when young, glandular-puberulent; inflorescence a narrow, strict, interrupted thyrsus; branches very short, few-flowered; calyx-tube about $6 \mathrm{~nm}$. long, puberulent, scarious except the green angles; teeth short, broadly roundedovate, abruptly contracted into a subulate acumination; corolla pink, 3-4 cns. long; tube narrow, very gradually broadening upwards ; lobes ovate-lanceolate, acute, about $8 \mathrm{~mm}$. long ; stamens very unequally inserted; capsule obovoid, about I $\mathrm{cm}$. long.

This is closely related to G. aggregata, but differs in the scarious calyx with short, abruptly cuspidate-acuminate lobes. The lobes of the corolla are also acute rather than acuminate. The 
species is common in Colorado, in open valleys. It was first collected by James in Long's expedition : but James' specimen in the Torrey herbarium is a mere scrap. I have therefore selected as the type a better specimen, viz. :

Colorado: Veta Pass, 1896. C. L. Shar 3590.

\section{Gilia spergulifolia sp. nov.}

Gilia congester cribrifolia Wats, King's Exp. 5: 268, in part. 1871. Not G. crebrifolia Nutt.

Low perennial, more or less woody at the base, more or less cespitose; flowering branches 5-10 cm. high, more or less pubescent with white, crisp hairs or puberulent; leaves linear-filiform, entire or the upper rarely with $1-2$ similar lobes, tipped with a pungent point ; flowers in capitate clusters, which are usually on naked peduncles; bracts similar to the leaves but smaller; calyx villous with short subulate pungent teeth; corolla 4-5 mm. long, white; lobes oblong, obtuse, a little over $1 \mathrm{~mm}$. long.

This has been mistaken for G. crebrifoluc Nutt., but that species has much shorter fleshy leaves and very short copiously leafy flowering stems. It is nearer related to $G$. ibcridifolic, from which it differs in the entire leaves and solitary heads ending the branches.

ITyouns: Headwaters of Tongue River, is9s, Tavedy 576 (type).

Colorado: Arboles, 1899, liaker i3t.

UтAн: Bear River Valley, I 869. Il'atson 917.

\section{Gilia roseata sp. nov.}

Perennial with a woody base, cespitose; flowering branches about I dm. high, purple-tinged, more or less villous or crisphairy ; leaves pinnatifid with linear-filiform pungent-pointed lobes, about $2 \mathrm{~cm}$. long; flowers capitate at the ends of the leafy branches: bracts similar, shorter, rose-tinged and more villous; calyx also very pubescent and rose-tinged; lobes subulate and spinulose-pointed; corolla about $\$ \mathrm{~mm}$. long: its lobes $4-5 \mathrm{~nm}$. long, elliptic, obtuse.

This species is nearly related to $G$. ibcridifolur, but differs in the larger flowers (in $G$. ibcridifolia the corolla-lobes are rarely orer $2 \mathrm{~mm}$. long), the rose-colored bracts, purplish stem and more solitary heads.

Colorado: Grand Junction, i 892, Alice Easizucel. 


\section{Gilia polyantha sp. nov.}

Perennial with a short woody base; stems several, $3-4 \mathrm{dm}$. high, striate and simple up to the inflorescence, glandular-puberulent; leaves 3-4 cm. long, pinnatifid, glabrous or with a few white hairs; lobes linear filiform, pungent-pointed; flowers numerous in a narrow thyrsus; calyx campanulate, about $5 \mathrm{~mm}$. long, more or less scarious at the sinuses; lobes broadly ovatetriangular, abrubtly cuspidate-pungent ; corolla white, about I cm. long, funnelform-salvershaped; lobes about $5 \mathrm{~mm}$. long, lanceoblong, obtusish; filaments about equaling the corolla-lobes, somewhat incurved.

This has been mistaken for $G$. multiflord Nutt., but is more closely related to $G$. Macombii Torr., chffering mainly in the shorter corolla and shorter pubescence.

Colorado: Pagosa Springs, is99. Baker 538.

\section{Gilia Tweedyi sp. nov.}

Annual, branched, 2-4 dm. high; stem and branches glandular-puberulent, especially the upper part; leaves $2-3 \mathrm{~cm}$. long, pinnatifid, with lanceolate cuspidate lobes; flowers paniculate: pedicels I-S mm. long; calyx about $3 \mathrm{~mm}$. long, scarious between the green ribs; lobes lanceolate; corolla funnelform, about $4 \mathrm{~mm}$. long, bluish ; capsule ovoid, about $4 \mathrm{~mm}$. long.

This species is related to $G$. inconspicuer and $G$. minutiffora. From the former it differs in the smaller corolla, of which not only the corolla-tube but also the throat is included in the calyx; from the latter it differs in the pinnatifid leaves. G. Tu'cety $i$ grows in river bottoms and on sandy soil, at an altitude of IOOC$2200 \mathrm{~m}$.

Wroming: Encampment, Carbon County, igor, Tacedy +122 (type); between Sheridan and Buffalo, I900, Tatectly $3+S_{I}$; Fort Steele, I90I, Trocedy +421 ; also, I898, Aicn Vitson 4502.

\section{Gilia Crandallii sp. nov.}

Perennial with a woody tap-root; stem 3-5 dm. high, sparingly puberulent, glandular above, rather stout, much branched; basal leaves 3-10 cm. long, spatulate or oblanceolate, serrate or pinnately lobed, with lanceolate teeth or lobes; lower stem-leaves often similar; the upper narrower and usually entire; calyx glandular, about $5 \mathrm{~mm}$. long; teeth lanceolate, scarious-margined; corolla salvershaped, about $15 \mathrm{~mm}$. long, rose color; tube about $\mathrm{I} \mathrm{mm}$. 
wide below, about $2 \mathrm{~mm}$. at the throat; lobes oblong-spatulate, acutish ; capsule about $5 \mathrm{~mm}$. long, acute.

This has been mistaken for G. Hoydoni, but that species is a much more slender plant with shorter calyx, scarcely scariousmargined lobes, minute subulate stem-leaves and shorter $(3.5 \mathrm{~mm}$. long) obtuse capsule. It is more closely related to $G$. subnuda, but differs in the branched stems and the finer and sparser pubescence. It grows in dry soil, especially on "sage-plains," at an altitude of 1900-2100 m.

Colorado: Durango, 1898 , Crandall 2053 (type) and 2070 ; also I 896, Trucedy $+\not 8$; Mancos, I $\$ 98$, Bakr, Earlc \& Tracy' tof; also I $90 \mathrm{I}$, Trecland 885 .

\section{Polemonium robustum sp. nov.}

Perennial with a woody caudex; stem 4-Io dm. high, more or less short-villous and above glandular; leaves $6-10 \mathrm{~cm}$. long, glandular-pubescent; leaflets I I-17, lanceolate or lance-oblong, acute, $1.5-2.5 \mathrm{~cm}$. long; the upper confluent and decurrent on the rachis; inflorescence much branched and corymbiform, but the main axis usually overtopping the branches; calyx glandular-villous, 7-8 mm. long; lobes lanceolate; corolla rose or purplish, I 2-I 5 $\mathrm{mm}$. high ; lobes rounded and obtuse.

This species is a close relative to $P$. foliosissimm, but differs in the large flowers and the more conical or obovoid inflorescence. It grows in the mountains of Colorado, especially along streams, at an altitude of $2400-3000 \mathrm{~m}$.

Colorado: Bob Creek, La Plata Mountains, I 998 , Baker, Earle \& Tracy $27+$ (type): Keblar Pass, I90 I, Baker 796 ; Clear Creek Cañon, I\$85, Pattirson Iof; Sangre de Cristo Creek, I900, Rydberg \& Trecland $571 S$; Veta Pass, I900, Rydborg \& Irecland 5717 .

\section{Polemonium Grayanum sp. nov.}

Perennial with a cespitose rootstock; stems about I dm. high, glandular-villous; leaves $3-5 \mathrm{~cm}$. long, glandular-villous; leaflets at least of the basal leaves more or less verticillate, obovate or spatulate, 2-6 mm. long, obtuse ; calyx about i $8 \mathrm{~mm}$. long, villous with white hairs; lobes linear-lanceolate; corolla about $2 \mathrm{~cm}$. long, campanulate-funnelform with a wide tube; lobes rounded.

This species is nearest related to $P$. riscosum Nutt., but is characterized by the long white hairs on the calyx. It grows on the 
higher peaks of Colorado among rocks, at an altitude of 2700$4000 \mathrm{~m}$.

Colorado: Gray's Peak, 1895, Ryelberg (type); also i 886, Lettermern 323; Graymount, Lettcman 322; Central City, I 869, Lcoille.

\section{Phacelia sericea ciliosa var, nov.}

Usually taller than the typical $P$. scricce, often $5 \mathrm{dm}$. high, not silvery, green; pubescence very sparse and short, except some long silky hairs on the pedicels and lower portion of the stem.

This variety has been mistaken for P. Ly'allii and P. idahoensis. It has been confused with the first on account of the similar pubescence, but $P$. Ly allii is a much smaller plant and with less deeply dissected leaves. It resembles $P$. iddrocnsis very closely in general habit, but in that species the stamens are only slightly exserted and the corolla smaller. The variety has the same range as the species, but grows usually at a lower altitude. As the type may be taken :

Colorado: North of Merker, 1902, Ostcrhont 2619.

\section{Lappula Besseyi sp. nov.}

Biennial; stem 5-ro dm. high, hirsute, branched above ; lower leaves petioled, 6-I $5 \mathrm{~cm}$. long; blades spatulate or oblanceolate, obtuse, hispidulous and hirsute on the veins ; upper leaves sessile, lanceolate; inflorescence branched; bracts small; pedicels in fruit 4-5 mm. long, more or less reflexed; corolla dark blue, scarcely over $1.5 \mathrm{~mm}$. wide; fruit about 3 mm. wide; marginal spines distinct and in one row; back flat, spineless, but minutely hispidulous.

In general habit this species resembles most $L$. floribunda, but is distinguished by the very small flowers and fruit. It grows in cañons at an altitude of about $2400 \mathrm{~m}$.

Colorado: Cheyenne Cañon, 1895, E. A. Bessey' (type); also in 1896.

\section{Lappula angustata sp. nov.}

Biennial or short-lived perennial ; stem strict, hirsute, 6-\$ dm. high; lower leaves petioled, 9-I $5 \mathrm{~cm}$. long, strigose or hirsute on the petioles; blades narrow, linear-oblanceolate, mostly acute; stem-leaves linear-lanceolate, sessile; inflorescence with strongly ascending branches; pedicels reflexed in fruit, about $5 \mathrm{~mm}$. long; corolla blue, about $4 \mathrm{~mm}$. wide; fruit $4-5 \mathrm{~mm}$. wide: marginal 
prickles united $1 / 3-I_{2}$ their length into a distinct wing, the alternate ones usually much smaller; back sliglutly keeled, without prickles, minutely hispidulous or glabrous.

In habit this species also resembles L. floribunda, but is distinguished by the narrow leaves and the united marginal prickles of the fruit. These characters would place it near L. scaborrima, which, however, has a different pubescence.

South Dakota: Oreville, 1902, Rydberg $89 I$ (type).

Colorado: La Veta, isg6, Shcar 36 fo.

\section{Oreocarya argentea sp. nov.}

Cespitose perennial; stems 3-4 dm. high, hispid; basal leaves spatulate or oblanceolate, obtuse, 5-6 cm. long, densely white- or yellowish-pubescent, partly with stiff bristle-like hairs, partly with fine hairs, but all strictly appressed; stem-leaves oblanceolate, with the bristles more spreading; inflorescence narrow and virgate; calyx in fruit $8-10 \mathrm{~mm}$. long, hispid; its lobes linear-lanceolate; corolla white, less than $5 \mathrm{~mm}$. long ; its tube included and limb 5-6 mm. wide; nutlets about $3.5 \mathrm{~mm}$. long, papillose and with more or less distinct cross-ridges.

This species is perhaps nearest related to $O$. scricod, which, however, is a much smaller plant and has mammillate-papillose nutlets without cross-ridges. It grows on dry hills in Colorado.

Colorado: Rifle, Garfield County, I 900, Osterhont 2122.

\section{Oreocarya eulophus sp. nov.}

More or less cespitose perennial; stem about $2 \mathrm{dm}$. high, hispid with yellowish hairs; basal leaves numerous, spatulate, 4-5 $\mathrm{cm}$. long, finely cincreous and appressed hispid; stem-leaves oblanceolate, with the hispid hairs more spreading and often yellowish; inflorescence a narrow and almost spikelike thyrsus; calyx in fruit about $7 \mathrm{~mm}$. long, yellowish hispid; its lobes lanceolate; corolla white, $10-12 \mathrm{~mm}$. long; tube exserted from the calyx; limb about $5 \mathrm{~mm}$. wide; nutlets $4-5 \mathrm{~mm}$. long, with irregular honeycomb-like crests.

This species is a near relative of $O$. fultocanescens and 0 . cristatc, but easily distinguished in fruit by its nutlets. It grows on gravelly hills at an altitude of $1800-2300 \mathrm{~m}$.

Colorado: Dolores, IS92, Cramda'l (type); McCoy's, I903. Osterhout 2750 .

UTан: Price, I 900, Stokis. 


\section{Mertensia picta sp. nov.}

Peremnial, perfectly glabrous, except the hispidulous-ciliate margins of the leaves and calyx-lobes; stem 3-5 dm. high, pale and somewhat bluish below, more or less angled; lower leaves petioled; blades oval or elliptic-ovate, $5-9 \mathrm{~cm}$. long, obtuse or acutish, rounded or somewhat truncate at the base, finely pustulate but not hairy on the surfaces, thin ; upper leaves lanceolate or ovate-lanceolate and subsessile; inflorescence leafy and with short branches; pedicels and calyx more or less pustulate; calyx-lobes linear-oblong, obtuse, in fruit nearly $2 \mathrm{~mm}$. long, the back with a thickened pale spot; corolla blue; its tube $6-7 \mathrm{~mm}$. long and $2-3 \mathrm{~mm}$. wide; throat and limb together $5-6 \mathrm{~mm}$. long, the latter about $5 \mathrm{~mm}$. wide; filaments dilated, about $2 \mathrm{~mm}$. long and wider than the anthers; nutlets ovate in outline, strongly and irregularly reticulate-crested on the back.

This is closely related to $M$. ciliater but distinguished by the pale-spotted and thickened calyx-lobes.

- Colorado: Estes Park, Larimer County, I903, Ostirhout 2823 (type); Mount Baldy, rgor, Climents 288 .

\section{Mertensia polyphylla platensis var. nov.}

Like the species, but the calyx-lobes linear, fully $3 \mathrm{~mm}$. long; basal leaves large; blades about $1 \mathrm{dm}$. long, cordate at the base and cuspidate at the apex.

Along streams at an altitude of $3000 \mathrm{~m}$.

Colorado: Bob Creek, La Plata Mountains, i 898 , Baker, Earle \& Tracy 1 \&o (in part).

\section{Mertensia alba sp. nov.}

Perennial; stem pale, 6-\$ dm. high, more or less branched; lower leaves petioled, upper sessile; blades lanceolate or ellipticlanceolate, acute or acuminate at both ends, glabrous beneath, hispidulous-strigose above and on the margins; pedicels and calyx strigose; lobes linear-lanceolate, acute, about half as long as the tube of the white corolla; corolla-tube about $8 \mathrm{~mm}$. long, and 4 mm. wide; throat and limb together of about the same length; the latter $8-10 \mathrm{~mm}$. wide; nutlets irregularly crested-tuberculated, and finely pubescent.

This is a species of the $M$. paniculata group and nearest related to II. pritensis, but it lacks the dense white pubescence of the calyx characterizing that species and the corolla in all specimens seen is white.

Colorado: La Plata River, is98, Baker, Earle of Tracy 25. 


\section{Mertensia viridula sp. nov.}

Perennial with a cespitose rootstock; stems slender, $2-3 \mathrm{dm}$. high, glabrous; leaves glabrous beneath, hispid-strigose above; the lower petioled, the upper sessile; blades of the basal ones spatulate, obtuse; those of the stem-leaves acute, elliptic, or the upper lanceolate; pedicels strigose; calyx glabrous, except the base and the margins of the lobes; these broadly lanceolate, about $2.5 \mathrm{~mm}$. long; corolla blue; tube about $4 \mathrm{~mm}$. long; throat and limb of about the same length ; filaments broader than the anthers ; nutlets muricate and somewhat irregularly ridged.

This species resembles $M$. airidis A. Nels. closely in habit, but the dilated conspicuous filaments associate it with MI. lincarifolia and $M$. orata, from which it is distinguished by the broader calyxlobes. It grows in the mountains at an altitude of 2700-3800 m.

Colorado: North Cheyenne Cañon, i 894, E. H. Bessey (type); West Spanish Peak, I900, Rydberg \& Treelant 5683 .

\section{Mertensia Parryi sp. nov.}

Perennial with a cespitose rootstock; stems about $2 \mathrm{dm}$. high, glabrous; leaves glabrous beneath, hispidulous-strigose above, only the basal ones petioled and spatulate; stem-leaves sessile, lanceolate or oblanceolate, about $5 \mathrm{~cm}$. long; inflorescence small and short; pedicels strigose; calyx glabrous except the very base and the ciliate margins of the lobes; these narrowly linearlanceolate, about $3 \mathrm{~mm}$. long; tube of the blue corolla about 5 mm. long and about equaling the length of the throat and limb together; limb about $8 \mathrm{~mm}$. wide; filaments evident but short, broader than the anthers.

This species is nearest related to $M$. orita Rydb., but differs in the narrower leaves and the comparatively longer corolla-limb. In $M$. or'ata the tube is longer than the throat and limb together. M. Parryi grows in the higher mountains.

Colorado: Alpine ridges lying east of Middle Park, Prory 286 (type); Estes Park, 1903, Osterhout 28.18; Cameron Pass, 1896, Baker; Alpine Tunnel, 1897, Shar 3853.

\section{Mertensia perplexa sp. nov.}

Perennial with branched rootstock; stem about $3 \mathrm{dm}$. high, glabrous; basal leaves spatulate, $4-10 \mathrm{~cm}$. long, petioled; stemleaves sessile; the lower oblanceolate; the upper ovate, glabrous beneath, minutely hispidulous-strigose above; pedicels minutely 
hispid-strigose; the hairs with pustulate bases; calyx glabrous except the ciliate margins of the lobes; these oblong-lanceolate, acute or obtuse ; corolla blue, about I $2 \mathrm{~mm}$. long; tube equaling the throat and limb; the latter $7-8 \mathrm{~mm}$. wide; tube densely villous at the base within; anthers subsessile, inserted a little below the throat.

This species is evidently nearest related to $M$. alpina, notwithstanding the much larger size and erect habit. The corolla is almost twice as long as in that species.

Colorado: Mountains south of Ward, Boulder County, I 90 I, Osterhout $2+39$.

\section{Mertensia canescens sp. nov.}

Low and cespitose perennial with woody caudex; stems about I dm. high, strigose; leaves linear or linear-oblanceolate, grayish strigose on both sides; pedicels and calyx strigose; calyx-lobes linear-lanceolate, acute, about $2 \mathrm{~mm}$. long, on the margin ciliate with longer hairs ; corolla blue, about $8 \mathrm{~mm}$. long ; tube $\mathrm{I} .5 \mathrm{~mm}$. wide and about as long as the throat and the limb, the latter about $3 \mathrm{~mm}$. wide; anthers subsessile at the margin of the corolla-tube.

Closely related to $M$. alfina, it is easily distinguished by the canescent and narrow leaves. It grows on the mountains at an altitude of $3360-3600 \mathrm{~m}$.

Colorado: Berthaud Pass, 1903, Turecly' $566+$ (type); mountains northwest of Como, i 895 , Cowen ISoS.

\section{Stachys teucriformis sp. nov.}

Perennial, 4-6 dm. high ; stem round-angled, glandular-villous ; lower leaves short-petioled, the upper sessile; blades oblong or oblong-ovate to ovate, cordate or truncate at the base, 5-10 cm. long, crenate, pubescent on both sides; calyx glandular, villous, its lobes linear-lanceolate, long-aristate, about equaling the tube; corolla I $2-15 \mathrm{~mm}$. long, light rose, with reddish-purple veins and blotches; upper lip narrow and nearly straight; lower lip large, 3-lobed; lateral lobes triangular; middle lobe rounded-reniform.

The species is closely related to $S$. scopulormm, but differs from it in the larger corolla, the longer calyx-lobes and the usually broader leaves. The type sheet contains two specimens: one of S. tucriformis and one of Tucrium occidentale, and the two are so alike in foliage that it is hard to distinguish them except by the flowers and bracts. 
Colorano: New IVindsor, I S94, Ostcrhout (type); McCoy, I S98, Shicar \& Bessiy 5302 ; Colorado Springs, i 896, Shicar 5189.

\section{Monardella dentata sp. nov.}

Cespitose perennial, somewhat ligneous at the base; stems slender, light brown, about $3 \mathrm{dm}$. high; leaves short-petioled; blades ovate, $1.5-2 \mathrm{~cm}$. long, serrate-dentate, finely pubescent and strongly punctate, obtuse, strongly veined beneath; heads terminal, solitary, about $\mathrm{I} .5 \mathrm{cn}$. in diameter; bracts lanceolate, obtuse, nearly I cm. long, finely canescent, strongly veined, rather thick, of fully as firm structure as the upper leaves; calyx about $8 \mathrm{~mm}$. long, grayish pubescent; lobes lanceolate; corolla about $\mathrm{I} 2 \mathrm{~mm}$. long; its lobes linear, $4 \mathrm{~mm}$. long.

This has been mistaken for $M$. odoratissima, but is easily distinguished by the distinctly toothed leaves and the narrow firm bracts.

Colorano: Gray's Peak, is 72 , Torrey.

\section{Solanum interius sp. nov.}

Annual, more or less branched; stem 3-6 dm. high, usually with narrow denticulate margins or wings, finely pubescent with short white appressed crisp liairs; leaves with short winged petioles, sparingly pubescent above, usually densely grayish-strigose beneath; blades deltoid or rhombic, $3-7 \mathrm{~cm}$. long, acuminate, usually sinuately lobed or dentate with acute or acuminate lobes or teeth ; peduncles $2-4 \mathrm{~cm}$. long, strigose ; inflorescence corymb1form, rarely umbelliform; pedicels in fruit about $\mathrm{I} \mathrm{cm}$. long, recurved but scarcely reflexed; calyx-lobes ovate, $2 \mathrm{~mm}$. long, abruptly acute, in fruit appressed or spreading ; corolla yellowishwhite; lobes ovate, acute, 3-4 $\mathrm{mm}$. long; filaments very short, less than $0.5 \mathrm{~mm}$. long, glabrous; anthers oblong, about $2 \mathrm{~mm}$. long, yellow, obtuse, opening by terminal pores; berry greenish black, nearly i $\mathrm{cm}$. in diameter.

This has gone under the name of S. nigmum throughout the interior region where it is a native plant; but the true $S$. nigmm of Europe has almost glabrous leaves with rounded lobes if lobed at all, very obtuse sepals, subumbellate inflorescence and usually reflexed pedicels in fruit. S. interins is in reality more closely related to $S$. Donglasii, which, however, differs in the much larger and bluish corolla. It is with some doubt I propose this species as new, as several North American species were described by 
Dunal in De Candolle's Prodromus; but our plant does not agree with the description of any of these, except perhaps that of S. pterocaulon; a specimen of the latter cited by Dunal is in the herbarium of Columbia University, and this shows that it is more closely related to $S$. nodiflorum than to S. nigrum.

S. intcrius grows in river valleys and on sandy soil among bushes at an altitude of 600-1 $800 \mathrm{~m}$.

Nebraska: On Middle Loup River, near Mullen, i S93, Rydberg $I_{3} 85$ (type).

Kavsas: Reno County, i 897 , Hitcheock 362- $\alpha$.

Colorado: Near Boulder, igo2, Tuicaly 5236; Timnath, I899, Ostcrhout; along Platte River, Denver, i 878, M. E. Jones 605; Cañon City, 1896, Share 3777; Bent's Fort, I\$46, Lt. Abort.

Arizora: Chiricehun Mountains, is94, Tommey.

New Mexico: Mesilla, Dona Ana County, isgs, ITooton jo.

\section{Pentstemon strictiformis sp. nov.}

Perennial with a woody caudex; stems 3-5 dm. high, glabrous and strict, simple; basal leaves petioled, 5-10 cm. long; blades oblanceolate, obtuse, glabrous and slightly glaucous; stemleaves sessile, lanceolate, acuminate, $4-S \mathrm{~cm}$. long ; inflorescence more or less secund; caly'x-lobes lanceolate, acuminate, S-Io mm. long, more or less scarious and dentate on the margin; corolla violet-purple, funnelform, somewhat gibbous, about 2.5 $\mathrm{cm}$, long and limb nearly $2 \mathrm{~cm}$. wide; anthers long-villous with white hairs; sterile stamen villous with yellow hairs.

This is closely related to $P$. strictus, but differs mainly in the long-acuminate sepals. It grows up to an altitude of $2800 \mathrm{~m}$.

Colorado: Mancos, 1898 , Batior, Earle \& Tracy 76 (type); Gray-Back Nlining Camp, I900, Rydterg \& I Treclend 56,30; Arboles, I 899, Baker 602.

\section{Pentstemon oreophilus sp. nov.}

lerennial branched at the base, perfectly glabrous throughout, 2-4 dm. high; basal leaves oblanceolate, obtuse, short-petioled; stem-leaves lanceolate and sessile, 5-10 cm. long, acute or acuminate; inflorescence dense and usually more or less one-sided, calyx 8-10 mm. long; lobes lanceolate, long-acuminate with toothed scarious auriculate sides; corolla funneltorm, more or less gibbous, bluish purple, $12-15 \mathrm{~mm}$. wide at the mouth; lower lip 
more or less bearded within; anthers hispidulous on the margin and more or less short-hairy on the back and sides; sterile stamen with yellow beard at the end.

This is closely related to $P$. glaber and $P$. alpinus, differing from the former in the lower habit and the shape of the calyxlobes, which in $P$. glaber are orbicular or short ovate and with very scarious erose margins. $P$. alpimes Torr. $(=P$. riparins A Nels.), is more or less puberulent throughout. P. oreophilus grows at an altitude of $\mathrm{s} S 00-3600 \mathrm{~m}$.

Colorado: Eldora to Baltimore, 1903, Trecedy 5711 (type) and 5710: Halfway House, IS96, Shcar +781 ; Manitou, 1 S96, Clinc'nts I7I; Larimer County, I \$93, Crandall; Quartz Ridge, Pike's Peak, Clemcnts 113: South Cheyenne Cañon, i S95, E. A. Besscy; mountains near Empire, I S92, Pattorson 256.

\section{Pentstemon cyathophorus sp. nov.}

Perennial and more or less cespitose at the base, glabrous throughout or the basal leaves minutely puberulent; stem very strict, 3-4 dm. high; basal leaves spatulate, petioled, $3-6 \mathrm{~cm}$. long; lower stem-leaves also spatulate; the others ovate or orbicular, often abrubtly acuminate or mucronate; bracts round, ovate or orbicular, abruptly short-acuminate, the upper usually scariousmargined and erose, reniform and the pairs together resembling a cup; calyx 6-S mm. long; lobes lanceolate, scarious-margined and more or less erose-dentate; corolla pink-purple, a little over I $2-15 \mathrm{~mm}$. long, more or less open funnelform from a narrow tube, little oblique and scarcely gibbous ; anthers glabrous ; sterile stamen spatulate at the apex and with a yellow beard.

This is closely related to the northern $P$. acuminatus and has been mistaken for it, but differs in the scarious-margined and toothed calyx-lobes and upper bracts. It grows in mountain meadows at an altitude of $2500-3000 \mathrm{~m}$.

Colorado: Pearl, igor, Tacecty 7307 (type); Grizzly Creek, IS96, Baker; also IS94, Crandall $1+3 \mathcal{S}$; North Park, IS96, Osterhout 59; also I $89 \mathrm{I}$, Crandall I 739.

\section{Castilleja brunnescens sp. nov.}

Perennial with a short cespitose caudex; stens 3-5 dm. high, more or less pubescent and purplish; leaves narrowly linearlanceolate, more or less distinctly 3-nerved, $4-5 \mathrm{~cm}$. long, finely pubescent; bracts ovate to oblong-lanceolate, obtuse or rouncled 
at the apex, entire or with a short tooth on each side, tinged with pale brown ; calyx about $2 \mathrm{~cm}$. long, densely and finely pubescent, cleft about equally deep in front and on the back; each division with 2 lanceolate lobes, about $3 \mathrm{~mm}$. long; corolla about $3 \mathrm{~cm}$. long; upper lip about I cm. long; lower about $3 \mathrm{~mm}$.

This species may be most closely related to $C$. confusa Greene, but is easily distinguished by the light brownish color of the obtuse bracts. On account of this light color the type-specimens were labeled $C$. pallida, which it resembles somewhat but has an altogether different corolla. It grows in the mountains at an altitude of $2700-3300 \mathrm{~m}$.

Colorado: Cameron Pass, i 896, Baker (type); Gray's Peak, IS7 I, Porter; Red Mountain, south of Ouray, I901, Underwood \& Sclby 293; Pike's Peak, I S94, E. A. Besscy'.

\section{Castilleja obtusiloba sp. nov.}

Perennial with a very short caudex; stem very sparingly hairy, 3-4 dm. high ; lower leaves oblong-lanceolate, 3-nerved, minutely pubescent, 3-4 cm. long, entire; the upper broader, 3-cleft ; lateral lobes lanceolate; the middle one oblong, obtuse; bracts similar, but broader, purple; middle lobe elliptic, rounded at the apex; calyx about $2.5 \mathrm{~cm}$. long, almost equaling the corolla, equally deeply cleft in front and on the back; lobes short, oblong and rounded at the apex; corolla yellowish and purple-tinged; upper lip nearly I cm. long; lower nearly $3 \mathrm{~mm}$.

This species is perhaps a near relative of $C$. rhcrifolic and $C$. confusa, but casily distinguished by the peculiar bracts and short and very obtuse calyx-lobes. It grows at an altitude of about $2700 \mathrm{~m}$.

Colorado: Leroux Park, Delta County, I S92, Coutin.

\section{Castilleja puberula sp. nov.}

Perennial with a short cespitose caudex; stems less than I dm. high, finely puberulent; leaves $2-3 \mathrm{~cm}$. long, pinnately divided into linear lobes or entire and linear, finely puberulent; bracts similar, but shorter and broader, tinged with yellowish, often more villous; calyx more or less villous, I-I.5 cm. long, deeper cleft in front than on the back; lobes lanceolate, acute; corolla yellowish, I $8-20 \mathrm{~mm}$. long; upper lip 6-8 $\mathrm{mm}$. long; lower lip 3-4 mm., very gibbous.

This species has been taken for C. brachyantha Rydb. (C. brait- 
flord A. Gray); but that species is a much taller plant and the galea is about three times as long as the lower lip. It grows at an altitude of $2500-3600 \mathrm{~m}$.

Colorado: i 872, Parry (type, in herb. Columbia University): Empire, 1903, Twucedy $57 t_{2}$; Berthoud Pass, 1903, Tuvecdy $57 t^{1}$.

\section{Valeriana trachycarpa sp. nov.}

Perennial with a thick fleshy root; stem glabrous or nearly so, 5-7 dm. high; basal leaves oblanceolate or spatulate, 7-1 8 $\mathrm{cm}$. long, finely puberulent, especially on the margins and veins; entire or with a few linear lobes, thick; stem-leaves I-2 pairs, pinnatifid with linear tobes; inflorescence large and branched; corolla of the staminate plant $2.5-3 \mathrm{~mm}$. wide; that of the essentially pistillate plant about $1.5 \mathrm{~mm}$. wide; fruit broadly ovate, not hairy, but strongly rugose.

This is closely related to $I^{\prime}$. colulis and $I^{\prime}$. purpurascons, but the former has pubescent ovary and fruit and narrower bracts, and the latter has narrower fruit, narrower leaves, more slender inflorescence and smaller staminate flowers, only $2 \mathrm{~mm}$. wide; $I$. trachycarpa grows at an altitude of $2500-3000 \mathrm{~m}$.

Color.1Do: Red Mountain, I90 I, Underwood \& Selby 352 (type): Alpine Tunnel, $4 f_{I}$; Marshall Pass, I90I, Baker $48 I$; Rabbit Ears Pass, i 896, Bakcr.

New Mexico: White Mountains, I897, Wooton 320.

\section{Valeriana ovata sp. nov.}

Perennial with a rootstock; stem about $3 \mathrm{dm}$. high, glabrous; basal leaves entire, petioled, glabrous; petioles $2-6 \mathrm{~cm}$. long; blades ovate, usually truncate or slightly cordate at the base, acute, entire or sinuate; stem-leaves $2-3$ pairs; lateral lobes oblong to linear-lanceolate; the terminal one lanceolate or of the lower leaves elliptic; inflorescence small and corymbiform; corolla funnelformsalvershaped, about $8 \mathrm{~mm}$. long; limb of the fertile flowers about $4 \mathrm{~mm}$. wide; of the staminate ones about $6 \mathrm{~mm}$. wide; fruit ovate, glabrous.

This species belongs to the $I$. septentrionalis group, but is characterized by its basal leaves. It grows on wooded hillsides at an altitude of $2400-2900 \mathrm{~m}$.

Colorado: Cameron's Cove, igor, Clements $2+1$ (type).

New Mexico: Cañon four miles east of Santa Fé, I 897, Heller:3613; Elizabeth Town, I 897, Berg. 


\section{Coleosanthus albicaulis sp. nov.}

Brickellic Wrightii and B. californica A. Gray, Syn. F1. I": 106 ; both in part. ISS4.

Shrubby at the base, $0.5-1 \mathrm{~m}$. high; bark of the older wood brownish, striate and fissured, that of the younger branches strawcolored or grayish, hirsute-puberulent, more or less flaky; leaves short-petioled; blades broadly cordate, $2-5 \mathrm{~cm}$. long, strongly veined, thick, scabrous-puberulent, crenate-dentate; inflorescence consisting of small axillary clusters scarcely exceeding the leaves, of 2-6 heads on short peduncles; heads I $0-20$-flowered; involucres turbinate; lower bracts short-ovate, the inner linear, all acutish or obtuse, greenish straw-color; corolla cream-color; pappus white.

This has been confused mostly with $C$. Ilirghtii, but the type of that species has more ovate leaf-blades, longer petioles, longer flower clusters, which exceed the leaves, and purple-tinged involucre, the bracts of which are very obtuse or rather rounded at the apex. It is rather nearer Coleosanthus reniformis (Brickellic reniformis A. Gray); from which it differs mainly in the longer, cordate, not reniform leaf-blades and larger and sharper teeth. It grows on the foothills and in cañons at an altitude of $1500-2500 \mathrm{~m}$.

Colokado: Manitou, igoo, Clements (type) ; Larimer County, ISgI, Coucen: Lower Boulder Cañon, I90I, Ostcrhout 2 III ; Spring Cañon, I 897, Crandall 2785; Manitou, I 896, Shar +589; Golden, I 895, Shear 3261; Mount Harvard, 1896, Clemcnts 63; Golden, I 895 , Rydberg; Boulder, I 885 , Letternan.

UTגн: Salt Lake City, ISSO, M. E. Jones I92I; Wahsatch Mountains, I 869, II'atson 495 ; Provo, I 887, Tracy \& Ez̃ans jog.

\section{Grindelia serrulata sp. nov.}

Biennial or perhaps slort-lived perennial; stem glabrous, about $6 \mathrm{dm}$. high; leaves sessile, oblanceolate or oblong, acutish, very viscid, $3-5 \mathrm{~cm}$. long, finely and densely serrate; inflorescence corymbiform; involucre very viscid, about $\mathrm{I} 5 \mathrm{~mm}$. broad; bracts subulate, very squarrose and reflexed; ligules $7-8 \mathrm{~mm}$. long, II. $5 \mathrm{~mm}$. wide; pappus-awns apparently smooth; barbules seen only under a compound microscope.

This is nearly related to $G$. perennis and $G$. squarrosa. From the former it differs in the closely and sharply toothed leaves, and from the latter in the oblanceolate instead of ovate or oval leaves. It grows on plains at an altitude of about $1500 \mathrm{~m}$. 
Colorado: Fort Collins, i 89 i, Cou'cu (type); Denver, i 869 , B. H. Smith.

\section{Grindelia aphanactis sp. nov.}

Apparently perennial; stem 3-4 dm. high, glabrous and striate ; leaves very viscid, oblanceolate, acute, $4-7 \mathrm{~cm}$. long, sharply dentate and sessile, or the lower more or less pinnatifid and petioled; inflorescence corymbiform; heads about $15 \mathrm{~mm}$. broad; bracts very viscid, subulate; all very squarrose and the lower reflexed; rays none; awns of the pappus apparently smooth.

This species has been confused with $G$. mudd Wood, but that species has broad leaves and large heads and resembles in general habit more the radiate $G$. squarrose. G. aphanactis grows in gravelly soil.

Colokado: Durango, i 898 , Biaker, Earle \& Tracy 526 (type). New Mexico: Lincoln, Earle.

\section{Gutierrezia linearis sp. nov.}

Shrubby and branched; leaves linear, about $3 \mathrm{~cm}$. long, I-2 mm. wide, puberulent and viscid, punctate; heads $5-6 \mathrm{~mm}$. high ; involucres campanulate, slightly turbinate at the base; bracts scarious-margined; the outer ovate or obovate, the inner elliptic, obtusc; inflorescence corymbiform; ray-and disk-flowers each 3-4.

This species resembles $G$. longifolia in habit but has the head of $G$. diatersifolia. It grows at an altitude of $1800-2300 \mathrm{~m}$.

New Mexico: Gray, Lincoln County, igoo, Earle tit (type).

Colorado: Gumison, igor, Baker $2_{2}$; Red Rock Cañon, Isgo, E. A. Bessey.

\section{Gutierrezia scoparia sp. nov.}

Wroody only at the base; flowering herbaceous branches numerous, about $3 \mathrm{dm}$. high, puberulent, mostly simple up to the inflorescence; leaves linear, $3-5 \mathrm{~cm}$. long, I-2 mm. wide, puberulent; inflorescence corymbiform ; involucre oblong-turbinate, orer $5 \mathrm{~mm}$. high ; outer bracts lanceolate, inner oblong ; disk-and rayflowers each about 4 .

This is closely related to G. dirersifolid, but has a longer, more turbinate involucre and narrower bracts. It grows at an altitude of $\mathrm{I} 500-2 \mathrm{IOO} \mathrm{m}$.

Colorado: Manitou, igoi, Clements if (type); Boulder, I902, Treecty 4988 . 


\section{Chrysopsis caudata sp. nov.}

Perennial, with a thick tap-root and a very short, erect and much-branched caudex; stems many, erect, purplish, hirsute with long white hairs; lower leaves oblanceolate, tapering into a short petiole, silky-strigose on both sides, $3-5 \mathrm{~cm}$. long ; middle leaves similar but sessile, uppermost elliptic or oblong; heads congested in small clusters at the end of the branches and subtended by the uppermost leaves; bracts linear-lanceolate, hirsute, the innermost with a subulate usually brownish and spreading tip; disk about 15 $\mathrm{mm}$. wide ; rays bright yellow, about $\mathrm{I} 2 \mathrm{~mm}$. long and $3 \mathrm{~mm}$. wide.

This species is closely related to $C$. villosa, but differs in the sessile heads subtended by oblong leaves and in the subulate tips of the involucral bracts. It grows on hills at an altitude of I $500-$ $2950 \mathrm{~m}$.

Colorano: Ruxton Dell, igor, Clements if3 (type); near Boulder, I 902, Titut!' +897 .

\section{Chrysopsis amplifolia sp. nov.}

Perennial, with a tap-root, rather simple; stem 3-5 dm. high, often branched, pubescent and sparingly hirsute; lower leaves spatulate, strigose, obtuse or slightly mucronate, middle and upper leaves broadly oblong or elliptic ; the upper cordate or truncate at the base, 3-4 cm. long, I 2-15 mm. wide; inflorescence corymbiform; heads usually subtended by oblong leaves; bracts hirsutestrigose, linear-lanceolate, acute; disk i $5 \mathrm{~mm}$. or more wide; rays golden yellow, about $12 \mathrm{~mm}$. long and $2.5 \mathrm{~mm}$. wide; achenes densely strigose-canescent.

This is also closely related to $C$. villosa, but distinguished by the ample upper stem-leaves with subcordate or truncate bases and the large sessile heads. It grows on plains and foothills at an altitude of about $\mathrm{I} 500 \mathrm{~m}$.

Colorado: Longmont, I 902 , Tiwedy $489 S$ (type): Ward, I 901 , Osterhout $27+t$.

\section{Chrysopsis horrida sp. nov.}

Perennial with a tap-root, more or less cespitose; stems about 2-3 dm. high, hirsutulous and hispid, more or less branched, especially above; leaves obovate, broadly oblanceolate or oblong, subsessile, except the lower, densely hirsute with short hairs and slightly glandular-puberulent; heads corymbose, peduncled, about $8 \mathrm{~mm}$. high; disk $\mathrm{I} \mathrm{cm}$. or less wide; rays about $8 \mathrm{~mm}$. long and I-I.5 mm. wide; achenes $2 \mathrm{~mm}$. long, canescent; pappus about $5 \mathrm{~mm}$. long, yellowish. 
This has been taken for C. hispida, but the original Diplopappus hispidus Hook. is less hairy with longer hairs and more viscid; the leaves are narrowly oblanceolate and petioled and the heads larger, the disk being $12-15 \mathrm{~mm}$. wide. C. horrida grows on dry hills and plains at an altitude of $1200-1600 \mathrm{~m}$.

Colorado: New Windsor, I900, Osterhout 2,326 (type), and I901, 2362; Platte, Frémont.

Nebraska: Pumpkin Seed Valley and Lawrence Fork, I 89I, Rydberg $I+I$.

\section{Chrysopsis alpicola sp. nov.}

Cespitose perennial; stems about I dm. high, silky-v1llous, numerous; leaves oblanceolate, about $3 \mathrm{~cm}$. long; nearly all petioled, white-silky strigose or the pubescence more spreading on the petioles; heads solitary, subsessile, about I cm. high ; bracts linear-lanceolate, hirsute, acute; disk about $12 \mathrm{~mm}$. in dianeter; rays about $8 \mathrm{~mm}$. long and $2 \mathrm{~mm}$. wide; achenes white silkyhirsute.

This is perhaps most closely related to C. Bakcri, but is much lower, more silky, with sessile heads and nore hirsute involucre. It grows on the higher mountains, at an altitude of about $3500 \mathrm{~m}$.

Colorado: Clark's Peak, i \$96, Berker.

\section{Solidago rubra sp. nov.}

Stout, about $3 \mathrm{dm}$. high ; stem pubescent or at the base merely puberulent, reddish; basal and lower cauline leaves broadly oblanceolate, 6-I $2 \mathrm{~cm}$. long, firm, bluish-green, glabrous, pinnately veined, serrulate and minutely scabrous on the margins, acute, petioled; upper stem-leaves sessile and lanceolate; inflorescence paniculate but very narrow and elongated; heads about $8 \mathrm{~mm}$. high. and as broad; bracts narrowly linear-lanceolate, acute, ciliolate on the margin ; rays rather pale yellow, about $4 \mathrm{~mm}$. long and $0.7 \mathrm{~mm}$. wide; achenes strigose.

This species is related to $S$. scopulormm, but is distinguished by the stouter habit, the broad leaves, the compound and dense inflorescence.

Colorado: North Park, I 899, Osterhout 5.

Solidago laevicaulis sp. nov.

Rather tall, 4-7 dm. high; stem glabrous up to the inflorescence, light-colored and shining; basal leaves narrowly oblanceo- 
late, indistinctly if at all triple-nerved, rather thin, obtuse, 5-10 $\mathrm{cm}$. long, entire or crenate above, glabrous except the scabrous margin ; lower stem-leaves similar; upper stem-leaves narrowly lanceolate, sessile; inflorescence paniculate, but rather narrow, with numerous heads; branches nearly erect; heads about $\$ \mathrm{~mm}$. high ; bracts narrowly linear-lanceolate, acute, ciliolate on the margin; disk about $8 \mathrm{~mm}$. wide; rays numerous, about $4 \mathrm{~mm}$. long and nearly I mm. wide; achenes sparingly strigose.

This is nearest related to the preceding, but taller and more slender, with narrower leaves and glabrous stem. It approaches the S. scrotina group but has neither triple-nerved leaves nor secund branches. It grows in the mountains of Colorado and southern Wyoming at an altitude of $250 \mathrm{~T}-3300 \mathrm{~m}$.

Colorado: North Park, I 899, Osterhout + (type); Berthoud Pass, I903, Truecdy 5857 .

IVyomisg: Copperton, Igoi, Tücaly toog.

\section{Solidago radulina sp. nov.}

Perennial; stem 3-4 dm. high, grayish-puberulent; basal and lower cauline leaves spatulate, obtuse, crenate at the apex, finely puberulent; upper stem-leaves elliptic or spatulate, acute; inflorescence narrow and elongated, paniculate; heads about 4 $\mathrm{mm}$. high; bracts oblong, obtuse, or the inner linear, ciliolate on the margin ; rays about $2.5 \mathrm{~mm}$. long, I $\mathrm{mm}$. wide; achenes hirsutulous.

This species is intermediate between $S$. nana and $S$. fulchrrima, but differs from the former in the taller habit and the elongated inflorescence and from the latter in the broader and shorter stem-leaves. In leaf-form it resembles somewhat $S$. radulc, but is a smaller plant, with smaller leaves and narrow inflorescence, the branches of which are short and only somewhat secund. The type grew at an altitude of $\mathrm{I} 800 \mathrm{~m}$.

Utah : Cottonwood Cañon, I 869 , IVatson 558 (type in herb. Columbia University).

Colorado: Meadow Park, i 895, Shear 5079.

\section{Solidago serra sp. nov.}

Perennial with a rootstock; stem simple up to the inflorescence, about $6 \mathrm{dm}$. high, more or less pubescent especially above; leaves lanceolate, about $8 \mathrm{~cm}$. long, acuninate, sharply toothed, rather 
thin, glabrous on both sides; inflorescence paniculate; branches arching and secund; heads numerous, $3-4 \mathrm{~mm}$. high; bracts linear or linear-lanceolate, acute; rays I-I.5 mm. long, less than $0.5 \mathrm{~mm}$. wide; achenes hirsutulous.

This is closest related to $S$. conadcnsis, but differs in the glabrous leaves and the less pubescent stem. It may also be confused with S. scrotina and S. clongata, but the former has much larger heads, fully $5 \mathrm{~mm}$. high, and in the latter the inflorescence is narrower, rhombic in outline and with ascending scarcely arched branches.

Colorado: Tampa, is98, Sheer \& Bessey $527+$ (type).

Wromng: Copperton, igo I, Tacetely too7.

\section{Solidago polyphylla sp. nov.}

Tall, sometimes a meter high; stem strict, simple and puberulent up to the more hirsutulous inflorescence; leaves narrowly lanceolate, sessile, acute at the base, acuminate at the apex, distinctly triple-nerved, serrate above the middle with small distant teeth, thick and firm, green, scabrous above, more softly shortpubescent beneath; inforescence panicled; branches more or less arching and secund; heads about $5 \mathrm{~mm}$. high ; bracts linear, acute ; rays $1.5-2 \mathrm{~mm}$. long, $0.5 \mathrm{~mm}$. wide; achenes hispidulous.

This species is closely related to $S$. procera and has been mistaken for it. It differs from that species in the larger heads (in S. procera only 3-4 $\mathrm{mm}$. high), the more compact inflorescence, the more toothed upper leaves and the shorter pubescence on the stem and lower leaf-surfaces.

Colorado: Cañon City, i S96, Clements 295 (type); Gumnison, 1901, Baker 999 ; Engelmann Cañon, 1901, Cluments foo.

New Mexico: Roswell, i goo, Earle j $f 6$.

\section{Solidago viscidula sp. nov.}

Low, about $2 \mathrm{dm}$. high; stem finely pubescent, reddish; basal leaves and lower stem-leaves narrowly linear-oblanceolate, finely puberulent and somewhat viscid, denticulate, obtuse or acutish, indistinctly triple-veined; upper stem-leaves sessile; inflorescence paniculate but flat-topped, branches scarcely secund; heads numerous, small, about $5 \mathrm{~mm}$. high ; bracts linear, obtusish, viscid ; rays pale, about $2 \mathrm{~mm}$. long and $0.5 \mathrm{~mm}$. wide.

This is closely related to S. missomiensis, but is distinguished by the viscid inflorescence and the indistinctly triple-nerved leaves.

Colokado: Grand Lake, isss, Hola'ar'. 


\section{Oligoneuron canescens sp. nov.}

Solidago rigida humilis Porter Syn. Fl. Colo. 63, I874. Not S. humilis Mill.

Stout perennial; densely yellowish-canescent throughout ; stem simple up to the inflorescence, 5-7 dm. high ; basal leaves longpetioled; blades oval, $7-12 \mathrm{~cm}$. long, thick, canescent on both sides, in age scabrous, distantly crenulate with small callous teeth ; upper stem-leaves oval, sessile, entire or sinuate, crenulate, very densely canescent ; inflorescence corymbiform but much congested; heads about I cm. high; bracts oblong, striate, canescent; rays 3-4 min. long, less than I cm. wide, light yellow; achenes slightly hairy above, otherwise glabrous.

This differs from 0 . rigidum Small (Solidago rigida L.) in the shorter leaves, the smaller and denser inflorescence, the dense yellowish-canescent pubescence, and the achenes which are apparently always slightly hairy above. It grows on prairies and in valleys at an altitude of 900-1 $800 \mathrm{~m}$.

Wrosing: Buffalo, I900, Taucedy 3IIT (type); Dayton, I 899, Truedy 20I7; Devil's Tower, I 899, L. IV. Carter.

Nebriska: Plummer Ford, Dismal River, i 892, Rydlborg I666.

South Dakота: Custer, i $892, R_{y}$ dborg 769.

North Dakota: Tower, Is9i, Wright.

\section{Chrysothamnus patens sp. nov.}

Shrubby, half a meter or so high; stems white-tomentulose when young, soon glabrous and yellowish green; leaves $6-8 \mathrm{~cm}$. long, about I $\mathrm{mm}$. broad, soon glabrous, spreading or even reflexed; bracts lanceolate, acute, carinate, glabrous, in 5 vertical rows of about 3 each ; corolla-lobes about I mm. long, lanceolate, acute, in age more or less spreading; achenes strigose.

This is closely related to C. grarcolcus, but differs in the narrow, spreading leaves. It grows on dry hills at an altitude 0 I 300-2 I00 $\mathrm{m}$.

Colorado: I873, IVolf 752 (type); Grand Junction, I90I, Underaod \& Selby 1986; I900, Stokes; Manitou, I900, Clements; Alamosa, I896, Shear 3753; Zola, I901, Baker 668.

\section{Chrysothamnus Newberryi sp. nov.}

Shrubby below; stem white-tomentose, rather slender : leaves erect, linear-filiform, I-nerved, slightly tomentulose when young; 
the upper smaller; involucres turbinate; bracts in about 5 vertical rows, usually 3 in each row, narrowly lanceolate, attenuate into a long slender subulate spreading tip, carinate, slightly tomentulose and webby; achenes narrow, tapering downwards, strigose-pubescent ; corolla narrowly tubular-funnelform ; lobes erect, lanceolate.

This species is closely related to C. Parry and C. Hoarardi, but the former differs in the broad, 3-nerved leaves and broader bracts, and the latter by its spreading arcuate leaves, broader bracts, depressed habit and elongated upper leaves, which usually equal or exceed the heads. C. Vewboryi grows on dry hills.

New Mexico: Cañon Largo, i 859, Newbery (Macomb's Expedition ; type in herb. Columbia University).

Colorado: Mesa Verde, i 892, Eastwood.

\section{Sideranthus annuus nom. nov.}

Aplopappus mbiginosus A. Gray, Syn. 11. I²: I 30. ISS4. Not Torr. \& Gray, I1. 2 : $240 . \quad 1842$.

A little comparison between the descriptions of A. mbiginosus in Torrey and Gray's Flora and in Gray's Synoptical Flora will show that they are drawn from different plants. The first line in Torrey and Gray's description, viz. "suffruticose? branching from the base, viscidly pubescent and cinereous" and further down "scales of the involucre... in about 2 series, nearly equal, loose, at length spreading " do not at all fit the plant of the upper Platte, for that plant is strictly annual, simple at the base and branched above, viscid but can hardly be called cincreous; the bracts are in 4 or 5 series, well imbricated and the outer much shorter. The type of Aplopappus mbigmosus was collected by Drummond, and a specimen is in the Gray herbarium. This is very unlike the plant of the upper Platte region, which is described in Gray's Synoptical Flora, but agrees fully with the description of Torrey and Gray. It is more closely related to A. plyyllocepha'us DC., but perhaps distinct.

\section{Aster griseolus sp. nov.}

Perennial with a horizontal rootstock; stem I-I.5 dm. high, hirsute with ascending hairs, rather simple; leaves linear, $3-5 \mathrm{~cm}$. long, sparingly hairy on both sides, sessile, acute, entire; heads about $1 \mathrm{~cm}$. higll, I-4 in a small corymb; bracts oblanceolate or 
linear, the outer obtuse, the inner acute, green or the inner white on the sides below, pubescent on the back, but not bristle-pointed ; rays purple, about $8 \mathrm{~mm}$. long and $\mathrm{I} \mathrm{mm}$. wide; achenes pubescent.

This is nearest related to $A$. grisens Greene, but differs in the small size, the narrow short sessile leaves, and the pubescence which is not reflexed on the lower part of the stem. A. griscolus grows on the higher mountains of Colorado.

Colorado: Mt. Harvard, is96. Clements 37 (type); Twin lakes, is96, Shar 3 190 .

\section{Aster Underwoodii sp. nov.}

l'erennial with a horizontal rootstock; stems simple up to the inflorescence, 2-3 dm. high, often purplish, more or less hirsutestrigose; lower leaves spatulate or oblanceolate, tapering into a winged petiole, glabrous except the ciliolate margin or slightly pubescent when young; the other stem-leaves sessile and the uppermost linear-lanceolate; inflorescence racemiform or corymbiform with 4-8 heads; these fully $1 \mathrm{~cm}$. high; bracts oblanccolate, the outer obtuse, the inner acutish, all with a rather thick green tip, pubescent on the back; rays purple or bluish, about $1 \mathrm{~cm}$. long and $1-1.5 \mathrm{~mm}$. wide; achenes hirsute.

This is related to $A$. adscondins and A. Volsonii. From the former it differs in the hairy bracts and from the latter in the broad leaves. It suggests also 4 . griscus, but has shorter and almost glabrous leaves. It grows at an altitute of 2500-3000 m.

Colorado: Ironton Park, igor, Lnderriood and Selby is (type); Eldora to Baltinore, 1903, Tawedy $583 \pi$.

\section{Aster Osterhoutii sp. nov.}

Tall, branched and leafy, about I mm. high ; stem striate, glabrous below, hairy in decurrent ines above; leaves linear or linear-lanceolate, $5-12 \mathrm{~cm}$. long, $8 \mathrm{~mm}$. wide or less, scabrousciliolate on the margin, otherwise glabrous, entire-margined, sessile and half clasping; those of the branches much smaller; inflorescence open-paniculate; heads nearly I cm. high; bracts in $4-5$ series, the inner linear, acute, the outer oblanceolate, apiculate, green and with white margins below: rays white or rarely pinkish, nearly i cm. long and fully $1 \mathrm{~mm}$. wide.

This species is related to $A$. salicifolius, but differs in the narrow, thin, entire leaves. Mr. Fernald, to whom some of the specimens had been sent, named it $A$. salicifolius cacmlescens Gray, but that 
has very narrow, linear outer bracts and usually purplish or bluish rays. A. Ostcrhoutii grows along ditches at an altitude of about I $500 \mathrm{~m}$.

Colorado: New Windsor, 1899. Ostorhut 2506 (type); also 1898,9 , and I 900,2328 .

\section{Aster corymbiformis sp nov.}

About 3 dm. high; stem strict, branched above, pubescent on decurrent lines; leaves linear, 5-8 $\mathrm{mm}$. long, scabrous on the margins, otherwise usually perfectly glabrous, half-clasping; inflorescence leafy, corymbiform; heads about $8 \mathrm{~mm}$. high ; bracts linear-lanceolate, very acute, glabrous, rather firm, with an oblanceolate green tip, in about 3 series of nearly equal length; rays white or purplish, about $7 \mathrm{~mm}$. long and $\mathrm{I} \mathrm{mm}$. wide.

This is perhaps nearest related to $A$. panculatus, but in luabit reminding somewhat of $A$. adscoudens. From the former it differs in the strict habit, the corymbiform inflorescence and the entire leaves. From A. alsccudcus it differs in the more numerous heads and the bracts, the outer of which at least are oblanceolate and obtuse in $A$. adscondens.

Colorado: West Cliff, 1896 , Shar if6o (type); also is 13 and $3 S_{19}$ : Parlin, Gunnison Co., Igor, D. H. Smith IIt and I I 6 (?).

\section{Aster Tweedyi sp. nov.}

Perennial with a horizontal rootstock; stem simple, usually purplish, pubescent only on decurrent lines, about $4 \mathrm{dm}$. high ; leaves oblanceolate, acute, glabrous except the ciliate margin, rather firm, often I $\mathrm{dm}$. long; the lower with a winged petiole; the upper sessile and half clasping ; inflorescence paniculate, leafy ; heads about I cm. high; bracts in about 3 series, linear or oblanceolate, not very unequal in length, the outer mostly green and obtuse, the inner with green tips and midrib, whitish on the sides below; rays rose or purple, $8-10 \mathrm{~mm}$. long and $1.5 \mathrm{~mm}$. wide .

This species is related to 4 . adscondens but differs in the stouter habit, broader and firmer leaves and larger heads. It grows in valleys at an altitude of $\mathrm{I} 500-2600 \mathrm{~m}$.

Wroming: Copperton, I90 I, Taecedy fog6 (type); Big Horn Mountains, I 899, Treecty 2523; Laramie, 1897 , Elices Velson 152.

Colorado: Laramie River, Larimer County, I897, Ostrrum 2518 . 

CONTRIBUTIONS FROM THE NEW YORK BOTANICAL GARDEN-No. 66

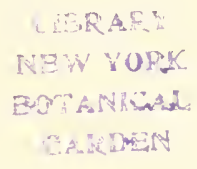

\section{STUDIES ON THE ROCKY MOUNTAIN FLORA-XIV}

BY PER AXEL RYDBERG

NEW YORK

1905

[From the BULletis of the TORBeY BOtaniCAL CLUB $32:$ 123-188. 1006] 



\section{Studies on the Rocky Mountain flora-- XIV}

\author{
Per Axel Rydrerg,
}

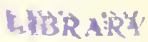

NEW YORK

BOTANICAL

OARDEN

\section{Machaeranthera Fremontii sp. nov.}

Biennial with thick taproot; stems several, glandular-hispid and somewhat puberulent, 4-5 dm. high, branched; basal leaves oblanceolate, petioled, glandular-hispid and scabrous, sharply dentate; upper leaves sessile, linear or lanceolate; heads over $1 \mathrm{~cm}$. high; bracts linear-lanceolate, cinereous, acuminate, well imbricated; herbaceous tip short, lanceolate, only slightly squarrose; rays purple, $8-10 \mathrm{~mm}$. long; achenes densely strigose; pappus brownish or reddish.

It grows in black soil of river bottoms.

Colorado: "Platte Waters," I 844 , Fremont $42 I$ (type in herb. Columbia Univ.).

\section{Machaeranthera Selbyi sp. nov.}

Biennial; stem reddish, branched above, glabrous below, puberulent or minutely strigose above, only slightly glandular in the inflorescence; lower leaves linear-oblanceolate to oblanceolate, petioled, glabrous or rarely slightly puberulent, dentate and ciliate on the margin ; upper leaves linear ; inflorescence branched and open ; heads about I cm. high; bracts in many series, well imbricated; glandular green tips small, lanceolate, strongly reflexed-squarrose; achenes minutely strigose.

This is perhaps nearest related to $M$. spectabilis, but that species has entire leaves and longer green tips to the bracts. It is also related to $M$. glabrella and $M$. ramosa, from which species it differs in the reflexed-squarrose bracts.

Colorado: Ouray, igor, Underaod \& Selby $93 a$ (type), $204,2045,201$ and 202 . 


\section{Machaeranthera viscosula sp. nor.}

Biennial with a rosette of basal leaves; stems few, about $2 \mathrm{dm}$. high, viscid-puberulent; basal leaves oblanceolate, petioled, the upper similar or linear, but sessile; all saliently and coarsely toothed; inflorescence narrow and racemiform, very viscid; heads about I $\mathrm{cm}$. high; bracts linear, with a long linear-subulate spreading or reflexed green and very glandular tip, usually longer than the chartaceous lower portion; rays reddish-purple, 8-IO $\mathrm{mm}$. long and fully I mm. wide; achenes sparingly strigose; pappus tawny.

This is closely related to $M$. riscosa, but differs in the lower stature, the racemiform inflorescence and the narrow saliently toothed basal leaves.

Colorano: Veta Pass, I 896 , Shear 3655; South Park, southeast of Jefferson, I 896 , Cowen 3222.

\section{Xylorrhiza Brandegei sp. nov.}

Perennial with a cespitose caudex, canescent throughout, almost I dm. high; leaves spatulate or the upper oblanceolate, 3-4 cm. long, firm, closely and sharply serrate with bristle-tipped teeth; disk about $3 \mathrm{~cm}$. wide; bracts narrowly linear-lanceolate, attenuate ; achenes oblong, densely grayish-strigose, pappus tawny; rays rose-purple, $15-20 \mathrm{~mm}$. long.

Closely related to $\mathrm{X}$. coloradensis (Astcr coloradensis Gray), but differs in the larger size, longer rays and scarcely spinescent bracts. It grows at an altitude of $3000 \mathrm{~m}$.

Colorado: San Juan Pass, i 875, Brandegee (type in the Gray herbarium).

\section{Erigeron nematophyllus sp. nov.}

Depressed cespitose-pulvinate perennial ; flowering stems several, strigose, about $5 \mathrm{~cm}$. high, few-leaved; both basal and cauline leaves linear-filiform, 2-4 cm. long, less than I mm. wide, strigose; heads solitary, $4-5 \mathrm{~mm}$. high; bracts linear in $\mathrm{I}-2$ series, scarcely at all imbricated, acute, hirsute-strigose; rays pinkish or white, 4-5 $\mathrm{mm}$. long and I mm. wide; achenes sparingly hirsute.

This is closely re'ated to E. radicatus, but differs in the very narrow and erect leaves. It grows on rocky hills.

Colorado: Dale Creek, I \$97, Osterhout (type).

Wroming: Fort Steele, I901, Taicedy f103: Sand Creek, i 900, Aien Nelson 6993. 


\section{Erigeron salicinus sp. nov.}

Perennial with a slender rootstock; stem simple, 4-7 dm. high, glabrous or minutely and sparingly strigulose above; lower leaves petioled, about $\mathrm{l} \mathrm{dm}$. long; blades oblanceolate, dark bluish-green, glabrous except the minutely ciliolate entire margins, more or less distinctly 3-nerved; upper leaves linear or linearlanceolate, sessile and half-clasping; inflorescence corymbiform, leafy; heads $7-8 \mathrm{~mm}$. high; bracts linear-subulate, acuminate, glandular-puberulent, not at all hirsute, in 2 series but almost equal and crowded; disk I $2-15 \mathrm{~mm}$. wide; rays very numerous, fully $1 \mathrm{~cm}$. long and less than $1 \mathrm{~mm}$. wide, purple.

This is perhaps nearest related to E. macranthus, differing in the bluish-green narrow leaves, which are minutely ciliolate on the margin instead of hirsute-ciliate, and in the smaller heads.

Colorado: Pagosa Springs, i 899, Baker 670.

\section{Erigeron Vreelandii sp. nov.}

Perennial with a rootstock; stem 6-7 dm. high, simple, sparingly pubescent and puberulent; lower leaves petioled, their blades oblanceolate; the rest sessile, lanceolate, somewhat clasping, entire, glandular-puberulent on both sides; inflorescence leafy, corymbiform ; heads fully I $\mathrm{cm}$. high; bracts linear-subulate, hirsute and glandular-puberulent, in 2 series, almost equal ; disk I 5-I $8 \mathrm{~mm}$. wide; rays fully I $\mathrm{cm}$. long, less than I $\mathrm{mm}$. wide, very numerous, dark-purple.

This is nearest related to E. subtrinereis, but the leaves are glandular-puberulent instead of hirsute. It grows in meadows at an altitude of about $2300 \mathrm{~m}$.

Colorado: Wahatoya Creek, 1900, Rydberg \& Trecland $5+17$.

\section{Erigeron Smithii sp. nov.}

Perennial with a rootstock; sten simple, glabrous below, glandular-puberulent above ; basal leaves $6-10 \mathrm{~cm}$. long, petioled ; blades oblanceolate or spatulate, glabrous, ciliate on the entire margins ; upper stem-leaves lanceolate, sessile, more or less clasping and often reduced; heads $\mathrm{I}-5$, on long almost erect branches, about $6 \mathrm{~mm}$. high; bracts linear-subulate, acuminate, glandularpuberulent, in two equal series; rays purple, IO- $12 \mathrm{~mm}$. long, I $\mathrm{mm}$. wide; achenes strigose; pappus double, the outer of very short bristles.

This is closely related to E. glabllus, but is more glabrous, and has glandular-puberulent, not hirsute, bracts. It grows in rich meadows at an altitude of 2100-3000 $\mathrm{m}$. 
Colorado: Parlin, Gunnison Co., 'igor, B. H. Smith II8 (type): Gunnison, 1901, Baker 558; Antonito, I898, Earle 42 ; Sargent, I896, Clements 127; Villa Grove, I896, Clenents 123; Leadville, I 90 I, Underwood \& Selby $+9+$.

\section{Erigeron Earlei sp. nov.}

Perennial; stems several, simple, 3-4 dm. high, strigose; basal leaves $5-6 \mathrm{~cm}$. long, narrowly oblanceolate, strigose on both sides, often callous-denticulate; stem-leaves linear and sessile, and reduced; heads about $3,6 \mathrm{~mm}$. high; bracts linear-subulate, acuminate, in about 2 series, nearly equal, densely strigose ; rays numerous and very narrow, white, about $S \mathrm{~mm}$. long.

This is related to E. glabcllus, but differs from all its relatives by the appressed, dense, strigose pubescence.

Colorado: Antonito, 1898 , Earle.

\section{Erigeron Peasei sp. nov.}

Depressed cestipose perennial; stem $5-8 \mathrm{~cm}$. high, scapiform or with $\mathrm{I}-2$ leaves, appressed-pubescent; basal leaves about $2 \mathrm{~cm}$. long, petioled, their blades oblanceolate, acute, strigose; stem-leaves linear, sessile; heads solitary, 6-7 mm. high; bracts linear-subulate, scarcely at all imbricated, acuminate, sparingly hirsute ; disk about I $\mathrm{cm}$. wide; rays numerous, about $7 \mathrm{~mm}$. long and $\mathrm{I} \mathrm{mm}$. wide.

This is nearly related to E. radicatus, but differs in the appressed pubescence and broader leaves.

Colorado: Lake City, is $88, H . N$. Pease (type in herb. Columbia Univ.).

\section{Erigeron vetensis sp. nov.}

Densely cespitose-puvinate perennial; stems $5-S \mathrm{~cm}$. high, hirsute, few-leaved; leaves linear or linear-oblanceolate, hirsute, 2-4 cm. long; heads solitary, about $7 \mathrm{~mm}$. high ; bracts linear, acuminate, hirsute as well as slightly glandular-puberulent; rays purple, S-Io mm. long, over I mm. wide; achenes strigose; pappus more or less double.

In dry places on high mountains of southern Colorado at an altitude of $2400-3000 \mathrm{~m}$. It is intermediate between E. radicatus and E. glandulosus, resembling the former most in pubescence, and the latter in habit.

Colorado: Mountains near Veta Pass, 1900, Rydberg \& I'reeland $5+29$ (type); Veta Mountain and Ojo, 5 721 , 5422 ; West Spanish Peak, 5727 . 


\section{Antennaria Sierrae-Blancae sp. nov.}

Depressed perennial, pulvinate-cespitose, rosulate, almost stemless; leaves broadly spatulate, less than I cm. long, abruptly acute, white-floccose beneath, glabrate above; heads subsessile in the rosettes, $6-7 \mathrm{~mm}$. in diameter; bracts broadly oblong to almost obovate, with a scarious brown upper portion.

Closely resembling $A$. rosulatc in habit, it differs however in the smaller heads, brown bracts and leaves that are glabrate above. It grows at an altitude of 3600-4000 m.

Colorado: Sierra Blanca, is 77 , Hooker \& Gray (type in Gray herbarium).

\section{Helianthus aridus sp. nov.}

Annual; stem 3-S dm. high, more or less hispid; leaves all petioled, the lower opposite, the upper usually alternate; blades lanceolate, $4-7 \mathrm{~cm}$. long, entire or crenate, acute, hispid-scabrous on both sides; heads rather few; bracts ovate, abruptly acuminate, hispid on the back and hispid-ciliate on the margins; disk $1.5-2 \mathrm{~cm}$. wide, purplish; rays oblong to oval, i 5-20 $\mathrm{mm}$. long, 6-S mm. wide; achenes cuneate, almost black, finely strigose, about $5 \mathrm{~mm}$. long and $2 \mathrm{~mm}$. wide.

This species has been mistaken for $H$. petiolaris, which it resembles most, but the bracts are hispid-ciliate and strongly acuminate in the manner of $H$. lenticularis. H. aridus grows in dry ground, especially in old fields and waste places.

Mostand: Great Falls, is $5, F . I^{T}$. Anderson (type); Polson, I90I, Uimbach 261 .

Wroming: Gros Ventre Mountains, I900, C. C. Curtis.

Colorado: Manitou, Igor, Cloments $S$ (mixed with H. petiolaris).

Nebraska: Kimball, i $S_{9}$, Rydberg I $f$.

\section{Tetraneuris Crandallii sp. nov.}

Cespitose, acaulescent perennial ; leaves narrowly linear-oblanceolate, conspicuously white-woolly at the base, 4-6 cm. long, 2$3 \mathrm{~mm}$. wide, sparingly long-hairy, soon glabrate; scape $\mathrm{I}-3 \mathrm{dm}$. long, sparingly strigose; involucre hemispherical; bracts about $\delta$ $\mathrm{mm}$. long, linear-oblong, silky-villous, but hairs rather appressed; rays about i $5 \mathrm{~mm}$. long, 5-S mm. wide, 3-lobed, 4-5-nerved.

This species is related to T. arisonica and $T$. pilose, but differs from the first in the narrow glabrate leaves, and from the latter in the narrow bracts and larger rays. 
Colorado: Grand Junction, I 894, Crandall (type); McCoy's, Eagle County, Ostcrhout 2757.

\section{Tetraneuris angustifolia sp. nov.}

Cespitose, acaulescent perennial; leaves narrowly linear-oblanceolate, 4-IO $\mathrm{cm}$. long, 4-5 $\mathrm{mm}$. wide, loosely and sparingly long-villous or glabrate in age, not densely villous at the base; scape $2-3 \mathrm{dm}$. high, strigose ; involucre hemispherical ; bracts oblong, obtuse, densely villous; disk IO-1 $2 \mathrm{~mm}$. wide; rays about I $\mathrm{cm}$. long and $4 \mathrm{~mm}$. wide, 3-toothed and conspicuously 4nerved.

This species is nearest related to $T$. scaposa, from which it differs in the narrow leaves. It has therefore been mistaken for $T$. lincaris; but in that species the branches of the caudex are rather slender and elongated and the leaves are narrowly linear, $\mathrm{I}-2 \mathrm{~mm}$. wide. T. angustifolic grows on rocky hills up to an altitude of $2000 \mathrm{~m}$.

New Mexico: White Mountains, I 897, Wooton 377 (type).

Colorado: Fort Lyon, is63, Palmer.

Texas: Kerrville, I894, Hiller I61t; Great Cañon of Mt. Carmel, I852, Parry (Mex. Bound.) 638; Belknap, I858, Hayes; Rock Creek and Limpia, i 852, Bigclow (Mex. Bound); Rio Bravo del Norte, between San Pedro and Puercos, I 852, Schott.

\section{Artemisia dracunculoides Wolfii var. nov.}

Stout, usually with broader leaf-segments or leaves; heads larger, $3-5.5 \mathrm{~mm}$. in diameter ; outer bracts longer, lanceolate or linear-oblong, mostly acutish, nearly equaling the inner (in $A$. dracunculoides oblong, obtuse, about half as long as the inner).

Colorado: Twin Lakes, I873, Wolf 530 (type); Hamor's Lake, north of Durango, I\$98, Baker, Earle \& Tracy 628; Grizzly Creek, i 896 , Baker.

New Mexico: Chama, i899, Baker 63I.

\section{Artemisia saxicola nom. nov.}

Artemisia Chamissoniana saratilis Besser; Hook. Fl. Bor. Am. I : 324. I 833. Not A. saxatilis Waldst.

A. norvegica A. Gray. Syn. Fl. I²: 37 I. I884. Not $A$. noregica Fries.

The American plant differs from the North European in having more numerous smaller heads on shorter peduncles, more hairy 
leaves, lanceolate in outline, and taller stem. In the true A. norregica the basal leaf-blades are as broad as long and have usually only 5 principal divisions.

\section{Artemisia Brittonii sp. nov.}

Perennial with a horizontal rootstock; stem rather stout, 3-6 $\mathrm{dm}$. high, white-floccose ; lower leaves cuneate or oblong-oblanceolate, 3-5-lobed mostly above the middle, densely white-tomentose on both sides, the lobes lanceolate; upper leaves ovate-lanceolate, entire; inflorescence paniculate; panicles narrow and heads conglomerate, $3-4 \mathrm{~mm}$. high, about $2 \mathrm{~mm}$. broad; bracts ovate and densely floccose ; flowers about I 5 , heterogamous, light-brown or yellow; achenes and receptacle glabrous.

This is related to A. Intoriciana Nutt., but differing in the stouter habit, more crowded inflorescence, and principally in the leaves, which are equally tomentose on both sides.

Colorado: Golden, IS82, N. L. Britton (type, in herb. Columbia College); Boulder, I 891, Pencrd 285; also I902, Tie'cedy' 1906 .

UTAн: Green River, is5o, Stansbury; Salt Lake Valley, Lauderdale'; Salt Lake City, i 884 , Harry Edacords.

\section{Artemisia Underwoodii sp. nov.}

Perennial, with a horizontal much-branched rootstock; stems slender, 2-6 dm. high. somewhat floccose, usually simple up to the inflorescence; leaves $3-5 \mathrm{~cm}$. long, pinnately parted, with 3-7 (usually 5) linear or linear-lanceolate acute lobes, densely white-floccose beneath, green and slightly tomentose above at first, but in age glabrate; inflorescence paniculate, but panicle narrow and the small heads crowded; heads campanulate, scarcely over $3 \mathrm{~mm}$. high and $2.5 \mathrm{~mm}$. broad; bracts ovate, tomentose, slightly scarious on the margin; flowers I 5-20, heterogamous, brown; achenes and receptacle glabrous.

This is nearest related to A. Indoriciana, but differs in the deeply parted leaves and their narrow lobes. It grows on chaparral-covered hills and mountain-sides at an altitude of $2300-2700 \mathrm{~m}$.

Colorado: Ouray, I901, Cinderaiod \& Selly' $7+$ (type) and 3t; Georgetown, I 895 , Ry'tierg. 


\section{Artemisia pudica sp. nov.}

Perennial with a horizontal rootstock; stem 4-6 dm. high, simple up to the inflorescence, white-floccose; leaves linear or narrowly linear-lanceolate, $\sigma-10 \mathrm{~cm}$. long, $6-8 \mathrm{~mm}$. wide, entire, white-floccose on both sides; inflorescence a narrow panicle, the branches long and nearly erect, racemiform; heads nodding on short peduncles, campanulate, about $5 \mathrm{~mm}$. high and $4 \mathrm{~mm}$. broad; bracts ovate, densely tomentose, with a darker midrib and slightly scarious margin ; flowers about 20, heterogamous, yellow ; receptacle and aclienes glabrous.

This species is related to $A$. gnaplalodes, but is characterized by the racemiform branches of the inflorescence with peduncled, nodding heads. It grows at an altitude of about $2300 \mathrm{~m}$.

Colorado: Gunnison, igoi, Bakir 573.

\section{Pyrrocoma lagopus sp. nov.}

Perennial with a taproot; stems decumbent, I-2 dm. long, more or less villous, especially at the base and the nodes; basal leaves petioled, 6-10 cm. long; blades lanceolate or linear-lanceolate, firm, distantly serrate with almost spinulose teeth; stemleaves narrowly linear-lanceolate, sessile, with partly clasping bases; inflorescence racemiform; involucre $S-9 \mathrm{~mm}$. high, more or less villous, especially at the base; bracts imbricated in about 3 series, oblong, acute, green on the back, yellowish on the sides and base; disk about $12 \mathrm{~cm}$. wide; rays about $\delta \mathrm{mm}$. long and over I mm. wide; achenes hirsute-strigose.

This species is nearest related to $P$. Trascyi, but differs in the villous stem and involucre. In habit it also reminds one of $P$. uniflora and $P$. imuloides, but in these species the bracts are nearly in a single equal series. P. lagopus grows on dry plains and in saline flats.

Wroming: Hams Fork and La Barge, igoo, C. C. Curtis (type).

Colokano: North Park, i $\$ 99$ (collector not given, but plants distributed from Herb. State Agr. Coll., under no. 3232 ).

\section{Tetradymia linearis sp. nov.}

A low, unarmed shrub; bark of the older stems shining and flaky, that of the young branches more or less white tomentulose; leaves linear, white-tomentose, somewhat keeled, more or less arcuate-squarrose and pungent-pointed; bracts of the invo- 
lucre usually 4, oblong, acute, white-tomentose, about $8 \mathrm{~mm}$. long: flowers about 4 ; lobes of the corolla linear, about $3 \mathrm{~mm}$. long; pappus very copious, yellowish ; bristles scabrous ; achenes hirsute-villous.

This species grows on dry hills and tablelands up to an altitude of $2300 \mathrm{~m}$. It is nearest related to $T$. inmmis Nutt, but is distinguished by the narrow, more or less squarrose, and pungent leaves.

Uta : Rock Creek, is77, Palmer 26 ftype, in herb. Columbia University).

Colorado: Gunnison, I9OI, Baker $S_{33}$.

\section{Arnica coloradensis sp. nov.}

Perennial, about $2 \mathrm{dm}$. high and with about 3 pairs of leaves ; stem villous; basal leaves obovate, nearly sessile, sparingly pubescent, 4-5 cm. long; stem-leaves sessile, ovate or ovate-lanceolate, 5-nerved; heads often solitary or few; mvolucre hemispherical; bracts broadly oblanciolate, acute or acuminate, often tinged with purple, sparingly villous and somewhat glandular, 8-9 mm. long; rays bright-yellow, over I $\mathrm{cm}$. long and $5 \mathrm{~mm}$. wide; achenes finely strigose.

This species is perhaps nearest related to $A$. subplumosi, but differs in the low habit, the single or few heads, and the broad involucral bracts.

Colorado: is72, Prmy' (in herb. Columbia University).

\section{Carduus Osterhoutii sp. nov.}

Stout; stem round-angled and striate, more or less tinged with purple, more or less arachnoid-hairy ; leaves pinnately parted about halfway to the midrib, glabrate above, white-tomentose beneath; lobes at least of the larger leaves oblong, obtuse with a weak spine; heads $2.5-3 \mathrm{~cm}$. high and about $2 \mathrm{~cm}$. broad; bracts arachnoid-hairy, linear-lanceolate, without glandular dorsal ridge, gradually tapering into an almost erect, stout, flat spine; pappus scabrous.

This is nearest related to $C$. Hookcrimmus and $C$. orcophilus, but differs from both in the oblong, obtuse lobes of the larger leaves and the long, stout, flat spines of the involucre.

Colorado: Red Cliff, Eagle Co., I 902, Ostorlout z7o6 (type); Tennessee Pass, $26 \neq 0$. 


\section{Carduus perplexans sp. nov.}

Rather slender, about $5 \mathrm{dm}$. high; stem striate, purplish, slightly tomentose; lower leaves oblanceolate, the upper lanceolate and clasping, all merely toothed, with weak yellowish spines, glabrous and somewhat glaucous above, rather thinly white-tomentose beneath; heads about $3 \mathrm{~cm}$. high and broad; bracts well imbricated, usually with a glandular back, the outer shorter and tipped with a short weak spine, the inner tipped with a dilated, deltoid, erose appendage ; corolla rose or red-purple.

The appendages of the bracts would place this species nearest C. Centaureae, but the bracts are broader and have a distinct glandular back, the corolla is pink or purplish, and the whole plant suggests $C$. altissimus and its relatives. In fact the species combines characters of the Cerlinoidcs and the Altissimus groups. It grows at an altitude of nearly $2100 \mathrm{~m}$.

Colorado: Cimarron, igo I, Betker 286.

\section{Cardu coloradensis sp. nov.}

Cnicus Drummondii A. Gray Syn. Fl. $\mathbf{I}^{2}: 402$, in part, i. c., as to the Colorado specimens.

Rather stout, simple, 3-5 dm. high; stem striate, sparingly arachnoid; leaves $1.5-2 \mathrm{dm}$. long, $4-7 \mathrm{~cm}$. wide, linear or oblong in outline, pinnately lobed about half-way to the midrib, sparingly arachnoid abore, more or less white-tomentose beneath; lobes ovate, tipped with yellowish spines $2-5 \mathrm{~mm}$. long and bordered with smaller spines; heads $3-4 \mathrm{~cm}$. high and about as broad; bracts glabrous or nearly so, firm, more or less yellowish, without dorsal glandular ridge, well imbricated in many unequal series; the outer with weak spines; the inner unarmed and with slightly dilated crisp tips; corolla white or slightly pinkish.

This species has gone under the name of $C$. Drummondii, but the latter has larger heads often $5 \mathrm{~cm}$. high and broad, broader and thin flat brownish or greenish bracts, broader erose appendages, red-purple corolla, and the leaves more deeply dissected, more arachnoid and scarcely at all tomentose. In reality $C$. coloradensis is more closely related to $C$. scariosus, from which it differs mainly in the less deeply dissected leaves and broader segments.

Colorano: Pagosa Springs, I 899, Baker 6 ft (type); Gunnison, 1901, Baker 592; Wolcott, 1902, Osterhout $265 I$. 


\section{Carduus floccosus sp. nov.}

Stout, about I m. high; stem angled, loosely floccose; leaves oblanceolate in outline, about $2 \mathrm{dm}$. long, loosely floccose on both sides, divided two-thirds to the midrib; lobes 2 -cleft, each division lanceolate, $1.5-2 \mathrm{~cm}$. long, tipped with a spine about $5 \mathrm{~mm}$. long; heads about $3 \mathrm{~cm}$. high, $1.5-2.5 \mathrm{~cm}$. wide; bracts slightly floccose on the margin and with a very narrow glandular dorsal line; the outer lanceolate, the inner linear-lanceolate, all with a short and weak spine; corolla red-purple.

This species belongs to the C. undulatus group and has been mistaken for that species. It has almost the same kind of leaves, although more loosely floccose; but the heads are very different, resembling more those of $C$. Flodmanii and $C$. altissimus, the bracts having a very slender glandular dorsal line.

Colorado: Wolcott, 1902, Osterhout 2652.

\section{Carduus Tracyi sp. nov.}

Simple below; stem 3-7 dm. high, striate and loosely floccose; leaves oblanceolate in outline, divided to near the base, green but slightly floccose above, more or less tomentose beneath ; lobes oblong to linear-lanceolate, tipped with yellow spines $5-8 \mathrm{~mm}$. long; heads $3-3.5 \mathrm{~cm}$. high and about $3 \mathrm{~cm}$. or less wide; bracts slightly floccose when young, yellowish with a very broad and dark glandular spot on the back, the outermost and inner narrowly lanceolate, the middle ovate-lanceolate, all with a short spreading spine; corolla ochroleucous.

This is nearest related to C. Nelsonii Pammel, but is less tomentose, has smaller heads, more acute leaf-segments, and broader bracts with shorter, more slender and spreading spines. It grows in dry fields at an altitude of about $2 \mathrm{I} 00 \mathrm{~m}$.

Colorado: Mancos, is98, Baker, Earle G Tracy go (type); Green Mountain Falls, I 895, E. A. Bessey.

\section{Gaertneria linearis sp. nov.}

Perennial, shrubby at base; stems about $2 \mathrm{dm}$. high, sparingly hirsute, branched; leaves once or twice pinnate, $3-4 \mathrm{~cm}$. long, strigose above, minutely tomentulose beneath; lobes linear, obtuse, $3-5 \mathrm{~mm}$. long; staminate racemes about $3 \mathrm{~cm}$. long; heads nodding, 3-4 mm. wide; involucre strigose, cleft scarcely halfways into rounded-ovate lobes; pistiliate involucre with few slender spines. 
This is perhaps nearest related to $G$. temifolia, but is shrubby at base; the leaves are smaller, finely tomentulose beneath and with linear obtuse (instead of oblong acute) divisions, of which the terminal is not conspicuously elongated. G. linearis grows at an altitude of $2100 \mathrm{~m}$.

Colorado: Calhan, i 893 , Saunders.

\section{Crepis tomentulosa sp. nov.}

Scapose perennial, with a taproot; leaves basal, glabrous and glaucous, I-I.5 dm. long, oblanceolate in outline, acute, sessile, dentate with sharp salient or reflexed teeth; scape $4-5 \mathrm{dm}$. high ; stem-leaves, if any, linear-lanceolate, bract-like, entire; involucre turbinate, about $12 \mathrm{~mm}$. high, as well as the upper part of the branches of the inflorescence tomentulose when young; bracts linear-lanceolate, acuminate, with dark backs, and with a few calycculate ones at their base; ligules bright-yellow, nearly I cm. long.

This species is nearest related to $C$. glanca, from which it differs principally in the tomentulose involucre and peduncles. It grows at an altitude of nearly $3000 \mathrm{~m}$.

Colorado: Ruxton Dell, near Pikes Peak, I901, Clemcnts 372.

\section{Crepis petiolata sp. nov.}

Perennial; stem with $I-3$ leaves, glabrous and often purplish below, more or less glandular-hirsute above, especially the branches of the inflorescence; basal leaves long-petioled; blades oblanceolate or spatulate, usually obtuse, sinuate-dentate or entire, about I dm. long, glabrous and glaucous; stem-leaves oblanceolate and usually sessile; involucre about $12 \mathrm{~mm}$. high, turbinatecampanulate, pubescent with glandular black hairs; bracts linearlanceolate, acuminate; ligules about $\mathrm{I} 2 \mathrm{~mm}$. long and $3 \mathrm{~mm}$. wide ; achenes strongly ribbed; pappus white.

This specics is related to $C$. runcinata, but the leaves are glabrous and long-petioled, and the stem-leaves are usually ample. It grows in the mountains at an altitude of 2000-2700 m.

Colorado: Along Bear River, five miles east of Hayden, 1 899. Osterhout 2I (type); Georgetown, I 895, Rydberg.

IVroung: Headwaters of Clear Creek and Crazy Woman River, I900, Treecdy' $308 \$$.

Crepis perplexans sp. nov.

A scapose perennial; leaves about $1 \mathrm{dm}$. long, glaucous and glabrous or rarely with a few hairs on the midrib below and on 
the margin of the narrower base, oblanceolate, sessile or shortpetioled, usually more or less runcinate-toothed; scape glabrous; involucres turbinate-campanulate, about $\mathrm{I} \mathrm{cm}$. high, more or less glandular-hairy with yellowish hairs and slightly tomentulose when young; bracts linear-lanceolate, acuminate; rays yellow, about I cm. long; achenes brown, strongly ribbed; pappus white.

This has been confused with $C$. mncinata, but that species has thinner hairy leaves, which are scarcely glaucous. C. confusa is really more closely related to $C$. glauea, from which it differs only in the pubescence of the involucre and the usually broader leaves. C. confusa grows in valleys from North Dakota and Alberta to Nebraska and Colorado. As the type may be regarded:

Wroming: Encampment, Carbon Co., I90 I, Tueedy 4081.

\section{Crepis denticulata sp. nov.}

Scapose perennial ; leaves basal, obovate or more rarely obovate-oblanceolate, glabrous or nearly so, obtuse, less than $\mathrm{I} \mathrm{cm}$. long, denticulate or with a few lobes towards the base; scape $\mathrm{I}-3$ $\mathrm{dm}$. high, glabrous up to the inflorescence; involucre turbinate, scarcely I cm. high, hirsute with glandular black hairs, as well as the branches of the inflorescence ; ligules about $S \mathrm{~mm}$. long; achenes brown, strongly ribbed; pappus white.

This species is nearest related to C. riparia, but is a much smaller plant in every part and with glabrous leaves. It grows in the mountains.

Colorado: Lake John, North Park, I 898, Shear \& Bissey foot (type).

Wroming: Fort Bridger, I 873 , Porter.

UTAн : 1875, Parry 62; Jordan Valley, I 869, Watson 7I2.

Crepis angustata sp. nov.

Crepis gracilis Rydb. Mem. N. I. Bot. Gard. I : 46I, in part. I 900. Not C. ocidentalis gracilis D. C. Eaton.

Perennial, whole plant more or less canescent-puberulent and scabrous ; stem 3-7 dm. high; basal leaves and lower stem-leaves petioled, runcinate; main body narrowly linear-lanceolate, acuminate; lobes linear or linear-lanceolate, usually curved forward upper stem-leaves entire and sessile; involucre cylindric, about I $\mathrm{cm}$. high and $5 \mathrm{~mm}$. broad; bracts $5-7$, linear-lanceolate, acute, canescent but not glandular, with a few minute calyculate ones below ; flowers 5-10. 
This species has been taken for $C$. gracilis, or $C$. intermedia sracilis, under which name it is more commonly known, but the latter has much narrower leaves, the main portion not being wider than the long lobes. C. intermedia, to which it is more closely related, has much broader main portion of the leaves, and the lobes are lanceolate and usually directed downward. C. angustata grow on hillsides from Montana and Washington to Colorado and Oregon.

Colorado: North Park, is96, Bakcr (type).

Agoseris maculata sp. nov.

Leaves oblanceolate, more or less pubescent, especially on the margins and veins; scape $1-2 \mathrm{dm}$. high, often sparingly hairy and villous under the head; involucre campanulate, about $2 \mathrm{~cm}$. high; outer bracts ovate or ovate-lanceolate, more or less villous especially on the margins, dotted with blackish dots; inner bracts lanceolate; ligules yellow or the outer tinged with reddish; achenes with a short striate beak.

This is somewhat related to $A$. villosa, but differs in the broad acuminate outer bracts. It grows in the mountains of Colorado at an altitude of $3000-3900 \mathrm{~m}$.

Colorado: Silver Plume, I 895, Shear 7605 (type); Tennessee Pass, I 902, Osterhout 2673.

\section{Agoseris attenuata sp. nov.}

Leaves narrowly oblanceolate, I-I.5 dm. long, glabrous and glaucous, usually denticulate, tapering into a short petiole; scape about $1.5 \mathrm{dm}$. high, villous near the head; involucre campanulate, about $2 \mathrm{~cm}$. high; outer bracts lanceolate, somewhat villous on the margins, purplish on the back; inner bracts linear-lanceolate long-attenuate, equaling the pappus; achenes light-brown, with thick ribs, contracted above into a short striate beak.

This is related to A. pumila and A. glanca, but differs from the former in the smaller heads and narrower leaves, from the latter in the more or less villous involucre, and from both in the elongated inner bracts. It grows at an altitude of nearly $3000 \mathrm{~m}$.

Colorado: Mountain west of North Park, I900, Osterhout 22,5 .

Agoseris roseata sp. nov.

Leaves about $2 \mathrm{dm}$. long, long-petioled; blades oblanceolate, acute, denticulate or entire, glabrous and glaucous; scape $5-6 \mathrm{dm}$. 
high, slightly villous above; involucre campanulate, $1.5-2 \mathrm{~cm}$. high ; bracts oblong-ovate, acute, nearly glabrous, often with a rosecolored spot in the middle; corolla rose-colored; achenes about I $\mathrm{cm}$. long, as well as the short beak strongly striate.

In habit and flowers this resembles most 4 . aurantiaca, but is glabrous and glaucous, and the achene with its short beak places it in the 4 . glance group.

Colorado: Bear River, 20 miles below Steamboat Springs, I S99, Osterhont.

\section{Agoseris humilis sp. nov.}

Leaves spreading or ascending, oblanceolate or linear-oblanceolate, 6-ro cm. long, entire or denticulate, glabrous or slightly hairy on the short petioles; scape I-I.5 (seldom 2) $\mathrm{cm}$. high, slightly villous below the head; involucre I.5-2 cm. high; bracts linear-lanceolate, slightly villous-ciliate; corolla rose-purple, or at first orange; achenes I $2-15 \mathrm{~mm}$. long, with a long, scarcely striate beak.

This is closely related to $A$. sracilcns, but differs in the low habit, small heads and more spreading leaves. It grows at an altitude of about $2700 \mathrm{~m}$.

Colorado: Ironton Park, igor, Undiriood \& Selly' 308 (type): Tennessee Pass, 1902, Ostirhont 2710.

\section{Agoseris rostrata sp. nov.}

Leaves narrowly linear-]anceolate, about $2 \mathrm{dm}$. long, usually more or less laciniate with linear lobes, glabrous and glaucous: scape $2-6 \mathrm{dm}$. ligh, more or less villous, especially under the head; involucre fully $3 \mathrm{~cm}$. high; outer bracts oblong or ovate, obtuse, glabrous, about half as long as the elongated linear or linear-lanceolate inner ones; corolla orange or purple; achenes fully $2 \mathrm{~cm}$. long, with a very long and slender, not striate, beak.

In habit this most resembles $A$. clata, but the bracts and the achenes associate it with $A$. grandiflora.

Colorado: Lower Boulder Cañon, igor, Ostirhout 2778 (type); between Sunshine and Ward, I902, Tiuccity +895.

\section{Taraxacum leiospermum sp. nov.}

Leaves spreading, oblanceolate, less than I dm. long, darkgreen, obtuse or acutish, retrorse-dentate, rarely lobed; scape about I dm. high, slightly villous when young; outer bracts $7-$ Io $\mathrm{mm}$. long, lanceolate with spreading tips; inner linear, about 
twice as long; neither corniculate; achenes greenish, ribbed, tuberculate above, but otherwise smooth.

Probably related to $T$. augustifolium Greene, but that is described as having much narrower leaves and erect outer bracts. It differs from $T$. montamum in the longer, narrower and spreading bracts and the less lobed leaves.

Colorado: Tennessee Pass, 1902, Osterhout 2675 (type); Seven Lakes, i 896, E. A. Bessey. 
CONTRIBUTIONS FROM THE NEW YORK BOTANICAL GARDEN-No. 73

\section{STUDIES ON THE ROCKY MOUNTAIN FLORA-XV}

\section{By PER AXEL RYDBERG}

NEW YORK

1905

[From the Bulletin of the Torrey Botanical Club 32: 597-610. 1905] 



\section{Studies on the Rocky Mountain flora - XV}

In preparing my Flora of Colorado, to be issued as a Bulletim from the Agricultural College at Fort Collins, Colorado, and now in press, I have found it necessary to change the nomenclature of a number of species. As the scope of the Flora comprises only keys to the families, genera and species, and an enumeration of localities where specimens have been collected, it has been impossible to include therein any fuller synonomy with citations, or any discussions. It has, therefore, seemed advisable to make the publication of these changes and notes elsewhere.

Caryopitys monophylla (Torr. \& Frém.) Rydb.

Pinus monopluyllus Torr. \& Frém. Rep. 3 I9. I 845 .

Dr. Small in his Flora of the Southeastern United States has followed the more modern views in dividing genera, which consist of very natural sections or subgenera, into as many separate genera. The genus Pinus as usually treated contains at least four distinct subgenera, better defined and more easily distinguished from each other, than for instance Picer and Tsuga. Three ot these had already generic names, aiz.: Pimus L. (proper), Apinus Necker and Strobus Opiz. Dr. Small had to give the fourth group, which is wholly American, a new name, Coryopitys. In the Rocky Mountain region the genus is represented by the type species $C$. edulis (Engelm.) Small, and by the species given above. One of the four genera is not represented within the area covered by Dr. Small's work, wiz..:

\section{Apinus Necker, Elem. Bot. 3: 269. I 790}

Most of Necker's genera are hard to determine, but in this case Necker not only gives the characters by which he distinguishes the genus from Pinus proper, but also cites two species, viz.: combra and pinca. In the Kew Index, the genus is given, but no species are mentioned. The way in which Necker makes 
his statement, there is all the reason to claim that the two species are there published as Apinus. Necker states that Larix contains 3 species, riz.: decidua, ccdrus and strobus; Pimus 2, sylvestris and terda: Apinus also 2, ais.. combra and pinea, but Abies 5, etc. If Necker had meant that these were the Linnaean species of Pimus to be distributed among the different genera, he would have stated it differently. There was no Pinus decidua L., but a Pinus Larix I. and a Larix decidua Miller. Apinus is most related to Strobus, but differs in the thick cone-scaies, the erect or horizontal instead of pendent cone and a very hard-shelled seed with only a vestige of a wing. In the Rocky Mountains, it is represented by the two following species:

Apinus flexilis (James) Rydb.

Pinus flcxilis James, in Long's Exped. 2: 34. I 823.

Apinus albicaulis (Engelm.) Rydb.

Pinus albicaulis Engelm. Trans. Acad. St. Louis 2: 209. I 863.

Sabina utahensis (Engelm.) Rydb.

Juniperus californica utahensis Engelm. Trans. Acad. St. Louis 3 : $588 . \quad$ I 877 .

Haller's genus Sabina is also one just as consistently taken up by Dr. Small. I shall here give only the Rocky Mountain species to be referred to this genus.

Sabina monosperma (Engelm.) Rydb.

Junipcrus occidentalis monosperma Engelm. Trans. Acad. St. Louis 3: 590. I 877 .

Sabina Knightii (A. Nels.) Rydb.

Juniperus Krnightii A. Nels. Bot. Gaz. 25: I 98. I 898.

Sabina scopulorum (Sargent) Rydb.

Junipirus scopulorum Sargent, Garden and Forest I0: 420. I 897.

Sparganium multipedunculatum (Morong) Rydb.

Sparganium simplex multipadunculata Morong, Bull. Torrey Club I5: 79. I 888 . 
This is quite distinct from S. simplex $\mathrm{L}$. To the characters given by the late Dr. Morong may be added the broad scarious margins of the leaf-sheaths. This character it has in common with S. amcricanmm Nutt. of the eastern United States and S. subiagmatum Meinsh. of Europe. In fact, Meinshausen included C. C. Parry's plant from Colorado in the latter. It is, however, very doubtful if it belong there, for the original description of S. subuaginatum does not fit our plant very well. S. multipcdunculatum ranges from the Mackenzie River and Washington to Colorado.

\section{Potamogeton Richardsonii (Bennett) Rydb.}

Potamogeton perfoliatus lancelatus Robbins, in A. Gray, Man. ed. 5. 488. I 867 . Not P. perfoliatus lanceolatus Blytt. I 86 I. Potamegcton porfoliatus Richarlsonii Bennett, Jour. Bot. 27: 25 . I 889.

Our common North American plant does not seem to intergrade at all with the true $P$. porfoliatus $L$.

\section{Stipa Porteri Rydb.}

Stipa mongolica (Thurber, in A. Gray, Proc. Acad. Phila. I863: 79, hyponym. i 863.) Port. \& Coult. Syn. Fl. Colo. I 45. I 874 . Not $S$. mongolica Turcz.

In the enumeration of Hall and Harbour's plants, Thurber determined this plant as S. mongolica Turcz, which is evidently erroneous. He gives the name and a short discussion but no description. A good description was afterwards given by Porter and Coulter in the Synopsis of the Flora of Colorado.

Muhlenbergia cuspidata (Torr.) Rydb.

IFilfa cuspidater Torr.; Hook. F1. Bor. Am. 2: $238 . \quad$ I 839. Sporobolus cuspidata Wood, Bot. \& Fl. 385 . 1870.

The group of grasses, which Torrey, Trinius and Thurber regarded as a good generic type and for which they adopted the name Vilfa, is altogether out of place in the genus Sporobolus, where its species have been placed by authors. They are no "Drop-seed" grasses at all, the grain remaining enclosed in the firm flowering glume. They should be taken out of Sporobolus, but if they should constitute a genus by themselves is question- 
able. The generic name Irlfa is not available, for the type of Filfa Adans. is apparently a species of Agrostis. As there is no character, whatever, to separate these plants from Muhlenbergia as now limited, the only rational way to treat them at present is to transfer them all to Muhlcubrgia. At any rate, they are congeneric with $M$. Wrightii Vasey, slender specimens of which are very hard to distinguish from $M$. cuspidata here proposed. The other Rocky Mountain species are:

\section{Muhlenbergia Richardsonis (Trin.) Rydb.}

Vilfa Richardsonis Trin. Mem. Acad. St. Petersb. VI. Nat. 52: IO3. I 840.

? Agrostis brevifolia Nutt. Gen. I : 44. I 8 I 8 .

The specific name breifolia may have to be taken up for this species, but it is doubtful if Agrostis brevifolia is a synonym of this. Professor Scribner claims that it belongs to the preceding species. What Irilfa Richardsonis Trin, is, is not doubtful, and that specific name is therefore preferable.

Muhlenbergia simplex (Scribn.) Rydb.

Sporobolus simplex Scribn. Bull. U. S. Div. Agrost. II : 48 . I 898.

Muhlenbergia filiformis (Thurber) Rydb.

ITilfa depauperata filifornis Thurb.; S. Wats. Bot. King's Expl. 376. I 87 I.

Vilfa gracillina Thurb. Bot. Calif, 2: 268. I880. Not Muhlenbergia gracillima Torr. 1856 .

Sporobolus filiformis Rydb. Contr. U. S. Nat. Herb. 3: I 89 . I $\$ 95$.

Muhlenbergia aristulata Rydb.

Sporobolus aristatus Rydb. Bull. Torrey Club 28: 266. I90I. Not Muhlcubergia aristata Pers. I 805.

Muhlenbergia Wolfii (Vasey) Rydb.

ITilfa minima Vasey, Bot. Wheeler Surv. 282. Is78. Not $V$. minima Trin. I 855 .

Sporobolus Wolfii Vasey, Bull. Torrey Club Io: 52. ${ }_{1} 88_{3}$. 
Muhlenbergia Thurberi Rydb.

Sporobolus filiculnis Vasey; Beal, Grasses N. Am. 2 : 288. I 896.

Not S. filiculmis Dewey. I 894.

Iilfa filiculmis Thurber; Beal, l.c., as a synonym.

Both Sporobolus filiculmis Vasey and I ilfa filiculmis Thurber appeared in I 885 in Vasey's Catalogue of the Grasses of United States, on page 44 ; but both are there nomina nuda and the first place where a description is published is, as far as I can find, in Beal's Grasses of North America. In the meantime Dewey had published another Sporobolus filiculmis which invalidates that specific name.

\section{Sporobolus flexuosus (Thurber) Rydb.}

Sporobolus cryptandrus flculosus Thurber; Vasey, Bot. Wheeler Surv. 282. I 878 .

This is evidently specifically distinct from S. cryptandrus.

Deschampsia alpicola Rydb. sp. nov.

De'schampsia cacspitosa alpina Vasey; Beal, Grasses N. Am. 2 : 368 ; at least in part. I 896 . Not $D$. alpina R. \& S. I 8 I 7 .

Densely cespitose, tufted perennial; sterile shoots numerous; sheaths $2-3 \mathrm{~cm}$. long, glabrous, striate; ligules linear-lanceolate, acuminate, about $5 \mathrm{~mm}$. long; blades $\mathrm{I}-2 \mathrm{dm}$. long, I-2 $\mathrm{mm}$. wide, stiff, often more or less involute; culm-leaves with sheaths $1-1.5 \mathrm{dm}$. long and blades $1-4 \mathrm{~cm}$. long; culms 3-5 dm. high ; panicle short, open, 8-I $5 \mathrm{~cm}$. long, its branches in 2's to 5 's, 3-6 cm. long, soon spreading; spikelets about $5 \mathrm{~mm}$. long; empty glumes about $4 \mathrm{~mm}$. long, lanceolate, acute; flowering glume nearly as long, hirsute at the base; awn attached one third or one-fourth from the base, one and a half to two times as long as the glume, bent and twisted.

This differs from $D$. cacspitosa in the large flowers and the long awns. It has been mistaken for D. bo'tnica, but that species has long narrow inflorescence and comparatively longer empty glumes. D. alpicola is rather common in alpine regions of Colorado. A similar if not identical form is aisio found in Alaska. As the type may be designated :

Colorado: Mountain meadow's, Pike's Peak, Sept. 4, I90 I, at an altitude of 3600 meters, L. M. Lindiriood .T. 
Graphephorum Shearii (Jcribn.) Rydb.

Trisctum argiutium Scribn. Bull. U. S. Div. Agrost. II : 49. I 89 S. Not T. argenteum R. \& S. ISI7.

Trisctum Shcarii Scribn. Circ. U. S. Div. Agrost. 30 : S. 190 r.

Professor Scribner has merged Graphcphorum into Trisetum. I think, though, that they should be retained as two distinct genera, even if the former should be transferred to the tribe Aicueac.

Distichlis stricta (Torr.) Rydb.

Uniola stricta Torr. Ann. Lyc. N. Y. I : 155. I 824. Distichlis maritima stricta Thurber, Bot. Calif. 2: $306 . \quad$ ISSO. Distichlis spicata stricta Scribn. Mem. Torrey Club 5 : 5 I. I894.

\section{Eatonia robusta (Vasey) Rydb.}

Eatonia obtusata robusta Vasey; Beal, Grasses N. Am. 2: 493. I 896 .

To the characters given in the original description should be added: intermediate nerves of the second glume very strong, and leaf-blades firm, much broader than the sheaths, and therefore forming distinct auricles at the base. The nerves mentioned are in this species almost as prominent as the lateral nerves. In $E$. obtusata they are faint, while the lateral ones are very prominent.

Eatonia intermedia Rydb. sp. nov.

Culm 6-S dm. high, 1.5-2.5 mm. thick, striate, shining; slieaths 5-15 cm. long, striate, minutely scabrous; ligules about 2 $\mathrm{mm}$. long, truncate, erose and often cleft; blades $S-\mathrm{I} ; \mathrm{cm}$. long, 3-5 $\mathrm{mm}$. wide, usually flat, broader than the sheaths and therefore forming distinct auricles at the base; inflorescence rather narrow and dense, $8-15 \mathrm{~cm}$. long, $\mathrm{I}-3 \mathrm{~cm}$. wide; spikelet usually 2flowered ; first empty glume about $2 \mathrm{~mm}$. long, subulate, scabrous on the back; second empty glume oblanceolate in side view, rather firm, slightly scarious on the margin, with prominent scabrous nerves, obtusish, about as wide as the flowering glumes, a little over $2 \mathrm{~mm}$. long and $0.5 \mathrm{~mm}$. wide; flowering glume oblonglanceolate in side-view, rather firm, with faint nerves and minutely scabrous; palate narrowly linear, scarious.

This species has been named both E. obtusata and E. pinusylranica, and is intermediate between the two. From the former it 
differs in the narrower second glume, which is scarcely broader than the flowering glume and neither truncate nor cucullate at the apex; from E. pennsylanica it differs in the denser inflorescence and the firmer and less acute second glume, which has the texture of that of E. obtusata. In E. pennsylianica the second empty glume is thin, very acute and with a broad scarious margin.

A few of the specimens to be referred to this are given here:

Montana: East Gallatin Swamps, July 24, I896, $P$. A. Rydborg $317+$ (type) and 3173; Columbia Falls, I 893, R. S. Williams; Blue Cloud, near Helena, is87, F. D. Kilscy.

Colokado: Gunnison, igor, C. F. Baker 527; Pagosa Springs, I 899, Baker 160; Durango, I898, Baker, Earle \& Tracy 950 (the last determined as Agrostis crarata).

\section{Poa callichroa Rydb, sp. nov.}

Perennial with a horizontal rootstock, but more or less matted ; culm about $3 \mathrm{dm}$. high, mostly leafy at the base; sheaths strongly striate, $2-10 \mathrm{~cm}$. long; ligules lanceolate or ovate, acute, about 3 $\mathrm{mm}$. long; blades of the lower leaves $6-10 \mathrm{~cm}$. long, 3-4 $\mathrm{mm}$. wide, firm, dark-green, strongly veined; blades of the upper leaves about $3 \mathrm{~cm}$. long, erect; panicle 6-9 cm. long, open; branches mostly in 3's or 4's below, the lowermost $2-3 \mathrm{~cm}$. long; spikelets $6-8 \mathrm{~mm}$. long, 5-7-flowered; empty glumes lanceolate in sideview, about $5 \mathrm{~mm}$. long, acuminate, purple with greenish or brownish margins; flowering glumes 4-5 mm. long, lanceolate, acuminate, with strong nerves, green below, then purple, then brown, and white and scarious above; nerves and internerves more or less villous; cobweb at the base present but scant.

This species is a relative of $P$. arctica and $P$. conisia, but differs from both in the taller habit, broader leaves and larger, 5-7flowered (instead of 3-4-flowered) spikelets.

Colorado: Dead Lake, near Pike's Peak, August 14, I90 I, F. E. \&. E. S. Cloments 457 .

Poa pudica Rydb. sp. nov.

Perennial with a short rootstock and often tufted; culm 2-3 $\mathrm{dm}$. high; lower leaves with short sheaths, which are often rather loose ; ligules truncate, about $2 \mathrm{~mm}$. long ; blades $4-5 \mathrm{~cm}$. long, usually conduplicate, strongly nerved; sheaths of the stem-leaves 5-7 cm. long; blades $2-4 \mathrm{~cm}$. long, erect; panicle $4-8 \mathrm{~cm}$. long, 
open ; branches usually in pairs, in age reflexed ; the lowest $4-5 \mathrm{~cm}$. long, bearing the spikelets near the ends; spikelets $4-5 \mathrm{~mm}$. long, mostly 3-flowered; empty glumes lanceolate in side view, strongly veined, usually purple, acuminate; flowering glumes lanceolate, sharp-acuminate, greenish below, then purplish and scarious at the apex; cobweb present but scant; internerves glabrous and nerves pubescent.

The type specimens were determined by Professor Scribner as $P$. arctica, but it differs from that species in the smaller more sharply acuminate flowering glumes and their glabrous internerves. These characters would place it closer to P. reffexa. The latter species is, however, taller, and the intermediate nerves of the flowering glumes are glabrous.

Colorado: Stephen's Mine, below Gray's Peak, Aug. 23, I 895, P. A. Rydberg 27t3 (type); near Pagosa Peak, Aug. I 899, C. F. Baker 200 (determined as P. reffera); high mountains about Empire, I $992, H$. N. Patterson 272.

Poa macroclada Rydb. sp. nov.

Perennial with a horizontal rootstock; culm 6-8 dm. high ; sheaths 5-I $5 \mathrm{~cm}$. long, rather loose, strongly striate, slightly scabrous; ligules ovate, acute, about $2 \mathrm{~mm}$. long; leaf-blades 7-10 cm. long, $2 \mathrm{~mm}$. or less wide, flat, glabrous, firm and dark-green ; panicle $2-3 \mathrm{dm}$. long, open; branches in 3's-5's, in fruit reflexed or spreading, the lower often I dm. long, with the spikelets near the ends; spikelets often about $5 \mathrm{~mm}$. long, 2- or 3-flowered; empty glumes lanceolate, very acute, more or less purplish ; flowering glume lanceolate, acute or acuminate, glabrous, slightly purple-tinged; intermediate veins faint and cobweb scant.

This species is related to P. aporta, but differs in the long slender branches of the panicle and the glabrous flowering glumes.

Colorado: Roger's, Gunnison Watershed, August I4, I90 I, C. F. Baker So?.

Poa interior Ryclb. sp. nov.

Foa nomoralis Scribn. Bull. U. S. Div. Agrost. I7: 250. I 899. Not P. nomoralis L. 1753.

? Poa cacsia Coult. Man. Rocky Mt. Reg. 42I. I885. Not P. cacsia Smith. 1 Sco.

The grass common throughout the Rocky Mountain region and extending in the north from Alaslia to the Dakotas and gen- 
erally known as $P$. nemoralis is quite different from the European plant. The latter is found in America as sparingly introduced in the Eastern States. The European plant is taller, with soft, flaccid leaves, ovate or lanceolate acute ligules, larger spikelets and narrowly lanceolate empty glumes which are tapering gradually at the apex and much narrower than the flowering glumes. The American plant is usually lower and stiffer, has rather firm leaves, truncate ligules, smaller spikelets, broader empty glumes, which are rather abruptly acuminate and at least the second almost as broad as the flowering glumes. The name $P$. ncmoralis was used for the American plant by Hooker and Arnott, ${ }^{*}$ but appears there without a description. It was adopted by several authors on western botany; but, as far as I know, never described under that name, until I $\$ 99$ by Professor Scribner. His description and plate illustrates the American rather than the European plant. As the type may be designated:

IVyoming: Headwaters of Clear Creek and Crazy IVoman River, 1900, Frank Truecdy' 3706.

\section{Poa phoenicea Rydb. sp. nov.}

Perennial with a horizontal rootstock and extravaginal innovations; culm 5-6 dm. high, leafy ; sheaths loose, 5-15 cm. long, striate; ligules triangular-lanceolate or ovate, acute, about $5 \mathrm{~mm}$. long; blades $\mathrm{I}-2 \mathrm{dm}$. long, about $2 \mathrm{~mm}$. wide, rather firm, strongly veined; panicle 6-10 cm. long, open, its branches mostly in pairs, the lower $5-6 \mathrm{~cm}$. long; spilielets $4-5$-flowered, 6-7 mm. long; empty glumes lanceolate, acuminate, purple or green below and purple above, glabrous and shining; flowering glumes lanceolate, green at the base, purple in the middle and brownish-scarious at the top; both nerves and internerves villous; cobweb none; intermediate nerves very faint.

This species resembles somewhat $P$. pscudo-pratcnsis, $P$. cpilis and $P$. furpurascons Vasey (see below). From the first it differs by the more acuminate glumes, the faint intermediate nerves of the flowering glumes and the longer, narrower leaves; from the other two by the open inflorescence, the villous, not scabrous flowering glumes and the creeping rootstock.

Colorado: Pike's Peak Valley, Aug. 21, igoi, F. E. \& E. S. Clements 466 .

* Hor. Heech. Voy. I 32.1832 . 
Poa subpurpurea Rydb. nom. nov.

Poa purpurasecus Vasey, Bot. Gaz. 6: 297. I88 I. Not P. purpurascens Sprengel. I 8 I 9.

\section{Poa tricholepis Rydb. sp. nov.}

Perennial with a creeping rootstock and extravaginal innovations; sheaths of the basal leaves short, $2-4 \mathrm{~cm}$. long, strongly striate, rather loose, minutely retrorse-striate; blades $5-10 \mathrm{~cm}$. long, a little over I mm. wide, scabrous; sheaths of culnu-leaves 7-1 $2 \mathrm{~cm}$. long; blades $2-6 \mathrm{~cm}$. long, sometimes nearly $2 \mathrm{~mm}$. wide; ligules lanceolate, acuminate, about $4 \mathrm{~mm}$. long; culm slender, 3-5 dm. high; panicle 6-8 $\mathrm{cm}$. long, open, its branches in pairs, 2-3 cm. long; spikelets 3-4-flowered, 5-8 mm. long; empty glumes about $4 \mathrm{~mm}$. long, lanceolate in side view, acute, green and purple towards the apex; flowering glumes about 4 $\mathrm{mm}$. long, villous below, strigose above, green, bordered with purple and a scarious border, obtuse.

This is related to P. Whecleri and P. I ascyanc, but is easily distinguished from both by the obtuse flowering glume, which is villous below. In the two species mentioned the flowering glume is very acute and strigulose or scabrous throughout, or in $P$. Taseyana hairy on the nerves only.

Colorado: Near Pagosa Peak, Aug. i S99, C. F. Baker 210.

Poa nematophylla Rydb. sp. nov.

A cespitose bunch-grass; basal leaf-blades short, striate, minutely retrosely strigulose; stipules lanceolate, acuminate, about 3 $\mathrm{mm}$. long; blades $\mathrm{I}-\mathrm{I} .5 \mathrm{dm}$. long, filiform, strongly involute, less than $0.5 \mathrm{~mm}$. wide, scabrous-strigulose; culm-leaves few, near the base; sheatlıs $4-6 \mathrm{~cm}$. long; blades $3-5 \mathrm{~cm}$. long; culm about 3 $\mathrm{dm}$. high, filiform ; inflorescence narrow, raceme-like, $2-5 \mathrm{~cm}$. long ; branches 2-10 $\mathrm{mm}$. long, bearing often only a single spikelet; spikelets 7-9 mm. long, about 4-flowered; empty glumes about $4 \mathrm{~mm}$. long, lanceolate, glabrous and shining; flowering glumes about $6 \mathrm{~mm}$. long, light-green, with a silvery scarious margin, very acute, strigose below, scabrous-strigulose above.

Related to Poa idahocnsis, but distinguished by the narrow inflorescence and few racemosely disposed spikelets.

Colorado: Meeker, Rio Blanco County, June 8, igo2, G. E. Osterhout $260 \mathrm{I}$. 
Poa confusa Rydb. sp. nov.

A tufted bunch-grass with intravaginal innovations; sheaths of the basal leaves short, striate, glabrous; blades $1-2 \mathrm{dm}$. long, 2-3 mm. wide, flat or involute, puberulent; culm-leaves several; sheaths I-I. $5 \mathrm{dm}$. long; blades about I dm. long; ligules broadly ovate or rounded, obtuse or acutish, about $2 \mathrm{~mm}$. long; culm 6-9 dm. high; panicle narrow, I-I.5 dm. long, dense; branches short, strongly ascending; spikelets $7-8 \mathrm{~mm}$. long, usually 4-flowered; empty glumes lanceolate in side-view, shining, minutely strigulose above; flowering glumes narrow, about $3.5 \mathrm{~mm}$. long, obtuse or rounded at the apex, rounded on the back below, strigulose, yellowish-green with brownish scarious margin.

This species has been confused with P. lacizgerta, P. lucida and $P$. nordensis. It differs from the first two by the short and broad ligules (in both the ligules are lanceolate and acuminate), and from the last by the empty glumes and in being scarcely scabrous. In $P$. neradcusis the empty glumes are strongly nerved, elongated-lanceolate, almost equaling the oblong, very scabrous flowering glumes; in I'. confusa they are faintly nerved, broadly lanceolate, shorter than the flowering glumes. P. confuser grows in open "parks" and on hills from Nebraska and Montana to Colorado. As the type may be assigned:

Wromng: Medicine Bow Mountains, Albany County, July 28, I goo, dien ielson 7787 .

\section{Poa truncata Rydb. sp. nov.}

A species related to the preceding but stiffer; basal leaves withering early; sheaths of culm-leaves IO- I $5 \mathrm{~cm}$. long, with conspicuous hard auricles at the mouth; ligules very short, about I $\mathrm{mm}$. long, truncate; blades $\mathrm{I}-2 \mathrm{dm}$. long, $2-3.5 \mathrm{~mm}$. wide, scabrous on the back; culm about $9 \mathrm{dm}$. high, stiff; panicle about I. $5 \mathrm{dm}$. long, narrow, with almost erect scabrous branches; spikelets 3-5-flowered, 7-9 mm. long; empty glumes 5-6 mm. long, tinged with purple, scabrous on the nerves; flowering glumes narrow, about $5 \mathrm{~mm}$. long, straw-colored or tinged with purple, strigulose throughout and slightly scabrous on the veins.

The short truncate ligules separate this from the prececling and all other related species.

Colorado: Dillon, Summit County, August 26, is96, F. E. Clancuts 373 . 
Festuca Earlei Rydb. sp. nov.

Perennial with rootstocks and extravaginal innovations; basal leaves with short ligules; blades filform, 5-10 cm. long, strongly involute, $0.5 \mathrm{~mm}$. wide or less; sheaths of the culm-leaves $3-5$ $\mathrm{cm}$. long, striate, smooth; ligules very short, truncate; blades $3-5$ $\mathrm{cm}$. long, I $\mathrm{mm}$. wide or less; culm about $3 \mathrm{dm}$. high, very slender; panicle narrow and spike-like, $3-5 \mathrm{~cm}$. long; branches short and erect, smooth; spikelets 2-3-flowered, about $5 \mathrm{~mm}$. long; first empty glume about $2 \mathrm{~mm}$. long, narrowly lanceolate; the second about $3 \mathrm{~mm}$. long, ovate-lanceolate, 3 -nerved; flowering glumes narrowly lanceolate, about $4 \mathrm{~mm}$. long, smooth, usually awned; awn $1 \mathrm{~mm}$. or less long.

This species is related to F. mbra, but differs in the smaller few-flowered spikelets, the smaller flowering glumes, and the fine, soft leaves.

Colorano: Ia Plata Cañon, July i i, is98, Baker, Earle \& Tracy' 920.

Festuca ingrata (Hack.) Rydb.

Festuca oind ingrata Hack.; Beal, Grasses N. An. 2 : 59S. I $\$ 96$.

This is the common plant of the Rocky Mountain region, which has been known under the name F. orina. It is quite different from the European F. orind L. The latter is found in America only in the northeastern part of the continent.

\section{Festuca minutiflora Rydb. sp. nov.}

Tufted perennial with intravaginal innovations; leaves mostly basal; sheaths smooth, I cm. or so long; ligules $0.75 \mathrm{~mm}$. long, obtuse or rounded at the apex; blades $5-10 \mathrm{~cm}$. long, narrow and flaccid, about $0.5 \mathrm{~mm}$. wide; sheaths of the culm-leaves $2-4 \mathrm{~cm}$. long; blades $1-3 \mathrm{~cm}$. long; culm very slender, $1-1.5$ (seldom 3 ) dm. high; panicle very narrow, lax, $2-4 \mathrm{~cm}$. long, with very short erect branches; spikelets, excluding the awns, about $5 \mathrm{~mm}$. long, $2-3$-flowered; first empty glume narrowly lanceolate, $2-2.5 \mathrm{~mm}$. long, acute; the second $2.5-3 \mathrm{~mm}$. long, ovate-lanceolate, shortacuminate or awn-pointed; flowering glume oblong-lanceolate, about $2 \mathrm{~mm}$. long, purple-tinged above, abruptly contracted into a short awn, I.5 mm. or less.

This is closely related to $F$. brachyphllla, but differs in the smaller spikelets, the more abruptly acuminate flowering glumes, the shorter awns, the laxer panicle and the soft filiform leaves. It 
grows in alpine situations of Colorado, at an altitude of 30004000 meters, and is found apparently also in California.

Colorado: Cameron Pass, July I 3, rS69, C. F. Baker (type); near Pagosa Peak, I S99, Bakir I76; "Colorado," E. Hall I2; Mt. Lincoln, John IVolf; Tennessee Pass, I 893, De Alton Saunders; Mt. Ouray, I $896, F$. E. Clemcnts 210 I⿳2; ; near Manitou, I 896 , Clements f $^{6}$.

California: Bolander 5066.

Elymus strigosus Rydb. sp. nov.

A cespitose perennial; sheaths $3-8 \mathrm{~cm}$. long, striate, glabrous or minutely puberulent, with distinct auricles at the mouth; ligules very short, truncate, I $\mathrm{mm}$. long or less; blades I-2 dm. long, about $3 \mathrm{~mm}$. wide, flat or involute, scabrous; culm 5-7 dm. high ; spike I-I.5 dm. long; spikelets I or 2 at each node; empty glumes linear-subulate, 7-9 mm. long, very scabrous; flowering glumes lanceolate, scabrous-strigose, awn-pointed or short-awned, without the awn about I cm. long.

This is closely related to E. ambiguns, but distinguished by the scabrous strigose flowering glumes, the more scabrous empty glumes and the narrower leaves.

Colorado: Near Boulder, at an altitude of 2300 meters, July 31, I 886, C. W. Lettcrman 553 (type, labeled Agropyrum dasystachy'tm).

Wromng: Naked shale slopes, Point of Rocks, Sweetwater County, i 9oo, Aven Nelson $75^{1}$ (labeled Elymus salinus).

Elymus villiflorus Rydb. sp. nov.

A cespitose perennial; sheaths 4-IO $\mathrm{cm}$. long, striate, glabrous; blades I-2 dm. long, about $2 \mathrm{~mm}$. wide, strongly involute, scabrous above; culm 4-6 dm. high, finely retrorse-pubescent above; spike I-I.5 dm. long; spikelets I or 2 at each node; empty glumes subulate, $7-9 \mathrm{~mm}$. long; flowering glumes lanceolate, 5-nerved, villous-hirsute, without the short awn about I $\mathrm{cm}$. long.

Closely related to the preceding and $E$. ambiguns, this is characterized by its long-haired and more strongly nerved flowering glume. It grows on plains and foothills at an altitude of I joOI Soo meters. 
Colorado: Near Boulder, July, I902, F. Tueedy $\neq 8$ I $S$ (type). Alberta: Banff, July 21, 1900, H. B. Lam'son.

\section{Juncoides intermedium (Thuill.) Rydb.}

Juncus intormedius Thuill. Fl. Env. Paris. ed. 2. I78. 1799.

Juneus multiflorus Ehrh.; Hoffm. Fl. Deutschl. ed. 2. I : I69.

I 800 . Not J. multiflorus Retz. I 795.

This is the plant that has been known in America under the name Lusula campestris or Jun oides campestre, but this North European species is found, if at all on this continent, only in the extreme northeastern portion. It is distinguished from /. intirmedium by its fewer, larger and nodding spikelets. The name Juncus multiflorns dates back as far as I79I, when Ehrhart issued his set of grasses, sedges, etc., but as far as can be ascertained, it was never published for this plant before 1800 , in the revised edition of Hoffmann's Flora.

\section{Nemexia lasioneuron (Hook.) Rydb.}

Smilax lasionuron Hook. F1. Bor. Am. 2: I 73 . I 838 .

Nomexia horbacea melica Aven Nelson, Proc. Biol. Soc. Wash.

I 7 : I75. 1904.

Ibidium porrifolium (Lindl.) Rydb.

Spiranthes porrifolia Lindl. Gen. \& Sp. Orch. 467. I 840.

Mr. House $*$ has shown that Ibidium Salisb. is the name that properly should be used for Spiranthes Richard and Gyrostachys (Pers.) Kuntze; Ophry's L. for Listera R. Br. and Cytherea Salisb. for Calypso Salisb. The Rocky Mountain species of these genera, which have not already been transferred, are given here.

Ophrys borealis (Morong) Rydb.

Listera borealis Morong, Bull. Torrey Club 20: 3I. I \$93.

Ophrys nephrophylla Rydb.

Listera niploropleylla Rydb. Mem. N. I'. Bot. Gard. I: Ios. 1900.

$$
\text { Ophrys caurina (Piper) Rydb. }
$$

Listera caurina Piper, Erythea 6: 32. 1898.

NEW Frok boTaNical Giadex.

* Bull. Torrey Club $32: 378-382$. I905. 
CONTRIBUTIONS FROM THE NEW YORK BOTANICAL GARDEN-No. 82

\title{
STUDIES ON THE ROCKY MOUNTAIN FLORA-XVI
}

\author{
By PER AXEL RYDBERG
}

NEW YORK 1906 

Studies on the Rocky Mountain flora - XVI

Per Axel Rydberg

Salix Watsonii (Bebb) Rydb.

IHBRAKV

NEW YURI

BOTANI A

Gateder

Salix cordata Watsonii Bebb, Bot. Calif. 2: $86 . \quad$ I $\$ 80$.

Salix flara Rydb. Bull. Torrey Club 28: 273. 190I. Not S.

flai'd Schoepf. 1796.

Chenopodium oblongifolium (S. Wats.) Rydb.

Chenopodium leptophyllum oblongifolium S. Wats. Proc. An. Acad.

9: 95. I 873.

Atriplex subspicata (Nutt.) Rydb.

Chcnopodium suhspicatum Nutt. Gen. Am. I : I99. I S I 8.

Atriplex patula sulispicata S. Wats. Proc. Am. Acad. 9: I o7. I 873 .

Rumex praecox Rydb. sp. nor.

Perennial with a thick fleshy rootstock; stem 2-3 dm. high, striate; basal leaves petioled, rather thick; petioles $5-10 \mathrm{~cm}$. long; blades oval or elliptic, 4-IO $\mathrm{cm}$. long, 2-4 cm. wide, rounded at both ends; stem-leaves similar, but snaller, shortpetioled and more acute; flowers perfect, in terminal and axillary panicles; perianth-lobes oval, rouncled at the apex; the outer I. $5 \mathrm{~mm}$., when fully developed about $3 \mathrm{~mm}$. long, the inner $3-5$ $\mathrm{mm}$., without tubercles; fruit developed before the perianth-lobes become much enlarged, shining.

This species is related to $R$. occidentalis, but is characterized by its fleshy tuber-like rootstocks and its precocious fruiting.

Colorado: Grayback mining camps, I 900, Rydloreg \& Irecland 6328 (type); Bob Creek, La Plata Mountains, I 898 , Baktr. Earle \& Tracy 270 .

Paronychia brevicuspis (A. Nels.) Rydb.

Paronychia sissiliflora braicuspis A. Nels. Bull. Torrey Club 26: 237. I 899 . 
LIMNIA L. (Kongl. Sv. Vet. Ak. Hand. I746: I 30. I 746); Haw. Syn. P1. Succ. 11. ISI2.

Greene, Howell and Robinson have transferred a number of species from Claytonia to Montia; but none of them has given any obvious reason. 1)r. Greene satisfied himself by transferring the sections Alsinastrum, Naiocrene and Montrastrum. These evidently come nearest to Montia of all the sections of Claytonia. Prof. Howell, followed by Dr. Robinson, also transferred the section Limna, and the rhizomatous species of Euclaytonia of Gray. The difference between the two genera Claytonia and Montia as now limited is practically reduced to the number of ovules; 6 in the former, 3 in the latter. In Montia we find now both regular and irregular flowers, free petals and partly united petals, 5 stamens and 3 stamens, opposite stem-leaves and alternate stemleaves, annuals and perennials, and of the latter several kinds, viz., with horizontal rootstocks, with short stolons bearing offsets, with slender runners bearing cormlets at the ends, or with axillary bulblets. In the olden time, Montia was easily distinguished from Claytonia by its gamopetalous corolla cleft on one side. It may be that all the sections mentioned above should be removed from Claytonia, but they should not be transferred to Montia. making this genus more unnatural than Claytonic ever was. I think that in a family like Portulacaceac, in which the modifications in the flowers are so slight, generic characters should to some degree be sought in the general habit. Instead of transferring the sections to Montia it would have been better to restore the Linnaean genus Limia (which was adopted by Haworth), and to include in it all the American species of Montia, except $1 \%$. fontana; or else to continue the splitting and propose several new genera. The typical Rocky Mountain species of Limnia are the following:

Limnia asarifolia (Bong.) Rydb.

Clay'tonia asarifolia Bong. Veg. Sitcha 137 . I $8_{3}$ I.

Liminia simirica (L.) Haw. Syn. Pl. Succ. I1. IS I 2. Claytonia sibirica L. Sp. Pl. 204. I 753.

Limnia arenicola (Henderson) Rydb.

Claytonia arenicola Henderson, Bull. Torrey Club 22: 49. I 895. 
Limnia perfoliata (Donn) Haw. Syn. Pl. Succ. i i. isiz. Claytonia perfoliata Donn, Ind. Hort. Cantab. 25. 1796. - Villd. Sp. Pl. I : i i $86 . \quad$ I 798.

Limnia depressa (A. Gray) Rydì.

Claytonia pariflora depressa A. Gray, Proc. Am. Acad. 22: 28 I. I 887 .

Limnia parviflora (Dougl.) Rydb.

Claytonia parifflora Dougl.; Hook. Fl. Bor. Am. I : 225. I 832.

At least two of the species of Claytonic transferred to Montia are, however, so unlike the rest that they can not very well be included in Limnia, but are better regarded as types of distinct genera.

\section{CRUNOCALLIS Rydb. gen, nov. .}

Procumbent or decumbent water or mud-plants, rooting at the nodes and producing long rumners, which develop small globose cormlets at the apex. Leaves several pairs, opposite. Sepals two, nearly equal. Corolla regular. Petals 5, similar and equal. Stamens 5. Ovary 3-ovuled. Capsule I-3-seeded. Seeds granular-muriculate.

This genus has the flowers of Claytonic, but the general habit of Montia; the mode of propagation and the seeds are different from both.

Crunocallis Chamissonis (Ledeb.) Rydb.

Claytonia Chamissoi Ledeb.; Spreng. Syst. I : 790. I825.

NAIOCRENE (T. \& G.) Rydb. gen, nov.

Claytonic \& Vaiocruc T. \&. G. Fl. N. Am. I : 20I, in part. I $s_{3} 8$.

Sarmentose, spreading or decumbent plants, with alternate fleshy leaves, bearing bulblets in their axils. Sepals very unlike, one broad and 2 -lobed at the apex. Corolla regular or nearly so. Stamens 5. Ovary 3-ovuled. Seeds I-3, shining.

Naiocrene parvifolia (Moç.) Rydb. Claytonia paraifolia Moc.; DC. Prodr. 3: 36 I. I 828.

EROCALLIS Rydb. gen. nov.

Perennials with globular corms. Radical leaf usually solitary, not present at flowering time. Stem low, with 2 or 3 
whorled leaf-like bracts. Sepals 2, somewhat unequal. Petals 3-10, oblong. Capsule oblong-conical, circumscissile.

The genus is closely related to Claytonia, and the only distinctive character is the circumscissile capsule. Howell included it in Orcobroma and Robinson in Lcwisia ; in both genera, especially the latter, it is out of place on account of its habit.

Erocallis triphylla (S. Wats.) Rydb. Claylonia triphylla S. Wats. Proc. Am. Acad. Io: 345. I875.

Alsinopsis propinqua (Richardson) Rydb. Arenaria propinqua Richardson, Franklin Journey 738 . 1823 . Arenaria ienu hirta S. Wats. Bot. King Exp. 4r. I87 I. Not -1. hirta IVormskj.

Arenaria árna (a)cquicaulis A. Nels. Bull. Torrey Club 26: 352. I 899 .

Alsinopsis Rossii (Richardson) Rydb.

Arenaria Rossii Richardson, Franklin Journey 738 . I823.

Alsinopsis quadrivalvis ( $R$. Br.) Rydb. Arenaria quadriatais R. Br. in Parry ist Voy. app. cclxxi. 1824.

Alsinopsis obtusiloba Rydb.

Arenaria obtuse Torr. Ann. Lyc. N. Y. 2: I70. 1827. Not A. obtusa All. I 785 .

Arenaria biflora $\mathrm{S}$. Wats. Bibl. Index 94. 1878. Not A. biflora L. 1767.

Arenaria sajancnsis Robinson, Proc. Am. Acad. 29: 304. I 894. Not A. sajanensis Willd. I 8 I 6.

Delphinium reticulatum (A. Nels.) Rydb.

Dilphinium occidentale reticulatum A. Nels. Bull. Torrey Club 27 : 261. 1900.

ODOSTEMON Raf. Am. Monthly Mag. 2: 265. F is Is. Mahonic Nutt. Gen. Am. I : 2 I1. ISIS.

Both Odostemon Raf. and Mahonia Nutt. were published in the same year, but the former a few months earlier. The Rocky Mountain species are: 
Odostemon Aquifolium (Pursh) Rydb.

Berboris Aquifolimm Pursh, Fl. Am. Sept. 2 I9. IS I4.

Bcrberis repens Lindl. Bot. Reg. pl. I I76. I828.

Burberis mana Greene, Pittonia 3: 98. I $\$ 96$.

Odostemon nutkanus (DC.) Rydb.

Marhonia Aquifolium mutkana DC. Syst. 2: 20. IS2I.

Berbcris Aquifolim Lindl. Bot. Reg. sub pl. II76. IS2S.

Odostemon nervosus (Pursh) Rydb.

Buberis nerrosa Pursh, FI. Am. Sept. 2 I 9. I 814.

Odostemon Fremontii (Torr.) Rydb.

Berberis Fremontii Torr. Bot. Mex. Bound. 30. I 859 .

Lepidium crenatum (Greene) Rydb.

Thelypodium crenatum Greene, Pittonia 4: 20, I 899.

The species was described from flowering specimens, but the ovaries or young fruit were developed enough to indicate the true genus. Dr. Greene was probably led astray by the fact that the specimens were labeled Thelypodinm intigrifolinm.

\section{Erysimum asperrimum (Greene) Rydb.}

Chciranthus asporrimus Greene, Pittonia 3: i 33 . I 896.

Erysimm pumilum Rydb. Mem. N. Y. Bot. Gard. I : I S9. I 900.

In my Flora of Montana I took up Nuttall's E. prmmilum for this species. This was evidently an error into which I was led by Dr. Greene's discussion in Pittonia, loc cit. E. prmilnm Nutt. remains as yet unknown, but from the description it must be a close relative of E. nivale and E. radicatmm, if not one of these species.

\section{Erysimum Bakeri (Greene) Rydb.}

Chciranthus aridus Greene, Pittonia 4: 198. I900. Not C. midns

A. Nelson. I 899 .

Cheiranthus Bakcri Greene, Pittonia 4: 235. I90I.

Erysimum argillosum (Greene) Rydb.

Chiranthus argillosus Greene, Pittonia 3: i 36. I 896. 
Erysimum amoenum (Greene) Rydb.

Chciranthus nivalis amoenus Greene, Pittonia 3: I37. I 896.

Lesquerella stenophylla (A. Gray) Rydb.

I'esicance stcnophylla A. Gray, Bost. Jour. Nat. Hist. 6: 149. I 850 .

This was included in L. Fendleri by Dr. Watson, but I think it well distinct.

\section{Euklisia crassifolia (Greene) Rydb.}

Streptanthus crassifolius Greene, Pittonia 3: 227. I S97.

Dr. Greene in Leaflets (I: 81-85. D 1904) took up Euklisia of Nuttall, only changing its spelling, but he overlooked that it had already been proposed as a genus in Dr. Small's Flora of the Southeastern United States. About three years ago I intended to publish it as a genus, making Streptanthus cordatus Nutt. the type. Unfortunately my notes were never published and forgotten. Dr. Small, who had seen them, took up the name in his flora, giving me the credit for the same. As he published only one species, $E$. hyyacinthoides, this becomes the type. Dr. Greene took up the name for a group, to which neither Dr. Small's type nor my intended type (which I also think was Nuttall's) belong. If Stretptanthus should be split up into as many genera as Dr. Greene suggests, neither his species of Euklisia nor those known to Nuttall would fall within Euklisia. My intention was only to divide the genus into two genera, Streptanthus and Euklisia. So limited the latter genus will contain the Rocky Mountain species here given.

Euklisia cordata (Nutt.) Rydb.

Streptanthus cordatus Nutt.; T. \& G. Fl. N. Am. I: 77. 1838 .

Euklisia longirostris (S. Wats.) Rydb.

Arabis longirustris S. Wats. Bot. King Exp. I7. I87 I.

Streptanthus longirostris S. Wats. P'roc. Am. Acad. 25: 127. I 890.

Peritoma Sonorae (A. Gray) Rydb.

Cleome Sonorae A. Gray, Pl. Wright. 2: I6. 1853 . 


\section{Potentilla platyloba Rydb.}

Potcntilla bipinnatifida flatylola Rydb. Mem. Dep. Bot. Columbia Univ. 2: roo. I 898.

This is as distinct from $P$. bipinnatifida as most species of $P_{0-}$ tentilla are from their relatives.

\section{Potentilla rubripes Rydb.}

Potentilla mbricanlis Rydb. Mem. Dep. Bot. Columbia Univ. 2: IOI. I 998 . Not P. mbricanlis Lehm. is 30.

Lehmann's species, for which I mistook this Rocky Mountain plant, is the same as P. prostrata Rottb.

\section{Argentina argentea Rydb.}

Argentina ansirina concolor Rydb. Mem. Dep. Bot. Columbia Univ. 2: I60. I 898 . Not Potontilla anscrina concolor Ser. I 825 .

The European plant to which this was referred differs in having more deeply and more sharply toothed leaflets, and smaller flowers.

Fragaria ovalis (Lehm.) Rydb.

Potcntilla oralis Lehm. Ind. Sem. Hort. Bot. Hamb. I849: 9. 1849 .

Fragaria furma Rydb. Mem. Dep. Bot. Columbia Lniv. 2: ISA. I 898 .

Dr. Wolf, of Dresden, Germany, has called my attention to the fact that $P$. orolis Lehm. is no Potintilla at all. Prof. Lehmann did not cite any type, but his herbarium shows that it was Fondler 206, which I included in Fragaria firma.

Fallugia acuminata (Wrooton) Rydb.

Fallugia paradoxa acuminata Wooton, Bull. Torrey Club 25: 306. I 898 .

Prunus melanocarpa (A. Nelson) Rydb.

Cerasus demissa melanocarpa A. Nels. Bot. Gaz. 34: 25.1902.

The common Rocky Mountain tree is well distinct from the original Cerasus demissa Nutt. or Prums demissa Walp. The latter, which was from the Columbia Valley, has thin, very pubescent 
leaves, and is more related to the eastern $P$. airginiana. $P$. melanocarpa is rather nearer the Mexican species known as $P$. Copalin, and it is sometimes very hard to distinguish it from that species.

ANISOLOTUS Bernh. Sem. Hort. Erf. I 837. - Linnaea I2: Litt. Ber. 75 . I $\$_{3} 8$.

I think that this genus, well characterized by Bernhardi, should be restored. It is well distinct from the Old World Lotus and from Hosackia. I think that Dr. Greene's merging all our North American species usually known as Hosackia into Lotus was very unfortunate, for we do not have any native species which could be included in Lotus, even if made broad enough to include Tetragonolobus and other Old World genera.

The Rocky Mountain species of Anisolotus are:

Anisolotus Wrightii (A. Gray) Rydb.

Hosackia IVrightii A. Gray, Pl. Wright. 2: 42. I 853.

Anisolotus brachycarpus (Benth.) Rydb.

Hosackia brachycarpa Benth. Pl. Hartw. 306. I 848 .

Lotus huministratus Greene, Pittonia 2 : I $39 . \quad$ I 890.

Anisolotus rigidus (Benth.) Rydb.

Hosackia rigida Benth. Pl. Hartw. 305. I 848.

Aragallus Hallii (Bunge) Rydb.

Orytropis Hallii Bunge, Mem. Acad. Sci. St. Petersb. VII. 22 ${ }^{1}$ : I62. I 874 .

Vicia dissitifolia (Nutt.) Rydb.

Lathyms dissitifolius Nutt.; T. \& G. Fl. N. Am. I : 277. I 838 .

Lathyrus incanus (Rydb. \& Smith) Rydb.

Lathrirts ornatus incamus Rydb. \& Smith, Fl. Neb. 2 I : 64. I 895.

Chamaesyce flabelliformis (Engelm.) Rydb.

Euphorbia petaloidea flagelliformis Engelm. Bot. Mex. Bound. I 85 . I 859 .

Euphorbia flagclliformis Engelm. Bull. Geol. Surv. Terr. 2 : 243. 1876. 
Chamaesyce rugulosa (Engelm.) Rydb.

Euphorbia serpyllifolia rugulose Engelm.; Millsp. Pittonia 2:85. I 890.

\section{Chamaesyce albicaulis Rydb.}

Euphorbia albicaulis Rydb. Mem. N. Y. Bot. Gard. I: 266. 1900.

Tithymalus arkansanus coloradensis (Norton) Rydb.

Euphorbia arkansana coloradensis Norton, Rep. Missouri Bot. Gard. II : 105. 1900.

Sida sagittaefolia (A. Gray) Rydb.

Sida lepidota sagrittacfolia A. Gray, Pl. Wright. I : IS. I852.

\section{Sphaeralcea marginata York, sp. nov.}

Perennial, herbaceous; stem usually branching from the base, with ascending branches, $2-6 \mathrm{dm}$. tall, densely stellate-canescent ; leaf-blades subrotund, rounded-ovate or subcordate, $1.5-4 \mathrm{~cm}$. long, $1.5-3 \mathrm{~cm}$. wide, cordate or truncate at the base, crenate or imperfectly dentate, slightly 3 -5-lobed, the middle lobe acute or obtuse, the upper surface with close stellate pubescence, more densely pubescent beneath, petioles less than , 2 as long as the blades or sometimes longer; flowers borne in narrow panicles; involucre of 3 small setaceous bracts: calyx-tube densely stellate-pubescent, about $3 \mathrm{~mm}$. long: lobes 5, ovate, acute or acuminate, almost glabrous or sparingly stellate-pubescent on dorsal surface, densely pubescent on the margin, glabrous within, $2-3 \mathrm{~mm}$. long, in fruit 4-5 $\mathrm{mm}$. long; petals pink, obovate, $10-12 \mathrm{~mm}$. long; carpels I O-12 in number, $3-4 \mathrm{~mm}$. long, cuspidate, the lower half reticulated; ovules two; usually only one seed developed in the lower part of each carpel, upper part somewhat aborted; seeds reniform, glabrous.

In general appearance this plant resembles Splacralcia Munroand (Doug.) Spach; but in the former, the mature carpels separate from the central axis by a small thread attached to the base of each carpel, while in the latter, the carpels do not separate from the central axis by a thread. Sphacralcia marginater also resembles S. incana Torr.; but the latter is taller, the leaves are larger, the pubescence on both sides of the leaves is much denser and finer, the paniculate clusters of flowers are longer and more open and the carpels are nearly always two-seeded. 
Colorado: Grand Junction, igor, C. F. Baker 93 (type); also is93, Di Alton Samndirs; McElmo Cañon, igor, F. K. Irechind 860 .

New Mexico: I gor, F. K. Frecland S23. .

Cactus similis (Engelm.) Rydb.

Mamillaria similis Engelm. Bost. Jour. Nat. Hist. 5: 246. 1845. Mamillaria missouriensis cacspitosa S. Wats. Bibl. Index 403. $18 ; 8$.

Echinocereus aggregatus (Engelm.) Rydb.

Mamillaria aggregata Engelm. in Emory, Notes Recon. I 57. I 848 .

Echinocerus coccincus Engelm. Wisliz. Rep. 9. I 848 . Not E. coccine'ts DC.

Cercus phocnicus Engelm. Proc. Am. Acad. 3: 284.1856.

Echinocereus Roemeri (Muhlenf.) Rydb.

Cerus Rocmeri Muhlenf. Allg. Gart. Zeit. I6: I $9 . \quad$ I 848.

Cercus conoidus Engelm. Pac. R. R. Rep. 4: 35. I 856.

Epilobium adenocladon (Haussk.) Rydb.

Epilobinm paniculatmm adcnocladon Haussk. Mon. Gatt. Epil. 247. 1884.

Anogra latifolia Rydb.

Oinothera pallidar latifolia Rydb. Contr. U. S. Nat. Herb. 3 : I 59. 1895 .

Pachylophus marginatus (Nutt.) Rydb.

Ocnothere marginate Nutt.; Hook. \& Ar11. Bot. Beechey 342. $1 S_{3} 8$.

Ocnothere iderhocnsis Mulford, Bot. Gaz. I9: II 7. IS94.

Sphaerostigma pubens (S. Wats.) Rydb.

Oenothere strigulose futens S. Wats. Proc. Am. Acad. 8: 594. 1873 .

Sphaerostigma minutiflora (S. Wats.) Rydb.

Ocnothere aly'ssoides minutiftere S. Wats. Proc. Am. Acad. 8: 591. I 873 . 
CORNELLA Rydb. gen. nov.

The type of the genus Cormus L. is C. mas L. which has no congener in this country, except perhaps $C$. sessilis Torr. of California. Opiz segregated from Cormus the genus Sitida, to which the European $C$. sanguinea and most of our American cornels belong. Rafinesque in his Alsographia Americana made the genus Cynoxylon based on C. floride L., and also another genus (or subgenus) Eukrania in which he placed C. cancelensis L. and C. succica L. Unfortunately he made C. mascula of Europe, which is congeneric with and some claim the same as C. mas L., the type, and $C$. canadensis and $C$. suecia have no available generic name, unless they are included with $C$. florider and $C$. Nuttallii in Cynoxylon. Outside of the great difference in habit and fruit between the Dwarf Cornels and the Flowering Dogwoods, the former have one character not found in any of the groups usually included in Cormus. The sepals of the Dwarf Cornels have a small hornlike, at last deciduous, spine on the back near the apex. This, together with the peculiar habit, makes them deserve generic rank.

Cornella canadensis (L.) Rydb.

Cormus canadensis L. Sp. Pl. I I S. I753.

Cornella suecica (L.) Rydb.

Cormus succica L. S.p. Pl. I I 8.1753.

Cornella unalaschkensis (Ledeb.) Rydb.

Cormus unalaschkensis Ledeb. F1. Ross. 2: $378.18+4$.

Pseudocymopterus multifidus Rydb.

Pscudocymoptorus montams multifidus Rydb. Bull. Torrey Club 31: 574 . 1904 .

Pseudocymopterus purpureus (C. \& R.) Rydb.

Pseudocymopterns montams purpureus C. \& R. Rev. N. Am. Umbell. 75. I $88 S$.

Pseudocymopterus tenuifolius (A. Gray) Rydb.

Thaspum montanum timuifolium A. Gray, P1. Mright. 2: 65. 1853. 
Ligusticum montanum tenuifolium S. Wats. Bibl. Index 426. 1878 .

Vaccinium oreophilum Rydb.

Vaccinium myrtilloides S. Wats. Bot. King Exp. 209. I87 I. Not I. myrtilloides Michx. ISO3.

Iraccinium Myrtillus A. Gray, Syn. F1. $2^{1}: 24$. I878. Not $I^{?}$. Myrtillus L. I 753 .

The American plant has depressed globular-ovoid corolla, fully as wide as long, while the original European $V$. Myrtillus has ovoid-urceolate corolla, decidedly longer than broad.

Androsace subulifera (A. Gray) Rydb.

Androsace septentrionalis subulifora A. Gray, Syn. Fl. $2^{1}$ : 60. 1878 .

\section{Dodecatheon sinuatum Rydb.}

Dodecatheon radicatum sinuatum Rydb. Bull. Torrey Club 3I: 63I. 1904.

Erythraea arizonica (A. Gray) Rydb. Erythraca calycosa arizonica A. Gray, Syn. Fl. $2^{1}$ : I I 3. is 8 8.

Anthopogon elegans (A. Nels.) Rydb.

Gontiana elegans A. Nels. Bull. Torrey Club 25: 276. I S9s.

Anthopogon barbellatus (Engelm.) Rydb.

Gentiana barbellata Engelm. Trans. Acad. St. Louis $2: 2$ I6. I863. Gentiana Moseleri A. Nels. Bot. Gaz. 31 : 396. 1901.

Amarella monantha (A. Nels.) Rydb.

Gentiana tenclla A. Gray, Syn. Fl. $2^{1}$ : I I 7 , in part. I878.

Gentiana monantha A. Nels. Bull. Torrey Club 31: 244. I904.

Amarella plebeia Holmii (W'ettst.) Rydb.

Gentiana plibia Holmii Wettst. Oester. Bot. Zeitsch. 50 : 195. I 900.

Dasystephana Romanzovii (Ledeb.) Ryddb.

Gentiana Komanarii Ledeb.; Bunge, Nouv. Mém. Soc. Nat. Mosc. I : 2 I 5. I $\$ 29$. 
Gentiana frigida A. Gray, Syn. F1. 21: 120. is78. Not G. frigida Haenke. I $7 \delta 8$.

Dasystephana Parryi (Engelm.) Rydb.

Gentiana Parryi Engelm. Trans. Acad. St. Louis 2: 2 I $8 . \quad$ I 863.

Dasystephana affinis (Griseb.) Rydb.

Gentiane affinis Griseb. Gen. et Sp. Gent. 289. IS39.

Dasystephana Forwoodii (A. Gray) Rydb.

Gentiana Forecoodii A. Gray, Syn. Fl. 2': 406. [Ed. 2.] 1886.

Dasystephana Bigelovii (A. Gray) Rydb.

Gentiand Bigeloiii A. Gray, Syn. F1. 2 : 406. [Ed. 2.] I 886.

Dasystephana interrupta (Greene) Rydb.

Gentiana intermpta Greene, Pittonia 4: 182.1900.

Frasera scabra (M. E. Jones) Rydb.

Frascra speciosa scabra M. E. Jones, Zoe 4: $277 . \quad 1893$.

Frasera stenosepala Rydb.

Frascra spiciosa stenosifala Rydb. Rull. Torrey Club 31: 632. 1904.

Frasera angustifolia Rydb.

Frasera speciosa angustifolia Rydb. Bull. Torrey Club 31: 632. 1904 .

Phlox depressa (E. Nels.) Rydb.

Phlox multiflora depressa E. Nels. Rev. IV. N. Am. Phloxes 20. $1 \$ 99$.

Leptodactylon Watsonii (A. Gray) Rydb.

Gilia Watsonii A. Gray, Proc. Am. Acad. 8: 267. I870.

Leptodactylon Nuttallii (A. Gray) Rydb.

Gilia Nuttallii A. Gray, Proc. Am. Acad. 8: 26\%. I870.

\section{Phacelia ciliosa Rydb.}

Phacelia sericea ciliosa Rydb. Bull. Torrey Club 31: 636. I904. 
Oreocarya hispidissima (Torr.) Rydb.

Eritrichum glomeratum hispidissimum Torr. Bot. Mex. Bound. I $40 . \quad$ I 859 .

Oreocarya perennis (A. Nels.) Rydb.

Orcocarye affinis pormuis A. Nels. Erythea 7: 67. I 899.

Mertensia platensis Rydb.

Mertensia polyplylla platinsis Rydb. Bull. Torrey Club 31: 63s. 1904.

Agastache pallidiflora (Heller) Rydb.

Brittonastrum pallidiflorum Heller, Bull. Torrey Club 26: 62 I. I 899 .

Brittonastrum Grecni Briquet, Ann. Conserv. \& Jard. Geneve 6 : I 57.1902.

Madronella parvifolia (Greene) Rydb.

Monardella parifolia Greene, Pl. Baker. 3: 22. 1901.

Madronella dentata Rydb.

Monardella dentata Rydb. Bull. Torrey Club 31 : 64I. 1904.

Mentha Penardi (Briquet) Rydb.

Mentha aremsis Penardi Briquet, Bull. Herb. Boiss. 3 : $215 . \quad$ I 895.

Androcera rostrata (Dunal) Rydb.

Solamm rostreatum Dunal, Hist. Sol. 234. I 8 I 3. Androcera lobata Nutt. Gen. Am. I : $129 . \quad 18$ IS.

Pentstemon unilateralis Rydb. nom. nov.

Pintstimon secundifloms A. Gray, Syn. Fl. $2^{1}: 26_{3}$. I878. Not P. secundiflorus Benth.

In Proc. Am. Acad. 6: 61, Dr. Gray gives $P$. sccundiftorns as a synonym of $P$. acuminatus Benth. This was correct as far as Dr. Gray's conception of the latter is concerned. Dr. Gray included in $P$. acuminatus at least four different plants. Of these, two have very broad rounded clasping and abruptly acuminate upper leaves, 
viz. : the original $P$. acuminatus Dougl. and my P. cyethophorus; and two with lanceolate upper leaves, viz.: P. Fondliri A. Gray and the original $P$. sicundiflorus Benth. Fremont's plant, the type of the latter, is in the Torrey herbarium. On the sheet is written in Dr. Gray's own handwriting: "This is only $P$. acuminatus, Dougl.; small. A. G. 1862." Dr. Gray afterwards transferred the name $P$. sicundifforus to an entirely different plant, describing it in the Synoptical Flora. This therefore needs a new name.

\section{Pentstemon angustifolius caudatus (Heller) Rydb.} Pentstimon cautatus Heller, Minn. Bot. Stud. 2: 34 . IS98.

$P$. candatus Heller is in my opinion the southern more luxuriant and broad-leaved form of I'. angustifolius. The two grade absolutely into each other in Colorado.

\section{Pentstemon trichander (A. Giay) Rydb.}

Pintstemon barbatns trichander. A. Gray, Proc. Am. Acad. I I : 94. I $8 ; 6$.

This, as well as P. Torreri Benth., I think should be kept distinct from P. burbatus (Cav.) Nutt. of Mexico.

\section{MYZORRHIZA Phil. Linnaea 29: 36 . I 857.}

The Nothaphyclox subgenus of Aflyllon as limited in Gray's Synoptical Flora has been shifted back and forth between the genera Philipaca, Anoplanthus and thlullon, and has lately been restored to Orobanchi, where its original species were described. The typical species of Orobanche have a bilabiate calyx, while the species here discussed have a 5-parted one. As far as I find, the only genus described to which they can be referred is the one given above. The following two species are found in Colorado:

Myzorrhiza ludoviciana (Nutt.) Rydb.

Orobanche ludoriciand Nutt. Gen. Am. 2: 58 . I 8 I 8. Aphyllon ludoricianum A. Gray, Bot. Calif. I : 585. I $8,6$.

\section{Myzorrhiza multiflora (Nutt.) Rydb.}

Orobanche multiflore Nutt. Jour. Acad. Nat. Sci. Phila. II. I : I 79. I 848 . Aphyllon mutiflorm A. Gray, Bot. Calif. I : 585 . I 8,6 . 


\section{Galium subbiflorum (Wieg.) Rydb.}

Galium trifudum subbiftorum Wieg. Bull. Torrey Club 24: 399. I 897.

Distegia involucrata (Richardson) Rydb.

Iylostemi inwolucratum Richardson, Frankl. Journey 733. IS23. Lonicura indolucratum Banks; Spreng. Syst. I : 759. 1825. Disteria mutans Raf. New Fl. Am. 3: 21. I\$36.

Chrysothamnus serrulatus (Torr.) Rydb.

Linosyris semulata Torr.; Stansbury, Expl. 389 . I 852. Chrysothammis glancus A. Neison, Bull. Torrey Club 25:377. I 898 .

Chrysothamnus latifolius (D. C. Eaton) Rydb.

Linosyris aiscidifure latifolic D. C. Eaton, Bot. King Exp. 157. $\mathrm{I} 87 \mathrm{I}$.

Bigeloria Douglasii latifolia A. Gray, Proc. Am. Acad. 8: 646. 1873 .

Isocoma Wrightii (A. Gray) Rydb.

Linosyris Wrightii A. Gray, P1. Wright. I : $95 . \quad$ I 852. Bigclowia Itrightii A. Gray, Proc. Am. Acad. 8: 639. IS73.

OREOCHRYSUM Rydb. gen. nov.

Plants with slender horizontal rootstoch, leafy, viscid-puberulent above. Involucral bracts oblong, pale, rather obscurely Iribbed, chartaceous or the outer foliaceous, in about three moderately unequal ranks. Rays several, short. Disc-corollas narrowly trumpet-shaped, deeply 5-toothed. Style-appendages lanceolate, longer than the stigmatic portion. Achenes angled. Pappus white or slightly tawny, of soft scabrous bristles.

When Dr. Greene made his segregations of the old genus Aplopappus, he transferred the type of the genus here proposed to Solidego, but it is just as much out of place here as among its old associations, i. $e_{\text {. }}$, the present genus Stonotus. It is true that in general habit it reminds one of a group of species formerly included in Solidago, but now segregated as a genus Oligoncuron Small; the character of the involucre and the style-appendages, however, distinguish it from Oligoneuron as well as from Solidago proper. 
Oreochrysum Parryi (A. Gray) Rydb.

Aplopaptus Pamyi A. Gray, Am. Jour. Sci. II. 33: 239. I 862. Solidago Parryi Greene, Erythea 2: 57 . I894.

Solidago pallida (Porter) Rydb.

Solidago speciosa pallika Porter, Bull. Torrey Club I9: I 30. I 892.

Solidago scabriuscula (Porter) Rydb.

Solidago canadensis scabra T. \& G. F1. N. Am. 2: 224. 1842. Not S. scabra VVilld.

Solidago canalensis scabriuscula Porter, Mem. Torrey Club 5: 318.1894.

\section{Solidago gilvocanescens Rydb.}

Solidago canadensis giliocanescens Rydb. Contr. U. S. Nat. Iferb. 3: 162. I 895.

Aster polycephalus Rydb.

Aster scoparius DC. Prodr. 5: 242. 1836 . Not A. scoparius Nees. I $S_{32}$.

Leucelene serotina (Greene) Rydb.

Lencelene cricoides surotina Greene, Pittonia 3: I 49. IS96.

Leucelene hirtella (A. Gray) Rydb.

Diplopappus cricoffolius hivtella A. Gray, Mem. Am. Acad. 4: 69. 1849 .

Erigeron Wootonii Rydb.

Erigeron cincrus var. $\gamma$ A. Gray, Mem. Am. Acad. 4:68. Is49.

ESCHENBACHIA Moench, Meth. 573. I 794.

Conyar Less. Syn. Comp. 203, in part. 1832. Not Conyar (Tourn.) L. I 753 .

The type of the Linnaean genus Conyor is Conyor squarosa L. but this as well as most of the original species are now included in Inula. Lessing transferred the name Cony a to an entirely different group of plants. Dr. Greene united our North American species with some species of Erigeron into the genus Conyolla Rupi. 
( I 869 ), which is antedated by Leptilon Raf. ( I 8 I 8 ). Hence Conyztlla becomes a synonym. I do not think that Conya Coulton should be included in Leptilon, which it resembles in habit but not in the composition of the heads. It has several relatives in Mexico and Central America as well as in the Old World. The oldest available name for these is, if I am not mistaken, Eschubachia Moench.

Eschenbachia Coulteri (A. Gray) Rydb. Conyar Coultiri A. Gray, Proc. Am. Acad. 7: 355. 1868.

\section{BERTIELOTIA DC. Prodr. 5: 375 . I 836.}

A sericeous composite shrub of the southwestern United States has been variously referred to Plucher and Tessario, but is rather out of place in either genus. It was originally made a genus by itself, Polypappus, by America's keenest botanist, Thomas Nuttall, and I think it should have remained a genus distinct from both Pluchic and Tissaria. It has evidently a congener, however, in the desert regions of the Orient. This was described by De Candolle as Berthiclotio.

Berthelotia sericea (Nutt.) Rydb.

Pulypoppus sericus Nutt. Jour. Acad. Nat. Sci. Phila. II. I : I $78 . \quad$ I 848 .

Tissaria borcalis "DC.;" T. \& G. in Emory, Notes Recon. I43. 1848 .

Pluther borcalis A. Gray, Proc. Anr. Acad. 17: 2 I 2. I882.

Ximenesia exauriculata (Rob. \& Greenm.) Rydb. rirbesina inclinites cerariculata Rob. \& Greenm. Proc. Am. Acad. 34: 544. 1 S99.

PLATYSCHKUHRIA (A. Gray) Rydb. gen. nov. Schkuhria \$ Platyschkuluric A. Gray, Am. Nat. 8: 2 I 3 . I874. Bahic \& Platpschkuluric A. Gray, Syn. F1. $2^{1}: 332 . \quad$ I 884.

The genus Bahir as limited in Gray's Symoptical Flora is a rather unnatural one. The group most unlike the rest is the one constituting the section Platyschkulria, which I think deserves generic rank. I adopt the sectional name, although its etymology and form are rather bad. 
Platyschkuhria integrifolia (A. Gray) Rydb. Schkuria integrifolic A. Gray, Am. Nat. 8: 213. I874. Bahia nuaicaulis A. Gray, Proc. Am. Acad. I9: 27.1883.

\section{Platyschkuhria oblongifolia (A. Gray) Rydb.} Bahic oblongifolia A. Gray, Proc. Am. Acad. 19: 27. Iss3.

Tetraneuris glabriuscula Rydb.

Tetrancuris glabra Greene, Pittonia 3: 268, in part. I 898 . Not Aitinclla glabre Nutt. I $S_{+} \mathrm{I}$.

What Actinclla glabre Nutt. was is not exactly known. It is not, however, the plant for which Dr. Greene adopted the name Totrancuris glabra. If it is a Titrancuris at all, it must be a species related to $T$. Fiesiana, $T$. argenter and $T$. Icptocleata, as it is described as having stem-leaves. None of these grows near the original locality of -1 . glethre, viz., Shawnee villages on the Missouri (near Kansas City). The only species that are found within 300 miles from this station are $T$. horbace Greene of Illinois, and $T$. fastigiata Greene and the following from central and western Kansas. None of these answers the description.

\section{Tetraneuris stenophylla Rydb.}

Perennial with a branched caudex, the branches of which are partly subterranean, 2-IO cm. long; leaves basal, very narrowly linear-oblanceolate, $2-4 \mathrm{~cm}$. long, $\mathrm{I}-2 \mathrm{~mm}$. wide, strongly punctate, glabrous or with a few long hairs near the base; bases dilated and scarious-margined, only slightly long-hairy; scape $5-10 \mathrm{~cm}$. long, striate, punctate and sparingly strigose; involucre about 5 $\mathrm{mm}$. high and $10 \mathrm{~mm}$. wide, hemispheric; bracts elliptic, obtuse; rays hight-yellow, about $10 \mathrm{~mm}$. long and $5 \mathrm{~mm}$. wide, $3-4$-toothed and 5-7-nerved.

This is closest related to $T$. fastigiata Greene, in which, however, the bases of the leaves are arachnoid-hairy and the involucres densely villous.

Kansas: Ford County, I89I, L. D. Ellis (type).

Colokado: Banks of Cimarron, I 860, Newhery.

CHAMAECHAENACTIS Rydb. gen. nov.

Cespitose scapiferous perennial, branching below the surface of the ground and with a woody root. Leaves all basal and simple, 
coriaceous, white-strigose below, sparingly hirsute and punctate above. Involucral bracts about twelve, in two series; the inner series longer and with scarious-margined reddish tips. Corolla fleshcolored, with equal lobes. Stamens included. Style-lips broad. Achenes clavate, densely villous. Pappus of eight nearly equal scales, with prominent midrib and erose tips.

Miss Eastwood, the discoverer of the plant, referred it to Cha: nactis, to which it is not closely related, resembling this genus only in the color of the corolla. The structure of the fruit and pappus would place it nearer Bahior and Titranuris. In general habit it resenbles most that exceedingly rare plant described by Nuttall under the name Bolophyte aifina, which by Dr. Gray was tranferred to Parthcnium.

Chamaechaenactis scaposa (Eastw.) Rydb.

Chacnactis scaposa Eastw. Zoe 2: 231. I891.

Rydbergia Brandegei (A. Gray) Rydb.

Actinclla grandiflora slabrata Porter, in Port. \& Coult. Syn. Fl. Colo. $76 . \quad$ I 874 .

Actinclla Brandegei Porter; A. Gray, Proc. Am. Acad. I3 : 373. I 878.

Rydbrgia glabrata Greene, Pittonia 3: 270. I $\$ 9$ S.

Hymenoxys macrantha (A. Nels.) Rydb.

Picratcmia macrantha A. Nels. Bot. Gaz. 28: i 30. I 899.

Hyminory's Richarasonii macrantha Cockerell, Bull. Torrey Club

\section{I : 475 . I904.}

Evidently Professor Cockerell was correct in uniting Hymcno.rys and Picralinia under the older generic name. To his conception of species I am not willing to assent, however. In this respect I would rather agree with Dr. Greene and Prof. Aven Nelson. The changes in nomenclature of the Colorado species are here giren.

Hymenoxys pumila (Greene) Rydb.

Picradenia pumila Greene, Pittonia 3: 27 1. I S98. Hymcnoxys Richardsonii pumila Cockerell, Bull. Torrey Club 3 I : 472. I 1904 . 
Hymenoxys multiflora (Buckley) Rydb.

Phileosora multiflora Buckley, Proc. Acad. Nat. Sci. Phila. I86I: 459. I S62.

Picradchia multiflora Greene, Pittonia 3: 273. I 898.

Hymenorys chrysanthonoides multiflora Cockerell, Bull. Torrey Club 3r: 507. 1904.

\section{Hymenoxys multiflora Osterhoutii (Cockereli) Rydb.}

Picradenia odorater Osterhoutii Cockerell, Bull. Colo. College Mus. I I D 1903.

Hymenoxys chrysanthemoides Osterhoutii Cockerell, Bull. Torrey Club 31 : 505. I 904.

Achillea alpicola Rydb.

Achillea lamulesa alpicola Rydb. Mem. N. Y. Rot. Gard. I : 426. 1900.

Artemisia Scouleriana (Besser) Rydb.

Artcmisia descrtorum Sconleriana Besser; Hook. Fl. Bor. Am. I : 325. 1833 .

Artemisia pabularis (A. Nels.) Rydb.

Artemisia rhisonata pahularis A. Nelson, Bull Torrey Club 27: 34. 1900.

Artemisia viscidula (Osterholit) Rydb.

Artmisia cana riscidula Osterhout, Bull. Torrey Club 27:507. 1900.

Carduus filipendulus (A. Gray) Rydb.

Cirsinm virginianum flipondulum A. Gray, Man. ed. 5. 273. I 880.

Cirsium filifundulum Engelm.; A. Gray, loc. cit., as a synonym. Cnicus altissimus filipendulus A. Gray, Proc. Am. Acad. I9: 57. I $S_{3}$.

\section{Senecio Flintii Rydb. sp. nov.}

Perennial with a cluster of fibrous-fleshy roots; stem about $3 \mathrm{dm}$. high, striate, sparingly arachnoid-hairy; basal leaves about $8 \mathrm{~cm}$. long; blades orbicular or rounded-oval, abruptly con- 
tracted into short petioles, sparingly arachnoid when young, glabrous and rather thick in age; stem-leaves lanceolate, sinuately toothed, auricled and clasping at the base, arachnoid when young; inflorescence small, with 3-6 heads, which are about $\mathrm{I} \mathrm{cm}$. high; bracts linear, $7-S \mathrm{~mm}$. long, abruptly acute at the apex, with a triangular black tip; rays light-yellow, broad; achenes striate, glabrous.

Related to S. cxaltatus and S. integerrimus, but differing from the former in the entire basal leaves and small corymb, from the latter in the abruptly acute black-tipped bracts, and from both in the lower stature and the broader basal leaves.

Southwestern Colorado: $\boldsymbol{I}^{\mathrm{T}}$. F. Flint.

Senecio Harbourii Rydb. sp. nov.

Perennial with a branched cauclex; stem I-2 dm. high, striate, white-floccose, leafy; basal leaves and most stem-leaves petioled, 3-ro cm. loner, deinsely white-floccose; blades oblanceolate or linear-spatulate, entire; uppermost stem-leaves sessile, lanceolate, $1-3 \mathrm{~cm}$. long, more or less auricled at the base; inflorescence corymbiform, with 2-7 heads, which are mostly $10-15 \mathrm{~mm}$. high ; bracts narrowly linear, long-attenuate, light yellowish-green and slightly floccose; the calyculate ones minute, subulate; rays bright-yellow, over I $\mathrm{cm}$. long and $2 \mathrm{~mm}$. wide; achenes brown, shining, glabrous, angled.

This species is most nearly related to $S$. Purshimus and $S$. cants. From the former it differs in the large heads, longer rays and more leafy stem, and from the latter in the lower habit, narrower and always entire leaves, and the turbinate-campanulate instead of hemispheric heads. It grows in the mountains of Colorado at an altitude of 2700-4000 m., and was first collected by Hall \& Harbour.

Colorado: Mountains south of Ward, Boulder Co., July i 8 , I 90 I, G. E. Osterhout 2 2 2f (type): mountains between Sunshine, and Ward, I902, F. Tritedy $f 861$; Silver Plume, Aug. 24, IS95. C. L. Shear 7599 ; also at the same date and locality, P. A. Ridherg.

Senecio oodes Rydb. sp. nov.

Perennial, with a stout rootstock and caudex; stem 3-4 dm. high, slightly floccose below, branched; basal leaves long-petioled, loosely villous-floccose when young, in age glabrous; petioles 
4-9 cm. long; blades thick, oral, 3-6 cm. long, $1.5-4 \mathrm{~cm}$. wide, rounded or obtuse at the apex, abruptly contracted below, coarsely dentate-crenate with triangular-ovate, obtuse teeth; lower stemleaves similar, the petioles with enlarged toothed or lobed stipulelike bases; the upper short-petioled and narower; inflorescence corymbiform; heads many, about I cm. high; bracts linear, abruptly acute, $5-7 \mathrm{~mm}$. long, slightly villous ; rays bright-yellow, $\mathrm{I}^{-}-\mathrm{I} 2 \mathrm{~mm}$. long, about $2 \mathrm{~mm}$. wide; achenes glabrous, roundangled.

This is perhaps most closely related to $S$. cymbalarioidis, but differs in the stouter, more branched and more leafy stem and the large ample stem-leaves. It grows in the higher mountains of Colorado.

Colorado: Mit. Harvard, i 896, F. E. Clements 39 (type); Robinson, Aug. 23, I 896, C. L. Shial 3333.

Senecio Tracyi Rydb.

Perennial with a short rootstock; stem about 4 dm. high, glabrous; basal leaves glabrous, long-petioled; petioles $3-10 \mathrm{~cm}$. long, slender ; blades round-oval or oval, thin, $1.5-5 \mathrm{~cm}$. long, $\mathrm{I}-3 \mathrm{~cm}$. wide, entire or merely wavy, rounded at the apex, rounded, truncate or subcordate at the base; stem-leaves lanceolate, acuminate, 2-6 cm. long or the uppermost still smaller, sinuate-crenate, the lower cuneate at the base, the upper auriculate-clasping; inflorescence a small compact cyme; heads 8 -II, broadly turbinate, $6-7 \mathrm{~mm}$. high; bracts linear, abruptly acute, glabrous, the calyculate ones subulate, sparingly arachnoid; rays yellow, 6-S $\mathrm{mm}$. long, about $2 \mathrm{~mm}$. wide.

The species belongs to the S. amrens group and is somewhat intermediate between S. crocatus, S. pyrrochrous and S. fidifolins. From the two first it differs in the paler rays and the form of the stem-leaves and from the last in the much larger size and the presence of rays. It grows at an altitude of 3 I $50 \mathrm{~m}$.

Colorado: Bob Creek, west of Mt. Hesperus, July I, I 898 , Baker, Earle \& Tracy 276 .

Senecio turbinatus Rydb. sp. nor.

Perennial with a cespitose rootstock; stem scapiform, about I.5 dm. high, more or less floccose; basal leaf-blades cuneateobovate, thick, 2-3 cm. long, $8-1 S \mathrm{~mm}$. wide, loosely floccose when young, dentate above the middle, rounded at the apex. 
tapering below into petioles about $3 \mathrm{~cm}$. long; inflorescence corymbiform; heads about 4, about $12 \mathrm{~mm}$. high ; involucres obconicturbinate, floccose at the base; bracts linear, gradually acute; rays pale-yellow, s-9 mm. long, $3 \mathrm{~mm}$. wide.

This species is probably most closely related to S. pontodontus, but distinguished by the peculiar involucre, which tapers gradually into the peduncles.

Colorado: Lake City, is 8 , H. . V. Piase.

\section{Senecio multicapitatus Greenman, sp. nov.}

Perennial with a thick woody root; stem 4-1o dm. high, yellowish, glabrous, branched and broom-like, leafy; leaves irregularly pinnately dissected into linear-filiform lobes, $1-1.5 \mathrm{~mm}$. wide, or the upper simple and linear-fitiform, somewhat fleshy, glabrous and yellowish-green; heads in a corymbiform inflorescence, numerous, almost cylindric, $7-S \mathrm{~mm}$. high, about $4 \mathrm{~mm}$. in dianeter; bracts $8-10$, yellowish, linear, gradually acute, glabrous and shining; calyculate ones small, subulate; rays pale-yellow, 7-8 mm. long and $2 \mathrm{~mm}$. wide; achenes striate, grayish strigosehispidulous.

This species has been included in S. Douglasin, whıch has long calyculate bracts and is confined to the west coast. S. multicapitatus resembles closely $S$. Ridddlii in habit, but differs in the narrow heads and few bracts. In S. Riddcllii the bracts are I 2-I 5 and the involucre campanulate. S. multicapitatus grows on plains and in mountain valleys of Colorado, New Mexico, and Arizona.

Colorado: Huerfano Valley, near Gardner, igoo, F. R. Irecland 651 ; Mt. Princeton Station, 1901 , Cinderceod \& Selby ${ }^{6} 65$.

New Mexico: Gray, Lincoln Co., F. S. Earle \& Estor $S$. Earle; high plains north of El Capitan Mountains, F. S. Earle \& Fister S. Earto $38 S$.

Arizona: Holbrook, i 896, Myrtli Zuck.

PRENANTHELLA Rydb. gen. nov.

Low diffusely branched annuals, with numerous small heads terminating the branches. Lower leaves ample, oblong or spatulate in outline, more or less runcinate; the upper reduced and bract-like. involucres oblong, 4-5-flowered with as many oblong bracts and I or 2 small calyculate ones. Achenes gradually tapering downward from the truncate summit, 4-5-ridged. Pappus of white soft capillary bristles. 
The species on which this genus is based was first described as a Prenanthes and later transferred to Lygodesmia. It is so unlike the other species of Lygodesmia in habit, that the labit alone would suggest a distinct genus. But the best character is found in the achenes, which are ribbed and tapering downward from the summit instead of upwards from the base. The fruit agrees better with that of Nabalus (Prenanthes), but from this genus Prenanthella is distinguished by the habit and the structure of the involucre.

Prenanthella exigua (A. Gray) Rydb.

Prenanthes exigua A. Gray, Pl. Wright. 2: 105. I 853. Lygodesmia exigua A. Gray, Proc. Am. Acad. 9: 217.1874.

New York botanical Garden. 

CONTPIBUTIONS FROM THE NEW YORK BOTANICAL GARDEN-No. 87

\section{ST'UDIES ON THE ROCKY MOUNTAIN FLORA-XVII}

By PER AXEL RYDBERG

NEW YORK 



\title{
Studies on the Rockv Mountain flora-XVII
}

\author{
Per Axel Rydierg
}

\section{Pedicularis siifolia}

Perennial with a rootstock; stem glabrous, 3-6 dm. high, leafy ; leaves pinnately divided to the midrib, glabrous, $5-15 \mathrm{~cm}$. long; divisions lanceolate, narrowed at the base, $\mathrm{I}-4 \mathrm{~cm}$. long, more or less doubly serrate-dentate; spike short, $3-8 \mathrm{~cm}$. long; bracts linear, oblong, or lanceolate, entire or slightly toothed; calyx glabrous or with a few scattered hairs, $8-9 \mathrm{~mm}$. long, its lobes lanceolate; corolla yellowish, nearly $2 \mathrm{~cm}$. long; galea about $8 \mathrm{~mm}$. long, curved, upper portion helmet-shaped with a short conical beak; lip $4 \mathrm{~mm}$. long, rather deeply 3-cleft with rounded lobes.

This species is somewhat intermediate between $P$. Canby $i$ and $P$. bractcosa. In habit it resembles closely the latter, but the corolla is that of the former, having an evident although short beak. It grows in the mountains of western Montana and Idaho at an altitude of 600-1200 m.

Montana: Grant Creek, June 7, I 897, M. J. Elrod and assistants 97 .

\section{Adenostegia ciliosa}

Annual; stem more or less branched, puberulent, purplish, I.5-2 dm. high; leaves $2-3 \mathrm{~cm}$. long, finely puberulent, 3-5cleft into filiform divisions; flowers in small headlike clusters; bracts similar to the leaves but with broader bases and more or or less hirsute-ciliate with white flat hairs; calyx nearly $1.5 \mathrm{~cm}$. long, more or less ciliate; its divisions about 5-ribbed; corolla about I $5 \mathrm{~mm}$. long; galea 5-6 mm. long, hooded at the apex; lip nearly as long, pubescent without; stamens 4, anthers 2celled, sparingly short-bearded.

This species is probably most closely related to $A$. ramosa Nutt., but is easily distinguished by the ciliate bracts and calyces. It grows on dry mesas at an altitude of about $2000 \mathrm{~m}$.

Wroming: Spread Creek, r 897, Frank Triecdy $5+5$.

\section{Castilleja arcuata}

Perennial, more or less tufted at the base; stems erect, strict, usually simple, 2-4 dm. high, shining, yellow or tinged with 
purple, glabrous or short-villous in the inflorescence; leaves narrowly linear, 2-6 cm. long, I $-3 \mathrm{~mm}$. wide, glabrous or the lower sparingly white-villous; bracts brownish, I-2 cm. long, 3-cleft with lanceolate lobes, white-villous with short hairs; calyx 1 2-I 5 $\mathrm{mm}$. long, deeply cleft below, less deeply so above, its lobes lanceolate, about $\mathrm{r} \mathrm{mm}$. long; corolla $2.5-3 \mathrm{~cm}$. long, at last strongly curved, greenish with yellow margins; galea $12-15 \mathrm{~mm}$. long; lip about $3 \mathrm{~mm}$. long, with linear-lanceolate lobes.

This species is related to $C$. cognata and $C$. linariacfolia. From the former it differs in the color of the bracts, different pubescence and the more arching corolla, from the latter in the color of the bracts, the lower habit and the smaller corolla. It grows in meadow land with alkaline soil.

Utaн: South end of Fish Lake, August io, I905, Rydberg \& Carlton 7508 .

\section{Castilleja magna}

Perennial; stem a meter or so high, glabrous and shining, angled; leaves lanceolate, 4-6 cm. long, glabrous, 5-ribbed and reticulate, more or less acuminate; inflorescence short and dense ; bracts ovate, entire, tipped with crimson, as well as the axis of the inflorescence viscid-ciliate; calyx about $2.5 \mathrm{~cm}$. long, cleft halfway down both above and below, its lobes lanceolate, acuminate, 4-5 mm. long; corolla $4-5 \mathrm{~cm}$. long, greenish, tinged with crimson and with crimson margins; galea fully $2 \mathrm{~cm}$. long; lip about $3 \mathrm{~mm}$. long, its lobes lanceolate.

This species somewhat resembles C. Thexifolia, but is a taller plant, with smaller bracts and much larger corolla. The latter is of about the size of that of $C$. Suksdorfii, which however is a much smaller and more pubescent plant and has narrow leaves.

British Columbia: Trail above Carbonate, 1904, Charles H. Share 205.

\section{Castilleja Leonardi}

Perennial, with a short woody caudex; stems several, 2-3 dm. long, more or less viscid-villous; leaves ovate-lanceolate or oblong-lanceolate, I.5-3 cm. long, densely puberulent, 3-ribbed, acute or acuminate; bracts broadly ovate or obovate, rounded at the apex, about equaling the flowers, densely pubescent, entire, tipped with crimson; calyx $1.5 \mathrm{~cm}$. long, densely puberulent, equally cleft above and below, its lobes ovate, I.5-2 mm. long, obtuse; corolla $2 \mathrm{~cm}$. long or less, densely puberulent; galea about I cm. long; lower lip about $2 \mathrm{~mm}$. long, its lobes lanceolate. 
This species is related to C. lauta and C. Hexifolia. From the former it differs in the broad leaves and dense pubescence, and from the latter in the small size of both the plant and the flower, the thick leaves and more copious pubescence.

UTAн: Head of American Fork Cañon, is85, F. E. Leonard $I_{5} \mathrm{I}$ in part (type); mountains around the south fork of Big Cottonwood Creek, 1905, Rydberg \& Carlton 6592.

\section{Castilleja humilis}

Peremial, with a short woody caudex; stems several, about $2 \mathrm{dm}$. high, glabrous below, somewhat viscid-pubescent above; leaves oblong to elliptic-lanceolate or the uppermost ovate, $2-3$ $\mathrm{cm}$. long, obtuse or acute, finely puberulent; bracts entire, obovate, tipped with dark crimson, a little shorter than the corollas; inflorescence short and dense; calyx densely puberulent, Io-I $2 \mathrm{~mm}$. long, equally cleft above and below, its lobes ovate, obtuse, about I.5 mm. long; corolla about $15 \mathrm{~mm}$. long, densely puberulent, greenish with purple margins; galea $7-8 \mathrm{~mm}$. long; lip $2 \mathrm{~mm}$. long, its lobes lanceolate, acuminate.

In habit this species most resembles $C$. rhexifolic, but the plant is much smaller and the corolla of about half the size. It grows in alpine woods.

Wyoming: Medicine Bow Mountains, Albany County, I900, Acen Nelson 7919.

\section{Castilleja variabilis}

Perennial with a rootstock; stems usually single, more or less pubescent, 4-S $\mathrm{dm}$. high; leaves linear-lanceolate or lanceolate, 4-6 cm. long, 3-ribbed, puberulent and more or less short-hirsute, rarely glabrous; bracts lanceolate, deeply 3 -cleft, greenish at the base, otherwise yellow with scarlet or brick-red tips or sometimes almost wholly brick-red; calyx viscid-villous, about $2.5 \mathrm{~cm}$. long, tinged with yellow; corolla yellowish-green with scarlet or yellow margin, about $4 \mathrm{~cm}$. long; galea nearly $2 \mathrm{~cm}$. long; lip darkgreen, $3 \mathrm{~mm}$. long, with lanceolate lobes.

This species somewhat resembles $C$. lanceolata, but has larger flowers and differently colored bracts. These are nearly of the same color as those of C. lutescens and $C$. desertorum, but both of these species have smaller flowers and 3 -cleft upper leaves. $C$. rariabilis grows in mountain valley's and on hillsides, at an altitude of $2500-3000 \mathrm{~m}$.

Utah: Big Cottonwood Cañon, belorv Silver Lake, I905, 
P. A. Rydberg 6773 (type) and 6800; divide between Big Cottonwood Cañon and Heber Valley, I905, Rydberg \& Carlton 66,6; Big Cottonwood Cañon, i905, A. O. Garrett, 1507.

\section{Castilleja Vreelandii}

Perennial with a rootstock; stem usually single, 6-8 dm. high, glabrous or nearly so, shining; leaves lanceolate, 3-5-ribbed, glabrous or nearly so, $4-6 \mathrm{~cm}$. long, somewhat acuminate; bracts lanceolate, usually 3-lobed with acute lobes, tipped with crimson; calyx $2-2.5 \mathrm{~cm}$. long, tinged with crimson, equally cleft, viscidvillous below, puberulent above, its lobes lanceolate, acute, 6-S mm. long; corolla dark-green with purplish margins; galea about $2 \mathrm{~cm}$. long; lower lip $2 \mathrm{~mm}$. long, with lanceolate teeth.

This species is related to $C$. lanccolata, but differs in the larger flowers and the broader, almost glabrous leaves. It grows in the mountains from Montana and Idaho to Wyoming and Utah. As the type is regarded the following:

Montana: Divide between McDonald and Camas Lakes, I 90 i, F. K. Treelend rooo.

\section{Castilleja purpurascens}

Perennial with a short caudex; stems several, I-3 dm. high, glabrous or slightly puberulent, villous above, usually dark-purple; leaves narrowly linear, finely puberulent, $3-5 \mathrm{~cm}$. long, $2-3 \mathrm{~mm}$. wide; inflorescence short and dense; bracts lanceolate, acute or obtuse, the lower usually entire, the upper more or less cleft, tipped with crimson; calyx I 5-20 mm. long, more or less villous, especially towards the base, equally cleft, its lobes $2-3 \mathrm{~mm}$. long, obtuse; corolla $2.5-3 \mathrm{~cm}$. long, green with crimson margins; galea about I cm. long; lower lip $3 \mathrm{~mm}$. long, with narrowly lanceolate lobes.

This is probably most closely related to $C$. Treeedyi and $C$. miniata, but differs in the lower habit, the darker coloration of the bracts, the narrow leaves, obtuse calyx-lobes, and usually purplish stem.

British Columbia: Flood-plains of Kicking Horse, ig04, $H$. Peterson II (type).

Alberta: National Park, Banff, is97, Mr. \& Mrs. C. Tan Brunt 70; Pipestone Pass, I904, J. Maconn 67903.

\section{Castilleja viscida}

Cespitose perennial with a short woody caudex; stems I-3 $\mathrm{dm}$. high, viscid- or glandular-puberulent and with scattered crisp 
white hairs ; leaves $1.5-3 \mathrm{~cm}$. long, $3-5$-cleft at the middle, densely glandular-puberulent, the body lanceolate, 3 -ribbed, the lobes narrowly lanceolate and directed forward; bract similar to the leaves, tipped with crimson or scarlet; calyx equally deeply cleft above and below, I $8-20 \mathrm{~mm}$. long, its lobes lanceolate, $5 \mathrm{~mm}$. long, acuminate or acute ; corolla about $2.5 \mathrm{~cm}$. long, dark-green, with crimson margin; galea about I cm. long; lip $3 \mathrm{~mm}$. long, its lobes lanceolate.

This species is related to C. hisfida, C. Bradburyi and $C$. mpicola. From the first two it differs in the lower habit and viscid or glandular pubescence, and from the last one in the shorter galea. It grows in the mountains among rocks at an altitude of $2700-3300 \mathrm{~m}$.

UTAH: Mountains near the headwaters of Big Cottonwood Creek, 1905, Rytluerg \& Carlton 6593 (type), 6565, 65t0, 655t, 6635 and $65+6$; Mount Nebo, no. 7703,7750 and 7755 .

\section{Castilleja ampliflora}

Perennial, cespitose and somewhat woody at the base; stems 3-4 dm. high, usually branched, ascending, puberulent and somewhat villous; most of the leaves entire, lanceolate, $2-3 \mathrm{~cm}$. long with a short and rather dense pubescence; the upper 3-5-lobed, the middle lobe being broad and the lateral ones small; bracts 3-lobed with a broad rounded middle lobe, crimson, I $-\mathrm{I} .5 \mathrm{~cm}$. long; calyx $1.5-2 \mathrm{~cm}$. long, villous, equally cleft above and below, its lobes $3-4 \mathrm{~mm}$. long; corolla nearly $3 \mathrm{~cm}$. long, more turgid than usual; galea fully $\mathrm{I} .5 \mathrm{~cm}$. long; lip $3 \mathrm{~mm}$. long, with lanceolate lobes.

This is perhaps most closely related to C. Fradluryi, but the stems are more branched, the corolla more turgid, the leaves more

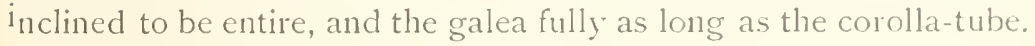
It grows at an altitude of 1 I $50-1350 \mathrm{~m}$.

Montana: Divide between McDonald and Camas Lakes, July 29, I90 I, F. K. Firceland 995.

\section{Castilleja gracillima}

Perennial with a rootstock; stems usually solitary, slender, purplish, 2-4 dm. high, sparingly villous; leaves linear-lanceolate, 2-4 cm. long, 3-ribbed, sparingly short-rillous; bracts ovate, entire, toothed or 3 -cleft, rose or brownish, puberulent, villousciliate; calyx about i $5 \mathrm{~mm}$. long, equally cleft above and below, its lobes lance-oblong, obtusish, $3 \mathrm{~mm}$. long; corolla purplish, 
slightly longer than the calyx; galea $8 \mathrm{~mm}$. long; lip about 3 mm. long, its lobes ovate.

This species is closely related to $C$. pallida, but differs in the leaves, which are shorter, neither long-attenuate nor falcate, and in the different color of the bracts and corolla.

In mountain meadow's especially on the geyser formations at an altitude of 2000-2700 $\mathrm{m}$.

ITroming: Lower Geyser Basin, Yellowstone Park, I897, Rydbug \& Bessey $196+$ (type); Lone Star Geyser Basin, no. 4961 ; Upper Hoback Basin, I900, C. C. Curtis.

Montana: Mountains near Indian Creek, I 897, Rydberg \& Besse'y 1967 .

Alberta: Vicinity of Banff, I899, W. C. Mc Calla 2187.

\section{Castilleja parvula}

Cespitose perennial with a short caudex; stems many, 5-I5 $\mathrm{cm}$. high, puberulent ; leaves lanceolate, $\mathrm{I}-2 \mathrm{~cm}$. long, puberulent ; bracts ovate, dark brownish-crimson, finely puberulent, entire or with short lobes; calyx I2-I4 mm. long, puberulent, equally cleft above and below, its lobes oblong, obtuse, $2-3 \mathrm{~mm}$. long; corolla I $7-18 \mathrm{~mm}$. long, greenish with purplish margins; galea about $7 \mathrm{~mm}$. long; lip 2.5-3 $\mathrm{mm}$. long, its lobes lanceolate.

This species is closely related to $C$. occidentalis, but differs in the bracts, which are darker, of a deep crimson shade and not at all villous, and also in the corolla, which is decidedly greenish and with a shorter lip. It grows among rocks on high mountains, at an altitude of nearly $3000 \mathrm{~m}$.

UTAн: Mountains north of Bullion Creek, near Marysvale, I905, Rydberg \& Carlton 7158 (type) and 7090 .

\section{Castilleja pulchella}

Perennial with a cespitose caudex; stems $5-15 \mathrm{~cm}$. high, ascending, more or less villous especially above; leaves $\mathrm{I}-4 \mathrm{~cm}$. long; the lower entire and linear-lanceolate, the upper broader and 3 -cleft, puberulent and slightly villous; lobes linear-lanceolate, attenuate; bracts elliptic, usually 3-cleft, the middle lobe broad and rounded, tinged with brownish, villous; calyx yellowish, tipped with brownish, about i $8 \mathrm{~mm}$. long; lobes very short and rounded; corolla slightly exserted; galea $7 \mathrm{~mm}$. long; lip 5 $\mathrm{mm}$. long, its lobes lanceolate, obtuse.

This species is intermediate between $C$. lutea and $C$. occidcntalis. 
It has the habit, pubescence and coloration of the latter but the leaves, bracts and calyx-lobes of the former; the form of the corolla is intermediate between those of the two. C. fulchilla grows on high mountains at an altitude of 2500-3300 m.

Montana: Mountains near Indian Creek, I 897, Rydberg \& Bessiy 4967 (type); Electric Peak, no. 1968.

Wroming: Big Horn Mountains, I S99, Tweedy' 2375; Dome Lake, I896, Aven Nelson 2735; Teton Forest Reserve, I897, Tiecedy' $2+7$.

\section{Castilleja Pecten}

Perennial; stem stout, $4-5 \mathrm{dm}$. high, puberulent throughout; lower leaves linear, entire, 5-6 cm. long, puberulent; the upper 3-5-cleft with linear divisions; bracts rhombic-obovate or broadly cuneate in outline, almost pectinately cleft into linear divisions, puberulent, upper portion yellowish or the tips brownish; calyx about $2 \mathrm{~cm}$. long, puberulent, equally cleft above and below; lobes lanceolate, about $3 \mathrm{~mm}$. long; corolla a little over $2 \mathrm{~cm}$. long ; galea 8-9 $\mathrm{mm}$. long ; lip about $4 \mathrm{~mm}$. long, its lobes oblong.

In general habit and coloration it resembles somewhat $C$. descrtormm and $C$. lutescens, but the lower lip is nearly half as long as the galea and of different shape, and the bracts are peculiar. The structure of the corolla places this species nearest to C. fasciculata, but it is a much larger plant.

Id aho: Beaver Cañon, i 895, C. L. Shear jotI (type) and 3039.

\section{Lupinus marianus}

Stem 5-10 dm. high, striate, hirsute-villous with rather short hairs, slender, leafy; stipules setaceous; petioles $4-8 \mathrm{~cm}$. long, or those of the basal leaves even $2 \mathrm{dm}$. long, hirsute-villous; leaflets $6-8$, narrowly oblanceolate, $3-7 \mathrm{~cm}$. long, acute, glabrous above, appressed, short-hairy beneath ; inflorescence lax, I-I.5 dm. long; pedicels $4-5 \mathrm{~mm}$. long; calyx villous, gibbous but not spurred at the base on the upper side; lips lanceolate, the upper $7 \mathrm{~mm}$.; the lower $8 \mathrm{~mm}$. long; bracts linear-subulate, longer than the caly'x, deciduous; banner 8-IO mm. long, light-blue or white with a darker spot; wings light-blue or white, 10-1 $2 \mathrm{~mm}$. long; legume 3-4 cm. long, 8-9 mm. wide, densely pubescent.

In habit resembling $L$. pseudoparifforts and $L$. larifloms, but differing in the spreading pubescence of the stem. This cliaracter would associate it with L. amplus and L. ornatus glabratus S. Wats. From the former it differs in the lax spike, slender stem, 
and the paler and smaller corolla; from the latter in the long linearsubulate bracts and narrow leaflets.

Uтан: Along Bullion Creek, above Marysvale, July 21, I905, Rydberg \& Carlton 7027 (type) and 7025.

\section{Lupinus stenophyllus (N்utt.)}

Lupinus foliosus stenophyllus Nutt.; T. \& G. Fl. N. Am. I : 377 (synonym). I 840 .

Stem slender, probably I m. high, finely silky-strigose; stipules small, subulate; petioles of the stem-leaves about $3 \mathrm{~cm}$. long, strigose; leaflets about 5 , narrowly linear-oblanceolate, about $3 \mathrm{~cm}$. long, $4 \mathrm{~mm}$. wide, usually conduplicate, acute, green, glabrous above, sparingly silky-strigose beneath; raceme about I dm. long, lax, more or less one-sided; bracts lanceolate, shorter than the calyx, deciduous; calyx densely silky-strigose, more or less spurred at the base; upper lip ovate, $4 \mathrm{~mm}$. long, the lower lanceolate, $6 \mathrm{~mm}$. long; corolla light-blue, $7-\$ \mathrm{~mm}$. long; banner slightly shorter than the broad wings; fruit unknown.

This species has been included in L. laxiflorus and L. tenellus. It resembles the latter in habit but differs in the spurred calyx and green leaves. From the former it differs in the narrower leaves, glabrous above, and the smaller flowers. The type was collected on the "Oregon Plains" by Nuttall.

\section{Lupinus laxispicatus}

Perennial; stems 3-4 dm. high, slender, striate, sparingly strigose; stipules small, lanceolate; petioles strigose, $5-15 \mathrm{~cm}$. long; leaflets 7-I O, narrowly oblanceolate, acute, green, glabrous above, strigose beneath, $4-5 \mathrm{~cm}$. long, about $6 \mathrm{~mm}$. wide; inflorescence lax, rather few-flowered; bracts lanceolate, shorter than the calyx, deciduous; calyx grayish silky-strigose, gibbous; lips lanceolate, the upper $6 \mathrm{~mm}$., the lower $7 \mathrm{~mm}$. long; corolla blue, about $10 \mathrm{~mm}$. long; banner only slightly shorter than the wings.

This species is nearest related to L. Schubcrac, which however has broader leaves, larger flowers and the upper lip of the calyx is ovate and much shorter than the lower. L. laxispicatus grows on high mountains.

IDAho: Kootenai County, July, is87, J. H. Sandberg.

\section{Lupinus Macounii}

Perennial with a short caudex; stems several, 3-6 dm. high, silky-strigose, somewhat branched; stipules lance-subulate; petioles 
2-5 cm. long, strigose; leaflets about nine, linear-oblanceolate, $2-3 \mathrm{~cm}$. long, usually conduplicate, silky-strigose on both sides; racemes dense, 5-IO cm. long; bracts narowly lanceolate, not exceeding the buds, deciduous; calyx gibbous at the base, shortsilky with spreading hairs ; lower lip lanceolate, 6-7 mm. long, the upper hardly $4 \mathrm{~mm}$. long, ovate; corolla $8-9 \mathrm{~mm}$. long, darkblue, the banner with a lighter spot, somewhat shorter than the wings; legume densely silky, villous, about $2 \mathrm{~cm}$. long, $6 \mathrm{~mm}$. broad, 3-4-seeded.

The type was labeled L. argenteus argophyllus. Its relationship is closer however to the true L. argontcus, differing in the smaller, darker flowers, the spreading pubescence on the calyx and pedicels and above all in the shorter upper lip of the calyx. It grows at an altitude of $1000-2500 \mathrm{~m}$.

Saskatcheivan: Cypress Hills, i 894, John Macoun fo7o (type in herb. Columbia Univ.).

Montana: Spanish Peaks, is96, Flodman 629 (in part).

Wroming: Big Horn Mountains, I 899, Taeedy 2363 ; Leckie, I90 I, Merrill \& IVilcox 759 .

\section{Lupinus subulatus}

Perennial with a short caudex; stem 4-5 dm. high, densely silky-strigose, striate, leafy; stipules subulate; petioles silkystrigose, 3-6 cm. long; leaflets 7-IO, narrowly oblanceolate or linear-oblanceolate, densely appressed, silky on both sides, 2-4 $\mathrm{cm}$. long, cuspidate $\mathrm{or}^{-}$mucronate; raceme dense, I-I.5 dm. long; bracts subulate-setaceous, much exceeding the buds; calyx appressed silky-canescent, scarcely gibbous; lower lip $8 \mathrm{~mm}$. long, narrowly lanceolate, the upper ovate-lanceolate, $6 \mathrm{~mm}$. long; corolla dark-blue with keel and a spot on the banner light-colored, about I cm. long; petals subequal, banner rather densely pubescent without.

This is related to L. holosericcus, L. canescens, and L. oreoplitus, but easily distinguished by the long subulate-setaceous bracts.

Montana: Columbia Falls, June 3, i 897, R. S. Williams (type).

IVAshington: Spokane, I898, Piper 2823; also I892, Henderson.

\section{Lupinus flavicaulis}

Perennial with a short caudex; stems several, with erect branches, densely pubescent with short yellowish spreading hairs, almost velutinous, $3-5 \mathrm{~cm}$. high; stipules subulate; petioles $2-4$ 
cm. long, velutinous; leaflets 7-IO, narrowly oblanceolate, usually conduplicate, densely silky on both sides, acute, $2-4 \mathrm{~cm}$. long; racemes dense, $5-10 \mathrm{~cm}$. long; bracts subulate, shorter than the buds; calyx gibbous, villous; lower lip lanceolate, 7 mm. long; upper lip ovate, 5-6 $\mathrm{mm}$. long; corolla about $10 \mathrm{~mm}$. long, light-purple or pink; banner with a darker spot, pubescent without; legume $2-2.5 \mathrm{~cm}$. long, $7 \mathrm{~mm}$. wide, densely silkyvillous, 3-4-seeded.

In general habit, size, form, and color of the corolla and leaflets, this resembles $L$. decumbcus very closely, but differs in the dense, short, spreading pubescence of the stem and the denser, longer, looser pubescence of the leaves. These characters place it in the same group as L. Bakcri and L. dichrous, which it otherwise little resembles. It grows on dry plains and hills.

IVromeng: Snake River, I 894, Aven Nelson rogs (type in herb. Columbia Univ.); Evanston, $1882, N$. L. Britton.

UTaH: Divide, I 898 , Isabel Mlulford 268.

\section{Lupinus macrostachys}

Perennial with a short caudex; stem 5-10 dm. high, puberulent and with long silky spreading or reflexed hairs; stipules setaceous; petioles short-pubescent with spreading hairs, 2-10 $\mathrm{cm}$. long; leaflets $7-8$, linear-oblanceolate, acuminate, $3-6 \mathrm{~cm}$. long, appressed-silky on both sides, grayish-green ; raceme dense, 2-3 dm. long; bracts lanceolate, acuminate. merely equaling the buds; calyx velutinous, gibbous; lower lip broadly lanceolate, obtuse, about $S \mathrm{~mm}$. long; upper lip ovate, almost as long; corolla IO-I $2 \mathrm{~mm}$. long, dirty-white, tinged with blue; banner with a darker spot; legumes fully $2 \mathrm{~cm}$. long, densely silkyvillous, 4-5-seeded.

This species is related to L. lcucophyllus, from which it differs in the less dense and strictly appressed silky pubescence (scarcely canescent) and the color of the flowers. In L. lawcophyllus they are rather light-blue or pink with darker striations (rarely white), the banner with a lighter spot. It grows at an altitude of about $1000 \mathrm{~m}$.

Montana: Jocko Creek, igoi, D. T. MarcDougal 253 (type in herb. N. Y. Bot. Gard.).

\section{Lupinus roseolus}

Perennial with a cespitose caudex; stems ascending or decumbent, about I dm. high, sparingly strigose, 3-5-leaved, slender; 
stipules setaceous; petioles I-3 cm. long, slender, usually redtinged; leaflets about 7 , narrowly linear-oblanceolate, acute, $I-2$ $\mathrm{cm}$. long, sparingly silky, short-strigose; raceme $2-4 \mathrm{~cm}$. long; bracts subulate, shorter than the buds; calyx gibbous, silky with short spreading hairs; lips broadly lanceolate, subequal, 5-6 mm. long; corolla nearly white, tinged with rose, about $\$ \mathrm{~mm}$. long; pod densely silky, perhaps $1.5 \mathrm{~cm}$. long when fully developed.

This resembles L. argentins in the form and color of the flowers. It has also the peculiar hue and pubescence of that species, but it is a much smaller plant and of a different habit. The latter will place it near L. Lycrllii. It is an alpine plant growing at an altitude of $3000 \mathrm{~m}$.

Wroming: Continental Divide, Buffalo Fork, August i $897, \mathrm{~F}$. Treecty' 270 .

\section{Lupinus scaposus}

Annual, with sessile clasping cotyledons; stem branched at the base, I-I.5 cm. high, sparingly ciliate; stipules lanceolate, acuminate; petioles $3-5 \mathrm{~cm}$. long, ciliate, slender; leaflets about 7 , spatulate, I $\mathrm{cm}$. long, sparingly silky-hirsute on both sides or glabrous above; peduncles longer than the leaves, ciliate; raceme short, I-4 cm. long; bracts lanceolate, short; calyx ciliate, the lower lip broadly lanceolate, entire, $5 \mathrm{~mm}$. long, the upper 2 -cleft, ovate; corolla purplish, $6 \mathrm{~mm}$. long, paler at the base; banner shorter than the wings; legume ciliate, I cm. long, $6 \mathrm{~mm}$. wide, 2 -seeded.

In habit mostly resembling L. hrericaulis but more evidently caulescent, with longer peduncles. The most distinctive characters, however, are the different calyx and its entire lower lip. This associates it with L. pusillus, from which it differs in the long peduncles and smaller flowers.

Colorado: Glenwood Springs, i S99, Geo. E. Osterhout.

\section{Lupinus rubens}

Annual, with sessile, clasping cotyledons; stem ciliate, tinged with red, branched near the base, about I dm. high; petioles densely ciliate, $2-4 \mathrm{~cm}$. long; leaflets $6-7$, spatulate, $I-1.5 \mathrm{~cm}$. long, ciliate on both sides or glabrous above, acute; raceme lax, 5-10 cm. long, overtopping the leaves; bracts minute, subulate; caly $\mathrm{x}$ ciliate, the lower lip lanceolate, $5 \mathrm{~mm}$. long, the upper barely $3 \mathrm{~mm}$. long; corolla $7 \mathrm{~mm}$. long ; banner dark-purple with a yellow spot; wings and keel lighter, tinged with lilac. 
This species is related to L. pusillus, but differs in the more elongated racemes, which much exceed the leaves, the smaller flowers of a different color and the short upper lip of the calyx.

Utah : Southern Utah, is74, Parry $f^{I}$ (type in herb. Columbia Univ.); St. George, I 877 , Palmer 86.

\section{Trifolium confusum}

Perennial with a rootstock; stems erect, simple, 2-3 dm. high, glabrous below, sparingly strigose above; stipules ovate, acute, about $2 \mathrm{~cm}$. long, glabrous, veiny; leaflets of the lower leaves oval and rounded at the apex, of the upper ones lanceolate, and acute, $2-3 \mathrm{~cm}$. long, finely denticulate, glabrous or nearly so; peduncles $5-7 \mathrm{~cm}$. long; head globose; flowers reflexed in fruit; calyx-tube $2 \mathrm{~mm}$. long, glabrous except the villous margin; teeth villous, 4-5 mm. long, subulate-setaceous; corolla rose or purplish, I 3-I $5 \mathrm{~mm}$. long; ovary 4-ovuled; legume sparingly hairy, stipitate.

This species belongs to the $T$. longipes group. It is probably most nearly related to $T$. Rydbergii and T. pedunculatum. From the former it differs in the nearly glabrous calyx-tube and the rose-colored and larger corollas; from the latter in the larger and reflexed flowers. It differs from T. longipes and T. Rusbyi in its different habit and nearly glabrous calyx.

Southern Utah: is74, C. C. Parry 35 (type in herb. Columbia Univ.).

\section{Trifolium Aitonii}

Perennial with a rootstock; stem 3-4 dm. high, glabrous below, strigose above; stipules ovate, short-acuminate, about 2 $\mathrm{cm}$. long, veiny ; leaflets ovate, thin, obtuse or rounded and mucronate at the apex, finely denticulate, $2-4.5 \mathrm{~cm}$. long, glabrous above, sparingly hairy beneath; peduncles several, I-2 $\mathrm{dm}$. long; heads globose; flowers reflexed in fruit on pedicels 2-3 $\mathrm{mm}$. long; calyx pubescent throughout; tube $2 \mathrm{~mm}$. long; teeth subulate, about $4 \mathrm{~mm}$. long; corolla about $12 \mathrm{~mm}$. long; legume stipitate, strigose, about 2 -seeded.

This species is related to $T$. latifolizm, from which it differs mainly in the different habit, larger size, longer peduncles and larger ovate instead of oval or obovate leaflets.

InAho: Palouse County, i $892, G$. B. Aiton 65 (type in herb. N. Y. Bot. Gard.). 


\section{Trifolium uintense}

Trifolium dasyphyllum S. Wats. Bot. King Exp. 60, in part. I 87 I. Not T. dessphyilum Torr.

Cespitose, subacaulescent perennial ; stipules large and scarious; petioles I-4 cm. long, sparingly strigose; leaflets oblanceolate, broadest above the middle, acute and mucronate, entire, $\mathrm{I}-2 \mathrm{~cm}$. long, sparingly pubescent or glabrate above; peduncle about 6 $\mathrm{cm}$. long, sparingly strigose; head obovate, rather few-flowered; bracts lanceolate, 5-S mm. long, 3-nerved, slightly if at all scarious-margined; calyx only slightly pubescent; tube $2.5 \mathrm{~mm}$. long; teeth subulate-setaceous, about $7 \mathrm{~mm}$. long; corolla purple, about I $5 \mathrm{~mm}$. long; ovary pubescent, about 6-ovuled.

This is a member of the $T$. dersyphyllum group, but differs from its relatives in the broader, decidedly oblanceolate leaflets and the 3-nerved bracts.

Utah: Uintas, I 869, S. I'otson 2.7 (type in herb. Columbia Univ.).

\section{Trifolium inaequale}

Cespitose glabrous perennial, with very short stems; stipules ovate, short-acuminate, about I cm. long; petioles $3-10 \mathrm{~cm}$. long, glabrous; leaflets oblanceolate or oblong, acute or obtuse, minutely denticulate, rather fleshy, $1.5-3 \mathrm{~cm}$. long; peduncles I-2 dm. long; heads sub-globose; bracts ovate or lanceolate, 5-7 mm. long, usually shorter than the calyces, usually cleft or toothed at the apex; calyx glabrous; tube $3 \mathrm{~mm}$. long; teeth unequal, the upper $2-2.5 \mathrm{~mm}$., the lower $3.5-4 \mathrm{~mm}$. long, lancesubulate; corolla purple, about $1.5 \mathrm{~cm}$. long; ovary 4 -ovuled; legume glabrous, stipitate.

This is related to T. Parryi and T. montanense. From the former, it differs in the decidedly unequal caly'x-teeth, the narlower and smaller, ovate instead of obovate, bracts and stipules, and the less sharply denticulate leaflets; from the latter in the larger size and the ovate instead of obovate bracts.

UTAн : Bear River Cañon, i 869, S. Watson 243 (type in herb. Columbia Univ.); Dyer Mine, Uintah Mountains, I902, Goodding I24.

\section{Tium variegatum}

Peremnial with a taproot and short cespitose caudex; stems numerous, strigose, more or less mottled with purplish-brown; stipules triangular or deltoid, $4 \mathrm{~mm}$. long, distinct; leaves $5-\$$ $\mathrm{cm}$. long; leaflets obovate to nearly orbicular, rounded or retuse 
at the apex, thick, sparingly strigose, soon glabrate, 5-10 $\mathrm{mm}$. long; peduncles $4-7 \mathrm{~cm}$. long; raceme short, $I-2 \mathrm{~cm}$. long, in fruit 3-6 cm. long, 5-I 5-flowered; calyx black-hairy ; tube $2-2.5$ mm. long; teeth subulate, $\mathrm{I}-2 \mathrm{~mm}$. long; corolla ochroleucous; banner $6-7 \mathrm{~mm}$. long; wings and keel $5 \mathrm{~mm}$. long; pod scarcely stipitate, about $2 \mathrm{~cm}$. long, $4 \mathrm{~mm}$. broad, oblong, tapering at both ends, slightly arcuate, sulcate on the lower suture except at the ends, acute on the upper suture, mottled with purplish-brown and minutely strigose.

This is perhaps most nearly related to $T$. sparsiflorum (A. Gray) Rydb., but is a much larger and coarser plant. The latter species has usually smaller leaves, smaller corolla, white and tinged with violet, strongly oblique calyx and pods of about half the length, more curved and more distinctly stipitate.

Colorado: Platte Cañon, May I9, I 894, State Agricultural college, Colorado, distribution no. I5 (type in herb. N. Y. Bot. Garden).

\section{Hamosa atratiformis}

Perennial; stem 2-3 dm. high, erect, branched, strigose; stipules triangular, strigose, $\mathrm{I}-2 \mathrm{~mm}$. long; leaves $3-5 \mathrm{~cm}$. long; leaflets I 3-I 9, oblong, strigose below, glabrous above, 4-6 mm. long; peduncles $5-7 \mathrm{~cm}$. long: raceme lax, $2-3 \mathrm{~cm}$. long; calyx black-strigose; tube about $2 \mathrm{~mm}$. long; teeth subulate, I $\mathrm{mm}$. long; corolla ochroleucous, about $7 \mathrm{~mm}$. long; pod linear, straight, minutely strigillose.

This is closely related to $\mathrm{H}$. atrata (Astragalus atratus S. Wats. Bot. King Exp. 69. I $87 \mathrm{I}$ ), but differs in the short leaves and the smaller flowers, which are scarcely more than half as long as in that species.

Southern Utah: 1874, C. C. Parry 77 (type in herb. Columbia Univ.).

\section{Xylophacos aragalloides}

Cespitose perennial; stems I dm. or less long, decumbent at the base, densely white-strigose ; stipules scarious, strigose, triangular, with a subulate acumination, $5-8 \mathrm{~mm}$. long; leaves IO-I 5 cm. long; leaflets I I-I 9, lanceolate to elliptic, silky-canescent, 5-I $2 \mathrm{~mm}$. long, acute; peduncles about I dm. long; raceme short, 4-IO-flowered; calyx ascending, strigose with black and white hairs; tube cylindric, about $8 \mathrm{~mm}$. long; teeth subulate, 3-4 $\mathrm{mm}$. long ; corolla purplish, about $2 \mathrm{~cm}$. long; legume lunate, about $4 \mathrm{~cm}$. long, tapering at both ends, rather deeply sulcate be- 
low, transversely reticulate, sparingly strigose ; upper suture prominent.

This species is related to X. amplioxys (A. Gray) Rydb., but differs in the long subulate instead of triangular calyx-teeth, in the banner much exceeding the wings, and in the narrower leaflets.

Utrah: St. George, I880, M. E. Jones I633 (type in herb. Columbia Univ.); is 877 , Dr. E. Palmer 101.

\section{Homalobus uniflorus}

Pulvinate-cespitose perennial with a much-branched caudex; stipules ovate, scarious, ciliate; leaves reduced to oblanceolate or linear-spatulate phyllodia, appréssed silky-canescent, $\mathrm{I}-2 \mathrm{~cm}$. long, I-3 $\mathrm{mm}$. wide; peduncles $\mathrm{I}-2 \mathrm{~cm}$. long, usually I-flowered; calyx silky-canescent; tube campanulate, $2 \mathrm{~mm}$. long; teeth subulate, of about the same length; corolla dark bluishpurple, $8 \mathrm{~mm}$. long.

This species is closely related to $H$. simplicifolins and $H$. brachycarpus Nutt. From the former it differs in the dark bluishpurple, not ochroleucous corolla; the elongated peduncles, the longer and broader leaves, and the comparatively longer calyxlobes; from $A$. brachycarpus it is distinguished by its solitary flowers and darker corolla.

Wroming: Evanston, I 897, Aien Nelson 2971 (type in herb. N. Y. Bot. Gard.).

Homalobus campestris Nutt.; T. \& G. Fl. N. Am. I : 35 I. i 838. Astragalus campestris A. Gray, Proc. Am. Acad. 6: 229, in part. I 866. Not Astragalus campestris L. I 753. Astragalus convallarius Greene, Erythea I : 207. I 893 .

There has been a confusion concerning the identity of this species, evidently because Dr. Gray, when he transferred the species to Astragalus, had in mind something entirely different from Nuttall's Homalobus campestris. All the specimens of this species (except the type and one more) in the herbaria of the New York Botanical Garden and Columbia University have been referred to $H$. juncens. H. campestris is also closely related to that species, differing in the black-hairy calyx, the longer calyx-lobes, and the pod, which tapers gradually to the base. The black-hairy calyx and the shape of the pod it has in common with Homalobus junciformis (A. Nelson) Rydb., but it has longer calyx-teeth and narrower and longer leaflets. In both H. juncens and H. jumiformis 
the calyx-teeth are triangular, about as broad as long. All three species have rootstocks, or a deep-set root and the stems branching below ground, the corollas are ochroleucous, the keel curved from near the base and without any purple. What Dr. Gray and many later writers regarded as Astragalus campestris is a combination of several species characterized by a cespitose caudex or stronglybranched rootstocks, white, pink- or purple-tinged corollas, and the keel curved only at the tip and with a dark-purple tip. The aggregate consists of Homalobus decurrens Rydb., H. hylophilus Rydb., H. tcnuifolius Nutt., H. divergens Blankinship (H. camporum Rydb.), and other species.

The range of $H$. campestris seems to be limited to Wyoming, northern Colorado and northeastern Utah.

\section{Homalobus oblongifolius}

Homolobus hyloplitus Rydb. Bull. Agr. Exp. Sta. Colo. Ioo : 2 I0, in part. 1906.

Perennial with a cespitose caudex; stems ascending, branched, 2-3 dm. high, glabrous or nearly so ; stipules ovate, scarious, 4-5 $\mathrm{mm}$. long ; leaves $8-\mathrm{IO} \mathrm{cm}$. long ; leaflets I I-I9, usually oblong, but varying from elliptic to lirear-oblong, I-2 cm. long, 3-6 mm. wide, glabrous above, sparingly strigose beneath, rounded at the apex; peduncles $5-10 \mathrm{~cm}$. long; raceme short, $3-5 \mathrm{~cm}$. long, 5-IO-flowered; bracts lanceolate, scarious, I $\mathrm{mm}$. long; caly'x strigose with black hairs; tube campanulate, 2-2.5 mm. long; teeth subulate, fully I mm. long; corolla I $\mathrm{cm}$. long, white, tinged with purple; keel with a narrow dark-purple tip; legumes $2-2.5$ $\mathrm{cm}$. long, strigose, $4 \mathrm{~mm}$. wide; the lower suture strongly curved, the upper straight or slightly upturned towards the apex.

This species was included in $H$. hylophilus in my Flora of Colorado, $i . c_{\text {. }}$, as far as the Colorado specimens are concerned. It resembles $H$. hylophilus, but the leaflets are thicker and the pod decidedly strigose and of another shape. In H. hylophilus the legume is straight and glabrous from the beginning. H. oblongifolins is found as far as known only in the mountains of Colorado, while H. hylophilus belongs to Montana, northern Wyoming and Idaho.

Colorado: Cerro Summit, i 90 i, Baker 409 (type); Leadville, I 884, M. E. Jones; North Park, near Teller, i 884, C. S. Sheldon Iof; Marshall Pass, M. E. Jones.

New York liotanical Garden. 
CONTRIBUTIONS FROM THE NEW YORK BOTANICAL GARDEN-No. 96

\section{STUIDIES ON THE ROCKY MOUNTAIN FLORA-XVIII}

BY PER AXEL RYDBERG

NEW YORK 

. 



\section{Studies on the Rocky Mountain flora - XVIII}

\section{Per Axel, Rynberg}

Homalobus divergens (Blankinship) Rydb.

Astragalus dizergens Blankinship, Mont. Agric. Coll. Sci. Stud. Bot. I : 73. I 905 .

Homalobus camporum Rydb. Bull. Torrey Club 32: 666. 1906.

When I described Homalobus camporm I overlooked the facts that the same species had already been published by Prof. Blankinship and that he had even cited the type number of my type. He had described the pod, however, as having a stipe, something that I cannot find in any specimens at hand.

\section{Homalobus humilis sp. nov.}

Perennial with a cespitose caudex; stems $2-10 \mathrm{~cm}$. long, grayish-strigose, decumbent or spreading ; stipules ovate, scarious, $2-3 \mathrm{~mm}$. long; leaves $2-6 \mathrm{~cm}$. long; leaflets I 1-1 5 , oblong, 3-6 mm. long, about $2 \mathrm{~mm}$. wide, grayish-strigose beneath, glabrate above; peduncles $2-8 \mathrm{~cm}$. long; raceme short, I-2 cm. long, 3-8-flowered; calyx strigose with black hairs; tube campanulate, I.5-2 mm. long; teeth triangular or triangularsubulate, I-I.5 mm. long; corolla purple, $7-8 \mathrm{~mm}$. long; legume about $\mathrm{I} .5 \mathrm{~cm}$. long, $3 \mathrm{~mm}$. wide, widest near the abruptly acute apex, tapering towards the base, the upper suture nearly straight, the lower strongly arched at the apex.

This species most resembles $H$, dirergens (Blankinship) Rydb. in habit, but differs in the shape of the legumes, the darker corollas, and in the less canescent leaves, which are glabrate above. It grows on high arid mountain tops at an altitude of nearly $3,000 \mathrm{~m}$.

UTAH: Mountain north of Bullion Creek, near Marysvale, 1905, Rydberg \& Carlton 7 It7 (type); Delano Peak, I905, nos. 1219 and $1219 a$.

Homalobus microcarpus sp. nov.

Homalobus campestris Rydb. Bull. Agr. Exp. Sta. Col. I0o: 209, in part. I906. Not H. campestris Nutt. 
Homalobus camporum Rydb. loc. cit., in part.

Perennial with a cespitose caudex; stems decumbent, about I dm. high, strigose; leaves 5-S cm. long; stipules ovate, scarious, 2-3 mm. long; leaflets 9-I 5 , elliptic to linear, 5-I $5 \mathrm{~mm}$. long, $\mathrm{I}-3 \mathrm{~mm}$. wide, glabrous above, sparingly strigose beneath; peduncles 4-6 cm. long; racemes short, 3-8-flowered; calyx strigose with black hairs; tube campanulate, about $2 \mathrm{~mm}$. long; teeth about I mm. long, subulate; pod sessile, strigose, straight, I 2-I $8 \mathrm{~mm}$. long, $3 \mathrm{~mm}$. wide.

This species is intermediate between H. oblongifolins Rydb. and H. diargons (Blankinship) Rydb. Baker's specimens from North Park were referred to the latter, which the present species resembles in general habit and the pod; but it is a greener plant, the leaflets being glabrous above and only slightly strigose beneath. The smaller size, and the smaller pod of a different shape, separate it from H. oblongifolins.

Colorado: East slope of Rabbit Ear Range, I 894 (type distributed from the State Agricultural College of Colorado, collector not given); Forls of Poudre and Big South, IS94; North Park, I897, C. F. Faker; Steamboat Springs, 1903, Osturhont 2774.

\section{Homalobus paucijugus sp. nov.}

Perennial with a cespitose caudex, bushy; stems $\mathrm{I}-2 \mathrm{dm}$. high, sparingly strigose; leaves numerous, 5-10 cm. long; leaflets $\mathrm{I}-5$, the lateral ones lanceolate to linear-subulate, $\mathrm{I} \mathrm{cm}$. or less long, glabrous above, sparingly strigose beneath, or none; the terminal one $\mathrm{I}-2 \mathrm{~cm}$. long, linear or linear-oblanceolate, gradually tapering into the rachis; stipules scarious, ovate, $2-3 \mathrm{~mm}$. long; peduncles $3-6 \mathrm{~cm}$. long; racemes short, 3-6-flowered; calyx strigose with black hairs; tube campanulate, about $2 \mathrm{~mm}$. long; teeth subulate, fully I mm. long; legume I $2-\mathrm{I} 5 \mathrm{~mm}$. long, $2 \mathrm{~mm}$. wide, straight, strigose.

This species resembles $H$. decurrens in the peculiar terminal leaflet, but differs in the few small and narrow lateral leaflets, the small size of the plant, the small flowers and the small pod. It grows at an altitude of nearly $3000 \mathrm{~m}$.

UTAH: Big Cottonwood Cañon, in sheltered places near the summit of the divide between Lake Solitude and Twin Lakes, I 905 , A. O. Garrett 1580 .

The species confused with H. tencllus and usually included in it may be distinguished by the following characters : 
Legume glabrous.

Stipe rarely exceeding the tube of the calyx ; leares usually spreading in age; leaflets oblong to oval, obtuse and mucronate.

11. dispar.

Stipe of the mature legume usually exceeding the calyx-teeth; leaves strongly ascending; leaflets narrowly linear to linear-oblong, nostly acute.

Stipe 3-4 mm. long; leafiets linear or linear-oblong; stem usually conspicuously strigose; calyx-leeth half as long as the tube. H. lenelluts.

Stipe 5-7 mm. long; leaflets narrowly linear; stem glabrous or nearly so; calyx-teeth usually nearly equaling the tube. H. stifitatzrs.

Legume strigose.

II. strigulosus.

Homalobus dispar Nutt.; T. \& G. Fl, N. Am. I : $350 . \quad$ I 838. Orolus dispar Nutt. Gen. 2: 95 . I 8 I 8.

This is much less common and has a more restricted range than H. tenclus. The range of $H$. disferr includes the extreme western portion of Nebraska, Wyoming, northern Colorado and northeastern Utals, while that of $H$. timellus extends from Saskatchewan to Nebraska, Colorado, Utah, and the Yukon Territory.

\section{Homalobus stipitatus sp. nov.}

Somewhat cespitose perennial; stems slender, 3-4 dnu. high, erect, branched, sparingly strigose or glabrate, leafy; leaves strongly ascending, 4-6 cm. long; stipules lance-subulate; leaflets 9-1 5, narrowly linear, I-2 cm. long, $\mathrm{I}-2.5 \mathrm{~mm}$. wide, glabrous or sparingly strigose beneath; peduncles about I cm. long; racemes lax, 2-IO cm. long, 5-20-flowered; calyx strigose; tube campanulate, about $\mathrm{I} .5 \mathrm{~mm}$. long; teeth subulate, about as long; corolla ochroleucous, 8-IO mm. long; legume glabrous, stipitate, flat; body oblong, about $1 \mathrm{~cm}$. long, $3 \mathrm{~mm}$. wide, acute, gradually tapering into the stipe, which is $5^{--7} \mathrm{~mm}$. long.

This species is related to H. tencllus (Pursh) Britton [Astra $\gamma$ galus multiflorus (Pursh) A. Gray', but is a more slender and more glabrate plant, with narrower leaflets and longer stipe. It belongs to the prairie region east of the range occupied by $H$. tencllus.

North Dakota: "Upper Missouri" [from the data given in Nicollet's report, on the hills somewhere between Fort Pierre and Devil's Lake], 1839, Geyer (type in herb. Columbia University); Valley City, is97, L. L. Perrine.

Minnesota: Lake Belmont, Otter Tail Co., ı892, E. P. Sheldon.

Saskatchewan : i 858 , E. Bourgeau $t$. 


\section{Homalobus strigulosus sp. nov.}

Cespitose perennial; stems erect or ascending, branched, $\mathrm{I}-3$ dm. high, strigulose; stipules short, ovate; leaves $3-4 \mathrm{~cm}$. long; leaflets linear, acute, $8-12 \mathrm{~mm}$. long, $\mathrm{I}-2 \mathrm{~mm}$. wide, thick, glabrous above, strigose beneath; peduncies I $\mathrm{cm}$. or less; raceme lax, 1.5-3 cm. long, 4-7-flowered; bracts minute, subulate; calyx strigulose ; tube campanulate, $1.5 \mathrm{~mm}$. long; teeth subulate, less than I mm. long ; corolla ochroleucous, about $6 \mathrm{~mm}$. long ; pod strigose, shining, stipitate ; body oblong, 7-8 $\mathrm{mm}$. long, $3 \mathrm{~mm}$. wide, rather gradually contracted into the stipe, which is about $3 \mathrm{~mm}$. long.

This is closely related to $H$. tencllns, but differs in the smaller flowers and the smaller and hairy pod. It grows at an altitude from $1800-3000 \mathrm{~m}$.

Nevada: East Humboldt Mountains, I860, S. Watson $28_{3}$ (type).

UTAH: P. V. Junction, Wasatch Mountains, I883, M. E. Jones (mixed with $H$. tenellus).

\section{Diholcos micranthus sp. nov.}

Somewhat cespitose perennial; stems erect or ascending, sparingly strigose or glabrate, $2-4 \mathrm{dm}$. high ; stipules ovate, about $5 \mathrm{~mm}$. long; leaves $4-6 \mathrm{~cm}$. long ; leaflets i $7-25$, linear or lanceoblong, acute at both ends, $7-20 \mathrm{~mm}$. long, glabrous above, strigose beneath; peduncles $4-7 \mathrm{~cm}$. long; racemes many-flowered, 3-7 cm. long; calyx strigose ; tube campanulate, slightly gibbous, $2-2.5 \mathrm{~mm}$. long; teeth subulate-filiform, I-2 $\mathrm{mm}$. long, the upper somewhat shorter; corolla $6-7 \mathrm{~mm}$. long, ochroleucous; pod strigose, obsoletely if at all cross-ribbed; stipe $3-4 \mathrm{~mm}$. long; body scarcely I $\mathrm{cm}$. long, $3 \mathrm{~mm}$. wide, very acute.

This species is related to D. Haydcnianus (A. Gray) Rydb. [Astragalus Haydenianns A. Gray], differing in the smaller flowers and fruit, the more acute leaflets, the narrower calyx-lobes, and especially the almost total lack of cross-ribs on the more acute legumes. D. micranthus was included in D. Haydenianus in my Flora of Colorado.

Colorado: La Veta, I $\$ 96$, C. L. Shear 3569 (type); Gunnison, I 896, Clements Ioo; Ridgeway, I 895, Tweedy 228; Rio Blanco, south of Pagosa, I $88_{3}, B$. H. Smith.

\section{Kentrophyta minima sp. nov.}

Perennial with a woody root and cespitose caudex, forming cushions $\mathrm{I} \mathrm{dm}$. in diameter; herbaceous stems $\mathrm{I}-2 \mathrm{~cm}$. high; 
leaves $5-8 \mathrm{~mm}$. long ; stipules scarious, lanceolate, $\mathrm{I}-3 \mathrm{~mm}$. long, more or less united ; leaflets $5 \mathbf{5}-9$, linear-lanceolate, conduplicate, pungent, 3-4 mm. long, finely strigose; flowers usually solitary, subsessile; calyx strigose; tube $\mathrm{I}-1.5 \mathrm{~mm}$. long, campanulate; teeth subulate, scarcely I mm. long; corolla ochroleucous, about $3 \mathrm{~mm}$. long; keel tipped with purple; pod ovoid, rather turgid, acute, $3 \mathrm{~mm}$. long.

This is related to $\mathrm{K}$. tegetaria (S. Wats) Rydb. [Astragelus tegetarius S. Wats.] and K. Wolfii Rydb. From the former it differs in the subsessile flowers and the shorter calyx-lobes; $K$. tegetaria has $1-3$-flowered racemes, exceeding the leaves in length and calyx-lobes which are longer than the tube. From $K$. Wolfi, it differs in the appressed pubescence, the smaller flowers and the shorter legume. It is an alpine species growing at an altitude of 2800-3100 m.

Yellowstone National Park: August is84, Tuocidy $\mathcal{S}_{3}$ (herb. Columbia Univ.).

\section{Aragallus patens sp. nov.}

Acaulescent perennial; leaves spreading or ascending, 5-IO $\mathrm{cm}$. long; leaflets 9-17, elliptic or oblong, acutish at both ends, $1-2$ $\mathrm{cm}$. long, 4-6 mm. wide, somewhat silvery with closely appressed hairs; scape $\mathrm{I}-1.5 \mathrm{dm}$. high, strigose with short silky hairs; raceme short, $3-7 \mathrm{~cm}$. long; bracts linear-lanceolate to lanceolate, 5-8 mm. long; flowers usually spreading; calyx sparingly appressed-silky with short hairs, often somewhat tinged with purple above, 5-6 $\mathrm{mm}$. long, $3 \mathrm{~mm}$. wide; teeth subulate, the upper $2 \mathrm{~mm}$., the lower $3 \mathrm{~mm}$. long; corolla dark bluish-purple, about I $5 \mathrm{~mm}$. long; banner narrow; wings broad, slightly emarginate, the upper lobes narrow and acutish; keel with a very dark purple spot, and a short, porrect tip ; legume ascending-spreading, thincoriaceous, nearly straight, less than $2 \mathrm{~cm}$. long, $4 \mathrm{~mm}$. thick, long-acuminate, minutely strigose, half 2 -celled.

This is related to A. Lambertii and A. siricens. From the former it differs in the shorter and broader leaflets and the more spreading leaves ; from the latter in being greener, less hairy, and having narrower bracts and calyx-tube and darker flowers, and from both in the smaller size, thinner and more spreading legumes and smaller flowers.

Colokado: Plains and foothills near Boulder, I 902, F. Triecdy $516+$ (type); between Sunshine and WVard, 10. 5165 ; Eldora to 
Baltimore, no. 5637; Sargents igor, C. F. Baker 37t; Cimarron, 120.277.

IVyoming: Laramie Plains, I903, Goodding I 722 ; Centennial, I900, Azen Vison 7680 .

Nebraska: Hay Springs, igor, MacDougal $7+$.

\section{Aragallus angustatus sp. nov.}

Acaulescent perennial; leaves spreading or ascending, 6-Io $\mathrm{cm}$. long; leaflets $7-\mathrm{I} 3$, narrowly linear-lanceolate to narrowly linear, $1-2 \mathrm{~cm}$. long, $2-4 \mathrm{~mm}$. wide, sparingly strigose; scape about I dm. high, sparingly strigose; raceme $3-5 \mathrm{~cm}$. long; bracts lanceolate, about $5 \mathrm{~mm}$. long; calyx finely silky-strigose; tube 5-6 $\mathrm{mm}$. long; teeth subulate, about $2 \mathrm{~mm}$. long; corolla purple, $15 \mathrm{~mm}$. long or less; banner rather broad; wings broad and slightly emarginate; keel with a very dark blue-purple spot and a very short porrect tip; legume ovoid, less than $I .5 \mathrm{~cm}$. long, coriaceous, $3.5 \mathrm{~mm}$. thick, rather abruptly contracted into a spreading beak, minutely strigose, lualf 2 -celled.

This resembles, somewhat, a low, narrow-leaved $A$. Lambertii, but differs in the more spreading leaves, and smaller, more spreading flowers, and especially by the short pod, with an abrupt spreading beak. The specimen designated as the type has the best developed fruit.

Nebraska: Hills, Rush Creek, i $\$_{91}$, Rydlerg $82 c$ (fruit, type in herb. Columbia Univ.); prairies, Banner Co., no. $\delta 2 \alpha$, in part (fruit); hills, Banner Co., no. $\mathcal{S} 2 b$ (flowers); Hay Springs, Igor, MacDougal 6 fb (llowers).

Aragallus Blankinghipil A. Nelson

Prof. J. W. Blankinship * writes :

"O.rytropis Besscyi (Rydberg); Aragallus Besscyi Rydberg, Flora 250 is A. Blankinshifii Nelson, Erythea, 7: 58. The types of both were collected within a few miles of each other. The fruiting specimens of Nelson were pathogenic, infected with uredo, causing the ovary to remain undeveloped and an abnormal calyx, the legume in the species usually exceeding the calyx; otherwise they are identical."

This statement is only partly correct. Professor Blankinship some time ago sent us specimens of Aragallus Blankinshipii from

* Mont. Agr. College Sci. Stud. Bot. I : 8o. 1905. 
the type collection. The flowering specimen is identical with my A. Besscyi, but the fruiting specimen is not. The flowering specimen has long linear-subulate calyx lobes, $4 \mathrm{~mm}$. long, and linearlanceolate, acute bracts, while in the fruiting specimen the calyxlobes are almost triangular and about half as long and the bracts lance-oblong and obtuse. If the fruit of the type sheet is infected by uredo, there is no evidence of it in the duplicate here at the Botanical Garden. The trouble is that Aragallus Blonkinshipii was described from flowering specimens of one species (A. Besscyi) and fruiting specimens of another. They are both well known to me. I intended to describe the second species in the Flora of Montana when in the meantime Professor Nelson's article in Erythea appeared. I had no authentic specimens of his new species. As I knew of no species answering to Professor Nelson's description of $A$. Blankinshipii, never suspecting it to be a composite one, and knowing one agreeing fairly with his description of $A$. collinus except as to the color of the corolla, I referred the specimens of my supposed new species to this. The New York Botanical Garden has since received authentic specimens of both $A$. Blankinshipii and A. collinus and I have been able to correct my mistake. The specimens referred to $A$. collinus in my Flora of Montana are specifically the same as the fruiting specimens of $A$. Blankinsliipii. Mr. Gooding has also collected good fruiting specimens in Wyoming at Alcona, Natrona County, in 1901 (no. 1 +7). These were determined as A. Blankinshipii.

This species is closely related to A. namus, differing mostly in the erect stiff scape and more elongated spike. A. Besscyi, together with $A$. argophyllus, forms a small group more related to A. Lambertii.

I adopt the name A. Blankinshipii for this species, represented by the fruiting specimens of the original description for the following reasons: ( I) Prof. Nelson has laid most stress on the structure of the pod, associating A. Blankinshipii with A. collinus, A. multiccps, A. Lagopus and A. namus, to which this species is related; (2) The characters of the fruit in the genus Aragallus are more reliable then those of the flowers to show the actual relationship : (3) The species represented by the flowering specimens has already received a name. The synonymy of the two species is as follows: 
Aragallus Blankinshipi A. Nelson Erythea 7: 58 (fruiting specimens). I 899 .

Areagallus collinus Rydb. Mem. N. Y. Bot. Garden. I : 254.

I900. Not $A$. collimus A. Nelson i 899 .

Aragallus Besseyi Rydb. Mem. N. Y. Bot. Garden I: 250. 1900.

Oxytropis argentata Pursh F1. Am. Sept. 473. ISI4. Not. O. argentata Persoon.

Aragallus Blankinshipii A. Nelson. Erythea, 7: 58 (flowering specimens). I 899 .

Aragallus monticulus A. Nelson, Erythea 7: 62, in part. IS99.

Not Oxytropis monticola A. Gray.

Oxytropis Besseyi Blankinship, Mont. Agr. Coll. Sci. Stud. Bot. I :

So. 1905 .

\section{Aragallus atropurpureus sp. nov.}

Acaulescent perennial ; leaves numerous, $3-7 \mathrm{dm}$. long ; leaflets oval to oblong, canescently silky-villous, 5-1 $5 \mathrm{~mm}$. long, 3-5 $\mathrm{mm}$. wide, obtuse or acute; scape $6-10 \mathrm{~cm}$. long, loosely villous; raceme short and headlike; $2-3 \mathrm{~cm}$. long; bracts linear-subulate, 5-IO mm. long; calyx dark, villous with mixed black and white hairs; tube $5 \mathrm{~mm}$. long, $3 \mathrm{~mm}$. wide; teeth black-hairy, subulate, $4 \mathrm{~mm}$. long; coralla dark-purple, about $\mathrm{I} 5 \mathrm{~mm}$. long; wings deeply emarginate; keel with a rather long ascending tip; legume ovoid, less than I. $5 \mathrm{~cm}$. long, I $5 \mathrm{~mm}$. thick, abruptly acuminate with a spreading beak, villous, partly black-hairy, thin, half 2-celled.

In pubescence and leaf-form, this species most resembles $A$. scriceus, but it is a much smaller plant, has only half 2-celled, shorter and more curved pod. It is easily distinguished from all the other purple-flowered species of the $A$. Lambertii group by the black-hairy calyx and long calyx-teeth.

Wroming: Headwaters of Tongue River,'Big Horn Mountains, IS98, F. Treecdy 125 (type, in flower); 110.126 (in fruit).

\section{Hedysarum utahense sp. nov.}

Perennial with a rootstock; stem 4-6 dm. high, finely strigose, stipules triangular, acuminate, $5-\$ \mathrm{~mm}$. long; leaves $-\mathrm{I} 5 \mathrm{~cm}$. long; leaflets II-I7, elliptic, oval or oblong, usually rounded at both ends, I-3 cm. long, 5-Io mm. wide, glabrous above, finely 
cinereous-strigose or more glabrate beneath; peduncles about I $\mathrm{dm}$. long; raceme $4-10 \mathrm{~cm}$. or in fruit even $2 \mathrm{dm}$. long; bracts ovate to lanceolate, scarious; calyx cinereous-strigose; tube nearly $3 \mathrm{~mm}$. long; teeth lance-subulate, $5 \mathrm{~mm}$. long, attenuate; corolla rose-purple; banner I 5-I $8 \mathrm{~mm}$. long; keel I $8-20 \mathrm{~mm}$; loments minutely strigose ; internodes $2-5,6-8 \mathrm{~mm}$. long, 5-6 mm. wide; nodes narrow, $2.5 \mathrm{~mm}$. or less.

This is related to the subarctic H. Mackensii, from which it differs in the denser pubescence on its calyx, its broader calyr-teeth, its fewer and larger internodes of the loment, its taller habit, broader bracts and lighter and redder flowers. It grows on hillsides at an altitude of $\mathrm{I} 400-2000 \mathrm{~m}$.

UTAII : Vicinity of Salt Lake City, I 883 , Leonard 55 (type); 1900, Stokes; I869, II'atson 29t; near Ogden, Conlter; Stansbury; Wahsatch Mountains, i 888 , Dr. Eccles.

\section{Lathyrus brachycalyx sp. nov.}

Perennial with a creeping rootstock; stem simple or slightly branched, I.5-3 dm. high, usually finely pubescent, sharply 4angled; stipules semi-sagittate, 5-IO mm. long, I.5-3 $\mathrm{mm}$. wide, pubescent; rachis $2-5 \mathrm{~cm}$. long, somewhat winged; leaflets $2-5$ pairs, linear-oblong or oblanceolate, firm, strongly veined, finely pubescent, acute at both ends, $\mathrm{I}-3 \mathrm{~cm}$. long, 2-8 mm. wide; tendrils of the lower leaves reduced to mere tips, those of the upper leaves better developed, but usually simple; peduncles $5-10 \mathrm{~cm}$. long; raceme short, 2-6-flowered; calyx puberulent; tube 4-5 mm. long; upper teeth broadly triangular, scarcely $2 \mathrm{~mm}$. long, the rest lance-subulate, the lowest one $3 \mathrm{~mm}$., rarely $4 \mathrm{~mm}$. long; corolla purple, $2-2.5 \mathrm{~cm}$. long: legume glabrous, $3-4 \mathrm{~cm}$. long, 7 mm. wide.

This species has been confused with $L$. decapctalus and is closely related to it. It differs in the much shorter calyx-tube and calyx-teeth, the broader, more upturned banner, the more pubescent foliage and less well developed tendrils. It grows on hillsides and in cañons and washes at an altitude of $1400-$ $2500 \mathrm{~m}$.

UTAн: City Creek Cañon, I $8_{3}$, F. E. Leonard IOI (type), 20 and 29; 1900, S. G. Stokes; I880, MI. E. Jolles I 7on; near Salt Lake City, 1904, Gamett 998; 1905, Rydbirg 6I62; Mt. Majestic, Gorrett I656; Mount Nebo, 1902, Goodding IIO5; Wahsatch Mountains, I 869. S. II Tatson 295. 


\section{Capnoides hastatum sp. nov.}

Glabrous green peremnial, I-I.5 m. high, branched above; leaves $2-4 \mathrm{dm}$. long, thrice pinnatifid; ultimate divisions elliptic or oval, $\mathrm{I}-2 \mathrm{~cm}$. long, mucronate; racemes $\mathrm{I} \mathrm{dm}$. long or more; bracts oblanceolate, about I $\mathrm{cm}$. long; pedicels about $3 \mathrm{~mm}$. long; sepals narrowly hastate with broad often toothed, divergent basal lobes, about $2 \mathrm{~mm}$. long; corolla with the spur i $5-18 \mathrm{~mm}$. long, salmon-pink; hood scarcely crested.

This species is closely related to C. Cusickii (S. Wats.) Heller, but differs in the smaller corolla, less crested hood and the sepals which are hastate instead of reniform and laciniate.

IDAHo: Lolo Creek, I902, C. I. Piper 1057 (type in herb. N. I. Bot. Garden).

\section{Capnoides brachycarpum sp. nov.}

Glabrous and glaucous perennial with thick root; stem 3-6 $\mathrm{dm}$. high, branched above; leaves $2-3 \mathrm{dm}$. long, thrice pinnatifid; ultimate divisions lanceolate or lance-elliptic, $2-3 \mathrm{~cm}$. long, 5-I 2 $\mathrm{mm}$. wide; racemes $\mathrm{I}-2 \mathrm{dm}$. long, the upper often branched; bracts linear-subulate, about $5 \mathrm{~mm}$. long; pedicels ascending, about $5 \mathrm{~mm}$. long: sepals ovate, acute, $2-3 \mathrm{~mm}$. long with toothed auricles at the base; corolla, including the spur, about I $5 \mathrm{~mm}$. long, yellowish, the inner petals tipped with purple or brown: spur about the length of the body of the petals, horizontal ; crest of the hood obsolete; pod horizontal or reflexed, obovoid, about $\mathrm{I} \mathrm{cm}$. long and $6 \mathrm{~mm}$. wide.

This species was included in the original description of Corydalis Brondegei S. Wats, but the type of the latter and all Colorado specimens can easily be distinguished by the green, scarcely glaucous foliage, the broader oval or obovate mucronate divisions of the leaves, the broader and obtuse sepals, the longer corolla, which is fully $2 \mathrm{~cm}$. long and has an almost erect spur, and the fruit, which is fully $1.5 \mathrm{~cm}$. long but scarcely more than $4 \mathrm{~mm}$. thick. C. brachycurpum grows along streams at an altitude of nearly $3000 \mathrm{~m}$.

Utah: Alta, I879, M. E. Jones II97 (type in herb. N. Y. Bot. Gard. ); I 905, Rydbers 68,8; Silver Lake, American Fork Cañon, I 895 , MI. E. Jones; Wahsatch Mountains, I 884, Lconard 175 . 


\section{Lepidium Crandallii sp. nov.}

L. Jonesii Rydb. Bull. Ag. Ex. Sta. Colo. I00 : 1 52, in part. I 906. L. Eastzwootiac Rydb. l. c. in part.

Perennial; stems several, branched and leafy throughout, glabrous or puberulent above, 3-5 dm. high; basal leaves and lower stem-leaves pinnatifid, 5-7 cm. long, glabrous, with oblanceolate or oblong, entire or slightly toothed divisions; upper stem-leaves, especially those of the branches, oblanceolate or linear, entire or toothed; sepals oblong, nearly 2 mm. long, whitemargined; petals clawed, about $3 \mathrm{~mm}$. long, white, their blades obovate; stamens 6 ; fruiting racemes 5-ro cm. long; pedicels divergent ; pods oval or ovate, about $4 \mathrm{~mm}$. long, glabrous, slightly wing-margined above; style $\mathrm{I} \mathrm{mm}$. long, about twice as long as the wing-margin.

This species is related to the two species to which it has been referred and to L. allyssoides. From the latter and L. Eastwoodiae it differs in the more commonly dissected stem-leaves, the broader and shorter segments of the leaves and the comparatively longer style. From L. Joncsii it differs in the broader leaf-segments, thinner leaves, and more branched habit. From L. scofulomm it differs in the less woody base, the branched and leafy stem, thinner leaves and shorter styles.

Colorano: Palisades, May I4, is98, Crandall IzI (type in herb. N. Y. Bot. Gard.); Glenwood Springs, I 902, Ostcrhont 2599 ;

\section{Lepidium brachybotryum sp. nov.}

Biennial or perennial with a tap-root; stem 2-3 dm. high, branched, puberulent throughout; basal leaves puberulent, bipinnatifid, about $5 \mathrm{~cm}$. long, with elliptic or obovate lobes; stemleaves oblanceolate, pinnatifid or toothed; sepals oblong, about I $\mathrm{mm}$. long, white-margined; petals white, clawed, $2 \mathrm{~mm}$. long, their blades broadly obovate; stamens 6 ; fruiting racemes short, 2-5 $\mathrm{cm}$. long ; pedicels divergent, 5-7 mm. long; pod rounded-ovate, $3 \mathrm{~mm}$. long, $2.5 \mathrm{~mm}$. wide, wing-margined above; styles less than $0.5 \mathrm{~mm}$. long, scarcely exceeding the wing-margins.

This is related to L. montanm but differs in the short style, more rounded pods, and short racemes. It grows on sage-brush flats.

Utaн: Juab, I902, Goodding 1075 (type in herb. N. Y. Bot. Gard.); Wasatch County, near Midway, Carlton \& Garrett 6728 (poor specimen doubtfully referred here). 


\section{Lepidium Fletcheri sp. nov.}

Annual or biennial; stem erect, 3-5 dm. high, puberulent with short cylindric spreading hairs, branched above with ascending branches; leaves narrow, pinnatifid with linear divisions or saliently toothed, $2-5 \mathrm{~cm}$. long, puberulent ; those of the inflorescence linear and entire ; sepals oblong, scarcely I mm. long, green, with white margins; petals none; stamens usually 2, scarcely exceeding the sepals; fruiting racemes $3-5 \mathrm{~cm}$. long; pedicels 4 mm., terete; pod glabrous, scarcely $3 \mathrm{~mm}$. long, obovate in outline, glabrous, strongly wing-margined above; lobes of the wings nearly $0.5 \mathrm{~mm}$., triangular-ovate, acutish or obtuse; seed $\mathrm{I} \mathrm{mm}$. long, brown, wingless.

This species is related to L. densiflom and L. mderale, but differs from both in the deeper, more open notch of the pod and the prominent lobes of the wing. From the former it differs also in the smaller pod and the narrow divisions of the leaves and from the latter in the leaves, of which none, apparently, are bipinnatifid. In the fruit it resembles L. Bourgcauanum Thelling, but differs in the simple erect habit and in the pinnatifid leaves.

Manitoba: Roadsides, Winnipeg, 1905. J. Fletcher (type in herb. N. Y. Bot. Gard.) ; apparently also

Saskatchewax: Cherryfield, I 906, Macoun \& Herriot $6988 I$.

\section{THELYPODIUM Endl.}

This genus as treated in the Synoptical Flora represents at least half a dozen different types of plants. Whether they should be regarded as one or more genera depends upon the individual tastes and inclinations of the botanist treating them. Dr. Greene, in splitting up the genus Streptanthus, expressed the opinion that either these two genera, Stanfordia and Caulanthus, should be united into one, or else Streptanthus should be divided into several. The writer agrees so far with Dr. Greene and thinks that Thelypodium and Coulanthus should be treated the same way. He has not been able to follow Dr. Greene in his segregation, however, partly because he does not know well enough the West American species treated by Dr. Greene, and partly because his opinions differ considerably in some cases. One of these cases will be given below.

Thelypodium was established by Endlicher, and based wholly 
on Pachypodium Nutt.* A generic diagnosis was given but no species were cited. In IValpers' Repertorium (I : I 72), the genus was again taken up and the three species of Pochypodium found in Torrey and Gray's Flora, were taken up in the same order as these. Hence Thelypodium is a mere substitute for Pachypodim, which name had been used for another genus, and the type of the latter genus is the type of the former. The three species of Pachiz' podium are the following, given in the order in which they appear: $P$. laciniatum, $P$. integrifolium, $P$. sagittatum. The last of the three need not be considered, for in Torrey and Gray's Flora it is regarded as doubtfully belonging to the same genus as the preceding and perhaps belonging to a section of Arabis. The type of Pachypodinm Nutt., and hence of Thelypodim Endl., must then be either $P$. laciniatum or $P$. integrifolimm. There is nothing that points directly to either of the two, but everything favors the former. It is not only the first species mentioned, but it is also the only one previously known and figured. It was first described as Macropodium laciniatum. Hooker compared it with the original $M$. nizale, gave figures for both and emphasized the differences between the two, the oblong anthers and the long, slender pubesent stipe of $M$. mivale and the linear anthers and the short, stout stipe of $M$. laciniatzm. Nuttall remarked "evidently not a Macropodium." It is evident that he selected the name Pachypodium from the short, stout stipe.

If Macropodium laciniatum Hook, is regarded as the type of Thelypodium Endlicher, and the writer can not regard it otherwise, the closest relatives of it we find in T. utahense Rydb. and the groups of Thelypodia on which Dr. Greene based his genus Guillcnia. It is hard to see how Thelypodium lasiophyllmm Greene, the type of the latter genus, can be generically distinct from $T$. laciniatum (Hook.) Endl. Every character pointed out by Dr. Greene for his Guillenia agrees with the latter and is even found in Hooker's description. It will be admitted that there are some habitual differences, by which T. laciniatum is isolated from Guillenia, but $T$. utahonse, originally named $T$. laciniatum, has the habit of that genus, while the flower and fruit are essentially those of T.lasiophyllum.

* T. \& G. Fl. N. Am, I : 96.1838 . 
Dr. Greene evidently intended to inciude in Guillenia, Arabis longirostris or Streptanthus longirostris, but in enumerating the species of his new genus he has no $G$. longirostris. He has one G. rostrata based on Arabis rostrata S. Wats., a name the publication of which I have been unable to find. Arabis longirostris is hardly congeneric with Tilypolinm lasiophyllum, however. It has the flat pod of Strcptanthus, but the short anthers, merely cordate at the base, and not spirally curved, place it as very doubtfully belonging to any of the Streptanthoid genera.

The second species of Pachypodiuin in Torrey and Gray's Flora, now usually known as Thelypodium integrifolium (Nutt) Endl., is so different in habit, that the writer has always found it hard to regard it as congeneric with the rest, but the differences in the structure of the flower and of the pod externally are so slight that a segregation based on habit alone would not be desirable. There is however, a character in the pod, unique to this species and two or three segregates from it and making them stand isolated from all the other Thelypodioid plants, viz., the strong and broad midrib of the septum of the pod. There is no distinct midvein in any of the typical Thelypodia.

A species closely resembling $T$. integrifolium in habit, foliage and flowers, is T. linearifolium or Lodanthus or Streptanthus linearifolins, but it lacks the rib on the septum. Besides it has two characters not found in the other Thelypodia. Two of the rather firm and purple sepals are strongly saccate at the base and the stigma is conical, not truncate nor 2 -lobed as in the other species. It could be referred to Hisperis, which it resembles especially in the flowers, if it were not for the stipitate, terete pod and the curved anthers, which characters are strongly thelypodioid.

In describing the subgenus Enthelypodium in the Synoptical Flora, Dr. Robinson gives $T$. clegans Jones as an exception having a 2 -lobed stigma with the lobes expanding over the septum. In the whole tribe the stigma is either undivided or else the lobes are expanded over the valves. This exceptional character is most pronounced in the species mentioned above, but it is also found in less degree in T. aureum Eastw. and T. Bakeri Greene. Mr. George Osterhout, of New Windsor, Colorado, who has collected a specimen of $T$. clegans, has written on the label: "near to 
Streptonthus a'yomingensis A. Nelson but probably rather a Thelypodium." This note made the writer compare the latter species. When S. ayromingensis was first described, it was thought that it was the closest relative of $S$. maculatus Nutt., the only original Streptantlus, but a closer comparison now has shown that the pod is not flat as in Streptanthus and the lobes of the stigma are turned the wrong way. Its relationship is with the three Thelypodia just mentioned above, with which it also agrees in luabit.

Two other species of Theiypodium are said by Dr. Robinson to have the lobes of the stigma placed in the same way, viz.: $T$. micranthum and T. longifolium, but here that character is scarcely noticeable. There are other characters in which they disagree with the other Tholypolia. The branched or stellate pubescence is unique in the whole tribe and should place them according to the classification used in Engler \& Prantl's Pflanzenfamilien in another grand division of the family. The stamens and the pods are, however, more or less thelypodioid. In both species the flowers are more or less irregular, the lower sepals being longer (this is best shown in T. longifolium) and there is scarcely any distinction between claw and blade in the petals.

The most interesting of the Thelypolic is perhaps T. Mrightii. In the pod, the texture of sepals and petals, the form of the latter, etc., this is close to the typical Thelyporlic. The habit is not so essentially different either, but the sepals are spreading-reflexed and early deciduous as in Stanleye and the glands at the base of the stamens and the thickening of the pedicel, both so conspicuous in most thelypodioid plants, are here inconspicuous. The plant could not be included in Stenleyer, on account of the short stipe, the different habit and the structure of the petals.

The genera may be distinguished as follows:

Sepals equal or nearly so; hairs simple or none.

Sepals erect or ascending in anthesis.

Stigma distinctly lohed, its lobes expanded over the septum.

Thelypodiopis.

Stigma entire or, if indistinctly lobed, the lobes expanded over the valves.

Stigma truncate; sepals scarcely gibtous at the base.

Septum of the pod without a distinct midrib.

Septum of the pod with a strong midrib.

Thelypodium.

Pleurophragma.

Stigma conical: the outer sepals gibbous at the base.

Hesperidanthus.

Sepals strongly spreading or reflexed in anthesis, soon deciduous.

Stanl'yella. 
Sepals unequal, the lower longer ; hairs, at least some of them, stellate or branched, Ilelerolhrix,

THELYPODIOPSIS gen. nov.

Biennials with rather thick and glaucous foliage and glabrous except the lower part of the stem. Basal leaves spatulate or oblanceolate, more or less toothed, with winged petioles; stem-leaves auriculate-clasping with rounded auricles. Sepals thin, erect or ascending, not gibbous, more or less petaloid, linear or oblong. Petals more or less clawed, white or purplish or in one species yellow. Filaments distinct, slender, filiform or subulate; anthers long, linear, sagittate at the base, soon spirally curved. Pod slender, terete, more or less torulose, usually with short stipe and style; stigma 2-lobed, the lobes expanded over the septum ; cotyledons obliquely incumbent.

The first species of this genus as well as of the following new genera is regarded as the type.

Stipe very short, less than I mm. long or almost none; petals white or tinged with purple.

Style $2 \mathrm{~mm}$, or nearly so.

Pod $7-9 \mathrm{~cm}$. long.

Pod about $4 \mathrm{~cm}$. long.

Style less than I mm. long; pod 5-7 cm. long.

Stipe $2-5 \mathrm{~mm}$. long; petals and sepals yellow.
T. eleyans.

7. Bakeri.

T. wyomingensis.

T. aurea.

Thelypodiopsis elegans (M. E. Jones).

Thelypodium elegans M. E. Jones, Zoe 4: 265. IS93.

Thelypodiopsis Bakeri (Greene).

Thelypodium Bakeri Greene, Pl. Baker. 3: S. I90 I.

Thelypodiopsis wyomingensis (A. Nelson).

Streptanthus ayomingensis A. Nelson, Bull. Torrey Club 26: I 26. I 899 .

Thelypodiopsis aurea (Eastw.).

Thelypodium aurcun Eastw. Zoe 2: 227. 1 S9I.

\section{Thelypodium Palmeri sp. nov.}

Biennial or perennial with a tap-root; stem 3-5 dm. high, sparingly hirsute below, glabrous above; basal leaves oblanceolate or spatulate, $2-4 \mathrm{~cm}$. long, more or less hirsute beneath, especially on the veins; stem-leaves sagittate, $2-4 \mathrm{~cm}$. long, glabrous or nearly so; inflorescence usually branched with ascending branches; pedicels nearly erect, 5-8 mm. long; sepals ablong, 3-4 $\mathrm{mm}$. long; petals 5-6 $\mathrm{mm}$. long, white or rose; claw about $3 \mathrm{~mm}$. long; blade spatulate or oblanceolate; pod about $2-5 \mathrm{~cm}$. long, I mm. wide. 
This species has been confused with T. sagittatum (Nutt.) Endl., but differs in the smaller and narrower petals, nearly erect pedicels and narrow pod.

Southern Utah: i 877 , E. Palmer 25 (type in herb. Columbia Univ.).

Thelypodium leptosepalum sp. nov.

Annual or biennial, glabrous throughout; stem 4-6 dm. high, branched; leaves thin, glabrous, 6-10 cm. long, lyrate-pinnatifid with lanceolate divergent lobes; flowering pedicels about $3 \mathrm{~mm}$. long; sepals lance-subulate, $6 \mathrm{~mm}$. long, $\mathrm{I}-\mathrm{I} .5 \mathrm{~mm}$. wide at the base, white; petals narrowly linear-oblanceolate, almost strapshaped, with scarcely any distinction between blade and claw, 8 $\mathrm{mm}$. long, $0.5 \mathrm{~mm}$. wide or less; filaments filiform, about $\mathrm{I} \mathrm{cm}$. long when well developed; anthers linear, sagittate at the base, soon curled.

This is closely related to T. laciniatum (Hook.) Endl., but differs in the narrow tapering instead of oblong sepals. It grows at an altitude of 450-600 m. on rocky banks.

Idpho: Lewiston, Nez Perces County, I \$96, A. A. \& E. Gertrude Heller 3022 (type in herb. Columbia Univ.); Valley of Peter Creek, Nez Perces County, I S92, Sandborg, MacDougal \& Hellor I22.

\section{PLEUROPHRAGMA gen. nov.}

Tall glabrous perennials or biennials with paniculate inflorescence and thick entire leaves. Basal leaves oblanceolate or spatulate; stem-leaves linear-lanceolate, sessile but not clasping. Sepals ascending, thin, more or less petaloid. Petals white or purplish with slender claws. Filaments distinct, subulate, white, somewhat dilated below and witl conspicuous glands at their bases; anthers linear, sagittate at the base, curved. Receptacle dilated. Pod slender, terete, torulose, tapering at both ends into a short stipe below and a short slender style above; stigma minute, entire; septum with a strong midrib.

\section{Pleurophragma integrifolium (Nutt.)}

Fachypodium integrifolium Nutt.; T. \& G. Fl. N. Am. I : 96. I $\delta_{3} 8$.

Thelypodium integrifolium Endl.; Walp. Rep. I : I 72. I 842.

\section{Pleurophragma gracilipes (Robinson)}

Thelypodium integrifolium gracilipes Robinson, Syn. F1. $I^{1}{ }_{17} 6$. I 895 . 


\section{Pleurophragma platypodum sp. nov.}

Glabrous perennial with a tap-root; stem simple up to the inflorescence, $\mathrm{I}-2 \mathrm{~m}$. high : basal leaves spatulate, $5-10 \mathrm{~cm}$. long, entire; stem-leaves 3-6 cm. long, linear-lanceolate or oblanceolate, dark-green, thick; inflorescence paniculate; racemes dense, at first corymbiform, in fruit about I dm. long; sepals oblong, yellowish- or greenish-white, $4 \mathrm{~mm}$. long; petals white, clawed, 6-7 $\mathrm{mm}$. long; blades spatulate; pedicels in fruit about $3 \mathrm{~mm}$. long, divergent or somewhat reflexed, dilated and flattened at the base, pod $1.5-2 \mathrm{~cm}$. long, I-I.5 mm. thick, torulose; stipe $\mathrm{I}-2 \mathrm{~mm}$. long; style short.

This is related to Pleuropluragma integrifolium (Thelypodium integrifolim Endl.), but differs in the shorter inflorescence, the shorter pedicels, broadened at the base, the shorter pod with longer stipe and shorter style.

Utall : Moab, IS9I, M. E. Joncs (labeled Thelypodium Wrightii, type in herb. N. Y. Bot. Garden).

Arizona: is 76, E. Palmer.

To this genus belongs also Thulypodium lilacimum Greene, Pl. Baker. 3: 9. I 901 , if distinct from T. integrifolium. The only specimens at hand differ from that only in the stronger purple color of calyx and corolla. They are without fruit, which, however, may furnish distinctive characters.

HESPERIDANTHUS (B. L. Robinson) Rydb., gen. nov.

Thelypodium \& Hesperidanthus B. L. Robinson, Syn. F1. I': I 74. I 895.

Erect, slender, glabrous perennials, with pale foliage ; corymbosely branched above. Basal leaves obovate, toothed; stemleaves linear, entire. Sepals rather firm, erect ; the outer strongly saccate at the base. Petals purple, with obovate blades. Anthers linear, sagittate at the base, strongly curved. Stigma conical or ovate, neither truncate nor 2 -lobed. Pod terete, linear, shortstipitate.

\section{Hesperidanthus linearifolius (A. Gray).}

Streptanthus lincarifolins A. Gray, Pl. Fendl. 7. IS49.

Iodanthus or Pachypodium linearifolum A. Gray, Proc. Am. Acad. 6: I 87. I 863 .

Thelypotium linearifolium S. Wats. Bot. King's Expl. 25. I 87 I. 


\section{STANLEYELLA gen. nov.}

Tall branched biemnials. Leaves thin, the lower ones lyrately pinnatifid, the upper entire. Sepals thin, petaloid, white, oblong or linear, spreading or even reflexed in anthesis. Petals white, with oblanceolate or spatulate blades gradually tapering into a short claw. Filaments distinct, filiform; anthers linear, sagittate at the base, soon more or less spirally recurved. Pod slender, terete with short stipe and short style; stigma small, truncate or nearly so; cotyledons incumbent and somewhat conduplicate.

\section{Stanleyella Wrightii (A. Gray)}

Thelypodium Wrightii A. Gray. Pl. Wright. I : 7. 1852.

HETEROTHRIX (B. L. Robinson) Rydb., gen. nov.

Thelypodium S Heterothix B. L. Robinson, Syn. Fl. I $\mathbf{I}^{1}:$; 8 . I 895 .

Slender biennials, more or less pubescent at least below with stellate or branched hairs. Basal leaves oblanceolate, more or less toothed; stem-leaves lance-linear or linear, entire. Racemes elongated, slender. Calyx more or less oblique, the lower sepals being longer than the upper, all ascending, rather firm and more or less purplish. Petals oblanceolate or spatulate, indistinctly or broadly clawed. Filaments subulate, broad at the base, distinct, scarcely exserted; anthers linear, sagittate at the base, spirally curved. Pod slender, terete, sessile; stigma minute, entire or slightly lobed, the lobes expanding over the septum ; cotyledons obliquely incumbent.

\section{Heterothrix Iongifolia (Benth.)}

Streptanthus longifolius Benth. P1. Hartw. IO. 1839 .

Thelypodium longifolium S. Wats. Bot. King's Expl. 25. IS7I.

\section{Heterothrix micrantha (A. Gray)}

Streptanthus micranthus A. Gray Pl. Fendl. 7. I 849.

Thelypodium micranthum S. Wats. Proc. Am. Acad. I7:32I. I $S S 2$.

\section{CHLOROCRAMBE gen. nov.}

Perennial glabrous herbs; stem simple at least up to the inflorescence. Racemes lax with slender horizontal or reflexed pedicels. Leaves thin, petioled, with usually hastate blades. Sepals greenish, ascending. Petals greenish-white, with short claws and lanceolate dentate blades. Anthers sagittate at the 
base, linear-oblong, at last curved, greenish. Pod slender, somewhat torulose, short-stipitate and short-styled; stigma minute, entire.

The plant referred here has been included in Caulanthus, but the type of that genus, $C$. crassicaulis, and its allies have an urnshaped, more or less closed calyx; linear, oblong, or spatulate petals, which have practically no claws, are thin and membranous except the upper third or fourth, which is thicker, brownish or purplish, curved and crisp ; and a conspicuous, two-cleft stigma.

Chlorocrambe hastata (S. Wats.) Rydb.

Caulanthus hastatus S. Wats. Bot. King's Expl. 28. i 87 I.

\section{Sophia magna sp. nov.}

Annual; stem branched, 5-IO dm. high, sparingly stellatepuberulent or glabrous, stout; basal leaves twice to thrice pinnatifid, I-2 dm. long, nearly glabrous; segments obovate, often toothed; stem-leaves similar but with narrower segments; sepals yellow, $2 \mathrm{~mm}$. long, oblong; petals spatulate, nearly $3 \mathrm{~mm}$. long, rather light-yellow; pedicels in fruit $\mathrm{I} 5-20 \mathrm{~mm}$. long, ascending; pod glabrous, more or less clavate, I $2-15 \mathrm{~mm}$. long, I. $5-2 \mathrm{~mm}$. thick; seeds more or less in two rows.

This species is related to $S$. intermedia and $S$ filipes, but differs from both in the broad segments of the basal leaves. In habit it therefore resembles $S$. incis, but has an evidently clavate pod. It has the conspicuous flowers of S. filipes, but the terminal segment of the leaves is not elongated. It was first mistaken for S. brachy' carpa; but the style is evident although short. It grown on riverbluffs at an attitude of $\mathrm{I} 500-2500 \mathrm{~m}$.

Colorado: North of La Veta, I900, Rydberg \& Treeland $6{ }_{16} 6_{3}$ (type in herb. N. Y. Bot. Gard.); South of La Veta, 6I62; Plains near Denver, 6167 .

\section{Sophia Nelsonii sp. nov.}

Slender annual; stems $2-4 \mathrm{dm}$. high, slightly stellate or glabrate; leaves pinnatifid or bipinnatifid with linear or oblong divisions, slightly stellate or glabrate; sepals oblong, $1 \mathrm{~mm}$. long; petals light-yellow, spatulate, $1.5 \mathrm{~mm}$. long; fruiting pedicels ascending, 4-6 mm. long; pods clavate, 5-8 mm. long, glabrous, slightly over I mm. thick; style minute.

This species is probably nearest related to $S$. intermedia, but 
differs in the shorter pod and pedicels and the smaller flowers. From $S$. pinnata it differs in being nearly glabrous and by the shorter pedicels and the erect pods. It grows on gravelly flats, sandy plains and rocky hills, at an attitude of I 300-2000 m.

Wrosing : Wraith Falls, Yellowstone Park, I 899, Aiecn _telson GElias Nelson 5710 (type in herb. N. I. Bot. Gard.); Green River. I 895, Ryelberg; Fort Steele, I 90 I, Tiecedy +779 and $+7 \mathcal{S}$ (?),

UTAн : Salt Lake City, I884, Leonard 212.

\section{Arabis oreophila sp. nov.}

Arabis Drummondii alpine S. Wats. Bot. King's Expl. I 7 , in part. I 87 I.

Perennial with a more or less branched caudex; stems I-2 dm. high ; basal leaves numerous, broadly oblanceolate or spatulate, stellate-pubescent; stem-leaves rather few, lanceolate, slightly auriculate-clasping; sepals oblong, 3-4 mm. long, margined with purplish, obtuse, glabrous ; petals $7-8 \mathrm{~mm}$. long, yellowishwhite below, upper portion rose or purplish; pedicels $4-10 \mathrm{~mm}$. long, erect or ascending; pods glabrous, $3-6 \mathrm{~cm}$. long, slightly arcuate, $2 \mathrm{~mm}$. wide, acute, but beak obsolete; seeds in 2-rows, winged above and on one side.

This species is nearest related to $A$. Ly'allii S. W'ats., and was included therein, but differs in the broader and shorter basal leaves, which are decidedly stellate, and in the pod which lacks a distinct beak. It grows on the higher mountains at an altitude of $2500-$ $3500 \mathrm{~m}$.

UTAH : Divide between Big Cotton-wood Cañon and Heber Valley, I905, Rydbcrg \& Carlton 6678 (type in herb. N. Y. Bot. Garden, flowers and young fruit); Alta, I 879 , Jones $127 \mathcal{S}$ (fr.); Uintas, I 869, Watson 75 (fl.)

Wroming: Union Peak, I 894, A. Nelson 1007 (fl.); upper Buffalo Fork, i 899, C. C. Curtis.

Montana: Old Hollowtop, i 897, Rydberg \& Bessey (fl.).

NFw York Botanical Gardex. 

CONTRIBUTIONS FROM THE NEW YORK BOTANICAL GARDEN-No. 128

\section{STUDIES ON THE ROCKY MOUNTAIN FLORA-XIX}

BY PER AXEL RYDBERG

NEW YORK

1909

Reprinted, without change of paging, from BULletiN of THE TORREY BOTANICAL CLUB 36 : 531-5.1. 101509 

Studies on the Rocky Mountain flora - XIX

PER AXEl RYDBerg

Muhlenbergia squarrosa (Trin.) comb. nov.

Iilfa squarrosa Trin. Mém. Acad. Pétersb. VI. Sci. Nat. 5²: 100. I 840 .

Vilfa depanperata Torr. in Hook. Fl. Bor.-Am. 2: 257 . I 840.

Not Muhlenbergia depauperata Scribn. I 884.

Sporobolus depauperatus Scribn. Bull. Torrey Club ro: 63. I $88_{3}$.

The group of grasses which Torrey, Trinius, and Thurber included under the generic name lilf $a$ has been transferred from Sporobolus to Mullenbergia. See Bull. Torrey Club 32: 599, 600. As this species is a member of that group, it also should be transferred. It is doubtful which of the two specific names, squarrosa or depauperata is the older, but the latter is not available, as there is already a Muhlenbergia depauperata Scribn.

\section{Agrostis atrata sp. nov.}

A somewhat tufted perennial; stems $1.5-3 \mathrm{dm}$. high, fewleaved, more or less bulbous at the base; sheaths glabrous, shorter than the internodes; ligules ovate, I. $5-2.5 \mathrm{~mm}$. long; leaf-blades 5-IO cm. long, about $2 \mathrm{~mm}$. wide, flat, smooth; panicle $5-8 \mathrm{~cm}$. long, rather open; branches ascending, the lower ones $2-3 \mathrm{~cm}$. long; spikelets dark purple, about $2 \mathrm{~mm}$. long; empty glumes nearly; equal, abruptly acute or acuminate; flowering glume nearly as long, obtusish; palet slightly shorter and more than half as broad.

The type number of this species was determined by Professor A. S. Hitchcock as A. Thurberiana, but it differs from that species in the following respects: The empty glumes are dark purple as in $A$. acquiratis, abruptly acute or acuminate; the inflorescence is short and open and the stem is few-leaved. In A. Thurberiana the empty glumes are green, only tinged with purple at the apex, narrowly lanceolate and gradually acute; the inflorescence is long and narrow, and the stem is very leafy. It differs from A. acquivaluis in the smaller spikelets, only $2 \mathrm{~mm}$. long, instead of $3 \mathrm{~mm}$., 
and the shorter rachilla, which is barely one third as long as the flower.

Britisn Columbia: Yoho Valley, Sept. 6, igo4, John Macom $6+787$ (type, in herb. N. Y. Bot. Gard.); also 6+788; Selkirk Mountains, I904, C. H. Slawe t27; Roger's Pass, July 3 I, I S9o, John Macoun.

\section{Agrostis Bakeri sp. nov.}

A cespitose perennial; stem about $3 \mathrm{dm}$. high, erect, slightly geniculate below, glabrous; basal leaves numerous; sheaths close, slightly scabrous, those of the stem-leaves often shorter than the internodes, ligules ovate, $2 \mathrm{~mm}$. long, dentate; leaf-blades flat, I-2 mm. wide, 5-IO cm. long; panicle ovoid, $8-10 \mathrm{~cm}$. long, open; branches ascending, branched above the middle, the lower $3-5$ cm. long; pedicels somewhat scabrous, thickened below the spikelets; empty glumes nearly equal, purple, $2-2.5 \mathrm{~mm}$. long, acuminate; flowering glume three fourths as long, obtuse, bearing above the middle a dorsal straight awn a little exceeding the glume; palet none or minute.

The type specimen of this species was determined as A. tenuis erecta by Professor Scribner and included by Professor Hitchcock in $A$. idahoensis (the latter united $A$. idahoensis Nash and A. temis Vasey). Professor Hitchcock remarked that Baker's no. 150 " is yet more robust and there is a short straight awn on the flowering glume." These are the essential characters by which it is to be separated from A. idahoensis. The empty glumes are also larger and more acuminate. One of the other specimens referred to Agrostis Bakeri, viz. no. 37, was included in A. hiemalis geminata by Hitchcock. Of this he remarked that it has "the awn but a more diffuse panicle." It is evident that Baker's no. 37 and no. 150 belong to the same species, the former being younger and less well developed. Agrostis Bakeri is most closely related to A. geminata Trin., differing in the broader leaves, ascending instead of divaricate branches of the panicle, smaller spikelets, and shorter awns. In A. geminata the basal leaves are filiform and involute, the spikelets about $3 \mathrm{~mm}$. long and the awn equaling the empty glumes. A. Bakeri grows in the mountains at an altitude of $3000-3200 \mathrm{~m}$.

Colorado: Near Pagosa Peak, August, i 899, C. F. Baker 150 (type, in herb. N. I'. Bot. Gard.); no. 37 and no. I 78 . 
Deschampsia confinis (Vasey) sp. nov.

Deschampsia caespitosa confinis Vasey; Beal, Grasses N. Am. 2: 369. I 896.

The only character given by Professor Beal is the unusual length of the ligules. To this should be added a narrow inflorescence with strongly ascending branches and a long awn inserted near the base of the floral glume. I think that these characters make the plant specifically distinct from $D$. cacspitosa. $D$. confinis ranges from southern Utah and Arizona to southern California.

Sphenopholis intermedia (Rydb.) comb. nov.

Kooleria truncata major Torr. Fl. U. S. I : I I 7. 1824.

Eatonia intermedia Rydb. Bull. Torrey Club 32: 602. 1905. Sphcnopholis pallens major Scribn. Rhodora 8: I 45. 1906.

\section{Poa callida sp. nov.}

Perennial, with a creeping rootstock; stem 3-5 dm. high, somewhat flexuose, striate and glabrous; ligules lanceolate, longattenuate, 5-6 mm. long; leaf-blades flat, flaccid, 5-I $2 \mathrm{~cm}$. long, about $3 \mathrm{~mm}$. wide, smooth; sheaths exceeding the internodes; panicle open, $1-1.5 \mathrm{dm}$. long; branches spreading or reflexed, scabrous; the lower ones in 4's to 6 's, $5-7 \mathrm{~cm}$. long, spikelet-bearing above the middle; spikelets about $3 \mathrm{~mm}$. long, 2-or 3 -flowered, light green, strongly compressed; first empty glume subulate, I-nerved, $2 \mathrm{~mm}$. long; the second slightly broader, 3-nerved, $2.5 \mathrm{~mm}$. long, glabrous; floral glumes $3 \mathrm{~mm}$. long, strongly 5nerved, acuminate, glabrous except the keel, which is slightly silky below; cobweb scant but long.

This species is related to Poa occidentalis Vasey, but is a weaker and more flaccid plant, has very long and conspicuous ligules, narrow flowering glumes, which are still more strongly nerved. The spikelets resemble those of $P$. ncrosa, but are smaller; the floral glumes are smooth and with a distinct cobweb. The type was named $P$. serotina, which also it resembles, but in that species the floral glumes are less compressed, with obsolete intermediate nerves.

Montana: Warm Springs, Helena, July I 3, I \&95, Rydberg 2145 (type, in herb. Columbia Univ.). 


\section{Poa scaberrima sp. nov.}

A tufted perennial, with numerous intravaginal innovations; stem 3-5 dm. high, 2- or 3-leaved, glabrous; ligules lanceolate, acuminate; leaf-blades filiform, involute, very scabrous, pale green ; blades of the basal leaves $8-15 \mathrm{~cm}$. long, less than I $\mathrm{mm}$. wide; those of the stem-leaves $\mathrm{I}-5 \mathrm{~cm}$. long, erect; panicle elliptic, dense, $4-7 \mathrm{~cm}$. long; branches short, strongly ascending; spikelets about I cm. long; empty glumes ovate, nearly equal, 4-5 $\mathrm{mm}$. long, glabrous ; floral glumes ovate, acuminate, pale, slightly tinged with purple, 5-6 mm. long, strongly 5-nerved, and conspicuously scabrous.

The type was named by Professor Scribner Poa Cusickii, from which it differs, however, in the larger, paler, very scabrous, acuminate floral glumes and the pale scabrous filiform leaves. In habit it more resembles $P$. iddahoensis and $P$. subaristata. From the former it differs in the dense inflorescence and broader glumes; from the latter in the broader glumes and the lanceolate ligules.

IdAho: Beaver Cañon, June 27, IS95, Ry'dberg 2055 (type, in herb. N. Y. Bot. Gard.).

\section{Poa Helleri sp. nov.}

A tufted perennial ; stem slender, 4-6 dm. high, often purpletinged below; ligules lanceolate, acuminate; leaf-blades very slender, flaccid, 5-I $5 \mathrm{~cm}$. long, I $\mathrm{mm}$. wide, more or less involute, scabrous; panicle rather loose, $8-10 \mathrm{~cm}$. long; branches ascending; spikelets about I cm. long, 4- or 5-flowered; empty glumes linearlanceolate, 3-nerved, glabrous, unequal, 4-5 mm. long; floral glumes linear-lanceolate, about $5 \mathrm{~mm}$. long, strigulose below, scabrous on the upper part.

The type was named Poa Sandbregii, but it can scarcely be referred to that species. It differs in the pale inflorescence, larger and much narrower, conspicuously strigose floral glumes. In habit it resembles $P$. itahoensis, but evidently belongs to the same group as $P$. nowadensis, from which it differs in the slender habit and the narrower glumes with a different pubescence.

Id AHo: Lake Waha, A. A. \& E. Gertrude Heller $327+$ (type, in herb. Columbia Univ.).

Poa curta sp. nov.

Perennial, with a horizontal rootstock; stem glabrous, 4-5 dm. high ; sheaths short, glabrous; ligules about I mm. long, truncate; 
leaf-blades $2-5 \mathrm{~cm}$. long, $3-5 \mathrm{~mm}$. wide, abruptly acute, spreading, dark green ; inflorescence short, open, $4-5 \mathrm{~cm}$. long; branches in 2's to 4's, spreading, I-2 cm. long, spikelet-bearing above the middle; spikelets light green, strongly compressed, about $6 \mathrm{~mm}$. long, 2-4-flowered; empty glumes glabrous, but scabrous on the veins, lanceolate, the first $3 \mathrm{~mm}$. long, $\mathrm{I}$-nerved, the second $4 \mathrm{~mm}$. long, 3-nerved; floral glumes lanceolate, scabrous-strigulose, strongly 5-nerved, $5 \mathrm{~mm}$. long.

This species is related to $P$. occidentalis (Vasey) Rydb. (P. flexuosa occidentalis Vasey), but differs in the short ligules and the short broad leaves.

Wroming: Spread Creek, at an altitude of $2900 \mathrm{~m}$., July,

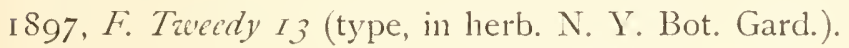

\section{Poa subreflexa sp. nov.}

Perennial, with a horizontal rootstock ; stem ascending, 5-6 dm. tall; lower sheath finely and retrorsely strigulose; ligules very short and truncate ; leaf-blades flat, flaccid, 7-1 $\mathrm{cm}$. long, 3-4 mm. wide, spreading; panicle open, about I dm. long; branches reflexed, the lower in 3's or 4's, I-3 cm. long; spikelets pale green, 6-7 mm. long, 3- or 4-flowered; empty glumes glabrous, with broad scarious margins, lanceolate, the first I-nerved, about $3 \mathrm{~mm}$. long, the second 3 -nerved and about $4 \mathrm{~mm}$. long; flowering glumes lanceolate, $5 \mathrm{~mm}$. long, scabrous-strigulose, strongly 5nerved.

This species is related to $P$. Whecleri and $P$. Olncyae, but differs from both in the reflexed branches of the panicle and the broad flaccid leaves.

Colorado: In shade of spruces on the bank of a creek, mountains north of Steamboat Springs, July 26, I89I, State Agricultural College distribution no. $373 I$ (type, in herb. N. Y. Bot. Gard.).

\section{Poa subtrivialis sp. nov.}

Perennial, with a rootstock; stem slender, 4-6 dm. high, smooth ; ligules very short and truncate; sheaths narrow, striate, exceeding the nodes; leaf-blades erect, flaccid, $8-15 \mathrm{~cm}$. long, about $2 \mathrm{~mm}$. wide, flat, dark green; panicle narrow, I-2 dm. long; branches erect, scabrous, spikelet-bearing above the middle; spikelets light green, 3-4 mm. long, 2-3-flowered; first empty glume very narrow, $2 \mathrm{~mm}$. long, smooth; the second lanceolate, $2.5 \mathrm{~mm}$. long, prominently 3-nerved; floral glumes 2.5 mm. long, glabrous, obscurely nerved; cobweb very scant. 
This is closely related to the European P. nemoralis, but differs in the truncate ligules, the smaller spikelets, and more strongly ncrved empty glumes. It has the narrow inflorescence and narrow empty glumes of $P$. nemoralis and thereby differs from $P$. intcrior, which also has been confused with the European relative.

Wroming: Big Horn Mountains, July, I 899, F. Trueedy 2I 7 , (type, in herb. N. Y. Bot. Gard.); Gros Ventre River, Aug., I 897, F. Triecedy IOI.

IDAHO: Northern Idaho, i892, J. H. Sandberg 373.

\section{Distichlis dentata sp. nov.}

Perennial, with a creeping branched scaly rootstock; stem I$3 \mathrm{dm}$. ligh, very leafy; leaf-blades 5-1 $2 \mathrm{~cm}$. long, $2-3.5 \mathrm{~mm}$. wide, flat or slightly involute; panicle of the pistillate plant $4-8$ $\mathrm{cm}$. long, $2-2.5 \mathrm{~cm}$. wide ; spilielets $\mathrm{r}-2 \mathrm{~cm}$. long, $5-8 \mathrm{~mm}$. wide, 7-I7-flowered; empty glumes lanceolate, about $5 \mathrm{~mm}$. long, short-acuminate, scarious-margined; floral glume ovate in lateral view, $6 \mathrm{~mm}$. long, fully $2 \mathrm{~mm}$. wide from keel to margin, shortacuminate; palet nearly as long, dentate on the keels; panicle of the staminate plant looser, 5- IO cm. long; spikelets more compressed, floral glumes lanceolate in lateral view, straw-colored, acute, thin.

This species differs from $D$. spicata and $D$. stricta in the broader leaves, larger and broader spikelets, larger and broader floral glumes and palets in the pistillate plant, and the distinct dentation on the keels of the latter. It has the broad leaves and the habit of $D$. thalassica, but lacks the loose sheaths of that species. The latter lacks the dentation of the palet characteristic of $D$. dentate.

Washington: 1893, Sandberg \& Leiberg 463 ( + , type, in herb. Columbia Univ.); Okanagon Valley, 1897, Elmer 508 ( 9.$)$

Oregon: Wild Horse Meadow, Southeastern Oregon, Igor, Griffiths \& Morris $50+\left(\sigma^{\top}\right)$.

Saskatchewax: Carlton House, Richardson 28 (Franklin's Second Journ.).

Nerida: Pleasant Valley, I865, Stretch $203\left(\sigma^{\top}\right)$; Carson, $278(f)$.

Festuca saximontana sp. nov.

? Festuca ovina psendovina Beal, Grasses N. Am. 2: $595 . \quad$ I 896. Fistuca psendorina Rydb. Mem. N. Y. Bot. Gard. I : 56.1900. Not F. psendoina Hack. I 880 . 
Festuca orina pseudorina Piper, Contr. U. S. Nat. Herb. Io : 26, 27. 1906. Not F. orina psendorina I Iack. I 88 I.

Densely cespitose, perennial, with intravaginal innovations; stem 2-4 dm. high, slender, glabrous; basal leaf-sheaths short, closed only at the base, loose above; ligules very short and rounded; leaf-blades very slender, $3-10 \mathrm{~cm}$. long, less than half a millimeter wide, strongly involute, in age becoming strongly striate; panicle very narrow and spike-like, 4-10 cm. long; its branches erect or nearly so, short; spikelets 4-6-flowered; first empty glume I-nerved, about $2 \mathrm{~mm}$. long, the second 3-nerved, $2.5 \mathrm{~mm}$. long; floral glumes lanceolate, $3-5 \mathrm{~mm}$. long, glabrous; awn I-2 mm. long.

This species is rather common on dry hillsides and mountains from Saskatchewan to Colorado and British Columbia up to an altitude of $3600 \mathrm{~m}$.

It has been mistaken for the European $F$. pseudovina llackel. The latter was based on F. ovina Host, Gram. Aust. 2 : pl. $\mathcal{S}_{f}$. This plate does not at all represent our North American plant. The figure represents a small plant with a short open panicle, while our plant has a very narrow, rather long panicle with erect branches. Piper in his monograplı (Contr. U. S. Nat. Herb. I0: 27. 1905) cites Host's plate no. 86, instead of no. 8 . Whether this is a mere misprint or whether Piper really had the former plate in mind, I do not know. Plate 86 , representing F. stricta, illustrates a plant in habit much more like our plant. Whether Beal (Grasses N. Am. 2: 595) had in mind the same plant as Piper and myself is very doubtful, as he cites only specimens from Michigan, and I have seen no specimens of $F$. saximontana from that state. As the type the following may be assigned:

Alberta: Vicinity of Banff, I 899, IV. C. MacCalla $233 \mathrm{I}$ (type, in herb. N. Y. Bot. Gard.).

\section{Festuca calligera (Piper) sp. nov.}

Festuca amethystina asperrima Hack.; Beal, Grasses N. Am. 2 : 60 I. I 896. Not F. asperrima Link, i 822.

Festuca orina calligera Piper, Contr. U. S. Nat. Herb. Io: 27. I 906.

This I think is specifically distinct from F. ovina. In the herbaria at the New York Botanical Garden are found the following sperimens : 
Arizona: Southern slope of San Francisco Mountains, 1904, Cannon \& Lloyd; Flagstaff, I 883, Rusby gor (dupl. of type); near Tucson, I 892 , Toumey.

Uтан : Fish Lake Plateau, Aug. 9, 1905, Rydberg \& Carlton 7689 and 7680 .

Colorado: Camp on Grizzly near foot of Rabbit Ear Range, State Agric. College distribution no. 3679; Breckenridge, I 896, Shear 1080.

Vulpia megalura (Nutt.) comb. nov.

Festuca megalura Nutt. Jour. Acad. Phila. II. I : i $88 . \quad$ i 848.

The group of annual grasses with usually but one stamen, generally included in Festuca, is so unlike the typical species of that genus that it very well deserves generic rank. The genus I ulpia Nees should therefore be reëstablished.

Vulpia reflexa (Buckley) comb. nov.

Festuca reflexa Buckley, Proc. Acad. Phila. I862: 98. I863.

Vulpia pacifica (Piper) comb. nov.

Festuca pacifica Piper, Contr. U. S. Nat. Herb. Io: I 2.1906.

Vulpia octoflora (Walt.) comb. nov.

Festuca octoflora Walt. Fl. Car. 81. i 788.

\section{Bromus Flodmanii sp. nov.}

Bromus aleutensis Rydb. Mem. N. Y. Bot. Gard. 2: 61. I 900. Not $B$. alentensis Trin. 1853 .

A short-lived perennial ; stem glabrous, 6-1 o dm. high ; sheaths retrorsely pilose; ligules $3-4 \mathrm{~mm}$. long, laciniate; leaf-blades $2-3 \mathrm{dm}$. long, 6-10 mm. wide, minutely scabrous; panicle $1-2 \mathrm{dm}$. long; branches erect or nearly so; spikelets $2.5-3.5 \mathrm{~cm}$. long, 5-7 mm. wide; empty glumes lanceolate in lateral view, about I cm. long, glabrous, acute, the first 3-nerved, the second 5nerved; floral glumes about I $5 \mathrm{~mm}$. long, scabrous, narrowly margined, acuminate, slightly bifid; awn 4-6 mm. long; palet nearly as long as the floral glumes.

The first two specimens cited below were included in B. marginatus latior by Shear. He, however, has made on the sheet the following note: "very near aleutensis," to which species the speci- 
mens were originally referred. $B$. Flodmanii differs from $B$. marginatus latior in the scabrous, not pilose floral glumes, and the narrow inflorescence; from $B$. aleutensis it differs in the shorter awns, the smaller florets, and the less open inflorescence, and from $B$. Hookerianus in the smaller spikelets, shorter awns, and narrower scarious margins of the floral glumes. It agrees very well with the description and figure of Cratochloa brcinaristata Hook., but the palet is nearly as long as the floral glume.

Montana: Sheep Creek, Aug. 8, I 896, J. H. Flodman I87 (type, in herb. N. Y. Bot. Gard.); same locality and date, Rydberg 3308 .

UTAн : Mount Nebo, I905, Rydberg \& Carlton 7595.

Wroming: Buffalo Fork, i $897, F$. Tiveedy 65.

Agropyron latiglume (Scribn. \& Smith) sp. nov.

Agropyron violacenm latiglume Scribn. \& Smith, U. S. Div. Agrost. Bull. 4: 30. 1897 .

Agropyron inerme (Scribn. \& Smith) sp. nov. Agropyron divergens inemis [c] Scribn. \& Snith, U. S. Div. Agrost. Bull. $4: 27$. I 897 .

Hordeum depressum (Scribn. \&. Smith) sp. nov.

Hordeum nodosum depressum Scribn. \& Smith, U. S. Div. Agrost. Bull. 4 : 24. I 897 .

Elymus jejunus (Ramaley) sp. nov.

Elymus airginicus jcjunus Ramaley, Minn. Bot. Stud. I : I I4. I 894 .

Elymus virginicus minor Vasey; Rydb. Contr. U. S. Nat. Herb.

3: I $93 . \quad$ I $\$ 95$.

This was well described by Professor Ramaley. The description was overlooked when I a year later took up Dr. Vasey's manuscript name.

Elymus marginalis sp. nov.

Perennial, with a rootstock, somewhat tufted; stem 6-Io dm. high, glabrous or pubescent at the nodes; sheaths close, at least the lower ones retrorsely pilose; leaf-blades spreading, I-2 dm. 
long, 7-10 mm. wide, flat, scabrous beneath, usually pilose above; ligules almost obsolete; spike I.5-2 dmı. long; spikelets usually in pairs, 4-5. flowered; empty glumes $10-12 \mathrm{~mm}$. long, narrowly lanceolate, scabrous on the 4 or 5 nerves, with white or pink scarious margins; floral glumes r o-I $2 \mathrm{~mm}$. long, glabrous and shining; awns $8-20 \mathrm{~mm}$. long.

This is closely related to E. glaucus, but differs in the glabrous floral glumes and the hairy sheaths and the hairy upper surface of the leaf-blades.

British Columbia: Lower Arrow Lake, June is, i $890,1 / a-$ coun $f+$ (type in herb. Columbia University).

Washington: Clallam, i900, Elmer I905.

\section{Elymus Petersonii sp. nov.}

Perennial, with a rootstock; stem 6-8 dm. high, slender, glabrous; sheaths glabrous, striate, shorter than the internodes; ligules very short and truncate; leaf-blades flaccid, $1-1.5 \mathrm{dm}$. long, 4-5 mm. wide, light green, minutely scabrous on the veins of both sides, or sparingly pilose above; spike very slender and lax; spikelets in pairs or single; empty glumes narrowly lanceolate, acuminate or awn-pointed, about $S \mathrm{~mm}$. long, 3-nerved, purpletinged; floral glumes about I cm. long, glabrous; awn about I $\mathrm{cm}$. long.

This species is also related to E. glancus, but differs in the lax, interrupted spike, glabrous glumes, and the flaccid and more or less hairy leaf-blades.

Britisi Columbia: Roger's Pass, Selkirk Mountains, Aug. 9, I 904, H. Peterson [Shaw's distribution no.] $+f^{6}$ (type, in herb. N. Y. Bot. Gard.).

\section{Elymus vulpinus sp. nov.}

Perennial, with a short rootstock; stems $5-7 \mathrm{dm}$. high, striate, erect ; sheaths close, striate, glabrous, often shorter than the internodes; ligule I mm. long or less, truncate, brown; spike exserted, I-I.5 dm. long, 6-7 mm. thick, sometimes slightly nodding; spikelets I or 2 at each node, 4-6-flowered; empty glumes linear-lanceolate, 8 -10 mm. long, 5-nerved, scabrous on the back; awn scabrous, of about the same length; floral glumes linearlanceolate, long-acuminate, about $S \mathrm{~mm}$. long, hispidulous; awn S-IO mm. long, scabrous.

This is one of the species connecting the genera Ely'mus and Agropyron. The type was originally named Agropyron cani- 
num unilaterale (Cassidy) Vasey, which is the same as A. Richardsonii. J. G. Smith in his revision referred it to $A$. Gmelini. It resembles both a great deal in habit, but is distinguished by the hispidulous floral glumes and by the empty glumes, which are attached more or less obliquely, a character which would place the species in Elymus rather than in Agropyron. It is a close relative of E. Saundersii and E. Macommiz, which also could be referred almost equally well to either genus. In habit E. vulpinus is intermediate between the two, but is distinguished by the hispidulous, instead of glabrous, floral glumes and broader empty glumes.

Nebraska : Lake region of Grant Co., northeast of Whitman, Rydberg I6I7 (type, in herb. N. Y. Bot. Gard.).

Alberta: Devil's Head Lake, Aug. 8, i 89I, Macoun II 752 in part, mixed with Agropyron subuillosum and named $A$. dasystachyum.

New York Botanical Garden. 

CONTRIBUTIONS FROM THE NEW YORK BOTANICAL GARDEN-No. 129

\title{
STUDIES ON THE ROCKY MOUNTAIN FLORA-XX
}

\author{
BY PER AXEL RYDBERG
}

\author{
NEW YORK \\ 1909
}

Reprinted, without change of paging, from BULLETIN OF THE TORRE BOTANICAL CLUB 36 : 675-698. 28 D 1909 

Studies on the Rocky Mountain flora - XX

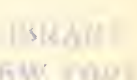

Per Axel Ry DBERG

\section{Phacelia nervosa sp. nor.}

Phacelia alpina Rydb. F1. Colo. 283 , in part, as to the Colorado specimens. Igo6.

Perennial, with a short rootstock; stens decumbent at the base, I-3 dm. high, more or less hirsute and with short grayish hairs intermixed; lower leaves with petioles $2-7 \mathrm{~cm}$. long, simple or with a pair of smaller lobes on the petioles ; blades lanceolate, $2-5 \mathrm{~cm}$. long, acute, hirsute on both sides, veins rather strong beneath; upper leaves subsessile; inflorescence soon open; the racemes peduncled, in fruit 4-9 cm. long; calyx more or less tinged with purple, about as long as the corolla ; sepals narrowly linear, acute, hirsute, with a strong midrib; corolla white or nearly so, pubescent, about $5 \mathrm{~mm}$. long; filaments about twice as long as the corolla, slightly bearded at the base with short hairs; seeds lance-ovoid, $2.5 \mathrm{~mm}$. long, brown, faveolate.

This was mistaken for Placelia alpina, which it resembles in habit, but it differs in the longer and more open racemes, the longer calyx-lobes, which about equal the corolla and have a strong midrib, in the almost glabrous filaments, in the whitish instead of lilac corolla, and in the more acute seeds. It grows on high mountains at an altitude of $3000 \mathrm{~m}$. or more.

Colorado: Silver Plume, Aug. 24, I S95, P. A. Rrelberg (type, in herb. N. Y. Bot. Gard.); same locality and date, C. L. Shear 3253; Mt. Harvard, Aug. I7, IS96, C. L. Shear 3790 ; I $896, F$. E. Clements fos; near Ironton, San Juan County, July, I S99, C. C. Curtis.

\section{Phacelia Burkei sp. nov.}

Perennial, with a taproot; stems 2-3 dm. high, canescent; basal leaves 3-ro cm. long, petioled; blades lanceolate, entire, strongly veined, densely white-canescent on both sides; inflorescence branched, open; racemes elongated, $2-8 \mathrm{~cm}$. long; calyx canescent and hispid-ciliate; lobes narrowly linear, obtuse, two thirds as long as the corolla, with a 1 ather strong midvein ; corolla pubescent, white, $4-5 \mathrm{~mm}$. long; stamens about twice as long as 
the corolla, villous-bearded; seeds 4, dark chestnut-brown, 2 mm. long, puberulent, ellipsoid, strongly but finely faveolate.

This resembles P. leucophylla Torrey in general habit, but differs in the narrow and more strongly ribbed calyx-lobes, the smaller and white corolla, and the more finely faveolate seeds.

I рано: Snake Country, Burke (type, in herb. Columbia Univ.).

WAshington: Collector not given.

\section{Phacelia leptosepala sp. nov.}

Perennial, with a taproot and a more or less cespitose rootstock; stems ascending, hirsute, $\mathbf{I}-3 \mathrm{dm}$. high; leaves usually simple, hirsute on both sides, 5-10 cm. long, oblanceolate or elliptic; the lower ones petioled; inflorescence with several short branches; calyx hirsute; lobes narrowly linear, hirsute, nearly as long as the corolla, acute; corolla white, glabrous or nearly so, 5 $\mathrm{mm}$. long; filaments about twice as long, sparingly villous-bearded.

This species is probably most nearly related to Phacelia nemoralis Greene, but differs in the low, slender, ascending stems, the cespitose habit, the longer and narrower, azute sepals, and the less bearded stamens. It somewhat resembles $P$. alpina in habit, but differs in the narrow calyx-lobes almost equaling the white corolla and in the hirsute pubescence. which consists only of coarse hairs.

British Columbia: Vermilion Lake, Aug. 5, ig05, Edith 1 .

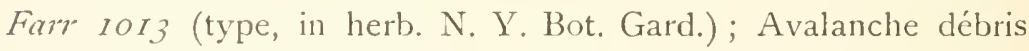
above Lardo, Selkirk Mountains, June I6, 1905, Shaw 695.

Montana: Mount MacDougal, I90 I, Umbach I39; Sperry Glacier, 1903, Umbach 826.

\section{Lappula leucotricha sp. nov.}

Annual; stem 2-4 dm. high, slender, branched above, densely pilose, especially below, with long white hairs; basal leaves oblanceolate, $2-4 \mathrm{~cm}$. long, softly pilose on both sides; stem-leaves linear or oblong, numerous; bracts linear-lanceolate; sepals linear, $2.5-3 \mathrm{~mm}$. long, in fruit $4-5 \mathrm{~mm}$.; corolla white, $3-3.5 \mathrm{~mm}$. long, $3 \mathrm{~mm}$. broad; fruit erect, about $5 \mathrm{~mm}$. wide; nutlets about $2.5 \mathrm{~mm}$. long, light, almost straw-colored; marginal prickles in one row, not united into a disk, but broadened below and flat, scarcely grooved; back strongly muricate.

This species is related to Lappula occidcntalis (S. Wats.) Greene, but differs in the soft white spreading pubescence, the white 
flowers, the smaller fruit with broader, flattened prickles. In $L$. occidentalis the prickles are only slightly broadened below, not flattened, and strongly grooved on the inside.

Arizona: Tucson, Apr. 20, I 894, Toumey (type, in herb. N. Y. Bot. Gard.); vicinity of Flagstaff, June 16, I898, MacDougal I22; Clifton, Apr., isS I, Rusby' 281.

Utah : St. George, I877, Palmer 359.

\section{Eremocarya muricata sp. nov.}

Annual; stem slender, branched throughout with ascending branches, strigose; leaves linear, 2-5 mm. long, hispidulous, the hairs with pustulate bases; racemes short and dense, usually less than I cm. long; bracts oblong, I-2 mm. long; sepals linear, obtuse, $1.5 \mathrm{~mm}$. long, hispidulous on the margins and midvein; corolla white, I mm. long; limb scarcely $0.5 \mathrm{~mm}$. wide; nutlets lanceolate in outline, long-acuminate, dull, finely muricate.

This species is somewhat intermediate between Eremocarya micrantha and E. lefida. It resembles the former most in habit, but differs in the more ascending branches, the shorter leaves, and especially in the narrower, muriculate and dull, instead of smooth and shining, nutlets. The latter resemble much those of E. lepida, but are narrower and more tapering upwards. E. lipida has much broader leaves and larger flowers.

Utah: Southern Utah, Is74, Parry i6 type, in herb. Columbia Univ.).

Arizona: Near Camp Lowell, Apr. I3, is8 I, Pringle; Prescott, Is83, Rusby 745; Tucson Mountains, Apr. I2, I 903, Thornber; Plains of Tucson, Apr., I 881 , Lemmon 203; Mesa, near Tucson, May I4, I883, Pringle; Apr. 25, I906, Shar 4235; Tucson, Apr. 3, I 894, Tonmey'.

Greeneocharis circumscissa (H. \& A.) Rydb. comb. nov.

Lithospermum (.) circumscissum H. \& A. Bot. Beech. 370. I 840 .

Piptocaly'x circumscissus Torr.; S. Wats. Bot. King's Exp. 240. 1871 .

Eritrichum circumscissum A. Gray, Proc. Am. Acad. 10: 58. I 874 .

Krynitakia circumscisse A. Gray, Proc. Am. Acad. 20 : 275. I 885 . 
Wheclerella circumscisssa Grant, Bull. So. Calif. Acad. Sci. 5: 28. I 906 .

Piptocaly $x$ Torr. of $187 \mathrm{I}$ is antedated by Piptocaly $x$ Oliver of I 870 and therefore Greencocharis Gürke \& Harms was proposed instead of the former in the appendix to the Register of the Engler \& Prantl, Natürlichen Pflanzenfamilien.* This name was properly published, although no binomials were used. There was therefore no need of substituting another generic name 1 Vheclerclla as was done by Grant. The fact that the etymology is not as good as it might be does not at all invalidate Grecncocharis. Reluctantly the writer is forced to add another binomial to the already too many names of this plant.

\section{Oreocarya spicata sp. nov.}

Perennial, with a taproot; stem solitary and simple, virgate, hispid throughout; basal leaves numerous, spatulate, $2-5 \mathrm{~cm}$. long, hispid on both sides ; the hairs usually with pustulate bases; stem-leaves linear-oblanceolate or linear, 4-9 cm. long, those of the inflorescence many times longer than the short flower clusters; inflorescence elongated, spike-like; calyx hispid, 4-5 mm. long, lobes oblong-lanceolate, obtuse; corolla $6 \mathrm{~mm}$. long, $4 \mathrm{~mm}$. broad; nutlets $4 \mathrm{~mm}$. long, ovate in outline, scarcely keeled on the back, white and shining, smooth on the back, margins merely acute.

This species is closely related to Orcocarya airgata, from which it differs in the light-colored, smooth nutlets, the smaller corollalimbs, shorter and broader basal leaves. The nutlets in $O$. virgata are more acuminate, brown or brownish gray, with a more distinct ridge on the back, more or less transversely rugose and tubercled on the back, and with sharper margins.

Colorado: Artist's Glen, Aug. I, Igor, Clements 102 (type, in herb. N. Y. Bot. Gard.); North Cheyenne Cañon, July I 4, I 896, Ernst A. Bessey"; "Colorado," G. IV. Itulsc.

\section{Cryptanthe leptophylla sp. nov.}

Annual; stem simple, slender, erect, strigose throughout, 1.5-3 dm. high; leaves narrowly linear, $\mathrm{I}-3 \mathrm{~cm}$. long, $0.5-1.5 \mathrm{~mm}$. broad, strigose; inflorescence cymose, short, at the end of the stem, and on a few small branches; calyx-lobes linear-filiform,

*Gesamtregister 462. IS99. 
3-4 mm. long, in fruit S-IO mm. long, white-silky with long spreading hairs; corolla minute, shorter than the calyx ; limb hardly $0.5 \mathrm{~mm}$. wide; nutlets $3 \mathrm{~mm}$. long, narrowly lanceolate, long-acuminate, strongly muricate; groove closed, 2 -forked at the base.

The type sheet of this species was determined by Dr. Watson as Eritrichimm barbigermm. It is abundantly distinct from Cryptanthe barbigera, however, the main distinctions being the narrow strigose leaves, the strigose instead of hirsute or hispid stem, the minute corollas, and the narrower and differently shaped mutlets.

Utan: St. George, i 877 , E. Palmer 350 (type, in herb. Columbia Univ.).

\section{Cryptanthe confusa sp. nov.}

Cryptantlue affinis Rydb. 'Mem. N. Y. Bot. Gard. I : 330, in part. I 900 .

Annual ; stem rather stout, hispid, branched; leaves oblong or oblong-oblanceolate, 2-5 cm. long, 3-8 mm. wide, coarsely hirsute ; spikes at first very short, subcapitate, in age $4-5 \mathrm{~cm}$. long; calyxlobes $2 \mathrm{~mm}$. long, lance-subulate, hispid, in fruit $3-4 \mathrm{~mm}$. long; corolla about $3 \mathrm{~mm}$. long; limb scarcely I mm. wide; nutlets ovate, $2 \mathrm{~mm}$. long, light-colored, smooth, shining, thin-walled, attached by the lower half or two thirds; groove closed and simple to the base.

This species is related to Cryptanthe affinis and C. leiocarpa, but differs from both in the broader leaves. The nutlets are most like those of the former but the attaclument extends somewhat higher.

Wromng: Upper Madison Cañon, Yellowstone Park, Aug. 3, IS97, Kydberg \& Bessey fSS + (type, in herb. N. Y. Bot. Gard.).

IDAно: Beaver Cañon, June 27, IS95, Rydberg; Latah County, July 6, IS94, Piper I pfo.

UTAн : Central Utah, i 875, Pary 67 (?).

\section{Cryptanthe grandiflora sp. nov.}

Anuual; stem branched, 2-4 dm. high, hirsute with white hairs ; leaves broadly linear, lanceolate, or oblong, $3-5 \mathrm{~cm}$. long. 5-IO mm. wide, hirsute, the hairs with pustulate bases; spikes lax, in fruit often I dm. long; calyx-lobes $3 \mathrm{~mm}$. long, in fruit 5 mm., very hispid; corolla white, 4-5 mm. long; limb 5-6 mm. wide; nutlets ovate, $2.5 \mathrm{~mm}$. long, shining, smooth, rather thinwalled; groove narrow, 2 -forked at the base. 
This species has been variously named Cryplanthe leiocarpa, $C$. ambigua, and $C$. Torreyana. It differs from the first in the 2-forked groove, from the second in the smooth nutlets, and from all in the large corolla. It is most related to C. Torrejana, having somewhat similar nutlets, but is easily distinguished from it by the large flowers and broad leaves. It may be the same as the large-flowered form of C. Torreyana calycosa referred to by Piper; ${ }^{*}$ but it does not have the elongated calyx-lobes of that species and has three to four times as broad corolla.

IDAho: Valley of Clearwater River, April 23, I\$92, Sandberg, Mac Dougal \& Heller Io (type, in herb. N. Y. Bot. Gard.) ; about Lewiston, April 30, i 896, A. A. \& E. Gertrude Heller 2998.

Washington: IVawawai, May, I 897 , Elmer 775 ; near Montesano, June 10, I898, A. A. \& E. Gertrude Heller 3924.

\section{Mertensia pallida sp. nov.}

Perennial, with a thick rootstock; stem glabrous, very pale, 5-8 dm. high, leafy ; lower leaves oblanceolate, the upper narrowly lanceolate, $5-8 \mathrm{~cm}$. long, glabrous or minutely muriculate, ciliolate on the margins, pale; inflorescence narrowly paniculate; pedicels usually strigulose or sometimes the hairs represented only by the somewhat pustulate bases; calyx-lobes oblong, about $\mathrm{I} \mathrm{mm}$. long, obtuse, ciliate on the margin; corolla about I $\mathrm{cm}$. long, the tube about equaling the limb; filaments about $\mathrm{I} \mathrm{mm}$. long, dilated and at the apex broader than the anthers, which are about $2 \mathrm{~mm}$. long.

This is related to Mertinsia ciliata but differs in the paler narrower leaves, the smaller corolla, and the usually strigulose pedicels.

Montana : Lima, June 28, i 895, Rydberg 2777 (type, in herb. N. Y. Bot. Gard.) ; June 30, I895, Shear 3395; Spanish Basin, July I I, I 896 , Flotman 75 I.

\section{Mertensia Leonardi sp. nov.}

Perennial, with thick rootstock; stem erect, glabrous, pale, 5-IO dm. high, leafy; leaves thin, glabrous and smooth beneath, more or less pustulate-muricate above, and ciliolate on the margins; the lower short-petioled; blades oblanceolate, $4-7 \mathrm{~cm}$. long; the upper sessile, lanceolate or ovate, 5-15 cm. long; inflorescence much branched; pedicels sparingly pustulate; calyx-lobes lanceo-

\footnotetext{
* Contr. U. S. Nat. Herb. I I : 484. 1906.
} 
late, $4 \mathrm{~mm}$. long, twice as long as the calyx-tube, ciliolate on the margins; corolla-tube $6-7 \mathrm{~mm}$. long; limb $8-10 \mathrm{~mm}$. long, $7-8$ mm. wide.

This is related to Mertensia arisonica, $M$. intermedia, and $M$. stenoloba. From the former it differs in the long calyx-lobes and the short calyx-tube and from the latter two in the long and ample limb of the corolla. It is a larger plant than any of the three and often reaches a height of $\mathrm{I} \mathrm{m}$.

Utah : Mill Creek Cañon, July 3 I, I884, F. E. Leonard (type, in lierb. N. Y. Bot. Gard.).

\section{Mertensia humilis sp. nov.}

Perennial, with a woody tap-root and cespitose caudex; stem I-2 dm. high, ascending or decumbent, glabrous; basal leaves petioled, 3-8 cm. long; blades thick, elliptic to ovate, glabrous beneath, pustulate-muricate above, ciliolate on the margins, stemleaves sessile, elliptic or ovate, rarely oblong, $2-4 \mathrm{~cm}$. long; pedicels with scattered large pustules; calyx-lobes lanceolate, $2-3$ $\mathrm{mm}$. long, hispid-ciliolate on the margins; corolla 7-8 $\mathrm{mm}$. long; tube slightly shorter than the limb; stamens inserted in the tube of the corolla; filaments short and narrow.

The specimens referred to this species were all named $M_{\ell} r$ tensia alpina by the collectors. A few years ago the present writer regarded them as representing the typical $M$. alpina and redescribed the true $M$. alpina (Torr.) Don under the name $M$. obtusiloba. A reëxamination of James's plant (type of $M$. alpina) has convinced me of the identity of $M$. alpina and $M$. obtusiloba. $M$. Intmilis combines the corolla and stamens of $M$. alpina with the leaf-surface, pedicels, and calyx of $M$. lanceolate. In habit it is intermediate between the two.

Wroming: Sand Creek, Albany Co., June 2, I900, A. Nelson 7073 ; (type, in herb. N. Y. Bot. Gard.); Laramie Hills, May I6, I 894, A. Nelson 33; May i4, I900, E. Nelson 184.

\section{Scutellaria veronicifolia sp. nov.}

Perennial, with creeping rootstock; stem 2-4 dm.. high, finely puberulent, more or less purplish ; leaves below the inflorescence ovate, obtuse, coarsely crenate, $\mathrm{I}-4 \mathrm{~cm}$. long, minutely puberulent or glabrate, short-petioled; those of the inflorescence and branches oblong and entire or nearly so; pedicels $3-5 \mathrm{~mm}$. long; calyx 
finely pubescent, $6 \mathrm{~mm}$. long; corolla $25-30 \mathrm{~cm}$. long, its tube rather abruptly widening, $7-8 \mathrm{~mm}$. broad at the throat.

This species is related to Scutellaria angustifolia and S. antirrhinoides, but differs from both in the broader corolla-tube. From the former it differs also in the broader and usually toothed stemleaves and from the latter in the large flowers.

I DaHo: Sandberg, MacDougal, \& Hcller II5 (type, in herb. N. I. Bot. Gard.).

California: Mokelumne Hill, i 853-4, Bigclow (Whipple Exp.); I 846 , Frcmont LIII.

\section{Stachys asperrima sp. nov.}

Perennial, with a rootstock ; stem stout, 4-6 dm. high, coarsely hispid on the angles with spreading or reflexed hairs; leaves nearly sessile, oblong, elliptic, or oblong-lanceolate, $5-8 \mathrm{~cm}$. long, truncate or rounded at the base, coarsely crenate, hispid above, hispid on the veins and also puberulent beneath; spike $1-2 \mathrm{dm}$. long; calyx densely hispid and somewhat glandular; lobes lancesubulate, spinulose-tipped; corolla purplish, IO-I $2 \mathrm{~mm}$. long, puberulent, and more or less hirsute on the lips outside.

This species belongs to the Stachy's palnstris group, but little resembles that species in general habit. In leaf-form, pubescence, and general habit, it reminds one of S. arcuicola Britton, but the leaves are crenate instead of serrate and the pubescence is coarser. It resembles also S. rivularis Heller, but the pubescence is coarser and the calyx-lobes are lance-subulate instead of lanceolate.

Utain: Towards Jordan City, July 7, i $884, F$. E. Leonard I 38 (type, in herb. N. Y. Bot. Gard.).

\section{Stachys Leibergii sp. nov.}

Perennial, with a horizontal rootstock; sten 3-6 dm. high, sharply angled, glabrous below, softly hirsute above; leaves sessile, lanceolate, acute, $4-8 \mathrm{~cm}$. long, crenate-dentate, pubescent on both sides with short appressed hairs or in age glabrate; bracts lanceolate, mostly entire, often purplish-tinged; calyx softly pubescent, often purplish; tube obpyramidal, about $4 \mathrm{~mm}$. long; lobes lanceolate, gradually setose-acuminate, almost as long as the tube; corolla about I $2 \mathrm{~mm}$. long, rose-colored, glabrous.

This species is related to Stacluys palustris and S. scopulorum. 
From the former it differs in the more gradually acuminate and almost erect calyx-teeth, and from the latter in the short appressed pubescence of the leaves, and the usually glabrous lower part of the stem.

IDAho: Loiv meadow, Blue Creek, alt. 700 m., Coeur d'Alene Mountains, July 20, I 895 , John B. Leiberg 1328 (type, in U. S. Nat. Herb. no. 250,811); Valley of Coeur d'Alene River, Kootenai Co., July I 3, I 892, Sandberg, MacDougal, \& Heller 639, in part.

\section{Stachys ampla sp. nov.}

Perennial, with a rootstock ; stem 5-7 dm. high, softly hirsute and more or less viscid, especially above; leaves ovate to lanceolate, 5-IO cm. long, sessile or nearly so, rounded or subcordate at the base, acute at the apex crenate-serrate, softly pubescent on both sides and more or less glandular-granuliferous; spike interrupted, very leafy; calyx soft-pubescent and glandular, about 9 $\mathrm{mm}$. long; lobes lance-subulate, spinulose-tipped; corolla rosecolored or pink, about $15 \mathrm{~mm}$. long, somewhat puberulent without; lower lip very broad; lateral lobes half as broad and three fourths as long as the middle one.

This species is related to $S$. scopulorum and S. tcucriformis but differs from both in the larger corolla, the broader lower lip, and the unusually large lateral lobes of the lip.

South Dakota: Custer, Black Hills, Aug. 20, I S92, Rydberg I 208 (type, in herb. N. I. Bot. Gard.).

\section{Audibertiella argentea sp. nov.}

A low shrub; branches cinereous-puberulent ; leaves petioled, I-2 cm. long; blades rounded, obovate-spatulate, rounded or retuse at the apex, scurfy-cinereous, at first silvery white; bracts broadly obovate, about I $\mathrm{cm}$. long, membranous, strongly veined, puberulent and ciliate; corolla blue, about $1 \mathrm{~cm}$. long; lower lip only slightly longer than the upper one, its lobes short and rounded; longer filaments about I $2 \mathrm{~mm}$. long, anther-bearing connective 2.5-3 mm. long, sterile comnective lacking.

Dr. E. L. Greene* separated Audibertia polystachy a Benth. from the rest of the genus, as understood by Bentham and Gray, and proposed the name Ramona for this species. The other species he reduced to Salvia. Briquet, ignorant of Greene's work, discov-

* Pittonia $2: 235$. 
ered (as Greene had done) that Audibertia could not hold for this genus, as the name had been applied two years earlier to a section of Mentha, proposed the name Audibertiella,* and renamed all the known species under this genus. Later he discovered that Greene had proposed the name Ramona for one of the species. He, however, did not agree with Greene that the genus, with that species excepted, should be merged in Salvia. He therefore restored the genus as understood by Bentham and Gray, adopted Greene's name, and renamed the species under Ramona. The writer agrees with Greene in keeping Ramona as a distinct genus for Audibertia folystachya, but agrees with Briquet that none of the species should be merged into Salvia. It is therefore necessary to restore Audibertiella Briq. As this name was a substitute for the invalid Audibertia, the type species of the latter becomes the type of the former. The type is therefore Audibertia incana Benth. The type of Ramona was Audibertia polystachya. Audibertia grandiflora may represent a third genus.

The present species is a close relative to $A$. incana and has been confused with it. It differs in the broad rounded obovatespatulate leaves, the smaller flowers and the comparatively shorter lower lip of the corolla. In $A$. incana the leaves are oblong-spatulate, often 3-4 cm. long, the corolla almost $\mathrm{I} .5 \mathrm{~cm}$. long, and its lower lip about half longer than the upper one. A. incana ranges from Washington to Idaho and Oregon. The range of A. argented is much more southerly.

Arizona : Mokia Pass, i 877 , Palmer 395 (type, in herb. Columbia Univ.); I 876, Palmer 358.

Uтан: St. George, I 874 , Parry I59; I872, Bishop.

NevadA: Monitor Valley, I 868, S. Watson 829; Kernan, Meadow Valley Wash, April 29, 1902, Goodding 655; Palisade, June I 4, I 882, M. E. Jones 70.35 ; Miller Mountain, I 883, Shockley'; Charleston Mountain, I 898, Purpus 6072.

California : Surprise Cañon, Panamint Mountains, Coville $\mathcal{E}$ Funston 6oI; Panamint Cañon, May 4, I897, M. E. Jones; Providence Mountains, May, I902, Brandegee; Mojave Desert, May 30, I90 , Parish 4935.

* Bull. Herb. Boiss. 2 : 73 . 


\section{Hedeoma longiflora sp. nov.}

Perennial, with a slender taproot; stems branched at the base, decumbent or ascending, finely puberulent ; leaves spreading, linearlanceolate, lanceolate or oblong, $\mathrm{I}-2 \mathrm{~cm}$. long, grayish-puberulent, subsessile; calyx 7- $\$ \mathrm{~mm}$. long, strongly ribbed, puberulent, somewhat saccate below; teeth subulate, the lower $2 \mathrm{~mm}$., the upper I $\mathrm{mm}$. long; corolla about $\mathrm{I} 2 \mathrm{~mm}$. long, puberulent, with an ample limb.

This has been confused with Hediona Drummondii, but differs in the broader leaves, which are divergent, and in the calyx, which is distinctly saccate. H. Drtmmmondii differs from the related species in the narrow, ascending or suberect leaves and the narrow calyx, scarcely at all saccate. H. longiflor has the long corolla of $H$. Drummondii and is distinguished thereby from $H$. sancta, $H$. thymoides, and H. or'ata, which have all been included in H. Drummondii. It grows on cliffs and in cañons of the Great Plains region.

Nebraska: Cliffs of cañons of Banner Co., i $\$ 90, R y d b e r g$ X 297 (type, in herb. N. Y. Bot. Gard.); Court House Rock, IS9 I, Rydberg 297.

South Dakota: Custer, June 16, is92, Rydberg ofI ; Rapid Creek, IS9I, T. A. Williams.

Kansas: Wet rocks, Stanton Co., Aug. 5, 'I 895, Hitchcock 402.

\section{Madronella sessilifolia sp. nov.}

Perennial, with a short caudex; stems stout, about $3 \mathrm{dm}$. high, finely puberulent, densely so above ; leaves sessile or nearly so, ovate or lanceolate, entire, obtuse, rather pale, finely puberulent or in age glabrous; bracts oval, I O-I $2 \mathrm{~mm}$. long, puberulent on the back, ciliate on the margins; calyx $8-9 \mathrm{~mm}$. long, pilose, striate; lobes lanceolate, about I mm. long; corolla I $2-13 \mathrm{~mm}$. long, pubescent.

The type was determined as Monardella odoratissima, but it differs from that species in the pale foliage, the shorter and finer pubescence, the broader leaves, and the less distinctly ciliate calyxlobes.

UTah: St. George, I 877 , Palmer 393 (type, in herb. N. Y. Bot. Gard.). 


\section{Madronella obIongifolia sp. nov.}

Peremnial, suffruticose at the base; stems I-3 dm. high, grayish puberulent or in age glabrate; leaf-blades oblong, $\mathrm{I}-3 \mathrm{~cm}$. long, minutely puberulent, or in age glabrate, entire, obtuse, usually with distinct, but short, slender petioles; bracts pale or tinged with rose, finely puberulent, ciliate on the margins, oval, 9-1 $2 \mathrm{~mm}$. long; calyx about I cm. long, pilose ; its teeth lanceolate, and strongly ciliate; corolla white to rose-colored, 12-14 $\mathrm{mm}$. long, puberulent.

This has been confused with $M$. odoratissima, but differs in the shorter pubescence, which is sometimes wholly lacking on the older leaves, the merely puberulent instead of pilose bracts, the more distinctly petioled leaves, and more suffruticose habit. It grows on mountain sides at an altitude of I 500-3000 m.

UTAH: Mount Nebo, 1905, Rydberg \& Carlton 7706 (type, in herb. N. Y. Bot. Gard.), 7757 and 7700 ; mountains north of Bullion Creek, near Marysvale, 7178 ; American Fork, 1885, Leonard I7S; Logan, Aug. 9, 1895. Shcar 3167; same locality and date, Rydberg; Alta, July 30, I879, M. E. Jones II09; Central Utah, I 873 , Parry 75.

Mentha glabrior (Hook.) Rydb. sp. nov.

Mentha canadensis glabrata Benth. Lab. 181. I833. Not $M$. slabrata Vahl. I 794.

Mentha canadensis glabrior Hook. Fl. Bor,-Am, 2: II I. I $s_{3} 8$.

Mentha canadensis borcalis Piper, Contr. U. S. Nat. Herb. I I : 492, in part. I go6. Not M. borealis Michx. 1803.

This differs from Mintha canadensis in the almost glabrous leaves and stem, and much shorter pubescence on the calyx. Recently several botanists have included $M$. Penardi (M. arensis Penardi Briq.) in M. canadensis glabrata or M. arensis glabrata, but I think they are distinct. In M. Penardi the leaves have much shorter petioles, nearly always shorter than the flower-clusters, the stem is more hairy and the calyx-tecth are lanceolate and acute, much longer than broad. M. glathior has the abruptly acuminate calyx-lobes of M. canadinsis but they are not so short. This species has been taken as $/$. borcalis Michx., and even Benthạm cited the latter as a synonym, but by reading Michaux's 
description, one can easily see that it without any doubt refers to the true $M$. canadensis. M. canadensis is not found in the Rocky Mountain region, and $M$. glabrior is very rare. The common plant of the Rockies is $M$. Penurdi and that of the Pacific slope is II. lanati, discussed below.

Mentha lanata (Piper) Rydb. sp. nov.

Mentha arensis lanata Piper, Bull. Torrey Club 29: 223. 1902.

Mentha canadensis lanata Piper, Contr. U. S. Nat. Herb. I I : 492. 1906.

I think that this deserves specific rank, differing not only in the amount but also in the kind of pubescence and in the shape of the calyx lobes. Sometimes the leaves are very densely villous, almost white. Its range extends from British Columbia to Idaho and California. The specimens from Maine accredited to this by Robinson and Fernald * probably represent unusually hairy specimens of $M$. canadensis and not this.

\section{Mentha occidentalis sp. nov.}

Perennial, with a rootstock; stem 3-6 dm. high, with short crisp pubescence, at least on the angles above; petioles $5-10 \mathrm{~mm}$. long; leaf-blades ovate or ovate-lanceolate, short-acuminate, strongly serrate, $4-8 \mathrm{~cm}$. long, minutely pubescent on both sides or in age glabrate; bracts linear-lanceolate, I cm. long or more, usually exceeding the flowers; calyx about $3 \mathrm{~mm}$. long, pilose, teeth lanceolate, acute or acuminate, longer than broad; corolla white or pink, 5-6 mm. long; its lobes oblong, obtuse.

This has been confused with Mcutha canadensis and M. glabrata, but differs from all the species of this group in the long linear-lanceolate bracts, longer than the flower clusters, and the larger corollas, Otherwise it comes nearest 11 . Pinardi.

Idaho: Forest, Nez Perces County, ı $896, A$. A. \& E. Gertrude Heller $3 \neq 86$ (type, in herb. Columbia Univ.).

Washington: I889, l'asey' 763 ; Chehalis River, I 897, Lamb 1235 .

Montana: Jocko River, Aug. 27, 1897, Elrod and assistants 213.

\footnotetext{
* Gray's New Manual 7 II. I908.
} 
Scrophularia serrata sp. nov.

Perennial ; stem I-2 m. high, angled, sparingly puberulent or glabrous, slightly glandular in the inflorescence; leaf-blades ovate or cordate, $5-15 \mathrm{~cm}$. long, regularly serrate with the teeth directed forward, acute or short-acuminate, minutely glandular-puberulent on both sides; bracts rather conspicuous, linear-lanceolate, the lowest $2-3 \mathrm{~cm}$. long; calyx-tube hemispheric, glabrous or nearly so, $2 \mathrm{~mm}$. long; lobes rounded, $2 \mathrm{~mm}$. long; corolla-tube short, 6-7 $\mathrm{mm}$. long, nearly $5 \mathrm{~mm}$. thick; upper lip 4-5 $\mathrm{mm}$. long; sterile stamen obovate-spatulate, purple.

This species is related to Scrophularia marilandica and $S$. neglecta. From both it differs in the stout, strongly ascending, instead of more or less spreading branches of the inflorescence; from the former in the larger corolla (about twice as large) and from the latter in the shorter corolla-tube, scarcely twice as long as the calyx, and the finely glandular-puberulent, instead of densely pubescent lower leaf-surfaces. In S. neglecta the corolla-tube is about three times as long as the calyx. S. occidentalis, the common Rocky Mountain species, has doubly toothed or incised leaves with spreading teeth and a reniform greenish sterile stamen.

Idaho: Wet places, Granite, N. Idaho, July, is87, J. $H$. Sandberg (type, in herb. N. Y. Bot. Gard.).

Pentstemon subglaber Rydb. nom. nov.

Pentstemon glaber utahensis S. Wats. Bot. King's Exp. 2 I 7. $187 \mathrm{I}$.

Pentstcmon utahensis A. Nels. Bull. Torrey Club 26: 242. I 899. Not P. utahensis Eastw. . I S93.

Pentstemon alpinus [a] Torr. Ann. Lyc. N. Y. I : 35 . I 823

Pentstemon creophilus Rydb. Bull. Torrey Club 31: 642 . 1905 .

A reëxamination of the type of Pentstemon alpinus has persuaded me that it is the same as my $P$. oreophilus and not as I thought, the same as P. riparius A. Nelson. The latter should therefore be restored.

Pentstemon auricomus A. Nels. sp. nov.

Pintstemon Jamesii A. Nelson, Bull. Torrey Club 25: 547. I 898 . Not $P$. Jamesii Benth. I 846 . 
I had some correspondence with Professor A. Nelson in I 898 , when the latter segregated Pentstcmon similis from $P$. Jamesii. I think that I then led Professor Nelson astray. At least, I had made a rather serious mistake. Professor Nelson made the following statement in his article in the BuLLETin cited above:

"Before I began work upon these collections Dr. Rydberg had satisfied himself that his Dakota plant closely duplicated the type of $P$. Jamesii which is preserved in the Torrey Herbarium at Columbia University, and with which he has done me the favor of comparing my specimens."

A more thorough investigation of the South Dakota plant shows that the sterile stamens are but slightly bearded and of a different shape and the specimens must be referred to a form of $P$. albidus. The type of $P$. Jamesii consists of two scraps, only the tops of the plant. The bracts, the calyx, and corolla of these scraps resemble closely those of Nelson's plants from Wyoming. The basal leaves of $P$. Jamesii are, however, entirely different from those of Nelson's plant. At the time, there were no good specimens of $P$. Jamesii in the herbaria here in New York, but I have myself collected good specimens near the type locality, which was somewhere on the upper Arkansas River. These show that $P$. Jomesii is much closer to $P$. similis A. Nels., differing in the smaller corolla, the less secund inflorescence, the longer bracts and narrower basal leaves. Typical P. Jamesii is represented by Rydberg \& Trecland $5637,5636,6610,5635$ and 5633 ; also by Baker 6 of I 901 and Osterhout $208+$ of $\mathrm{I} 900$.

As the plant described by Professor Nelson at the place cited above is very distinct I adopt the name under which Professor Nelson had distributed the plant, viz., Pentstemon anricomus, especially as $I$, at least indirectly, was the cause of its being suppressed.

Pentstemon suffrutescens Rydb. Bull. Torrey

Club 28: 503. 30 S I 901

P. caespitosus suffruticosus A. Gray, Syn. Fl. $2^{1}: 270 . \quad 1878$.

P. procumbens Greene, Pl. Baker. 3: 23. I \& N 1901.

Professor A. Nelson, in describing Pentstemon Xylus, * expressed his opinion that the latter was the same as $P$. caespitosus suffruti-

* Bot. Gaz. 34: 31. 1902. 
cosus A. Gray. A careful reading of the original short description of Gray's variety will reveal to anyone that it cannot apply to $P$. Xylus. As P. suffrutescens was based exclusively on Gray's variety, it can by no means be called a nomen mudum as Professor Nelson is inclined to regard it. To it I refer also P. procmmbens Greene published nearly two months later.

Pentstemon Thompsoniae (A. Gray) Rydb. sp. nov.

Pentstemon pumilus Thompsoniac A. Gray, Syn. Fl. $2^{1}: 269$. I $S 78$.

This is a very distinct species, not related to $P$. prmilus. Dr. Gray at first* placed Pentstemon pumilus with $P$. albidus, $P$. Jamesii, and $P$. cristatus, $i$. $e_{\text {., }}$ in a group to which it rightly belongs, notwithstanding its small size. Afterwards, $\dagger$ he transferred it wrongly to the $P$. caespitosts group, with which it has little in common. $P$. Thompsoniae on the contrary belongs to this group and is a close relative to $P$. caespitosus. I suspect that Dr. Gray has redescribed the true $P$. pumilus Nutt. under the name $P$. miser. I have not seen the type of the latter but the description agrees well with $P$. pumilus.

\section{Pentstemon platyphyllus sp. nov.}

Pentstemon heteroplyyllus latifolius S. Wats. Bot. King's Exp. 222. I 87 I. Not P. latifolins Hoffmgg. I 824.

Dr. Gray in the Synoptical Flora \& refers this doubtfully to Pentstemon asureus Jaffrayanus Gray ( $P$. Jaffrayanus Hook.). The two resemble each other in leaf form and general habit, but there are differences important enough to make them distinct species. I am also inclined to think that $P$. Jaffrayamus is specifically distinct from $P$. asureus, although $I$ have not seen any authentic specimen of the latter. The leaves in P. Jaffray amus are strongly glaucous and the upper are subcordate and clasping at the base; the calyxlobes are oval or obovate, abruptly short-acuminate or mucronate with an erect tip; the anthers are somewhat hirsutulous at the. sinus as well as papillose-hispidulous on the margins; and the sterile

* Proc. Am. Acad. 6: 67. 1862.

† Syn. Fl. $2^{1}: 269$. 1878 .

$\ddagger$ Syn. Fl. ed. $2,2^{1}: 441$. 1886 .

$82^{1}: 272 . \quad 1878$. 
stamen is filiform. In $P$. platyplyyllus the leaves are less glaucous, never subcordate or clasping at the base; the calyx-lobes are ovate, long-acuminate, with more or less spreading tips; the anthers are merely papillose-hispidulous on the margins but otherwise without pubescence; and the sterile stamen is decidedly broadened upwards. $P$. platyphyllus, as far as the writer knows, is found in Utah only, while $P$. Jaffrayanus grows in California and Oregon. To the former belong the following specimens :

Utall : Cottonwood Cañon, July, i 869, S. Wertson 787 ; City Creek Cañon, July 25, I $\$ 79, M$. E. Jones 1080 ; also July 7 , i 880 ; same locality, July 4, I $\$ 8_{3}$, Leondrd $I f I$, and Aug. 9, I $88_{4}, 208$; mountains near Ogden, July, is 7 I, Coulter.

\section{Pentstemon coccinatus sp. nov.}

(?) Pcntstcmon Eatonii undosus Jones, Proc. Calif. Acad. 5: 7 I $5 . \quad$ I 895 .

Perennial, with a woody caudex; stem erect, 3-6 dm. high, puberulent; basal leaves petioled; blades ovate or elliptic, acute at both ends, $3-7 \mathrm{~cm}$. long, densely puberulent; lower stem-leaves spatulate to elliptic; the upper ovate or ovate-lanceolate, acuminate; inflorescence lax, more or less secund; calyx about $5 \mathrm{~mm}$. long, puberulent ; lobes broadly ovate, abruptly short-acuminate, scariousmargined and denticulate; corolla red, about $2.5 \mathrm{~cm}$. long, nearly tubular, not ventricose, slightly bilabiate, lobes short, rounded; anthers papillose on the margin, glabrous; sterile stamen glabrous, club-shaped, truncate; capsule about $\mathrm{I} \mathrm{cm}$. long.

This has been confused with $P$. Eatonii, but differs in the puberulent stem and leaves, the more acuminate upper leaves and sepals.

Arizona: Grand Cañon of the Colorado, is98, MacDougal I73 (type, in herb. N. Y. Bot. Gard.) ; Oak Creek, June 23, I $S S_{3}$, Rusby; Red Cañon Trail, June Iо, I90 I, L. F. Ward.

UTaн: Court House Wash, Nay, I892, Eustzeood; South Utah, I 877 , Palmer 372 ; I 874, Parry' 179.

\section{Synthyris dissecta sp. nov.}

Synthyris pinnatifide Rydb. Mem. N. Y. Bot. Gard. I : 353. 1900. Not S. Wats. I 87 I.

Acaulescent perennial, with a short, thick, erect rootstock; leaves 5-IO cm. long, petioled, villous-tomentose; blades oval in 
outline, twice or thrice pinnatifid into oblong or lanceolate divisions; scape villous-tomentose, 5-20 cm. high; spike dense or in fruit more lax; bracts and calyx densely white-villous; corolla about $6 \mathrm{~mm}$. long, dark-blue or purple, or in age paler; lobes broadly obovate; stamens slightly exserted; ovary villous; fruit obovate, $6 \mathrm{~mm}$. long, villous or in age glabrate.

This species is related to Synthyris pinnatifida, and has been mistaken for it, but it differs in the more copious pubescence, especially on the calyx and ovary (in $S$. pinnatifida these are glabrous or merely puberulent on the margins), in the larger dark corolla with obovate instead of oblong lobes, and in the larger fruit. S. dissecta grows at an altitude of 2000-3000 m.

Montand: Near Bozeman, June II, I900, Chesmut \& Jones I99 (type, in herb. N. I. Bot. Gard.); Bridger Mountains, June 15, 1897 , Rydlerg \& Bessey 7927 ; same locality, I 899, Flaherty, and June 26, I 899, Blankinship; Old Hollowtop, July 7, I 897, Ry'dberg \& Bessey' 1926 ; Beaver Head Co., June, i 888, Twecdy 70.

Wroming: Headwaters, Cliff Creek, Aug. 9-is, igoo, C. C. Curtis (good fruit).

Thalesia Sedi (Suksd.) Rydb. comb. nov.

Aphyllon Sedi Suksd. Deuts. Bot. Monats. I8: I 55. I 900.

The three species of the Columbia River region, which have usually been included in Thalesia uniflora, differ from the plant of the eastern United States in their longer attenuate calyx-lobes. In all three the lobes are about twice as long as the calyx-tube and narrowly subulate from a broad base; in $T$. uniflora they are scarcely longer than the tube, lanceolate and gradually tapering from the base of the apex. T. Sedi differs from the other two Columbian species in the lighter-colored corolla, with narrower, oblong acutish or obtuse lobes, while T. purpured Heller and $T$. minuta (see below) have dark purple corolla and broad, oval or semiorbicular lobes rounded at the apex or sometimes even retuse. It grows on species of Sidum and is distributed through parts of Oregon, IVashington, and western Montana.

Thalesia minuta (Suksd.) Rydb. comb. nov. Aphyllon mmutum Suksd. Deuts. Bot. Monats. I8: I 55.1900. This resembles Thalesia purpurea in the color of the flower 
and the form of the calyx, but the corolla is much smaller, only I 5-20 mm. long, more strongly curved, and less funnelform. The corolla of $T$. purpurea is $2-3 \mathrm{~cm}$. long, and more open at the throat. T. minuta has been reported parasitic on Lithophrogma, but may grow on other hosts. It has been collected in Oregon, Washington, Montana, and British Columbia.

Thalesia lutea (Parry) Rydb. comb. nov.

Phelipace luted Parry, Am. Nat. 8: 214 . I 874.

Aphyllon fasciculatum lutcum A. Gray, Syn. Fl. $2^{1}: 312$. 1878 .

This differs from Thalesia fasciculata not only in the sulphuryellow corolla, but also in the acutish corolla-lobes and in the acute rather than acuminate calyx-lobes. It is parasitic on grasses instead of on composites, etc.

Myzorrhiza Philippi, Linnaea 29: 36 . I 857

Aphyllon \$ Nothaphyllon A. Gray, Bot. Calif. I : $584 . \quad$ i $\$ 76$. Orobanche \$ Mysorrhiza G. Beck, Bibl. Bot. 4: 78. IS90.

Following Beck von Mannagetta, many botanists in this country have reduced Gray's section Nothaphyllon of Aphyllon to Orobanche, while they have kept Thalesia distinct. Both, as well as a part of Boschniakia, were included in Orobanche by Beck. The editors of Gray's New Manual evidently took the genus Orobanche in the same sense as Beck. In contrasting Conopholis and Orobanche in the generic key, they give as characters for the former: "Calyx deeply cleft in front"; and for the latter: "Calyx 5-cleft." On the following page, however, they give as characters of Orobanche minor: "Calyx cleft before and behind almost or quite to the base," and for $O$. ramos "Calyx 4-lobed." O. minor is the only typical Orobanche found in this country, and this does not agree with the characterization of the genus, as given in the New Manual. Evidently the editors had Gray's genus Aphyllon in mind when the key was made.*

* Another inaccuracy in the treatment of Orobanche in the New Manual may be pointed out: Orobanche purpurea and O. ramosa are there characterized as having "each flower with 3 bracts (I large and 2 small) at the hase of the calyx," $O$. minor and $O$. ludoviciana as having "each flower with $\mathbf{I}$ or 2 bracts at the base of the calyx," and $O$. uniflor $a$ and $O$. fusciculata as being "without bracts." The characters 
The typical Orobanche has the calyx characteristic of, for instance, Castillijir in Scrophulariaceae, i. $c$., the calyx is deeply cleft in front and behind, with the lateral divisions entire or 2-cleft. None of our native American plants has this structure. They have all (except those included in Boschniakia by Gray) an almost equally 5 -toothed calyx. There is a group of Old World plants, of which Orohanche purpurea and O. remose are introduced into this country, which have a 4 -toothed or only occasionally 5-toothed calyx, but in that case the upper tooth is much smaller. In Gray's New Manual the former is described as having a "5-lobed" calyx. This is only occasionally the case. These species constitute the genus Kopsia Dum. or Phelipaea Nees (not Desf.). The writer thinks that the five sections of Beck's monograph should be regarded as genera. Mysom hisa Philippi is the only available name for Aphyllon \$Nothaphyllon Gray. This genus differs from Thalesia in habit and in the arrangement of the placentae, from Crobenche in the regularly 5 -toothed instead of 2 -cleft calyx, and from both in the presence of bractlets. The type of the genus is

Myzorrhiza chllensis Philippi, Linnaea 29:36. I 857

Orobanche chilensis G. Beck, Bibl. Bot. 4:82. 1890.

This is closely related to our most common North American species :

Myzorrilza ludoviciana (Nutt.) Rydb.; Small, Fl. SE. U. S. I093. 1903

Orobanche lndoriciana Nutt. Gen. 2: 58 . 18 I 8 .

Phelipaea ludoriciana Walp. Rep. 3: 46 I. I 844.

Aphyllon ludoriciemm A. Gray, Bot. Calif. I : $585 . \quad$ I 876.

? Aphyllon arenosum Suksd. Allg. Bot. Zeits. 12: 27.1906.

given for the two first are correct; there are three scales under the flower, one bract and two lateral bractlets; Orobanche minor has one bract and no bractlets, while $O$. ludoviciani has 1 or 2 bractlets under the flower. It has exactly the same arrangement as $O$. purpurea and $O$.ramosa, except that one of the bractlets is sometimes lacking and the bract is usually some distance below the calyx. Orobanche unifora and $O$. fasciculat $a$ are not without bracts. They are without bractlets, but the bract is found at the base of the longer pedicel. They are like O. minor (a typical Orobanche) in having no bractlets, but differ in the 5 -toothed instead of 2 -cleft calyx. O. Indoviciana has bractlets and should have been associated with the two first species, if the presence or absence of bractlets was taken as the dividing character. In all the species the bracts are present although situated at different distances from the calyx, depending upon the length of the pedicels. 
Myzorrhiza multiflora (Nutt.) Rydb. Bull. Torrey

$$
\text { Club } 33 \text { : 15 I. I } 906
$$

Orobanche multiflora Nutt. Jour. Acad. Nat. Sci. Phila. II. I : 1 79. I 848 .

Phelipaca erianthera Engelm.; A. Gray, Proc. Am. Acad. $7: 372$. I 867 .

Aphyllon multiflorum A. Gray, Bot. Calif. I : 585 . I 876.

Myzorrhiza Cooperi (A. Gray) Rydb. comb. nov. Aphyllon Coopcri A. Gray, Proc. Am. Acad. 20:307. I885. Orobanche ludoriciana Cooperi G. Beck, Bibl. Bot. 4: S I. I 890.

Myzorrhiza tuberosa (A. Gray) Rydb. comb. nov. Phalipaca tuberosa A. Gray, Proc. Am. Acad. 7 : 37 I. I867. Aphyllon tuberosum A. Gray, Bot. Calif. I : 585. 1876 . Orobanche bulbosa G. Beck, Bibl. Bot. 4: 83 . I 890.

Myzorrhiza pinorum (Geyer) Rydb. comb. nov.

Orobanche finorm Geyer; Hook. Kew Jour. Bot. 3: 297. I $85 \mathrm{I}$.

Phelipaca pinctorum A. Gray, Proc. Am. Acad. $7: 37$ I. I 867. Aphyllon pinetorum A. Gray, Bot. Calif. I : 585. I 876.

Myzorrhiza Grayana (G. Beck) Rydb. comb. nov.

Crobanche comosa Hook. Fl. Bor.-Am. 2: 92. I 838 . Not O. comosa Wallroth. I 822 .

Anoplanthus comosus IValp. Rep. $3: 480 . \quad$ I 844 .

Phelipaca comosa A. Gray, Pac. R. Rep. 4: I I 8 . I 857.

Apleyllon comosum A. Gray, Bot. Calif. I : 584. I 876 .

Phelipaec carnosa [error] T. \& G. ; Coop. \& Suckl. Nat. Hist. Wash. $50 . \quad 1859$.

Orobanche Grayana G. Beck, Bibl. Bot. 4: 79. I89o.

Myzorrhiza californica (Cham. \& Schlecht.) Rydb. comb. nov.

Orobanche californica Cham. \& Schlecht. Limnaea 3: I 34. I 828 .

Phclipaca californica G. Don, Gen. Syst. 4: 632. 1838 . Aphyllon califormicum A. Gray, Bot. Calif. I: 584. 1876.

Myzorrhiza violacea (Eastw.) Rydb. comb. nov. Aphyllon violacimm Eastw. Zoe 5: 85. 1900. 
Myzorrhiza xanthochroa (Nels. \& Cockerell) Rydb. comb. nov. Orobanche xanthochroa Nels. \& Cockerell, Bot. Gaz. 37 : 278. I904.

\section{Myzorrhiza corymbosa sp. nov.}

Stem 5-IO cm. high, corymbosely branched, glandular-puberulent; scales about I cm. long, lance-ovate, acute; bracts linear, about I cm. long; pedicels 5-IO $\mathrm{mm}$. long; bractlets linear-subulate, half as long as the calyx; calyx-tube obconic, glandularpuberulent, $4 \mathrm{~mm}$. long; lobes lance-subulate, about $\mathrm{I} \mathrm{cm}$. long ; corolla dark purple, about $2.5 \mathrm{~cm}$. long, tube $4-5 \mathrm{~mm}$. wide; upper lip 7-8 mm. long, cleft about one third its length into ovate, obtuse or sometimes retuse lobes; lower lip cleft to the base into three lanceolate acutish divisions; anthers woolly.

This species has been confused with M. californica and $M$. Indoviciana, but is evidently most nearly related to M. Grayana (Orobanche comosa Hook.). In Hooker's Flora, the latter is described and figured as having emarginate corolla lobes. I doubt if that is a constant character. There is a fragment of Hooker's type in the Torrey herbarium; some of the lobes are evidently so, but in others this character is rather obscure. Good specimens, collected by Dr. Cooper on the Stevens' Expedition and also preserved in the Torrey herbarium, and a colored drawing, made for the report of the Wilkes' Expedition but never published, illustrate a plant with the lobes of the lower lip lanceolate, acute and entire at the apex. These and the specimen received from Hooker agree otherwise wholly in habit, size, structure, and color of the corolla. Whether the notching of the lower lobes is a specific character or not, may be decided by further field study. It is evident that the specimens cited here below are distinct enough from both. Hooker's and Cooper's plants have a corolla fully $3 \mathrm{~cm}$. long, light purple and of a thinner texture, the lips are I $2-\mathrm{I} 5$ $\mathrm{mm}$. long, $i$. $\epsilon$, about twice as long as in the plant here described, the upper lip is cleft to about the middle and the lobes of the lower lip are relatively narrower. The corolla of $M$. corymbos $\alpha$ resembles more in form, size, texture, and color that of $M$. ludoriciana, although the upper lip is less deeply 2-cleft. Occasionally one finds stunted specimens of M. Indoviciana, which in habit resemble this, but they can easily be recognized by the shorter calyx- 
lobes and the glabrous anthers. The type of $M$. corymbosa was labeled Aphyllon californicm, but $M$. californica is a much larger plant in every respect, and its anthers are glabrous or nearly so.

Inaнo: Reynold's Creek, July 2, I S92, Isabd Mulford (type, in herb. Columbia Univ.).

Wroming: Jackson's Hole, July 30, I 901 , Mcrrill \& Hilcox II 77 .

Montana: Mountains near Indian Creek, July 22, i 897, Rydberg \& Bessey 4988 .

\section{Valeriana pubicarpa sp. nov.}

Perennial, with a rootstock; stem $2-4 \mathrm{dm}$. high, finely puberulent, not bearded at the nodes; basal leaves spatulate or oblanceolate, $2-6 \mathrm{~cm}$. long, thin, glabrous or nearly so ; stem-leaves $2-4$ pairs, the lowest pair similar to the basal ones, the rest 3-5foliolate or the uppermost minute and simple; leaflets oblong or lanceolate, rarely elliptic, $2-5 \mathrm{~cm}$. long, entire; inflorescence short and dense, corymbiform or subcapitate; flowers mostly perfect; corolla funnelform, 4-6 mm. long, more or less pubescent; limb about $4 \mathrm{~mm}$. wide ; fruit finely pilose, $5 \mathrm{~mm}$. long, $2 \mathrm{~mm}$. wide.

This species has the habit of T'aleriana occidentalis and $T$. micrantha, but the corolla of $T$ '. Siculeri. From the first, it differs in the longer corolla and the pubescent fruit; from the second, in a corolla twice as long and a denser inflorescence; from the last, in the narrower entire leaflets, and the pubescent fruit; and from all in the puberulent stem, which lacks the beard at the nodes and on the sheaths. It grows in the mountains at an altitude of 2,000-3,000 m.

UTAH : Mount Nebo, Aug. I 5, I905, Rydberg \& Carlton 7717 (type, in herb. N. Y. Bot. Gard.); also Big Cottonwood Cañon, June 28, 6377 and 6517 ; Provo, June I6, I902, Goodding I I 4 . 8 .

IDAно: Ketchum, July 23, I 892, Miss Mulford.

Montana: Lima, June 29, IS95, Ryitberg 2797; also C. L. Shear 3.389 .

Valeriana puberulenta sp. nov.

Perennial, with a thick rootstock; stem finely puberulent, not bearded at the nodes, I.5-3 dm. high; basal leaves spatulate, $2-5$ $\mathrm{cm}$. long; stem-leaves I-3 pairs, usually 3 -foliolate; terminal 
leaflet elliptic or oblong, or in the uppermost reduced pair lanceolate, $1-3 \mathrm{~cm}$. long, the lateral ones oblong or lanceolate, about half as long; plant usually polygamo-dioecious; inflorescence of the essentially pistillate plant dense-corymbiform, that of the somewhat smaller essentially staminate plant subcapitate; corolla funnelform, 4-5 mm. long; limb $2.5-3 \mathrm{~mm}$. wide; fruit glabrous, nearly $5 \mathrm{~mm}$. long and $2 \mathrm{~mm}$. wide.

This species has the pubescence of the preceding, but differs in the smaller stature, the smaller flowers, fewer and smaller leaves, glabrous fruit and a stronger tendency to be polygamo-dioecious. It grows in the mountains of Utah, at an altitude of 2,000-3,000 m.

UTAн: Mountains north of Bullion Creek, near Marysvale, July 23, 1905, Rydborg \& Carlton 7065 (type, in herb. N. Y. Bot. Gard.); also Big Cottonwood Cañon, June 28, 6390, 6371, and 6532; Mount Barette, July 26,7238; near Alta, July Io, I 883 , Leonard I77; Central Utah, I 875, Parry 36; Wahsatch Mountains, Aug., I 869, S. Watson 788 , in part.

\section{CORRECTION}

Mertensia cana Rydb. nom. nov.

Mertensia canescens Rydb. Bull. Torrey Club 31 : 640. 1904. Not Mertensia canescens Kaulf. I824.

Professor T. D. A. Cockerell has called my attention to the fact that my Mcrtensia cancscens is antedated by $M$. canescens Kaulf., a fern.

New York Butanical Garden. 
CONTRIBUTIONS FROM THE NEW YORK BOTANICAL, GARDEN-No. 131

\section{STUDIES ON THE ROCKY MOUNTAIN FLORA-XXI}

By PER AXEL RYDBERG

NEW YORK

1910

Reprinted, without change of paging, from the BULLETIN OF THE TORBKY BOTANICAL CLUB 37: 127-148. $31 \mathrm{Mr} 1910$ 





\section{Studies on the Rocky Mountain flora-XXI}

P'HR AXFL, RYHERr;

\section{Ambrosia media sp. nov.}

Annual; stem 4-6 dm. high, hispid with ascending or appressed short hairs, more or less strigose, branched; leaves pinnately divided, thick, 5-10 cm. long, scabrous and glandulargranuliferous above, hispid-strigulose beneath, all except the uppermost with shorter or longer, hirsute-ciliate, narrowly winged petioles; divisions oblong or lanceolate, usually more or less cleft or toothed, the lobes or teeth lanceolate, acute; staminate racemes rather dense; involucre nodding, slightly lobed with 5 rounded lobes and crenulate, 4-5 mm. in diameter, hispid-strigose; hairs about $0.5 \mathrm{~mm}$. long, with more or less pustulate bases; receptacle with few narrow lance-subulate scales; fruit obovoid; body about $3 \mathrm{~mm}$. long, puberulent or in age glabrate, with $5-7$ sharp spines $0.5 \mathrm{~mm}$. long and strongly directed forward; beak about $1 \mathrm{~mm}$. long, pubescent.

In the form and texture of the foliage, this species resembles 4. coronopifolia T. \& G. ( 4 . psilostachy'r of most authors) as closely as to make it almost impossible to distinguish the two by the leaves alone, the only difference being that the leaves of A. midic are more inclined to be petioled and the petioles distinctly hispidciliate. Otherwise, the plant is more closely related to $A$. clatior and $A$. artemisiifolia, the root being annual and the fruit spiny. A. coronopifolic has a larger fruit, which is inclined to be roundelliptic instead of obovoid, is more pubescent, without spines, either perfectly smooth or rarely with small rounded tubercles.

Colorado: Fort Collins, Aug. 27, i 885, C. S. Crandull (type, in herb. N. Y. Bot. Gard.).

New Mexico: Pecos, San Miguel County, Aug. 20, I898, Standlcy 5I38; Kingston, I904, Mtctcalfe I337 (?).

Coahula : Saltillo i 898 , Palmer 293.

Montana: Sand Coulee, Sept. 7, 1885, R. S. Williams.

Nebraska: Chadron, Oct. 9, I897, J. M. Bates 706 (plants predominantly pistillate). 


\section{Grindelia integerrima sp. nov.}

Perennial, with a cespitose base; stems about 3 dm. higlı, glabrous, somewhat angled by the decurrent lines; leaves narrowly oblanceolate, $2-4 \mathrm{~cm}$. long, acute, strongly resinous-dotted, entire; heads numerous, corymbose ; involucre about $7 \mathrm{~mm}$. high and I cm. wide; bracts lanceolate, with very short, terete, squarrose tips; ligules $6-7 \mathrm{~mm}$. long; pappus-bristles slightly flattened, curved and twisted, $3 \mathrm{~mm}$. long, about the length of the achenes.

This somewhat resembles Grinddio nana in general liabit but differs in the broader bracts with much shorter tips and the strongly curved and twisted pappus-bristles.

IDAно: Sandy soil near Granite Station, Kootenai County, July 29, IS92, Sandborg, Mac Dongal, \& Heller $7 \delta_{f}$ (type, in herb. N. Y. Bot. Gard.).

Grindelia columbiana (P'iper) Rydb. comb. nov.

Grindelia discondea Nutt. Trans. Am. Plil. Soc. 7: 315 . IS40. Not G. disculdea H. \& A. I 836 .

Grindelia nand discoiden A. Gray, Syn. Fl. I²: I I9. I 884. Grindelia nana columbiana Piper, Contr. U. S. Nat. Herb. I I : 556. I 906.

\section{Chrysopsis angustifolia sp. nov.}

Cluysopsis stemophylle Britt. \& Brown, Ill. Fl. 3: 327. IS98. Not C. stemophylla (A. Gray') Greene. 1884.

Perennial, with a cespitose caudex; stems erect, 2-4 dm. high. canescent and more or less hirsute ; leaves narrowly linear-oblanceolate, the lower short-petioled, the upper sessile, $2-5 \mathrm{~cm}$. long, $2-5$ mm. wide, acute, grayish-strigose on both sides, somewhat hispidciliate on the lower portion; involucres turbinate-canpanulate, S-ro mm. high and about as broad; bracts narrow and linear, acute, rrayish-strigose; rays about I cm. long; achenes canescent : outer pappus of short bristles; inner pappus-bristles tawny.

This is intermediate between Chrysopsis foliosa and C. stenophylla. It resembles the latter in leaf-form but differs in being more canescent, less hispid, not at all viscid, and in the bracts, which are narrower, and strigose-canescent instead of hispid and viscid-puberulent. From $C$. foliose it differs in the narrower, spreading leaves, the more distinctly peduncled heads, and less white pubescence. 
Nebraska : Middle Loup River, near Mullen, Hooker County, Sept. I 4, I S93, P. A. Rydberg I766 (type, in herb. N. Y. Bot. Gard. and Columbia Univ.); Long Pine, Sept. I4, IS90, J. M. Bates; Deuel County, Aug. 24, I S9I, Rydberg I 49 .

Kansas : Kiowa County, Sept. 4, I $\$ 98, L$. F. Ward.

Alberta: Vicinity of Banff, Aug. 14, I 899, Mc Calla 2032, in part.

\section{Chrysopsis Butleri sp. nov.}

Perennial; stem decumbent at the base or erect, grayishhispidulous and slightly hirsute; leaves $\mathrm{I}-3 \mathrm{~cm}$. long, the lower obovate, the upper oblong or elliptic, obtuse or apiculate, often spreading, sessile, grayish-hirsute with short hairs; heads peduncled but usually subtended by an oblong small leaf; involucres 8 mm. high, IO-I $5 \mathrm{~mm}$. broad; bracts linear, acute, hirsutulous, but not at all glandular or viscid; ligules about $8 \mathrm{~mm}$. long; achenes silky-strigose; pappus tawny, the outer of minute bristles.

This species is characterized by the small, obovate or elliptic, subsessile leaves, which are often spreading and with short spreading pubescence. Nearly all the species of the Chrysopsis aillosi group, with spreading pubescence, are more or less viscid or glandular, but this is not at all the case with $C$. Butleri. In leafform it resembles $C$. villosa, but both leaves and heads are smaller and the pubescence is different. In $C$. cillosa the hairs are at least in the young state appressed.

Montana: Gateway, Aug. 17, Igo8, B. T. Butler 620 (type, in herb. N. Y. Bot. Gard.); Midvale, Sept. 3, I 901, Umbach 567 ; Wild Horse Island, Aug. I3, I go $S$, Butler $780,48 I,+85,49 I$.

Wyoming: Near Fort Laramie, i $\delta_{42}$, Fremont $\oint_{2}$.

Utah : City Creek Cañon, I875, M. E. Jones; same locality, Oct. 7, I905, Garett I703.

\section{Chrysopsis grandis sp. nov.}

Perennial, with a cespitose caudex; stems about $3 \mathrm{dm}$. high, leafy, long-hirsute, hispidulous and resinous-granuliferous; leaves spatulate or oblanceolate, $3-5 \mathrm{~cm}$. long, the lower petioled, the upper sessile, hirsute or hispid and conspicuously resinous-granuliferous, apiculate; heads corymbose, short-peduncled, rarely subtended by a small leaf; involucres $8 \mathrm{~mm}$. high, I2-I $8 \mathrm{~mm}$. broad; bracts densely hirsute, only slightly granuliferous; rays golden yellow, about I cm. long; achenes strigose; pappus yellowish tawny, the outer of short bristles. 
This species is related to Chry'sopsis hispida and C. colmmbiana, but differs from both in the larger heads; it differs also from the former in the more copious pubescence and the more decidedly oblanceolate and petioled leaves; from the latter in the longer pubescence, the more copious resinous granules and the more decidedly petioled leaves.

Montana: Jocko Creek, June I6, I901, MacDongal 275 (type, in herb. N. Y. Bot. Gard.); also 265.

\section{Chrysopsis barbata sp. nov.}

Perennial; stems about $3 \mathrm{dm}$. high, more or less tinged with purplish or red, hirsute with long white hairs and somewhat puberulent ; leaves sessile, lanceolate, $3-5 \mathrm{~cm}$. long, the upper acuminate, long-hirsute and somewhat resinous-granuliferous; heads subsessile; involucres I cm. high and I $2-15 \mathrm{~mm}$. broad; bracts linear, acute, sparingly long-hirsute and resinous-granuliferous; ligules about $7 \mathrm{~mm}$. long, golden yellow; achenes strigose; pappus brownish tawny, the outer squamulate, I-I.5 mm. long.

This species is related to Chrysopsis hispida but differs in the long, dense pubescence, a much less abundance of resinous granules, larger leaves and heads, and more conspicuous outer pappus. It grows on sandy plains.

I DAно : Valley of Spokarie River, Kootenai County, July I 7 , I893, Sandborg, MacDougal, \& Heller $66+$ (type, in herb. N. Y. Bot. Gard.).

Chrysothamnus attenuatus (Jones) Rydb. sp. nov.

Bigeloria Howardi attcmata Jones, Bull. Calif. Acad. Sci. II. 5 : 691. I 895 .

Chrysothamms affinis attematus A. Nels. Bot. Gaz. 28: 374. I 899 .

\section{Chrysothamnus salicifolius sp. nov.}

A shrub 3-10 dm. high; branches erect, white or gray, finely pannose-tomentulose; leaves linear, 3-nerved, 4-6 cm. long, 3-6 $\mathrm{mm}$. wide, minutely tomentulose; heads in a dense corymbiform cyme; involucres $7-8 \mathrm{~mm}$. long; bracts elliptic, oval or ovate, the outer acutish, the inner obtuse or rounded at the apex, eroseciliate, the outer slightly tomentose, the inner glabrous; corollas about I cm. long; teeth I.5-2 mm. long, lanceolate, obtusish; achenes coarsely strigose, angled. 
This species resembles Chrysothammus graveolens in habit, but the leaves are broader, more tomentulose; the bracts are slightly tomentulose, erose-ciliate, and broader than in that species. Ward's specimens were determined by Dr. Gray as Bigelovia gravcolens latisquamea and included therein in the Synoptical Flora; but it is wholly distinct therefrom. The true C.latisquamea (A. Gray) Greene has very white filiform-revolute leaves and the bracts more rounded at the apex.

Utah : Strawberry Valley, Sept. 3, I883, F. E. Leonard 288 (type, in herb. N. Y. Bot. Gard.); Twelve-mile-Creek, Aug. 29, i 875 , L. F. Ward 659.

\section{Chrysothamnus stenolepis $\mathrm{sp}$. nov.}

Low shrub, 2-3 dm. high, somewhat spinescent; branches short, erect, glabrous or finely puberulent above; leaves narrowly lance-linear, $\mathrm{I}-2 \mathrm{~cm}$. long, 2-4 $\mathrm{mm}$. wide, glabrous, scabrousciliate on the margins, convolute and somewhat twisted; inflorescence corymbiform, of few heads; involucres about $8 \mathrm{~mm}$. long; bracts 4 -ranked in 3 series, narrowly lanceolate, or the inner linear, acute, glabrous, keeled, somewhat viscid; corollas scarcely exceeding the involucre; lobes lanceolate, $2 \mathrm{~mm}$. long; achenes hirsute-strigose.

This species is related to Chrysothammus riscidiflorus and $C$. glaucus, but differs from both in the very narrow acute bracts.

Montana: Pass Creek, near Bridger Pass, H. Engelmann (type, in herb. Columbia Univ.).

UтAн : Saleratus River, Aug. I889, C. K. Dodge.

\section{Chrysothamnus marianus sp. nov.}

Undershrub, I-2 dm. high, with a woody thick caudex; branches erect, at first green, soon straw-colored or white, densely and finely puberulent; leaves linear or the lower linear-oblanceolate, acute, thick, densely puberulent, I-2 cm. long, I-I $5 \mathrm{~mm}$. wide, I-nerved, somewhat twisted ; heads narrow, in small, corymbiform-cymose panicles, involucres about $5 \mathrm{~mm}$. high; bracts yellowish, glutinous, erose-ciliate on the margins, 4-ranked and in about 3 series, the outer ovate, acutish, the inner spatulate-oblong, rounded at the apex ; achenes sparingly strigose ; corollas scarcely exceeding the involucres.

This species has many characters of Chrysothammus puberulus, 
but differs in the more yellowish-green herbage, the whiter stems, the narrower, more erect, thick, I-nerved instead of 3-nerved leaves, the finer pubescence, and the involucres, which are narrower and with different bracts. In C. puberulus the inner bracts are linear or linear-lanceolate and acute. The young achenes are only slightly strigose, in which respect it approaches C. Bakeri and C. Traseyi.

Utah : Along Sevier River, below Marysvale, July 20, I 905 , Ryaberg \& Carlton 6993 (type, in herb. N. Y. Bot. Gard.) ; also $698_{3} ;$ Mount Rarette, July 26, 7253.

Solidago missouriensis Nutt. Jour. Acad.

Phila. $7: 32 . \quad 1834$

Solidago Tolmicana A. Gray, Syn. Fl. I' : 15 1. 1834.

Dr. Gray in the original publication of S. Tolmicana adds the following note: "Has been taken for a form of S. missonriensis var. Montana;" but he overlooked the fact that it was identical with the original S. missomiensis. He might have been led astray by Nuttall himself, who later included in S. missouricnsis the common plant of the upper Missouri Basin with recurved secund branches. That the latter is not the original S. missouriensis may be seen from Nuttall's diagnosis, of which I here give a copy:

" 55 Solidago * mssouriensis. Pumila, glabra, racemis erectis, foliis lineari-lanceolatis, acutis, inciso-subserrulatis, superioribus integris, panicula brevi laxa, floribus majusculis."

"Stem slender, smooth, leafy, about a foot or so high. Leaves scabrous at the margin. Panicle about three inches long, the branches slender, the flowers pedicellate, and brought together in a somewhat rhomboidal raceme. Rays as long as the calyx."

This agrees with S. Tolmicand but not with the plant described by Gray as S. missonticnsis.

The original Solidago missommensis was collected by Wyeth on the upper branches of the Missouri. There is a specimen of this collection in the Torrey Herbarium which agrees with the description and this matches very well the type of S. Tolmicana in the Gray Herbarium. The plant described by Gray as S. missomiensis is characterized by its flat-topped or round-topped inflorescence with recurved-spreading, secund branches, in variance with Nuttall's characterization: "racemis crectis," and " the flow- 
ers pedicellate, and brought together in a somewhat rhomboidal raceme." The synonymy of Gray's plant is as follows :

Solidago glaberrima Martens, Bull. Acad.

$$
\text { Brux. 8: 68. I } 84 \mathrm{I}
$$

Solidago missouriensis Nutt. Trans. Am. Phil. Soc. II. 7: 327, in part. I 840. Not S. missouriensis Nutt. I 834 . Solidago missouriensis A. Gray, Syn. Fl. I²: I $55 . \quad$ I 884. Solidago serotina Hook. Comp. Bot. Mag. I : 97. I 835 . Not $S$. serotina Ait. I 789 .

\section{Solidago glaucophylla sp. nov.}

Perennial, with a branching rootstock; stems slender, pale, glabrous up to the sparingly pubescent inflorescence; leaves glabrous, glaucous, minutely ciliolate on the margins, rather thick, linearoblanceolate or the upper linear, triple-nerved, 6-10 cm. long, 4-I $\mathrm{mm}$. wide, entire, acute ; inflorescence a round-topped panicle, the branches somewhat recurved-spreading and somewhat secund; heads about $5 \mathrm{~mm}$. high; bracts oblong, obtuse, or the outer lance-oblong, acutish; rays short, $2-2.5 \mathrm{~mm}$. long, $0.7-0.8 \mathrm{~mm}$. wide; achenes slightly strigose-hirsute.

This species is related to Solidago missouriensis and S. glaberrima, but differs from both in the narrow, entire, glaucous leaves and the thicker, oblong and obtuse instead of linear-lanceolate and acute bracts. The type grew on dry plains at an altitude of I $000 \mathrm{~m}$.

Montana: Dry plains near Kalispel, Flathead Valley, July 25 , I90 I, MacDougal 760 (type, in herb. N. Y. Bot. Gard.).

Wyoming: Buffalo, July 25, i $896 ;$ A. Nolson $250 I$ (?, similar but with narrower inflorescence).

\section{Solidago nivea sp. nov.}

Perennial, with a woody cespitose rootstock and short caudex; stems I-2 dm. high, clecumbent at the base, canescent-puberulent; basal leaves 2-4 cm. long, short-petioled; blades obovate-spatulate, rounded at the apex, entire or nearly so; stem-leaves oblanceolate, sessile, the upper acutish; all leaves thick, densely canescent-puberulent, almost velvety and almost white; inflorescence a flat-topped corymbiform panicle; heads slightly nodding at first, but not secund on the branches, about $6 \mathrm{~mm}$. high; 
bracts yellowish with a greenish midrib, lanceolate and acute; achenes hirsute-strigose; ligules $3 \mathrm{~mm}$. long and nearly I $\mathrm{mm}$. wide.

This is closely related to Solidago nana, but differs in the narrower, lanceolate, and acute bracts. Its pubescence is usually also denser and whiter. Platt's specimens were labeled S. missouriensis v. montana Gray, to which it has no relationship, only resembling it a little in habit and in the narrow bracts.

Montana: Lima, Aug., I905, Rydbcrg 2804 (type, in herb. N. Y. Bot. Gard.); Hot Sulphur Springs, July 24, I87 I, $I$. $B$. Platt.

\section{Solidago Garrettii sp. nov.}

Perennial, with a creeping rootstock; stem $2-3 \mathrm{dm}$. high, sparingly puberulent or glabrous; leaves obovate-spatulate or the upper oval, entire or the lower toothed towards the apex, rather thin, triple-nerved, minutely and sparingly scabrous-puberulent or nearly glabrate, scabrous-ciliolate on the margins, $3-6 \mathrm{~cm}$. long; inflorescence more or less leafy, with a few secund branches; heads 5-6 mm. high; bracts lanceolate, acute, yellowish; ligules $2 \mathrm{~mm}$. long and fully $0.5 \mathrm{~mm}$. wide, golden yellow; achenes sparingly hirsute.

This species is related to Solidago mollis, S. radulina, and S. Radula. It differs from the first in the thinner, green, more decidedly obovate, and sparingly pubescent leaves, and the open, fewbranched panicle; from S. radulina in the larger, thinner leaves, the open and more leafy inflorescence, and the acute instead of obtuse bracts; and from S. Radnla in the thin, broad leaves, large, ample upper stem-leaves, the small inflorescence, and acute bracts.

Utah: Big Cottonwood Cañon, Aug. 28, i 906, A. O. Garrett $20+1$ (type, in herb. N. Y. Bot. Gard.); same locality and collector, Aug. 14, I905, 1608, and Aug. 5, 1905, 1587.

Wroming: Headwaters of Cliff Creek, Aug. 9-18, I900, C. C. Curtis.

Aster Richardsonil Sprengel, Syst. 3 : 528 . 1826 Aster montanns Richards. App. Frankl. Journ. 749. I823. Not A. montanus Nuttall. is Is.

Aster salsuginosus Less. Linnaea 6: 124. I 831 . Not A. salsuginosus Richards. 1823. 
Aster Richardsonil, var. gigantea Hook. Fl. Bor.-Am. 2: 7. I 834. Aster sibiricus giganteus A. Gray, Syn. Fl. I²: I 77. I 884. Aster gigantens Rydb. Bull. N. Y. Bot. Gard. 2: I84. I 90 I.

In describing Aster meritus, * Professor Aven Nelson evidently was correct in referring the name A. Richardsonii Spreng. to the subarctic species, characterized by the densely villous peduncles and involucres, which the writer has named $A$. gigantens. Richardson collected both, as shown by specimens in the Columbia University herbarium, and evidently included both under the name A. montanus, but his description applies only to the plant which Hooker afterwards named and described as A. Richardsonii, var. gigantea. There are, however, two points in Professor Nelson's discussion which are a little erroneous, ambiguous, and unclear, wherefore I add the following.

Professor Nelson has made the following remarks: "It is equally clear that $A$. Richardsonii is the name given to the $A$. montanus Nutt." If this was true, A. Richardsonii should be a synonym of $A$. sericeus montamus of the Southern States, and I received that impression when I read Professor Nelson's discussion. Evidently this was not Professor Nelson's intention. He evidently meant $A$. montants Richardson.

From Professor Nelson's discussion, one also gets the impression that $A$. meritus Nels. is not found in the subarctic regions, and is a plant of the Rocky Mountains only, but this is not the fact. The specimens regarded as A. Richardsonii by Hooker and cited in his Flora, as collected in the "barren country from lat. $64^{\circ}$ to the Arctic Seas" belong to A. meritus. Two of Richardson's specimens are in the herbarium of Columbia University. These cannot be distinguished from Nelson's nos. $233 \mathrm{f}$ and 6610 cited under $A$. meritus.

As said before, Richardson collected both plants. Hooker was the first one to distinguish them and made one the species, the other the variety of $A$. Richardsonii Spreng., as A. montants Richardson was not available on account of the older $A$. montamus Nutt., A. Richardsonii Spreng. being only a substitute for the former. Under ordinary circumstances, we should have followed Hooker's interpretation and used $A$. Richardsonii for the short-pubescent

* Bot. Gaz. 37 : 268. I 904. 
plant. The writer made such a ruling in $\mathbf{1 9 0 1}$, when he raised A. Richardsonii, var. gigantca to specific rank. But it is evident from Richardson's description that his $A$. montanus characterized rather the more villous-tomentose plant. Not only was Sprengel's A. Richardsonii based upon $A$. montanus Richardson, but his description also characterizes Hooker's var. gigantca.

The synonymy of the more southern plant is as follows:

Aster meritus A. Nelson, Bot. Gaz. 37 : 269. 1904 Aster montanus Richardson, App. Frankl. Journ. 32, in part (?). I 823 .

Aster Richardsonii Hook. Fl. Bor.-Am. 2: 7. I834. Not $A$. Richardsonii Spreng. I $\$ 26$.

Aster sibiricus A. Gray, Syn. Fl. I²: I 76. I 884 . Not A. sibiricus L. 1753 .

Aster Williamsii sp. nov.

Perennial, with cespitose rootstock; stems erect, about $3 \mathrm{dm}$. high, more or less villous; leaves oblanceolate, 3-10 cm. long, the lower petioled, the upper sessile, finely villous on both sides; heads few in a corymbiform inflorescence; involucres $8 \mathrm{~mm}$. high, I $\mathrm{cm}$. broad; bracts linear or lance-linear, acute, sparingly and finely villous on the back, slightly scarious-margined below, imbricate in 3 series; rays lilac, about I $\mathrm{cm}$. long; achenes sparingly and finely pilose; pappus tawny.

This species is somewhat intermediate between Aster andinus and $A$. meritus. From the former it differs in the taller and more slender, erect stem, the finely villous leaves, the shorter, more numerous and more pubescent involucral bracts; and from the latter in the narrower leaves, which are always entire, in the comparatively higher involucre, and the narrower bracts.

Wyoming: Dry hills, North Fork of Clear Creek, Big Horn Mountains, Aug. I 2, I 898, T. A. Williams (type, in herb. N. Y. Bot. Gard.); eastern slope of Big Horn Mountains, headwaters of Clear Creek and Crazy Woman River, July 20-Aug. I 5, I 900 , Truecely $3096 \mathrm{~A}$.

\section{Aster Macounii sp. nov.}

Perennial, with a rootstock; stem 3-6 dm. high, sparingly hispid-strigose, purple-tinged; leaves thick, oblanceolate or lanceolate, $2-8 \mathrm{~cm}$. long, hispidulous-ciliate, otherwise glabrous; in- 
florescence corymbiform; heads solitary on branches with lanceolate bract-like leaves; involucre 8 -IO $\mathrm{mm}$. high, I $2-\mathrm{I} 5 \mathrm{~mm}$. broad; bracts oblanceolate, squarrose, acute and spinulose-tipped, pubescent on the back and ciliate on the margins; rays $7-8 \mathrm{~mm}$. long, rose-colored; achenes strigose, pappus pinkish tawny.

This species combines the characters of two different groups of asters. It has the habit, leaves, middle-sized heads, pappus, and pubescence of the bracts of Aster Nelsonii, A. griseus, and their allies, but has the spinulose- or callus-tipped bracts and upper leaves of $A$. multiflorus, A commutatus, etc.

Canada: Old Wives Lake, Northwest Territory [Keewatin], July, I SSo, Jolu Macoun (type, in herb. Columbia Univ.).

\section{Aster Lindleyanus T. \& G. Fl. N. Am. 2: 122. I $\$ 4$ I} Aster paniculatus, var. ò Lindl. in Hook. Fl. Bor.-Am. 2 : 8. I 834.

Dr. Gray in his Synoptical Flora* stated: "The original of this species was raised by Gordon from Labrador seeds and has more extended inflorescence of smaller heads than is common in the wild plant." Dr. Gray evidently referred to Aster paniculatus Ait. ; $\dagger$ however, $A$. Lindliyanus was not based on $A$. paniculatus Ait., but principally on $A$. paniculatus, var. $o$ of Lindley in Hooker's Flora, although $A$. paniculatus of the same work was partly included. The var. $\delta$ was collected by Richardson near Slave Lake. Whether this plant is the same as $A$. paniculatus Ait. is very doubtful. Aster Lindleyanus has been reported from many stations in eastern North America as far south as Ohio, but the eastern plant differs somewhat from that of the Mackenzie basin and the northern Rockies in thinner more decidedly cordate basal leaves, and in its bracts with more conspicuous green tips. As these differences are hardly specific it is best to leave the eastern plant in A. Lindleyanus. In the northern Rockies and the Saskatchewan region there are found plants which have been referred to $A$. Lindleyanus but which the writer thinks are distinct. They can be distinguished as follows :

Basal leaf-blades cordate or broadly ovate; upper stem-leaves lanceolate; achenes glabrous.

Petioles, midribs, and usually also the stem pubescent with long white hairs.. A. II ilsonii.

* I $\mathrm{I}^{2} \mathrm{IS}_{2}$. ISS4.

+Hort. Kew. $3:$ 207. I7E9. 
Plant glabrous or sparingly short-pubescent.

A. Lindleyanus. Basal leaf-blades lanceolate; upper stem-leaves narrowly lanceolate or those of the inflorescence lance-linear.

Heads few; involucres $8-9 \mathrm{~mm}$. high ; rays about $15 \mathrm{~mm}$. long; achenes glabrous. A. Mai Callae.

Heads numerous; involucres 5-6 mm. high; rays 8-10 mm. long; achenes hispidulous-strigose A. Butleri.

\section{Aster Wilsonii sp. nov.}

Aster Lindlyanus $\beta$ T. \& G. F1. N. Am. 2: I 22. I 84 I.

Perennial, with a horizontal rootstock; stem 3-6 dm. high often purplish, more or less pubescent with long white, curved, somewhat deciduous hairs; basal leaves petioled; petioles 5-IO $\mathrm{cm}$. long, densely white-ciliate, together with the midrib; blades ovate or subcordate, $5-10 \mathrm{~cm}$. long, usually more or less hirsute on both sides, but in age glabrate, serrate, acuminate at the apex ; the lower stem-leaves similar; the upper lanceolate, sessile, subentire or those of the paniculate inflorescence narrowly lanceolate; involucre $7-8 \mathrm{~mm}$. high, scarcely I $\mathrm{cm}$. wide; bracts subulate, attenuate, with a green midrib which widens somewhat above the middle; rays $\$-10 \mathrm{~mm}$. long, bluish purple; pappus tawny; achenes glabrous.

This species is related to Aster Lindleyanus and may grade into it, but the typical specimens are very distinct, characterized by the long white hairs on the petioles, midribs, and often the stem, by the narrower upper leaves, the smaller heads, and the more ascending branches.

Britrsh Columbia: Armstrong, i904, E. Wilson 419 (type, in lierb. N. Y. Bot. Gard.); also 414,716 , and 393.

Alberta: Grattan Creek, Aug. I6, I 906, Macoun \& Horriot $77073 ;$ also Edmonton, Aug. 26, 1906, 77074.

Western Ontario: Fort Williams, Sept. 7, i $\$ 89$, Dr. and Mrs. N. L. Britton and Miss Millie Timmerman.

Mackenzie: Fort Resolution and Mackenzie River, IS6I-2, R. Kennicott.

\section{Aster MacCallae sp. nov.}

(?) Aster praceon Lindl. in Hook. Fl. Bor.-Am. 2: 9. I 834. Not $A$. praccox Willd. I 8 I 3 .

Perennial, with a horizontal rootstock; stems 3-6 dm. high, often purplish, glabrous up to the inflorescence, the branches of which are slightly pubescent in lines; lower leaves with winged 
petioles, which are slightly dilated and ciliate at the base; blades broadly lanceolate, $8-15 \mathrm{~cm}$. long, usually more or less serrate with ascending teeth, acute, glabrous or essentially so, hispidulousciliolate on the margins, rather thick; upper leaves lanceolate, sessile or those of the inflorescence lance-linear; inflorescence or its few principal branches racemiform; involucres $8-9 \mathrm{~mm}$. high, I $\mathrm{cm}$. broad; bracts subulate, glabrous, with linear-lanceolate green tips and green midveins below; rays blue or bluish purple, about $15 \mathrm{~mm}$. long; disk-flowers red-purple; achenes glabrous, at least in age.

This may be the A. praecox of Hooker's Flora Boreali-Americana; but the name is preoccupied by $A$. praccox Willd. It is related to $A$. Lindleyanus, but differs in the narrower leaves, of which the lower are neither cordate nor broadly ovate and those of the inflorescence are lance-linear, in the larger rays, which are about $15 \mathrm{~mm}$. long, and in the more ascending branches of the simpler inflorescence.

Alberta: Along streams, edge of woods on the Sulphur Mountain, Aug. I6, I 899, Mc Calla 2026 (type, in herb. N. Y. Bot. Gard.) ; roadside, Spray Avenue, Banff, Sept. I 8, I 899, McCalla 2027; below Wapta Lake, Aug. 6, 1904. J. Macoun 69480 ; gravelly banks, Second Lake, Rocky Mountain Park, Aug. 3, 1891, Macom 7770.

\section{Aster Butleri sp. nov.}

Perennial, with a horizontal rootstock; stem 4-IO dm. high, glabrous, slender ; lower leaves petioled; blades lanceolate, about I dm. long, distantly serrate with ascending teeth, hispidulousciliolate on the margins, otherwise glabrous; upper stem-leaves sessile, narrowly lanceolate, or those of the inflorescence lancelinear, entire; inflorescence paniculate with numerous heads; involucres 5-6 mm. high. about $8 \mathrm{~mm}$. wide; bracts subulate, with green midribs and narrowly lanceolate green tips, attenuate, glabrous; rays bluish purple, 8 -- IO $\mathrm{mm}$. long; achenes hispidulousstrigose.

This is related to the preceding, but differs from it in the large inflorescence with numerous small heads, and in the pubescent achenes. In the latter respect it differs from all the species of the Aster Lindleyenus group.

Montana: Gateway, Aug. I6, 1908, B. T. Butler $7+3$ (type, in herb. N. Y. Bot. Gard.); also 4.3. 
Alberta: Field, Aug. 28, I904, J. Macoun 65,85.

British Columbia: Flood plains of Columbia at Beavermouth, Aug. I 8, I905, C. H. Shaw 1165; Armstrong, I904, E. Wilson 422 (?); Emerald Lake, Aug. 30, I904, J. Macoun 65.788 (in part).

\section{Aster subsalignus sp. nov.}

Perennial, with a rootstock; stem glabrous throughout, 6-io dm. high ; leaves nearly erect, glabrous, glaucous, entire, clasping but scarcely auricled, 5-10 $\mathrm{cm}$. long, narrowly linear, 6-7 $\mathrm{mm}$. wide, or the lower narrowly linear-oblanceolate, or those of the branches lance-linear and reduced; inflorescence paniculate; involucres about $7 \mathrm{~mm}$. high and $8 \mathrm{~mm}$. wide; bracts linear or the outer linear-lanceolate, glabrous, acute, with a green midrib and narrowly lanceolate green tip, or the outer nearly wholly green; rays bluish or bluish purple, about $8 \mathrm{~mm}$. long; achenes glabrous; pappus tawny; disk-flowers dark, red-purple.

This is related to Aster Geyeri, but differs in the narrow leaves, scarcely auricled at the base; they are also more erect or strongly ascending and wholly entire. It stands in the same relation to Aster Geyeri as $A$. virgatus and $A$. concimms do to $A$. laceis. It has the narrow green tips of the bracts found in $A$. Geyeri but not in the others. The spreading branches of the inflorescence with their very small bract-like leaves characteristic of the three are not found in this species, and scarcely in A. Geyeri.

Colorado: Glenwood Springs, Aug. i 8, igo6, G. E. Osterhout 3397 (type, in herb. N. Y. Bot. Gard.).

Aster Wootonil Greene, Leaflets I : I 46.1905.

Aster hespcrius IVootonii Greene, Bull. Torrey Club 25: I I 9. I 898.

In raising the variety to specific rank, Dr. Greene stated: "Mr. Baker's n. 8I from near Gunnison represents well that of Mr. Wooton's distribution from New Mexico, and I judge the form worthy of specific rank." In the herbarium of the New York Botanical Garden there are duplicates of both Baker 817 and IVooton 329, the latter the type of A. hesperins Wootonii. The two are not the same. The latter has the subequal loose bracts and entire leaves of $H$. hesperius, and is best referred to that species; in fact it matches very closely Wright I $_{5} 8$, which number I take to be the type of $A$. hesperius. In the former the bracts are well 
imbricated in 3 or 4 unequal series and the leaves are distinctly dentate and it agrees in every respect with specimens of $A$. paniculatus. In the writer's judgment it is nothing but the not uncommon pinkish- or light lilac-flowered form of that species.

\section{Aster roseolus sp. nov.}

Perennial, with a horizontal rootstock; stem 3-5 dm. high, often purple-tinged, glabrous, pilose in lines on the branches; leaves linear, glabrous or nearly so, scabrous-ciliolate on the margins, 5-10 cm. long, 5-1 $2 \mathrm{~mm}$. wide, inflorescence paniculate but the heads usually few; involucres about $5 \mathrm{~mm}$. high, 8-9 $\mathrm{mm}$. broad; bracts glabrous, oblong or oblong-linear, acute, in about 3 series, often wholly green, with broadly lanceolate tips; rays rose-colored, 5-6 mm. long; achenes hispidulous-strigose.

This species is related to Aster longulus and A. Tradescanti, but differs in the bright rose-colored rays, the less numerous heads, simpler plant, and broader leaves. It grows in meadows at an altitude of $1500-2000 \mathrm{~m}$.

Montaxa: Melrose, I895, Rydberg 2817 (type, in herb. N. Y. Bot. Gard.) ; Lima, Aug. 5, I $\$ 95$, Ry'dberg; Logan, July 28, I 895, Shear 5253; Emigrant Gulch, Aug. 23, I 897, Rydlberg \& Bessey 5121 .

Aster Franklinianus Rydb. nom. nov.

Aster salicifolius Richardson, in Frankl. Journ. 748. I823. Not Aster salicifolizes Lam. $\mathrm{I}_{7} 8_{3}$.

Aster laxiflorus Lindl. in Hook. Fl. Bor.-Am. 2 : Io, mainly. 1834.

Not Aster laxiflorus Nees. I 833.

Aster laxiflon borealis T. \& G. Fl. N. Am. 2 : I 3 \&, in part. I 84 I.

Dr. Gray referred this to Aster juncens but it is more closely related to $A$. longifolins, having the subequal bracts and the dark green leaves of that species, but the bracts are narrower and strictly appressed and the leaves are very narrowly linear and as far as I know perfectly entire. It is A. lariflonts of Lindley mainiy but he included a specimen of Mrs. Percival's from eastem Canada (apparently of $A$. junceus), and this very specimen is the type of A. laxiflorus borealis T. \& G. Otherwise the species would have become $A$. borealis Prov., as Provancher raised the variety to specific rank. He also characterized the eastern plant. The following specimens belong to A. Franklinianus: 
Mackenzie Terr. : Slave Lake, Richardson; Wooded Country, Richardson; Mackenzie River I86I-2, Kennicott; Fort Resolution, I $86 \mathrm{I}-2$, Onion, Kemicott \& Hardisty.

Saskatchewan: i 857-8, E. Bourgeau.

Montana: Gateway, Aug. I7, i908, Butler 477,473 , and 434: Helena, Aug. I6, I 892, Kelsey.

\section{Aster junciformis sp. nov.}

Aster junceus Coulter, Man. I6 $\mathrm{I}$, in part. I $\$ 85$.

Aster longulus Rydb. F1. Colo. 356. I 906. Not Aster longulus

Sheldon. I 894 .

Perennial, with a slender horizontal rootstock; stem slender, 3-5 dm. high, simple below, with pilose lines or wholly glabrous below; leaves narrowly linear, 4-8 cm. long, 2-4 mm. wide, scabrous-ciliolate on the margins, light green; inflorescence corymbiform, with the rather few heads terminating the stem and leafy branches; involucres about $6 \mathrm{~mm}$. high, about I $\mathrm{cm}$. broad; bracts glabrous, erose-ciliolate; the inner bracts linear, acute, with green midrib and green lanceolate tips, the outer oblong or somewhat oblanceolate, obtuse, and often almost wholly green; rays white, $6-8 \mathrm{~mm}$. long; achenes sparingly hairy or nearly glabrous.

This has been known under the name of $A$. junceus in nearly all western botany, but differs in the always white rays, the subcorymbose inflorescence, and the broader bracts. In the eastern $A$. junceus the bracts are narrowly linear or linear-subulate and the rays are always described as light purple.

Montana: East Gallatin Swamps, July 24, I 896, Flodman 833 (type, in herb. N. Y. Bot. Gard.).

North Dakota: Butte, Aug. 5, I906, Luncll.

South Dakota: Custer, Aug. I 5, i 892, Rydberg 775.

Colorado: West Cliff, i 896, Shear 3763, 3817 ; Twin Lakes, Clements 388 and 379 .

Minnesota: Minneapolis, I89I, G. B. Aiton; Hennepin County, i 890, Sandberg.

Saskatchewan: Cypress Hills, is8o, J. Macoun; Lake Manitou, July 23, 1906, Macoun \& Herriot 77052; also Bear Hills, July 29, $7705 \mathrm{I}$.

Alberta: Five miles west of Battle River, i 906, Macoun \& Herriot 77053 ; also Grattan Creek, Aug. I6, 77050. 
British Columbia: Swamps at Gold Stream, Aug. 3, 1905 , Share IoSI.

\section{Aster eriocaulis sp. nov.}

Perennial, with a rootstock; stems about $S \mathrm{dm}$. high, leafy, more or less villous, especially above, purplish ; stem-leaves lanceolate, $3-7 \mathrm{~cm}$. long, ciliolate on the margins, otherwise glabrous, more or less auriculate-clasping; inflorescence a round-topped panicle; involucres $8 \mathrm{~mm}$. high, 10-1 $2 \mathrm{~mm}$. broad; bracts linear, acute, more or less ciliate, in 2-3 series, with green midrib and lanceolate green tips, or the outermost almost wholly green; rays purple, 8 -IO inm. long; achenes sparingly hirsute-strigose.

This species is perhaps most nearly related to Aster lonchophyllus but differs in the longer villous pubescence of the stem, the more or less clasping leaves, less imbricated and not purpletinged bracts. In general habit and leaf-form it resembles somewhat $A$. Jessicae, but differs in the glabrous leaves and narrower glabrous bracts.

I DAно: Mountain meadows, valley of 'Traille River, Kootenai County, Aug. 9, I892, Sandberg, MacDougal, \& Heller 877 (type, in herb. N. Y. Bot. Gard.).

\section{Aster subcaudatus sp. nov.}

Perennial, with a creeping rootstock; stem 3-6 dm. high, more or less purple, glabrous below, with villous or pilose peduncles and lines above; lower leaves petioled, $\mathrm{I}-2 \mathrm{dm}$. long; blades lanceolate, 4-IO $\mathrm{cm}$. long, often sparingly dentate with ascending sharp teeth, dark green, glabrous, ciliolate on the margins; upper leaves sessile, linear-lanceolate, attenuate; panicle open, with rather few heads; involucres 7-S mm. high, about I $2 \mathrm{~mm}$. broad; bracts linearsubulate, in 2 or 3 series, but nearly of the same length, attenuate, the inner almost caudate, only slightly white-margined below; rays purple, about $\mathrm{I} \mathrm{cm}$. long; achenes nearly glabrous.

The type was determined as Aster Fremontii (?), but is evidently distinct; differing from that species as well as its relatives, A. occidentalis, $A$. ciliomarginatus, etc., in the narrow attenuate bracts. It is also a taller plant with a tendency to having dentate leaves. If one should use Piper's key in his Flora of Washington it would fall under $A$. occidentalis Nutt. The latter, as described in Gray's Synoptical Flora, has well-imbricated bracts, of which the outer are shorter; but neither the present species nor Gray's 
description agrees with the original diagnosis of Aster occidentalis. It may be that the plant described by Gray should receive a new name. I have not seen Nuttall's type and shall await the chance of seeing it before making such a change.

Alberta: Laggan, Lake Louise region, alt. 1950 m., Aug. 23, 1902, Rosendahl Io\&g (type, in herb. N. Y. Bot. Gard.); also $106 r$.

Idaho: Priest Lake, Aug. i 901 , Piper 4120, 3723, 3682.

Montana: Rost Lake, July I 5-16, I90 I, MacDougal 66 I; Big Fork, July 24, I908, Butler 697.

\section{Aster Umbachii sp. nov.}

Perennial, with a slender rootstock; stem slender, erect, simple, glabrous below, sparingly pilose above, $3-5 \mathrm{dm}$. high ; lower leaves about I dm. long, petioled; blades broadly oblanceolate or lanceolate, dark green, more or less crenate, acute, glabrous, ciliolate on the margins; middle stem-leaves similar but the petioles with dilated, clasping bases; upper stem-leaves lanceolate, sessile; heads $\mathrm{I}-3$ in a corymbiform inflorescence; involucres $8-9 \mathrm{~mm}$. high, I $2-15 \mathrm{~mm}$. broad; bracts in about 2 series, oblong-oblanceolate, acute, not very unlike in length, glabrous, slightly ciliate, with broad lanceolate green tips; rays dark bluish-purple, fully $\mathrm{I} \mathrm{cm}$. long; achenes almost glabrous; pappus tawny.

This species is most nearly related to Aster ciliomarginatus Rydb. (A. glastifolius Greene); but differs in the dark green and mostly crenate leaves and broader and more conspicuously greentipped bracts. In $A$. ciliomarginatus the leaves are light green, more or less glaucous and entire.

Montana: River bank, Lake McDonald, Aug. 20, I9o I, Umbach 275 (type, in herb. N. Y. Bot. Gard.); also 267.

\section{Aster Mearnsii sp. nov.}

Perennial, with a rootstock; stem 3-10 dm. high, leafy, branched, glabrous below, sparingly pubescent above; leaves linear, 5-10 cm. long, ascending-spreading, sessile, entire, glabrous and smooth beneath, scabrous or glabrate above, scabrousciliolate on the margins; inflorescence large, paniculate, leafy; heads numerous, disk about $8 \mathrm{~mm}$. high and barely $\mathrm{I} \mathrm{cm}$. broad; bracts oblanceolate, acute, some longer than the disk; rays about $8 \mathrm{~mm}$. long, white or pinkish; achenes strigulose. 
This species is intermediate between $A$. oreganus Nutt. and $A$. proximus Greene. It has often been mistaken for the former, as it has the same narrow leaves and general habit, but differs in the involucre, which is essentially that of $A$. proximus, consisting of foliaceous oblanceolate outer bracts and shorter merely greentipped inner ones; but the bracts are less squamose and the leaves much narrower, darker in color, and firmer.

Wyoning: Mammoth Hot Springs, Oct. I I, I902, Mearns 4806 (type, in herb. N. Y. Bot. Gard.); same locality and collector, Aug. 2, $273 I$ (?); Aug. 17, 3390; Gardiner River, Sept. I I, I902, Mearns 3915 ; Mt. Leidy, Aug., I897, Trvecdy' 561.

Montana: Bozeman, Aug. 24, I 892 , Kelsey' ; near Rost Lake, Aug., I90I, MacDongal $887 a$; Belt River, Oct., ISs $3, F$. IV. Anderson $3803 \%$.

Saskatchewan: Cypress Hills, Aug. 5, i 850, J. Macom 7938.

Alberta: Crows Nest Pass, July 3 I, I 897, J. Maconn 23076 ; overflow from Middle Spring, Banff, July I6, I 899, Sanson 22 7 ; Banff, Sept. 24, I 904, J. Macoun $65+86$.

\section{Aster phyllodes sp. nov.}

Aster foliaceus Britt. \& Brown, Ill. Fl. 3: 37 I (excluding figure). I 898. Not $A$. foliacens Lindl. I 835 .

The plant described in Britton \& Brown's Illustrated Flora is not Aster foliaceus Lindl. of the Northwest, which is a simple plant, with I-3 large heads and narrowly linear-lanceolate leaves. The figure in the Illustrated Flora was not drawn from my Kimball County plant as stated there. It probably does not represent an Aster at all. Evidently some illustrations have been interchanged. The Nebraska plant is nearer to $A$. puniceus in habit than to $A$. foliacens, although the pubescence and bracts approach the latter. It is more closely related to $A$. proximus Greene, but differs in the more or less toothed and more distinctly auriculate, darker leaves.

The only specimens seen are the following :

Nebraska : Lodge Pole Creek, near Kimball, Kimball County, Aug. I 2, I 89 I, Rydberg I6 5 (type).

Colorado: West of Livermore, Larimer Co., Aug. 26, i 896 , Osterhout 2953. 


\section{Xylorrhiza lanceolata sp. nov.}

Shrubby perennial, with white stems; branches more or less villous; leaves lanceolate, 4-6 cm. long, more or less villous, especially when young, reticulately veined, dentate with spinulose-subulate teeth, which are directed forward and then falcately curved outward; peduncles I-2 dm. long; involucre fully I $\mathrm{cm}$. high, I 5-20 mm. broad; bracts lance-subulate, villous and slightly glandular, attenuate and spinulose-tipped, the inner about equaling the disk, a few of the outer ones often longer and squarrose; rays purple, about $2 \mathrm{~cm}$. long; achenes hirsute; pappus brownish tawny.

This is related to Xylorrliza tortifolia (T. \& G.) Greene, but differs in the broader leaves and their teeth. In $X$. tortifolia, the body of the leaves is linear or narrowly linear-lanceolate, the teeth are shorter and broader and diverge at almost right angles to the midrib; the outer bracts are neither elongated nor spreading.

Utan : St. George, I 877 , Palmer 208 (type, in herb. Columbia Univ. and N. Y. Bot. Gard.); South Utah, i 875, J. E. Johnson; I 874, C. C. Parry gI (?).

Unamia alba (Nutt.) Rydb. comb. nov.

Inula (Chry'sopsis) alba Nutt. Gen. 2: I 52. I 8 I 8.

Aster albus Eat. Man. Bot. I27. I 829. Not Aster albus Willd. I 826.

Docllingeria ptamicoides Nees, Gen. \& Sp. Ast. 183. I833. Chrysopsis alha Nutt.; Nees, Gen. \& Sp. Ast. I $8_{3}$, as a synonym. I 833 .

Diplopappus albns Hook. Fl. Bor.-Am. 2: 21.1834. Heliastrum album DC. Prod. 5: 264. I 836.

Encephalus albus Nutt. Trans. Am. Phil. Soc. II. 7 : 299. I 840. Aster ptamicoides T. \& G. Fl. N. Am. 2: I60. I84I.

Unamia ptarmicoidis Greene, Leaflets I : 6. 1903.

From the various disposition which has been made of this plant, it is evident that the species has been out of place in all the genera to which it had been referred. I therefore agree with Dr. Greene that it represents the type of a distinct genus. Unfortunately Dr. Greene did not use the first available specific name, which is here accepted. Usually the original publication is given as Chrysopsis alba Nutt. Gen. 2: I52. I 8 I8. In that work 
Nuttall, however, did not publish it as Chrysopsis but as Imula, Chrysopsis being only a subgeneric name. The Kew Index cites DC. Prod. (l.c.) as the place of publication of the combination Chrysopsis alba, but it appeared at least one year earlier in Nees's Genera. In describing the genus Unamia, Dr. Greene stated: "And that the bristles of the pappus are visibly dilated at the tip is a character, here for the first time noted." This appears to be not quite the fact, for we find in the sectional description in Torrey \& Gray's Flora: "the longer bristles clavellate-thickened at the apex;" and in Gray's Synoptical Flora: "pappus white, of rather rigid bristles, longer ones manifestly clavellate at tip." The expressions used by these authors are even more characteristic than Greene's description, for the pappus-bristles are by no means flattened, as the word "dilated" usually implies.

Unamia lutescens (Lindl.) Rydb. comb. nov.

Diplopappus albus $\beta$ Hook. F1. Bor-Am 2: 2 I. I 834.

Diplopappus lutescens Lindl.; DC. Prod. $5: 278.1834$. Aster lutescens T. \& G. Fl. N. Am. 2 : I60. I $84 \mathrm{I}$.

Aster ptamicoides lntescens A. Gray, Syn. Fl. I² : I99. I 888.

The color of the rays, yellow or ochroleucous as it has been described, is probably of little value specifically and may vary; but in the specimens seen the bracts are "very obtuse" as described in Torrey \& Gray's Flora, the inner even rounded at the apex and therefore different from those of the typical $U$. alba. The range of this species seems to be more restricted than that of $U$. alba, extending from Illinois and Wisconsin to Saskatchewan.

Doellingeria pubens (Gray) Rydb. sp. nov. Aster umbellatus pubens A. Gray, Syn. Fl. I²: I $97 . \quad$ I 884.

This I think specifically distinct from D. umbellata (Mill.) Nees.

Machaeranthera angustifolia nom. nov.

Machaeranthore lincaris Rydb. Mem. N. Y. Bot. Gard. I : 398. I900. Not M. lintaris Greene. I 897 .

\section{Machaeranthera leptophylla sp. nov.}

Biennial, cespitose at the base; stems slender, simple up to the inflorescence, green, sparingly puberulent, 3-5 dm. high; 
lower leaves petioled, $2-5 \mathrm{~cm}$. long, finely cinereous-puberulent, in age sparingly so; blades spatulate or oblanceolate, entire or sparingly dentate, thin; upper leaves linear-oblanceolate or linear, entire; branches strongly ascending; involucre turbinate, $8 \mathrm{~mm}$. high, 8 -Io mm. broad; bracts in 6 or 7 series, linear, acute; green tip short, glandular-puberulent, much shorter than the chartaceous portion, only slightly squarrose; rays rose-purple, about $8 \mathrm{~mm}$. long; achenes finely strigose.

This agrees fairly well with the description of $M$. laetevirens Greene, except that the plant is evidently cinereous-puberulent.

Utah: Logan, Aug. 9, I 895, Rydberg (type, in herb. N. Y. Bot. Gard.).

New York Botanical Garden. 
CONTRIBUTIONS FRON THE NEW YORK BOTANICAL GARDEN-No. 134

\section{STUDIES ON THE ROCKY MOUNTAIN FLORA-XXII}

By PER AXEL RYDBERG

NEW YORK

1910 



\title{
Studies on the Rocky Mountain flora - XXII
}

\author{
Per AXel Rydberg
}

\section{ERIGERON}

Just as the writer resumed his work on Erigeron, Coulter and Nelson's New Manual of Botany of the Central Rocky Mountains came out. From all evidences it is apparent that most of the work in connection with the new book has been done by Professor Aven Nelson, of the University of Wyoming. The work is a great improvement on the old Coulter's Manual and it is perhaps the best manual that has been put out treating on the botany of the West. It has, however, many features to which the present writer is unwilling to subscribe. Dr. B. L. Robinson in his recent review* has pointed out the unevenness in the nomenclature, in that the Vienna Code has been followed in some cases, in other cases not. But this is easy for me to understand, for Professor Nelson has until lately followed the "Rochester Code," and it is not so easy to change the nomenclature of one's thinking and writing and make it self-consistent.

A few years ago, when Professor Nelson published his "New Plants from Wyoming" in the Bulletin of the Torrey Botanical Club, he was about as "radical" as the present writer, and had about the same limitation of species. If we should judge from the New Manual, his conception of a species seems to have changed considerably, as seen from the number of specific names reduced to synonymy. Whether this change of attitude has slowly grown upon Professor Nelson or is due to influence from his collaborators, I can not tell. There is, however, one feature in this connection that seems to me somewhat unexplainable. Professor Cockerell in his review $\dagger$ of the book stated:

"I have had the curiosity to count the number of species admitted as valid in the new manual, which were undescribed at the time of the publication of the first edition in 1885 . They

*Rhodora 12: I3-I6. Ja I9Io.

†Science II. 31: 302. I910. 
number 787 , about 28 per cent. of the whole flora . . Of the 787 , no less than 244 were proposed by Professor Aven Nelson himself; 152 are by Dr. Rydberg, of the New York Botanical Garden, and I 48 by Dr. E. L. Greene, now of the U. S. National Museum, but at one time a resident of Colorado. . . The number of species accepted as valid is 2,733 , while no less than I,788 specific names are rejected as synonyms or insufficiently known. Many of those latter were proposed by Professor Nelson himself, more by Rydberg and Greene."

Why should more (nearly 66 per cent. more) of Professor Nelson's species be acceptable and "many more" of Dr. Greene's and my own be reduced to synonymy? Not counting the time before the first edition of the Manual of the Rocky Mountain Region appeared, Dr. Greene published on the flora for ten years, between I 885 and I895, when practically no work was done by Professor Nelson or myself, and he has published at least twice as many new species from the Rocky Mountain Region as Professor Nelson. Both Dr. Greene and myself have had access to much larger herbaria and libraries than has Professor Nelson, and have seen specimens from the Rockies which he has not seen. The New Manual, therefore, seems to show a decided partiality for the species proposed by Professor Nelson himself. Some partiality would be expected, but in this case it seems out of proportion. Professor Nelson is a very conscientious worker, and it would be unjust to claim that this imparity in treatment was intentional. The main cause, I think, is that he had not seen the types or authentic material of many of the species so reduced. He knew his own species, but not all of those proposed by other botanists. It was not fair to them simply to reduce their species to synonymy, if such species were unknown. If question-marks had been added to show probable synonymy, the matter would have been improved considerably. There are many cases in which I am confident that Professor Nelson had no specimens illustrating species reduced to synonymy.

Some years ago I spent considerable time on Erigeron as repreented in the Rockies and had seen the type or a duplicate of the type of nearly every species described. In fact, I knew the genus (one of the largest in the region) as well as any of the composite genera. That I should have resumed the work on that genus just 
as I received the New Manual was a curious coincidence. 'There is scarcely a genus, in which I, from my standpoint, could pick out so many flaws of treatment in the New Manual. This paper, therefore, has become an adverse criticism of the New Manual more so than I had intended or wished.

The way in which the authors of the New Manual have determined what species should be regarded as good and which names should be reduced to synonymy, is rather interesting. Many of Dr. Greene's species and my own have been reduced, while others of older authors and of Nelson's have been kept up. The uneven treatment, as I have said before, is due in some cases to the fact that the authors had not seen the types. Erigeron lapiluteus A. Nels. (E. yellowstonensis A. Nels.) is regarded as distinct from the exceedingly close E. droebachensis, and E. trifidus from E.compositus; while E. jucundus Greene is made a variety of the little related E. acris L., E. multifidus Rydb. is made a synonym of E. compositus, and E. flabellifolius Rydb. one of E. trifidus. The fact is that Erigeron multifidus $\mathrm{Ry} d \mathrm{~b}$. is much closer to E. trifidus than to E. compositus and grades directly into it. The typical E. compositus is rare and more distinct. I think, though, that they are all three forms of one species, while E. flabellifolius has nothing to do with either. It has a stoloniferous rootstock instead of a cespitose caudex and the leaves do not at all suggest $E$. trifidus but are more like those of Ranunculus Eschscholt:ii in outline.

Erigeron conspicuts Rydb. is made a synonym of E. speciosus DC. In the herbarium of Columbia University there is a duplicate of the type of E. speciosus DC., collected by Douglas. In this the stem and leaves are perfectly glabrous except the ciliate margins of the latter and the plant is closely related to $E$. macranthus Nutt., perhaps not distinct. E. conspicuus Rydb. is considerably hairy on both the stem and the leaves, and if reduced should be included in E. subtrinervis Rydb. rather than in $E$. speciosus. If the type of E. conspicuns were placed before a student and he used the key of the New Manual, it would be named E. subtrinervis.

Both Erigeron salicinus Rydb. and E. platyphyllus Greene are made synonyms of E. macranthus Nutt. While the first is 
closely related to that species, the second can scarcely be said to be so. Its habit, foliage, and pubescence are those of E. subtrinervis and only the involucral bracts are those of E. macranthus.

Erigeron incanescens Rydb., E. eximius Greene, and E. viscidus Rydb. are all made synonyms of E. formosissimus Greene. The first has a hirsute involucre and is related to E. subtrinervis; the third and fourth have glandular-puberulent involucre and may well be united. The authors have included Erigeron formosissimus also among the annuals or biennials, though it is evidently a perennial. The third has also glandular involucres, but is almost glabrous and should have been included in E. asper of the New Manual if reduced.

Erigeron glabellus Nutt., E. consobrinus Greene, E. oblanceolatus Rydb., and E. Earlei Rydb. are made synonyms of $E$. asper Nutt. E. glabellus and E. Earlei have perennial branched rootstock; the rest are biennial with tap-roots. They may perhaps sometimes be perennial, but there is no evidence of a branched rootstock. In E. glabellus the pubescence is spreading, in $E$. Earlei closely appressed.

Erigeron nematophyllus Rybd. is made a synonym of $E$. Eatonii A. Gray. The latter is not uncommon in Utah, where I have collected it myself. A duplicate of the type is in the Columbia University herbarium. It has narrowly linear-oblanceolate, distinctly triple-nerved basal leaves and decidedly flattened achenes. In E. nematophyllus the leaves are almost filiform and strictly one-nerved. Evidently Professor Nelson did not know E. Eatonii, for what he has distributed under that name is E. nematophyllus. The only specimens of the real E. Eatonii from Wyoming in our collections are from Wind River Mountains, and there collected by Merrill \& Wilcox and by Tweedy.

Erigeron curvifolius Piper is made a synonym of E. luteus A. Nels., although they are not closely related, the former being a coarsely hirsute plant, with leafy stem, the latter being a closely strigose subacaulescent plant. It would have been much better to reduce Nelson's own E. luteus to a synonym of E. peucephyllus A. Gray, to which it is closely related.

Erigeron Parryi Canby \& Rose, E. Scribneri Canby, and E. 
vetensis $\mathrm{Rydb}$., are made synonyms of E. radicatus. E. vetensis has an involucre of two series of subequal bracts, a simple pappus, consisting of bristles only, of which some are occasionally shorter. Both E. Parryi and E. Scribneri have 3 or 4 series of bracts, more imbricated and more flat, obovate-cuneate achenes and double pappus, the outer squamellate. Both are closely related to $E$. montanensis, which Nelson refers to Wyomingia.

Erigeron yellowstonensis A. Nels. Bot. Gaz. 31: 198. igoo Erigeron lapiluteus A. Nels.; Coult. \& Nels. New Man. Cent. Rocky Mts. 530. I909.

Professor Nelson states in the New Manual that Erigeron yellowstonensis is a name to be rejected, but he does not state on what ground, probably because it is of barbaric origin, regarded from a Latin standpoint. But what should be said about E. lapiluteus which is to replace it? Is it Latin? It is probably meant to be derived from lapis, stone, and luteus, yellow. In making a compound word the Romans usually took the stem of the first word and connected it with the second word by means of the connecting vowel $i$. The stem of lapis is lapid, as seen from the genitive lapidis. The proper form would then have been lapidiluteus. But what would that have meant? Usually the Romans placed the modifying word first (not always though), as is done in the English, and the name Erigeron lapidiluteus would mean the "stone-yellow fleabane." The intention was evidently to name it the "fleabane of the yellow stone." The only proper way to express this would be by the specific name lapidis lutei or, as it has become the custom in botany to capitalize proper names, and use a hyphen when the specific name consists of more than one word, Lapidis-lutei or Lutei-lapidis, as the order of the adjective is indifferent.

Professor Nelson states also that "the variety droebachensis [of E. acris] probably does not occur in our range." Erigeron droebachensis Muell., is as common in the Rockies as is E. yellowstonensis. The question is whether they should be kept apart specifically. The only difference I can find is that the latter is more hairy with shorter hairs, decidedly glandular-puberulent in the inflorescence, and the involucre is more decidedly hirsute. In the 
herbarium of the New York Botanical Garden there are several Scandinavian specimens of E. droebachensis Mueller (E. Muelleri Lund.), one from the vicinity of Christiania; the town of Droebach is only a short distance south of Christiania. These specimens are perfectly matched by specimens from Quebec, Subarctic America, Yukon, Canadian Rockies, and Colorado. Erigeron acris L., which is included in the New Manual, is on the contrary not found in America. It differs from all the North American species of the group, except the very rare E. alpinus, in having villous rather than hirsute or puberulent involucres.

Erigerox commixtus Greene, Pittonia 5: 58. 1902 E. cinereus A. Gray, Mem. Am. Acad. 4: 68. I849. Not E.cinereus H. \& A. $\quad 1836$.

E. colo-mexicanus A. Nels.; Coult. \& Nels. New Man. Cent. Rocky Mts. 529. 1909 .

Another specific name proposed by Professor Nelson, Erigeron colo-mexicanus, to replace the untenable E. cinereus A. Gray, is in my opinion rather distasteful. Fortunately I do not need to use the name, as the same species has been described by Dr. Greene under the name E. commixtus.

\section{ERigeron uniflorus L. Sp. Pl. 864. I753}

The typical form of this species is, so far as I know, not found on this continent. As Dr. Greene has pointed out, the European species is characterized by narrow erect or ascending rays. ' This character is found also in Erigeron pulchellus unalaschkensis DC. Prod. 5: 287 (E.uniflorus pulchellus Fries), which is not uncommon in America from Greenland to Labrador, Montana, and Alaska. In the latter the involucre is more or less turbinate, tapering into the enlarged end of the stem, and black-hairy, while in the typical E. uniflorus the involucres are hemispheric, and more or less whitehairy, and the stem is not thickened. Whether the two are specifically distinct or not is hard to tell. In Greenland both forms are found. If the variety is to be regarded as a species, Erigeron unalaschkensis (DC.) is the only available name, as E. pulchellus has been used by Michaux for another species.

The plant referred to Erigeron uniflorus in the Flora of Colorado 
is distinct and easily distinguished by its broad spreading rays. The name it should bear is E. simplex Greene. E. lencotrichus Rydb. is a more luxuriant form of the same. It is questionable if E. melanocephalus Nelson should not be included in it also, differing only in the blackish hairiness of the involucre.

Professor Piper in his flora of Washington has transferred the name Erigeron filifolius (Hook.) Nutt. to what was usually known under the name E. peucephyllus A. Gray. This change was wholly unwarranted, I think. There are duplicates of the types of both Diplopappus filifolius Hook. and Erigeron filifolius Nutt. in the Columbia University herbarium, and they both belong to the species described under the latter name in Gray's Synoptical Flora. What probably led Professor Piper astray was the following words in Hooker's description: "radiis flavescentibus." This does not necessarily mean that the plant has yellow rays. The original meaning of flarescens is turning (light) yellow. White flowers often turn yellowish in drying. As E. filifolius has white as well as violet rays, the rays are often yellowish in drying.

\section{WYOMINGIA}

As instituted in the New Manual this genus is very unsatisfactory, for if the more imbricated bracts with thickened backs are made the distinguishing character separating IVyomingia from Erigeron, then E. Garrettii A. Nels., E. tener A. Gray, E. Tweedyi Canby, E. caespitosus Nutt., E. nevadensis A. Gray, E. luteus A. Nels., E. filifolius Nutt., etc., should be included in Wyomingia. If the achenes should count for anything, E. montanensis and perhaps E. canus could not very well be included. The former has flattened achenes and the latter has glabrous and 8-ro-nerved achenes, while the rest of the genus has pubescent and $4-5$-angled achenes. It would be desirable to take out Wyomingia as a genus, for the plants fit rather poorly in Erigeron, but the question is where to draw the line. The species with flattened achenes with the involucre of Wyomingia would constitute a rather natural genus, but such species as E. utahensis destroy the distinctness.

\section{ANTENinaria}

A footnote under this genus in the New Manual states: "The treatment of this genus is largely an adaptation of Professor Elias 
Nelson's clear and discriminating revision of a large part of the genus." While Elias Nelson's treatment is in the main excellent, the writer is inclined to take some exceptions to this as well as to that of the New Manual. In the latter we find the following key of the $A$. alpina group:

Stems very slender, $2-7 \mathrm{~cm}$. high.

I. A. media.

Stems medium, 8-15 cm. high.

Leaves broadly spatulate; involucres $6-7 \mathrm{~mm}$. high.

2. A. fusca.

Leaves spatulate-oblanceolate; involucres about $5 \mathrm{~mm}$. high.

Leaves obtuse, tomentose.

3. A. reflexa.

Leaves acute, canescent.

4. A. umbrinella.

The only species that can be separated out by this key is Antennaria fusca. The key is not workable otherwise. A. media is often $8-10 \mathrm{~cm}$. high and $A$. umbrinella and $A$. reflexa are of ten less than $7 \mathrm{~cm}$. high. In both $A$. reflexa and $A$. umbrinella as limited in the New Manual and in E. Nelson's paper are the leaves both tomentose and canescent, as the one word indicates the kind of pubescence, and the other word the color of the same. E. Nelson merges A. mucronata E. Nels. in A. umbrinella Rydb. and A. flavescens $\mathrm{Rydb}$. in $A$. reflexa $\mathrm{E}$. Nels. Under the latter he makes the following statement: "In describing A. umbrinella Dr. Rydberg confused two specics ... The male and female plants of his type are of different species. One of these he later named A. flavescens, and the staminate plants of this and his A.umbrinella are identical." It is true that there were a few staminate specimens of Antennaria flavescens mixed in the type collection of $A$. umbrinella, but there were also a few staminate specimens of the latter. I saw the plant in field, as I was present when Professor J. Flodman collected the type, but we did not then notice that another species was growing with it. The staminate plants of A. umbrinella, $A$. flavescens, and $A$. reflexa are very much alike and hard to separate. A. flavescens has somewhat narrower bracts and the leaves are usually more or less yellowish and with a very fine and closely appressed silky tomentum. The difference between the staminate plants of $A$. umbrinella and $A$. reflexa I can not describe. The staminate plant of $A$. mucronata is very different, more resembling that of $A$. media, but the inner bracts are nearly white, the outer very dark brown. E. Nelson states that typical staminate plants are unknown. The only ones I 
have seen and which I think belong here are Goodding 430, from Ten Sleep Lakes, Big Horn County, Wyoming, and labeled $A$. nardina.

The pistillate plants of the four species are easier to distinguish. Antennaria mucronata has very dark greenish brown bracts, as dark as those of $A$. media but the inner bracts are oval, obtuse or even rounded at the apex, and inclined to be white-tipped. The leaves of the rosettes are narrower and with more appressed pubescence. The bracts of the pistillate head of $A$. umbrinella have about the same shape as those of $A$. mucronata but are from light umber-brown to almost yellowish, and of the same color throughout. The leaves are much shorter and broader, like those of $A$. media, but with appressed tomentum. The bracts of the pistillate heads of $A$. flavescens are still lighter than those of $A$. umbrinella, being yellowish or brownish white, oblong and scarcely more than half as broad, but still obtuse. The leaves are yellowish. It would have been better to have designated Rydberg $\&^{\circ}$ Bessey 5146 instead of 5145 as the type, because the former number contains pistillate as well as staminate plants. The pistillate heads of $A$. reflexa have bracts of a color similar to that of A. umbrinella but they are decidedly acute and resemble those of A. media in shape.

The staminate plants of this group are very rare, except in Antennaria flavescens, in which it is the common form, the pistillate plant being comparatively rare. In the herbarium of the New York Botanical Garden the staminate plants are represented by the following specimens:

Antennaria alpina (L.) Gaertner: J. Källström (Tronfjeld, Norway).

A. monocephala DC.: Wm. Horne (Karluk, Alaska), Blaisdell (Cape Nome, Alaska).

A. media Greene: Hall \& Chandler 686 (Mt. Goddard, Calif.); Sonne 160 in I $\$ 88$ (Bear Creek, Placer Co., Calif.) and in 1892 (Coldstream, Calif.).

A. mucronata, E. Nels.: L. Goodding 430 (Ten Sleep Lakes, Wyo.). A. umbrinella Rydb.: Flodman 859 (partly) (Long Baldy, Mont.); Macoun 69339 (Meyer's Creek, B. C.); Umbach 6I5 (Midvale, Mont.); Rydberg \& Bessey 5 I64 (Mt. Chauvet, Idaho); Shear \& Bessey 397 I (Steamboat Springs, Colo.). 
A. flavescens Rydb.: many specimens.

A. reflexa E. Nels.: Goodding I I4 (Pedro Mountains, Wyo.); Goodding 380 (Doyle Creek, Wyo.); A. Nelson 853 (Union Pass, Wyo.).

A. pulvinata Greene: Richardson (?), from Hooker's herbarium.

Antennaria rosea (D. C. Eat.) Greene has a peculiar history. The citation of Eaton should perhaps be omitted, for Eaton* gave no description. The first description was given by myself under the name $A$. parvifolia, $\dagger$ on the supposition that it was the same as $A$. parvifolia Nutt. + It might have been included partly in the description of that species, but Professor Piper has shown that Nuttall's type belongs rather to $A$. aprica Greene. It was afterwards described by Greene as $A$. rosea, $\S$ the author giving $A$. dioica rosea Eaton as a synonym. As that was a nomen nudum, it should be "ignored" as Greenell stated later, and A. rosea is based wholly upon Greene's description. The type of $A$. rosea would then be Sheldon I28, which is first cited, rather than Watson 652, which is not cited at all. Sheldon $I 2 S$ is the monotype of Greene's $A$. sordida. The proposer of the latter must have forgotten or ignored what he had done a year earlier. E. Nelson gives $A$. sordida as a synonym of his $A$. rosea angustifolia, based on my A. angustifolia.** There is no use of keeping up a varicty if the type of the species belongs to the variety! Besides, Sheldon I28 and Watson 652 are almost identical. A. angustifolia Rydberg is somewhat similar, but has narrower involucral bracts, of which the inner are very acute. It is not found in the Rocky Mountain region.

In the New Manual, A. anaphaloides Rydb. is made a synonym of A. pulcherrima. Piper, who is fully as "conservative" as A. Nelson, keeps them distinct, however. So did also E. Nelson. The description of Antennaria pulcherrima in the New Manual is an almost verbatim copy of my description of $A$. anaphaloides. The description, especially that of the pistillate head, does not

*Bot. King Exp. I86. I87 I.

†Bull Torrey Club 24: 301. I897.

$\ddagger$ Trans. Am. Phil. Soc. II. 7: 406.

§Pittonia 3: 28I. I898.

||Pittonia 4: 8I. I899.

TPittonia 4: 8I. I899.

**Bull. Torrey Club 26: 546 . I 899 . 
at all agree with a duplicate of the type of $A$. pulcherrima in the Torrey herbarium. In the latter, the bracts are imbricated in 6 or 7 series, wholly brown, the innermost very narrow and acuminate. A. foliacea Greene is wholly ignored, although E. Nelson had it in his paper. A. Sierrae-Blancae Rydb. is made a synonym of $A$. rosulata, although the words "leaves glabrate above" are added after the reference. Probably the authors had not seen any specimens. The characters of the bracts (not referred to) are a better distinction than the mere lack of tomentum. On the other hand, Antennaria oblanceolata Rydb. is kept distinct from the closely related $A$.luzuloides. In the key the latter is placed under the heading "bracts tomentose except the scarious tips"; but in the description is stated "involucres glabrous nearly or quite to the base." The latter characterization is correct and A. luzuloides should be associated with $A$. oblanceolata instead of A. pulcherrima in the key.

\section{Antennaria acuta sp. nov.}

A surculose-stoloniferous perennial; stems slender, $5^{-I} 2 \mathrm{~cm}$. high; stolons short and mostly ascending; basal leaves and those of the stolons narrowly oblanceolate, greenish-white, tomentose on both sides, glabrate in age, $15-25 \mathrm{~mm}$. long, 2-4 mm. wide, acute or abruptly short-acuminate; tomentum very fine and appressed; stem-leaves narrowly linear or linear-oblanceolate; heads 3-5, conglomerate, sessile; involucres about $6 \mathrm{~mm}$. high, tomentose below; bracts of the pistillate heads lanceolate to linearlanceolate, dark greenish brown with slightly lighter tips, the inner acute.

This is related to Antennaria alpina and A. media. It resembles perhaps most the former but the leaves are equally tomentose on both sides. From A. media it differs in the narrower, acute or acuminate leaves with a finer, closely appressed tomentum.

Alberta: Marsh near Lake O’Hara, Aug. 8, i 904, J. Macoun 65423 (type in herb. N. Y. Bot. Gard., duplicate in herb. Geol. Surv. Canada); also Bow River at Laggan, July 25, 1904, 65413 ; and Pipestone Creek, July 6, 1904, 65422.

\section{GNAPHALIUM}

In Coulter \& Nelson's New Manual both Guaphalium sulphurescens Rydb. and $G$. thermale E. Nels. are cited as synonyms of 
G. Wrightii. G. thermale is closely related to that species and may be regarded as a form thereof by a conservative systematist, but the first one named is not.

At the end of the description of Gnaphalium Wrightii the following note is given: "G. thermale E. Nels. Bot. Gaz. 30: I 2 I. I 900, the description of which is here used." If $G$. thermale is to be included in G. Wrightii, it is at least not the normal condition of that species and the description of the small $G$. thermale gives a poor idea of $G$. Wrightii, which is a tall plant, 3-5 $\mathrm{dm}$. high. To use the description of one species for another is as a rule very unsafe, unless the identity is established without any doubt.

Gnaphalium albescens Osterh., G. proximus Greene, and $G$. lagopodioides Rydb. are not accounted for at all in the New Manual, although they were described from material collected in the region covered by the work. The first, I think, is a pure synonym of $G$. Wrightii; the other two, as well as G. sulphurescens, are closely related to $G$. chilense Sprengel (G. Sprengelii H. \& A.). All three have the obtuse bracts and subdecurrent leaves of that species. G. proximus was based on Aven \& Elias Nelson 6036 and is closest to $G$. chilense. The specimens were distributed as $G$. Sprengelii and are evidently included in G. chilense in the New Manual. If $G$. sulphurescens should be reduced to synonymy it should be under $G$. chilense not under $G$. Wrightii.

Gnaphalium uliginosum $\mathrm{L}$. is also omitted, although it has been collected in both Colorado and Utah.

Gnaphalium angustifolium A. Nels. is antedated by both $G$. angustifolium Lam. and G. angustifolium Loisel.; but as those species now are referred to Helichrysum it may be that G. angustifolium is tenable according to the Vienna Rules. A poor rule indeed, when the validity of the name $G$. angustifolium A. Nels. depends upon whether two species of the Old World are kept in Gnaphalium or not. Three years after G. angustifolium A. Nels. was published, the proposer of that species substituted the name G. exilifolium, which name is wholly ignored in the New Manual.

\section{Gnaphalium Williamsii sp. nov.}

Probably biennial; stem 3-6 dm. high, branched above, loosely floccose; leaves linear or linear-lanceolate, decurrent, $5-10 \mathrm{~cm}$. long, 
almost equally floccose on both sides with loose, not dense tomentum, sometimes slightly glandular; inflorescence large, corymbosely paniculate; heads soniewhat conglomerate at the ends of the branchlets; involucre hemispheric or nearly so, $6 \mathrm{~mm}$. high, only slightly tomentose at the base; bracts broadly ovate, acute, light straw-colored or white; achenes glabrous; pappus strawcolored.

This species is intermediate between Gnaphalium microcephalum and $G$. decurrens; perhaps more closely related to the latter, of which it has the general habit and the larger nearly hemispherical involucres, but the leaves are nearly as tomentose above as beneath. They are slightly if at all glandular; the stem is not at all so. The pubescence is that of G. microcephalum but the inflorescence is more open and inclined to be flat-topped and both the involucre and its bracts are much broader.

Montana: Columbia Falls, Aug. I I, I894, R. S. Williams (type, in herb. N. Y. Bot. Gard.); woods, Belton, Aug. 25, 1903, Umbach 752 .

\section{NACrea A. Nels.}

I believe that this genus is based on the essentially staminate plant of Anaphalis. There is a duplicate of the type of Nacrea lanata in the herbarium of the New York Botanical Garden, but the specimens are so young that the real structure of the flowers can not be made out. It may be that Nelson had better developed material on hand. The expressions "akenes (immature in these specimens)" indicate, however, that he did not have developed fruit. The so-called staminate flowers of Anaphalis are in reality hermaphrodite flowers with sterile pistils. (See Bentham \& Hooker, Genera Plantarum.) The styles in them are undivided and the achenes remain undeveloped. In the description of Nacrea there is nothing said about the styles being undivided or 2 -cleft. In the herbarium of the New York Botanical Garden there are two specimens collected in the Big Horn Mountains, one by 'T. A. Williams in 1898 , and the other by Dr. H. Hapeman in 1892 , which (especially the first mentioned) are so close in every respect to the duplicate of the type of Nacrea lanata, that anybody would take them for the same species. They are better developed and belong without doubt to an Anaphalis. Whether they can be separated specifically from A. subalpina is doubtful. 
Anaphalis angustifolia sp. nov.

Perennial with a creeping rootstock; stems slender, strict, simple, white-tomentose, $3-6 \mathrm{dm}$. high; leaves narrowly linear, I-nerved, 5-10 cm. long, $2-5 \mathrm{~mm}$. wide, ascending, densely whitetomentose beneath, less so above, greener and often glabrate in age; inflorescence small, corymbiform, $2-3 \mathrm{~cm}$. high, $3-4 \mathrm{~cm}$. wide; heads hemispheric; involucres about $5 \mathrm{~mm}$. high; bracts pearly white, elliptic, obtuse or acutish.

This species is more related to the eastern Anaphalis margaritacea than to $A$. subalpina, having narrow and I-ribbed leaves, but differs in the smaller inflorescence, smaller heads, narrower bracts, and narrower and ascending instead of spreading leaves.

Montana: Mount MacDonald, July, I900, Elrod \& assistants (type, in herb. N. Y. Bot. Gard.); Big Fork, Aug. 9, I901, Umbach 15.

\section{BALSAMORRHIZA}

Professor Nelson has reduced Balsamorrhiza hirsuta Nutt. and B. terebinthacea Nutt. to varieties of B. Hookeri and B. macrophylla respectively. Although the first has a superficial resemblance in the cutting of the leaves to B. Hookeri, it is much more closely related to $B$. macrophylla in every respect, differing only in the smaller heads and more dissected leaves. In his key Professor Nelson gives the following characters:

Leaves entire or somewhat toothed.

I. B. sagillata.

Leaves not entire, laciniately dentate to bipinnatifid.

Green, glabrous or sparingly hisute.

2. B. macropinylla.

Canescent or lanate.

The sericeous pubescence appressed or spreading.

The white tomentum often floccose.

3. B. Hookeri.

4. B. incana.

How would it be possible to locate $B$. Hookeri hirsuta by means of this key? As its leaves are pinnatifid, green, and hirsute, it would key into B. macrophylla instead of B. Hookeri. On the following page Professor Nelson gives only the following: "The pubescence roughish hirsute and spreading, not canescent or tomentose," as distinguishing the var. hirsuta from B. Hookeri, just the same characters which he in the key has used as separating B. macrophylla from B. Hookeri. The latter is not found within the range.

Balsamorrhiza terebinthacea Nutt, is not closely related to $G$. 
macrophylla. In the latter the outer involucral bracts are elongated and reflexed; the former has the involucre of $B$. Careyana with appressed bracts. I doubt that $B$. terebinthacea is found east of northwestern Idaho.

It is a kind of puzzle to me, to determine what rule Professor Nelson followed in making these reductions. The specific name terebinthacea (I 833) is much older than macrophylla (I 84I), and even where Nuttall transferred the former from Heliopsis to Balsamorrhiza it has page priority. If united, $B$. terebinthacea should be the species and $B$. macrophylla the variety.

Balsamorritiza floccosa Rydb. and B. tomentosa Rydb. were reduced to synonyms of $B$. incana and $B$. sagittata respectively. It may be admitted that they (especially $B$. tomentosa) are closely related to the species to which they are referred, but I doubt if the authors of the New Manual have seen authentic material of either. In the Bulletin of the Torrey Botanical Club, November, I900, I gave a synopsis of the Rocky Mountain species of this genus, and have not found any material change to make since that time.

\section{Gymnolomia linearis sp. nov.}

Perennial with a rootstock or slender caudex; stems $3^{-4} \mathrm{dm}$. high, terete, strigose; leaves opposite, short-petioled, narrowly linear, 3-4 cm. long, 2-4 mm. wide, entire, hirsutulous, indistinctly 3 -nerved, sparingly hispid-ciliate at the base; heads long-peduncled; involucres about $6 \mathrm{~mm}$. high, I $2-15 \mathrm{~mm}$. broad; bracts linear-lanceolate, canescent-strigose; rays $10-12 \mathrm{~mm}$. long, 3-4 mm. wide.

This species resembles Gymnolomia longifolia and $G$. annua in leaf form and general habit, but it is a perennial. From G. muitiflora it differs in the narrow leaves and the slender perennial base, which would be classified rather as a rootstock than a caudex. The type number was included in G. multiflora by Robinson and Greenman* as a narrow-leaved form. The other specimens cited by them as belonging to this form, I have not seen, but probably they should be included in G. linearis.

Utah: St. George, I877, E. Palmer 24I (type, in herb. Columbia Univ.).

*Proc. Boston Soc. Nat. Hist. 29: $92 . \quad 1899$. 
Gymnolomia ciliata (Robins. \& Greenm.) Rydb. sp. nov.

Gymnolomia hispida, var. ciliata Robins. \& Greenm. Proc. Boston Soc. Nat. Hist. 29: 93. I 899 .

\section{Helianthus}

The authors of the New Manual have reduced Helianthus aridus Rydb. to a synonym of $H$. petiolaris. Although the forms of its leaves resemble those of that species, $H$. aridus is much more closely related to $H$. lenticularis ( $H$. anmms of the Manual), which is indicated by the form of the bracts and the pubescence. If it should be reduced at all, it should be made a variety of $H$. lenticularis. It may even be a depauperate form of that species.

Helianthus giganteus is omitted, although unquestionable specimens have been collected in Colorado. (See my Flora of Colorado, page 372.)

\section{Helianthella}

In the New Manual Helianthella uniflora is described in the key as having a purple disk. In all specimens I have seen the diskcorollas are yellow. H. Douglasii is not included in the flora, although it has been collected in Montana by F. W. Anderson and Tweedy, in the Yellowstone Park by Tweedy, and south thereof in Wyoming by C. C. Curtis. (See also my Flora of Montana and the Yellowstone National Park.)

\section{ENCELIOPSIS}

Enceliopsis mutans (Eastwood) A. Nels., from Colorado and Eastern Utah, is omitted in the New Manual. This is strange, as Professor A. Nelson is the author of the name Enceliopsis as well as of the combination E. nutans.

\section{BiDENS}

Bidens bipinnata L. is included in Coulter \& Nelson's New Manual. I have not seen any specimens from the Rocky Mountain region that could be referred to that species. B. Bigelovii is, however, found in Colorado. Crandall 2726, Shear 4587, Clements 64 and 82 , all resemble so closely the Mexican Boundary Survey no. 582 and no. $582 a$, from which B. Bigelovii was described, that there is no doubt about the identity. Duplicates of 
these two numbers of the Boundary Survey are in both the herbarium of the Columbia University and that of the New York Botanical Garden. The structure of the marginal achenes distinguishes B. Bigelovii at once from B. bipinnata.

\section{THELESPERMA}

In the description of Thelesperma ambiguum in Coulter \& Nelson's New Manual, we find the following: "bracts of the outer involucre 8 , subulate-linear, almost equalling or half the length of the inner," etc. In Wright's specimens, from which T. ambiguum was described, the outer bracts are ovate or elliptic, scarcely one fourth as long as the inner involucre. What is described in the New Manual is evidently T. intermedium Rydb. When I described the latter, I had known it for about ten years and had never been able to make it agree with Dr. Gray's description of $T$. ambigunm in the Synoptical Flora. In the original publication of Thelesperma ambigunm no diagnosis is given, only a few characters distinguishing it from related species. In habit $T$. ambiguum resembles most $T$. subuudum, having the creeping rootstock of that species, the long naked peduncles, and the leaves found near the base of the stem only. The range is given as Montana to New Mexico and Texas. This was probably taken from the Synoptical Flora. The specimens on which Dr. Gray extended the range to Montana belong to $T$. marginatum, in many respects closely related to $T$. ambigumm but with discoid heads. T. ambigunm, as far as I know, is not found north of southern Colorado. T. intermedium, which is really described under the name of $T$. ambigumm in the New Manual, does not have a "creeping rootstock" (as Gray described T. ambiguum) but has a biennial or perennial taproot; and it has a leafy stem. As the authors of the New Manual did not at all consider the differences in the subterranean parts of T. ambiguum and T. intermedinm, it was natural that they would not consider the same parts in $T$. trifidum and $T$. tenue, which resemble each other much more closely, and we find the latter as a synonym of the former. Thelesperma marginatum Rydb. is ignored altogether, although in my Flora of Montana four collections from that state are cited. 


\section{HrMenopappus}

Professor Nelson divides this genus into two groups: one with stems leafy throughout, mostly corymbosely branched and with numerous heads; the other with stems leafy below, the leaves reduced upwards, few or wanting, heads not numerous. In the first group, he places Hymenopappus temifolius and H. luteus. The first of these two always has a leafy stem and many heads, but in $H$. luteus the stem is not more leafy than it often is in $H$. filifolius and $I$. cinereus, and as a rule has less numerous heads than either of them. In the key of the New Manual H. scaposus is distinguished from the rest by the following character: "stem scapose, less than $2 \mathrm{dm}$. high." These characters we often find in both $H$. luteus and $H$. araneosus.

Hymenopappus cinereus Rydb. and H. ochroleucus Greene are made synonyms of $H$. araneosus. I take the two first to be the same, but think that the last one should be kept distinct. It is characterized by the denser, more permanent tomentum, a tuft of dense matted white tomentum on the caudex, and achenes with silky and more appressed pubescence. This is characteristic of neither H. cinereus nor H. ochroleucus. Hymenopappus parvulus Greene is made a synonym of $H$. scaposus, but it has a smaller head, no matted white tomentum on the caudex and subcylindraceous corolla-throat. The last character would associate it with $H$. macroglottis, H. lugens, and H. eriopodus, but its corollas are scarcely more than half the size of those of the other species. $H$. scaposus is not found in the region, as limited in the New Manual.

Hymenopappus lugens Greene is to be added to the region, having been collected above Marysvale, Utah, July 2I, I905, Rydberg \& Carlton 7049, and $H$. eriopodus A. Nels., found in Diamond Valley, May I9, I902, Goodding 880 , and at Springdale, May I 4, I 894, Jones 526I. The last has much broader segments to the leaves than the type and resembles $H$. tomentosus in habit, but has the corolla of $H$. eriopodus. It may prove to be distinct.

\section{OTHAKE}

In describing Polypteris maxima, Dr. J. K. Small overlooked the fact that the original Palafoxia Hookeriana was based on Drummond's plant, which he referred to Polypteris maxima. Mr. Bush, 
in reëstablishing Rafinesque's genus Othake did not notice this discrepancy and the name Othake Hookerianum has hitherto been applied to the wrong species. The synonymy of the two species is as follows:

Othake Hookerianum (T. \& G.) Bush, Trans. Acad. Sci. St. Louis 14: 177. 1904

Palafoxia texana Hook. Ic. Pl. pl. 148. I837. Not P. texana DC. 1836 .

Palafoxia Hookeriana T. \& G. Fl. N. Am. 2: 368. 1842.

Polypteris maxima Small, Fl. SIV. U. S. I288. 1903.

Othake maximum Bush, Trans. Acad. Sci. St. Louis 14: 179. I904.

Both Hooker's description of Palafoxia and Torrey and Gray's description of $P$. Hookeriana were based on Drummond's specimens, of which there is a duplicate in the Columbia herbarium, and this belongs to Polypteris maxima Small. Hooker's plate also illustrates the same thing. It was not strange that Dr. Small was led astray, for the true O. Hookerianum is a very rare plant and it was natural to think that the common plant which had been taken for it by Gray, Porter, Coulter, Greene, A. Nelson, myself, and others, should be regarded as O. Hookerianum. The latter species should be known as

\section{Othake sphacelatum (Nutt.) Rydb. nom. nov.}

Stevia sphacelata Nutt.; Torr. Ann. Lyc. N. Y. 2: 2 I4. 1827. Palafoxia Hookeriana subradiata T. \& G. Fl. 2: $368 . \quad$ I $8+2$.

Polypteris Hookeriana A. Gray, Proc. Am. Acad. 19: 30, mainly. Othake Hookerianum Bush, Trans. Acad. Sci. St. Louis 14: 177, as to the description. 1904.

Bush gives as a doubtful synonym Othake longifolium Raf., but the description does not fit this plant. O. longifolium is compared with O. tennifolium Raf., i. e., Othake callosım (Nutt.) Bush, and said to be much smaller in every respect than that species. O. sphacelatum has about twice as large heads as O. callosum.

Torrey's description of Nuttall's Slevia sphacelata is rather poor and not ample enough to recognize any species by, but the type, collected by James, is in the old Torrey herbarium and it is un-

*New F1. Am. 4: 74. I838. 
mistakably the plant here considered. Being the only available and certain specific name of the plant, sphacelatum is therefore taken up.

\section{Othake macrolepis sp. nov.}

Annual; stem 3-4 dm. high, strigose-puberulent, and glandular on the upper parts, with ascending branches; leaves alternate, linear, indistinctly $\mathbf{I}$-ribbed, strigose-puberulent on both sides, 3-5 cm. long, 2-3 mm. wide, short-petioled; involucres obconic, 9-10 $\mathrm{mm}$. high and about as wide; bracts $8-\mathbf{I} 2$, in two subequal series, linear-oblanceolate, abruptly acute, scabrous-hispidulous and slightly glandular, green, with scarious tips, and the inner with narrow scarious margins; rays none; disk-corollas rose-purple, $\mathbf{I}_{4}^{-}$ I $5 \mathrm{~mm}$. long; limb 4-5 mm. long, with linear lobes; achenes linearobpyramidal, $7 \mathrm{~mm}$. long, I mm. thick at the apex, strigose-canescent, pappus-scales 6-8, lanceolate, caudate-acuminate $5-6 \mathrm{~mm}$. long.

This species is most closely related to O. roseum Bush, but has much larger heads, flowers, and fruit, and the leares have a less distinct midrib. In the type of $O$. roseum the disk-corollas are only about $12 \mathrm{~mm}$. long. There is no full-grown fruit in the type sheet, but other specimens show that the achenes are only $4^{-5} \mathrm{~mm}$. long and their pappus-scales $2-3 \mathrm{~mm}$. long, acute rather than caudate.

Colorado: Rule Creek, Bent Co., Aug. 17, 1909, G. E. Osterhout 4097 (type, in herb. N. Y. Bot. Gard.).

\section{PiCRADENIOPSIS}

In the New Manual, my genus Platyschkuhria is accepted, but Picradeniopsis Rydb., fully as distinct from Bahia, is retained in the latter genus. In Picradeniopsis and Achyropappus the foliage is impressed-punctate, and the leaves opposite, which is not the case in the other genera included by Gray in Bahia. Bahia is a shrubby plant of South America with white rays. Using Professor Nelson's generic key, Picradeniopsis would key into Hymenoxys. It stands nearest to that genus, which has been known under the name Picradenia, but differs in the free bracts. Picradeniopsis is amply distinct from the non-punctate and alternate-leared Bahia but may have been included in Achyropappus. The annual habit and rayless heads of that genus seem to be distinction enough. 
Picradeniopsis Woodhousii (A. Gray) Rydb. comb. nov. Achyropappus Woodhousii A. Gray. Proc. Am. Acad. 6: 546. I 865. Schkuhria Woodhousii A. Gray, Proc. Am. Acad. 9: 199. I874. Bahia Woodhousii A. Gray, Syn. Fl. 12: 333. I884.

Dr. Gray in the work last cited includes this species in the annual species of Bahia. The plant is, however, perennial with a creeping rootstock, and in habit so closely resembling $P$. oppositifolia that it is often hard to distinguish the two. The flowers are of a much lighter color in $P$. Woodhousii, the rays being ochroleucous or straw-colored, and the pappus-scales are much narrower, lancesubulate, and only slightly scarious-margined.

This should have been included in the New Manual, as the type was collected in northern New Mexico.

\section{Platyschkuhria}

Platyschkuhria oblongifolia (A. Gray) Rydb. should have been included in Coulter \& Nelson's New Manual. It has been collected in southwestern Colorado. See Gray's Synoptical Flora $1^{2}: 332$, and my Flora of Colorado 377.

Platyschkuhria desertorum (Jones) Rydb. comb. nov. Bahia desertorum M. E. Jones, Zoe 2: 249. I89 I.

This species is a close ally to $P$. integrifolia, differing mainly in the acuminate bracts.

\section{Villanova}

By an oversight Bahia dissecta (A. Gray) Britton (B. chrysanthemoides A. Gray) was retained in Bahia in my Flora of Colorado. It should have been restored to Villanova. As nobody seems to have used this generic name in connection with the earliest specific one, the plant should be known as:

Villanova dissecta (A. Gray) Rydb. comb. nov. Amauria? dissecta A. Gray, Mem. Am. Acad. 4: 104. I849. Villanova chrysanthemoides A. Gray, Pl. Wright 2: 96. 1853. Bahia chrysanthemoides A. Gray, Proc. Am. Acad. 19: 28. I883. Bahia dissecta Britton, Trans. N. Y. Acad. Sci. 8: 68. I889. 


\section{ChaEnactis}

Chaenactis achilleaefolia $\mathrm{H}$. \& A. and $C$. pedicularia Greene are both reduced in the New Manual, the former to a variety of $C$. Douglasii, the latter to a synonym of $C$. alpina. I think that both should be kept up as species. The characters separating the former from C. Douglasii are not so much the dwarf habit and reduced crowded segments of the leaves, for such conditions are found in the true $C$. Douglasii, as the permanent tomentum and the longer and acute pappus-scales. C. alpina is subscapose with peduncles $2-7$ cm. long and its involucre is much shorter than the corollas. C. pedicularia has leafy although short stems, very short peduncles $\mathrm{I}-2 \mathrm{~cm}$. long, and involucral bracts, in the specimens seen, fully as long as the flowers. Apparently C. pedicularia is the same as $C$. Douglasii, var. montana M. E. Jones, ${ }^{*}$ of which the author states that it has been confused with $C$. alpina, but at the same time points out several distinctions.

\section{Chamaechaenactis}

In reviewing Coulter \& Nelson's New Manual, Dr. B. L. Robinson $\dagger$ stated: "No mention, for instance, is made of Encelia nutans Eastwood and Chaenactis scaposa Eastwood." This is not exactly true, for the latter is included in the New Manual. It was not strange, however, that Dr. Robinson should overlook the fact, for who would expect to find it under the name Actinella carnosa A. Nels.? I doubt if Professor Nelson has seen any specimens, for if he had I do not think he would have transferred it to Actinella. The description in the New Manual is a verbatim copy of Miss Eastwood's description. The plant is evidently more closely related to Chaenactis, in which genus it was first placed, than to Actinella. If Professor Nelson was unwilling to adopt my generic name Chamaechaenactis, it would have been much better to retain the species in Chaenactis than to transfer it to Actinella, where it is wholly out of place. Besides, Chamaechaenactis is fully as good as Nelson's own genera Tonestus and Wyomingia, and far more so than Nacrea and Enomegra. The last has no scientific standing at all, being distinguished from Argemone only by the

* Proc. California Acad. Sci. II. 5 : 700.1895.

$\dagger$ Thodora 12: i6. 19г0. 
yellow instead of milky white sap. In which genus should a species with ochroleucous or white sap, turning yellowish, be placed?

\section{Correction}

The California specimens referred to Scutellaria veronicifolia in a previous installment of the studies belong to $S$. californica A. Gray, and not to the former, having a different corolla.

New York Botanical Garden. 

CONTRIBUTIONS FROM THE NEW YORK BOTANICAL GARDEN-No. 137

\section{STUDIES ON THE ROCKY MOUNTAIN FLORA-XXIII}

BY PER AXEL RYDBERG

NEW YORK

1910

Reprinted, withoutchange of paging, from the BULLETIN OF THE TORREY BOTANICAL CluB 3\%: 443-171. 501910 



\section{Studies on the Rocky Mountain flora - XXIII}

Per AXel RYDBerg

\section{Gaillardia Mearnsii sp. nov.}

Annual; stem I-3 dm. high, leafy only towards the base, finely pubescent; basal leaves oblanceolate or spatulate, petioled, $5^{-10} \mathrm{~cm}$. long, puberulent, entire or round-lobed; upper leaves similar or sometimes pinnatifid with rounded lobes; peduncles 1-2 dm. high; involucres about $2 \mathrm{~cm}$. broad; bracts lanceolate, acute, grayish-pubescent; disk-corollas purple, their lobes short and rounded, fimbriate; pappus-scales lanceolate, each gradually attenuate into a slender awn equaling the corolla; rays yellow, IO- $15 \mathrm{~mm}$. long.

The type sheets were labeled $G$. aristata, which it somewhat resembles in general habit, but the lobes of the disk-corollas are not attenuate. It resembles, however, still more, G. arizonica in the annual root, the stem naked above, and the leaf-form, although the leaves are more inclined to be entire; but it differs from that species in the purple disk and the gradually acuminate and long-aristate pappus-scales. On the whole, it is therefore more nearly related to $G$. pinnatifida, although the plant is evidently an annual and the leaves are seldom pinnatifid. When pinnatifid, their lobes are short and rounded.

Arizona: Fort Verde, May 4, I888, Mearns 322 (type, in herb. N. Y. Bot. Gard.).

¿'TAH: Sandy bluffs near Green River, June I2, I900, Stokes.

\section{TETRANEL RIS}

In Coulter \& Nelson's New Manual the name Actinella Nutt. has been readopted for this genus, apparently in conformity with 
the Vienna Rules. Nuttall, however, did not intend to propose a new genus Actinella, but thought that the Galardia acaulis of Pursh belonged to Actinella Pers., based on Actinea Juss. In reality there is no such thing as Actinella Nutt. Actinella Pers. is a synonym of Cephalophora, to which even DeCandolle thought Galardia acaulis belonged.

The way Professor Nelson has handled other persons' species of this genus and his own is very arbitrary. Actinella simplex A. Nels., A. incana A. Nels., and A.eradicata A. Nels. he keeps distinct from A. acaulis (Pursh) Nutt. Both Actinella depressa A. Gray and Tetraneuris brevifolia Greene he makes synonyms of his own Actinella acaulis caespitosa, and Tetraneuris glabra Greene and T. glabriuscula Rydb. of his own Actinella epunctata. $\mathrm{He}$ unites $T$. linearis Greene (Nutt.) and T. angustifolia Rydb.; $T$. fastigiata Greene and T. stenophylla Rydb.; and lumps under Actinella leptoclada A. Gray not only Tetraneuris mancosensis A. Nels. and T. intermedia Greene but also T. Crandallii Rydb., $T$. arizonica Greene, and T. pilosa Greene (?).

My studies of the genus have given me quite different results. Galardia acaulis Pursh was collected by Bradbury in "Upper Louisiana." Any one who knows a little about Bradbury's travels knows that this meant along the Missouri River, somewhere between St. Louis, Mo., and Fort Mandan, N. D. Further, the type locality must have been in South Dakota or North Dakota, as no species of Tetraneuris is known to grow near the Missouri south thereof. The common plant of the plains and hills of the western part of the Dakotas and Nebraska has densely silky, linear-oblanceolate leaves. It is well represented by my own nos. 106 and 106, by MacDougal 53 from Nebraska, and by Bolley 404 from Mendora, N. D. It is true that the type of Tetraneuris incana A. Nels. (Elias Nelson 5006) is slightly more delicate and whiter than these, but $A$. Nelson $\$ 265$, determined by the author himself as T. incana matches perfectly my no. Io6. Actinella or Tetraneuris incana A. Nels. is therefore in my opinion the true $T$. acaulis (Pursh) Greene. It is the only one that has been collected in the neighborhood of the type locality. The only other species that has been collected in the Dakotas or Nebraska is T. simplex A. Nels. and that only in the very extreme western 
portion. The latter does not agree with the description of $G a$ lardia acaulis.

I have come to the conclusion also that Tetraneuris eradiata $\mathrm{A}$. Nels. is but a rayless form of T. acaulis. My no. 106 contains both radiate and rayless specimens. The disk-flowers of $T$. eradiata are said to be "almost orange." They usually turn more or less orange in age in $T$. acaulis and the type of $T$. eradiata is pretty well advanced in age. There are no other distinctive characters either in the description or in the specimens that I can see.

Even Tetraneuris simplex is not too good a species and it is very close to $T$. acaulis on one hand and $T$. trinervata Greene on the other. The latter I had reported for Colorado in my Flora of Colorado; but it is wholly ignored by Nelson. As the New Manual includes northern New Mexico, the type locality even of $T$. trinervata, viz., Sandia Mountains, N. M., between Santa Fé and Albuquerque, is within the range.

What Professor Nelson's interpretation of Actinella acaulis really is, is hard to tell, for some of the specimens he has distributed under that name and Tetraneuris acaulis belong to T. lanata and others to $T$. acaulis caespitosa A. Nels. Most of them were distributed before the latter was segregated. Both E. Nelson 4329, distributed as T. acaulis, and A. Nelson 4607, distributed as T. lanata?, match perfectly a part of the type of Nuttall's Actinella lanata in the Torrey herbarium. All three are very young.

It is evident that Actinella acaulis caespitosa A. Nels. is more closely related to $A$. lanata than to $A$. acaulis. It has the loose pubescence of A. lanata, a character best seen in age. I am inclined to think that it is the same as Tetraneuris brevifolia Greene, although I have not seen the type of the latter. It should then bear that name, unless it is reduced to a variety of A. lanata. The plant was first collected by James in Long's Expedition on James Peak (now Pikes Peak), the type locality of T. brevifolia. Torrey* referred this specimen to Actinea integrifolia Kunth; but in Torrey and Gray's Flora, $\dagger$ it was referred to Actinella lanata with the following remark: "The specimen of

*Ann. Lyc, N. I. 2: 2 I 3 .

$\dagger 2$ : 382 . 
A. integrifolia? Torr. loc. cit. is so imperfect that we can not very confidently refer it to the present species; but it certainly is not the same with the foregoing" [A. Torreyana].

When preparing the manuscript of the Flora of Colorado, I overlooked the publication of Tetraneuris epunctata A. Nels. Otherwise I should not have proposed $T$. glabriuscula to replace the untenable $T$. glabra Greene. I am perfectly willing to reduce the last two to synonymy. This is, however, not the case with T. angustifolia. In the key Professor Nelson has a division, "Crowns of the caudex short" in contrast to "Crowns of the caudex fastigiate and elongated, I-2 dm. high." Inder the first division he includes Actinella linearis. If he had given A. angustifolia instead it would have been correct. The type of $A c$ tinella scaposa linearis was collected by Riddell in Texas and is preserved in the Torrey herbarium. It has elongated branches of the caudex as have Tetraneuris fastigiata and T. stenophylla, and differs from them mainly in the fact that the bases of the leaves are scarcely dilated. I think that Tetraneuris fastigiata and T. stenophylla also are distinct. This is only a matter of difference in opinion as to limitation of species. If they are to be united, they should be included in .T. linearis, which is just as closely related. Tetraneuris angustifolia on the contrary is more distinct and related to T. Torreyana, but lacks the hair-tufts at the bases of the leaves.

Tetranenis mancosensis A. Nels. is a synonym of Actinella leptoclada A. Cray. I am now inclined to regard $T$. intermedia Greene also as such, although I kept it distinct in the Flora of Colorado. But I think it goes too far in "lumping," if one tries to include the acaulescent Tetranenris Crandallii, $T$. arisonica, and $T$. pilosa in the leafy-stemmed T. leptoclada. Besides the difference in habit the acaulescent species have abruptly aristate pappus-scales, while in $T$. leptoclada the scales taper gradually into the bristle-point. Tetraneuris Crandallii in habit closely resembles $T$. Torreyana, but the scape in not villous and the pappus is different. T. arizonica, in which I am inclined to include $T$. pilosa, resembles $T$. cpunctata, but the leaves are more hairy, more punctate, and have conspicuous hair-tufts at the bases. It seems as if enough species have been proposed in this genus, 
but still there is a plant of Montana, Idaho, and Saskatchewan, related to Tetraneuris acaulis, though differing in so many respects that it would be inconsistent to include it in that species. I therefore propose it as new:

\section{Tetraneuris septentrionalis sp. nov.}

An acaulescent perennial, with a short, thick cespitose-pulvinate caudex; leaves spatulate or oblanceolate, mostly rounded at the apex, I.5-4 cm. long, 5-8 mm. wide, canescent-tomentose, subvelutinous; scape 5 -Io dm. high, rather thick, appressed-tomentose; involucres $6-7 \mathrm{~mm}$. high, $12-15 \mathrm{~mm}$. broad, densely villous; bracts elliptic, rounded at the apex; rays $8-10 \mathrm{~mm}$. long, 5-6 $\mathrm{mm}$. wide, very strongly veined; achenes silky-strigose; pappus scales ovate, abruptly short-aristate.

This is related to Tetraneuris acaulis and T. simplex, but differs from both in the broader leaves, the looser pubescence, the usually shorter and stouter scape, and short bristle-tips of the pappus scales; from the former of these also in the less silky pubescence and the larger and more strongly veined rays, and from the latter in the dense pubescence.

IDaho: Palouse Country, June-July, i 892, G. B. A iton (type, in herb. N. Y. Bot. Gard.).

Montana: Fort Benton, John Persall 926; Livingston, June, I 899, Tweedy.

Saskatchewan: Cypress Hills, June 23, I894, John Macoun 5078 .

Wroming: Yellowstone Park, June, i888, C. H. Hall.

Hymenoxys Macounii (Cockerell) Rydb. comb. nov. IIymenoxys Richardsoni, var. Macounii Cockerell, Bull. Torrey Club 31: 474. I904.

It is not plain whether Prolessor Cockerell intended this as a variety of $I$. Richardsoni or of his $H$. Richardsoni, subsp. pumila. From the discussion, the latter interpretation seems most probable, but technically it seems to have been made a variety of the species. In habit it is most like $H$. pumila, but it has one character that was overlooked by Professor Cockerell, viz., the outer bracts are much thickened on the back, even subcarinate. This would associate the plant with $I$. floribunda 
rather than with II. Richardsoni. The rays are, however, not so broad or so decidedly cuneate as in that species. The following specimens belong to $I$. Macouni.

Saskatchewax: i 858, Bourgeau; Cypress Hills, i 880, John Macoun; Medicine Hat, I894, John Macoun 5077; Bare Hills, I906, Macoun \& Herriot 72840 .

Montana: "Northwest Boundary," I874, Coues; Falls of Missouri, r886, R. S. Williams 4520; Midvale, r903, Umbach I50; Manhattan, I895, Rydberg 2936.

Hymenoxys Greenei (Cockerell) Rydb. comb. nov.

Picradenia biennis Greene, Pittonia 3: 272 , in part. I898.

Not Actinella biennis A. Gray. 1878 .

IIymenoxy's Lemmoni Greenei Cockerell, Bull. Torrey Club 31:

479. I904.

I think this is specifically distinct from Hymenoxys Lemmoni. The best character to distinguish the two was not pointed out by Professor Cockerell or by Dr. Greene. The inner bracts in Palmer 26I, the type number of II. Greenei, of which there are five specimens on two sheets in the Columbia University herbarium, are broadly obovate and more or less erose-dentate on the margins, while in all specimens seen of H. Lemmoni they are elliptic and entire. Watson 616 , from Nevada and referred to the subpecies Greenei, belongs to II. Lemmoni.

\section{DUGALDEA}

Professor Nelson included in this genus Hymenoxys helenioides Cockerell (Picradenia helenioides Rydb.), on what ground I do not know. Both I, who, with Mr. Vreeland, discovered the plant, studied it in the field, and described it, and Professor Cockerell, who has spent so much time on IIymenoxys, believed it a good species of that genus. In Dugaldia Hoopesii the bracts are in more than two series, distinct, and in age reflexed; in IIymenoxys helenioides they are as in the rest of that genus not reflexed, in strictly two series, and those of the outer series are united at the base.

\section{Drsonia}

Nelson in the New Manual has evidently given Dysodia Cav. the same limitation as it has in Engler \& Prantl's Pflanzen- 
familien, i. e., including Adenophyllum, Hymenatherum, Aciphyllaea, Thymophylla, and Lowellia. If so, the name Dysodia papposa (Vent.) Hitch. and D. aurea (A. Gray) A. Nels. can be used; but if these genera are to be regarded as distinct or if they are limited as by Gray and by Hemsley; the names are not the correct ones. The monotype of Dyssodia Cav. (originally spelled with two s's), is D. Porophyllum = Adenophyllum Hemsl., which is not congeneric with either of these species according to Hemsley. The only available generic names for the two species of the Rocky Mountain region would be Boebera Willd. and Lowellia A. Gray, respectively.

\section{ARTEMISIA}

The treatment of Artemisia in the New Manual of the Central Rocky Mountains is very unsatisfactory. The author has kept up five of his own species and reduced every species proposed by any one else since $\mathbf{1} 88+$ and some before that year, either to synonymy or else to a variety of some older species, except Artemisia saxicola Rydb., which was a substitute for the North American so-called $A$. norvegica. Now let us see what the facts really are. There are only two species of Professor Nelson's that I am inclined to uphold, viz., Artemisia aromatica and A. nova. In such a "conservative" work as the New Manual generally is, even these ought to have been reduced to varieties.

It is questionable if Artemisia aromatica A. Nels. can be kept specifically distinct from $A$. dracunculoides. The latter is fully as common in the Rockies as is A aromatica, and even one specimen distributed from the University of Wyoming and named A. aromatica, viz., Goodding 602, is typical A. dracunculoides. Also an older specimen, Nelson 2.769 , belongs here.

Artemisia nova A. Nels. was not altogether new when it was described. In fact, several specimens were found in herbaria before that time under the name Artemisia arbuscula. If I am not mistaken, it constituted a part of Nuttall's original A. arbuscula, although the description fits better the other part, which therefore may be regarded as the type. Dr. Gray* states: "Two forms, passing into each other (both collected by Nuttall, ***); one with involucres more campanulate, $7-9$-flowered; in the other oblong and only $4^{-5}$-flowered." The latter is A. noz A A. Nels. 
The other Nelsonian species have in my opinion no claim to specific rank. Two duplicates of the type of Artemisia gracilenta A. Nels., one in the Columbia University herbarium and the other in the New York Botanical Garden collection, are almost identical with the two original specimens of $A$. floccosa Rydb. The only difference is that the segments of the leaves of the former are somewhat narrower. There are also two duplicates of $A$. paucicephala A. Nels., which differs from A. floccosa only in the fact that the upper leaves are entire. As Nelson himself unites $A$. paucicephala and A. gracilenta and the original A. floccosa is intermediate between the two, I see no reason why they should not be reduced to synonyms of $A$. floccosa, which is three years older.

A rtemisia subglabra A. Nels., of which there are two duplicates here, is identical with A. graveolens Rydberg, three years older. The leaves of even Nelson's own specimens show traces of tomentum on the lower surface. The species is related to $A$. discolor, not to $A$. saxicola, with which Nelson has placed it.

Artemisia natronensis A. Nels. is, according to a duplicate of the type and several specimens distributed from the University of Wyoming, the same as A. longifolia Nutt., as that species is understood. The specimens which I referred to $A$. natronensis in my Flora of Colorado do not belong there. They are unusually large-headed $A$. diversifolia or at least closely related to it. I wish to make this correction here.

Now let us take up the species reduced by Professor Nelson. Artemisia Scouleriana (Besser) Rydb. and A. Forwoodii S. Wats. are reduced to synonyms of $A$. canadensis.

Artemisia canadensis Michx. is a subarctic plant and not found in the Rocky Mountains within the United States. The type came from the shores of the Hudson Bay. It is a low plant with the leaves mostly basal, with narrowly linear divisions, and comparatively few heads nearly as large as those of $A$. spithamaea Pursh (A.borealis Auct. Am.) and in a narrow panicle. I have seen specimens from the White Mountains; Vermont; the Gaspé Peninsula, Que.; Keweenaw Point, Mich.; and the Yukon Territory; but from nowhere in our western states. The specinens named Artemisia canadensis from there belong to A. Forwoodii or A. Scouleriana. Whether the latter two should be regarded as 
distinct is questionable, but they are evidently different from $A$. canadensis, and Besser, regarding them as such, referred them, first to $A$. desertorum and later to A. commutata. In the original publication,* Dr. Watson compares A. Forwoodii with A. discolor, to which it has no close relationship. It is the same as A. desertorum Hookeriana Besser. $\dagger$

Artemisia kansana Britton and A. stenoloba Rydb. are given as synonyms of $A$. Wrightii. The description of the last in the New Manual is mostly copied from Dr. Gray, who perhaps included A. kansana, but the type, Wright 1279, is not the same as A. kansana Britton. The plant Professor Nelson had in mind is evidently $A$. kansana and not the true $A$. Wrightii, judging from the key and from the association with A. coloradensis Osterhout. The true Artemisia Wrightii has an involucre only slightly tomentose and the leaves glabrate above and is very close to $A$. Bakeri Greene, differing mainly in the erect instead of nodding heads. If Artemisia Bakeri should be reduced to a variety of A. mexicana, A. Wrightii should also. A. stenoloba Rydberg was never described, but the specimens so named in manuscript belong to kansana. There is however, an older name for this species, viz., A. Carruthii Wood, as pointed out by Mr. Mackenzie.

Artemisia rhizomata A. Nels., A. pudica Rydb., A. pabularis (A. Nels.) Rydb., A. Purshiana Besser, and "probably" A. candicans and $A$. floccosa Rydb. are reduced to synonyms of $A$. gnaphalodes Nutt. If A. rhisomata and A. pabularis (originally described as a variety by Nelson) are reduced to synonymy I shall enter no protest. I do not know what the first really is. One specimen in the Columbia herbarium bears the type number, but it does not agree with the original description and the label evidently has been interchanged. Some of the specimens distributed later under that name belong to the form of $A$. gnaphalodes common in the Rocky Mountain region. The form growing in Visconsin, the type state of A. gnaphalodes, looks quite different, although it is almost impossible to characterize the differences in words. Artemisia pabularis is a peculiar plant, in some respects intermediate between A. gnaphalodes and A. microcephala Wooton,

*Proc. Am. Acad. 25: I33. т890.

†Hook. Fl. Bor.-Am. 1: 325. I 833 . 
but with narrower leaves than either. A. pudica Rydb. is related to $A$. gnaphalodes and $A$. diversifolia, but in my opinion distinct. This is, of course, a matter of individual opinion. $A$. Purshiana is a northern plant with much broader leaves and denser inflorescence than the ordinary $A$. gnaphalodes. It is common in British America and Montana, has been collected in the Dakotas, and one specimen from Nevada I have referred doubtfully here, but I have seen no specimens from IVyoming or southward. Perhaps this species is unknown to Professor Nelson.

I must protest, however, against the reduction of Artemisia candicans Rydb., and A. floccosa Rydb. to synonyms of A. gnaphalodes. Artemisia floccosa, as stated above, should take the place of $A$. paucicephala and $A$. gracilenta, and the $A$. candicans is related to it. Using Nelson's key, one would place it in A. paucicephala, but the heads are still broader, sessile in small clusters, nodding or spreading, instead of erect, and the tomentum is more loose.

Artemisia Underwoodii Rydb., A. Brittonii Rydb. and A. latiloba (Nutt.) Rydb. are made synonyms of $A$. ludoviciana Nutt. I doubt if Professor Nelson knew what the first two are. One specimen of A. Underwoodii, viz., Goodding 1934, was distributed from the University of Wyoming under the name $A$. silvicola G.E.O. Both $A$. Underwoodii and $A$. silvicola are perhaps more closely related to $A$. mexicana than to $A$. $l u$ doviciana.

Artemisia Brittonii Rydb. has the leaves permanently tomentose on both sides and would be placed in A. gnaphalodes if Nelson's key were used. It is most nearly related to $A$. Purshiana, but has at least the lower leaves deeply lobed.

Artemisia latiloba (Nutt.) Rydb. should be known as $A$. Hookeriana Besser. I have seen a duplicate of the latter in the Gray herbarium and there is no doubt that it is the same as my A. latiloba. It is a northern plant, not found in Wyoming and rare in Montana. It has the same leaf-form as $A$. elatior and $A$. Suksdorfi, but the inflorescence is denser and the involucre is densely tomentose. It is sometimes hard to distinguish from, and in the west seem to grade into, what has been known in California and Nevada as A. heterophylla Nutt. The latter name is 
untenable and belongs evidently to A. Suksdorfii. The California-Nevada plant has been described as A. Kennedyi A. Nels., but even this must pass into synonymy, for the plant has an older name, A. Douglasiana Besser.

Under Artemisia discolor is given as a synonym: "A. elatior (T. \& G.) Rydb. as to our range." A. discolor and A. elatior can never be confused, but perhaps this could happen with the latter and A. incompta Nutt, which Nelson has regarded as a variety of $A$. discolor, following Dr. Gray. Crood specimens of $A$. elatior, resembling the type in the Columbia University herbarium, have been collected in Montana and one specimen which I can refer to no other described species we have from Colorado. Artemisia spiciformis Osterhout is reduced to a synonym of A. arbuscula Nutt. It is not related to that species but is related to A. Rothrockii A. Gray. The specimens from Utah collected by Ward and Parry and referred to by Dr. Gray,* belong to $A$. spiciformis Osterhout.

Nelson has also reduced several species to varieties, viz., A. Parryi A. Gray, A. coloradensis Osterhout, A. diversifolia Rydb., A. silvicola Osterhout, and A. Bakeri Greene.

There is scarcely any better species than $A$. Parryi and it can never be justly referred to $A$. saxicola. Not only has the plant "a tendency to become glabrate," but the pubescence, if any is present, is not that of $A$. saxicola, but is short-silky and appressed, the heads are usually much more numerous than in that species and not racemose, and the corollas are perfectly glabrous. If it were not for the absolute lack of tomentum I should place it next to $A$. franserioides and $A$. discolor. It is strange that Professor Nelson reduced this species to a variety, while he regarded A. Pattersonii as distinct from A. scopulorum. Besides, what rules of nomenclature was he following, when he reduced the older species A. Parryi to a variety of the later A. savicola?

Artemisia coloradensis Osterhout is made a variety of $A$. Wrightii. As A. Wrightii of Nelson is not the original A. Wrightii A. Gray, but A. kansana Britton (see above), a new combination is necessitated, if the specific rank of $A$. coloradensis is not upheld. Artemisia diversifolia Rydb. is made a variety of A. gnapha. *See Syn. F1. $1^{2}: 375$. 
lodes Nutt. This is of course a matter of individual opinion. It is fully as good as the two Nelsonian species $A$. aromatica and $A$. nova, which I am inclined to admit.

Artemisia silvicola Osterhout and A. Bakeri Greene are made varieties of $A$. mexicana. The former is, as stated before, related to $A$. mexicana, but the latter is very hard to distinguish from the original A. Wrightii. A. mexicana is not found in the Rockies and not even near them. What goes under that name from New Mexico and Arizona is mostly either A. neo-mexicana Greene or A. microcephala Wooton. The latter extends into southern L'tah and Nevada.

So many species have already been proposed in this genus that it may seem a little hazardous and unnecessary to add more to the already too large number. There are, however, two plants, both collected by Bourgeau on the Palliser Expedition in Saskatchewan, that can not be included in the species known by me, so that it seems better to give descriptions of them here. The second one was rediscovered in Alberta by Macoun and Herriot.

\section{Artemisia Bourgeauana sp. nov.}

Perennial with a tap-root and short caudex; stem silkypubescent, more or less tinged with red, 3-4 dm. high; basal leaves petioled, $4^{-6} \mathrm{~cm}$. long, sericeous-canescent on both sides, twice-pinnatifid with oblanceolate divisions; stem-leaves pinnatifid with linear, crowded divisions, rather small; heads numerous in a narrow panicle; involucres nearly $5 \mathrm{~mm}$. wide, silliyvillous, yellowish and shining; bracts oval, broadly scariousmargined; flowers light yellow, the central ones sterile.

This species is perhaps most closely related to Artemisia Forwoodi, having the same habit and leaf form, but the plant is more silky and the heads are twice as broad, fully as large as in $A$. spithamaea and A. canadensis. From the former it differs in the numerous heads, compound inflorescence, yellow instead of brown flowers, and taller stem. From A. canadensis it differs in the compact inflorescence, the densely silky leaves, and broader leaf-segments.

Saskatchewax: i 857-9, Bourgean (type, in herb. Columbia University). 


\section{Artemisia Herriotii sp. nov.}

Perennial with a rootstock; stem 6-Io dm. high or more, tomentose; leaves entire or sparingly and sharply toothed, 5-20 $\mathrm{cm}$. long, $5^{-15} \mathrm{~mm}$. wide, glabrate and green above, densely white-tomentose beneath, rather thin, margins not revolute; inflorescence a narrow compact panicle with very numerous small heads; branches erect, racemiform; heads erect; involucres about $5 \mathrm{~mm}$. high, $2.5^{-3} \mathrm{~mm}$. broad; bracts oblong-ovate to ovate, acute or obtuse, yellowish, densely tomentose; flowers yellow, the central ones fertile; receptacle naked.

Bourgeau's specimens were referred to Artemisia longifolia by Dr. Gray, but they are not closely related to that species. The leaves are not revolute-margined and the heads are not half the size of those of that species. It is most closely related to $A$. silvicola and A. Hookeriana Besser (A. latiloba Rydb.). It differs from the former in the denser and narrower inflorescence, the erect heads, the denser tomentum on the involucres, and the firmer leaves, and from the latter in the more entire leaves and the smaller, more cylindric heads.

Alberta: Edmonton, Aug. 25, 1906, Macoun \& IIerriot 72825 (type, in herb. N. Y. Bot. ( Gard.).

Saskatchewax: 1858 , Bourgeau (in herb. Gray).

\section{ACIILLEA}

A great diversity of opinion exists among botanists as to the number of species of this genus found in America. Dr. Ciray admitted three species, Achillea Millefolium, A. multiflora, and $A$. Ptarmica. Evidently Nelson held the same view, as he admits only A. Millefolium, the other two not being found in the Rocky Mountain region. Piper in his Flora of Washington* admitted $A$. lanulosa Nutt. as variety of A. Millefolium. Robinson and Fernald $\dagger$ regarded $A$. lanulosa as a good species. Pollard $\ddagger$ admitted Io species as North American. Of these one is Mexican and three escaped or introduced. Afterwards he, in coöperation with Cockerell,§ described an additional species from New Mexico. With the exception of $A$. multiflora and perhaps A. laxiflora,

*Contr. U. S. Nat. Herb. vol. I I.

†Gray's New Manual $8+5$.

†Bull. Torrey Club 26: 365-375. I 899 .

\$Proc. Biol. Soc. Wash. 15: 179. 1902. 
which is unknown to me, all the North American species are closely related to $A$. Millefolium and may be only forms of that species. Notwithstanding the fact that Achillea borealis, on account of its large heads and numerous rays, has been placed in the Ptarmica section of the genus, it is closely related to A. Millefolizm, and can be connected with it through two different lines of relationship. (See below.) It is very hard to say whether the native species of the Millefolium group admitted by Pollard should be regarded as species or as varieties of A. Millefolium and my intention here is not to express any opinion on that subject. I only wish to clear certain points regarding which there seems to be a great deal of confusion. I shall here use the specific names that have been applied to the different forms, whenever such are available.

\section{Achillea Millefolium L.Sp. Pl. 899. I 753}

This is a native of northern Europe and I think also of northern New York and New England and eastern Canada; at least it has naturalized itself in that part of North America. Elsewhere it is only sparingly introduced. It is a characteristic northern plant. It differs from all the other native forms in being less villous and having shorter hairs. The rachis of the leaves is distinctly wingmargined and the primary segments more or less decurrent; they are usually decidedly spreading. The secondary segments are short, lanceolate, and spinulose-tipped. The rays are comparatively large, $2-3.5 \mathrm{~mm}$. broad. The bracts have usually brown margins. In the far north, the plant often becomes more hairy and the margins almost black, and it approaches $A$. borealis on one hand and A. lamulosa on the other. Of such specimens we have one from North Iceland, collected by Olasur Davidson, and two collected by Collins and Fernald, one at Carleton Point, Que., in I904 (labeled A. lanulosa) and the other at Mt. Albert, Que., in I 906, no. 257 (labeled A. borealis).

Achillea occidentalis Raf.; DC. Prod. 6: 24. 1837, as a synonym under

A. Millefolium occidentalis DC. loc. cit.

A. Millefolium Pollard, Bull. Torrey Club 26: 37 I, in part. I899. Not A. Millefolium L. I753.

This is evidently the plant that Pollard took for the real 
Achillea Millefolium. It is characterized by the small rays, only $1.5^{-2.5} \mathrm{~mm}$. broad, and straw-colored bracts, pointed out by Pollard. It differs also from A. Millefolium in the narrow linear and usually more elongated segments of the leaves. There is also only a trace of a wing-margin on the rachis and the stem is usually more hairy and with longer hairs. DeCandolle regarded it as a variety of $A$. Millefolium and stated that it in intermediate between that species and $A$. setacea, a native of Southern Europe. In my opinion it is nearer to $A$. setacea, having the small rays and narrow segments of that species, but is more hairy. It is the common native form of the prairie region from Wisconsin to Kentucky, Arkansas, and eastern Nebraska, but specimens have been collected as far east as Pennsylvania and South Carolina. Three specimens from southern Colorado I have also referred here.

Achillea lanulosa Nutt. Journ. Acad. Nat. Sci. Philadelphia 7 : 36. 1834

A. tomentosa Pursh, Fl. Am. Sept. 56r. i8I4. Not A.tomentosa $\mathrm{L}$. $\mathrm{I} 753$.

This resembles the foregoing in many respects; the pubescence (although often more copious) and the color of the bracts are the same. The segments of the leaves are much shorter and more crowded and more directed forward; the rachis has not even a trace of a wing margin and the rays are much larger, $2.5-7 \mathrm{~mm}$. (Pollard gives them up to $6 \mathrm{~mm}$.) broad. This is the common plant of the Rocky Mountain region and its range extends from Saskatchewan to Kansas, New Mexico, northern Mexico, the mountains of California, and British Columbia.

Achillea subalpisa Greene, Leaflets 1: I 45.1905

A. lanulosa alpicola Rydb. Mem. N. Y. Bot: Gard. 1: 426.1900. A. alpicola Rydb. Bull. Torrey Club 33: I57. 1906.

This resembles a depauperate Achillea lanulosa in habit, but the margins of the bracts are strongly colored, usually almost black, though sometimes only brown, and such specimens approach closely A. lamulosa. The inner bracts as are a rule decidedly acute and in this respect it resembles $A$. borealis. It differs, however, from that species in the small heads, not over $+\frac{1}{4}$ 
mm. broad, the less numerous rays, and the short and crowded leaf-segments. It belongs to the higher Rocky Mountains.

\section{Achillea Borealis Bong. Veget. Sitcha I49. I 832}

In many respects this is close to the typical Achillea Millefolium. The heads are usually larger and have more rays; the bracts are usually darker but not always so. The main differences are in the inner bracts, which are decidedly acute, the narrow and usually long segments of the leaves, the rachis, which is almost without a wing margin, and the longer pubescence. The leaves resemble much those of $A$. occidentalis and $A$. californica. The range of $A$. borealis extends from the Mackenzie to Alberta, British Columbia, and Alaska. The plant of Newfoundland and Labrador, which has been referred to this species is somewhat different. So far as I know, it has not received any specific name, but it has been described under the following name:

Achillea Millefolium nigrescens E. Meyer, Pl. Labrad. 65. 1830

It has the large heads and dark-margined bracts of $A$. borealis, but the bracts are not acute, the leaf-segments are broad and short, and the rachis has a decided wing-margin. It agrees therefore in every respect with $A$. Millefolium, except the larger head and the more numerous flowers.

Achillea Californica Pollard, Bull. Torrey Club 26: 369 . I 899

This, so far as I know, is not found in the Rocky Mountain region. It is restricted to the Pacific Coast. It is usually taller and more robust than any of the species mentioned above. The character of the head is practically the same as in A. Millefolium, but the heads are larger, about as large as in $A$. borealis. The margins of the bracts are usually not so dark as in that species and none of the bracts are acute. The leaf-form is more that of A. borealis and A.occidentalis, but the segments are usually still more elongated and more divaricate. The leaves are usually thrice rather than twice pinnatifid. 
Achillea ARenicola Heller, Muhlenbergia 1: 6I. I904

This resembles in many respects the preceding but is much more copiously villous than any of the other species. The inflorescence is compact and of many large heads. The leaf-segments are short and crowded as in A. lanulosa, but the plant is stouter, the heads much larger and the margins darker. It has been mistaken for $A$. borealis, but has neither the blackish margins nor the acute inner bracts of that species.

Achillea Gigantea Pollard, Bull. Torrey Club 26: 370. I899, and

Achillea laxiflora Pollard \& Cockerell, Proc. Biol. Soc. Wash. I5: I79. I902, are both unknown to me.

The species or forms discussed above are fairly distinct when typical specimens from the centers of their distribution are compared. It must be admitted that intermediate forms are not altogether lacking. Intermediate forms between Achillea Millefolium and A. Millefolium nigrescens have been collected in Newfoundland. In northern New England A. Millefolium seems to be the only species. In New York, New Jersey, and Pennsylvania, both this and $A$. occidentalis are found, but intermediate forms seem to be very rare. In the center of distribution of $A$. occidentalis, viz., in Wisconsin, Illinois, Iowa, and Kentucky, A. Millefolium seems to be unknown, while in the north it has been collected in Manitoba, Saskatchewan, Alberta, and even British Columbia. It has been found also in Colorado; but judging from the localities, these specimens might have been escapes from cultivation. I have seen yarrows planted around miners' cabins. From Colorado and Nebraska I have seen a few specimens that were somewhat intermediate between Achillea occidentalis and A. lanulosa, but in almost every case they could be referred either to one or the other. A. lanulosa and A. subalpina both belong to the Rockies, but they grow at different altitudes; the former grows also on hillsides of the Great Plain region and at an altitude of $1000-3500$ $\mathrm{m}$.; the latter only in the high mountains at an altitude of $3000^{-}$ $4000 \mathrm{~m}$. Hence at an altitude of $3000-3500 \mathrm{~m}$., they are both found. Here intermediate forms might be expected. In California both Achillea lanulosa and A. californica are found, but 
I have seen no intermediate forms. There are several specimens from Utah, Idaho, and Washington which I refer to A. lamilosa, though they approach $A$. californica in the stoutness of the plant and the larger heads. From Washington I have seen a specimen intermediate between Achillea californica and $A$. borealis and another between $A$. arenicola and A. borealis. Achillea borealis is not found in the Rockies within the United States and $A$. subalpina not in British America outside of the Rockies. The only specimen which I refer to $A$. borealis though approaching $A$. subalpina, is from the Canadian Rockies of Alberta.

Petasites corymbosa (R. Br.) Rydb. comb. nov. Tussilago corymbosa R. Br. in Chloris Melv. 2r. I823.

Petasites palmata frigida Macoun, Cat. Canad. Pl. 1: 553. I 886.

Not $P$. frigida (L.) Fries. $\mathbf{I} 845$.

This has been included in Petasites frigida (L.) Fries, but differs in the deeply lobed leaves, the lobing extending one third to one half the distance to the midrib. It is the more common plant of the Canadian Rockies, known as P. frigida.

\section{ARNICA}

This genus, as represented in western North America is one of the most perplexing, and the last word concerning it is far from being said. I doubt if all the species proposed by Dr. Greene and Professor A. Nelson can be maintained. One of my own, Arnica monocephala, must be regarded as a low broad-leaved form of $A$. pedunculata, and A.tenuis Rydb. might be an entireleaved and monocephalous form of $A$. Rydbergii Greene. On the other hand there are evidently forms of this genus that have not been described.

Considerable confusion has existed in regard to Arnica Chamissonis Lessing and A. mollis Hook. Gray in his Synoptical Flora united the two. In the old Torrey herbarium there are two specimens. One of these bears the printed label "Arnica Chamissonis Lessing, Unalaschka" and was received from St. Petersburg. It is evidently from the original collection. It is a plant of the A. foliosa group, with longer loose villous pubescence. We have several specimens similar to it from British Columbia, Alberta, and Saskatchewan and at least one from Mon- 
tana. The other specimen is a duplicate of the type of A. mollis, received from Hooker. This is almost identical with $A$. subphimosa Greene, or A. Chamissonis longinodosa A. Nels., except that the involucral bracts are broader, oblanceolate, and abruptly short-acuminate. It represents a plant not uncommon in the Rockies, from northern Wyoming northward. The Arnica that is not uncommon in New England was referred to A. Chamissonis in Gray's Manual, 6th edition, and to $A$. mollis by Robinson \& Fernald in the Gray's New Manual. It has nothing to do with the former. It is related to the latter, but is, I think, distinct enough. It has more affinity to $A$. amplexifolia Rydb. (A. amplexicaulis Nutt.) and $A$. rivularis Greene than to $A$. mollis Hook. It does not have the broad bracts of $A$. mollis. It should be known as Arnica lanceolata Nutt. A duplicate of the type (if not the actual type) of the last named is found in the Torrey herbarium.

What Professor Nelson had in mind as Arnica mollis when preparing the manuscript of the New Manual, I can not imagine. In his key he separates it from Arnica subplumosa by the "leaf blades decurrent on the petioles." The blades are slightly and but slightly decurrent in both. His description is very vague and evidently drawn from several species. As synonyms he cites "A. Chamissonis in part, but mostly $A$. latifolia as to our range (A. latifolia A. Gray, Bot. Calif. 1: +15. I885; A. tomentulosa Rydb. loc. cit. 28: 20. I90I)." It is true that Gray and others referred $A$. mollis to $A$. Chamissonis, but I do not know that it has been referred to $A$. latifolia, unless by Prof. Nelson. Arnica latifolia A. Gray in the Botany of California comprises A. latifolia Bong., A. Mensiesii Hook. (this perhaps not specifically distinct from $A$. latifolia) and $A$. diversifolia Greene ( $A$. latifolia viscidula A. Gray). None of them has anything to do with A. mollis. A. tomentulosa Rydb. is related to A. Chamissonis Less., but differs in the short pubescence and the broad involucral bracts, rounded at the apex. If the form of the bracts should happen to be a variable character and of no specific value, Nelson's own Armica rhizomata should be reduced to a synonym of $A$. tomentulosa, as there are practically no important differences except the form of the bracts and the latter name is nearly five months older.

Greene's idea of Arnica Chamissonis is also wrong. He states 
under A.columbiana: "It can not be referred to A. Chamissonis, since it lacks the distinctly obovate leaf-cut, the broad, short diskcorollas and the tawny subplumose pappus of that species." These characters belong to A. mollis, not to A. Chamissonis.

There are more exceptions to be made to the treatment in the New Manual. Under Arnica ventorum Greene are given as synonyms $A$. platyphylla A. Nels. and A. grandiflora Greene. I have not seen the type of $A$. platyphylla, but $A$. grandiflora Greene is closely related to $A$.cordifolia Hook., and is not of the A.latifolia group. One specimen collected by R. S. Williams and referred to $A$. platyphylla by Nelson in his original publication is exactly like a specimen sent to Dr. Torrey as A. Menziesii by Dr. Hooker and included by him in his Flora. Both of these are very close to the original Arnica latifolia Bong., of which there is a duplicate in the Torrey herbarium. The only essential difference is that $A$. latifolia has perfectly glabrous achenes, while in A. Menziesii and Williams' plant the achenes have a few scattered hairs toward the upper end and are sparingly glandular-granuliferous.

Arnica sylvatica Greene is made a variety of $A$. subplumosa, and specimens distributed from the University of Wyoming under the name Armica subplumosa syliatica are nothing but a lowstemmed A. subplumosa. But the original A. sylvatica, of which there are two duplicates in the herbarium of the New York Botanical Garden, is quite different. It has cordate basal leaves and coarsely and saliently toothed stem-leaves. It is related to A. diversifolia Greene (A. latifolia viscidula A. Gray).

Professor Nelson has also united Arnica fulgens Pursh and $A$. pedunculata Rydb. What the original A. fulgens was, I do not really know, as I have not seen Bradbury's specimen; but $A$. fulgens, as interpreted by myself and by Piper, ${ }^{*}$ has a horizontal slender rootstock, without any tufts of brown hairs, while $A$. pedunculata, including $A$. monocephala Rydb., is characterized by its short, thick, almost erect rootstock, with dark brown hairtufts in the manner of Plantago eriopoda. It is the only species in North America that has this character, so far as I know. 
Arnica caudata Rydb. sp. nov.

Perennial, with a short cespitose rootstock; stems $2-3 \mathrm{dm}$. high, leafy, villous, and densely glandular-puberulent; leaves nearly erect, linear-lanceolate, mostly sheathing at the base, densely glandular-puberulent and with scattered villous hairs, $5^{-10} \mathrm{~cm}$. long, $5^{-8} \mathrm{~mm}$. broad, caudate-attenuate at the apex, with entire, somewhat revolute margins; heads mostly 3 , cymose, with the lateral peduncles usually exceeding the terminal one; involucres turbinate, about I cm. high, glandular-puberulent and hirsute; bracts linear-lanceolate, almost subulate, attenuate; ligules nearly I $\mathrm{cm}$. long, I-I.5 $\mathrm{mm}$. broad, deeply toothed or cleft; achenes slender, cylindric, glandular-granuliferous, and sparingly hispidulous; pappus short, sordid, plumose; corollas more or less pubescent.

This species is perhaps related to Arnica longifolia but is easily distinguished by the low habit, the caudate-attenuate leaves, and the hirsute as well as glandular-puberulent bracts.

UtAн: Big Cottonwood Cañon, near Lake Catherine, Aug. 3, I905, alt. $9300 \mathrm{ft} .$, A. O. Garrett 1547 (type, in herb. N. Y. Bot. Gard.).

\section{Senecio}

The original Senecio Bigelorii was collected by Bigelow on the Whipple Expedition and a specimen is in the herbarium of Columbia University. It differs from all that have been known under that name in later years by the lower leaves having long petioles and ovate-lanceolate blades. The petioles are longer than the blades, and the latter are abruptly contracted below. In $S$. chloranthus Greene and S. contristatus Greene the basal leaves have comparatively short petioles, and the blades taper gradually below. These two species, which it may be, should be united in one, are therefore fully as distinct from $S$. Bigelovii as is $S$. scopulinus Greene. The latter is acknowledged as a variety in Coulter \& Nelson's New Manual under the name S. Bigelorii Hallii A. Cray. It is in reality much closer to $S$. chloranthus than either is to S. Bigelovii. Dr. Creene* in proposing S. scopulinus says: "True Bigelorii is still unknown except from southern New Mexico, and is of very different aspect, with thin and not at all succulent deep-green herbage, usually no trace of any pubescence,

*Pittonia 4: II 7-II8. 
but consisting of short stiff straight hairs whenever present. This, the real S. Bigelovii, was distributed by Mr. Wooton, from the White Mountains of New Mexico, as S. Rusbyi, an error for which I am solely responsible. The species is nearer to $S$. Rusbyi than it is to $S$. scopulimus, which latter I have until recently assumed to be the typical S. Bigelovii." These statements of Greene are correct in as far as that the specimens distributed by Wooton and referred to by Greene are the most like the original S. Bigelovii of any that we have in the herbarium of the New York Botanical Garden, but Wooton's specimens have narrow leaves, the blades of the basal ones are not abruptly contracted at the bases, and the heads are smaller than in S. scopulinus, while those of the type of $S$. Bigelovii are much larger, even larger than those of $S$. contristatus.

The treatment of Senecio in the New Manual of the Botany of the Central Rocky Mountains is fairly good. There are many cases, however, in which the authors have reduced species to synonymy under closely related species, where the writer is inclined to keep them distinct, but where this is merely a matter of difference of opinion. But there are other cases in which such reductions are wholly unwarranted, misleading, and destructive to real science. Such a case for instance, is where Senecio solitarius Rydb. is made a synonym of S. subnudus DC. A mere reading of the description of the former would show that it is related to the group comprising S. integrifolius Nutt., S. columbianus Greene, S. perplexus A. Nels. etc., while S. subnudus is related to $S$. aureus. Another case is where Senecio Flintii Rydb. is made a synonym of S. glancescens Rydb. The former is closely related to $S$. exaltatus Nutt. and has a short crown with fascicled roots, characteristic of the $S$. integrifolins group, while S. glaucescens has a distinct rootstock, and is related to $S$. anacletus Greene.

Under Senecio perplexus A. Nels. we find the following statement: "(S. columbianus Rydb. in F1. Col., not S. columbianus Greene, of which S. atriapiculatus Rydb. is a synonym.)" The true typical Senecio columbianus Greene is found in Colorado and not uncommon. The only question in my mind is whether S. perplexus A. Nels. is really specifically distinct. The only 
difference is the more distinct toothing of the leaves of the former and the tendency of the upper stem-leaves to be narrower and more distinctly auriculate-clasping. S. columbianus and S. perplexus are really more closely related to each other than $S$. dispar A. Nels. is to S. perplexus, of which Professor Nelson has made it a variety.

Both Senecio IIarbourii Rydb. and S. Howellii Greene have been made synonyms of $S$. canus. Before I published the former I visited the Cray Herbarium and had a conference with Dr. Greenman. I found that two of the species I had in manuscript he also intended to publish, viz., S. IIarbourii Rydb. and $S$. multicapitatus Greenm. I published the latter under Greenman's name, and retained my own for the former. S. multicapitatus Greenm., Professor Nelson reduces to a synonym of S. Riddellii T. \& G. I know that at least a few years ago, Dr. Greenman, our best student of Senecio, regarded both $S$. Harbourii and $S$. multicapitatus as good species. In Piper's Flora of Washington,* S. Howellii is kept distinct from S. canus. The manuscript of the genus was prepared by the aid of Dr. Greenman.

Senecio salicinus Rydb., S. canovirens Rydb., and S.lanatifolius Osterhout are given as synonyms of S. Fendleri. S. salicimus is more closely related to $S$. rosulatus Rydb. than to $S$. Fendleri. The other two are somewhat related to $S$. Fendleri but I think perfectly distinct, having an altogether different foliage. $S$. lanatifolius has besides discoid heads.

Regarding Senecio rosulatus Rydb., I may say that when that species was proposed we had but one sheet of $S$. Nelsonii and that not a duplicate of the type. This sheet bears two undeveloped plants, one of them evidently belonging to the variety uintahensis. My conception of S. Nelsonii was therefore rather S. wintahensis A. Nels. I am willing therefore to accept S. rosulatus as a synonym.

Senecio uintahensis A. Nels. is related to S. multilobatus T. $\&$ G., as Nelson indicates; but the latter is not a winter annual or biennial, but a perennial with a tap-root, just as $S$. nintahensis is. $\dagger$ The main differences are that $S$. multilobatus is more glabrous, 
has narrower divisions to the stem-leaves, and has hispidulous instead of glabrous achenes.

Under Senecio cymbalarioides Nutt., in the New Manual is given the following: "(S. Jonesii, S. subcuneatus, S. acutidens Rydb. *** and $S$. oodes Rydb. *** seem to be impossible to discriminate satisfactorily)." S. subcuneatus and S. acutidens, especially the latter, are closely related to S. cymbalarioides, but the others are not. S. Jonesii is more closely related to $S$. mintahensis than to $S$. cymbalarioides and is perhaps not specifically distinct. If not, S. Jonesii is the older name and should be used.

Senecio Hartianus Heller is given as a synonym of S. pseudaureus Rydb. Professor Nelson may have been led astray by myself, for the specimens referred to $S$. Hartianus in my Flora of Colorado are but depauperate specimens of S. pseudaureus. The true S. Hartianus is closely related to S. flavulus Greene.

Senecio pyrrochrous Greene and S. Tracyi Rydb. are made synonyms of S. longipetiolatus Rydb. They are both more related to S. pseudaureus, having cordate or reniform, although entire, basal leaves, while in S. longipetiolatus the basal leaves are narrow and oblanceolate, tapering into the petioles.

Senecio fediifolius Rydb. and S. nephrophyllus Rydb. are made synonyms of $S$. discoideus (Hook.) Britton, perhaps because all three have usually discoid heads. The original descriptions show that they are entirely different plants. S. discoideus should be replaced by $S$. pauciflorus Pursh, which is an older name. Greenman and Blankinship* think that S. nephrophyllus is the same as $S$. debilis Nutt. I have not seen the type of the latter and can not express any opinion.

Dr. Greenman some years ago called my attention to the fact that the plant usually known as Senecio eremophilus Richardson, does not agree with the original. There is a duplicate of the latter in the Columbia University herbarium and it differs from the Colorado plant in the larger heads, which are $10-12 \mathrm{~mm}$. high and about $\mathrm{I} \mathrm{cm}$. wide and ascending or spreading instead of erect. In the Colorado plant the heads are less than I cm. high. S. eremophitus is a northern plant, its range extending from Manitoba to 
North Dakota, Montana, and northward far down the Mackenzie. Dr. Greenman thought that the Colorado plant should be referred to S. MacDougalii Heller, and so I adopted that view in the Flora of Colorado. I have seen two specimens from Colorado which may be included in S. MacDougalii, but the rest belong to what I think should be recognized as a distinct species.

\section{Senecio ambrosioides sp. nov.}

Senecio eremophilus Porter \& Coulter, Syn. Fl. Colo. 82, mainly. I874. Not S. eremophilus Richards.

Senecio MacDougalii Rydb. Fl. Colo. 397. I906. Not S. MacDougalii Heller. I 899 .

Perennial, with a stout rootstock; stem glabrous, leafy, 4-Io $\mathrm{dm}$. high; leaves lanceolate or oblanceolate in outline, pinnatifid to near the midrib or the lower incised, glabrous, all except the uppermost short-petioled, the lobes lanceolate, coarsely dentate or incised; heads numerous, corymbose-paniculate, 9-10 $\mathrm{mm}$. high, erect; involucres glabrous, $6 \mathrm{~mm}$. high and about as broad; bracts carinate, linear, acute, with black tips, the calyculate ones subulate, $4^{-5} \mathrm{~mm}$. long; ligules light yellow, 5-6 $\mathrm{mm}$. long, I.5-2 $\mathrm{mm}$. wide; achenes minutely scabrous-puberulent on the angles.

This species differs from Senecio MacDougalii in the larger heads (in S. MacDougalii only about $7 \mathrm{~mm}$. high), more campanulate involucres, lanceolate instead of linear divisions of the leaves, and the achenes scabrous-puberulent on the angles. From $S$. eremophilus it differs in the smaller and erect heads (in S. eremophilus I0-12 $\mathrm{mm}$. high), shorter rays, and smaller leaves. $S$. ambrosioides grows in damp places at an altitude of $1800-3000 \mathrm{~m}$.

Colorado: Green Mountain Falls, El Paso County, Aug. 2, I892, C. S. Sheldon (type, in herb. N. Y. Bot. Gard.); above Beaver Creek, July 8, 1896, Crandall 3030; Pagosa Peak, I899, Baker 706; Parrott City, I898, Baker, Earle \& Tracy 475; Ute Pass, I896, Clements Igo; Colorado Springs, July, I893, Saunders; Parlin, Aug. I6, I901, B. H. Smith 127; Ruston Park, i901, Clements 152; Mesa Yempa, I898, Shear 3943; Chambers Lake, I896, Baker; Ute Pass, I896, Shear 3695; mountains between Sunshine and Ward, 1902, Tweedy 4863; Empire, 1903, Tweedy 5783; Silver Plume, I895, Shear 4999; La Veta, I896, Clements I66; Silver Plume, I894, E. A. Bessey; Georgetown, I878, M. E. Jones 728; Gunnison, I90I, Baker 596. 
Wroming: Bridger Peak, I903, Goodding I942; between Sheridan and Buffalo, I900, Tweedy 3034; Upper Buffalo Fork, 1899, C. C. Curtis; Centennial Mountain, Albany Co., I902, Aven Nelson 8773; also I900, 7719; Copperton, I901, Treedy 4I36; Eastern slope of Big Horn Mountains, 1900, Tweedy 3033.

New Mexico: Mineral Creek, I904, Metcalfe I 415 ; Santa Fé Cañon, i897, Heller $3819 .^{1}$

Senecio Kingii sp. nov.

Senecio eremophilus D. C. Eat., Bot. King's Exp. I9I. I87I. Not S. eremophilus Richards. I823.

Perennial, with a thick rootstock; stems glabrous, 3-6 dm. high, rather stout, leafy; leaves obovate or oblanceolate in outline, $4-7 \mathrm{~cm}$. long, the lower petioled, all pinnately lobed one third to one half the distance to the midrib, with ovate or lanceolate, more or less toothed lobes; heads numerous, corymbosepaniculate, 9-I I mm. high; involucres glabrous, campanulate, 7-8 $\mathrm{mm}$. high, 6-7 mm. broad; bracts linear, acute, carinate, sometimes with small black tips; the calyculate ones few, subulate; rays $5^{-7} \mathrm{~mm}$. long; achenes scabrous-papillose on the rounded angles.

This species is related to S.eremophilus, but differs in the somewhat smaller and erect heads, less deeply dissected leaves, and their broad and short divisions, and shorter rays. One of the specimens cited below was determined some years ago as $S$. glaucifolins, but that species differs from this as well as from the rest of the group in the narrower and scarcely carinate bracts.

UtAн: Cottonwood Cañon, Aug. i 869, S. Watson 676 (type, in herb. Columbia University); Alta, Wahsatch Mountains, I879, M. E. Jones I144; American Fork Cañon, July i895, M. E. Jones; Big Cottonwood Cañon, Aug. I905, Garrett I59I; near Marysvale, 1905, Rydberg \& Carlton 7068; Mount Barrette, 7206; Fish Lake, 7506 .

\section{Senecio Leonardi sp. nov.}

Perennial, with a short rootstock; stem 4-5 dm. high, loosely floccose; basal leaves long-petioled; petioles $5^{-15} \mathrm{~cm}$. long; blades obovate or oval, $2-6 \mathrm{~cm}$. long, densely crenate, rather thick, loosely floccose, or in age glabrate, rounded at the apex; lower stem-leaves similar but with shorter petioles, the middle ones more or less lyrate-pinnatifid at the base; upper stem-leaves $\mathrm{I}-3 \mathrm{~cm}$. long, lanceolate in outline, pinnately lobed and somewhat 
auriculate-clasping; heads in a rather clense corymb, $8-9 \mathrm{~mm}$. high; involucres somewhat turbinate and floccose at the base, 5-6 mm. high, 6-7 mm. broad; bracts linear, acute, carinate, brownish-black on the backs, yellowish brown on the margins; rays orange, about $6 \mathrm{~mm}$. long, $2 \mathrm{~mm}$. wicle; achenes glabrous.

This species resembles most the eastern Senecio tomentosus in habit and pubescence, but differs in the shorter blades of the basal leaves, which are obovate or oval instead of ovate, in the dark involucres, and the glabrous achenes. It grows in meadows at an altitude of $1500-2000 \mathrm{~m}$.

UTAн: Near divide, head of American Fork Cañon, July 29, I 885 , Leonard 143 (type, in herb. N. Y. Bot. Gard.); Wahsatch County, near Midway, July 6, 1905, Carlton \& Garrett 67or.

\section{Senecio Tweedyi sp. nov.}

Senecio flavovirens Rydb. Bull. Torrey Club 27: I8I, in part. I 900 .

Senecio Balsamitae A. Nels., Coult. \& Nels. New Man. Cent. Rocky Mts. 583, in part. 1909.

Perennial, with a rootstock; stem glabrous, or slightly floccose at the leaf-axils, 4-6 dm. high, striate; basal leaves $3^{-1} 5 \mathrm{~cm}$. long, petioled; blades elliptic or oval to oblanceolate, crenate-dentate, often lyrate-pinnatifid with a few lobes below the large terminal one; lower stem-leaves similar, but more pinnatifid; upper stemleaves deeply pinnatifid, with oblong toothed divisions; heads corymbose, 9-10 $\mathrm{mm}$. high; involucres glabrous, somewhat turbinate at the base, about $8 \mathrm{~mm}$. high and as broad; rays narrow, bright yellow, $8-\mathrm{I}$ o $\mathrm{mm}$. long and a little over I mm. wide; achenes hispidulous on the margins.

This species has been mistaken for Senecio flavulus Greene (S. flavovirens Rydb.). In fact, the type was included in the original publication of S. flavovirens and the characters of the achenes were drawn from it. The type of $S$. flavovirens is just in bloom and the achenes only slightly developed, but a closer investigation shows that they are perfectly glabrous. So are the young achenes of all the specimens cited under S. flavovirens except Treed 586 . As this had well-developed achenes, I unfortunately described the achenes from it. The type of S. flavovirens and the other specimens cited under it, with the single exception mentioned, belong to S. flazulus Greene, described a few months earlier. Be- 
sides the difference in the achenes, Tweedy 586 has longer and narrower rays and more deeply dissected stem-leaves than has $S$. flavulus. Since the publication of $S$. flavovirens we have received more specimens with long and narrow rays, but otherwise resembling closely S. flavulus. All these specimens have also hispidulous achenes.

Wyoming: Buffalo Fork, Aug. I897, Treeedy 586 (type, in herb. N. Y. Bot. Gard.); Snake River, Aug. I2, I899, Aven Nelson \& Elias Nelson 6402; headwaters of Clear Creek and Crazy Wroman River, I900, Tweedy 303I; low ground, Adams Ranch, Jackson's Hole, July I 5, I 90I, Merrill \& Wilcox, 967.

Montana: Lima, June 30, I 895, Shear 3409.

The following species described from within the range of the New Manual or known to exist therein are not accounted for at all in that publication: S. seridophyllus Greene, S. lanceolatus T. \&. G., S. pereziifolius Rydb., S. neomexicanus A. Gray, S. laramiensis A. Nels., S. Hallii Britton, S. exaltatus Nutt., S. Scribneri Rydb., S. Porteri Greene, S. alpicola Rydb., S. turbinatus Rydb., S. pentadontus Greene, S. cognatus Greene, and S. Wardii Greene.

Greene and Greenman regard Senecio altus Rydb. as a synonym of S. sphaerocephalus Greene, and I think that S. perennans A. Nels. is but a broad-leaved form of S. werneriaefolius A. Gray.

Blankinship in his Supplement to the Flora of Montana adopts Senecio saxosus Klatt, giving under it the synonyms: S. petraens Klatt, S. petrocallis Greene, and S. alpicola Rydb. I can not find that $S$. saxosus Klatt was ever published. S. petraeus Klatt, or $S$. petrocallis Greene, is not found in Montana and $S$. alpicola is well distinct, being more closely related to S. werneriaefolius than to $S$. petrocallis.

\section{TETRADYMIA}

In the New Manual, Tetradymia multicaulis A. Nels. and $T$. linearis Rydb. are given as synonyms of $T$. inermis Nutt. The first I regard as a low depauperate form of $T$. inermis, but the second can not well be reduced to a synonym thereof. It is somewhat intermediate between Tetradymia canescens and $T$. glabrata. Except in the early spring it bears fasciculate leaves, as does $T$. 
glabrata, but these leaves are more tomentose. The primary leaves are neither erect nor subulate and somewhat spine-like as they are in $T$. glabrata. It differs from $T$. canescens in the narrower, more or less falcate primary leaves and the presence of secondary fasciculate ones.

Tetradymia longispina (M. E. Jones) Rydb. comb. nov. Tetradymia spinosa longispina M. E. Jones, Proc. Calif. Acad. Sci. II. 5: 698. I 895 .

This I think deserves specific rank.

New York Botanical GardeN. 

CONTRIBUTIONS FROM THE NEW YORK BOTANICAL GARDEN-No. 140

\section{STUDIES ON THE ROCKY IIOUNTAIN FLORA-XXIV}

By PER AYEL RYIBERO:

NEW YORK

1910

Reprinted, witboutchange of paging, from the BULLETIN OF THE TURREY BOIANICAI. CluB 37: 541-557. $30 \mathrm{~N} 1910$ 





\title{
Studies on the Rocky Mountain flora - XXIV
}

\author{
Per Axel Rydberg
}

Saussurea densa (Hook.) Rydb. sp. nov.

Saussurea alpina densa Hook. Fl. Bor.-Am. 1:303. I833.

Saussurea alpina Ledebouri A. Gray, Syn. Fl. 12: 397. I884.

Not S. Ledebouri Herder, I8Io.

Saussurea Ledebouri. Herder was based on S. subsinuata, S. nuda, and S. Tilesii of Ledebour, which Herder united into one species under another name. All three are illustrated in Ledebour's Icones Fl. Ross., and it is evident that S. alpina densa Hook. is different from each of them. None of the three illustrations shows the elongated, acuminate outer bracts, characteristic of S. densa. Only S. muda shows a dense inflorescence with subsessile heads and a low stem, but the heads are fewer and less crowded, the stem is naked above, and the leaves entire.

$S$. densa is a plant of the higher mountains of the Canadian Rockies.

Saussurea remotiflora (Hook.) Rydb. sp. nov.

Saussurea alpina remotiflora Hook. F1. Bor.-Am. 1: 303. I833. Saussurea alpina A. Gray, Syn. F1. 1²: 396, in part. I884.

Saussurea muda Britt. \& Rydb. Bull. N. Y. Bot. Gard. 2: I87.

I90r. Not. S. muda Ledeb. I829.

This species is nearer to Saussurea subsinuata Ledeb. than to either S. alpina or S. muda, but the inflorescence is laxer and the involucre is different, judging from Ledebour's illustration. $S$. remotiflora grows on low ground from northern Saskatchewan to Yukon and Alaska.

\section{CarduUs}

So many species of thistles have lately been described from the Rocky Mountains that the number has more than doubled since the issue of Gray's Synoptical Flora. Some of these species should be reduced to synonymy and some of them are probably hybrids, but I think that the larger number will remain as good 
species. It seems as if it should be unnecessary to propose more, but it has been impossible for me to include the following four in any known species.

\section{Carduus polyphyllus sp. nov.}

Carduus scopulorum Rydb. Mem. N. Y. Bot. Gard. 1:449. I900. Not C. scopulorum Greene. 1892.

Perennial; stem stout, $3-8 \mathrm{dm}$. high, very leafy, angled, arachnoid-hairy; leaves $\mathrm{I}-2 \mathrm{dm}$. long, linear in outline, deeply pinnatifid, with lanceolate divisions ending in ycllow spreading spines, green on both sides, sparingly arachnoid-hairy; heads hemispheric, about $3 \mathrm{~cm}$. high and broad, usually numerous, sessile in the axils of the leaves, often forming a leafy spike $2-3 \mathrm{dm}$. long; bracts linear-subulate, densely arachnoid-hairy, the outer with rather long yellow spines often I cm. long, the inner attenuate into slender straight tips; corollas straw-colored; pappus plumose with slender, barbellate tips.

In my Flora of Montana, I referred this species to Carduus scopulorum Greene. The latter was based on Cnicus eriocephalus or Cirsium eriocephalum A. Gray, the type of which was collected by Parry in Colorado. The rather common Colorado plant is characterized by its leaves, which are grayish-tomentose beneath, and by its heads conglomerate at the end of the stem, forming a cluster which at first is nodding. Carduus polyphyllus is more closely related to $C$. Kelseyi and $C$. Tweedyi. From the latter it differs in the straw-colored instead of red corollas, the narrower bracts, and more numerous leaf-lobes, and from the former in the deeply dissected and decidedly crisp leaves. If the leaves are lobed at all in $C$. Kelseyi the spines are directed forward and the blades are almost perfectly flat.

Montana: Mountains near Indian Creek, July 21, I897, Rydberg \& Bessey 5216 (type, in herb. N. Y. Bot. Gard.); Park Co., Aug., I887, Tweedy 349.

\section{Carduus Butleri sp. nov.}

Perennial or biennial; stem angled, striate, purple, sparingly arachnoid-hairy, very leafy, 6-1o dm. high or more; leaves linearoblanceolate or linear, almost entire or sinuately lobed, spinuloseciliate and if lobed the short lobes ending in slightly stronger spines, green and sparingly arachnoid above, grayish-tomentose 
beneath; heads few, ending the stem and short branches, subtended by narrowly linear spinulose-ciliate leaves, hemispheric, about $4 \mathrm{~cm}$. high, $4^{-5} \mathrm{~cm}$. wide; outer bracts lanceolate, brownish, glabrous or nearly so, ending in short weak spines $2-3 \mathrm{~mm}$. long, the innermost linear-lanceolate, attenuate, ending in slender brownish or purplish somewhat twisted and spreading lancelinear tips, these neither dilated nor erose; corollas pinkish; pappus plumose; tips more or less clavate.

This species resembles Carduus Kelseyi and C. foliosus in the leaves, but differs from both in the scattered few heads and purplish stem. In both species mentioned, the heads are conglomerate at the end of the stem. In Carduns Kelseyi the involucral bracts are much narrower and decidedly arachnoid. In C. foliosus the bracts are somewhat broader than in C. Butleri, the inner ones have dilated, lanceolate and erose tips, and the leaves are usually more lobed.

Montana: Big Fork, July 28, igo8, B. T. Butler, 674 (type, in herb. N. Y. Bot. Gard.); also near Rost Lake, 677.

\section{Carduus lacerus sp. nov.}

Probably biennial; stem stout, 6-Io dm. high, sparingly arachnoid, angled and striate; lower leaves oblanceolate, 2-3 dn. long, pinnatifid, with rather broad, ovate or lanceolate divisions ending in weak spines, glabrous or slightly long-hairy and green above, grayish tomentose beneath; upper leaves lanceolate, sessile and clasping, with somewhat narrower lobes and rather stout spines; heads more or less clustered, about $+\mathrm{cm}$. high and broad; outer bracts ovate-lanceolate, glabrous, without glutinous ridge, ending in short stout spreading spines $3-5 \mathrm{~mm}$. long; inner bracts with dilated, ovate, abruptly acuminate, erose and crisp, spreading tips; corollas rose-colored; pappus plumose; tips slightly clavate.

This species was probably included in Cnicus scariosus by Gray, judging from his description in the Synoptical Flora; but it is not Cirsium scariosum Nutt., for Nuttall characterized the latter as having arachnoid-hairy involucres, the bracts with dilated erose tips, and the leaves tomentose beneath. I know of only one species which agrees with this characterization. This is well represented by Flodman 880 , which was distributed as Carduus Hookerianus.

UTAн: Wahsatch County, near Midway, July 6, I905, Carlton 
$\&$ Garrett 6732 (type, in herb. N. Y. Bot. Gard.); apparently also, Salt Lake City, August, I880, M. E. Jones 1905, and the same locality, Sept., I905, A. O. Garrett $17 I 8$.

\section{Carduus olivescens sp. nov.}

Perennial; stem slender, somewhat tinged with purple, more or less floccose, $4^{-8} \mathrm{dm}$. high, leafy; leares linear in outline, $\mathrm{I}^{-2} \mathrm{dm}$. long, densely white-tomentose beneath, loosely floccose above, deeply pinnatifid, with numerous lanceolate, often 2-or 3-cleft lobes, ending in short yellow spines; heads few, peduncled, about $3 \mathrm{~cm}$. high, $3-3.5 \mathrm{~cm}$. wide; bracts slightly floccose on the margins, light olive-colored, darker towards the apex, ending in yellow spines $2-+\mathrm{mm}$. long, or the innermost with lance-linear, slightly twisted yellowish tips; corollas straw-colored; pappus plumose; tips slightly clavate.

This species was first determined questionably as Carduns Tracyi, to which it is not closely related, not having the conspicuous broad glutinous dorsal ridges or the broad bracts of that species. In leaf-form it resembles somewhat $C$. pulcherrimus, although the upper surface is more floccose, but otherwise it is not close to that species.

UтAн: Aquarius Plateau, August 5, I905, Rydberg \& Carlton 7450 (type, in herb. N. Y. Bot. Gard.).

Thistle hybrids are very common in Europe and even tertiary hybrids have been reported. No attempt has been made in this country to segregate or recognize hybrids in this genus. As a rule specimens of thistles are not so common in herbaria as would be expected, probably owing to the difficulty in collecting and preparing them.

Thistles are not uncommon in the Rocky Mountains, especially in Colorado. No person has perhaps contributed more to the knowledge of these plants of that state than Mr. George E. Osterhout, of New Windsor, Colorado. He has described a few species himself and others have been described from material collected by him. There are still more forms recognized by him and distributed under manuscript names, but which he has been reluctant to describe. With the aid of the material sent me by him, augmented by other specimens collected by Baker, Shear, Clements, myself, and others, it has been possible to recognize 
a good many forms which I regard as hybrids. The two species which seem to have produced the most hybrids are Carduus americanus (A. Gray) Greene (not Rydb.) and C. griseus Rydb. The former of these is comparatively common in Colorado, but the latter is rather rare. Several of the specimens cited under the latter in my Flora of Colorado do not belong to it, but are hybrids of Carduns americanus and various species. The original of $C$. griseus and later specimens collected by Osterhout do not have the bracts dilated at all or erose; the spines of the involucral bracts are long and somewhat flattened, and the leaves are darker and less deeply divided than in C. americams. The following probable hybrids have been recognized, but, like Mr. E. P. Bicknell, in the matter of Rubus hybrids, *we wish "to divest the subject from all nomenclatorial clains" and "to be understood merely as pointing out the probability of the occurrence of the hybrids mentioned."

\section{CarduUs aMericanus Xgriseus}

This has the leaves of $C$. griseus, $i$. e. dark green above, grayishtomentose beneath and with short lobes, as well as the strong and broad spines of the involucral bracts of that species, and some of the outer bracts are spinulose-ciliate; but most of the bracts are erose on the margins and the inner ones have dilated tips as in C. americanus. The following specimens are to be referred here:

Colorado: Toland, Gilpin Co., July 20, I906, Osterhout 3266; Ward, Boulder Co., July I 7 , I90I, Osterhout 2429.

The former of these was labeled by Osterhout Carduus erosus Rydb. (?). The original C. erosus is quite different. To strengthen the probability of hybridity, it may be mentioned that Mr. Osterhout has sent in specimens of one of the supposed parents, viz., $C$. griseus, also from Toland, Gilpin Co., collected on the same date, his 3267 , the next number, and that $C$. americanus is a rather common plant in Colorado.

The latter of the two specimens was determined by me as $C$. griseus, although I now regard it as a hybrid of that species and C. americanus. C. americanus has been collected at Ward, by Tweedy.

\footnotetext{
* Bull. Torrey Club 37: 399. I9I0.
} 


\section{CarduUs americanus X SPATHulatus}

This resembles most $C$. americanus in habit and leaf-form; the bracts are somewhat erose on the margins as in that species, but they are scarcely at all dilated, and if so only the innermost, and they are tipped with the short and broad spines characteristic of C. spathulatus. To this are referred:

Colorado: Estes Park, Aug. I6, I905, Osterhout 3091; Sulphur Springs, July I6, I905, Osterhout 3057; Happy Hollow, July I4, I 898 (collector not given), Herb. State Agric. College, no. 2801.

The last was distributed as Carduns griseus and has perhaps given rise to a wrong impression of that species. C. spathulatus was then undescribed and the bracts excluded no. 280 I from $C$. americanus. We have no specimens of either of the supposed parents, from exactly the same locality, but C. americanus is found nearly everywhere in the mountains of northern Colorado, and Osterhout in the original description of $C$. spathulatus states that it is common on both sides of the range of mountains east of the North Park.

\section{CARduUs AMERICANUS $\times$ COLORADENSIS}

Carduus erosus Rydb. Bull. Torrey Club 28:507. I90 I.

This was originally described as a distinct species. Professor Nelson reduces it to a synonym of Carduus americanus. The broad hemispheric head, the broad bracts with less dilated tips, and the more spiny leaves with more numerous and lanceolate lobes are very different from those of the typical C. americanus. The form and structure of the involucre, the form of the leaves, and the habit approach those of $C$. coloradensis. The upper surface of the leaves and the midrib beneath show some of the arachnoid hairs characteristic of $C$. coloradensis and its allies. We have no specimens of the two supposed parents from Durango, the type locality of C.erosus, but the locality is not without the range of either.

Colorado: Durango, is $896, F$. Tweedy $5 I 7$.

\section{CarduUs aCAULESCENS XaMericanus}

This resembles most $C$. americanus, but the stem is lower, the heads crowded, the involucral bracts elongated and less dilated 
at the tip, the leaves have more lanceolate lobes and stronger spines, and the stem and midribs of the leaves are more or less arachnoid-hairy. The clustered heads, the arachnoid pubescence on the stem, and almost glabrous bracts, with broad bases gradually tapering upwards, would suggest $C$, acaulescens as the other parent.

Colorado: Plains and foothills near Boulder, July, I903, Tweedy 5852 .

\section{Carduus acaulescens $\times$ COlORADEnsis}

Carduus acaulescens (A. Gray) Rydb. and C. coloradensis Rydb. are closely allied and many regard them as forms of the same species. As they often grow together and intermediate forms are found, this disposition seems plausible, but these intermediate forms may as well be explained by hybridity. The typical C. acaulescens has practically no stem and the small campanulate heads, seldom more than $3 \mathrm{~cm}$. wide, are sessile and congregated in a flat-topped head-like cluster, while the typical C. coloradensis has a stem 3-Io dm. high and the larger heads are more or less peduncled, 4-7 cm. broad, hemispheric, and scattered. The intermediate forms are usually low-stemmed and the heads, intermediate in size and shape, are in a dense flat-topped cluster at the end of the stem. At the south end of Fish Lake, Utah., C. acaulescens and C. coloradensis were found together by myself and Mr. Carlton and the specimens in the New York Botanical Garden bear the numbers 7547 and 7546 , respectively. The supposed hybrid also was collected, although I can not find any specimens now in the collection of the New York Botanical Garden. They may have met the same fate as some other specimens of the collection in being damaged by rain. There is one specimen, however, in our herbarium, which I regard as belonging to this hybrid, viz.

Colorado: Sulphur Springs, Grand Co., Aug. 8, i907, Osterhout 3615 .

\section{Carduus acaulescens Xscopulorum}

Carduus crassus Osterhout, MS.

This was distributed under the manuscript name cited above and regarded by Osterhout as a distinct species. I am inclined 
to think it a hybrid of the two species mentioned for the following reasons. The form and the pubescence of the leaves are almost exactly those of Carduus acaulescens. The small and clustered heads also suggest that species; but the plant has an evident stem and the involucre is decidedly arachnoid-hairy. As C. scopulorum and C. Parryi are the only species in Colorado which have arachnoid involucres, one of these may be supposed to be the other parent. As C. Parryi has also dilated erose bracts, it must be thrown out of consideration. In $C$. crassus the involucral bracts have also the long slender spines characteristic of C. scopulorum.

Colorado: Sulphur Springs, Grand Co., July 17, 1905, Osterhout 3072 .

Neither of the two supposed parents is represented by specimens from Sulphur Springs, but there is a specimen, Osterhout 3615 , just cited above, which I regard as a hybrid of $C$. acanlescens with another species.

\section{CARduUs griseus $\times$ LATERIFolius}

Carduus canalensis Osterhout, MS.

This I included in Carduus griseus in my Flora of Colorado but it differs in many respects from the type of that species, the leaves being much broader and less lobed, the upper leaves with broad auricles and the inner bracts with dilated erose tips. These two characters suggest $C$. laterifolizs, from which it differs in the long and broad spines of the outer bracts, characteristic of $C$. erosus.

Colorado: Canyon of Thompson River, Larimer County, August I6, I905, Osterhout 3089 .

This specimen was collected together with the type number of C. laterifolius, viz., Osterhout 3090 (the next number).

\section{CARDUUS GRISEUS $\times$ SCOPULORUM}

Carduus Osterhoutii Rydb. Bull. Torrey Club 32: I3I. I905.

This has the habit, the leaf form, and the long flat spines of the bracts of Carduus griseus, but the inflorescence is conspicuously arachnoid-hairy as in $C$. scopulorum and the leaf segments are rather more numerous than in $C$. griseus. The following specimens belong here: 
Colorado: Red Cliff, Eagle Co., July i7, i902, Osterhout 2706 ; Tennessee Pass, July 28, I902, Osterhout 2640.

The first of these specimens was associated with Carduns griseus, Osterhout 2707 (the next number), collected at the same date and locality. C. griseus was collected at Red Cliff in $\mathbf{1 9 0 6}$ also, Osterhout 3362. C. scopulorum, the other supposed parent, is rather common throughout the mountains of Colorado.

\section{CarduUs Griseus $\times$ PARRYi}

Carduns araneosus Osterhout, Bull. Torrey Club 32: 612. I905.

Osterhout in the original description of Carduns araneosus suggests the relationship with C. Parryi. C. araneosus differs from that species mainly in the less greenish corollas, the stouter and broader spines of the bracts, and the grayish under surface of the leaves. These characters suggest C. griseus, but the involucral bracts are decidedly arachnoid-pubescent and the inner bracts are more or less dilated above and erose. The following specimens belong here:

Colorado: Red Cliff, Eagle Co., June 26, igoo, Osterhout 2169; and also Aug. I6, I906, Osterhout 3363; Boreas, July 24, I897, Crandall 2806; without locality, J. W'olf 450 (Wheeler Exp.).

The first two specimens were collected at Red Cliff, where also two numbers of C. griseus (see under preceding hybrid) and one of C. Parryi, viz., Osterhout 2708, were collected.

\section{Carduus oreophilus $\times$ SCOPUloru}

This resembles $C$. scopulorum in the heads crowded at the ends of the stem, the arachnoid involucres and general habit; but the leaves are broader, with fewer lobes; the involucral bracts are broader at the base, and the flower-cluster not nodding. In these characters it approaches C. oreophilus, but it has less deeply dissected leaves with broader lobes, and the inflorescence is much more arachnoid.

Colorado: Silver Plume, Aug. 23, 1895, Shear 4948 and 4960.

Carduus oreophilus also was collected at Silver Plume the same day by Shear, no. 3258 , and also by Rydberg on the following day. C. scopulorum is common in the upper part of Clear Creek above Silver Plume. In the herbarium of the Garden there is one speci- 
men from near Gray's Peak, Shear 4734, collected on the same date as 4978 and 4960 .

\section{Carduus Coloradensis $\times$ Undulatus}

With the specimen cited below, Mr. Osterhout sent a slip of paper on which is written: "Do not think this is Carduus undulatus - do not know what it is." It resembles C.undulatus, the flowers being red, although paler, the bracts having a glandular dorsal ridge, and the general habit and leaf-form being similar, but the dorsal ridge is very inconspicuous. It resembles perhaps more C. coloradensis in habit, in the form of the bracts, and the lanceolate twisted tips of the innermost of these. There is also an indication of arachnoid hairs on the stem, but the corollas are pink, not dirty white, and there is an evident though narrow dorsal ridge towards the ends of the bracts.

Colorado: Wolcott, Eagle Co., July i i, I902, Osterhout 2653.

Mr. Osterhout collected also $C$. coloradensis at the same date and locality, viz., $265 \mathrm{I}$.

\section{CARDUUS FILIPENDULUS $X$ OCHROCENTRUS}

Carduus dispersus Osterhout MS.

This has the large heads and the long spines of C. ochrocentrus but the broad non-decurrent leaves and dark green glabrate upper surfaces of $C$. filipendulus.

Colorado: Home, Larimer Co., July 29, r904, Osterhout 2898.

Both of the supposed parents are common in Larimer County. Mr. Osterhout doubts that this can be a hybrid between the two supposed parents given above, as he has not seen either growing so far up in the mountains.

\section{Carduus Flodmanim $\times$ megacephalus}

This specimen cited below was determined as Carduns Flodmanii, but its leaves are much broader and with shorter and broader lobes, the heads are larger, and their bracts more glutinous than in the typical C. Flodmanii. The plant is almost exactly intermediate between that and $C$. megacephalus.

Colorado: Fort Collins, July 30, I 904, Osterhout 2903.

Both of the supposed parents are common around Fort Collins. 


\section{Carduls plattensis $\times$ undulatus}

The specimen cited below was sent me by Mr. Osterhout, who suggested that it was a hybrid of Carduus plattensis Rydb. and C. undulatus Nutt. It has the head of the former, but somewhat smaller and with narrower and less viscid bracts. The leaves also are those of that species but approach those of $C$. undulatus.

Colorado: Thompson's River, Larimer Co., Aug. I6, I905, Osterhout 3087 .

There are many features that suggest hybridity in Carduns perplexans Rydb. In the original description, attention was directed to its relationship to $C$. Centanreae $(=C$. americanus Greene) and also to the $C$. altissimus group. At that time I was inclined to regard it as a hybrid between C.americanus and $C$. filipendulus, but the broad leaves seemed to contradict such a disposition.

Since that time I have been inclined to regard it as a hybrid of C.laterifolius Osterhout and C. filipendulus, as the former has broad leaves resembling those of $C$. perplexans. The bracts, erose-tipped as they are, are not much like those of $C$. laterifolius. Mr. Osterhout suggests that it might be a hybrid of an undescribed species, specimens of which he has sent me. In these the bracts resemble those of $C$. perplexans very much and the flowers are also red; but the leaves are narrow and deeply pinnatifid. This species and $C$. filipendulus could scarcely produce a hybrid like C. perplexans.

All the supposed hybrids given above were collected in Colorado. Besides these the following are in the herbarium of the New York Botanical Garden from neighboring states.

\section{CarduUs megacephalus XOCHROCENTRUS}

There seem to be two rather distinct forms included in Carduns ochrocentrus. As both are found in Texas and New Mexico and I have not seen the type specimen, I am uncertain which of the two is C.ochrocentrus proper. One of them extends northward to Nebraska and northern Colorado and is the only one found within the range of my studies. For the present $I$ regard this as $C$. ochrocentrus, until further information can be had. It is characterized by strongly decurrent and strongly spinose, crisp leaves. 
with numerous short crowded lobes and densely white-tomentose beneath. The spines of the involucral bracts are also long and strong, in age usually strongly spreading. C. megacephalus, which resembles it in many respects, has much broader flatter leaves, with fewer lobes and short spines, scarcely decurrent and at least the upper ones with broad clasping bases. The spines of the involucres are also short and weak. The following two specimens have leaves resembling those of $C$. ochrocentrus but not decurrent and have involucral bracts with the short weak spines of $C$. megacephalus.

Nebraska: Banner County, July 6, i89i, Rydberg $215 a$.

Kansas: Plains, Ellis County, July I6, I895, Hitchcock 309.

The first of these was collected with Carduns megacephalus, Rydberg 215. C. ochrocentrus was common in the region. Rydberg 214 , belonging here, was collected a few miles further south. There are also forms intermediate between C.megacephalus and $C$. undulatus, but as these two species are so closely related that it is almost impossible to draw a line between them, I have not tried to distinguish any hybrids.

\section{CARduUs Foliosus X SCOPUlORUM}

This has the habit and bracts of Carduus foliosus, but the involucre is densely arachnoid as in C. scopulortm and the leaves have more numerous and crowded lobes, in that respect approaching those of the latter species.

Wromng: Big Horn Mountains, Aug., r899, Tweedy 2120.

Carduus scopulorum was evidently growing near it, for a specimen belonging to it and collected by Tweedy bears the number 2I22. C. foliosus is common in the Big Horn Mountains. Among others are Tweed y $305 \mathrm{I}$, collected there the following year.

Carduns Tweedyi, judging from the scarcity of the plant and from the fact that it combines the characters of two groups, may also be a hybrid. A plant of its type may be produced by the crossing of $C$. polyphyllus and a red-flowered species such as C. Macomii or C.edulis but neither of these two has been found east of the continental divide and $C$. Treedyi not west of it. A somewhat similar plant would be produced by the crossing of C. scopulorm and C. Eatoni, but I have seen no specimens of the latter outside of Utah. 


\section{Carduus Butleri $\times$ Kelseyi}

The leaves of the two supposed parents are very similar, so the differences are mostly found in the inflorescence and the involucral bracts. See under the description of Carduus Butleri.

The supposed hybrid has the inflorescence of $C$. Kelseyi, the bracts of $C$. Butleri, but slightly arachnoid-hairy.

Montana: Rost Lake, July 28, I908, Butler 703.

Carduns Butleri was collected at the same locality and on the same date, Butler 677; and C. Kelseyi three days later a little higher up in the mountains, Butler 398.

\section{Carduls Eatoni Xolivescens}

Cnicus Eatoni A. Gray included sereral forms. Three of these had been distinguished by D. C. Eaton, who, however, had applied wrong names for two of them. The first of the three Eatonian synonyms cited by Dr. Gray is Cirsium eriocephahum var. leiocephalum. Dr. Gray's description also applies principally to this. Hence Carduns leiocephalus (D. C. Eaton) Heller becomes a synonym. Cirsium foliosum D.C. Eaton, I think, is the same as Carduus nevadensis Greene and C.Drummondii D. C. Eaton is a Nevada plant, almost identical with C.oreophilus of Colorado.

The supposed hybrid under consideration resembles C. Eatoni in general habit, but the leaves have fewer and deeper lobes and are grayish tomentose beneath, and the involucres have shorter and weaker spines. It differs from C. olizescens in the broader segments of the leaves, the narrower bracts, of which the outer are spinulose-ciliate as in C. Eatoni.

UTAн: Aquarius Plateau, Aug. 4, 1905, Rydberg \& Carlton $7+22$.

Carduus olivescens also grew on the Aquarius Plateau. The type of it was collected the following day and bears the number 7450. C. Eatoni is common in the same region, although Carlton and myself did not preserve any specimens from the Aquarius Plateau.

\section{Cardues pulchellus $\times$ undulates}

This most resembles Carduns pulchellus in habit, but the involucres are more hemispheric instead of truly campanulate, the bracts are broader and with a narrow glutinous ridge, and the inner 
ones are not so elongated as in that species. From $C$. undulatus it differs in the narrower segments of the leaves, the glabrate upper surface of the same, the somewhat purple-tipped inner bracts, and the inconspicuous dorsal ridge.

UTAн: Fish Lake, near Twin Creeks, Aug. 8, 1905, Rydberg Eo Carlton 7499 and 7487; Beaver City, I877, Palmer 273.

Colorado: Grand Junction, June I5, I900, Mrs. Stokes.

Neither of the supposed parents was collected at the same date and locality, but both are found in Utah and Colorado. C. pulchellus was collected by Carlton and myself in the neighborhood of Marysvale, nos. 7016 and 7179 .

A good deal can be said about the treatment of this genus in the New Manual of Botany of the Central Rocky Mountains. Many of the species, reduced to synonymy, have little or no relationship to those of which they were made synonyms.

Under Carduns americanus we find the following synonyms: C. Centaureae Rydb., C. erosus Rydb., and C. griseus Rydb. The first is a pure synonym. When the name was proposed I was following the Madison amendments of the "Rochester Code," and according to those amendments an older varietal name invalidated the name $C$. americanus. $C$. erosus I now think is a hybrid of $C$. americanus and $C$. coloradensis. $C$. griseus, on the contrary, is a good species, easily distinct from $C$. americanus, and its bracts have no dilated erose tips. In my Flora of Colorado I included in it at least two hybrids of C. americanus with this species and related ones. This may have given Professor Nelson a wrong idea of $C$. griseus.

Under Carduns Hookerianus we find as a synonym C. Osterhoutii. C. Hookerianus is, so far as I know, not found within the United States. It is from the Saskatchewan region. I, as well as others, have referred specimens from Colorado to it, but all these belong to a form of $C$. scopulorum. This may have been the reason why Nelson has made the latter a variety of $C$. Hookerianus under the name C. Hookerianus eriocephalus. C. Osterhoutii is not closely related to C. Hookerianus, but more so to C. scopulorum. I think it is a hybrid of that species and C. griseus.

Under Carduus Hookerianus eriocephalus we find the follow- 
ing synonyms: "Cnicus eriocephalus Gray, Carduus scopulorum Greene 1.c., C. Tweedyi Rydb. 1.c., C. araneosus Osterh.*** C. Eatonii Gray,*** C. canovirens Rydb. I.c. (?) C. pulcherrimus Rydb." Of these the two first are pure synonyms. Carduus Twee$d y i$ is a related red-flowered species (see page 552). C. Eatoni. as I understand it and limited to $C$. eriocephalus var. leiocephalus D. C. Eaton, is a good species, forming a group by itself. C.araneosus is not related to $C$. scopulorum but to $C$. Parryi, as Osterhout suggested, and is probably a hybrid of that species and $C$. erosus. C. canovirens and C. pulcherrimus do not belong even near C. scopulorum, but to the C.undulatus group. C. canovirens has no very close relative. The nearest is perhaps $C$. canescens (Nutt.). Nelson once thought it a good species, distributed it under a manuscript name, and would have published it, if his attention had not been called to the fact that it was already published. C. pulcherrimus is most closely related to $C$. ochrocentrus and stands to that species nearly in the same relationship as C. undulatus does to C. megacephalus.

Under Carduus foliosus are found the following synonyms: C. scariosus (Nutt.) Heller and C.coloradensis Rydb. Judging from Nuttall's original description of Cirsium scariosum, it is not at all related to Carduus foliosus Hook. See remarks above under C. lacerus. Carduus coloradensis is not to be referred to $C$. foliosus. It was based mainly on Cnicus Drummondii of the Synoptical Flora, and is apparently the same as Carduus Drummondii of the New Manual, the corolla of which is described as white. The original Cirsium Drummondii T. \& G., of which there is a duplicate in the Torrey herbarium, has rose-purple corollas The only specimens I have seen from the United States, are from the Black Hills of South Dakota. All the others are from British America.

Carduus oreophilus Rydb. is given as a synonym under $C$. Drummondii. From what is just stated it may be seen that it is not the original C. Drummondii and a comparison between my description in the Bulletin of the Torrey Botanical Club and that of $C$. Drummondii in the New Manual shows that it is not $C$. Drummondii as understood by Professor Nelson. C. oreophilus is very local and many things suggest a hybrid, but I have failed 
to find two species that would produce a combination of characters found in C. oreophilus. A mixture of four species, C. pulchellus, C. spathulatus, C. scopulorum and C. coloradensis might do it. I think therefore that it is best to regard it at present as distinct.

Under Carduus bipinnatus (Eastw.) Heller, in the New Manual, we find: C. pulchella[us], C.truncatus Greene(?) and C. spathulatus Osterh. The only true synonym is $C$. truncatus Greene. $C$. pulchellus is related to it, but the leaves are white-tomentose beneath. C. spathulatus Osterhout is related to C. griseus, though its involucral bracts are much shorter. The plant resembles closely C. americanus, but the bracts are not at all fimbriate.

Carduus Tracyi Rydb. is, in the New Manual, made a synonym of $C$. Nelsonii Pammel (Pammel did not use the generic name Carduns and the page is wrongly cited), while the latter is kept distinct from C. plattensis Rydb.

A botanist with broad limitations of species might regard Carduus plattensis, C. Nelsonii, C. Tracyi, C. brevifolius, and C. palousensis as one species. They are all closely related but each has a definite range of its own. C. plattensis belongs to the sandy regions of Nebraska, Kansas, and northeastern Colorado; $C$. Nelsonii, as far as I know, is found only in Wyoming; C. Tracyi in southern Colorado; C. brevifolius in Wyoming and Montana; and C. palousensis in western Idaho and eastern Washington and Oregon. Carduus Nelsonii and C. plattensis are the most closely related of the four; the only difference I can find is that $C$. plattensis has the inner bracts prolonged into linear lanceolate, spreading, more or less crisp tip, a character not found in the rest. The characters given by Nelson in the key to distinguish $C$. Nelsonii and $C$. plattensis are useless, because the characters assigned to the latter are not true.

Under Carduus filipendulus (Engelm.) Rydb., in Coulter \& Nelson's New Manual, are given as synonyms: C. Flodmanii Rydb. and $C$. oblanceolatus Rydb. The description of $C$. filipendulus is a verbatim copy of my description of $C$. Flodmannii. Iittle could be said against this, if the two were the same, but this is not the case. In the key, Professor Nelson distinguishes C. filipendulus from C. undulatus, C. megacephalus, and C.ochrocentrus by the characters: "Leaves becoming 
green and glabrate on the upper side" against "Leaves permanently tomentose on both sides." The glabrate character is correct as far as C. filipendulus in concerned and was the reason why Dr. Gray associated it with C. altissimus; but it is not true of C. Flodmanii, for in that species the tomentum is as permanent as in $C$. undulatus and $C$. ochrocentrus and far more so than in C. megacephalus. In the key C. filipendulus is characterized, but the description is of $C$. Flodmanii under a wrong name. Dr. Gray included C. Flodmanii in his Cnicus undulatus canescens

Professor Nelson has admitted a variety Carduus undulatus canescens (Nutt.) Porter. Evidently this was unknown to him for he simply copies Gray's characterization of Cnicus undulatus canescens. Some years ago, while visiting the Gray herbarium, I was curious to see what Gray meant by this variety. I found that it contained a mixture of Carduus Flodmanii, C. oblanceolatus, another related species of Arizona, and Cirsium brevifolius Nutt. The last is a yellow-flowered species related to Carduus Nelsonii and $C$. plattensis, and antedates both. Of these $C$. Flodmanii agrees best with the description of Cirsium canescens Nutt., and it might be that species. I have seen, however, a specimen of another species with strong erect involucral spines, which bore the name Cirsium canescens in Nuttall's own handwriting. Whether that specimen was the type or not I do not know, but I have adopted the name Carduus canescens for that species. Pammel in his treatise on the Iowa thistles adopted the name Cnicus canescens for Carduus Flodmanii. If Nelson had followed him, I would not have made any criticism, as there is some doubt as to which the name canescens belongs to, C. Flodmanii or the species for which I have adopted it.

Professor Nelson has also omitted all the Utah species described by Marcus E. Jones, although most of them belong to the range of the New Manual.

\section{Centaurea and Arctium}

Neither of these two genera are included in the New Manual, although C. Cyanus has been collected at several places in Montana, C. solstitialis L. at Salt Lake City, Utah, and A. minus Schk. in Colorado.

New York Botanical Garden. 

CONTRIBUTIONS FROM THE NEW YORK BO'TANICAL GARDEN-No. 141

\section{STUDIES ON THE ROCKY MOUNTAIN FLORA-XXV}

By PER AXEL RYDBERG

NEW YURK

1911 



\section{Studies on the Rocky Mountain flora - XXV}

\section{Per Axel Rydberg}

Ptilocalais macrolepis Rydb. sp. nov.

Perennial with fusiform roots; stem glabrous, $2-5 \mathrm{dm}$. high, somewhat branched, glabrous or minutely puberulent; lower leaves somewhat petioled, the upper sessile; blades linear-lanceolate, entire or rarely pinnatifid with linear-lanceolate, divergent divisions; heads solitary at the ends of the slender naked branches; involucres turbinate, about $2 \mathrm{~cm}$. high. Calyculate bracts $8-10$, lanceolate or linear-lanceolate, 3-6 mm. long; bracts proper I2-I5, linear-lanceolate, attenuate; achenes about $7 \mathrm{~mm}$. long, puberulent on the rounded angles or glabrate; pappus-scales lanceolate, $4-5 \mathrm{~mm}$. long, gradually tapering upwards; bristles 6-7 mm. long.

In habit this species is intermediate between Ptilocalais mutans and $P$. major, with the head of the latter, but it differs from both in the pappus-scales. In the original description of Ptilophora major, Gray gives no description of the pappus, stating that his specimens were too young. In the Columbia University herbarium there is a duplicate of the type, collected by Spalding. This has fairly well developed fruit and shows that Ptilocalais major has practically the same pappus as P. nutans, i. e., the paleaceous portion is only $2 \mathrm{~mm}$. long, oblong in outline, truncate and somewhat 3 -toothed at apex. P. macrolepis grows in sandy soil at an altitude of $1200-1500 \mathrm{~m}$.

UTAh: Benches near Salt Lake City, Apr. 30, 1904, A. O. Garrett I 82 (type, in herb. N. Y. Bot. Gard.); Red Rock Cañon, June I I, I905, Rydberg 6105; Salt Lake City, May I2, I880, M. E. Jones I707 (at least in part); benches near Salt Lake, June I, I900, Stokes.

\section{PTILORIA}

Professor Nelson, in the New Manual of Botany of the Central Rocky Mountains, restores the name Stephanomeria, following the Vienna Rules. The only criticism I have to make of the treatment of the genus is that he has reduced Ptiloria ramosa 
Rydb. to a synonym of S. tenuifolia (Torr.) Hall. In the herbarium of the New York Botanical Garden there is a good specimen of P. ramosa collected by Aven Nelson and Elias Nelson, viz., no. 5985. This is labeled Ptiloria panciflora (Torr.) Raf. It agrees well with Nelson's description of $S$. panciflora, except as to the pappus, but it is very unlike the type of Prenanthes panciflora Torrey, collected by James and preserved in the herbarium of Columbia University. Ptiloria panciflora, so far as I know is not found so far north as Wyoming.

\section{ADOPOGON}

Professor Nelson has readopted Krigia for this genus and perhaps rightly so, as most of Necker's genera can scarcely be called published. However, he wrongly adopts the name Krigia virginica (L.) Nels. for the only species found in the region, notwithstanding the fact that there is an older Krigia irrginica (L.) Willd.

\section{CREPIS}

Under Crepis runcinata we find in the New Manual the Sollowing synonyms and remarks. " $C$. platyphylla Greene... ; C. glancella Rydb. ..., C. tomentulosa, C. perplexans, and C. petiolata Rydb.... To recognize the foregoing one would first have to assume a hypothetical C. runcinata.)" There is hardly need of assuming a hypothetical C. runcinata, for there are found in the region where the type of IIieracium runcinatum Torr.* was collected at least two plants which agree very well with the original description. One is the plant for which I have adopted the name Crepis runcinata, the other is C. riparia A. Nels. Most of James' plants are in the old Torrey herbarium, but the type of Hieracium runcinatum is not there. Torrey's description is very clear, however, and calls for a strongly hairy plant. All the synonyms cited above, except C. platyphylla, represent glabrous plants (except as to the involucres), and more closely related to $C$. glanca than to $C$. runcinata. Crepis platyphylla Greene is closely related to $C$. riparia and perhaps not distinc',

*Ann. Lyc. N. I. 2: 209. I826. 
at least it is more closely related to it than is C. denticulata Rydb., which Professor Nelson reduces to a variety. A "conservative" botanist would unite $C$. platyphylla Greene (C. runcinata hispidulosa Howell) and C. riparia. The latter would then be reduced to 'ynonymy, as the form $r$ name is three years older In Torrey and Gray's Flora, Hieracium runcinatum was transferred to Crepis and the authors cite four specimens, of which two, viz., those collected by Drummond (Crepis bienmis $\beta$ Hook.*) and by Nicollet are preserved in the Torrey herbarium. These agree with the description of 'Torrey's Hieracium runcinatum. I have adopted the name Crepis runcinata for these specimens rather than to transfer the name to $C$. riparia. If Professor Nelson had reduced $C$. tomentulosa to a synonym of $C$. glanca, I would have made no objection, for I myself am somewhat suspicious that it may be on $y$ a state or condition of that species. Crepis petiolata and C. glauc lla are closely related to it, and the glandular involucre is the only character which would associate it with $C$. runcinata. C. perplexans is closer to C. runcinata, but it also is a glabrous plant.

Both Crepis denticulata Rydb. and C. alpicola A. Nels. are included in C. riparia parva A. Nels. Crepis alpicola was tech. nically based on $C$. runcinata alpicola Rydb. The type of both the latter and $C$. denticulata are in the herbarium of the New York Botanical Garden and they are not at all alike. Nelson's description of $C$. riparia para agrees with $C$. alpicola but not with C. denticulata. Compare the original descriptions.

Crepis angustata Rydb. is made a synonym of C. gracilis (D. C. Eaton) Rydb. The plant described by Professor Nelson is, however, not $C$. gracilis but C. angustata. Crepis gracilis was established on $C$. occidentalis gracilis D. C. Eaton. $\dagger$ The type of this is Watson 716: a duplicate of which is in the Columbia. University herbarium. It is a plant exceedingly like $C$. scopulormm in habit, but the involucre is narrower, the bracts fewer, and the achenes distinctly ribbed. Some of the involucral bracts have a few black hairs as they have in C. scopulorm. Crepis angustata, like $C$. intermedia, never has black hairs. C. gracilis

*Fl, Bor.-Am. I: 297.

† Bot. King. Exp. 203. 1871 . 
I think has been redescribed under the name C.exilis Osterhout,* omitted by Nelson.

Crepis pumila Rydb. is made a synonym of $C$. occidentalis. C. pumila is not only a lower plant, without any trace of black glandular hairs, but it has different, perfectly columnar achenes. Apparently it was included by Dr. Gray in his C. occidentalis costata.

Crepis atribarba Heller is made a synonym of $C$. barbigera Leiberg. The two are not even closely related. The latter is not found within the region, and there was no need of even considering it.

\section{Crepis seselifolia sp. nov.}

Perennial with an ascending rootstock and short base covered by remains of old leaves; stem 4-6 dm. high, slender, canescenttomentulose or the upper part glabrous; basal leaves long-petioled; blades $\mathrm{I}-2 \mathrm{~cm}$. long, deeply twice pinnatifid, with linear filiform divisions, canescent-tomentulose, caudate-acuminate, with an elongated linear entire end 5-8 cm. long; stem-leaves subsessile, less divided or the uppermost entire and linear-filiform; heads corymbose-paniculate; involucre glabrous, cylindric, about $1 \mathrm{~cm}$. long; calyculate bracts ovate or ovate-lanceolate, only I-I.5 $\mathrm{mm}$. long; bracts proper $5-7$, linear, yellowish green; flowers $5^{-7}$; ligules nearly I cm. long; achenes somewhat fusiform, striate.

In habit this species resembles most Crepis gracilis (D. C. Eaton) Rydb., but the divisions of the leaves are much narrower and often again divided into very narrow divisions, and the involucre is glabrous as in C. acuminata. The leaves resemble those of certain species of the genus Seseli.

IDAHO: Rocky hillsides, scarce, valley of Big Potlatch River, Nez Perces County, Idaho, June 6, I 892, Sandberg, MacDougal \& Heller 326 (type, in herb. N. Y. Bot. Gard.).

\section{HiERACIUM}

Professor Nelson includes both IIieracium umbellatum L. and II. canadense Michx. in the flora of the Rocky Mountains. Neither is found in the region. H. umbellatum is exceedingly rare in America and confined to the extreme northeastern part, evidently an introduced plant. H. columbianum on account of its

\footnotetext{
* Muhlenbergia I: 142 . 1906.
} 
narrow leaves (narrower than in $H$. canadense) has sometimes been confounded with $H$. umbellatum, sometimes with $H$. canadense on account of its hairy stem. The common plant of the West, which has been confounded with both, is H. scabriusculum Schwein.* (H. macranthum Nutt. $\dagger$ ). Narrower-leaved specimens have been named $I$. umbellatum and broader-leaved ones, $I I$. canadense. It differs from $I I$. canadense in the glabrous stem and finely scabrous-puberulent leaves. H. columbianum has long white or yellow hairs on the lower part of the stem.

The true Hieracium Scouleri Hook. is not found in the region. A duplicate of the type is in the old Torrey herbarium. It is an almost scapose plant with the broad leaves obtuse at the apex and gathered near the base of the stem. The stem-leaves are few and small and the involucral bracts hirsute with short dark hairs. The plant resembles more Hieracium albiflorum in habit than it does $H$. griseum and $H$. cynoglossoides. The plant with long-hairy involucre which, mainly, Dr. Gray described in his Synoptical Flora and Professor Nelson described in the New Manual is not H. Scouleri. It should be known as H.albertianum Farr.

Heteropleura Fendleri (Schultz Bip.) Rydb. comb. nov.

Crepis ambigua A. Gray, Mem. Am. Acad. 4: Ir4. r849. Not C. ambigua Balb. I 805 .

Hieracium Fendleri Schultz Bip. Bonplandia 9: I73. I86I .

Heteropleura ambigua Schultz Bip. Flora 45: 435. I862.

Hieracium nigrocollinum S. Wats. Proc. Am. Acad. 25: I33. I 890.

This species has been included in Hieracium by Dr. Gray and others. It would be better to include it in Crepis than in Hieracium, for the achenes are tapering upwards and the pappus is tawny, not white. The involucral bracts are not thickened on the back, however, as they are in most species of Crepis, and the general habit resembles perhaps more that of Hieracium than of Crepis. It does not fit well in either genus, at the same time

*Long's Second Exp. 2: 394. I 824.

†Trans. Am. Phil. Soc. I1. 7: 446. I 841 .

‡Ottawa Nat. 20: I09. 1906. 
combining characters of both. Either the two genera should be united or else this species and several others of the southwestern United States and Mexico should be separated as a distinct genus. Even Fries in his Symbolae Hieraciorum recognized this fact and suggested the name Crepidispermum. He did not exactly publish the genus and no binomial names were given under the genus. Besides, in the same year a genus Crepidospermum B. \& H. was published. The two names differ only in one letter, the connecting vowel $i$ in one case and $o$ in the other. The former is the Latin connecting vowel, the latter the Greek, which is sometimes used in Latin for euphony's sake. The two names may therefore be regarded as identical. The two brothers Schultz of Zweibruecken adopted Fries' suggestion and established the genus under the name Heteroplenra, as alternate ribs of the achenes are stronger. The present species was given the name Heteroplenra ambigua, based on Crepis ambigua A. Gray. As there is an older C. ambigua Balb., that specific name is not available, and hence I have adopted Heteropleura Fendleri.

\section{Agoseris}

Professor Nelson reëstablishes the name Troximon for this genus, evidently following as he thought the Vienna Rules and cites Nuttall as authority for the genus. This is a similar case to that of Actinella and Tetraneuris. In fact Nuttall never established a genus Troximon. He thought that his two species belonged to the genus Troximon Gaert. Troximon of Gaertner was established in I79I on Tragopogon Dandelion, T. virginicum, and T. lanatum, of which the first two belong to one genus, Krigia or Adopogon, and the last is a Scorzonera. Even if Nuttall had established a genus Troximon, this would not hold, for then it was not published before $18 \mathrm{I} 8$ in his Genera, while Rafinesque's name dates from I8I7. It is true that Troximon appeared in Fraser's Catalogue of I8I3, but there it is without description. In his Genera, Nuttall credits Gaertner with the name. So does also Pursh in his Flora, I8I . There is therefore no warrant for reviving Troximon for the genus known in later years as Agoseris.

A good deal may be said regarding Professor Nelson's treatment of this genus, especially in the way synonyms have been 
cited. Agoseris attenuata Rydb. is given as a synonym of $T$. pubescens (Rydb.) A. Nels. A. attenuata has perfectly glabrous leaves, only the involucre and the upper part of the scape being villous. It would be included in Agoseris pumila (Nutt.) Rydb., were it not for the decidedly acuminate inner bracts. It has very little indeed to do with the decidedly pubescent $A$. pubescens.

Agoseris maculata Rydb. is made a synonym of Troximon villosum (Rydb.) A. Nels. It is true that they much resemble each other in general habit and pubescence, but the outer bracts in $A$. villosa are obtuse or even rounded at the apex, while those of A. maculata are abruptly and distinctly acuminate. A. villosa is a plant of the lowlands of Montana, westward and northward, while $A$. acuminata is an alpine or subalpine plant of the mountains of Colorado.

Troximon roseum Nutt., Agoseris agrestis Osterhout, and $A$. roseata Rydberg are made synonyms of Troximon glaucum. I have not seen the type of $T$. roseum Nutt., but, as I interpret it, it is a plant closely related to $T$. laciniatum Nutt., not to $T$. glaucum. Agoseris agrestis Osterhout is related to $A$. glauca, but if made a synonym of anything it should be of Troximon pumilum Nuttall, having the same pubescent involucral bracts, but the leaves are pinnatifid and caudate-acuminate instead of entire and obtuse or rounded at the apex.

Under Troximon glaucum dasycephalum Professor Nelson gives a citation from Piper's Flora of Washington: "This plant differs from $T$. glaucum only in having a pubescent involucre. It is scarcely worth nomenclatural recognition." I think that both Piper and Nelson are incorrect in this statement. In Agoseris glauca (Nutt.) Greene the involucre is decidedly obconic, and the leaves narrowly oblanceolate or linear and glaucous; in A goseris scorzoneraefolia (Schrad.) Greene (Troximon glaucum dasycephalum T. \& G.) the involucre is decidedly campanulate, sometimes in age almost hemispheric, the outer bracts and the leaves broader, and the latter scarcely glabrous. Those who have access to the Botanical Magazine may compare plate 1667 and plate $3+62$, which give good illustrations of Agoseris glanca and A. scorsoneraefolia respectively.

Under Troximon glaucum dasycephalum, Agoser.s altissima is 
given as a synonym. The latter plant is a decidedly pubescent plant and should be associated rather with A. villosa, but is taller and its flowers turn deep purple in age.

Under the variety pumilum we find Agoseris Leontodon Rydb. as a synonym. The latter was based on Macrorhynchus glaucus laciniatus D. C. Eaton. Dr. Gray included in his Troximon glaucum laciniatum a multitude of forms, in fact everything of the A. glanca group with laciniate leaves. Macrorhynchus glaucus laciniatus D. C. Eaton is not found east of Nevada. It is related to Stylopappus laciniatus Nutt.

Under Troximon arachnoideum (Rydb.) A. Nels. are found the following: "T. glaucum laciniatum in part (not $T$. laciniatum Gray ... ; Agoseris laciniata Greene; A. arachnoidea Rydb. ....)." The plant described by Professor Nelson is the same as Stylopappus laciniatus Nutt. A duplicate of Nuttall's type is in the old Torrey herbarium, and it is to be known as Agoseris laciniata (Nutt.) Greene. If Troximon is used the name should be T. laciniatum (Nutt.) A. Gray, although Dr. Gray described under that name an entirely different plant from Nuttall's Stylopappus laciniatus. The type of the latter did not have developed fruit and both Nuttall and Gray thought that it was related to Stylopappus grandiflorus Nuttall, or Troximon grandiflorm A. Gray. Its achenes are of the A. glauca type with short striate beak. (See further below.) To use the name Troximon arachnoideum for this plant was entirely out of place, for Agoseris arachnoidea Rydberg is an entirely different plant of the A. aurantiaca group, with long filiform, non-striate achene-beak, in age purple flowers, and with densely pubescent leaves. Evidently Professor Nelson did not know the plant.

Under Troximon purpureum we find the following synonyms: "Macrorhynchus purpureus A. Gray . . . ; T. gracilens A. Gray ... ; A. Greenei Rydb. as to our range." In the herbarium of Columbia University there is a duplicate of the type of Macrorhynchus purpureus A. Gray. It is a low plant scarcely more than I dm. high, with narrow, pinnatifid, glaucous and glabrous leaves and brightly spotted involucral bracts. Professor Nelson characterizes his Troximon purpureztm as being tall, 2-5 dm. high, with leaves tapering into long, slender, winged petioles. Evi- 
dently Professor Nelson did not have in mind the true Macrorhynchus purpureus, on which Troximon purpureum (A. Gray) A. Nels. should have been based, but a mixture of $A$. gracilens and A. Greenei Rydb. If any reduction should have been made, $T$. gracilens should have been made a synonym of Troximon aurantiacum Hook. In the herbarium of Columbia University there is a duplicate of the type of the latter and one specimen cited in the original description of the former. The only difference I can see is that the outer bracts in $T$. aurantiacum are broader and inclined to be obtuse. As to Agoseris Greenei Rydb. the name has to be changed. The plant should be known as

Agoseris graminifolia Greene, Bull. Torrey Club

25: 124.1898.

Troximon gracilens Greenei A. Gray, Proc. Am. Acad. I9: 7I. I 883.

Agoseris gracilenta Greenei Greene, Pittonia 2: I77. I891. Agoseris Greenei Rydb. Mem. N. Y. Bot. Gard. I: 459. I900.

Not Agoseris Greeneana O. Kuntze, Rev. Gen. Pl. 304. I89I. Troximon purpureum A. Nels., Coult. \& Nels. New Man. Cent.

Rocky Mts. 599, in part. I909. Not Macrorhynchus pur-

pureus A. Gray. I 859 .

For this species I had adopted the name Agoseris Greenei, basing it upon Troximon gracilens Greenei A. Gray, but I had overlooked the fact that there had been published an Agoseris Greeneana based on Troximon elatum Greene. The latter should be known, however, as A. major Jepson, published in September, I89I, while Kuntze's name was published in October, I 89I.

A closer investigation of Agoseris graminifolia persuaded me that it could not be kept distinct from A. Greenei (A. Gray) Rydb. although the leaves of the specimens from type collection are more entire than usual. On the sheet in the collection of the New York Botanical Garden they are wholly entire, but the figure published and drawn from the type specimen shows four leaves with a few short lobes.

Under Troximon arizonicum Professor Nelson gives as synonyms A goseris elongata Greene, $A$. rostrata $\mathrm{Rydb}$., and A. humilis Rydb. The first is only a manuscript name, but the specimens so named are rightly referred to T. arizonicum. Agoseris humilis 
is related to $A$. gracilens and A. aurantiaca and should have been included in the latter as characterized by Professor Nelson. Agoseris rostrata is not closely related to either but is the next relative to $A$. grandiflora of the Pacific Slope, having the same short outer bracts and elongated inner ones and the same very long and slender beak of the achenes, nearly three times as long as the body. It is the "T. grandiflorum as to our range," an expression which Professor Nelson erroneously uses under Troximon montanum.

\section{Agoseris turbinata sp. nov.}

Perennial with taproot and short caudex; leaves narrowly linear, $7^{-1} 5 \mathrm{~cm}$. long, $\mathrm{I}-5 \mathrm{~mm}$. broad, glabrous, bluish green, the midrein and base of ten purplish, entire, attenuate; scape about $3 \mathrm{dm}$. high, slender, sparingly villous, more densely so under the head; involucres turbinate, I $7-20 \mathrm{~mm}$. high; bracts all narrowly lance-linear, villous on the back as well as on the margins, with dark purple middle and yellowish green margins; ligules I $^{-1} 8$ $\mathrm{mm}$. long, yellow with purplish veins, turning pinkish in age: beak of the achenes short and striate.

This resembles in many respects Agoseris parviflora in habit, but differs in the villous scape and involucre and in the beautifully variegated bracts.

Alberta: Gravel Slope of Tunnel Mountain, Mc Calla 2063 (type, in herb. N. Y. Bot. Gard.).

Agoseris obtusifolia (Suksd.) Rydb. nom. nov.

Troximon grandiflorum obtusifolium Suksd. Deuts. Bot. Monats. 18: 98. I900.

This is characterized by the broad oblong obtuse lobes and the obtuse or even rounded apex of the leaves. I think that it deserves specific rank. It has been collected in western Idaho.

Agoseris tenuifolia (A. Gray) Rydb. nom. nov.

Troximon grandiflorum tenuifolium A. Gray, Bot. Calif. I: 438, in part. $18,6$.

Troximon laciniatum A. Gray, Proc. Am. Acad. 19: 72, in part. I883. Not Stylopappits laciniatus Nutt. Trans. Am. Phil. Soc. 1I. 7: 432. I $8+1$.

In the Botany of California Gray gives a short description of 
Troximon grandiflorum tenuifolium, and points out the characters distinguishing it from $T$. grandiflorum. He gives as a synonym Stylopappus laciniatus longifolius Nutt., but a duplicate of the type of the latter collected by Douglas is in the Columbia University herbarium and in this specimen the outer bracts are not dilated as they are in $A$. grandiflora and its relatives.

In the Proceedings of the American Academy, vol. I9, Dr. Gray adopts the name Troximon laciniatum, giving as synonyms Stylopappus laciniatus Nutt. and its variety longifolius; also Troximon grandiflorum var.tenuifolium and var. laciniatum of the Botany of California. A duplicate of Nuttall's type of Stylopappuslaciniatus is also in the Columbia University herbarium. In later years many specimens matching this specimen have been collected in Iyoming, Colorado, Utah, and Idaho. This is a species with achenes of the type of Agoseris glauca and was probably included in Gray's Troximon glaucum laciniatum, but it is not Macrorhynchus glaucus laciniatus D. C. Eaton. In my Flora of Colorado, I adopted the name Agoseris laciniata (Nutt.) Greene for this species. Professor Aren Nelson describes it in the New Manual as Troximon arachnoideum (Rydb.) A. Nels. It has nothing to do with Agoseris arachnoidea Rydb. See above, p. I8.

\section{TARAXACUM}

Professor Nelson's treatment of Taraxacum is good. He acknowledges six species, instead of only one as Dr. Gray did. The only criticism I have to offer is that Taraxacum leiospermum Rydb. is made a synonym of $T$. angustifolium Greene. It is true that in both the lower part of the achenes is smooth, but otherwise there are several discrepancies between the descriptions of the two. T. angustifolium is characterized as having narrow, oblong-linear leaves, and the outer bracts few and small, in a single series, and erect, while in T. leiospermum the leaves are broadly oblanceolate and the calyculate bracts are in 2 or 3 series and with spreading tips, as in T. dumetorum.

\section{LACTUCA L.}

Professor Nelson has given a new specific name to the more common prickly lettuce of the Rocky Mountain region. It has 
usually been known as Lactuca Scariola L., which name has included all the prickly lettuces found introduced in North America, viz., L. Scariola L., L. virosa L., L. saligna L., etc. The plants with merely toothed leaves were referred to $L$. virosa $\mathrm{L}$. by $\mathrm{Dr}$. N. L. Britton, but Mr. L. F. Dewey of the United States Department of Agriculture contends that it is not L. virosa but L. Scariola integrata Gren. \& Godr. Mr. Dewey is followed by Robinson \& Fernald in Gray's New Manual. So also by Professor Nelson: but he regards it as specifically distinct from L. Scariola and proposes the name L. integrata (Gren. \& Godr.) A. Nels. This was altogether unnecessary for L. Scariola integrata Gren. \& Godr.* was based on L. augustana All. $\dagger$ Allion :gives a good figure.

Linnaeus in his first edition had only one species, Lactuca virosa, with three varieties. In the second edition $L$. Scariola is adopted for $L$. virosa var. $\delta$ of the first edition. Both $L$. virosa and $L$. Scariola are based on figures in Morison's Historia, and the figure cited under $L$. virosa resembles indeed very much the more common plant introduced in the Rocky Mountain region, much more so than Allioni's plate of L. augustana does. The difference between $L$. virosa and $L$. Scariola given by Linnaeus is that the former has toothed horizontal leaves while in the latter they are pinnatifid and vertical. The plant answering the description of L. Scariola has been collected in Utah and Montana but the plant with merely toothed leaves is more common. Mr. Dewey's contention may be correct as far as the plant around Washington and Boston is concerned, but I think the plant of the Rockies and the Pacific Slope is L. virosa. So far as I know, the leaves are not turned on edge as they are in L. Scariola and Professor Nelson describes the achenes of his L. integrata as being dark-colored instead of pale. Dewey described the achenes of Lactuca virosa as being darker and broader than in L. Scariola, while he could not find any differences between those of the latter and the var. integrata. There is another character which helps to distinguish $L$. virosa and $L$. Scariola. In the latter, the branches of the panicle are inclined to be racemiform, while in L. virosa they are more branched with more or less diverging branchlets.

*F1. Tran. 320 . I 850 .

†Fl. Pedem. I: 224 . I 785 . 
The Rocky Mountain specimens agree in this respect with $L$. virosa. They have also the obtuse lower leaves of that species as figured by Morison, as illustrated in Sweet's English Botany, in Baxter's British Phaenogamous Botany, and in the Flora von Deutschland. Allioni's illustration of L. augustana shows only the upper part of the plant, but all the leaves shown are decidedly acute.

\section{Lactuca polyphylla sp. nov.}

Biennial; stem stout, about I m. high, glabrous; leaves sessile and slightly auriculate-clasping, very numerous, linear-lanceolate, entire, acuminate, $\mathrm{I}-2 \mathrm{dm}$. long, glabrous, not at all spinulose; panicle conical, much branched, about $3 \mathrm{dm}$. long, I.5 dm. broad; involucres about I $\mathrm{cm}$. high; outer bracts lanceolate, about half as long as the linear-lanceolate inner ones; achenes nearly black, 3-4 $\mathrm{mm}$. long, oval, indistinctly 3 -nerved, transversely rugose; beak about $2 \mathrm{~mm}$. long.

The type was determined as Lactuca integrifolia Bigel., but it differs from that purely eastern species in the numerous more willowlike leaves, the stout stem, the numerous heads in a more compact panicle and the short beak of the achenes.

Idaho: Lake Pend d'Oreille, Aug. 5, i885, E. L. Greene (type in herb. Columbia Univeristy).

New York Botanical Garden.

Bronx PARK, NEW lork City 

CONTRIBUTIONS FROM THE NEW YORK BOTANICAL GARDEN-No. 151

\title{
STUDIES ON THE ROCKY MOUNTAIN FLORA - XXVI
}

By PER AXEL RYDBERG

\author{
NEW YORK \\ 1912
}

Reprinted, without change of paging, from the Bulletin of the TORReY Botanical CluB 39: 99-111. 13 Ap 1912 



\title{
Studies on the Rocky Mountain flora-XXVI
}

\author{
Per Axel Rydberg
}

\section{PINACEAE and JUNIPERACEAE}

In the New Manual of Botany of the Central Rocky Mountains no reference is made to Picea canadensis, although it has been collected in the Black Hills of South Dakota and Wyoming. Blankinship in his supplement to the Flora of Montana,* reports $P$. alba, which is the same, from four localities in Montana. This, however, I think is erroneous. All specimens from Alberta, British Columbia, and Montana, that I have seen determined as $P$. canadensis or $P$. alba, belong to $P$. albertiana S. Brown. Probably the specimens reported by Blankinship belong there also. Abies grandis is also omitted in the New Manual. This is not uncommon in Montana west of the continental divide. Perhaps that part of the state is not intended to be included in the range covered by the New Manual, as it includes only "most of Montana." The species has been reported from the Yellowstone Park, but the reference is uncertain. Blankinship, loc. cit., also reports Juniperus virginiana from Montana and cites three localities. I have no evidence that the determinations were correct nor have I seen any specimens from the state. What makes me more doubtful as to the correctness of the determination is that two of the localities are situated west of the continental divide, and at Bozeman, the third locality, I have myself collected during parts of three summers and have not seen it.

I doubt very much if Juniperus Knightii A. Nelson can be upheld as a species distinct from $J$. utahensis (Engelm.) Lemmon. The characters given, apparently do not hold. The leaves are supposed to be 2-ranked in $J$. monosperma and $J$. utahensis and 3-ranked in $J$. Knightii. I know that in the first two they are both 2-and 3-ranked. I have not seen the type of J. Knightii, but in a specimen distributed under that name by Professor Nelson

* Montana Agr. Coll. Sci. Stud. Bot. I: 39. I905. 
himself the leaves are both 2-and 3-ranked on different twigs of the same branch. The seeds in J. utahensis are either obtuse or acutish at the apex, and these characters do not furnish any distinction. I have spoken to Dr. J. A. Shafer, who helped Dr. N. L. Britton in preparing North American Trees, and he told me that he had come to exactly the same conclusion as I.

The following two changes in the nomenclature seem to be advisable.

Hesperopeuce Mertensiana (Bong.) Rydb. comb. nov.

Pinus Mertensiana Bong. Mem. Acad. Sci. Nat. St. Petersb. VI. 2: $163 . \quad$ I 832.

Abies Mertensiana Lindl. \& Gord. Journ. Hort. Soc. Lond. 5: 2 I I. I 850 .

Abies Pattoniana Jeffrey"; A. Murray, Rep. Oregon Exped. I. I 853. Tsuga Pattoniana Sénéc. Conif. 21. I867.

Hesperopeuce Pattoniana Lemmon, Rep. Calif. State Board 3 Forestry 3: 126. I890.

Tsuga Mertensiana Sargent, Silva I2: 77. I898. Not T. Mertensiana Carrière, I 867 .

I agree fully with Mr. Lemmon that this species should be removed from Tsuga. Both its cones and its leaves are more like those of a spruce than those of a hemlock, and the habit of the tree is different from both. Mr. Lemmon, however, did not adopt the oldest available specific name.

Sabina horizontalis (Moench) Rydb. comb. nov.

Juniperus horizontalis Moench, Meth. 699. 1794.

Juniperus prostrata Pers. Syn. 2: 632. I807.

Juniperus Sabina procumbens Pursh, Fl. Am. Sept. 647. I8I4. Sabina prostrata Antoine, Cupress. Gatt. 57. I857-70.

\section{EPHEDRACEAE}

Marcus E. Jones* reduced Ephedra viridis Coville to a variety of E. nevadensis. I do not know exactly what E. viridis is, as I have not seen the type, but the Utah plant which Jones had in mind, does not seem to agree with the description. We have duplicates of some of the numbers cited by Jones, and these seem to be typical E. nevadensis.

* Proc. Calif. Acad. II. 5: 726. I895. 
SPARGANIACEAE

Sparganium simplex L. has been reported again and again from the Rocky Mountains, but all the specimens I have seen under that name belong either to S. longipedunculatum (Morong) Rydberg or to $S$. angustifolium Michx. S. longipedunculatum resembles $S$. simplex much in habit but is usually more slender, and the leaves are not so triangular-keeled as in that species. The main difference is, however, in the shorter style and stigma. S. simplex is very rare in the United States. I have seen specimens only from the State of Washington. It is otherwise found in British Columbia and along the St. Lawrence River in Ontario and Quebec.

\section{ZANNICHELLIACEAE}

Potamogeton perfoliatus is not found in the Rocky Mountain region. It is there represented by $P$. Richardsonianus. Notwithstanding the fact that $\mathrm{N}$. Taylor includes the latter in the former, I am convinced that they are distinct. This opinion is based on field studies. My contentions are also supported by M. L. Fernald.

I cannot find any specific distinctions between Ruppia curvicarpa A. Nels. and R. maritima L. The length of the pedicels is merely a matter of age and other conditions; the typical $R$. maritima has strongly oblique fruit, gibbous at the base as described in $R$. curvicarpa; slender or stout, straight and curved styles are found in the same individual even. Taylor, also, could find no distinctive characters.

\section{ALISMACEAE}

Alisma Plantago-aquatica L. is not found in America. In this European species the achenes have different beaks from those found in the North American species. The common species of the Rocky Mountain region should be known as $A$. brevipes Greene. Alisma Geyeri Torr. is also found in the regions. (See my Flora of Montana.) It has been collected later in Utah.

Blankinship* described one new species and one new variety of Sagittaria. S. paniculata Blank. is but a well developed $S$.

* Loc. cit. 40 . 
arifolia Nutt., ${ }^{*}$ and S. arifolia tenuior is but a depauperate form of the same. Both S. paniculata Blank. and S. arifolia Nutt. have to give way for the older name $S$. cuneata Sheldon, $\dagger$ which was described from the deep-water form of the same species.

\section{POACEAE}

Blankinship reported Panicum nitidum Lam. from Columbia Falls, Montana. This must be an error, for that species is known only from the eastern seaboard from southern Virginia to eastern Texas. Aristida fasciculata Hookeri of Blankinship's list is the same as $A$. longiseta.

Professor Nelson reports Aristida oligantha from Colorado. I have seen no specimens from that state and none from west of central Nebraska. Perhaps A. bromoides might have been mistaken for it.

The oldest available specific name for Eriocoma cuspidata is hymenoides, which is therefore adopted, and its name and synonymy is as follows:

Eriocoma hymenoides (R. \& S.) Rydb. comb. nov.

Stipa membranacea Pursh, Fl. Am. Sept. 728. x814. Not S. membranacea L. I 753 .

Stipa hymenoides R. \& S. Syst. 2: 339. I817.

Eriocoma cuspidata Nutt. Gen. I: 40. I818.

Oryzopsis cuspidata Benth.; Vasey, Special Rep. U. S. Dept. Agr.

63: 23. I 883 .

The following species of Muhlenbergia should be added to the flora of the Rocky Mountain region: M. pauciflora Buckl. ( $M$. neomexicana Vasey; M. Pringlei Scribn.), M. polycaulis Scribn., and M. curtifolia Scribn., which were collected by Professor A. O. Garrett and myself in southeastern Utah last summer. Alopecurus fulvus Smith is not found in America, except perhaps in Greenland. A. aristulatus Michx. is not the same, differing not only in the general habit, not being depressed-geniculate, but also in the different position of the awn of the floral glume. Alopecurus pallescens Piper has been collected in both Idaho and Montana.

* J. G. Smith. Rep. Missouri Bot. Gard. 6: 32. I894.

† Bull. Torrey Club 20: 283. I 893 . 
Professor Nelson, in the New Manual, includes Sporobolus vaginaefolius and Cinna armdinacea, which I think are erroneously reported for the region.

The following species of Calamagrostis have to be included in the Rocky Mountain flora: C. T'aseyi in Montana, C. rubescens and C. lucida in $\mathrm{W}_{\text {yoming. }}$.

Professor Nelson reduced Avena americana to a synonym of $A$. Mortoniana. I think they are distinct, but if united, they should bear the name Avena Hookeriana, an older name for the former. Arrhenatherum elatius has been collected in Colorado, and Danthonia spicata is common in the Black Hills.

\section{Deschampsia pungens sp. nov.}

A densely tufted perennial; stem 3-4 dm. high, glabrous and shining; basal leaves numerous, the old subchartaceous sheaths from preceding season remaining, strongly striate, glabrous, often slightly tinged with purplish; ligules triangular-lanceolate, 4-5 $\mathrm{mm}$. long: blades spreading, more or less arcuate, strongly involute, bluish green or in age straw-colored, strongly striate, minutely scabrous-pruinose, stiff and with a callous pungent point; stem leaves few; blades $2-5 \mathrm{~cm}$. long, similar; panicle open, branches in age spreading; peduncle and its branches more or less purplish, glabrous or minutely scabrous; empty glumes subequal, 3.5-4.5 mm. long, lanceolate, acute, purple, with scarious margins; rachis long-hairy; floral glumes $3-3.5 \mathrm{~mm}$. long, similar to the empty glumes; awn attached near the base, equaling or barely exceeding the floral glume.

This species is closely related to D. caespitosa but differs in the stiff, involute, pungent-pointed leaves and in the position of the dorsal awn of the floral glumes. This is attached near the base of the glume, while in $D$. caespitosa it is attached one fourth or one fifth the distance from the base. It grows near hot springs.

Alberta: Along stream below warm sulphur springs, vicinity of Banff, July Io, I899, Mc Calla 2309 (type in herb. N. Y. Bot. Gard.).

Wromag: Lower Geyser Basin, Yellowstone Park, August 4 , I897, Rydberg \& Bessey 3590.

Chloris brevispica Nash has been collected at Wray, Colorado, and Blepharidachne Kingii (S. Wats.) Hackel (Eremochloa Kingii 
S. Wats.) in eastern Utah, Eragrostis lutescens Scribn. and E. hypnoides Nees in Idaho, E. secundiflora Presl in Colorado, and E. neomexicana Vasey in southern Utah. Briza maxima L. has become introduced in Colorado.

Poa Multnomae Piper and P. ampla Merrill have been collected in Montana since 1909. Poa flava L. is not a Poa at all, as shown by Professor A. S. Hitchcock, and the name to be used for $P$. serotina Ehrh. is P. triflora Gilib. Poa laxa Haenke is not found in the Rocky Mountains, and what has been masquerading under that name is P. alpicola Nash. Poa paddensis Piper is an older name for $P$. subpurpurea Rydb., both being based on $P$. purpurascens Vasey. In the New Manual no reason is given why $P$. Buckleyana Nash, published in 1895 , should be used instead of $P$. Sandbergii Vasey of 1893 . They may be the same. P. Buckleyana Nash was a substitute for the untenable $P$. tenuifolia Buckl., while $P$. Sandbergii was described independently. I have not seen Buckley's type, but it is supposed to have been based upon the manuscript P. tenuifolia Nutt. Dr. A. Gray accused Buckley of having pilfered the species from Nuttall. There is in the herbarium of the New York Botanical Garden a specimen named by Nuttall $P$. tenuifolia, and this specimen belongs to $P$. Sandbergii. What has usually passed under the names $P$. temuifolia and $P$. Buckleyana is different, and I think represents a distinct although closely related species. The grass common in Wyoming and Colorado belongs to this and not to the typical $P$. Sandbergii, which ranges only west of the continental divide.

Although Poa pseudopratensis Scribn. \& Rydb. resembles the common bluegrass in habit it is entirely distinct from it and more closely related to $P$. arida Vasey. Like that species it lacks the cobweb at the base of the floral glumes altogether, while $P$. pratensis has the best developed cobweb of all our species. Likewise $P$. phoenicea Rydb., also cited as a synonym under $P$. pratensis in the New Manual, has no cobwel and belongs in another section of the genus. I am inclined to think that $P$. phoenicea Rydb. is the same as the original $P$. Grayana Vasey, while $P$. Grayana of my Flora of Colorado is a large-flowered P. Pattersonii or a closely related species.

Poa crocata Michx. is the same as $P$. caesia strictior. In the 
Torrey Herbarium there are a few spikelets of $P$. crocata Michx., and I have seen the type of $P$. caesia strictior. The plant is the most common species that has been known under the name $P$. nemoralis in the Rockies. It is intermediate between $P$. interior Rydb. and P. rupicola Nash, in habit resembling more the latter, but the cobweb is present.

In the New Manual of Botany of the Central Rocky Mountains, Poa Tracyi Vasey, P. flexuosa occidentalis Vasey, P. occidentalis Rydb., and $P$. callichroa Rydb. are given as synonyms under $P$. nervosa (Hook.) Vasey. In P. callichroa the cobweb is present, and that species is related to $P$. arctica although much larger. In the rest the cobweb is wanting. The plant described by Professor Nelson is P.occidentalis (Vasey) Rydb. If $P$. Tracyi Vasey is the same I do not know, but $P$. nervosa (Hook.) Vasey is a different plant. A duplicate of the type is in the Torrey Herbarium. In this species the glumes are very thin and the nerves very prominent, stronger than in any other species of Poa known to me.

Poa californica, P. andina Nutt., and P. brevipaniculata S. \& W. are given as synonyms under $P$. Fendleriana. Poa brevipaniculata is very hard to distinguish from $P$. Fendleriana and may well be reduced to synonomy. Poa californica, under which name $P$. Fendleriana has been masquerading and under which it is described in the old Coulter's Manual, is an entirely different plant, related to P. nevadensis and P. Buckleyana and not found in the Rocky Mountain region. $P$. andina Nutt. is also entirely distinct. $P$. arida Vasey and $P$. pratericola Rydb. \& Nash were based on $P$. andina Nutt. These two as well as P. juncifolia Scribn. are cited by Nelson as synonyms under P. Sheldonii Vasey. P. arida and $P$. Sheldonii are closely related to each other but $P$. juncifolia is more dosely related to $P$. laerigata.

In Festuca the following species have been collected in the Rocky Mountains: $F$. pacifica in Utah and Idaho, $F$. reflexa in Utah, F. megalura in Iclaho, F. ovina calligera Piper in Utah, $P$. idahoensis Piper in Idaho, F. viridula Vasey in Idaho, and $F$. dasyclada in Utah. Festuca Thurberi is one of the best species in the genus, characterized by its long acuminate ligules. It stands in the same relationship to $F$. campestris and F. scabrella, as Poa longiligula does to Poa Fendleriana and P. brevipaniculata. 
I regard the subgenus Hesperochloa of Festuca, proposed by Piper, as representing a distinct genus and here propose it as such.

HESPEROCHLOA (Piper) Rydb. gen. nov.

Festuca subgenus Hesperochloa Piper, Contr. U. S. Nat. Herb. Io: I0. I906.

Densely tufted dioecious perennial, occasionally stoloniferous. Inflorescence a narrow panicle. Spikelets turgid, 3-5-flowered; rachilla scabrous on the basal half. Empty glumes 2, broadly lanceolate, subscarious, shining, the lower I-nerved, the upper 3-nerved. Floral glumes ovate, acuminate, rounded on the back, faintly nerved. Petals scabrous-ciliate on the keels. Styles obsolete; stigmas hispidulous on all sides, not plumose; ovary deeply sulcate near the apex, sparsely hispidulous; grain beaked and bidentate at the apex.

Hesperochloa Kingii (S. Wats.) Rydb. comb. nov.

Poa (?) Kingii S. Wats. Bot. King Exped. 387. I87 I.

Festuca confinis Vasey, Bull. Torrey Club I I: I26. I 884 .

Festuca Kingii Scribn. U. S. Dept. Agr. Agrost. Bull. 5: 36. 1897.

Not Festuca Kingiana (Endl.) Steud. I 855.

Festuca ITatsonii Nash, Britt. Man. I 48. I 901.

This was originally described as a doubtful Poa and afterwards transferred to Festuca because the floral glumes are rounded on the back. There are, however, certain characters in the stigmas and the grains that make it fit poorly in either genus. In both Poa and Festuca the stigmas are plumose, that is, the branches are spreading bilaterally, while in Hesperochloa the short bristlelike branches stand out in all directions, a condition rather rare among the grasses.

Hordeum caespitosum Scribn. is found locally throughout the range, $I$. montanense was described from Montana, H. murinum and $H$. A egiceras have been introduced and are locally established especially in Utah.

Sitanion Raf. is a very perplexing genus, and it is very doubtful if the many species proposed by J. G. Smith can be upheld. It is evident that S. longifolium and S. brevifolium are but local forms of one species, depending on the amount of moisture. As this species is the only one found anywhere near the type locality of 
S. elymoides Raf., I think that the latter name should supplant the other two. S. lanceolatum J. G. Smith from Montana and S. marginatum Scribn. \& Merrill from Wyoming are the two species of the range best differentiated and seem to connect the genus with Elymus. S. insulare was described from northeastern Utah, and $S$. ciliatum has been collected in Wyoming.

\section{ARACEAE}

This family is omitted altogether in the New Manual, although Acorus Calamus is recorded in my Flora of Colorado and Lysichiton camtschatcense (L.) Schott in my Flora of Montana. The former has also been collected in Montana by Butler.

\section{LENAACEAE}

Lemna perpusilla Torr. is included by Nelson in his Manual with the remarks: "Frequent; northern ITyoming to New York." So far as I know this is wholly an eastern species. Specimens so labeled from the Rockies, which have come under my observation, are L. minor, L. minima, or L. cyclostasa, which all have been confused with it.

\section{COMMELINACEAE}

Professor Nelson admits two species of Tradescantia and gives the following key:

Freely branched; filaments folded; ovary pubescent in riblike lines. I. T. laramiensis. Simple; filaments straight; ovary pubescent at the apex.

2. T. occidentalis.

If these characters hold, as to separating the two species known to Professor Nelson, the second one is not T.occidentalis, for the specimen designated by Dr. Britton as the type of Tradescantia virginica occidentalis, viz., Rydberg I3 80 , from Thedford, Nebraska, has a branched stem and an ovary pubescent not only at the apex but almost to the base. It is not exactly like the type of $T$. laramiensis, however, for the lateral branches are shorter than the stem proper, the sepals are broader, the leares broader, and the plant more glandular. In $T$. laramiensis the lateral branches about equal the stem, giving the plant a flat top. If these are specific characters, I do not know. If the two species of the New Manual are distinct, the second one should bear the name $T$. universitatis Cockerell, for it was this form that Professor Cockerell described. 
Under the second species is given the following synonym and remark: "(T. scopulorum Rose, Contr. U. S. Nat. Herb. 5: 205. I899, as to the specimens from Colorado and northward)." This would have been correct if the word "mainly" had been inserted, for I have seen at least one specimen from Colorado that I refer without hesitation to $T$. scopulorum.* The latter differs from the other species of the region by its glabrous or nearly glabrous sepals, its smaller petals, only $10 \mathrm{~mm}$. long, and its subglobose capsule. There is also another species, which should have been included, viz., T. bracteata Small, the type of which was from the Black Hills.

\section{MELANTHACEAE}

Tofieldia occidentalis S. Wats. has been collected in Idaho; T. coccinea Richards. in the Canadian Rockies; Stenanthella occidentalis and Veratrum Eschscholtaianum in Montana and Idaho.

To me both Zygadenus dilatatus Greene and Z. alpinus Blankinship seem to be but synonyms of Z. elegans Pursh or Anticlea elegans Rydb. Anticlea porrifolia. (Greene) Rydberg (Zygadenus porrifolius Greene) was collected last summer in southeastern Utah. So also an undescribed species:

\section{Anticlea vaginata sp. nov.}

Perennial, growing in big clumps; cormlike rootstock fully $2 \mathrm{~cm}$. thick; stem 7-ro dm. high, at the base covered with numerous scarious sheaths; leaf blades linear, 3-7 dm. long, 6-Io mm. wide, with numerous veins; inflorescence paniculate, branched; lower bracts linear or subulate, $3-6 \mathrm{~cm}$. long, green, the upper ones ovate, 5-IO $\mathrm{mm}$. long, white; pedicels $5^{-10} \mathrm{~mm}$. long, of ten recurved; petals and sepals white, elliptic, obtuse, $7^{-8} \mathrm{~mm}$. long, usually 7 -nerved, the former sometimes a little longer than the latter; filaments linear-subulate, broad at the base, white, slightly shorter than the sepals; anthers nearly round; styles slightly exceeding the perianth, curved.

This differs from the other species of Anticlea in its habit of growing in big clumps, and in its numerous loose sheaths at the base of the stem. In the perianth segments it resembles $A$. coloradensis, and A. porrifolia in the few veins, the segments are smaller than in the former and broader than in the latter. It resembles

\footnotetext{
* Garrett and myself collected it also in southeastern Utah last summer.
} 
also A. porrifolia in the branched inflorescence but has shorter pedicels and broader leaves. A. vaginata grew in loose rich soil under overhanging canyon walls.

Utail: Armstrong Canyon, near the Natural Bridges, August 4-6, I9I I, Rydberg \& Garrett 9707 (type in herh. N. Y. Bot. Gard.).

Professor Nelson gives Zygadenus gramineus Rydb. as a synonym of $Z$. venenosus S. Wats. It is evidently $Z$. gramineus he described, although some modification was made. Z. venenosus is not found in IVyoming, the most eastern stations known are in the Snake River Valley of western Idaho. It is characterized by the long-clawed petals and sepals and the thick gland. Professor Piper, some years ago, criticized me for redescribing $Z$. venenosus. I think he referred to Z.intermedius Rydb. After some arguments on both sides he said that he would look up Watson's type. I do not know that he did, but evidently he came to the same conclusion as I, for in his Flora of Washington* he limited the range of $Z$. venenosus to "British Columbia to California" and hence excluded the Rockies. I have also been criticized for the same thing by Mr. M. E. Jones. Mr. Jonest remarked: "Part of his type of Zygadenus intermedius is my No. 209I from Farmington, Utah. These specimens have no distinct sheath to any of the leaves, except the basal ones. . . . This is a fair sample of Rydberg's accuracy in dealing with Zygadenus. ...." Turning to my original paper, $\ddagger$ one may see that J. II. Sandberg IO564 is expressly designated as the type and not Jones 209I, which I included in the species. I do not know what Mr. Jones' own specimens show, but there are two of Jones' specimens from Farmington distributed under the number $209 I$ in the Columbia University herbarium and in these even the upper leaves show short sheaths. One leaf attached near the middle of the stem shows a sheath $I .5 \mathrm{~cm}$. long. I do not think that the presence or absence of a sheath on the upper part is a specific character, but this as well as the citing of a wrong type shows that Mr. Jones is not more accurate than I am.

For my part, I think that $Z$. gramineus can not be upheld as a

* Contr. U. S. Nat. Herb. I I : I98. I906.

† Contr. West. Bot. 12: 77. 26 Mr I908.

$\ddagger$ Bull. Torrey Club 27: 536. I900. 
species distinct from $Z$. intermedius, being a dry hill state of the same with smaller flowers and narrower leaves. Z. falcatus Rydb., which Nelson reduced to a synonym, I think is perfectly distinct and nearer related to $Z$. paniculatus. It is what has been known as Z. Nuttallii from Colorado. The latter is not found in the range and should have been excluded.

I have here used the name Zygadenus, as the species were first described under that name. I have shown that this name belongs to $Z$. glaberrimus and that the plants here discussed should be known as Toxicoscordion.

\section{JUNCACEAE}

The following species of Juncus are found in the Rockies: Juncus uncialis Greene, J. Jonesii Rydb., J. Regelii Buch., $J$. Tracyi Rydb., and $J$. mexicanus in Utah; $J$. columbianus Coville and $J$. Regelii Buch. in Montana; and $J$. arizonicus in Colorado. Professor Nelson includes Colorado in the range of $J$. ensifolius Wikstr. I have seen no specimens of it from that state. The best character, beside the difference in the number of stamens, by which one can distinguish this from $J$. saximontanus, is that the scarious margin of the leaf sheaths in the latter ends in a small auricle, while in $J$. ensifolius the margin gradually diminishes and disappears in the blade.

\section{ALLIACEAE \\ DIPTEROSTEMON gen. nov.}

Plants with fibrous-coated bulbs, few basal elongated narrow leaves and naked scapes. Flowers in subcapitate umbels; bracts 3-5, membranous, colored, usually purple; perianth funnelform or campanulate, purple; segments united about half their length; lobes elliptic, ascending; stamens six; filaments subulate, adnate to the tube, becoming distinct at the throat; those opposite the sepals naked; those opposite the petals at the base with two lanceolate wings or lobes, surpassing the anthers; anthers basifixed; capsule ovate, 3-locular; cells many-seeded.

Some of the species formerly included in Brodiaea and lately in Dichelostemma differ from the rest enough, I think, to deserve generic rank. The type of Brodiaea is B. grandiflora Smith. This is the same as Hookera coronaria Salisb., published a few 
months earlier. As the latter is the type of Hookera, Brodiaea becomes a pure synonym. Dr. Greene, ${ }^{*}$ who was the first to segregate into genera the members of Brodiaea taken in the sense of Dr. Watson, retains both genera. Evidently he regarded Smith's second species, Brodiaea congesta, as the type. This can scarcely be done, as B. grandiflora is not only the first species, but it is more extensively described and discussed. Greene himself afterwards discarded Brodiaea and adopted Dichelostemma, proposed by Kunth on Brodiaea congesta Smith. Alphonso Wood had extended Kunth's genus to include also B. capitata Benth. and B. volubilis Baker (Stropholirion californicum Torr.). Wood was followed by Greene in including these species in the genus. Stropholirion has been generally recognized as a genus, even by S. Watson. The typical species of Dichelostemma, i. e., D. congesta (Smith) Kunth and its relative D. multiflora (Benth.) Heller, have only 3 stamens alternating with 3 staminodia and differ from the typical species of Hookera only in the rounded base of the perianth and the subcapitate inflorescence. If they are kept distinct then Sembertia should be regarded distinct from Triteleia. Brodiaea capitata has 6 fertile stamens with subulate filaments. At the base of each of the inner three there are two lanceolate lobes partly adnate to the perianth, forming together a crown of 6 instead of 3 members. To the new genus proposed here, belong:

Dipterostemon capitatus (Benth.)

Brodiaea capitata Benth. Pl. Hartw. 339. I 857.

\section{Dipterostemon pauciflorus (Torr.)}

Brodiaea capitata panciflora Torr. Bot. Mex. Bound. Surv, 2 I8. I 859 .

Dipterostemon insularis (Greene)

Brodiaea insularis Greene, Bull. Calif. Acad. Sci. 2: I34. 1887.

Dipterostemon pulchellus (Salisb.)

Hookera pulchella Salisb. Parad. 2: pl. II7. I 808.

New York Botanical Garden.

* Bull. Calif. Acad. Sci. 2: 125-144. 1886. 



\section{STUDIES ON THE ROCKY MOUNTAIN FLORA-XXVII}

By PER AXEL RYDBERG

NEW YORK

1912

Reprinted, without change of paging, from the BulletiN ofTHE TORRE BotaNical CLUB 39: $301-328.23 \mathrm{Jl} 1 ! 12$ 

Studies on the Rocky Mountain flora-XXVII

\author{
Per Axel Rydberg \\ SALICACEAE
}

Populus hastata Dode, Extr. Mon. Gen. Populus (Mém. Soc. Hist. Nat. Autun I8:) 64. 1905

Some years ago we were forced to admit one of Dode's species, $P$. Sargentii. I say forced, because Dode's paper is presented in such an unscientific way that any one might feel inclined to ignore it altogether. His differentiations are based wholly on the leaf forms, and in very few genera do the leaves show so great variation as in Populus. In working over Mr. Butler's collection of Montana plants I found numerous specimens of a poplar which has usually been regarded as $P$. balsamifera $L$., sometimes as P. trichocarpa T.\& G. A study of the fruit shows that this poplar has the sessile and 3-carpellary fruit and the large involucral cup of $P$. trichocarpa, but the capsule is proportionally longer than in that species and perfectly glabrous. The eastern P. balsamifera has evident pedicels and almost always 2 -carpellary ovary and much smaller involucral cup. The leaves are usually broader than in $P$. balsamifera and often subcordate at the base. They resemble much those of $P$. candicans Ait. in outline but are perfectly glabrous. P. candicans has also pediceled and 2-carpellary capsules. It is apparent that this species represented by Butler's material is $P$. hastata of Dode, for he associated it with $P$. trichocarpa and pointed out just the characters by which it differs from that species. The name hastata was given in reference to the 
form of the young leaves, which he described as being hastate. His idea of the term hastate must have been rather strange, for he figured the different leaf forms, and the form of leaf illustrated as representing the young shoots is elongate-ovate with slightly cordate base.

It is represented in the herbarium of the New York Botanical Garden by the following specimens:

Alberta: Bow River, May 26, I899, Mc Calla 2236.

Montana: Flathead Lake, July 23, I900, J. WW. Blankinship; Columbia Falls, September I 4 , I892, R. S. Williams (both determined as $P$. balsamifera candicans); various localities in Montana, Butler $124,125,126,127,128,137$. To this may also belong the following, which are in leaf only: Butler II2, II3, II4, I35, I47.

Idaiı: Salubria, July Io, I899, M. E. Jones 6541 (labeled $P$. trichocarpa).

Populus Besseyana Dode, loc. cit. 38

Another poplar collected by Butler seems to be impossible to identify with any of the accepted species. Butler's material is all in leaf only, but there is in our collection one specimen collected by Miss Isabel Mulford, in Idaho, which evidently belongs here, and this specimen is in fruit. It is evidently related to $P$. deltoides Marsh., but the leaf shape is different and the pedicels are very short, shorter than the capsule. The young stems are perfectly terete, not at all angled; the bases of the leaves of the mature branches are rounded or subcuneate at the base and more or less serrate along the base; the basal glands are small and the petioles flattened. In $P$. Sargentii Dode the leaves are flabellate-cordate, with an open concave sinus at the base, which is toothless. The leares resemble much P. acuminata Rydberg but are broader and less cuneate at the base, and in the latter species the petioles are terete. I adopt Dode's name, not because I can definitely identify it by his diagnosis but because his illustrations of the leaves resemble those of this species.

To this belong the following specimens:

IDAIIO: Fish Haven, August 8, I 898, Isabel Mulford 263.

Montana: Delta of Flathead River, Big Forks, Montana, August I4, I90I, Umbach I92; and from several localities, Butler I09, III, II5, II6, II7, I20, I36, I39, I40, I44, I45, I49, I53. 
Rydberg: Studies on the Rocky Mountain flora 303

\section{Populus Fremontil Torr.}

The known range of this species was extended last summer, when it was collected by Professor A. O. Carrett and the writer in and around the town of Noab, southeastern Utah; and specimens evidently also belonging to it were seen in the Cottonwood and White canyons about Ioo miles farther southwest.

Willow hybrids are not uncommon in Europe and rather common in cultivation; but we find very rarely any references to any spontaneous hybrids of American species mentioned. It will therefore not be out of place to record the following specimens probably representing hybrids, although no definite proof can be given of their origin.

\section{Salix cordata $\times$ S. monticola}

The shrubs referred here have capsules shorter than in $S$. cordata Muhl. but longer than in S. monticola Bebb; the habit and the bark are those of the latter; but the narrow leaves (although less serrate) and the bractlets are those of $S$. cordata angustata (Pursh) Anders, the form of $S$. cordata common in the Rockies. The capsules of the specimens seen usually remaincd undeveloped. The staminate catkins resemble most those of S. monticola. S. monticola was growing mixed in with the supposed hybrid. S. cordata angustata is also growing in the Big Cotton Canyon, although no specimens of it were noticed in the immediate vicinity where the plants were collected.

UTAн: Big Cottonwood Canyon, below Silver Lake, July I I, I905, Rydberg 6877,6878, and 6883; July 4, I905, Rydberg \& Carlton 6615 .

\section{Salix glaucops $\times$ S. monticola}

The specimens resemble S. glaucops Anders. in the capsules and bractlets, but the former are less densely hairy; the leaves are more like those of $S$. monticola, being finely serrate, glabrate in age and glaucous beneath; the young branches are somewhat villous. Both S. monticola and $S$. glaucops are growing in the Big Cottonwood Canyon.

UtAH: Big Cottonwood Canyon, Salt Lake City County, August 23, 1905, A. O. Garrett 1671 . 


\section{Salix Sandbergii sp. nov.}

Bark of the branches reddish chestnut brown, finely puberulent when young; leaves oval or elliptic, $2-4 \mathrm{~cm}$. long, densely whitesilky on both sicles, grayish above, silvery beneath, entire or nearly so; pistillate aments sessile, naked, about $4 \mathrm{~cm}$. long; bractlets purple, obovate-spatulate, $3 \mathrm{~mm}$. long, white-pilose; capsule glabrous, $4-5 \mathrm{~mm}$. long; stipe about $\mathrm{I} .5 \mathrm{~mm}$. long; style about $0.5 \mathrm{~mm}$. long; lobes of stigma short.

The type was distributed as. Salix lasiolepis Benth., to which it is not at all closely related. The leaves resemble somewhat those of S. sitchensis Sanson and S. bella Piper, but the capsule is glabrous and the plant belongs to the S. cordata group. On account of the white leaves it would be placed next to S. Hookeriana Barrett, but the leaves are silky, not villous, and entire, and the aments and capsules are much smaller. It grows on banks of streams.

IDAHO: Valley of Hatwai Creek, April 28, I892, Sandberg, MacDougal \& IIeller $7 I$ (type, in herb. N. Y. Bot. Garden).

The following species of willows are here recorded for the Rocky Mountain region: Salix erythrocoma Barrett (S. arguta erythrocoma Anderson), S. lucida Muhl., S. Hookeriana Barrett, S. conjuncta Bebb, S. MacCalliana Rowley, S. alexensis (An(ters.) Coville, S. Barrettiana Hook., S. Seemanii Rydb., S. Drummondiana Barrett, S. arbusculoides Anders., S. desertorum. Richards., S. saskatcherena Seem., and S. Fernaldii Blankinship, from the Canadian Rockies south of the $55^{\circ}$ parallel; and S. conjuncta Bebb and S. Fernaldii Blankinship also from Montana.

\section{ULMACEAE}

\section{Celtis rugosa sp. nov.}

A tree, 5-IO $\mathrm{m}$. high, with rounded crown; bark gray, corky; twigs brownish, pubescent when young; petioles 6-10 mm. long; leaf blades broadly ovate, oblique, $+-7 \mathrm{~cm}$. long, somewhat cordate at the base, short-acuminate, sharply serrate except at the base and at the apex, coriaceous, dark green, very shiny and slightly scabrous above, brownish or yellowish green, dull, puberulent beneath, strongly reticulate and rugose; pedicels $15-25 \mathrm{~mm}$. long; fruit globose, about $8 \mathrm{~mm}$. in diameter, brownish; style short but eviclent.

This species is related to $C$. reticulata Torr. but differs in its 
longer pedicels (in C. reticulata I $\mathrm{cm}$. long or less) and in its serrate, short-acuminate leaves, which are less pubescent, more shiny, and much less rough above. It grows in gulches and mountain valleys of Colorado.

Colorado: Golden, Aug. 29, i 895, P. A. Rydberg (herb. N. Y. Bot. Garden); Aug. 30, I 895, C. L. Shear 3263; gulch west of Pennock's mountain ranch, May 26, i 897, C. S. Crandall 2254.

Celtis occidentalis L. is included in the Rocky Mountain flora by Coulter \& Nelson, ${ }^{*}$ but erroneously so, the writer thinks. Celtis Douglasii Planchon, C. rugosa, and perhaps also C. reticulata Torr. have been mistaken for it.

\section{URTICACEAE}

\section{Urtica strigosissima sp. nov.}

Perennial, dioecious; sten I m. high or more, glabrous below, strongly retrorsely strigulose above, but almost without bristles; stipules narrowly linear-lanceolate, acuminate; petioles $2-3 \mathrm{~cm}$. long; leaf blades lanceolate, 3-5-ribbed, sharply serrate, rounded or acute at the base, long-acuminate at the apex, 5-10 cm. long, I.5-5 cm. wide, finely strigulose beneath; flower clusters slender, the upper almost equalling the leaves; sepals ovate, about equalling the achenes.

This species resembles $U$. gracilis Ait. in habit and leaf form, but is more strigose and rarely at all bristly. In pubescence it resembles $U$. Breweri S. Wats. but has narrower leaves and narrowly linear-lanceolate, acuminate, instead of oblong and obtuse, stipules. It grows on river banks at an altitude of $1,000-2,500 \mathrm{~m}$.

IdAho: Forest, Nez Perces County, July 29, I896, A. A. E E. Gertrude Heller 3475 (herb. Columbia University).

\section{Urtica viridis $\mathrm{sp}$. nov.}

Perennial with a horizontal rootstock, dioecious; stem $\mathbf{I}-\mathbf{I} .5$ $\mathrm{m}$. high, slender, glabrous or sparingly bristly, round-angled; stipules linear-lanceolate, acuminate, $5^{-8} \mathrm{~mm}$. long; petioles short, one fifth to one third as long as the leaf blades; these from narrowly lanceolate to ovate, coarsely toothed, $f_{-10} \mathrm{~cm}$. long, thin, light green, almost glabrous; panicles many-flowered, of ten equalling the upper leaves: sepals oval or ovate, usually half longer than the achenes. 
This species is closely related to $U$. cardiophylla Rydb. but differs in its narrower leaf blades, shorter petioles, longer and denser inflorescence, and longer sepals. In habit it closely resembles $U$. gracilis but differs in its practically glabrous stem and thinner and more glabrous leaves.

Mostaxa: Emigrant Gulch, Aug. 23, I897, Rydberg \& Bessey 3935 (type, in herb. N. Y. Bot. Garden); Jack Creek Canyon, July I5, I 897, 3936; Jocko Creek, June Io, 1901, D. T. MacDougal 275; Melrose, July 6, I895, P. A. Rydberg 2612; Lima, Aug. 6, I895, Rydberg 2613 .

Wroming: Halleck Canyon, July 4, I900, Aven Nelson 744.

Id Cooper's Wrarm Springs, July 1892, Isabel Mulford.

Alberta: Rocky Mountains, i858, E. Bourgeau.

\section{Parietaria occidentalis sp. nov.}

Annual; stem slender, erect, simple or branched at the base, longvillous, $1-4 \mathrm{dm}$. high; leaf blades thin, light green, lanceolate, acute at the base, obtuse at the apex, I- ${ }^{-} \mathrm{cm}$. long, $5^{-1} 8 \mathrm{~mm}$. wide, sparingly pubescent; bracts of the involucre linear, obtuse; sepals oblong or lance-oblong, obtuse or acutish.

This species is related to $P$. pennsylaranica Muhl. but differs in the long hairs of its stem, light green color, and the more obtusish sepals. It grows in moist shaded places.

Idaho: Clearwater River, Nez Perces County, May I4, I892, Sandberg, MacDougal \& Heller I76 (type, in herb. N. Y. Bot. Garden).

Wasmington: Wawawai, May i 897, Elmer 755; Alamota, June 1893 , Piper 1507 .

Nevadi: East Humboldt Mountains, August i868, S. Watson 1084 .

\section{POLYGONACEAE}

\section{Eriogonum biumbellatum sp. nov:}

Suffruticose perennial, branched at the base; leaves basal, clustered at the ends of the short branches, $2-5 \mathrm{~cm}$. long, shortpetioled; blades oblanceolate, finely tomentose on both sides when young, soon glabrate and green on both sides; scapes $2-3 \mathrm{dm}$. high, sparingly tomentose; involucres in compound umbels; bracts verticillate, similar to the leaves but smaller; involucres with a 
turbinate tube, which is about $2 \mathrm{~mm}$. long, slightly tomentose; its lobes oblong, $1.5^{-2} \mathrm{~mm}$. long, obtuse; perianth yellow, glabrous, 3-4 mm. long, with a stipelike base; divisions elliptic, obtuse, the outer slightly longer than the inner; filaments ciliate; ovary more or less hairy above, 3-angled.

This species is related to E. umbellatum Torr., E. neglectum Greene (E. umbelliferum Small), and E. croceum Small. It has the compound inflorescence of the last one, but the leaves are green and glabrate in age and much narrower than in the other species mentioned.

UTAH: Fish Lake around Twin Creeks, August 8, 1905, Rydberg \& Carlton 7376,7409, and 7483; Fish Creek Canyon, August 2, I909, A. O. Garrett 2568 .

\section{Eriogonum idahoense sp. nov.}

Shrub $4^{-6} \mathrm{dm}$. high with gray bark; branches more or less tomentose, erect; leaves $2-3 \mathrm{~cm}$. long, short-petioled; blades oblanceolate, white-tomentose beneath, loosely floccose and soon glabrate above; floral branches about I $\mathrm{dm}$. high; inflorescence a compound trichotomous flat-topped cyme; involucres in the axils peduncled; peduncles of the lower forks I $\mathrm{cm}$. long; branches of the cymes short, not over $5 \mathrm{~cm}$. long; involucres turbinate, about $3 \mathrm{~mm}$. long, floccose; lobes about I $\mathrm{mm}$. long, lanceolate-oblong, obtuse: perianth yellow, glabrous, about $2 \mathrm{~mm}$. long, without stipelike base; fruit unknown.

The type was labeled Eriogonum microthecum Nutt., which it resembles in habit, but the flowers are yellow instead of pink or white, and the lobes of the involucres are longer and not scarious. margined. It is more closely related to E. orendense A. Nels, and E. campanulatum Nutt. From the first it is distinguished by the leaves, which are glabrate above, the tall stem, and the more open inflorescence; from E.campanulatum by the tall shrubby habit and the tomentose involucre.

ID.4ho: Wieser, July 7, I899, M. E. Jones $651 I$ (type, in herb. N. Y. Bot. Garden).

\section{Eriogonum spathuliforme sp. nov.}

Perennial, shrubby at the base, leaves all near the base; petioles I-2 cm. long; blades elliptic to spatulate, I-3.5 cm. long, whitetomentose on both sides, densely so beneath; stem scapiform, 
2-3 dm. high, trichotomously branched, with ascending branches; bracts triangular, $5 \mathrm{~mm}$. long or less; involucres in the lower forks short-peduncled, the rest sessile, glabrous, turbinate, $3 \mathrm{~mm}$. long; lobes rounded, scarious-margined; perianth white, glabrous, 2-2.5 mm. long, campanulate; divisions equal, obovate; filaments slightly hairy below; ovary glabrous.

In habit and leaf form this species resembles E. spathulatum A. Gray, but the involucres are glabrous instead of tomentose, and the lower ones are peduncled; the stem is also perfectly glabrous. It differs from E. tristichum Small and E. salicinum. Greene in its broader leaves and the scarious-margined lobes of the involucre. Jones' specimens are smaller and more cespitose than the type.

UTAн: Sandy washes near Belknap, June I2, I900, Stokes (type, in herb. N. Y. Bot. Garden); Marysvale, August 30, I894, M. E. Jones 5969 (?).

\section{Eriogonum depressum (Blankinship) Rydb. comb. nov.}

Eriogonum ovalifolium depressum Blankinship, Mont. Agr. Coll. Sci. Stud. Bot. I : 49. 1905.

Eriogonum rubidum frigidum Gand. Bull. Soc. Bot. Belg. 42: I94. 1906.

Dr. J. K. Small has for some years regarded this as a distinct species, and it is found in the herbarium of the New York Botanical Garden under a manuscript name of his, which, however, was never published.

Eriogonum ramosissimum Eastwood is related to E. Wrightii Torr. and does not belong to the corymbosum group, to which it was referred.

Eriogonum crassifolium Benth. is the same as the original E. flavim Nutt. What Coulter \& Nelson and others have regarded as E. flavum should be known as E. chloranthum Greene. E. aurenm Nutt. is the same, but the name was first published as a hyponym, and when finally it was properly published there was already an E. aureum Jones.

Torrey and Gray, in their revision of Eriogonum, described E. strictum Benth. as having subequal sepals, and they have been followed by S. Watson and others. Bentham, in his original description of the species, did not mention whether the perianth 
lobes are equal or not, but in his subsequent treatise of the genus in De Candolle's Prodromus he expressly stated that they are unequal. In the only two specimens found in the herbarium of the New York Botanical Garden, in my opinion belonging to $E$. strictum, the outer perianth lobes are very broadly oval while the inner are oblong. The species should therefore be associaterl with E. dichotomum Dougl. and not with E. racemosum Nutt. and E. Wrightii Torr., differing from the first principally in the glabrous involucres. Both E. strictum and E. dichotomum have been collected in Idaho.

The genus Eriogonum is represented by over one huncled species in the Rocky Mountain region. The following ones are not recorded either by Coulter \& Nelson nor in my Flora of Colorado or in my Flora of Montana, but they should be included in the flora: E. androsaceum Benth. in Alberta, Montana, and British Columbia; E. thymoides Benth., E. compositum Dougl., E. proliferum Benth., E. elatum Dougl., E. strictum Benth., E. spergulinum A. Gray, and E. vimineum Dougl., in Idaho; E. dichotomum in Idaho and Montana; E. micranthum Nutt., E. nidularium Coville, and E. Baileyi S. Wats., in Idaho and Utah; E. Porteri Small, E. pulvinatum Small, E. longilobum M. E. Jones, E. ochrocephalum S. Wats., E. villiflorum A. Gray., E. Shockleyi S. Wats., E. polifolium Benth., E. Thompsonae S. Wats., E. aureum M. E. Jones, E. spathulatum A. Gray, E. leptophyllum Torr., E. bicolor M. E. Jones, E. clavellatum Small, E. sulcatum S. Wats., E. Mearnsii Parry, E. ramosissimum Eastw., E. densum Greene, E. turbinatum Small, E. insigne S. Wats., E. deflexum Torr., E. mutans T. \& G., E. Wetherillii Eastw., E. Thomasii Torr., E. subreniforme S. Wats., E. Parryi A. Gray, E. Ordii S. Wats., E. trichopodum Torr., E. angulosum Benth., and E. puberulum S. Wats., in Utah; E. Hookeri in Utah and Wyoming; E. tenellum Torr. in Colorado; and E. depatiperatum Small in the Black Hills of South Dakota.

\section{Chorizanthe spathulata Small sp. nov.}

A more or less branched annual; stem 5-20 cm. high, erect, strigose-canescent; branches erect, strict; lower leaves petioled, I.5-3 cm. long; blades broadly spatulate, somewhat fleshy, hirsutestrigose on both sides, rounded and sometimes mucronate at the 
apex; stem leaves few, spatulate or oblanceolate, much smaller; bracts linear or linear-oblanceolate, arcuate-recurved, spinulosetipped; involucre cylindroprismatic, $5 \mathrm{~mm}$. long, angled and grooved, strigose; lobes 6 , subulate, recurved, spinulose-tipped, the alternating ones somewhat narrower; perianth about $2 \mathrm{~nm}$. long, lobes ovate; stamens mostly 3 (?); filaments adnate to the lower part of the perianth.

This species is related to C. brevicormu Torr., and Torrey and Gray included doubtfully Watson's specimens in that species.* It differs in its broader lower leaves and its strict erect branches.

IdAlio: Big Butte Station, June 23, I863, Edward Palmer 230 (type, in herb. Columbia University).

NevadA: $1875, J . G$. Lemmon; Big Bend of the Truckee, May I 868, S. Watson IOH.

\section{CHENOPODIACEAE}

\section{Chenopodium pratericola sp. nov.}

Annual; stem 3-6 dm. high, striate and angled, nearly glabrous; leaves petioled; blades oblong, lanceolate, or elliptic, $2-6 \mathrm{~cm}$. long, 4-18 $\mathrm{mm}$. wide, entire or with a short tooth on each side, usually callous-mucronate, green and nearly glabrous above, more or less mealy beneath, usually distinctly 3 -nerved at the base; flowers in small clusters forming rather dense spikes or panicles; sepals scarious-margined, green on the back, slightly carinate; seeds easily separating from the pericarp, black, shining, about $1.5 \mathrm{~mm}$. in diameter.

This has been included in C. leptophyllum (Moq.) Nutt. by most botanists although sometimes confused with $C$. oblongifolium (S. Wats.) Rydb. on account of its broad leaf blades. It differs from the former in its broader leaves, which are practically glabrous on the upper side, distinctly 3 -nerved at the base, and at least the larger ones often toothed on the margins. From the latter it differs in its thin, more glabrate leaves and less dense inflorescence.

Kaxsas: Riley County, August 2, I 895, J. B. Norton 436 (type, in herb. N. Y. Bot. Garden).

Nebraska: Middle Loupe River, near Thedford, June 2 I, 1893. Rydberg 1386; Forks of Dismal River, July I I, I893, Rydberg 1835; Kearney County, June I3, I89I, Rydberg 318 .

Missouri: Courtney, June 25, 1896, Bush 367.

* See Proc. Am. Acad. 8: ig6. I870. 
Rydberg: Studies on the Rocky Mountain flora 311

IDAHO: Lewiston, June I3, I 896, Heller 3247.

New Mexico: Mesilla, June 3, I897, Wooton 8 .

Wroming: Platte River, July I4, I894, Aren Nelson 483; Snake River, I900, C. C. Curtis.

Arizora: i876, Palmer 478 .

Chenopodium succosum A. Nels. is in my opinion a synonym of C. rubrum L., being the common American form thereof, and C. desiccatum is prohably only a small form of C. oblongifolium (S. Wats.) Rydb.

Chenopodium lanceolatum Muhl. and C. paganum Reich., the former an eastern plant and the latter a European weed, both often erroneously known as C. viride L., have been collected in Colorado. The original $C$. viride $\mathrm{L}$. is the same as C. opulifolium Schrad. of Europe, not known as occurring in this country. $C$. viride and $C$. opulifolium were based on the same illustration.

Monolepis spathulata A. Gray has been collected in Idaho.

Atriplex odontophora Rydb. is not a synonym of A. canescens (Pursh) James but of A. aptera A. Nels. instead.

\section{Atriplex buxifolia sp. nov.}

A suffruticose perennial; stem branched near the base, with simple branches, 3-4 dm. high; leaves sessile, elliptic or oval, thick, I-2 cm. long; pistillate flowers in axillary clusters; fruiting bracts ovate, acute, $4^{-5} \mathrm{~mm}$. long, toothed on the margins, with thick. of ten flattened processes on the faces.

This is related to A. Nuttallii but distinguished by its short oral or elliptic, often fascicled leaves, its simple wandlike branches and small fruit. It grows on dry plains at an altitude of about $\mathrm{I}, 200 \mathrm{~m}$.

Wromac: Dayton, Sheridan County, September 1899, F. Tweedy 2656 (type, in herb. N. Y. Bot. Garden).

Atriplex tetraptera (Benth.) Rydb. comb. nov.

Obione tetraptera Benth. Bot. Sulph. 48 . I 844 .

This has usually been regarded as the same as $A$. canescens (Pursh) James but differs in its narrow, linear leaves, only $2-5$ $\mathrm{mm}$. wide, in its more strongly reticulate fruit wings, which have a broad sinus at the apex, and in that the free portion of the 
bracts is less than half as long as the width of the wing. It differs from A. occidentalis Torr. in its narrower and sharply toothed wing.

\section{Atriplex Garretti sp. nov.}

A low shrub, with straw-colored branches; leaves shortpetioled, oval, $2-3 \mathrm{~cm}$. long, grayish, scurfy on both sides, acute at the base, abruptly acuminate at the apex; flowers in axillary and terminal clusters; bracts about $8 \mathrm{~mm}$. long and about as broad, 4 -winged, coarsely toothed and occasionally with a few additional processes, with a broad open sinus at the apex; free portion $\mathrm{I}-2$ $\mathrm{mm}$. long.

The fruit would associate this species with $A$. canescens, $A$. occidentalis, and $A$. tetraptera, but the leaves are quite different in shape. The plant looks in general habit somewhat like $A$. confertifolia, but the fruiting bracts are altogether different. It grows in arid valleys at an altitude of about $1,200 \mathrm{~m}$.

UтAн: Vicinity of Moab, July I, I9 I I, Rydberg \& Garrett 8.465 (type, in herb. N. Y. Bot. Garden).

Endolepis phyllostegia (Torr.) Rydb. comb. nov. Obione phyllostegia Torr. in Wats. Bot. King Exp. 291. I871. Atriplex phyllostegia S. Wats. Proc. Am. Acad. 9: 108. 1874.

This species should be transferred from Atriplex to Endolepis, as sepals are present in the pistillate flowers.

\section{Eurotia subspinosa sp. nov.}

A dioecious shrub, 6-Io dm. high; branches ascending or spreading, becoming more or less spinescent, finely grayish stellatetomentose but without longer hairs; leaves linear or oblong, obtuse, entire, $\mathrm{I}-3 \mathrm{~cm}$. long, or the secondary ones only $5 \mathrm{~mm}$. long and comparatively broader, with revolute margins: flower clusters axillary, those of the staminate plant crowded and forming simple leafy spikes; fruiting bracts lanceolate, about $6 \mathrm{~mm}$. long; horns usually about $2 \mathrm{~mm}$. long.

This species is more decidedly shrubby than E. lanata (Pursh) Moq. and evidently always dioecious, has ascending or spreading branches, which become spinescent, lacks the long hairs intermixed with the stellate pubescence characteristic of E. lanata, and has usually longer horns. In E. lanata the branches are erect, and the plant is shrubly only at the base. The predominantly 
Rydberg: Studies on the Rochy Mountaln flora 313

staminate plant has a few pistillate flowers borne on the lower part of the branches. The predominantly pistillate plant has often a few staminate clusters above but is sometimes wholly pistillate. E. subspinosa grows on rocky hills in the desert regions.

Utan: Rocky summits, St. George, May i 5, 1903, Goodding 810 (type, in herb. N. Y. Bot. Garden); i 874, C. C. Parry 725 ; 1875 , E. Palmer; April 9, I880, M. E. Jones 1672; Virgin River, $18+4$, Fremont 740 .

Arizona: Fort Verde, October II, I887, E. A. Mearns I 88 ; Holbrook, August Io, I897, Myrtle Zuck; Total Wreck Mine, I903, Thornber 6o; Rincon Mountains, October 7, I900, D. Griffiths 1781 .

NeradA: Thousand Spring Valley, September i868, S. IT'atson 990 (in part); Muddy Valley, Lincoln County, May 6, I906, Kennedy \& Goodding.

Calmornia: Mohave Desert, April i905, Mrs. C. DeKalb; Radsburg, April I4, A. A. Ileller 7705; Red Hill, west of Bishop, May I $4, A$. A. Heller 8253 .

Sunori: Genaga di San Bernardino, i 855 . Schott.

Dondia calceoliformis (Hook.) Rydb. comb. nov.

Chenopodium calceoliformis Hook. Fl. Bor.-Am. 2: 126. I838.

This, I think, descrves specific rank. It is characterized from D. depressa (Pursh) Britton and D. erecta (S. Wats.) A. Nels. by its broad and short, ovate or ovate-lanceolate bracts over $2 \mathrm{~mm}$. wide.

\section{AMARANTHACEAE}

Amaranthus pubescens (Uline \& Bray) Rydb. comb. nov.

A maranthus graecisans pubescens Uline \& Bray, Bot. Caz. I9: 317. I 894 .

This probably deserves specific rank. It has been collected in Colorado.

Amaranthus carneus Greene and A. califormicus S. Wats. should be added to the region. The former has been collected in Montana, and both in Idaho. 


\section{PORTULACACEAE}

\section{Limnia utahensis sp. nov.}

Annual; stem 2-I5 cm. long; basal leaves petioled; blades spatulate to linear, $\mathrm{I}-3 \mathrm{~cm}$. long, 2-6 $\mathrm{mm}$. wide; stem leaves connate, forming an oblique, 2 -lobed disk, $\mathrm{I}-2 \mathrm{~cm}$. broad; inflorescence very short, corymbiform; fruiting sepals ovate, acute, $2-3 \mathrm{~mm}$. long, about equalling the pedicels; seeds about $1.5 \mathrm{~mm}$. in diameter, minutely muricate.

This species resembles in habit L. depressa (A. Gray) Rydb. and L. spathulata (Dougl.) Heller but differs from the former in the long and narrow blades of the basal leaves and more connate stem leaves, from the latter in the large and broad stem leaves, and from both in the large seeds.

Utah: St. George, I 877, Palmer 56 (type, in herb. Columbia University); 1874, C. C. Parry 23 and 24.

I have not seen the type of Montia Viae A. Nels., ${ }^{*}$ but from the description and specimens named by Professor Nelson I judge it is the same as Limnia depressa (Robinson) Rydb. $\dagger$ published a few months earlier.

Coulter and Nelson report Calyptridium roseum S. Whats. from

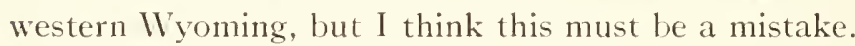

Professor A. O. Garrett and myself collected Talinum brachypodum S. Wats, in southeastern Utah. Miss A. Eastwood has reported it from the same region.

\section{ALSINACEAE}

\section{Cerastium thermale sp. nov.}

Cerastium arvense fuegianum Hollick \& Britton, Bull. Torrey Club 14: 50. 1887. Not Hook. I854.

Cerastium fuegianum A. Nels.; Coult. \& Nels. New Man. Bot. Rocky Mts. I84. I899.

Densely cespitose perennial; stems decumbent at the base, $5^{-10} \mathrm{~cm}$. long, viscid-puberulent; leaves yellowish green, less than I cm. long, lanceolate, acute, or the lower oblong or spatulate and often obtuse, coriaceous, with a very thick midrib, finely viscidpuberulent; cymes I-7-flowered, usually condensed and with short pedicels; sepals $4 \mathrm{~mm}$. long, glandular-puberulent, ovate, scarious-

* Bot. Gaz. 42: $48 . \quad 1900$.

$\dagger$ Bull. Torrey Club 33: I39. I906. 
margined; petals about $5 \mathrm{~mm}$. long; capsule about $6 \mathrm{~mm}$. long, slightly curved near the upper end.

This is Cerastium arense fuegianum Hollick \& Britton, but not that of Hooker. It differs from C. strictum L., its nearest relative, in the low, depressed stem, yellowish herbage, thicker and smaller leaves, the lower of which are often obtuse, and the smaller more condensed flowers. It grows on geyser formations in the Yellowstone National Park, at an altitude of about 2,000 m.

Wroming: Lower Geyser Basin, Aug. t, I897, Rydberg \& Bessey 7025 (type, in herb. N. Y. Bot. Garden); Aug. II, I872, J. M. Coulter.

\section{Alsine Palmeri sp. nov.}

A cespitose perennial; stems several, spreading, $5 \mathrm{~cm}$. high or less, glabrous; leaves ovate or ovate-lanceolate, $2-5 \mathrm{~mm}$. long, fleshy, acute; cyme 3-7-flowered; bracts lanceolate, green; sepals lanceolate, $2.5^{-3} \mathrm{~mm}$. long, acute; petals about equalling the sepals.

The type was named Stellaria borealis by Dr. Watson but is evidently not closely related to it. A. Palmeri has the thick leaves of A. Edwardsii (R. Br.) Rydb., but the midribs are not prominent, the flowers smaller, the sepals decidedly acute, and the petals only about equalling the sepals in length.

Utaн: Beaver Valley, I87\%, E. Palmer 5.t (type, in herb. Columbia University).

Alsine alpestris (Fries) Rydb. comb. nov. Stellaria alpestris Fries, Mant. I: Io. I832.

Alsine strictiflora Rydb. nom. nov.

Stellaria stricta Richards. Frankl. Jour. ed. 2. App. I5. I 823. Not Alsine stricta Wahlenb. I8I2.

This is the Stellaria longipes of most western reports and of Coulter \& Nelson's New Manual. It has a short pod and acute sepals, while the original Stellaria longipes Goldie has the pods twice as long as the obtuse sepals. If I am not mistaken the latter is the same as Stellaria zalida Goodding.

Alsine subvestita (Greene) Rydb. comb. nov. Stellaris subrestita Greene, Ottawa Nat. I5: 42. I90I. 


\section{Arenaria cephaloidea sp. nov.}

Somewhat cespitose perennial; stem strict, 2-4 dm. high, glabrous; leaves glabrous, erect, filiform-subulate, 3-Io cm. long; flowers in dense headlike cymes; bracts lanceolate, often I cm. long, scarious except the thick midrib, scabrous-ciliolate; sepals similar or somewhat broader, 4-5 mm. long; petals oblong, about half longer than the sepals.

This is related to $A$. congesta Nutt. but differs in its narrower bracts, which are wholly scarious, except the midrib, and scabrousciliolate on the margins; also in its larger flowers, stricter stem, and less cespitose base.

IVAsmingtox: Spokane, Sept. I0, I902, O. Kreager 6I7 (type, in herb. N. Y. Bot. Garden); Clark Springs, July I7, I902, Kreager IOO; Loon Lake, July 20, I897, J. B. Winston; Spokane County, June 27, I884, Suksdorf.

ID Little Potlatch River, June 2, I892, Sandberg, MacDougal Eo Heller 478 .

Arenaria lithophila Rydb. comb. nov.

Arenaria subcongesta lithophila Rydb. Mem. N. Y. Bot. Gard. I : I48. I900.

This, I think, deserves specific rank. Some of the specimens recorded as A. subcongesta (S. Wats.) Rydb. should also be referred to it.

Alsinopsis dawsonensis (Britt.) Rydb. comb. nov. Arenaria das'sonensis Britt. Bull. N. Y. Bot. Gard. 2: I69. I90I. This species has been collected in the Black Hills of South Dakota.

Alsinopsis pusilla (S. Wats.) Rydb. comb. nov. Arenaria pusilla S. Wats. Proc. Am. Acad. I7: 367. I882.

This species has been collected in Idaho.

Arenaria laxiflora nom. nov.

Arenaria Fendleri diffusa Porter, Syn. F1. Colo. I3. I874. Not A. diffusa Ell. I8I8. 
Ammodenia oblongifolia (T. \& G.) Rydlb. comb. nox. Arenaria peploides major Hook. Fl. Bor.-Am. I: 102. 1831. IIonckenya oblongifolia T. \& G. F1. N. Am. I: 176. $18,38$. Arenaria sitchensis Dietr. Syn. Pl. 2: 1565.18 40.

B. T. Butler has collected in Montana what scems to be Arenaria laricifolia $\mathrm{L}$. At least it is the same plant as the one collected by Turner on the Porcupine River, Alaska, on the strength of which A. laricifolia is included in the American flora.

Sagina occidentalis S. Wats. has been collected in Idaho by Leiberg.

\section{CARYOPHYLLACEAE}

\section{Wamlbergella Fries, Bot. Not. 1843: 143. 18+3}

The treatment of the Silenoid genera of this family has been very different in this country and in Europe. S. Watson and B. L. Robinson adnitted only two genera, Silene and Lychnis, while Pax* admitted beside Silene the genera Lychnis, Melandryum, and Viscaria, and Williams † admitted Lychnis, Coronaria, Viscaria, Eudianthe, and Melandrium. The only distinction given by Watson and Robinson is the number of styles, in Silcne 3 , in Lychnis 5, but Robinson admits that in some species of Silene the styles are sometimes + or 5 . The number of styles is therefore not a very reliable character. Continental authors usually differentiate Silene from Melandrium (1,y Americans included in Lychnis) by the partially septate capsule of the former. According to Robinson this character is unreliable in our American species. Perhaps the species included in Silene without septum should be remored to Melandrimm or to Eudianthe. As these doubtful species are not found in the Rockies, I shall give no opinion on them here. It is evident that the genus Lychnis as treated in America is an unnatural and composite group. Williams' treatment is perhaps the most logical. Pax included our native American species of Lychnis in Melandrium but divided the genus in three subgenera. One of these subgenera corresponds to Eudianthe with only 3 styles. The other two subgenera correspond to the original species of Melandrium and the genus IJ ahlbergella of Fries,

* Engl. \& Prantl, Nat. Pflanzenf. 3: 1b: 70, 73. 1889.

† Jour. Bot. 31: I70, I7I. I893. 
respectively. The typical species of Lychnis have 5-valved capsules with entire valves. In the typical species of Melandrium the valves are 2 -cleft at the apex. In Wrahlbergella the valves are also more or less notched. In that respect the species belong rather to Melandrium than to Lychnis. But the typical species of Melandrium are dioecious plants with ample long-exserted petals and of a different habit from that of our native species. These all have hermaphrodite flowers with very small and inconspicuous or even no petals. In my opinion the genus Wahlbergella should be taken up for our native species usually included in Lychnis. Lychnis Drummondii (Hook.) S. Wats. is somewhat different in habit and fruit and was referred to Elisanthe by Ruprecht, but I think it can well be included in Wahlbergella. Of course L. striata Rydl). is closely related to it and should be referred to the same genus, whatever disposition of it is made. The species of Wrahlbergella in America are as follows:

Wahlbergella Drummondii (Hook.) Rycib. comb. nov. Silene Drummondii Hook. Fl. Bor.-Am. I: 89. 1830. Elisanthe Drummondii Rupr. Fl. Cauc. I: 200. I869. Lychnis Drummondii S. Wats. Bot. King Exp. 37. 1871 .

Wahlbergella striata Rydb. comb. nov. Lychnis striata Rydb. Bu1l. Torrey Club. 3 I : fo8. 1904.

Wailbergella triflora (Vahl) Fries, Summa Veg. Scand, I 55. I $8+5$

Lychnis triflora R. Br. Ross. Voy. App. CXLII (hyponym). I8Io. Melandrium triflorum Vahl, in Liebm. Fl. Dan. I4 ${ }^{40}: 5$. I8+3.

Wahlbergella Taylorae (Robinson) Rydb. coml). nov. Lychnis Taylorae Robinson, Proc. Am. Acad. 28: 150. 189.3.

Whaliergella Afficis (Vahl) Fries, Bot. Not. I843: 1 $43.18+3$ Lychnis affris Vahl, in Fries, Nov. Mant. 3: 36. $18+2$. Melandrium affine Vahl, in Liehm. Fl. Dan. $4^{40}: 5.18+3$.

Wahlbergella montana (S. Wats.) Rydb. comb. nov. Lychnis montane S. Wats. Proc. An1. Acad. I 2: 247. I877. 
Rydberg: Studies on the Rocky Mountain flora 319

Wahlbergella Kingii (S. Wats.) Rydb. comb. nor. Lychnis Kingii S. Wats. Proc. Am. Acad. 12: 247. I877.

Wahlbergella attenuata (Farr) Rydb. comb. nor. Lychnis attenuata Farr, Contr. Bot. Lab. Univ. Pa. 2: +19. I904.

Wahlbergella Parryi (S. Wats.) Rydb. comb. nov. Lychnis Parryi S. Wats. Proc. Am. Acad. 12: 248. I877.

Whahliergella ipetala (L.) Fries, Summa Veg. Scand. I 55 . I 845 Lychnis apetala L. Sp. Pl. I: 437. $\mathbf{1 7 5 3 .}$

Melandryum apetalum Fenzl; in Ledeb. Fl. Ross. I : 326. I 842. Wahlbergella umiflora Fries, Bot. Not. I843: I 43 . I 843 .

\section{RANUNCULACEAE}

\section{Ranunculus rivularis sp. nor.}

Ranunculus repens S. Mats. Bot. King Exp. 9. I 87 I.

A perennial with a fascicle of fibrous roots; stem hirsute, producing long stolons sometimes over I m. long, rooting at the nodes and there producing plantlets; leaves ternate, $5^{-15} \mathrm{~cm}$. wide, divisions petiolate, ovate, usually truncate or subcordate at the base, 3-cleft and coarsely toothed; petals rounded-obovate, about $+\mathrm{mm}$. long, scarcely equalling the sepals; head of fruit globose; achenes glahrous, beaks about one third their length.

The type was determined as $R$. repens L. by Dr. Watson, but is not so closely related to that species as to $R$. Maconnii Britton. It was probably on account of the creeping and rooting habit that it was referred to the former. The small petals should at a glance have revealed the error, for in $R$. repens the petals are large and rounded, much exceeding the sepals. $R$. Macounii is occasionally decumbent but not rooting, and the outline of the leaflets or divisions is different and the beak about one half as long as the body of the achenes. My own specimens from Kimball, Nebraska, had stems orer I m. long. It grows on wet river banks.

Nevada: Huntington Valley, August I868, S. II'atson 27 (type, in herb. Columbia University).

Arizona: Clark Valley, August 1883, Rusby.

Nebraska: Kimball, August i 2, i 891, Rydberg 7.

TExAs. I sjt Tright 830 . 


\section{Thalictrum columbianum sp. nov.}

A plant resembling $T$. venulosum Trelease in habit; stem $3^{-5}$ $\mathrm{dm}$. high; leaves $2-+$ times ternate, petioled except the uppermost; leaflets rather crowded, thick, and veiny, $\mathrm{I}-2 \mathrm{~cm}$. long, cuneate to nearly orbicular, 3 -lobed and deeply toothed; inflorescence narrow ; achenes oblong- or ovate-lanceolate, somewhat flattened, 4-5 $\mathrm{mm}$. long, I.5-2 $\mathrm{mm}$. wide; veins strong, but not corky, and with broad and shallow grooves between.

The western specimens referred to T. venulosum by Dr. IV. Trelease belong to this species, which differs mainly in the structure of the achenes, these approaching those of $T$. megacarpum Torr.

Washington: Loomiston, August i897, Elmer 599 (type, in herb. N. Y. Bot. Garden); Yakima County, I892, Henderson 2376.

IDAнo: Pend d'Oreille River, I86I, Lyall; Lake Waha, July I 896, A. A. \& E. Gertrude Heller 3361; De Lamar, July 7, I892, Miss Mulford.

Oregon: i 886, Cusick I337.

\section{Delphinium Leonardi sp. nov.}

A perennial with a tuberous root; stem $2-5 \mathrm{dm}$. high, viscidpubescent, especially above; blades of the basal leaves $4^{-5} \mathrm{~cm}$. wide, dissected into oblong, obtuse divisions, more or less viscidpubescent; upper leaves with iinear, acute divisions; lower pedicels $4^{-8} \mathrm{~cm}$. long, ascending; sepals dark blue, oblong, obtuse or the upper acute; spur about $2 \mathrm{~cm}$. long, slightly $s$-curved; upper petals whitish, veined with blue, emarginate; lower petals blue, with short lobes; follicles over $2 \mathrm{~cm}$. long, curved, viscid-pubescent or in age glabrate; seeds dark brown, wing-margined.

It grows on river banks and beaches at an altitude of $1,800-$ $2,400 \mathrm{~m}$. It is related to $D$. bicolor Nutt. but differs in its longer spur, which is half longer than the obtuse instead of acute lateral sepals.

Utaн: Garfield, May 30, I884, Leonard 205 (type, in herb. N. Y. Bot. Garden); City Creek Canyon, April $2 \mathrm{I}$ and May I7, 1883, Leonard 32 and 27 .

\section{Delphinium coelestinum sp. nov.}

A perennial with a short rootstock and strong woody roots; stem $3^{-5} \mathrm{dm}$. high, glabrous or slightly pubescent above, leafy; leaves long-petioled; blades about $3 \mathrm{~cm}$. broad, sparingly pubescent, 
divided to the base into $3^{-5}$ narrowly cuneate divisions, these again cleft into linear-oblong, obtuse, mucronate lobes; sepals light blue, slightly pubescent outside, oblong, obtusish, about I cm. long; spur about I cm. long, usually somewhat curved; upper petals $8 \mathrm{~mm}$. long, yellowish white, slightly lobed; lower petals light blue, with obtusish, wary lobes; follicles 8-10 $\mathrm{mm}$. long, slightly puberulent, nearly straight.

This species is related to $D$. scuposum but differs in its more leafy stem and in the more deeply dissected basal leaves with narrower segments. It grows in arid places.

UTAH: Southern L'tah, i 877, Palmer II (type, in herb. Columbia University).

Arizona: i 876, Palmer 3 .

\section{Delphinium xylorrhizum sp. nov.}

A perennial with a stout woody root, related to $D$. scaposum but not at all scapiform; stem 2-3 dm. high, glabrous; leaves petioled, glabrous, fleshy; blades of the basal ones divided into $3^{-5}$ broadly cuneate divisions, these cleft and lobed with ovate or rounded lobes; stem leaves with linear-oblong lobes; sepals dark blue, oval, obtuse, pubescent outside; spur stout, about $15 \mathrm{~mm}$. long; upper petals yellowish, about $7 \mathrm{~mm}$. long, slightly cleft, with obtuse lobes; lower petals blue, with sinuate, obtuse lobes; follicles canescent-strigose.

This species differs from D. scaposum Greene in its leafy stem and its strigose follicles. It grows on clayey hillsides.

Montana: Lima, July I, I 895, Shear 3429 (type, in herb. N. Y. Bot. Garden).

\section{Delphinium Helleri sp. nov.}

A perennial with a short rootstock and fleshy roots; stem about $3 \mathrm{dm}$. high, viscid-pubescent throughout, few-leaved; leaf blades $3-5 \mathrm{~cm}$. broad; the lower dissected into linear, obtuse divisions, more or less viscid-pubescent; the upper with narrowly linear, acute divisions; flowers few; the lower pedicels $4^{-6} \mathrm{~cm}$. long, ascending; bractlets subulate, inserted some distance below the calyx; sepals dark blue, more or less pubescent, oval, about i5 $\mathrm{mm}$. long; spur $2-2.5 \mathrm{~cm}$. long, straight and attenuate; upper petals blue, tinged with yellow only on the lower edge, entire or slightly cleft, lower petals blue, with acute, crenate lobes; follicles viscid-pubescent, nearly straight, $2 \mathrm{~cm}$. long. 
This is related to $D$. bicolor, but the upper petals are dark blue and the spur is much longer.

IDAHO: Lewiston, April I896, A. A. E E. Gertrude Heller 295 I (type, in herb. Columbia University); region of Coeur d'Alene Mountains, June 24, I895, Leiberg I03I.

\section{Delphinium viscidum sp. nov.}

Perennial with a woody root; stem about $3 \mathrm{dm}$. high, grayish strigose below, densely glandular-viscid above; leaf blades $5^{-7}$ cm. broad, densely grayish strigose, dissected into narrowly linear lobes; inflorescence branched; sepals dark blue, $12-15 \mathrm{~mm}$. long, oblong, acute; spur IO-I2 $\mathrm{mm}$. long, somewhat $s$-curved; upper petals yellowish, tinged with blue, obtuse, entire; lower petals dark blue, with obtuse, sinuate lobes; follicles densely strigose.

This species is related to D. multiflorum and D. reticulatum, but the leaves are finely dissected as in D. Geyeri and D. scopulorum.

Wroming: Near Tie Siding, July 6, I896, Osterhout (type, in herb. N. Y. Bot. Garden); Evanston, August 1878, Harry Edwards.

\section{BRASSICACEAE}

\section{Lepidium hirsutum nom. nov.}

Lepidium intermedium v. pubescens Greene, Bot. Gaz. 6: I57. I880. Not L. pubescens Desv. I8I4.

Lepidium medium pubescens Robinson, Syn. Fl. I': 127. 1895. Lepidium virginicum subsp.texamum v. pubescens Thell. Mitt. Univ. Zürich 28: 230. 1906.

Physaria lanata (A. Nels.) Rydb. comb. nov. Physaria didymocarpa lanata A. Nels. Bull. Torrey Club 3I: $2+1$. 1904.

This, I think, deserves specific rank, but $P$. grandiflora Blankinship is nothing but the typical $P$. didymocarpa.

Radicula trachycarpa (A. Gray) Rydb. comb. nov. Nasturtium trachycarpum A. Cray, Bull. U. S. Geol. \& Geog. Surv. 2: 233.1876. 
Rydberg: Studies on the Rocky Mountain flora 32:3

Cheirinia Link, Enum. Hort. Berol. 2: 170. I822

The type of the genus Erysimum (Tourn.) L. is E. officinale L., usually known under the name Sisymbrium officinale Scop. If the genus which has usually passed under the name Erysimum is regarded as distinct from Cheiranthus, it must be known under another name. The oldest available name is Cheirinia, with Erysimum cheiranthoides as the type. As I regard the Rocky mountain species well distinct generically from the wallflower of Europe, I adopt Cheirinia as the name for the genus.

Cheirinia cheiraxthoides (L.) Link, Enum. Hort. Berol.

$$
\text { 2: } 170 . \quad 1822
$$

Erysimum cheiranthoides L. Sp. P1. 661. 1753.

Cheiranthus cheiranthoides Heller, Cat. N. Am. Pl. 4. 1898.

Cheirinia syrticola (Sheld.) Rydb. comb. nov.

Erysimum syrticolum Sheld. Bull. Torrey Club 20: 285. 1893.

Cheiranthus syrticola Greene, Pittonia 3: I 36. I 896.

Cheirinia inconspicua (S. Wats.) Rydb. comb. nov.

Erysimum parviflorum Nutt. in T. \& G. Fl. N. Am. I: 95. I838.

Not E. parviflorum Pers. I807.

Erysimum asperum inconspicuum S. Wats. Bot. King Exp. 24. 1871 .

Erysimum inconspicuum MacMillan, Metasp. Minn. Valley 268. I 892.

Cheiranthus inconspicuus Greene, Pittonia 3: 134. I896.

Cheirinia arida (A. Nels.) Rydb. comb. nov.

Cheiranthus aridus A. Nels. Bull. Torrey Chub 26: 35I. I 899.

Cheirinia aspera (Nutt.) Rydb. comb. nov.

Cheiranthus asper Nutt. Gen. N. Am. Pl. 2: 69. I8I8. Erysimum asperum DC. Syst. 2: 505. I82I.

Cheirinia elata (Nutt.) Rydb. comb. nov.

Erysimum elatum Nutt. in T. \& G. F1. N. Am. I: 95. 1838.

Cheiranthus elatus Greene, Pittonia 3: I35. I 896. 
324 Rydberg: Studies on the Rocky Mountain flora

Cheirinia asperrima (Greene) Rydb. comb. nov.

Cheiranthus asperrimus Greene, Pittonia 3: I33. 1896.

Cheirinia oblanceolata Rydb. comb. nov.

Erysimum oblanceolatum Rydb. Bull. Torrey Club 3 I : $557 . \quad$ I904.

Cheirinia Bakeri (Greene) Rydb. comb. nor.

Cheiranthus aridus Greene, Pittonia 4: 198. I900. Not C. aridus

A. Nels. I 899 .

Cheiranthus Bakeri Greene, Pittonia 4: 235. I90I.

Erysimum Bakeri Rydb. Bull. Torrey Club 33: I4I. I906.

Cheirinia argillosa (Greene) Rydb. comb. nov.

Cheiranthus argillosus Greene, Pittonia 3: I36. 1896.

Erysimum argillosum Rỵdb. Bull. Torrey Club 33: I4I. 1906.

Cheirinia nivalis (Greene) Rydb. comb. nov.

Cheiranthus nivalis Greene, Pittonia 3: I $37 . \quad$ I 896.

Erysimum nivale Rydb. Bull. Torrey Club 31: 558. I904.

Cheirinia radicata $\mathrm{Rydb}$. comb. nov.

Erysimum radicatum Rydb. Bull. Torrey Club 3 I: 558. I904.

Cheirinia Wheeleri (Rothr.) Rydb. comb. nov.

Erysimum Wheeleri Rothr. Rep. U. S. Geog. \& Geol. Surv. 6 : 64. 1878 .

Cheiranthus Wheeleri Greene, Pittonia 3: I 35. I 896.

Erysimum asperum alpestre Cockerell, Bull. Torrey Club I8: I68. I 891.

Erysimum alpestre Rydb. Bull. Torrey Club 28: 277. I90I.

Cheirinia amoena (Greene) Rydb. comb. nov.

Cheiranthus nivalis amoenus Greene, Pittonia 3: I37. 1896. Erysimum amoenum Ryddb. Bull. Torrey Club 33: I+3. 1906.

Cheirinia Pallasii (Pursh) Rydb. comb. nor:

Cheiranthus Pallasii Pursh, Fl. Am. Sept. 436. I8I4.

Cheiranthus pygmaens Adams, Mém. Soc. Nat. Mosc. 5: I44. I 817 . 
Rydberg: Studies on the Rocky Mountain flora 325

Hesperis pygmaeus Hook. Fl. Bor.-Am. I: 60. I830. Erysimum pygmaeum J. Gay, Erysim. Nov. 4. 1842.

\section{Cheirinia brachycarpa sp. nov.}

Biennial; stem 3-6 dm. high, from a taproot, grayish canescent, somewhat striate; leaves all linear-spatulate or oblanceolate, 5 io cm. long, sparingly canescent; the lower petioled and often minutely denticulate, the upper ones mostly entire; sepals oblong, about I cm. long, yellowish green; petals nearly $2 \mathrm{~cm}$. long; claw long and slender; blades rounded-obovate, about $7 \mathrm{~mm}$. wide, bright yellow; fruiting pedicels about $8 \mathrm{~mm}$. long, strongly ascending; pods erect, $4^{-6} \mathrm{~cm}$. long, $2.5 \mathrm{~mm}$. thick; beak about I $\mathrm{mm}$. long.

This species resembles $C$. oblanceolata, but the pod is much thicker and shorter and the flowers larger. It differs from $C$. aspera in its ascending, not divergent, and shorter pod. It grows on dry hillsides at an altitude of 2,500-3,000 $\mathrm{m}$.

UTAн: Abajo Mountains, August I7-20, I9I I, Rydberg $\varepsilon^{\circ}$ Garrett 9713 (type, in herb. N. Y. Bot. Garden, flowers and young fruit); 9765 (well-developed fruit); Cottonwood Canyon, June 27 and July I, I905, Rydberg \& Carlton 6333 and 6570 .

\section{Sophia leptostylis sp. nov.}

Annual; stem 3-6 dm. high, rather simple below, sparingly stellate-pubescent or glabrous; leaves $3^{-10} \mathrm{~cm}$. long, obovate in outline, twice pinnatifid, with oblong divisions, sparingly stellatepubescent; the uppermost reduced and with narrower lobes; flowers numerous; sepals elliptic, yellow, 1-1.5 mm. long; petals spatulate, a little surpassing the sepals; pedicels in fruit $5^{-8} \mathrm{~mm}$. long, spreading-ascending; pods about $5 \mathrm{~mm}$. long, tapering to each end, nearly erect, somewhat curved; styles $0.5^{-0.7} \mathrm{~mm}$. long; seeds more or less in two rows.

This resembles somewhat $S$. procera, especially in the form of the pods, but the inflorescence is more open and the pedicels more spreading. It grows at an altitude of 2,000-3,000 $\mathrm{m}$.

UtAн: Big Cottonwood Canyon, July +, I905, Rydberg \& Carlton 6629 (type, in herb. N. Y. Bot. Garden); also June 29, 6.198, and July 8, 6806; Big Cottonwood Canyon, June 1905, Gurrett 1361; near Milford, June 22, 1905 , Rydberg \& Carlton 6283; mountains north of Bullion Creek, near Marysvale, July 23, Rydberg \& 
Carlton 6283; Fish Lake, August 2, 1909, Garrett 2578; Elk Mountains, August 8, I9I I, Rydberg \& Garrett 9552; Head of Dry IVash, August II, I91 I, 9628; Mount Ellen, July 25, I894, M. E. Jones 568 fg; Logan Canyon, June 28, I910, C. P. Smith 2226.

\section{Arabis MacDougalii sp. nov.}

Perennial; stem 4-6 dm. high, simple below, densely stellatepubescent; basal leaves narrowly oblanceolate, $2-4 \mathrm{~cm}$. long, entire or denticulate, densely stellate-pubescent; stem leaves linear or linear-lanceolate, sagittate at the base; sepals oblong, stellate-pubescent; petals white, oblanceolate, 5-6 $\mathrm{mm}$. long; pedicels in fruit reflexed, $5^{-10} \mathrm{~mm}$. long; pods finely stellatepubescent, reflexed, $4^{-5} \mathrm{~cm}$. long, I.5 $\mathrm{mm}$. wide; seeds in one row.

This species is related to $A$. subpinnatifida but differs in its smaller white petals and its entire leaves.

Mostana: Old Sentinel, near Missoula, June 12, I90I, MacDougal 19I (type, in herb. N. Y. Bot. Garden).

Nevid.1: Fing Canyon, Ormsby County, June 4, I902, C.F. Baker 986 (referred here doubtfully).

\section{Arabis brevisiliqua sp. nov.}

Biennial; stems 3-4 dm. high, sparingly stellate-pubescent below, otherwise glabrous; basal leaves narrowly oblanceolate, I-2 cm. long, finely stellate-pubescent; stem leaves linear, sagittate at the base, glabrous; sepals scarious-margined, $3 \mathrm{~mm}$. long, glabrous or nearly so; petals purplish, about $6 \mathrm{~mm}$. long; pedicels in fruit $3-5 \mathrm{~mm}$. long, recurved pods $2-3 \mathrm{~cm}$. long, $2 \mathrm{~mm}$. wide, glabrous: seeds in two rows.

This species resembles $A$. lignifera $\mathrm{A}$. Nels., but the pod is much shorter, less than $3 \mathrm{~cm}$. long, with the seeds in two rows, and the sepals are glabrous instead of stellate-pubescent.

British Columbia: Skagit Valley, July 6, ig05, J. M. Macoun 70825 (type, in herb. N. Y. Bot. Garclen); near international loundary, between Kettle and Columbia rivers, July I6, 1902, J. M. Macoun $63+96$.

Alberta: Trail to Lake O'Hara, August 8, I904, John Macoun 64517 in part.

\section{Parrya platycarpa sp. nov.}

Parrya macrocarpa S. Wats. Bot. King Exp. I4. 1871. Not $P$. macrocarpa R. Br. I82I. 
Perennial with a stout candex; leaves basal, runcinate, more or less glandular-hirsutulous, thick, $6-8 \mathrm{~cm}$. long, oblanceolate in outline; scape I-I.5 dm. long, glandular-hirsutulous; sepals oblong, $8 \mathrm{~mm}$. long, saccate at the base; petals $15-18 \mathrm{~mm}$. long, purplish; claws long, exceeding the sepals; blades obovate; fruiting pedicels 8-15 $\mathrm{mm}$. long, ascending; pod erect, glandular-hispidulous, $3-+\mathrm{cm}$. long, 6-7 $\mathrm{mm}$. wide, acute at both ends, slightly constricted between the seeds, these broadly winged, $3^{-}+\mathrm{mm}$. wide.

This is characterized by its deeply lobed leaves, the hispidulous pubescence, the broad hispidulous pod, and the longer narrow petals with slender claws.

UTAH: Uintah Mountains, August i869, S. Watson $5+$ (type, in herb. Columbia ('niversity); also August I889 and Aug. II, I 890, M. E. Jones.

\section{Smelowskia lobata sp. nov.}

A densely cespitose perennial; earlier basal leaves cuneate or oblanceolate, merely lobed, with oblong divisions or even some of the earliest entire; the rest of the leaves pinnatifid, densely white stellate-floccose; stem I dm. high or less; sepals densely villous, $3 \mathrm{~mm}$. long, ovate, acute; petals white, clawed; blades rounded-olsovate; pod glabrous, about $5-6 \mathrm{~mm}$. long, oblanceslate, tapering at the hase; style very short.

This species has the pubescence of $S$. orata, but the pod is tapering at the base. It has whiter and longer pubescence than $S$. americana, and the pod is much shorter. It differs from both in the shape of the earlier leaves.

Aldzerta: Northern Rocky Mountains, Bourgeutu, Palliser Expedition (type, in herb. Columbia University).

Montaxa: Midvale, June 28 and July 9, 1903. Umbach 206 and .325 .

Machexzie: Richardson (Franklin's Journey).

Draba pectinata (S. Wats.) Rydb. comb. nov.

Draba glacialis pectinata S. Wats. Proc. Am. Acad. 23: 260. I888.

This has been confused with $D$. andina Nutt. and D. densiftora Nutt., but it is easily distinguished by the leaves. They are scarcely stellate-pubescent, merely strongly ciliate on the margins and with an incurved tip. In the other two species the leaves 
are densely stellate-pubescent and their tips not incurved but spreading. The pods of $D$. andina and $D$. pectinata are nearly the same, but that of $D$. densiflora is larger and more elongated.

Nelson, in the New Manual of the Central Rocky Mountain Region, cited Draba uber A. Nels., D. aureformis Rydb., and D. decumbens Rydh. as synonyms of $D$. luteola Greene. The species he described under that name is evidently D. aurea Vahl, of which $D$. uber apparently is a synonym. D. luteola and $D$. aureformis, on the contrary, are closely related to D. surculifera A. Nels. but have light yellow flowers. A "conservative" botanist would unite the three. D. decumbens Rydb. is not closely related to either. Very likely Professor Nelson had not seen a specimen of the last named.

Fortunately, Draba lapilutea A. Nels. and D. yellowstonensis A. Nels. become synonyms of $D$. praealta Greene. Draba deflexa Greene has erroneously become D. reflcxa in the New Manual.

New Jork Botanical Garden. 
CONTRIBUTIONS FROM THE NEW YORK BOTANICAL GARDEN - No. 156

\title{
STUDIES ON THE ROCKY MOUNTAIN FLORA-XXVIII
}

\author{
By PER AXEL RYDBERG
}

\author{
NEW YORK \\ 1913
}

Reprinted, without change of paging, from the Bulletin of THE TORkey Botanical Cieb 4n: 43-74. $18 \mathrm{Mr}, 1913$ 

Studies on the Rocky Mountain flora-XXVIII

\author{
PER Axel Rydierg \\ FABACEAE
}

Thermopsis ovata (Robinson) Rydb.

Thermopsis montana orata Robinson, Contr. U. S. Nat. Herb. I I : 349. I906.

This differs from T. montana not only in its broader leaflets (the only characters given in the original description) but in its spreading leaves, its large stipules, which in the lower leaves are ovate and very oblique, and in its elongate and lax raceme. It differs from $T$. xylorrhisa A. Nels. in its lax inflorescence and strictly straight pods.

Dr. S. Watson in publishing Lupinus Kingii described the plant as being perennial. This mistake of his led him as well as others astray, for he redescribed the same plant a few years later as an annual under the name L. Sileri. This fact has been called attention to several times and, among other places, in my Flora of Colorado. It is, therefore, surprising that the error should be repeated by Coulter and Nelson in the New Manual of Botany of the Central Rocky Mountains, where the description begins: "From a perennial rootstock, dwarf, cespitose," etc., characters which in no way apply to the type in the Gray Herbarium nor to the duplicates in the herbaria of Columbia L niversity and the United States National Museum. Furthermore, Coulter and 
Nelson give as a synonym under the same Lupinus aduncus Greene, which is the same as L. argenteus argophyllus, a plant of different habit.

The so-called Lupinus rivularis of the Columbia region and extending into Idaho should be known as L. cytisoides Agardh. Miss Alice Eastwood has seen the type of L. rivularis Dougl., which according to her belongs to an entirely different group from the plant called $L$. rizularis by Dr. Watson in his revision.

The following Lupines are to be added to the flora of the Rocky Mountains: Lupinus nootkatensis Donn has been collected in the Rockies of British Columbia and Alberta, L. plumosus Dougl. in Idaho and Utah, L. minimus Dougl. in Idaho and Alberta, L. lepidus Dougl. in Idaho, L. Cusickii S. Wats. in Idaho and Utah, and $L$. micensis Jones in Utah.

\section{Lupinus lupinus Rydb. sp. nov.}

Perennial with a woody caudex; stems $3-6$ dm. high, densely strigose-canescent, sparingly branched; leaves numerous; stipules subulate, about I $\mathrm{cm}$. long; petioles canescent, $5^{-8} \mathrm{~cm}$. long; leaflets $7-9$, oblanceolate, usually flat, 3-6 cm. long, appressedcanescent on both sides, less so above; peduncles about I $\mathrm{dm}$. long; raceme 5-10 $\mathrm{cm}$. long; bracts lanceolate, acute, 3-4 $\mathrm{mm}$. long, silvery-pubescent, early deciduous; calyx silvery-pubescent, saccate at the base; upper lip scarcely $3 \mathrm{~mm}$. long, the lower fully $5 \mathrm{~mm}$; corolla about I cm. long, dark blue or purple; banner orbicular, pubescent on the back, usually with a light spot in the center; keel strongly curved, rather broad, ciliate on the margins; pod densely villous, about $3 \mathrm{~cm}$. long, mostly 3 -seeded.

This is related to L. argentinus, L. aduncus, and L. oreophilus, but differs from the first in its grayish instead of silvery pubescence of the leaves, which are greener above and not conduplicate, and in its less spurred calyx; from L. aduncus in its broader leaves and the shorter upper lip of its calyx; and from L. oreophilus in its broader leaves and saccate calyx.

Along streams and in meadows at an altitude of 2,000-3,000 $\mathrm{m}$.

UTAн: W'estern Bear's Ear, Elk Mountains, Aug. 2, I9I I, Rydberg \& Garrett 9363 (type, in herb. N. Y. Bot. Gard.); also western slope of La Sal Mountains, July 6, 8595,8596 , and 8600; meadow south of Monticello, July 24, 9167; Head of Dry Wash, 
Abajo Mountains, August II, 9605; Hammond Canyon, Elk Mountains, August I0, 9583 .

Lotus texuts Waldst. \& Kit.; Milld. Enum. Hort. Berol. 797. I 809

Lotus tenuifolius (L.) Reich. Fl. Germ. 506. I 830. Lotus Macbridei A. Nels. Bot. Gaz. 53: 22 I. I9I2.

In looking over a collection received in exchange from the University of IIyoming, I found a specimen labeled Lotus Macbridei A. Nels. n. sp. To my surprise I found that this was a true Lotus, i. e. not belonging to any of the segregates of Hosackia but of the European type. As it would have been exceedingly strange if a species of Lotus in the restricted sense should be found native in America, I turned to our collection of Old World species of Lotus and found that it is the same as L. tenuifolius (L.) Reich. Before I had time to call Professor Nelson's attention to the fact, his description appeared in the Botanical Gazette.

Trifolium macrocephalum (Pursh) Piper, T. plumosum Dougl., T. eriocephalum Nutt., T. spinulosum Dougl., and cyathiferum Lindl. have been collected in Idaho; T. Rusbyi. Greene and ILedicago hispida Gaertner (M. denticulata Milld.) in Montana.

\section{Acuispox Raf. New Flora i: 53. I836}

I think that this genus should be restored. The Microlotus section sometimes referred to Hosackia, sometimes to Lotus, is out of place in either genus, and Acmispon is the oldest available generic name.

\section{Acmispon americanus (Nutt.) Rydb.}

Lotus sericeus Pursh, Fl. Anl. Sept. 489. I8I4. Not L. sericens DC. I 8 I3.

Trigonella americana Nutt. Gen. 2: I20. I8I8.

Hosackia Purshiana Benth. Bot. Reg. under pl. 1257. I 829.

Acmispon sericenm Raf. New Fl. I: 53. I 836.

Lotus americanus Bisch. Del. Sem. Hort. Heidelb. I 839.

Trigonella sericea Eat. \& Wright, N. Am. Bot. Ed. 8, 459. I8 fo. 


\section{Acmispon elatus (Nutt.) Rydb.}

Hosackia elata Nutt.; T. \& G. Fl. I: 327. I 838 .

The former of the two species is common on the plains from Minnesota to Arkansas, Sonora, and Idaho; the latter is found in Wrashington, Oregon, and Idaho. A few more species are found in California.

\section{Psoralea stenostachys Rydb. sp. nov.}

Perennial with a horizontal rootstock; stem adsurgent or erect, branched, sparingly strigose and glandular-dotted, 3-5 dm. high; leaves digitately 3 -foliolate; leaflets oblanceolate, $2-+\mathrm{cm}$. long, from rounded to acute at the base, mucronate at the apex, sparingly strigose and conspicuously glandular-punctate; peduncles 5-15 cm. long; racemes elongate, many-flowered and lax: calyx densely white-strigose; tube $1.5 \mathrm{~mm}$. long; teeth $0.5 \mathrm{~mm}$. long, lanceolate or lance-ovate, acute; corolla white, $+\mathrm{mm}$. long; pod densely white-hairy.

This species is related to P. lanceolata Pursh and P. Purshii Vail, but differs from both in the elongate racemes and the acute calyx-lobes; from the former it differs also in the hairy pod, and from the latter in the narrower leatlets. It grows on sandy soil at an altitude of about I,300-I,500 m.

Ut'AH: Government W'ell, Toole County, June 7 , I900, M. E. Jones 6221 (type, in herb. N. Y. Bot. Gard.); Utah. July 2, I 888. M. E. Jones 1833 .

\section{Psoralea stenophylla Rydb. sp. nov.}

Perennial with a horizontal rootstock; stem simple, about 5 dm. high, slender, sparingly strigose and glandular-punctate; leaves digitately 3 -foliolate or the lower 5 -foliolate; leaflets narrowly linear, $2.5-5 \mathrm{~cm}$. long, about $2 \mathrm{~mm}$. wide, glandular-punctate and sparingly strigose; stipules linear, $5^{-8} \mathrm{~mm}$. long; petioles about $3 \mathrm{~cm}$. long; peduncles 8 - Io $\mathrm{cm}$. long; racemes elongate, 5 $\mathrm{cm}$. long or longer, lax; pedicels usually longer than the calyx; calyx sparingly strigose, conspicuously punctate; lobes triangular, acute, $0.5 \mathrm{~mm}$. long; corolla about $+\mathrm{mm}$. long; fruit not seen.

This has the narrow leaflets of Psoralea micrantha, but the raceme is elongate and the sepals are acute as in the preceding species, from which it differs in the very narrow leaflets. If it has the densely hairy pod of that species and P. Purshii, it cannot be told from the material, but the young ovaries do not indicate 
such a character. It grows on sandy river banks at an altitude of about $\mathrm{i}, 600 \mathrm{~m}$.

UtAн: Proposed dam site, near Wilson Mesa, Grand County, July I, 1911, Rydberg \& Garrett 8367 (type, in herb. N. Y. Bot. Gard.).

Psoralea juncea Eastw. was described as being leafless, the leaves being reduced to scales. This is true as far as the stemleaves are concerned. The basal leaves, which soon wither away, are digitately $3-5$-foliolate with lanceolate leaflets, $2-3 \mathrm{~cm}$. long, grayish, strigose and strongly veiny.

Psoralea obtusilobn. Torrey has been collected in Colorado by Tweedy.

Parosela polydenia (Torr.) Heller, P. Fremontii (Torr.) Vai!, $P$. Johnsoni (S. Wats.) Vail, and P. amoena (S. Wats.) Vail have been collected in southern Utah.

Phaca ampullaria (S. Wats.) Rydb. Astragalus ampullarius S. Wats. Am. Nat. 7: 300. I873.

Phaca Wardii (A. Gray) Rydb. Astragalus Irardii A. Gray, Proc. Am. Acad. I2: 55. 1877.

Phaca subcinerea (A. Gray) Rydb. Astragalus subcinereus A. Gray, Proc. Am. Acad. 13: 366. I878.

Phaca Cusickii (A. Gray) Rydb. Astragalus Cusickii A. Gray, Proc. Am. Acad. I3: $370 . \quad 1878$.

Phaca sabulonum (A. Gray) Rydb. Astragalus sabulonum A. Gray, Proc. Am. Acad. I3: 368. I878.

Phaca Preussii (A. Gray) Rydb. Astragalus Preussii A. Gray, Proc. Am. Acad. 6: 222. I864.

Phaca serpens (M. E. Jones) Rydb. Astragalus serpens M. E. Jones, Proc. Cal. Acad. II. 5: 6+1I. I 895.

Phaca Silerana (M. E. Jones) Rydb. Astragalus Sileranus M. E. Jones, Zoe 2: 242. 1891 . 
Phaca jejuna (S. Wats.) Rydb. Astragalus jejunus S. Wats. Bot. King Exped. 73. I87I.

Phaca leptalea (A. Gray) Rydb. Phaca pauciflora Nutt.; T. \& G. F1. N. Am. I: 348, I838. Not $P$. panciflora Pers. $\mathrm{I} 806$. Astragalus leptaleus A. Gray, Proc. Am. Acad. 6: 220. I864.

Phaca artemisiarum (M. E. Jones) Rydb. Astragalus Beckwithii purpureus M. E. Jones, Zoe 3: 288. I893. Not A. purpureus Lam. 1783 . Astragalus artemisiarum M. E. Jones, Zoe 4: 369. I 894.

Phaca pubentissima (T. \& G.) Rydb. Astragalus multicaulis Nutt.; T. \& G. Fl. N. Am. I: 335.1838. Not A. multicaulis Ledeb. I83I. Astragalus pubentissimus T. \& G. Fl. N. Am. I: 693. I840.

Mr. Sheldon placed this between Astragalus crescenticarpus and A. cibarius, two species of Xylophacos; its pod is that of a Phaca.

Phaca sesquiflora (S. Wats.) Rỹdb. Astragalus sesquiflorus S. Wats. Proc. Am. Acad. 10: $346 . \quad 1875$.

Mr. Sheldon associated this erroneously with Astragalus vexilliflexus and other species of Homalobus. It is a true Phaca.

\section{Xylophacos cuspidocarpus (Sheld.) Rydb.}

A stragalus cuspidocarpus Sheld. Minn. Bot. Stud. I: I47. I894.

Xylophacos cibarius (Sheld.) Rydb.

Astragalus cibarius Sheld. Minn. Bot. Stud. I: I49. I894. Astragalus arietinus M. E. Jones, Proc. Calif. Acad. II. 5: 653. I 895 .

Xylophacos puniceus (Osterh.) Rydb. Astragalus puniceus Osterh. Muhlenbergia I: I 40.1906.

Xylophacos Zionis (M. E. Jones) Rydb. Astragalus Zionis M. E. Jones, Proc. Calif. Acad. II. 5: 652. I895. 
Xylophacos argophyllus (Nutt.) Rydb. Astragalus argophyllus Nutt.; T. \& G. F1. N. Am. I: 33 I. I838. Xylophacos cymboides (M. E. Jones) Rydb. Astragalus cymboides M. E. Jones, Proc. Calif. Acad. II. 5: 650 . I 895 .

Xylophacos musinensis (M. E. Jones) Rydb. Astragalus musinensis M. E. Jones, Proc. Calif. Acad. II. 5: 67 I. I 895 .

Xylophacos consectus (Sheld.) Rydb. Astragalus consectus Sheld. Minn. Bot. Stud. I: I $43 . \quad 1894$.

Xylophacos Watsonianus (Kuntze) Rydb. Astragalus eriocarpus S. Wats. Bot. King Exped.7 I. I87I. Not A. eriocarpus DC. 1802 .

Tragacantha Watsoniana Kuntze, Rev. Gen. Pl. 2: 942. I89I. Astragalus Watsonianus Sheld. Minn. Bot. Stud. I: It4. I894.

Xylophacos utahensis (Torr.) Rydb.

Phaca mollissima utahensis Torr. Stansb. Exped. 385. 1852. Astragalus utahensis T. \& G. Pac. R. Rep. 2: I20. 1855.

Xylophacos inflexus (Dougl.) Rydb. Astragalus inflexus Dougl. in G. Don, Gen. Syst. 2: $256 . \quad$ I832.

Tium eremiticum (Sheld.) Rydb. Astragalus eremiticus Sheld. Minn. Bot. Stud. I: I6I. I894.

Tium atropubescens (Coult. \& Fish.) Rydb. Astragalus atropubescens Coult. \& Fish. Bot. Gaz. I8: 300. I893. Astragalus Kelseyi Rydb. Mem. N. Y. Bot. Gard. I: 24r. 1900.

Tium arrectum (A. Gray.) Rydb.

Astragalus arrectus A. Gray, Proc. Am. Acad. 8: 289. I 873. Astragalus Leibergii M. E. Jones, Proc. Calif. Acad. II. 5: 663. I 895. Astragalns palousiensis Piper, Bot. Gaz. 22: 489. 1896. 
Hamosa calycosa (Torr.) Rydb. A stragalus calycosus Torr. in S. Wats. Bot. King Exped. 66. I87 I .

Ctenophyllum Grayi (Parry) Rydb. Astragalus Grayi Parry; Wats. Am. Nat. 8: 2 I2. I874.

Cystium platytropis (A. Gray) Rydb. Astragalus platytropis A. Gray, Proc. Am. Acad. 6: 526.1865.

Cystium Coulteri (Benth.) Rydb. Astragalus Coulteri Benth. Pl. Hartw. 307. I 848.

Cystium ineptum (A. Gray) Rydb. Astragalus ineptus A. Gray, Proc. Am. Acad. 6: 525. 1865.

Cystium lentiginosum (Dougl.) Rydb. Astragalus lentiginosus Dougl.; Hook. Fl. Bor.-Am. I: I5I. I83I.

Cystium araneosum (Sheld.) Rydb. A stragalus araneosus Sheld. Minn. Bot. Stud. I: I70. I 894.

Cystium boiseanum (A. Nels.) Rydb. Astragalus boiseanus A. Nels. Bot. Gaz. 53: 223. I9I2.

Atelophragma lineare Rydb. sp. nov.

IIomalobus aboriginum Rydb. Bull. N. Y. Bot. Gard. 2: 176, in part. 190I.

Perennial with a woody taproot and short cespitose caudex; stem grayish strigose, often tinged with purple, $2-+\mathrm{dm}$. high; stipules ovate or lanceolate, acute, $2-4 \mathrm{~mm}$. long; leaves $5-6 \mathrm{~cm}$. long; leaflets $9-\mathbf{I} 5$, linear, $\mathrm{I}-2 \mathrm{~cm}$. long, $\mathrm{I}-2 \mathrm{~mm}$. wide, gravish strigose; peduncles $5-10 \mathrm{~cm}$. long; raceme $2-3 \mathrm{~cm}$. long, in fruit $6 \mathrm{~cm}$. long; calyx densely black-hairy; tube $3 \mathrm{~mm}$. long; teeth subulate, $2 \mathrm{~mm}$. long; corolla about $8 \mathrm{~mm}$. long, ochroleucous or tinged with purple; keel tipped with dark purple; legume glabrous, stipitate; stipe $4^{-5} \mathrm{~mm}$. long; body $25-28 \mathrm{~mm}$. long, convexly curved on both sutures, but much more strongly so on the upper; the partial partition very narrow.

This is related to $A$. glabriusculum (A. Gray) Rydb. and $A$. aboriginum (Richardson) Rydb., but differs from the former in the 
grayish pubescence of the leaves, which are strigose instead of villous, and from both in the form of the pord. In both the lower suture of the pod is straight or slightly concavely curved.

Yukon Territory: Foot of Lake Lebarge, i 899, J. B. Turleton 346 (type, in herb. N. Y. Bot. Gard.); Dry Gulch, I899. Gorman IOI 4 .

Alberta: Rocky Mountains, i 857-1859, Bourgeau.

Atelophragma Forwoodii (S. Wats.) Rydb. Astragalus Forwoodii S. Wats. Proc. Am. Acad. 25: 129. 1890.

Sheldon places this species in the IIomalobus, but it is closely related to Atelophragma aboriginum and A. glabriusculum.

Atelophragma glabriusculum (Hook.) Rydb. Phaca glabriuscula Hook. Fl. Bor.-Am. I: 144. 1831 .

Atelophragma ibapense (M. E. Jones) Rydb. Astragalus ibapense M. E. Jones, Zoe 3: 290. 1893.

Atelophragma Arthuri (M. E. Jones) Rydb. Astragalus Arthuri M. E. Jones, Cont. West. Bot. 8: 20. 1898.

Onix Mulfordae (M. E. Jones) Rydb. Astragalus Mulfordae M. E. Jones, Cont. West. Bot. 8: i8. I898. This species is the only representative in America of a group of plants segregated from Astragalus by Medicus. The other representatives are Asiatic. Onix is related to Cystium in having a membranous inflated 2 -celled pod, but the pod is triangular in cross-section, the upper suture being acute and the lower more or less sulcate.

Microphacos parviflorus (Pursh) Rydb.

Dalea parviflora Pursh, Fl. Am. Sept. 47t. I8It. Astragalus gracilis Nutt. Gen. 2: 100. I8I8. Phaca parviflora Nutt.; T. \& G. Fl. N. Am. I: 348. I838.

Diholcos scobinatulus (Sheld.) Rydb. Astragalus Haydenianus major M. E. Jones, Zoe 2: 2+I. I89I. Astragalus Haydenianus neradensis M. E. Jones, Zoe 2: $2+\mathrm{I}$. I 89 I. Astragalus scobinatulus Sheld. Minn. Bot. Stud. I: 24. I894. 
Phacopsis scaphoides (M. E. Jones) Rydl). Astragalus arrectus scaphoides M. E. Jones, Proc. Calif. Acad. II. 5: 664. I 895 .

Cnemidophacos confertiflorus (A. Gray) Rydb. Astragalus confertiflorus A. Gray, Proc. Am. Acad. I3: $368 . \quad$ I 878.

Cnemidophacos argillosus (M. E. Jones) Rydb. Astragalus argillosus M. E. Jones, Zoe 2: 24I. I89I.

Cnemidophacos reventoides (M. E. Jones) Rydb. Astragalus reventoides Jones, Proc. Calif. Acad. II. 5: 66I. I 895.

Cnemidophacos reventus (A. Gray) Rydb. Astragalus reventus A. Gray, Proc. Am. Acad. 15: 46. I 880.

Kentrophyta tegetaria (S. Wats.) Rydb. Astragalus tegetarius S. Wats. Bot. King Exped. 76. 187 I.

Homalobus lingulatus (Sheld.) Rydb. Astragalus lingulatus Sheld. Minn. Bot. Stud. I: II $8 . \quad$ I 894.

Homalobus exilifolius (A. Nels.) Rydb. Astragalus exilifolius A. Nels. Bull. Torrey Club 26: Io. 1899.

Homalobus simplicifolius (Nutt.) Rydb. Phaca simplicifolia Nutt.; T. \& G. Fl. N. Am. I: $350 . \quad 1838$. Astragalus simplicifolius A. Gray, Proc. Am. Acad. 6: 23I. I864.

Homalobus lancearius (A. Gray) Rydb. Astragalus lancearius A. Gray, Proc. Am. Acad. I3: 370. I878.

Homalobus miser (Dougl.) Rydb. Astragalus miser Dougl.; Hook. Fl. Bor.-Am. I: I53. I83I.

Homalobus Dodgeanus (M. E. Jones) Rydb. Astragalus Dodgeanus M. E. Jones, Zoe 3: 289. 1893.

Mr. Sheldon placed this next to Astragalus glabriusculus (Hook.) Gray, but its pod has not a trace of a partition and the plant is a true Homalobus, not an Atelophragma. 
Homalobus debilis (Nutt.) Rydb.

Phaca debilis Nutt.; T. \& G. F1. N. Am. I: 345. I838.

Astragalus debilis A. Gray, Proc. Acad. Sci. Phila. I863: 60. I864.

Homalobus strigosus (Coult. \& Fish.) Rydb.

Astragalus strigosus Coult. \& Fish. Bot. Gaz. I8: 299. I893.

Astragalus griseopubescens Sheld. Minn. Bot. Stud. I: 24. I894.

\section{Homalobus episcopus (S. Wats.) Rydb.}

Astragalus episcopus S. Wats. Proc. Am. Acad. Io: 346.1875.

Homalobus collinus (Dougl.) Rydb.

Phaca collina Dougl.; Hook. Fl. Bor.-Am. I: IfI. I83 I.

Astragalus collina Dougl.; G. Don, Gen. Syst. 2: $256 . \quad$ I832.

Aragallus Bigelovii (A. Gray) Rydb.

Oxytropis Lambertii ${ }_{L}$ Torr. Pac. R. Rep. 4: 80. 1857. Not O. Lambertii Pursh. I8If.

Oxytropis Lambertii Bigelorii A. Gray, Proc. Am. Acad. 20: 7 . I 885 .

\section{Aragallus plattensis (Nutt.) Rydb.}

Oxytropis plattensis Nutt.; T. \& G. F1. N. Am. I: 340. I838.

Lathyrus graminifolius White and L. Torreyi A. Gray have been collected in southern Utah; L. Nuttallii S. Wats. and L. oboratus White in Idaho.

\section{EUPHORBIACEAE}

Chamaesyce Parryi (Engelm.) Rydb.

Euphorbia Parryi Engelm. Anı. Nat. 9: 350. 1875.

This has been collected in southern Utah.

Chamaesyce exstipulata (Engelm.) Rydb.

Euphorbia exstipulata Engelm. Bot. Mex. Bound. Surr. I89. 1859. Euphorbia Aliceae A. Nels. Bot. Gaz. 42: 50. 1906.

This has been collected as far north as Myoming. 


\section{ACERACEAE}

Negundo (Ray) Ludwig-Boehmer, Def. Pl. 508. i 760

Professor Nieuwland in the American Midland Naturalist* discussed the North American species of box-elder. He used the name Rulac, believing in a pre-Linnaean priority for genera. As both the Vienna Rules and the American Code have adopted 1753 as the starting point for bctanical nomenclature, few will follow him in the names adopted. If our box-elders are regarded as generically distinct from the maples, we must use the name Negundo. Professor Nieuwland recognizes six species. I think there should be recognized eight species in North America. The Texan form, Rulac californica texana Pax, is well distinct from Negundo californicum, Professor Nieuwland having overlooked the difference in the fruit, which in the Texan species agrees more with our eastern box-elder and was included in it by Dr. Britton. The following key was prepared by me over two years ago and two new species were named in manuscript. One of these has been described by Professor Nieuwland under the name Rulac Nuttallii; a description of the other is given below. I publish here the key, as several of the characters have not been pointed out by Professor Nieuwland.

Branches of the season glabrous or with a few scattered appressed hais; anthers acute, tapering into a tip $1 / 4^{-1 / 3}$ $\mathrm{mm}$. long, formed by the produced connective (in the first species unknown).

Fruiting pedicels glabrous, the lower $5^{-8} \mathrm{~cm}$. long, very slender: fruit glabrous, contracted below into a short stipe.

I. N. orizabense.

Fruiting pedicels sparingly pilose: the lower $2-3 \mathrm{~cm}$. long. Ovary and fruit finely pubescent; the latter sometimes becoming glabrate in age, distinctly constricted below into a narrow stipe-like base; leatlets broad, toothed, rarely lobed.

Ovary and fruit glabrous; the latter slightly or usually not at all constricted below; leaflets usua!ly lobed, with hair-tufts in the axils of the veins.

2. N. Negundo.

3. N. Nullallii.

Branches of the season densely velutinous with short spreading hairs; anthers obtuse, merely mucronate.

Leaflets coarsely dentate or lobed; style evident but short.

Fruit distinctly constricted at the base into a short stipe, densely and minutely pubescent; leaflets

* Vol. 2: 129-I40. I9II. 
broadly oval, short-acuminate, usually merely dentatc; the lateral ones of ten oblique at the hase.

Fruit not at all or slightly constricted at the base; leaflets lanceolate, orate or obovate, or the terminal one rhombic, long-acuminate, usually more or less lobed.

Fruit glabrous or with a few scattered harrs, similar to those of the pedicels; mucro of the anthers minute or obsolete; leaflets glabrate above in age.

Racemes seldom more than I dm. long; wings scarcely at all decurrent on the body of the fruit.

5. N. interius.

Racemes in fruit $\mathrm{I} \cdot 5^{-2} \mathrm{dm}$. long; wings decurrent on the body of the fruit almost to the bottom of the sinus.

6. N. Kingii.

Fruit densely puberulent; mucro of the anthers more distinct, nearly ${ }^{1}+\mathrm{mm}$. long; leaflets densely pubescent on both sides.

Leaflets sharply and evenly serrate except towards the base; style obsolete.

7. N. californicum.

8. N. mexicanum.

I. Negundo orizabense Rydb. sp. nov.

A tree with glabrous, brownish twigs: leaves 3 -foliolate; pedicels slender, glabrous, 5-10 $\mathrm{cm}$. long; leaflets thin, glabrous or with a few scattered hairs on the ribs below, acuminate at both ends, serrate above the middle, with broadly ovate teeth directed forward and mucronate; the terminal leaflet rhombic-oval, 5-Io cm. long, with petiolules $\mathrm{I}-2 \mathrm{~cm}$. long; the lateral ones lanceolate, oval or oblanceolate, short-petioluled; racemes in fruit $2 \mathrm{dm}$. long or more, the pedicels very long and slender, the lower $5^{-8} \mathrm{~cm}$. long; samaras ascending, glabrous; body oblong, about I $\mathrm{cm}$. long and $4 \mathrm{~mm}$. wide, acute but not constricted at the base, with one strong and several weak longitudinal veins; wing about $2 \mathrm{~cm}$. long and nearly I cm. wide, somewhat incurved above, not decurrent on the body.

Mexico: Orizaba, I853 and I855, Fred. Tiiller (type, in herb. Columbia University).

2. Negundo Negundo (L.) Karsten, Deuts. Fl. 596. I $880-3^{*}$ Distribution: From Ontario and Vermont to Georgia, Missouri and Illinois.

3. Negundo Nuttallii (Nieuwl.) Rydb. Acer fraxinifolium Nuttall, Gen. N. Am. I: 253. I8I8. Not Negundium fraxinifolium Raf. I808.

* For other synonyms sec Nieuwland, American Midland Naturalist 2: I36. I9I I. 
Rulac Nuttallii Nieuwl. Am. Midl. Nat. 2: I37. I9I.

Distributiox: From Michigan and Ohio (?) to Kansas, Colorado and Montana.

4. Negundo texanum (Pax) Rydb.

Acer Negundo texanum Pax; Bot. Jahrb. 7: 2I2. 1886.

Acer californicum texanum Pax; Bot. Jahrb. II: 75. I889.

Rulac texana Small, Fl. SE. U. S. 743. 1903.

Distribution: Texas and Oklahoma.

5. Negundo interius (Britton) Rydb.

Rulac texana Small, Fl. SE. U. S. 743, in part. I903. Not Acer texanum Pax. I886.

Acer interior Britton, N. Am. Trees 655. 1908.

Distribution: From Saskatchewan and Manitoba to Nebraska, New Mexico, Arizona and Montana. Nieuwland gives Negundo Fraxinus Bourgeau* as a synonym under this. At the place referred to Bourgeau enumerates a number of genera collected on May 6. Evidently a comma is omitted between Negundo and Fraxinus.

6. Negundo Kingii (Britton) Rydb.

Acer Kingii Britton, N. Am. Trees 656. I 908.

Rulac Kingii Nieuwl. Am. Midl. Nat. 2: I39. I9I.

Distribution: L'tah and Arizona.

7. Negundo Californicum T. \&. G. Fl. N. Am. I: $250 . \quad 1838$ Acer californicum Dietr. Syn. 2: I283. I840.

Rulac californica Nieuwl. Am. Midl. Nat. 2: I39. I9I I.

Distribution: California and according to Nieuwland extending into northern Mexico.

8. Negundo mexicanum DC. Prod. I: 546. I824 Acer mexicanum Pax; Bot. Jahrb. 7: 212. I886. Not Acer mexicanum A. Gray. I86I.

Rulac mexicana Nieuw1. Am. Midl. Nat. 2: 140. I9II.

Distribution: Southern Mexico to Guatemala.

* Journ. Linn. Soc. 4: 9. I859. 


\section{RHAMNACEAE}

Rhamnus betulacfolia Greene is to be added to the flora; it was collected in southeastern Utah in the summer of I9I I by Professor Garrett and myself.

\section{MALVACEAE}

Dr. Greene* in segregating Eremalche from Malvastrum made this statement: "and that there exists so much as one real IIalvastrum north of the Mexican border, I hold to be doubtful."

A little investigation in the history of the genus would show that this statement is untenable. It is evident that Dr. Gray did not base his conception of the genus Malvastrum on the section Malvastrum of Malva of De Candolle, for this section contains the typical species of Malia also.

The first subsection of this section of De Candolle's is Chrysanthae, and some species of this subsection must be regarded as the type of Malva section Malvastrum DC. Of this subsection Dr. Gray remarked: "If the yellow flowered species with a somewhat different habit and usually a manifest persistent involucre, which forms a second section (the Chrysanthae DC., etc.), are correctly referred to this genus, it will comprise a large number of species from tropical and South America, which need an elaborate revision. I enumerate below merely the North American species which are known to me." Furthermore, Dr. Gray did not include in his genus a single species of Malz'a given by De Candolle. This shows that Dr. Gray based his genus on the North American species and in publishing the genus he gave the name as "MALVAstrum Nor. Gen.," without citing De Candolle's section, although he had referred to it a few pages before in a footnote under Callirrhoe. As the type of the genus Malzastrum, therefore, we must desigate the first given binomial under Malzastrum, which is M. coccineum. Of the other species included in the original publication M. Fremontii Torr., M. Wrightii A. Gray, M. grossulariaefolium (Hook.) A. Gray, M. angustum A. Gray, M. Munroanum (Dougl.) Gray, and M. spicatum (L.) Gray are plants of the United States. I agree with Dr. Greene that $M$. rotundifolium A. Gray and M. exile A. Gray should not be included in Malias-

\footnotetext{
* Leaflets I: 207 . I906.
} 
trum; but I believe that that genus should be merged in Sphaeralcea. Malvastrum coccineum, the type of the genus, has the habit of the typical species of Sphaeralcea. The fruit is also the same except that the empty non-reticulate portion of the carpel is much reduced. M. grossulariaefolium and M. Munroanum with little more developed upper portions have been tossed back and forth between the genera Malvastrum and Sphaeralcea. Six species should be transferred from Malvastrum to Splaaeralcea under the following names.

Sphaeralcea grossulariaefolia (H. \& A.) Rydb.

(?) Malva Creeana Graham, Bot. Mag. pl. $3698 . \quad$ I 838.

Sida grossulariaefolia Hook. \& Arn. Bot. Beech. Voy. 326. I8+1. Malrastrum grossulariaefolium A. Gray, Mem. Am. Acad. 4: 2 I. I $8+9$.

Sphaeralcea pedata Torr. Mem. Am. Acad. 4: 23. I849.

Malvastrum coccineum grossulariaefolium Torr. Stansb. Exped. 384. I 852 .

Sphaeralcea dissecta (Nutt.) Rydb.

Sida dissecta Nutt.; T. \& G. Fl. N. Am. I : 235. 1838.

Malvastrum coccineum dissectum A. Gray, Pl. Wright. I: 17, in part. I 852 .

Sphaeralcea coccinea (Nutt.) Rydb.

Malva coccinea Nutt. Fras. Cat. I8I3.

Cristaria coccinea Pursh, Fl. Am. Sept. 45t. 18 I 4.

Sida coccinea DC. Prod. I: 465. I824.

Malrastrum coccineum A. Gray, Mem. Am. Acad. 4:2I. I849.

Sphaeralcea elata (E. G. Baker) Rydb.

Malvastrum coccineum elatum E. G. Baker, Jour. Bot. 29: I7I. I 89 I.

Malrastrum elatum A. Nels. Bot. Gaz. 34: 25. 1902.

Sphaeralcea digitata (Greene) Rydb.

Malvastrum cocineum dissectum A. Gray, Pl. Wright. I: I7, in part. $\quad$ I 852 .

Sphaeralcea pedata angustiloba A. Gray, Proc. Am. Acad. 22: 292. I 887. 
Maliastrum digitatum Greene, Leaflets I: I54. 1905. Malvastrum dissectum Cockerell, Bull. Torrey Club 27: 87, mainly. I 900.

Malvastrum Cockerellii A. Nels. Bot. Gaz. 34: 24. I902. Malvastrum dissectum Cockerellii A. Nels.; Coult. \& Nels. New Man. Bot. Cent. Rocky Mts. 3I8. I909.

Sphaeralcea leptophylla (A. Gray) Rydb. Malvastrum leptophyllum A. Gray, Pl. Wright. I: I7. 1852.

Sphaeralcea arizonica Heller, sp. nov.

Perennial with a woody caudex branching from the base; leaf blades reniform to cordate, 3-5 $\mathrm{cm}$. long, densely stel late on both sides, obscurely lobed and crenate; inflorescence paniculate, dense, with short branches; calyx densely stellate throughout; its lobes ovate, acute, about $3 \mathrm{~mm}$. long; petals pink, about I cm. long; carpels about $+\mathrm{mm}$. long and $\mathrm{I} .5 \mathrm{~mm}$. wide, mucronate or shortcuspidate, oblong, only about the lowest fourth reticulate.

Differing from $S$. ambigua in the short calyx-lobes and the narrow and dense inflorescence and from S. marginata in the dense stellate pubescence, which extends even to the calyx.

Ari $\_$onA: Flagstaff, June I6, I 898, MacDougal I20 (type, in herb. N. Y. Bot. Gard.); 30 miles east of Flagstaff, July I8, I893. Wooton; Fort Verde, May 4, I 888, Mearns 225; same locality I 887, I5o; Holbrook, June I8, I90I, L. F. Ward; Ash Fork, June Io, I883, Rusby 538 .

Utah: St. George, Apr. I4, I880, M. E. Jones I66o; proposed dam site, near Wilson Mesa, Grand Co., July I, I9II, Rydberg \& Garrett 8386; S. Utah, 1877, Palmer; 1874, Parry 25.

Sphaeralcea subrhomboidea Rydb. sp. nov.

Perennial with a woody caudex, branched at the base; stems stellate, 2-4 dm. high; leaf-blades rhombic in outline, $2-5 \mathrm{~cm}$. long, stellate but not densely so, grayish-green, cuneate at the base, 5-ribbed, 3-cleft about half way down, the divisions 2-4lobed; inflorescence a dense virgate panicle; calyx densely stellate, 4-5 $\mathrm{mm}$. long; lobes broadly ovate, obtusish; corolla scarlet, 8-9 $\mathrm{mm}$. long; fruit depressed-globose; carpels nearly round, obtuse, the lower half reticulate on the faces; seed solitary, without filiform attachment. 
Nearest related to $S$. grossulariaefolia but the leaf-blades are rhombic in outline and cleft only half way down, and the terminal lobe is decidedly acute. On account of the leaf-form it may be mistaken for S. Munroana, but the flowers are smaller, the leares more deeply divided, the fruit is smaller, the carpels less reniform, and the seed without filiform attachment.

UtAH: Wahsatch County, near Midway, July 6, I905, Carlton $\mathbb{E}^{\circ}$ Garrett 6691 (type, in herb.'N. Y. Bot. Gard.); Fish Lake, around Twin Creeks, Aug. 8, I905, Rydberg \& Carlton 7627.

There is a group of plants in Sphaeralcea, however, which differs from the rest not only in habit but also in the character of the fruit. The carpels are not, as in the typical Sphaeralcea, divided into a lower portion, reticulate on the faces and enclosing the seeds, and an upper smooth and empty portion; the whole carpel is in this group smooth and hirsute. Dr. Greene* took out this group and made a new genus under the name of Illiamna. I think that this was unnecessary, for the plants are evidently cogeneric with the West Indian Phymosia, usually also merged in Sphaeralcea. If the two genera should be merged, the name for the genus would be Phymosia, for it is the older of the two. The species to be renamed under Phymosia are the following:

Phymosia acerifolia (Nutt.) Rydb.

Sphaeralcea acerifolia Nutt.; T. \& G. F1. N. Am. I: 228. I838. Illiamna acerifolia Greene, Leaflets I: 206. I906.

Phymosia rivularis (Dougl.) Rydb.

Malva rivularis Dougl.; Hook. F1. Bor.-Am. I: I07. I831. Sphacralcea rivularis Torr. in Gray, Mem. Am. Acad. 4: 23. I 849. Illiamna rimlaris Greene, Leaflets I: 206. I906.

Phymosia grandiflora Rydb.

Sphaeralcea grandiflora Rydb. Buil. Torrey Club 31: 565. I904. Illiamna angulata Greene. Leaflets I: 206. 1906.

Phymosia Crandallii Rydb.

Sphaeralcea Crandallii Rydb. Bull. Torrey Club 31: 564. I904. * Leaflets I: 205-207. I 906 . 
Phymosia longisepala (Torr.) Rydl.

Sphaeralcea longisepala Torr. Bot. Wilkes Exped. 255. I874.

\section{LOASACEAE}

Nuttallia* humilis (A. Gray) Rydb.

Mentzelia multiflora humilis A. Gray, Pl. Wright I: 74. I852.

Touterea humilis Rydb. Bull. Torrey Club 30: 277. 1903.

Nuttallia integra (M. E. Jones) RĨdb.

Mentzelia multiflora integra M. E. Jones, Proc. Calif. Acad. II. 5: 689. I 895 .

Touterea integra Rydb. FI. Colo. 235. 1906.

Nuttallia Rusbyi (Wooton) Rydb.

Mentzelia Rusbyi Wooton, Bull. Torrey Club 25: 26I. I 898.

Touterea Rusbyi Rydb. Bull. Torrey Club 30: 276. 1903.

Nuttallia lobata Rydb. sp. nov.

Perennial with a thick root; stems strict, glabrous or nearly so, white and shining, $3^{-}+\mathrm{dm}$. high: leaves $5^{-8} \mathrm{~cm}$. long, $5^{-8} \mathrm{~mm}$. wide, narrowly oblanceolate, sinuately toothed or lobed with short triangular lobes: sepals lanceolate, acuminate, 8- $10 \mathrm{~mm}$. long; flowers diurnal, subtended by narrowly linear bracts; petals golden yellow, spatulate, obtuse, I2-I $8 \mathrm{~mm}$. long; petaloid staminodia similar and almost as large; filaments numerous, the outer dilated; capsule $5 \mathrm{~mm}$. long, $8-9 \mathrm{~mm}$. thick, acute, almost turbinate at the base; seeds suborbicular, broadly winged.

This species is related to $N$. multiflora (Nutt.) Greene and $N$. pterosperma (Eastwood) Greene. It differs from the former in the narrow merely toothed or lobed not pinnatifid leaves; from the latter in the acute teeth or lobes of the leaves and the capsule, which is acute not rounded at the base, and from both in the glabrous stem.

UtaII: Near St. George, I877, Palmer I72 (type, in herb. Columbia Univ.); 1874, Parry 76; 1902, Goodding 776.

Nuttallia acuminata Rydb. sp. nov.

Stout biennial; stem 3-Io dm. high, straw-color, white in age, rather dull, densely villous with barbed hairs; lower leaves

* "Nullalle" Rafin. Am. Mo. Mag. (I818): 175. I8 18; "Nutlallia", Greene. Leaflets I: 209. Io Ap. I906. 
oblanceolate, I-2 dm. long, sinuately dentate, densely scabrous with triangular teeth; upper stem-leaves lanceolate, long-acuminate, pinnatifid with lanceolate or rarely triangular lobes, the lower ones of which are usually large and salient, the base of the leaves, therefore, being very broad and truncate; flowers diurnal; their bracts narrowly linear, entire or with a few narrow lobes; sepals $2-3 \mathrm{~cm}$. long, lance-subulate, long-acuminate, light yellow, about $5 \mathrm{~cm}$. long; outer filaments slightly dilated, the rest filiform, three fourths as long as the petals; petaloid staminodia none; capsule $4 \mathrm{~cm}$. long, I cm. thick; seeds obovate, winged.

This species has been confused with $N$. laevicaulis (Hook.) Greene, but differs in the pubescent, duller stem (in N. laevicaulis this is glabrous or with a few scattered stiff hairs, very white and shining), broader petals, more deeply divided upper stem-leaves, which are characterized by their acumination and broad almost subhastate bases. N. acuminata extends farther eastward and northward than $N$. laevicaulis and is lacking in California.

IDAно: Spokane River, Kootenai County, I892, Sandberg, MacDougal \& Heller 65 I (type, in herb. N. Y. Bot. Gard.); Palouse County and Lake Cceur d'Alene, Aiton 6015.

Montana: Emigrant Gulch, I897, Rydberg \& Bessey 4546; Sedan, I902, W. W. Jones; Garrison, 1895, Rydberg 2737, and C. L. Shear 5248; Helena, I892, Kelsey.

IVyoming: Between Sheridan and Buffalo, ig0o, Tweedy 3617 ; Gardiner River, I899, Aven Nelson E Elias Nelson 6000.

UTAн: City Creek, I883, Leonard II6 and 227; Beck's Hot Spring, 1905, Garrett 1595; Antelope Island and Stansbury Island, Stansbury.

Washington: Loon Lake, I897, Winston; Spokane, 1902 , Kraeger 529.

\section{ONAGRACEAE}

Boisduvalia salicina (Nutt.) Rydb.

Oenothera densiflora $\beta$ T. \& G. Fl. N. Am. I : 505. I 840. Oenothera salicina Nutt. in T. \& G. loc. cit., as a synonym.

This is quite different in habit from the typical $B$. densiflora (Lindl.) S. Wats., having the foliage-leaves narrow, linear or linearlanceolate. It has a much more northern and eastern range, extending into British Columbia and Idaho. 
Epilobium latiusculum Rydb. sp. nov.

Epilobium Drummondii latiusculum Rydb. Mem. N. I. Bot. Gard. I : $276 . \quad$ I900.

To the characters given in the original description may be adcled that the leaves are distinctly petioled, not sessile as in $E$. Drummondii.

\section{Epilobium platyphyllum Rydb. sp. nov.}

Epilobium glaberrimum latifolium Barbey, Bot. Calif. I: 220. I876.

Not E. latifolium L. I753.

Epilobium paniculatum, as usually understood, contains several forms or species, connecting on one hand with E. minutum, on the other with E. jucundum. In order to facilitate the further study of the groups, I give the following key of the Rocky Mountain forms.

Tube of the hypanthium funnelform, I-3 $\mathrm{mm}$. (rarely $4 \mathrm{~mm}$.) long.

Petals white only slightly exceeding the calyx, 2-3 $\mathrm{mm}$. long; capsule glabrous; tube of hypanthium I- $.5 \mathrm{~mm}$. long.

I. E. Tracyi.

Petals pink or purple, $3 \cdot 5^{-7} \mathrm{~mm}$. long, about twice as long as the calyx.

Capsule and pedicels glabrous or sparingly puberulent.

Leaves and bracts very thick, horny at the apex, the latter very short; capsule glabrous; pedicels short.

2. E. subulatum.

Leaves and bracts not very thick, not horny at the apex; capsule usually puberulent. at least when young; pedicels slender.

Capsule and pedicels glandular-pubescent; pedicels very short.

3. E. paniculatum.

4. E. adenocladum.

Tube of the liypanthium 4-8 mm. long, cylindric or nearly so, abruptly widening into the calyx.

Tube of the hypanthium about $4 \mathrm{~mm}$. long; petals $6-7$ $\mathrm{mm}$. long.

Tube of the hypanthium $7^{-8} \mathrm{~mm}$. long; petals $10-12 \mathrm{~mm}$. long.

5. E. laericaule.

6. E. Hammondii.

Epilobium Tracyi Rydb. sp. nov.

Annual; stem 3-8 dm. high, perfectly glabrous, straw-colored; leaves $2+\mathrm{cm}$. long, linear. entire, glabrous; tube of the hypanthium I-I.5 $\mathrm{mm}$. long, funnelform; calyx-lobes about $2 \mathrm{~mm}$. long, very acute; petals white, $2-3 \mathrm{~mm}$. long; capsule more or less 
clavate, about $\mathrm{I} .5 \mathrm{~cm}$. long, perfectly glabrous; seeds obovoid, $1.5 \mathrm{~mm}$. long.

This species is related to $E$. paniculatum but differs in the small white flowers and the perfectly glabrous pod.

UtAн: Ogden, July 3I, I 887, Tracy \& Evans 547 (type, in herb. N. Y. Bot. (rard.); Salt Lake City, May i869, Watson 396.

Oregox: Washington County, July 4, I894, F. E. Lloyd.

W'ashington: Spokane, July I I, I902, Kraeger 152.

IDAнO: Little Potlatch River, Latah County, June I7, I892, Sandberg, MacDougal \& Heller 477.

Montana: Moraine near Polson, August i8, igor, Umbach.

British Columbia: Howser Lake, Selkirk Mts., June i 7 , I905, Charles II. Shaw 7If.

Nerada: Huntington Valley, August r 868, Watson 396.

Epilobium subulatum (Haussk.) Rỹdb.

Epilobium paniculatum subulata Haussk. Monog. Epil. 247. I884.

Epilobium laevicaule Rydb. sp. nov.

Annual; stem glabrous, 6-Io dm. high, glabrous and shining; the bark of the lower portion flaky; leaves linear or linear-lanceolate, $3^{-6} \mathrm{~cm}$. long; the upper mostly involute, usually entire; tube of the hypanthium about $4 \mathrm{~mm}$. long, rather abruptly widening into the calyx; calyx-lobes $3-4 \mathrm{~mm}$. long; petals rose-colored, $6-7$ mm. long; pods clavate, about $3 \mathrm{~cm}$. long, glabrous or almost so; seculs cbovoid, dark; coma dingy.

Montana: Manhattan, I895, Rydberg 2728 (type, in herb. N. Y. Bot. Gard.); Shear 3II4; Big Fork, Aug. 3, 1909, Butler 7016.

Wasmington: Pullman, Aug. 5, i893, Piper i6zi; Spokane, Sept. 1902, Kraeger 536 and 573 .

IdAho: Palouse County, I892, G. B. Aiton 69; Seven Devils Mountains, Aug. 5, 1899, M. E. Jones 6317.

\section{Epilobium Sandbergii Rydb. sp. nov:}

Perennial by means of turions; stem obtusely angled, 6-Io dm. high, finely puberulent throughout; leaves sessile, ovate, acute, dentate, 3-7 cni. long, pubescent on both sides, or glabrate bencath, except the veins; inflorescence crisp-hairy; calyx-lobes linear-lanceolate, about $5 \mathrm{~mm}$. long; petals rose, $7-8 \mathrm{~mm}$. long; pod 4-6 cm. long, glandular-pilose; seeds $1.5 \mathrm{~mm}$. long, almost leakless; coma tawny. 
It resembles somewhat E. Palmeri, but the flowers are nearly twice as large.

IDAHO: Moist places, valley of Mud Lake, Kootenai County, July 25, 1892, Sandberg, MacDougal. \& IIeller 737 (type, in herb. N. Y. Bot. Gard.).

Montaxa: Bozeman, July 22, I 895, Rydberg 2729.

Gayophytum Helleri Rydb. sp. nor.

Annual; stem branched with nearly erect, strict branches, I-3 dm. high, more or less pubescent with spreading hairs; leaves linear, $0.5^{-2} \mathrm{~cm}$. long, softly hirsutulous; pedicels very short, even in fruit scarcely more than I mm. long; sepals and petals scarcely $1 \mathrm{~mm}$. long; capsules linear, erect, 8-Io $\mathrm{mm}$. long, almost sessile, hirsutulous, not torulose; seeds about I mm. long, strigulose.

This resembles G. racemosum in habit and the pod, G. caesiun in pubescence and $G$. lasiospermum in the seeds.

IDAно: Forest, Nez Perces County, July I6, I 896, Heller 3433 (type, in herb. N. Y. Bot. Gard.).

Anogra leptophylla (Nutt.) Rydb.

Oenothera pallida leptophylla (Nutt.) T. \& G. FI. N. Am. I: 495. I 840 .

Oenothera leptophylla Nutt.; T. \& G. Fl. loc. cit., as a synonym.

Oenothera longissima Rydb. sp. nov.

A tall biennial; stem strict, 5-10 dm. high, densely canescent with short crinkled hairs as well as sparingly hirsute; leaves linear or narrowly linear-lanceolate, $\mathbf{I}-\mathbf{1 . 5} \mathrm{dm}$. long, densely canescent, entire, acute at both ends, the lower short-petioled; spike rather lax; bracts linear-lanceolate, $2-5 \mathrm{~cm}$. long; hypanthium tube $10-$ I $2 \mathrm{~cm}$. long, densely canescent, only slightly widening upwards; sepals linear-lanceolate, about $+\mathrm{cm}$. long; free tips about $4 \mathrm{~mm}$. long; petals golden yellow, $+\mathrm{cm}$. long; stamens and pistil of about the same length; capsule about $+\mathrm{cm}$. long, densely canescent, slightly tapering upwards.

This is related to O. macrosceles A. Gray and O. Jamesii T. \& G., but differs from the former in being canescent instead of glabrous and in the smaller and narrower bracts, and from the latter in the longer, narrower and entire-margined leaves, and in being more canescent and less hirsute. It grows on sandy river banks at an altitude of about $\mathrm{I}, 600 \mathrm{~m}$. 
UTAH: Armstrong and White Canyons near the Natural Bridges, Aug. 4-6, I9I I, Rybderg \& Garrett 94Io (type, in herb. N. Y. Bot. Gard.).

Oenothera ornata (A. Nelson) Rydb.

Onagra ornata A. Nels. Bot. Gaz. 52: 268. I9Ir.

Oenothera hirsutissima (A. Gray) Rydb.

Oenothera biennis hirsutissima A. Gray, Mem. Am. Acad. 4. 43. I 849 .

This usually has been regarded as the same as O. Hookeri T. \& G. The type of the latter came from California, that of the former from New Mexico. In the plant common in California and the Great Basin, the free tips of the sepals are about $4 \mathrm{~mm}$. long, the pubescence of the leaves is short and that of the calyx not very copious. In the type of O. biennis hirsutissima and other specimens from New Mexico and Colorado, the free tips of the sepals are only $2-2.5 \mathrm{~mm}$. long, the pubescence of the leaves and calyx long and loose, and that of the latter very copious.

\section{Oenothera subulifera (Rydb.)}

Onagra strigosa subulata Rydb. Mem. N. Y. Bot. Gard. I : 279. I900. Not O. subulata R. \& P. I802

Onagra Oakesiana Rydb. Fl. Colo. 244. 1906. Not Oenothera Oakesiana A. Gray. I867.

Chylisma tenuissima (M. E. Jones) Rydb.

Oenothera tenuissima M. E. Jones, Proc. Calif. Acad. II. 5: 683. I 895 .

Sphaerostigma macrophyllum (Small) Rydb.

Oenothera alyssoides villosa S. Wats. Proc. Am. Acad. 8: 59I. I873. Not O. villosa Thunb. 1794-1800.

Sphaerostigma alyssoides macrophyllum Small, Bull. Torrey Club 23: I92. I 896.

\section{AMMIACEAE}

Osmorrhiza intermedia Rydb.

Washingtonia intermedia Rydb. Mem. N. Y. Bot. Gard. I: 289. I 900. 


\section{Glycosma maxima Rydb. sp. nov.}

Perennial; stem I $\mathrm{m}$. high or more, puberulent or glabrous, pilose at the nodes; lower leaves twice compound, first pinnate and the lower primary divisions ternate; the upper leaves ternate or twice ternate; leaflets oblong-lanceolate, 5-Io $\mathrm{cm}$. long, minutely puberulent; brauches of the umbels $9-\mathbf{I 2}$, in fruit more or less spreading; pedicels in fruit $\mathrm{I}-\mathrm{I} .5 \mathrm{~cm}$. long; fruit fully $2 \mathrm{~cm}$. long, obtuse at the base, contracted above into a beak $2 \mathrm{~mm}$. long; stylopodium conical, $0.5 \mathrm{~mm}$. long, about as long as the styles.

This is related to G. occidentalis Nutt., but the fruit is much larger (in G. occidentalis only $12-16 \mathrm{~mm}$., rarely $18 \mathrm{~mm}$. long), and the rays of the umbels are in fruit usually widely spreading, while in $G$. occidentalis they are nearly erect. The spreading rays suggest $G$. ambigua and $G$. Bolanderi, but in both these species the stylopodium is flatter.

Utah: Mount Nebo, Aug. I5, I905, Rydberg \& Carlton 7585 (type, in herb. N. Y. Bot. Gard.); Rocky Canyon, Provo, Aug. I6, I 887 , Tracy 684 .

Montand: Midvale, July 24, I903, Umbach 508.

Atenia H. \& A. Bot. Beech. Voy. 349. i 840

This I think is a good genus, distinct from Carmm. Although the fruit is almost the same, the habit is quite different. The habit of Atenia is the same as that of Eulophus. In fact it is hard to distinguish the two genera without mature fruit, both having the fascicled tuberous roots, the narrow leaf-segments, the same inflorescence and flowers. The only essential differences are the deeply concave seed-face with a central ridge and the several oil tubes in Eulophus and the plane face and solitary oil tubes in Ataenia. The following species are found in the Rocky Mountains:

Atenia Gairdeneri H. \& A. Bot. Beech. Voy. 349. isto Edosmia Gairdncri Nutt.; T. \& G. Fl. N. Am. I: 6I2. I8+o. Carum Gairdneri A. Gray, Proc. Am. Acad. 7: 344. I867.

Atenia montana (Blank.) Rydb.

Carum montanum Blank. Mont. Agr. Coll. Sci. Bot. I: 9I. I905. 
Atenia Garrettii (A. Nels.) Rydb.

Carum Garrettii A. Nels. in Rose, Cont. U. S. Nat. Herb. I 2: $4+3$. 1909.

Oreoxis MacDougali (C. \& R.) Rydb. Aletes MacDongali C. \& R. Cont. U. S. Nat. Herb. 7: 107. 1900. This was doubtfully referred to Aletes by Coulter and Rose. The fruits in the type collection were very young and did not show their true nature. Anyhow, they showed distinct wings, a character inconsistent with the genus Aletes. Professor Garrett and myself collected good fruits in southeastern Utah in the summer of I9II; and these show that the plant is rather an Oreoxis than an Aletes, wings being present and these thick and corky. The two genera are, however, more closely related than has been recognized, having the same cespitose habit, the prominent calyx, teeth, etc.

Daucophyllum (Nutt.) Rydb. gen. nov.

Musenium \$ Daucophyllum Nutt.; T. \& G. Fl. N. Am. I: $6+2$. I 840.

Low cespitose perennials, acaulescent or nearly so, with a branched caudex. Leaves numerous, basal, or I or 2 cauline, pinnate or bipinnate with filiform or narrowly linear divisions. Flowers cream-colored to yellow, in dense umbels. Bracts wanting; bractlets few, narrow, linear. Calyx teeth prominent. Stylopodium wanting. Fruit ovoid or oblong, granular on the intervals. Ribs equal, rather strong, but not at all winged. Oil tubes 2 or 3 in the intervals, $4^{-6}$ on the commissural side. Seed terete or somewhat depressed; face plane.

The type, Musenium tenuifolium Nutt., was separated as a section in Torrey and Gray's Flora. The relationship is rather with Harbouria and Aletes than with Musineon Raf. The firstmentioned relationship was recognized by Coulter and Rose (see their Revision, p. III). It differs from Harbouria in not having thick corky ribs and in having several oil tubes in the intervals. It is still more closely related to Aletes, having the same habit, although narrower leaf-segments, the main differences being, however, the solitary oil tubes in Aletes and 2 or 3 in each interval in Daucophyllum, and the concave seed face in the former and the plane 
one in the latter. The second species given below was included questionably in Aletes by Coulter and Rose; but in the number of oil tubes and the plane seed face it agrees better with Musenimm tenuifolium Nutt. than with the typical species of Aletes.

Leaves bipinnate; segments filiform; bractlets not exceeding the pedicels; seed subterete.

I. D. tenuifolium.

Leaves pinnate; segments narrowly linear; bractlets longer than the pedicels; seeds somewhat depressed.

2. D. lineare.

\section{Daucophyllum tenuifolium (Nutt.) Rydb.}

Musenium tenuifolium Nutt.; T. \& G. Fl. N. Am. I: 6ł2. I8ło.

2. Daucophyllum lineare Rydb. nom. nov.

Aletes tenuifolia C. \& R. Cont. U. S. Nat. Herb. 7: Io8. I90o.

Coriophyllus (M. E. Jones) Rydb. gen. nor.

Cymopterus §Coriophyllus M. E. Jones, Cont. West. Bot. I2: 20. I 908.

Perennial herbs with more or less fleshy root, somewhat branched rootstock covered with fibrous sheaths, and leafy stems with internodes shorter than the leaf-sheaths. Flowers yellow to purple. Bracts none; bractlets present, but narrow. Leaves pinnately dissected, subcoriaceous, rigid, not fleshy, with ovate or lanceolate, cuspidate or spinulose-tipped lobes. Calyx teeth evident. Styloporlium wanting. Fruit orbicular to oval in outline, usually emarginate at both ends, compressed laterally if at all. Ribs with broad wings. Oil tubes $\mathrm{I}-5$ in the intervals, 2-8 on the commissural side. Seeds little if at all flattened dorsally; face deeply grooved.

I agree with Mr. Marcus E. Jones that the genus Aulospermum, as constituted by Coulter and Rose, is a rather unnatural one, made up of two groups of quite different habit; but instead of reducing both groups to sections of Cymopterus as Mr. Jones did, I rather regard them as two distinct genera, and adopt for the second group the sectional name first proposed by Mr. Jones. (See the discussion in Cont. West. Bot. I2: 19-20 and 27.) He, however, had the group under two different sectional names. The section is called Coriophyllus on page 20 and Scopulicola on page 27 .

The following species are found in the Rockies and are distinguished thus: 
Wings thickened at the insertion.

Leaves ternately bipinnatifid; oil tubes solitary in each interval.

I. C. Jonesii.

Leaves pinnate, with lobed or divided leaflets; oil tubes several in each interval.

2. C. Rosei.

Wings not thickened at the insertion.

Flowers purplish; oil tubes 8 on the commissural side.

Flowers greenish-yellow; oil tubes 4 on the commissural side.

3. C. purpureus.

4. C. Betheli.

I. Coriophyllus Jonesii (C. \& R.) Rydb.

Cymopterus Jonesii C. \& R. Rev. N. Am. Umb. 80. I 888.

Aulospermum Jonesii C. \& R. Cont. U. S. Nat. Herb. 7: I78. I 900.

2. Coriophyllus Rosei (M. E. Jones) Rydb.

Aulospermum Rosei M. E. Jones; C. \& R. Cont. U. S. Nat. Herb. 7: 179. 1900.

3. Coriophyllus purpureus (S. Wats.)

Cymopterus purpureus S. Wats. Am. Nat. 7: 300. 1872.

Aulospermum purpureum C. \& R. Cont. U. S. Nat. Herb. 7: I78. I900.

4. Coriophyllus Betheli (Osterhout) Rydb.

Aulospermum Betheli Osterhout, Muhlenbergia 6: 46. I9Io.

Pseudocymopterus C. \& R.

This genus is one of the most unnatural in Coulter \& Rose's Monograph. Jones* called attention to this fact, although he included the genus, as well as Oreoxys, Rhysopterus, Aulospermum, and Pteryxia in Cymopterus, and does not go to the bottom of the facts. The genus as constituted by Coulter and Rose contains at least three distinct groups of plants of little relationship to each other. The first group contains Pseudocymopterus montanus and its close relatives; the second of $P$. anisatus and $P$. aletifolius, and perhaps $P$. Hendersonii, which I do not know; and the third of $P$. bipinnatus and probably Cymopterus nizalis S. Wats., of which the fruit is unknown. P. montanus is the type of the genus, which latter therefore must be restricted to it and its relatives. Jones

* Cont. West. Bot. 12: 2.4-29. 1908. 
includes $P$. anisatus and P. bipinnatus in his section Oreoxis, but the genus Oreoxis has all ribs corky and the lateral ones scarcely more prominent than the dorsal ones, the fruit is not flattened dorsally, the styles and sepals are erect. In Pseudocymopterus anisatus the lateral wings are very prominent, the dorsal ribs narrowly winged or some of them merely acute, the styles are recurved, the sepals spreading and one or two of them larger than the rest, and the fruit is decidedly flattened dorsally. The plant is more related to Aletes than to Oreoxis, and $P$. aletifolius connects it with that genus. It can not be placed in Aletes, however, for in that genus the fruit is not compressed and the ribs not winged. It would be much better to include $P$. anisatus and $P$. aletifolius in Pteryxia, as they have the foliage and nearly the same fruit as in that genus, but the strictly acaulescent plant, the narrow and thick wings of the fruit and the very prominent and unequal calyx-teeth would make it rather abnormal even in that genus. Although it does not differ so much in the technical characters of the fruit from the typical Pseudocymopterus, the habit is quite different, so also the texture of the leaves, and in Pseudocymopterus the sepals are minute. It is better to regard $P$. anisatus as a type of a new genus.

\section{Pseudopteryxia Rydb. gen. nov.}

Densely cespitose, strong-scented, acaulescent perennials with multicipital caudices covered with numerous sheaths of old leaves. Leaves pinnatifid or bipinnatifid with thick, firm, pungent divisions. Flowers yellow; involucres wanting; bractlets linear-subulate, pungent. Calyx-teeth very prominent, spreading, unequal, one or two much longer than the rest. Stylopodium wanting. Fruit oblong, glabrous. Ribs thick, the dorsal and intermediate ones sharp or some of them with narrow wings; the lateral ones with broader wings, distinct from those of the other carpel. Carpels flattened dorsally. Oil tubes $\mathrm{I}-3$ in the intervals, $2-4$ on the commissural side. Seed face plane.

\section{Pseudopteryxia anisata (A. Gray) Rydb.}

Cymopterus (?) anisatus A. Gray, Proc. Acad. Phila. I862: 63. 1863.

Pseudocymopterus anisatus C. \& R. Rer. N. Am. Umb. 75. I888. 


\section{Pseudopteryxia longiloba Rydb. sp. nov.}

Densely cespitose perennial with a thick root and short caudex, covered by numerous old leaf-sheaths and petioles; leaves twice pinnatifid, with linear-subulate, pungent divisions; peduncles $2-3$ $\mathrm{dm}$. high, stout; bractlets linear-subulate, spreading, often $\mathrm{I} \mathrm{cm}$. long; flowers yellow; fruit about $6 \mathrm{~mm}$. long; lateral wings thick, narrow, some of the wings of the dorsal ribs often fully as broad; calyx-teeth less prominent than in $P$. anisata.

This is closely related to $P$. anisata, differing in the larger fruit (in $P$. anisata about $4 \mathrm{~mm}$. long), and longer leaf-segments. On account of the long leaf-segments, specimens collected in flower by Carlton and myself were mistaken for Cynomarathrum Nuttallii (A. Gray) C. \& R.; but good fruit was received in the summer of I9II.

UTAн: Abajo Mountains, Aug. I7, I9II, Rydberg \& Garrett 9761 (fruit; type, in herb. N. Y. Bot. Card.); also 9760 (fruit); La Sal Mountains, July 7 and 17,8724 and 9015 (young fruit); Mountains north of Bullion Creek, near Marysvale, July 23, Rydberg \& Carlton $70 \$ 5$ and 7096 (flowers); Mount Ellen, July $2+$ and 25, I 894, M. E. Jones 5677 (fruit, but poor).

\section{Pseudopteryxia aletifolia Rydb.}

Pseudocymopterus aletifolius Rydb. Bull. Torrey Club 31: 574 . 1904 .

Neither can Pseudocymopterus bipinnatus be retained in the genus; in fact, it is still more out of place. Not only is the habit strikingly different from that of $P$. montanus, but the fruit is not, as Coulter and Rose described it, "moderately flattened dorsally," for the fruit when well developed is moderately flattened laterally, which places it in the other division of the family. Furthermore, the seed face is concave, the bractlets broad and scarious, and a stylopodium, although strongly flattened, is present. Were it not for these characters of the fruit the plant could be placed in the same genus as $P$. anisatus. As it is, its relationship is with Daucophyllum and Aletes. I would place it in Daucophyllum were it not for the winged ribs, the concave seed face and the reflexed style. The fruit is nearer that of Aletes, but the oil tubes are several, the ribs winged, styles reflexed and stylopodium present. If a person were using the key given by Coulter and Rose 
in their Monograph and were trying to determine the plant, the key would lead to Aulospermum or Phellopterus, to either of which genera it is not even closely related. Mr. Jones included it in Oreoxis, to which I admit it is related, but the ribs are not corky, the stylopodium present, the styles reflexed, the flowers white, not yellow, and the bractlets scarious.

\section{Pseudoreoxis Rydb. gen. nov.}

Low cespitose acaulescent perennials, with branched caudex. Leaves bipinnate; the segments more or less cleft with small lanceolate divisions. Flowers white in small umbels; bracts wanting; bractlets ovate or lanceolate, cuspiclate or abruptly acuminate, scarious, white with a green midrib. Calyx-teeth evident but small. Stylopodium present but low and flat. Styles reflexed. Fruit somewhat flattened laterally, oblong. Ribs all with narrow wings, the lateral ones scarcely wider. Oil tubes 3 or $t$ in the intervals, 6-8 on the commissure. Seed face slightly concare.

Pseudoreoxis bipinnatus (S. Wats.) Rydb.

Cymopterus bipinnatus S. Wats. Proc. Am. Acad. 20: 368.1885. Pseudocymopterus bipinnatus C. \& R. Rer. N. Am. Umbel. 75. I 888 .

\section{Pseudoreoxis nivalis (S. Wats.) Rydb.}

Cymopterus niralis S. Wats. Bot. King. Exped. 123. I87I.

I do not hesitate to refer this species to the same genus as $P$. bipinnatus, although the fruit is unknown, for the habit, and flowers are so closely resembling those of P. bipinnatus.

Cynomarathrum latilobum Rydb. sp. nov.

Acaulescent perennial with densely cespitose caudex covered by old broad leaf-sheaths; leaves about I $\mathrm{cm}$. long,. pinnate, glabrous; leaflets entire or 2- or 3-cleft into broadly lanceolate, reticulate, thick, pointed segments $5^{-15} \mathrm{~mm}$. long; peduncles $\mathrm{I}-\mathrm{I} .5 \mathrm{dm}$. long, stout; rays $\mathrm{I}-2 \mathrm{~cm}$. long; bractlets linear or lance-linear, 5-6 mm. long; flowers apparently straw-colored or ochroleucous; fruit about $9 \mathrm{~mm}$. long, $6 \mathrm{~mm}$. wide; lateral wings about as broad as the body; dorsal ribs filiform or some of them narrowly winged; oil tubes $2-+$ in the intervals, $t^{-6}$ on the commissure, rather obscure.

The fruit of this species is intermediate between that of $C$. Nuttallii and C. Parryi, but the plant differs from both, as well as from all the known species, in the broad segments of the leares. 
The segments resemble those of some species of Cogswellia of the $C$. triternata group, but the leaves are pinnate, not ternate, the plant has the densely cespitose, sheath-covered caudex characteristic of Cynomarathrum, and the fruit is of that genus, having some of the dorsal ribs winged, and the calyx-teeth are prominent. It grows on sides of canyons at an altitude of $\mathrm{I}, 600 \mathrm{~m}$.

¿тан: Proposed dam site, near Wilson Mesa, Grand County, Utah, July I, I9II, Rydberg $\mathcal{F}^{\circ}$ Garrett $837 I$ (fruit; type, in herb. N. Y. Bot. Gard.); also 8414 (withered flowers).

\section{Cogswellia simplex (Nutt.) Rydb.}

Peucedanum triternatum platycarpum Torr. Stansb. Rep. 389. I852. Peucedanum simplex Nutt.; S. Wats. Bot. King. Exped. I29. I87 I. Lomatium platycarpum C. \& R. Cont. U. S. Nat. Herb. 7: 226. I 900.

Cogswellia platycarpa (Torr.) M. E. Jones, Cont. West. Bot. I2: 32. 1908 .

It was unfortunate that an amendment to the Rochester Code ever was passed at Madison, by which a varietal name could supersede a specific name, and I am glad that the amendment mentioned has been recalled and that we can return to the specific name well known by a long usage.

\section{Cogswellia leptophylla (Hook.) Rydb. sp. nov.}

Pencedanum triternatum leptophyllum Hook. Lond. Journ. Bot. 6: 235. 1847 .

This species is related to $C$. simplex, $C$. triternata, and $C$. robustior. In general habit, it resembles most the second, but the leaflets are narrower, the fruit is shorter and relatively broader and puberulent. C. simplex has less compound leaves, broader ltaflets, larger and glabrous fruit; C. robustior has much broader and more spreading leaflets, longer fruit with very narrow wing.

Mostana: Helena, June-July, i 89i, Kelsey; also May, i 890; University campus and hillsides, Missoula, I90I, MacDongal I30; Old Sentinel, June I2, I90I, MacDougal; Deer Lodge, June, I888, Traphagen; Mt. Ascension, Helena, 1909, Butler 4057.

ID.AHo: Hills near Boise, June 7, I 892, Isabel Mulford; Weiser, April i 8, I900, M. E. Jones 6336.

New York botanical Garden. 
CONTRIBUTIONS FROM THE NEW YORK BOTANICAL GARDEN - No. 160

\title{
STUDIES ON THE ROCKY MOUNTAIN FLORA-XXIX
}

\author{
PER AXEL RYDBERG
}

NEW YORK
1913

Reprinted, without change of paging, from the Bolletin of THE TORREY BOTANICAL CLUB 40: $461-485.12 \mathrm{~S} 1913$ 



Studies on the Rocky Mountain flora - XXIX

\author{
Per Axel Rydberg
}

\title{
MONOTROPACEAE
}

Hypopitys latisquama Rydb. sp. nov.

Plant pink, I-3 dm. high, more or less short-pubescent above; scales of the stem broadly ovate, obtuse, I-I.5 $\mathrm{cm}$. long; flowers usually IO-I5; sepals spatulate or cuneate, 8-Io mm. long, abruptly acuminate, ciliate; petals cunate or obovate, II-I $2 \mathrm{~mm}$. long, rounded and sinuate at the apex, pubescent and ciliate, filaments and style copiously hairy; stigma retrorsely bearded.

This is closely related to H. lanulosa (Michx.) Nutt., but differs in the large and broad scales on the stem and the larger flowers.

MovtaxA: Bridger Mountains, July 28, I896. Flodman 708 (type, in herb. N. Y. Bot. Gard.).

Wyoming: 1873 , Parry 196.

Washington: Olympic Mountains, Elmer 2464.

\section{PRIMULACEAE}

\section{Primula specuicola Rydb. sp. nov.}

Perennial with a short rootstock; leaves $5^{-13} \mathrm{~cm}$. long, thin, slightly farinose when young, in age glabrate, with winged petioles; blades spatulate or elliptic, obtuse at the apex, sinuate-dentate; scape I-I.5 cm. long; umbels I0-20-flowered; bracts linear-subulate, thin, 5-10 $\mathrm{mm}$. long, slightly gibbous at the base; pedicels $5^{-10} \mathrm{~mm}$. long in flower or $\mathrm{I}-4 \mathrm{~cm}$. long in fruit; calyx densely farinose; tube deeply campanulate, $3-5 \mathrm{~mm}$. long; lobes linearoblong, $2.5-3.5 \mathrm{~mm}$. long, obtusish; corolla-tube yellowish, 8-IO 
$\mathrm{mm}$. long, I.5 mm. in diameter; lobes cuneate, merely emarginate with a broad sinus, dark violet, about $3 \mathrm{~mm}$. long; stamens inserted in the middle of the corolla-tube; capsule about $6 \mathrm{~mm}$. long.

This species is related to $P$. farinosa L. and $P$. incana M. E. Jones, but differs from both in its very thin leaves, more exserted corolla-tube and slender bracts. In $P$. incana $\mathrm{M}$. E. Jones $(P$. americana $\mathrm{Rydb}$.), the only other species of the group in the Rocky Mountains, the bracts are thick, almost fleshy, obtusish, lanceolate, and often nearly equaling the pedicels. In the bracts and inflorescence, it resembles more $P$. farinosa L. of Europe and northeastern America. P. Ellisiae of the Sandea Mountains of New Mexico, though belonging to this group and of the same habit, has much larger flowers, the lobes of the corolla being $8-10 \mathrm{~mm}$. long. $P$. specuicola grows only in loose soil, under orerhanging cliffs in the alcove-like heads of the canyons, characteristic of the limestone bluffs of San Juan River.

UtAl1: Along San Juan River, near Bluffs, Aug. 25-29, I91 I, Rydberg 9882 (type, in herb. N. Y. Bot. Gard.); same locality, Feb., I912, Edna Scorup, and in I895, Alice Eastriood.

Androsace albertina Rydb. sp. nov.

Cespitose perennial, but scarcely pulvinate; leaves narrowly oblanceolate, about I cm. long, sparingly ciliate, not carinate; scape $5^{-10} \mathrm{~cm}$. long, slender, sparingly hairy; bracts linearlanceolate, 3-4 mm. long; pedicels $3-5 \mathrm{~mm}$.; calyx-lobes elliptic, obtuse; corolla-lobes $2-3 \mathrm{~mm}$. long.

This is most like the European A. Chamaejasme Host, but the leaves and bracts are narrower. It differs from $A$. carinata Torr. in the narrower leaves, not carinate beneath, less pulvinate habit, longer peduncles, longer pedicels, and smaller flowers.

Alberta: Lake Agnes, National Park, Banff, Aug. I897, Mr. and Mrs. C. Van Brunt 77 (type, in herb. N. I. Bot. Gard.); Jumping Pound Creek, June It, I897, Macoun 23478; Rocky Mountains I 858 , Bourgeau.

Moxtaxa: Yellow Mountain, June 24, I897, R. S. Williams.

Androsace simplex Rydb. sp. nov.

Annual; leaves oblanceolate, 3-6 mm. long, acute, entire, minutely puberulent; scape usually solitary, erect, very slender, $2-\tau \mathrm{cm}$. high; bracts oval or lance-oval, $2-4 \mathrm{~mm}$. long; pedicels 
5-I5 mm. long, suberect or strongly ascending; calyx-tube obpyramidal, about $2 \mathrm{~mm}$. long; lobes lanceolate, about I.5 $\mathrm{mm}$. long, acute; corolla small, shorter than the calyx.

This is related to $A$. occidentalis, but the plant is more delicate, the scapes solitary, bearing a I-4-flowered umbel with strongly ascending or nearly erect pedicels, the bracts smaller and distinctly acute.

Montana: Missoula, May, I897, Elrod \& assistants 33 (type, in herb. N. Y. Bot. Gard.).

Utah: Near Salt Lake City, May I882, M. E. Jones.

Britisir Columbia: Lytton, April i7, i889, Macoun.

Dr. Greene separates an American species Androsace capillaris Greene from the Asiatic A. filiformis Retz, and claims that the former is a perennial. All American specimens that I have seen are, however, annuals, and I can see no reason for such a separation.

Dodecatheon Jaffreyi Moore has been collected near Sawtooth, Idaho, by Evermann.

\section{GENTIANACEAE}

Anthopogon ventricosum (Griseb.) Rydb.

Gentiana ventricosa Griseb. in Hook. Fl. Bor.-Am. 2: 65. I838.

Anthopogon Macounii (Holm) Rydb.

Gentiana Macounii Holm, Ottawa Nat. I5: I10, I79. I90I.

Anthopogon tonsum (Lunell) Rydb. sp. nov.

Gentiana detonsa tonsa Lunell, Bull. Leeds Herb. 2: 7. I908.

This is closely related to $A$. Macounii (Holm) Rydb., but differs in the glabrous filaments, a character not pointed out by Dr. Lunell.

Amarella tortuosa (M. E. Jones) Rydb.

Gentiana tortuosa M. E. Jones, Proc. Calif. Acad. II. 5: 707. I895.

Amarella ventorum Rydb. sp. nov.

Gentiana arctophila densiflora Torr. Fremont's Rep. 94. I 845. Not G. arctophila densiflora Griseb.

Low annual or biennial, branched near the base; stems $5^{-10}$ $\mathrm{cm}$. long, branched, internodes shorter than the leaves; basal 
leares oblanceolate; stem-leaves linear or linear-lanceolate, about $2 \mathrm{~cm}$., acute; flowers $\mathrm{I}-3$ in the axils; pedicels $2-8 \mathrm{~mm}$. long; calyx-tube about $2 \mathrm{~mm}$. long; lobes linear-lanceolate, $3-\overline{5}$ $\mathrm{mm}$. long, acute, scabrous on the margins; corolla about $5 \mathrm{~mm}$. long; lobes ovate, obtuse or acute; crown none.

This little Amarella lacks the setaceous fimbriate crown at the base of the corolla-lobes and therefore should be classified with the arctic or subarctic $A$. propinqua (Richards.) Greene, and $A$. arctophila (Griseb.) Greene, but the corolla-lobes are acute or obtuse, instead of cuspidate.

Wroming: Wind River Moutainns, Aug. 4, I843, Fremont.

Dasystephana oregana (Engelm.) Rydb.

Gentiana oregana Engelm.; A. Gray, Syn. F1. 21: 122. I878.

Dasystephana glauca (Pall.) Rydb.

Gentiana glauca Pall. Fl. Ross. 2: I04. I $7 \delta_{4}$.

Dasystephana calycosa (Griseb.) Rydb.

Gentiana calycosa Griseb. Gen. et Sp. Gent. 292. I839.

Dasystephana monticola Rydb. sp. nor.

Gentiana calycosa stricta Griseb. Gen. et Sp. Gent. 292. 1839.

Gentiana calycosa monticola Rydb. Bull. Torrey Club 24: 252. 1897 .

Dasystephana obtusiloba Rydb. sp. nov.

Cespitose perennial; stems erect or ascending, about I $\mathrm{dm}$. high; internodes short, equaling or a little longer than the leares; leaves very broadly ovate, 3-5-ribbed, usually acute at the apex and subcordate at the base; calyx-tube broadly turbinate, 5-6 mm. long; lobes broadly oval, rounded at the apex, often overlapping, about $8 \mathrm{~mm}$. long; corolla dark blue, about $3.5 \mathrm{~cm}$. long; lobes rounded at the apex; lobes of the plaits about half as long as the corolla lobes.

This is related to D. calycosa, but differs in the lower habit and rounded corolla-lobes.

Montana: Mary Baker Lake and Sperry Glacier, Aug. 2I, I90I, Vreeland II62 (type, in herb. N. Y. Bot. Gard.); Lake MacDonald, Aug. 22, I90I, Umbach 37I; Mount MacDonald, July 25, I900, Elrod Eo assistants; Silloway Peak, July I7-I9, I90I, MacDougal 692; Blackfoot Indian Reservation, Aug. and Sept. I909, Gilman Thompson. 


\section{Swertia Fritillaria Rydb.}

Glabrous, light green, perennial; stem I.5-3 dm. high; basal leaves and lower stem-leaves alternate, 6-Io cm. long, thin, longpetioled; blades obovate, spatulate, rounded at the apex, abruptly contracted into winged petioles of about the same length; middle and upper stem-leaves all alternate or a single pair of opposite ones, oblanceolate or oblong; inflorescence rather lax, elongate; pedicels I-2 cm. long; sepals lanceolate, about $6 \mathrm{~mm}$. long; corolla-lobes lanceolate, mostly acute, greenish white along the midrib and azure along the margins, dotted all over with dark blue spots in the manner of many species of Fritillaria; filaments more or less dilated, some of them very broad; glands inconspicuous with rather long blue fringes.

UTAH: Wet places in caynons: Big Cottonwood Canyon, August 4, 1905, Garrett 1566 (type, in herb. N. Y. Bot. Gard.).

\section{APOCYNACEAE}

Amsonia Eastwoodiana Rydb. sp. nov.

Perennial, with a short woody base; stem $3-5 \mathrm{dm}$. high, gla brous; stem-leaves lanceolate, usually narrowly so, $3^{-5} \mathrm{~cm}$. long, glabrous, acute at each end; leares of the numerous strongly ascending branches linear; calyx-lobes subulate, $2 \mathrm{~mm}$. long or longer; corolla 16-20 mm. long; tube narrowly trumpet-shaped; lobes nearly $4 \mathrm{~mm}$. long; pod $5^{-8} \mathrm{~cm}$. long, about $8 \mathrm{~mm}$. thick, constricted and often breaking off between the seeds, $3-5$-seeded; seeds oblong, about I $\mathrm{cm}$. long and $6 \mathrm{~mm}$. thick.

This is most closely related to $A$. brevifolia, having the same flower and fruit, but the plant is in habit more like A. Fremontii, for which it has been mistaken. The latter has still longer calyx-lobes which are narrower, and its pod is not restricted between the seeds. In canyons of desert regions.

UтAн: Noab, July, I9I I, Rydberg \& Garrett 8468 (fruit, type, in herb. N. Y. Bot. Gard.); Willow Creek Canyon, August, I 895, Alice Eastwood 73 (fruit).

Arizond: Ten miles east of Holbrook, June 22, r9or, L. F. Ward (flowers); Lee's Ferry, I89o, M. E. Jones.

Amsonia texana (A. Gray) Heller of the Flora of Colorado and Coulter \& Nelson's Manual is A. latifolia Jones. A. brevifolia A. Gray, and A. tomentosa Torr. have been collected in southern Utah. 


\section{ASCLEPIADACEAE}

Astephanus utahensis Engelm., Philiberiella cynanchoides (Dec.) Vail and P. heterophylla (Engelm.) Vail, Asclepias erosa Torr., A. macrosperma Eastw. and A. labriformis Jones have been collected in Utah; Acerates lanuginosa (Nutt.) DC., in the Yellowstone Park; Asclepias ovatifolia, in Saskatchewan; and Asclepias mexicana Cav., in Idaho.

\section{CONVOLVULACEAE}

Cressa erecta Rydb. sp. nov.

Stem branched, with a woody base, erect, $2-3 \mathrm{dm}$. high with erect branches, silvery canescent; leaves elliptic, $5^{-7} \mathrm{~mm}$. long, acute at both ends, sessile, silvery canescent; pedicels in fruit 6-Io $\mathrm{mm}$. long, usually exceeding the leaves; bracts elliptic, 3 $\mathrm{mm}$. long; sepals $4-5 \mathrm{~mm}$. long, oval, equaling the corolla-tube; corolla white; lobes elliptic, acutish, rarely spreading; filaments filiform, slightly pubescent; ovary densely pubescent; styles filiform.

This differs from $C$. depressa Goodding in the erect stem and branches, the more silvery pubescence, the longer pedicels (in $C$. depressa shorter than the leaves) and the comparatively narrower corolla-lobes.

Utaн: Near Beck's Hot Springs, Salt Lake County, July, I905, Garrett S7of (type, in herb. N. Y. Bot. Gard.).

\section{CUSCUTACEAE}

Cuscuta curta (Engelm.) Rydb. sp. nov.

Cuscuta Gronovii curta Engelm. Trans. St. Louis Acad. I: 507. I 859 .

In saline districts of Utah and Colorado.

\section{POL.EMONIACEAE}

Dr. Brand* reduces the amply distinct Phlox muscoides Nutt. to

* Pflanzenreich, Vol. 4, Fam. 250. The following pages contain a good deal of criticism of Dr. Brand's monograph of this family. The monograph is one of the best, differing in that respect from most works done by Europeans on American plants. The citation of publication is very carefully prepared, correct, and complete; but Dr. Brand has fallen into the same errors as most foreigners do, in not trying to find out exactly what the types are or what plants the descriptions really represent. He made definite pronunciations as to species he had never seen, and made synonyms from mere guesses. My criticisms are limited to the Rocky Mountain species. If the Pacific Slope species are considered, probably as many more incongruities could be pointed out. 
a subspecies of $P$. caespitosa and makes $P$. Corillei E. Nels. and $P$. condensata (Gray) E. Nels. varieties of this subspecies. It is evident that Dr. Brand does not know what $P$. muscoides is; for the only Montana specimen he cites is Rydberg \& Bessey 4815 , which belongs to Phlox caespitosa and is so referred in my Flora of Montana. He also cites two specimens from California, Coville 20/2 from Mount Whitney and Hildebrand from Silver Mountains and also one from Charleston Mountains, Nevada, Purpus 6III. Phlox muscoides Nutt. is unknown to both California and Nevada. Neither $P$. Covillei nor $P$. condensata is closely related to $P$. muscoides. The relationship of $P$. muscoides is with $P$. bryoides on one hand, and P. Hoodii on the other; and the calyx is arachnoidvillous, not glandular as in $P$. caespitosa.

Dr. Brand made Phlox albomarginata M. E. Jones, $P$. costata Rydb., $P$. collina Rydb. and $P$. diapensioides Rydb. varieties of $P$. Kelseyi, while he kept $P$. alyssifolia Greene as distinct and described a new species, $P$. variabilis, from material which I had included in $P$. collina. It is evident that Dr. Brand did not know the plants he was so treating. Under his var. albomarginata he gives the following distribution:

"Montana (nach Jones)-Wyoming: Cooper Creek (Nelson n. 4336)."

Evidently he had not seen Jones's specimens and Nelson 4336 is typical P. Kelseyi, and has nothing of the habit of P. albomarginata.

Under each of his var. collina and var. diapensioides he gives the following: "Montana (nach Rydberg)." In other words, he had seen no specimens. Under his rar. costata he gives: "Nontana: Madison Co. (Nelson 5I+8)." This number is not found in the herbarium of the New York Botanical Garden, but judging from the rest $\mathrm{I}$ am inclined to think that this determination is just as unreliable. It may be that $5 I 4 \delta$ is a misprint for $54 I 8$, which is labeled Phlox Kelseyi, and should be referred to it, but is not typical. It has nothing to do with $P$. costata. Furthermore, $P$. costata is not closely related to $P$. Kelseyi, but intermediate between P. multiflora A. Nels. and P. glabrata (A. Nels.) Brand, but with a densely pubescent calyx.

In my opinion, $P$. aly'ssoides Greene, $P$. collina Rydb., and $P$. 
variabilis Brand are one and the same species. I included Hall \& Harbour 454 in the original description of P. collina, and I have no reason for changing my opinion. There is no essential difference between my diagnosis of $P$. collina and Brand's characterization of $P$.variabitis, except that I described the leaves as "oblong or ovate" and Brand gives them as "linear." The specimens in the Columbia University herbarium of Hall \& Harbour 454 have oblong leaves, hence agreeing better with my description. Furthermore, $P$. alyssoides $(=P$. collina), as I understand it, has been collected at several places in both Utah and Wyoming, and why not also in Colorado? Professor A. Nelson in Coulter \& Nelson's New Manual has followed Dr. Brand's treatment of this group very closely. It would have been much better for him to find out the real facts.

Brand's description of $P$. Douglasii is not correct; he describes the calyx as eglandulose-pilose, while the duplicate of the type in the Columbia University herbarium is densely glandular.

Phlox dasyphylla Brand is not better than P. zariabilis, being only a small-flowered and narrow-leaved form of $P$. multiflora, not uncommon in Colorado and Wyoming.

Phlox densa Brand is a low condensed from of $P$. austromontana, more like the type than Phlox austromontana prostrata E. Nels., which Dr. Brand regards as a mere variety. The only one of Dr. Brand's new species from the Rockies that I regard as good is P. glabrata (E. Nels.) Brand (P. Hoodii glabrata E. Nels.).

In describing Phlox aculeata* Prof. A. Nelson compares it with the $P$. caespitosa group. The intercostal portion of the calyx is replicate, however, which would associate it with $P$. Stansburyi. I can not distinguish it from $P$. viridis E. Nels.

Dr. Brand's conception of Gilia congesta Hooker is entirely wrong. He regards $G$. iberidifolia Benth. as the typical G. congesta. A duplicate of Douglas's plant is found in the Columbia University herbarium, and a closer study of the same shows that it is the same as Jenney's plant from the Black Hills, which constituted a part of G. spicata capitata A. Gray, and my number $\$ 86$, also from the Black Hills. These two specimens I included in my G. cephaloidea. Unfortunately I did not designate a type and some botanists might claim that Jenney's plant which was first

\footnotetext{
* Bot. Gaz. 52: 270 . I9II.
} 
mentioned should be regarded as such. The short characterization was, however, drawn principally from my number 2763 from Lima, Montana, and this is marked in our herbarium as the type. Since more specimens have been seen, both of the Montana plant and of that from the Black Hills, it has become evident that they are not exactly the same. As the Montana plant is marked as the type, I now limit my $G$. cephaloidea to it. If Jenney's plant or my $\$ 86$ were to be regarded as the type of $G$. cephaloidea, this would become a synonym of $G$. congesta and the Montana plant should have a new name. As it is, the $G$. cephaloidea of Brand's monograph should become G. congesta Hooker, and Brand's $G$. congesta is $G$. iberidifolia Benth.

Brand divides the Gilia spicata group in two divisions: one containing G. spicata, G. globularis and G. trifida, with the corollalobes (in dry state) dark purple; and G. cephaloidea and G. congesta, with lobes of the corolla (in dry state) whitish. The dark purple color is simply due to poor drying. Dr. Brand also describes the corollas of $G$. spicata as purple. In fact they are greenish white. We have specimens of $G$. spicata which still retain the greenish white color. Such a distinction is scarcely scientific.

Under Gilia congesta iberidifolia, Dr. Brand gives as synonyms G. spergulifolia Rydb. and G. roseata Rydb. Evidently Dr. Brand had not seen a specimen of $G$. roseata. This is perhaps closer related to his own $G$. globularis than to $G$. iberidifolia, except that the stems are branched and bear several heads. He had seen a specimen of Baker 534, which I referred to G. spergulifolia. When doing so I had in mind only the specimen in the herbarium of the New York Botanical Garden. I do not know by what this number may be represented elsewhere. However, I can not distinguish this from Nelson 5430, which Dr. Brand refers to the var. crebrifolia, evidently not knowing that the var. Merrillii (G. Merrillii A. Nels.) is the original G. crebrifolia Nutt. A duplicate of the type is in the Columbia University herbarium. The synonomy of this group of Gilias is therefore very mixed. In order to straighten out the matter I give the following synonymy:

Gilid spictta Nutt. Jour. Acad. Nat. Sci. Phila. II. I: I56. I 848 . 
Gilia globularis Brand, Pflanzenreich $4^{250}$ : 120.1907.

Gilia spicata capitata A. Gray, Proc. Am. Acad. 8: 274 (as to type). $\quad 1870$.

Gilia cephaloidea Rydb. Fl. Colo. 277, in part. 1906.

Gilia cephaloidea Rydb. Bull. Torrey Club 24: 293 (as to the Montana plant). I897.

Gilia congesta Hook. Fl. Bor.-Am. 2: 75. I 838 .

Gilia spicata capitata A. Gray, Syn. Fl. $\mathbf{2}^{1}$ : $\mathbf{1 4 4}$, in part. $\mathbf{1} 878$. Gilia cephaloidea Rydb. Bull. Torrey Club 24: 293, in part. I897.-Brand, Pflanzenreich $4^{250}$ : I2I. 1907.

Gilia iberidifolia Benth. in Hook. Jour. Bot. \& Kew Misc. 3: 290. I851.

Gilia congesta iberidifolia Brand, Pflanzenreich $t^{250}$ : $121 . \quad$ 1907. Gilia nuda (Eastw.) Rydb.

Gilia congesta nuda Eastw. Proc. Calif. Acad. II. 6: 308. 1896. Gilia roseata Rydb. Bull. Torrey Club 31: 633. I904.

Gilia spergulifolia Rydb. Bull. Torrey Club. 31: 633. I904. Gilia congesta crebrifolia S. Wats. Bot. King Exped. 5: 268, in part. $187 \mathrm{I}$.

Gilia congesta iberidifolia crebrifolia Brand, Pflanzenreich $4^{250}$ : I2I. 1907 .

Gilia crebrifolia Nutt. Jour. Acad. Nat. Sci. Phila. II. I: I56. I 848 .

Gilia congesta crebrifolia A. Gray, Proc. Am. Acad. 8: 273. I 870 .

Gilia Merrillii A. Nels. Bot. Gaz. 34: 27. 1902.

Gilia congesta iberidifolia Merrillii Brand, Pflanzenreich $4^{250}$ : I22. 1907 .

Gilia Burleyaxa A. Nels. Bot. Gaz. 54: I44. I9I2.

This species also belongs to this group. Prof. Nelson stated in the original description: "Until now this section contained no perennials." Both G. iberidifolia and G. roseata are perennials. Gray divides the group in "annuals and short lived perennials or biennials."

Gilia palmifrons (Brand) Rydb. sp. nov.

Gilia congesta palmifrons Brand, Pflanzenreich $4^{250}$ : 122.1907.

I think also that Dr. Brand has misidentified Gilia trifida Nutt. 
Dr. Brand evidently drew his description from Jones 5979, the only specimen he cited. He described the stamens as being inserted in the middle of the corolla-tube, while Nuttall described them as inserted in the throat. I have not seen Nuttall's type, but I have collected in the region of the type locality, Scott's Bluffs, Nebraska. The only species growing there are G. spicata and $G$. iberidifolia. I believe that Dr. Gray interpreted G. trifida Nutt. correctly as a depauperate form of G. spicata. If this is correct, Brand's G. trifida must receive a new name.

\section{Gilia frutescens Rydb. sp. nov.}

Fruticose, perennial; stems woody below, branched above, $3^{-5}$ $\mathrm{dm}$. high; herbaceous branches $2-3 \mathrm{dm}$., sparingly pubescent; leaves linear, glabrous or nearly so, simple, $2-5 \mathrm{~cm}$. long, I-2 $\mathrm{mm}$. wide, callous-tipped; flowers capitate at the ends of the branches; calyx crisp-hairy; teeth lanceolate, cuspidate, shorter than the tube; corolla white, 5-6 $\mathrm{mm}$. long, salvershaped; tube barely exserted; lobes about $2.5 \mathrm{~mm}$. long, oval, acute; stamens inserted in the throat; filaments short; style glabrous, nearly as long as the corolla tube.

The type was labeled Gilia multiflora, to which it is not related. It belongs to the $G$. iberidifolia group, and has as entire leaves as $G$. spergulifolia and $G$. crebrifolia, but the habit is different. It differs from all its relatives in the tall shrubby habit. The other species are at most suffruticose and less than $3 \mathrm{dm}$. high.

UтAн: Springdale, May I4, I894, M. E. Jones 5247 (type, in herb. N. I. Bot. Gard.; duplicate in U. S. Nat. Herb. no. 3260Io).

Dr. Brand has treated the G. aggregata group as carelessly as that of the $G$. congesta relatives. It is evident that he has had no specimens of $G$. candida Rydb. and still he makes it Gilia aggregata var. attenuata forma candida, giving Callisteris leucantha Greene as another synonym. If he had only read my description, he would not have committed this blunder, for I distinctly pointed out that the lobes of the corolla in $G$. candida are rounded or obtuse at the apex like those of G. longiflora. It is a plant with the habit and leaves of $G$. aggregata and the corolla of $G$. longiflora. Both Callisteris attenuata and C. leucantha have attenuate corollalobes and the former is a white-flowered form of Gilia pulchella Dougl., a species wholly omitted by Dr. Brand. Dr. Brand cited 
two specimens under the forma candida, viz. Nelson 4198 (should have been 4I89) and Clements 13 . The former is a white-flowered form of $G$. pulchella, the latter belongs to Gilia scariosa Rydb. Dr. Brand did not notice the different structure of the calyx, which places G. scariosa close to G. aggregata Bridgesii A. Gray. Nelson in the New Manual has also confused things. Gilia scariosa is made a synonym of $G$. aggregata and $G$. candida of $G$. attenuata. He has also overlooked the characters of the calyx of $G$. scariosa and the rounded corolla-lobes of G. candida.

Gilia arizonica (Greene) Rydb.

Callisteris arizonica Greene, Leaflets I: I60. 1905.

Gilia aggregata typica arizonica Brand, Pflanzenreich $t^{250}$ : I15. 1907.

Gilia tenuituba Rydb. sp. nov.

Biennial; stem about $3 \mathrm{dm}$. high, finely glandular-puberulent; leaves pinnatifid with narrowly linear, puberulent, cuspidate divisions; inflorescence a thyrsoid panicle, puberulent; flowers shortpedicelled; calyx campanulate, glandular-puberulent, distinctly scarious in the sinuses; teeth lance-subulate, cuspidate, longer than the tube; corolla flesh-colored, nearly $4 \mathrm{~cm}$. long; tube slender, I $\mathrm{mm}$. thick below and $2 \mathrm{~mm}$. at the throat; lobes narrowly lanceolate, attenuate, nearly I cm. long; stamens unequally inserted far down the corolla-tube, included; style slender, about equaling the corolla-tube.

Utah: Beaver City, I877, E. Palmer 329 (type, in herb. Columbia Univ.). This is also related to G. aggregata.

Gilia hutchinsifolia Rydb. sp. nov.

Gilia arenaria rubella Brand, Pflanzenreich $4^{250}$ : I03. I907.

This differs from $G$. arenaria Benth. and $G$. sinuata Dougl. in the acute corolla-lobes and broad and again lobed divisions of the leaves. The description "Caulis inferne (an morbo?) rufolanatus," from which Dr. Brand adopted the varietal name, is wholly erroneous. The red coloring is simply grains of red sand adhering to the specimens. This is the reason of my not adopting the varietal name.

Gilia straminea Rydb. sp. nov.

Annual; stem 2-3 dm. high, glabrous, or rarely slightly glandular-puberulent above, straw-colored, simple below, with a few 
almost erect branches above; basal leaves glabrous, firm, I-2 cm. long, pinnately lobed, with lanceolate cuspidate-tipped lobes; stem-leares sessile and partly clasping, lanceolate, sharply dentate with cuspidate teeth or entire; calyx-tube campanulate, $2 \mathrm{~mm}$. long, somewhat scarious in the sinuses, sparingly glandularpuberulent; teeth subulate, I mm. long; corolla trumpet-shaped, 7-8 $\mathrm{mm}$. long; tube nearly twice as long as the calyx; capsule exceeding the calyx; seeds 5 or 6 in each cell.

This is related to $G$. simuata, but differs in the simple, strawcolored, essentially glabrous stem, the glabrous, pale green leaves, and the form and toothing of the stem-leaves.

Utail: St. George, I877, E. Palmer $325,{ }^{*}$ in part (type, in herb. Columbia Lniv.); also 326.

Dr. Brand reduced Gilia Tweedyi Rydb. to a variety of $G$. minutiflora, without having seen a specimen. I do not think that it is rational to do so, for in $G$. Tweed yi the pod is not I-seeded, but bears I-3, usually 2 , seeds in each cell, i. e., it is 4 -seeded. The plant is more closely related to G. inconspicua.

Dr. Brand made Gilia Haydeni A. Gray a variety of G. subnuda Torr., and gave G. Crandallii Rydb. as a synonym of this variety. Professor Nelson regarded G. Crandallii as the same as G. subnuda and gave G. Haydeni and G. superba Eastw. as varieties of the same. Both arrangements are incorrect. G. superba Eastw. is the typical $G$. subumda Torr. characterized by the orange or scarlet corolla. In both G. Haydeni and G. Crandallii the corolla is rose-colored. They are quite distinct from G. submuda and in my opinion distinct from each other.

Dr. Brand's treatment of Leptodactylon pungens (Torr.) Nutt. or Gilia pungens (Torr.) Benth. and its relatives is far from satisfactory. He divides it in two subspecies: subsp. A. eu-pungens and subsp. B. Hallii (Gilia Hallii Parish), which is a matter of taste, but he also divides the former in four varieties: a. Hookeri (Dougl.) Brand; b. caespitosa (Nutt.) Brand; c. tenuiloba (Parish) Brand; and d. devestita Brand.

The first variety is based on Gilia Hookeri Benth. To make this species a variety of $G$. caespitosa could be also passed over, as

* The same number in the herbarium of the New York Botanical Garden is entirely different, and belongs to Gilia hutchinsifolia. Maybe some mixing of the labels occurred. 
a matter of taste, but Dr. Brand in his treatment usually meant by the variety $a$ the typical form. If that is his intention here, he is wholly mistaken, for the type is not viscid. Torrey's type should be placed under his variety $b$. caespitosa, and is exactly like Goodding 32 and Parry 236 from IYroming, which Dr. Brand also refers to that variety. In fact Dr. Brand seems not to know Leptodactylum caespitosum Nutt. (Gilia pungens caespitosa A. Gray), although he adopts this name for a variety which proves to be the original G. pungens. Leptodactylon caespitosum is amply distinct, not only by the characters given by Dr. Gray, but also by the 4 -merous flowers and the stamens inserted in the tube. All the other species have 5-merous flowers. Gilia Hookeri is confined to the western slope and does not extend into Utah, Colorado, New Mexico, and Arizona, as stated by Dr. Brand. The following specimens are wrongly referred to it: Elmer 502 is typical G. pungens; Jones $I 78+$ and MacDougal 183 belong to $G$. pungens squarrosa A. Gray. The Matthews' specimens I have not seen, but I think they also are wrongly referred to it. Of the specimens cited under the variety der'estita, all I have seen belong to typical $G$. pungens, some of them having slightly longer leaves than the type, but not all.

\section{Leptodactylon brevifolium Rydb. sp. nov.}

Suffruticose, branched perennial, I-2 dm. high; stems puberulent and slightly glandular above; leaves $3-5 \mathrm{~mm}$. long, glandularpuberulent or glabrate, 3-5-divided into subulate, acerose, ascending divisions; calyx about $8 \mathrm{~mm}$. long, glandular-puberulent; teeth subulate-acerose, much shorter than the tube; corolla trumpet-shaped, about $15 \mathrm{~mm}$. long; stamens inserted in the throat of the corolla.

This is related to Leptodactylon pungens (Torr.) Nutt. and L. Hookeri (Dougl.) Rydb. (Phlox Hookeri Dougl.; Gilia Hookeri Benth.) but has much shorter leaves. The habit and flower are more like the former, but the calyx and young foliage are more or less glandular, though not so copiously so as in the latter.

UtAH: Juniper Range, I898, Purpus 6306 (type, in L. S. Nat. Herb.; duplicate in herb. N. Y. Bot. Gard.); Cedar City, M. E. Jones 5207a; Montezuma Canyon, Eastwood; rocky hills on the San Juan, Neivberry. 
?Colorado: Gunnison, Aug. I6, I901, Baker $\delta_{30}$ (doubtful, without flower).

New Mexico: Cedar Hill, San Juan County, Standley 7998.

Washingtox: Coulee City to Ephrata, June i902, Griffiths \& Cotton 47 .

Nevada: Panaca, V. Bailey 197 I.

Dr. Brand excluded Gilia caespitosa A. Gray not only from the genus but also from the family. He makes the following remark: "Species foliis calcareo-glandulosis ab omnibus Polemoniaceis valde abhorret; fortasse Saxifragaceis attributa est."

The leaves are by no means "calcareo-glandulosis," but merely viscid-pubescent as described by Dr. Gray. In the type they are covered by grains of sand, that is all. It is without doubt a species of Gilia and probably, as Dr. Gray suggested, related to G. subnuda, but as the corolla was unknown the placing in the genus was uncertain. One thing is certain, it should not be placed next to $G$. rigidula as it is in the Synoptical Flora. The duplicate of the type in the National Herbarium bears a single withered and partly torn corolla; this is trumpet-shaped and about I cm. long; the real structure is not possible to make out, but the plant is probably related to $G$. subuuda.

Dr. Brand gives Micranthes diffusa as a synonym under Gilia gracilis subspecies humulis var. micrantha, while he cites Heller 3098 (its type) under $G$. gracilis subsp. eu-gracilis var. eritrichoides, which shows carelessness in identifying the different forms described. In the Columbia University herbarium there is a duplicate of Douglas's collection, which shows that Brand's var. eritrichoides is the typical form of Microsteris gracilis (Dougl.) Greene.

Dr. Gray in his Synoptical Flora* segregated out Gilia aristella from material he had previously included in Collomia linearis subulata. The latter he regarded as the same as Collomia tinctoria Kellogg. Notwithstanding this judgment of Dr. Gray, which always will weigh considerably, Dr. Brand made Collomia aristella (A. Gray) Rydb. a synonym of C. tinctoria Kellogg, while he named C. tinctoria subulata (A. Gray) Brand from Gray's variety C.

* $\mathbf{2}^{1}$ : Suppl, 408. I886. 
linearis subulata. Dr. Brand did not give any reason for this change. Furthermore, he did not cite any specimens of his $C$. tinctoria from California and I have seen no specimens of $C$. aristella from that state. Of the variety subulata, on the contrary, there are several collections from California in our herbaria. There is nothing either in Kellogg's description or in his figure which would indicate that Dr. Gray had made a misinterpretation. Kellogg's figure is drawn from a young, simple, undeveloped plant, and the peculiar branching of the var. subulata in age does not show. Whether $C$. tinctoria and $C$. aristella should be united into one species is another question, but in such a case the variety subulata should have been made the species, viz., C. tinctoria Kellogg, and C. aristella a variety thereof; and this for the following reason: The variety subulata is certainly found in the type region of Collomia tinctoria, while $C$. aristella apparently is not. Seen from another standpoint, the local and more specialized $C$. aristella must be regarded as the derivative of the more common and less specialized C. tinctoria (i. e., the var. subulata).

Brand transferred Gilia sinister M. E. Jones to Collomia without having seen the plant. This was probably because Mr. Jones placed it in the Collomia section and compared it with $G$. aristella. But Jones also made the following statement: "This has the general appearance of $G$. inconspicua, but without the basal leaves." The relationship is also with $G$. inconspicuta. Several of the species of that group have the calyx enlarged somewhat in fruit; this is true in G. sinister, but it is at last ruptured by the capsule and does not have the structure of the calyx in Collomia. It is in my opinion a true Gilia.

Dr. Brand included a number of forms, in my judgment several good species, under Polemonium pulcherrimum Hook. He divides it in three subspecies, tricolor, delicatum, and parvifolium. The first is separated by its tricolored flowers and equals $P$. tricolor Eastw. The other two subspecies he separated only by the length of the leaflets, a very poor character to use for separating subspecies.* He overlooked the fact that in all these forms included

* Under var. Haydenii Dr. Brand made the following remarks: "The forms from the southern Rocky Mountains, which could be counted to this, are better to be regarded as depauperate forms of subsp. delicatım." 
in the subspecies delicatum, the stem is pubescent with long white spreading hairs and the leaflets are decidedly acute, while in the forms included in the subspecies parvifolium, the stem is merely puberulent and the leaflets usually obtuse.

The specimens cited under the subspecies delicatum belong to three or four different species. Those from Colorado and Utah belong to $P$. scopulinum Greene and $P$. delicatum Rydb., which perhaps may not be specifically distinct. Those from California belong to $P$. californicum Eastw. Those from Washington and perhaps those from Oregon to an undescribed species, characterized below.

The subspecies parvifolium was divided in var. $\alpha$ Haydenii and var. $\beta$ pilosum ( $=P$. pilosum Greenman). It is very hard to interpret Dr. Brand's arrangement. He gives under the subspecies parvifolium the following synonyms: $P$. parvifolium Nutt.; P. coeruleum J. Hook.; P. mexicanum Nutt.; P. viscosum A. Gray, not Nutt., but cited no specimens. His usage as well as that of most European botanists is to designate the typical form by var. $\alpha$. Hence var. $\alpha$ Haydenii is the typical form of subsp. parvifolium, and still under this he has the following synonyms: P. Iaydeni A. Nels., P. montrosense A. Nels., and P. Tevisii Eastw. P. parvifolium Nutt. is the same as $P$. mexicanum Nutt. and $P$. viscosum A. Gray, and is characterized by its small dense inflorescence and its obtuse calyx-lobes, or the latter even rounded at the apex; but it is not the same as $P$. coeruleum $\gamma$ Hook., or P. Haydeni A. Nels., or $P$ Tevisii Eastw.

Polemonium coeruleum $\gamma$ Hook. is the original $P$. pulcherrimum Hook., and this should have been made subsp. A var $\alpha$, according to Brand's system. P. Haydeni resembles it closely in flowers, leaves and pubescence, but differs considerably in general habit and the inflorescence.

\section{Polemonium columbianum Rydb. sp. nov.}

Perennial, with a branched rootstock and caudex; stems several, 2-3 dm. high, viscid-pubescent with flattened hairs, and distinctly glandular in the inflorescence; leaves $5^{-15} \mathrm{~cm}$. long, likewise sparingly viscid-pubescent, pinnate; leaflets 9-I9, elliptic or lance-elliptic, acute, $\mathbf{I . 5}-3 \mathrm{~cm}$. long; inflorescence corymbiformpaniculate; calyx about $6 \mathrm{~mm}$. long, glandular-puberulent and 
pubescent; lobes lanceolate, acute, fully equaling the tube; corolla Io-12 mm. long, open-campanulate, violet with yellowish base; lobes rounded-truncate at the apex; stamens two thirds to three fourths as long as style and slightly longer than the corolla.

This resembles $P$. scopulinum Greene in habit, but is a larger plant with much larger flowers. It grows in the mountains of Idaho and Washington at an altitude of $\mathrm{I}, 500-2,000 \mathrm{~m}$.

IDAHO: Divide between St. Joseph and Clearwater Rivers, July 9, I896, Leiberg I205 (type, in herb. N. Y. Bot. Gard.); Wiesner's Peak, July 8, r892, Sandberg, MacDougal \& Heller I049.

Washington: Wenatchee Mountains, July, i897, Elmer 456; Goat Mountain, Aug. I2, I896, Allen 262; Clallam, July, I900, Elmer 2819; Palace Camp, I883, Mrs. Bailey Willis.

\section{Polemonium intermedium (Brand) Rydb. sp. nov.}

Polemonium occidentale intermedium Brand, Pflanzenreich $4^{250}$ :

33. 1907 .

This I think is well worth specific rank. It is confined to the Columbia River region of Idaho, Washington, and British Columbia.

Dr. Brand regarded Polemonium speciosum Rydb. as a good species. Professor Nelson on the other hand makes it a variety of $P$. mellitum (A. Gray) A. Nels., which is evidently erroneous. If it should be made a variety of any of the verticillate species of Polemonium, it should have been of $P$. viscosum Nutt. or rather of P. Grayanum Rydb., which species Professor Nelson does not regard as distinct. $P$. speciosum has a short blue corolla and subcapitate inflorescence.

\section{HYDROLEACEAE}

Hydrophyllum Watsonii (A. Gray) Rydb. sp. nov. Hydrophyllum occidentale Watsonii A. Gray, Proc. Am. Acad. I0: 3I4. I875.

Miltitzia foliosa (Jones) Rydb.

Emmenanthe foliosa M. E. Jones, Zoe 4:278. 1893.

The Miltitsia section of Emmenanthe of Gray's Synoptical Flora, I think is generically distinct from Emmenanthe proper, 
and DeCandolle's genus Miltitzia should be restored. The latter genus is represented in the Rocky Mountain region by this and the two following species.

Miltitzia salina (A. Nels.) Rydb.

Emmenanthe salina A. Nels. Bull. Torrey Club 25:38I. I898.

Miltitzia scopulina (A. Nels.) Rydb.

Emmenanthe scopulina A. Nels. Bull. Torrey Club 25: 380 . I 898 .

Phacelia orbicularis Rydb. sp. nov.

Biennial or annual; stems I-2 dm. high, glandular-villous, often tinged with red, branched; leaves petioled; blades suborbicular in outline, crenately lobed, $1: 5-2.5 \mathrm{~cm}$. long, hirsute as well as glandular; racemes many-flowered; calyx-lobes oblong or oblanceolate, obtuse, $3 \mathrm{~mm}$. long; corolla purplish, $6 \mathrm{~mm}$. long, campanulate-funnelform; lobes crenulate; filaments about twice as long as the corolla; seeds faveolate, crenately lobed on the margins and the median ridge.

This is related to $P$. integrifolia, but the plant is smaller and the leaf-blades shorter and broader.

UTAH: Marvin Laccelite, r894, M. E. Jones 5663 (type, in U. S. Nat. Herb.).

Phacelia crenulata Torr., P. bicolor Torr., P. affinis A. Gray, P. glechomaefolia A. Gray, P. hispida A. Gray, P. humilis T. \& G., P. demissa A. Gray, P. Palmeri Torr. (not P. Palmeri Vasey \& Rose), $P$. pinetorum Jones, and $P$. pusilla Torr. have been collected in Utah; $P$. glandulifera Piper and $P$. ramosissima Dougl., in Idaho. I cannot distinguish $P$. luteopurpurea A. Nels, from $P$. glandulifera Piper. Capnorea incana Greene, C. nana (Lindl.) Raf., C. nervosa Greene, and C. Watsoniana Greene have been collected in Idaho; the first one also in Montana and the last one in Wyoming; Emmenanthe penduliflora Benth. and Eriodictyon angustifolium Nutt. in Utah.

\section{BORAGINACEAE}

Gruvelia setosa (A. Gray) Rydb.

Pectocarya setosa A. Gray, Proc. Am. Acad. I2: 81. 1877.

I think that the genus Gruvelia A. DC. should be restored, being quite distinct from Pectocarya. The only other species is G. pusilla A. DC., the type of the genus. 
Professor Nelson both in the original diagnosis* and in Coulter $\&$ Nelson's New Manual $\uparrow$ described Lappula erecta as having the marginal prickles in a single row, but a duplicate of the type in the Columbia University herbarium and all specimens distributed as Lappula erecta by Professor Nelson himself in the herbarium of the New York Botanical Garden have a double row of marginal prickles, the prickles of the outer row being somewhat smaller than those of the inner.

Oreocarya pustulosa Rydb. sp. nor.

Perennial, branched at the base; stems $3-5 \mathrm{dm}$. high, glabrous or nearly so throughout, lower leaves linear-oblanceolate, the upper linear or linear-lanceolate, 3-10 cm. long, green, glabrous beneath, sparingly hairy above; the hairs short and at least in age with conspicuous pustulate bases; flowers paniculate; branches racemose, not secund; pedicels $\mathrm{I}-2 \mathrm{~mm}$. long; sepals triangularlanceolate, acute; corolla white; tube not exceeding the calyx; limb 5-6 mm. broad; lobes orbicular; fruit depressed-globose; nutlets smooth, nearly white, mottled with light brown, more or less separated from each other on the margins, often not all maturing.

This is related to Oreocarya multicaulis (Torr.) Greene, $O$. suffruticosa (Torr.) Greene and the Mexican O. Palmeri Greene. It differs from the first two in the glabrous stem, green leaves, and light nutlets, and from $O$. Palmeri in broader leaves and different habit. It grows in canyons at an altitude of $1,700-2,000 \mathrm{~m}$.

UтAн: Hammond Canyon, Elk Mountains, July 3I, I9I I, Rydberg \&a Garrett 9320 (type, in herb. N. Y. Bot. Gard.); also same locality, Aug. 9, I9I I, 9569; Dry Wash, southwest of Abajo Mountains, August I0, 9590.

\section{Oreocarya Macounii Eastw. sp. nov.}

Biennial or perennial with a slender tap-root; stem slender, I-2 dm. high, sparingly hirsute; leaves narrowly linear or narrowly linear-oblanceolate, sparingly hirsute; inflorescence racemiform with short branches; corolla white, $5 \mathrm{~mm}$. long, $4 \mathrm{~mm}$. wide; nutlets ovate, obtuse, $2 \mathrm{~mm}$. long, acutely margined, rounded on the back and coarsely muricate.

Saskatchewax: Moose Mountain Creek, July 6, r880, John

* Bull. Torrey Club 27: 268. I900.

† 412. I909. 
Macoun; also a specimen from Hooker's herbarium without date, probably collected by Richardson, at Carlton House. (Both in herb. Columbia University.)

Cryptanthe flexuosa A. Nelson is, I think, the same as $C$. calycosa (A. Gray) Rydb., and C. muriculata montana A. Nels. should be referred to C. ambigua (A. Gray) Greene, and C. Hillmani A. Nels, to C. Watsoni (A. Gray) Greene. C. flaccida (A. Gray) Greene has been collected in Idaho; C. recuriata Coville, in Utah and Colorado.

Mertensia coriacea A. Nels. is the same as M. lanceolata Pursh. Professor Nelson gives the range of $M r$. lanceolata as Colorado and Wyoming. The type came from western Montana. $M$. perplexa is not the same as $M$. coriacea, as stated by Professor Nelson, but belongs to the $M$. alpina group with subsessile anthers. Anchusa officinalis L. and Asperugo procumbens L. have been collected in Colorado; Plagiobotrys arizonicus (Gray) Greene in Utah; P. tenellus A. Gray in Idaho; Cynoglossum officinale L. in Wyoming and Montana; Eremocarya muricata Rydb. in Utah; Lithospermum arense L. in Utah; Mertensia brachycalyx Piper in Idaho; M. pulchella Piper, M. nutans Howell, and M. longiflora Greene in Idaho and Montana; Amsinckia hispidissima Suksd., $A$. retrorsa Suksd. and $A$. micrantha Suksd. have been collected in Idaho.

Pectocarya miser A. Nels. I can not distinguish from $P$. penicillata (H. \& A.) A. DC. Eddya hispidissima Torrey has been collected in Utah.

\section{VERBENACEAE}

Verbena remota Benth. was collected in southeastern Utah in I9II by Professor Garrett and myself. Verbena bipinnatifida Nutt. is very rare in the region and $I^{\prime}$. canadensis (L.) Britton does not occur at all. The range given in Coulter \& Nelson's New Manual is erroneous. The group is represented in the Rocky Mountains by $V$. ambrosifolia Rydb., I. Gooddingii Briq.. and V. ciliata Benth.

\section{LAMIACEAE}

Lamium amplexicaule $\mathrm{L}$. has been collected in Colorado; Micromeria Douglasii Benth. and Trichostoma oblongum Benth., in Idaho. 
Monarda Nuttallii A. Nels. or M. citriodora of Coulter's Manua! is Monarda pectinata Nutt.

Salvia Columbariae Benth. has been collected in Utah.

\section{SCROPHULARIACEAE}

Miss Eastwood has called to my attention that Pentstemon acuminatus, $P$. humilis Nutt., and $P$. glaucus Graham have been misinterpreted. $P$. acuminatus is a species confined to the Columbia Valley, has a more ample corolla, perfectly glabrous within; the tongue of the sterile filament is strongly curved and only short-bearded at the apex. Whether the so-called $P$. acuminatus of the Rocky Mountain region is a distinct species or should be included in P. nitidus Dougl. is hard to tell. A duplicate of the type of the latter is in the Columbia University herbarium, but this, as well as several other specimens, does not have the broad, abruptly acuminate bracts, characteristic of the so-called P. acuminatus, but there is no other distinction and intermediate forms are not lacking.

The original $P$, humilis Nutt, is, according to Miss Eastwood, the same as $P$. collinus A. Nels., which therefore passes into synonymy. Dr. Gray in describing $P$. humilis* makes Nuttall's plant the type, but evidently had another plant mostly in his mind, viz. Parry 257 and from this we have received our usual idea of $P$.hnmilis. This probably should be.known as $P$. albertinus Greene, $\dagger$ which apparently is the same. Professor Nelson gives $P$. pseudohumilis Rydb. as a synonym, but this is the same as his own $P$. Owenii.

Pentstemon glaucus Graham does not belong to the group where Dr. Gray placed it and has nothing to do with the Rocky Mountain plant $P$. stenosepalus (Gray) Howell ( $P$. glaucus stenosepalus A. Gray), but belongs to the $P$. confertus group. It is evidently the same as $P$. pinetorum Piper or closely related to it.

Pentstemon Macbridei A. Nels. $\downarrow$ and $P$. perpulcher A. Nels. are apparently $P$. Cusickii A. Gray and $P$. unilateralis Rydb., respectively. A duplicate of the type of $P$. Cusickii is in the herbarium

* Proc. Am. Acad. 6: 69. I862.

† Leaflets r: 167 . I906.

$\ddagger$ Bot. Gaz. 52: 272, 273. J9II. 
of Columbia University. The type of $P$. unilateralis is in that of the New York Botanical Garden. Recently botanists have overlooked the fact that in $P$. speciosus, the anthers are perfectly glabrous and not short-bearded as in P. glaber. Dr. Gray overlooked the fact that Pentstemon humilis Nuttall is a member of the $P$. erianthera group and closely related to $P$. miser A. Gray, and placed it near $P$. caespitosus Nutt. Gray's two varieties of $P$. humilis, however, have nothing to do with it, and belong to the $P$. caespitosus group. The variety Thompsoniae has been already raised to specific rank and var. incanus is probably a form of it.

\section{Pentstemon Leonardi Rydb. sp. nov.}

Low perennial, suffruticose at the base; stems $\mathrm{I}-2 \mathrm{dm}$. high, leafy, glabrous or minutely puberulent; leaves oblanceolate, $2-4$ $\mathrm{cm}$. long, short-petioled, glabrous; inflorescence short and often somewhat secund; calyx glabrous, about $6 \mathrm{~mm}$. long; lobes lanceolate, acuminate, not scarious-margined; corolla I2-15 mm. long, rose-purple, only slightly ampliatc, glabrous within; anthers horseshoe-shaped, saccate, opening only on the proximal one third, hispidulous on the margins of the pores, otherwise glabrous.

This belongs to the $P$. azureus group and has been confused with $P$. Kingii, but the leaves are broader and glabrous, the corolla less ampliate, the sepals not glandular and more acuminate. It differs from $P$. platyphyllus in the low habit and the smaller oblanceolate leares.

UTAH: Diehl's Grove, Wahsatch Mountains, Aug. I, I884, Leonard (type, in herb. N. Y. Bot. Gard.); Deer Creek, H. E. Jones; Wahsatch Mountains, July, I888, J.H. Paul; Central Utah I875, Parry 72 .

IDAHO: Franklin Basin, Bear River Range, July 24, I9Io, C. P. Smith 2278 .

Mimulus Eastwoodiae Rydb. sp. nov.

Mimulus cardinalis Eastw. Bull. Calif. Acad. II. 6: 312. I896. Not M. cardinalis Dougl. I842.

Perennial, with rootstock and stolons; stem I-2 dm. long, viscid-rillous; leaves sessile, coarsely dentate, viscid-rillous, 3-5ribbed, sessile, $2-5 \mathrm{~cm}$. long, the lower cuneate and truncate, the upper oborate or broadly oblanceolate and acute; stolons I-3 $\mathrm{cm}$. long, rooting at the end and nodes; their leares less than $\mathrm{I} \mathrm{cm}$. 
long; flowers mostly solitary; pedicels $\mathrm{I}-t \mathrm{~cm}$. long; calyx narrowly funnelform, strongly 5-angled; lobes nearly equal, lanceolate, about half as long as the tube; corolla crimson, $3-4 \mathrm{~cm}$. long, scarcely ventricose; anthers sparingly bearded.

This is related to Mimulus cardinalis, to which Miss Eastwood referred it with some hesitation. She also pointed out the low habit and more sharply toothed leaves, but did not notice the most striking feature of the plant, viz., its stolons, which are sent out after blooming. By means of these the plant, growing as it does in crevices of perpendicular or overhanging cliffs, can propagate itself in every direction. Wherever a stolon touches the rock and the root can get a foothold, a new plant is formed, even under the overhanging rocks. In the latter case the plantlet formed will be growing, the following year, with the roots up and the flowers down.

UTAH: In cervices of perpendicular or overhanging rocks, along San Juan River, near Bluffs, August 25-29, I9I I, Rydberg 9883 (type); also the same locality, Miss Eastwood.

Veronica Buxbaumii Tenore has been collected in Utah and $V$. arvensis L. in Idaho. Veronica peregrina L. is not found in the Rocky Mountain region. All specimens so named from there belong to V.xalapensis H. B. K. Antirrhinum Cooperi A. Gray and A. Kingii S. Wats. have both been collected in Utah; Monniera rotundifolia Michx. in Montana; Gratiola ebracteata Benth. in Montana and Idaho.

Triphysaria hispida (Benth.) Rydb.

Orthocarpus hispidus Benth. Scroph. Ind. I $3 . \quad$ I 835.

In the genus Cordylanthus [Adenostegia] Coulter \& Nelson* have transposed the color characters of the corolla of $C$. Wrightii and C. ramosa. Adenostegia capitata (Nutt.) Greene has been collected in Idaho and $A$. canescens is common around Great Salt Lake. Cordylanthus bicolor A. Nels. is evidently the same as Adenostegia ciliosa Rydb.

Castilleja subcinerea Rydb. sp. nov.

Perennial with a branched short caudex; stems $3-5 \mathrm{dm}$. high, canescent-strigose, stout; leaves more or less canescent, strongly

* See Manual 462 . I909. 
3-ribbed, 5-7 cm. long, the lowest entire, linear, the upper 3-cleft; bracts broadly cuneate in outline, 5-7-cleft, canescent, the lower grayish green, the upper tinged with yellow and often browntipped; calyx canescent, $2.5 \mathrm{~cm}$. long, equally cleft above and below, each lobe 2-cleft; corolla greenish yellow; upper lip $9 \mathrm{~mm}$. long; the lower about $3.5 \mathrm{~mm}$. long, slightly saccate.

It may be related to the $C$. hispida group, but the plant is grayish strigose, and the bracts yellow-tinged.

IdaHo: Beaver Canyon, June 28, I895, C. L. Shear $304 I$ (type, in herb. N. Y. Bot. Gard.); also 3038; mountains near Indian Creek, July 21, I897, Rydberg \& Bessey 4969 (at least in part).

Euphrasia mollis (Ledeb.) Wettst. has been collected in Montana; Pedicularis lanata Willd. and $P$. flammea L. in the Canadian Rockies; $P$. Oederi Vahl in Montana and $P$. centranthera A. Gray in Utah and Colorado.

\section{OROBANCHACEAE}

Thalesia purpurea Heller, T. minuta (Suskd.) Rydb. and T. Sedi (Suksd.) Rydb. have been collected in Montana and northern Idaho, and Myzorrhiza pinetorum (Geyer) Rydb. in Idaho.

\section{LOBELIACEAE}

Howellia aquatilis A. Gray and IIeterocodon rariflorum Nutt. have been collected in Idaho and Nemacladus ramosissimus Nutt. in south Utah.

New York Botanical Gardex, 




\section{The New York Botanical Garden}

Journal of the INev York Botanical Garden, monthly, illustrated, containing notes, news, and non-technical articles of general interest. Free to all members of the Garden. To others, Io cents a copy ; $\$ 1.00$ a year. [Not offered in exchange.] Now in its fourteenth volume.

Mycologia, bimonthly, illustrated in color and otherwise; devoted to fungi, including lichens; containing technical articles and news and notes of general interest, and an index to current American mycological literature. $\$ 3.00$ a year; single copies not for sale. [Not offered in exchange.] Now in its fifth rolume.

Bulletin of the New Yorks Botanical Garden, containing the annual reports of the Director-in-Chief and other official documents, and technical articles embodying results of investigations carried out in the Garden. Free to all members of the Garden; to others, $\$ 3.00$ per volume. Now in its eighth volume.

North American Flora. Descriptions of the wild plants of North America, including Greenland, the West Indies and Central America. Planned to be completed in 32 volumes. Roy. 8vo. Each volume to consist of four or more parts. Subscription price, $\$ 1.50$ per part; a limited number of separate parts will be sold for $\$ 2.00$ each. [Not offered in exchange.]

Vol. 3, part I, 1910. Nectriaceae-Fimetariaceae.

Vol. 7, part 1, 1906; part 2, 1907; part 3, 1912. Ustilaginaceae-Aecidiaceae (pars).

Vol. 9, parts I and 2, 1907; part 3, 1910. Polyporaceae-Agaricaceae (pars). (Parts 1 and 2 no longer sold separately.)

Vol. 16, part I, I909. Ophioglossaceae-Cyatheaceae (pars).

Vol. 17, part 1, 1909; part 2, 1912. Typhaceae-Poaceae (pars). (pars).

Vol. 22, parts 1 and 2, I905; parts 3 and 4, 1908. Podostenowaceae-Rosaceae

Vol. 25, part I, 1907; part 2, 1910; part 3, 1911. Geraniaceae-Burseraceae.

Memoirs of the New York Botanical Garden. Price to members of the Garden, \$I.oo per volume. To others, \$2.00. [Not offered in exchange.]

Vol. I. An Annotated Catalogue of the Flora of Montana and the Yellowstone Park, by Per Axel Rydberg. ix +492 pp., with detailed map. 1900.

Vol. II. The Influence of Light and Darkness upon Growth and Development, by D. T. MacDougal. $x v i+320$ pp., with 176 figures. 1903 .

Vol. III. Studies of Cretaceous Coniferous Remains from Kreischerville, New York, by Arthur Hollick and Edward Charles Jeffrey. viii $+13^{8}$ pp., with 29 plates. 1969.

Vol. IV. Effects of the Rays of Radium on Plants, by Charles Stuart Gager. viii +278 pp., with 73 figures and 14 plates. I9o8.

Contrlbutions from the INew Yorks Botanical Garden. A series of technical papers written by students or members of the staff, and reprinted from journals other than the above. Price, 25 cents each. $\$ 5.00$ per volume. In its seventh volume.

\section{RECENT TUMUERS 25 CENTS EACE}

152. The genus Struthiopteris and its Representatives in North America, by Jean Broadhurst.

153. Studies on the Rocky Mountain Flora-XXVII, by P. A. Rydberg.

154. Biochemical Studies of Soils Subjected to Dry Heat, by F. J. Seaver and E. D. Clark.

155. Polycodium, by C. B. Robinson.

156. Studies on the Rocky Mountain Flora-XXVIII, by P. A. Rydberg. 






\section{OK 176 . R9 19}

Rydberg. Per Axel/Studies on Rocky Mount

Rydberg, Per Axel/Studies on Rock Mount

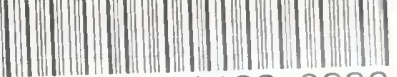

35185001338332 
H. H. 3.4 y. Hy) 3363

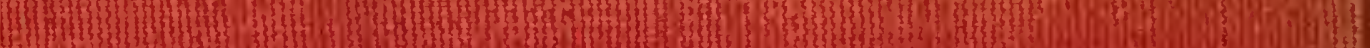
Q⿱一𫝀木口) 13)

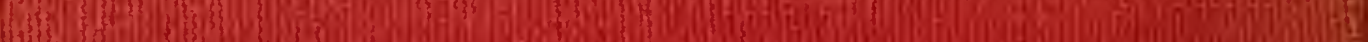
13 y my III

(3) 90. (a) 10 (1) 